UNIVERSIDADE DE SÃO PAULO

INSTITUTO DE ARQUITETURA E URBANISMO

LUCIANA DA ROSA ESPÍNDOLA

O wood frame na produção de habitação social no Brasil 



\section{O wood frame na produção de habitação social no Brasil}

\section{Versão Corrigida}

Tese apresentada ao Programa de PósGraduação em Arquitetura e Urbanismo do Instituto de Arquitetura e Urbanismo da Universidade de São Paulo para a obtenção do título de Doutora em Ciências.

Área de concentração: Arquitetura, urbanismo e tecnologia.

Orientadora: Profa. Dra. Akemi Ino 


\section{AUTORIZO A REPRODUCAO TOTAL OU PARCIAL DESTE TRABALHO, POR QUALQUER MEIO CONVENCIONAL OU ELETRONICO, PARA FINS DE ESTUDO E PESQUISA, DESDE QUE CITADA A FONTE}

Ficha catalográfica elaborada pela Biblioteca do Instituto de Arquitetura e Urbanismo com os dados fornecidos pelo(a) autor(a)

Espíndola, Luciana da Rosa
o wood frame na produção de habitação social no
Brasil / Luciana da Rosa Espíndola; orientadora Akemi
Ino.-- São Carlos, 2017 .
331 p.
Tese (Doutorado - Programa de Pós-Graduação em
Arquitetura e Urbanismo, Arquitetura, Urbanismo e
Tecnologia) -- Instituto de Arquitetura e Urbanismo,
Universidade de São Paulo, 2017.
1. construção leve em madeira. 2. habitação social.
3. inovação tecnológica. 4. sistema nacional de
avaliaçáturócnica. I. Ino, Akemi, orient. II. Título.




\section{FOLHA DE JULGAMENTO}

Candidato(a): Luciana da Rosa Espíndola

Título da tese: "O wood frame na produção de habitação social no Brasil”

Data da defesa: 24/03/2017

Orientador: Profa. Dra. Akemi Ino

Comissão Julgadora:

Profa. Dra. Akemi Ino

(IAU/USP)

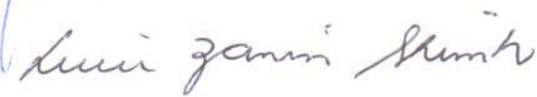

Profa. Dra. Lúcia Zanin Shimbo (IAU/USP)

Á a vleo

Profa. Dra. Ângela do Valle

(UFSC)

Profa. Dra. Margarete Regina Freitas Gonçalves
(UFPel)

Prof. Dr. Ivan Manøel Rezende do Valle (FAU/UnB)
Resultado:
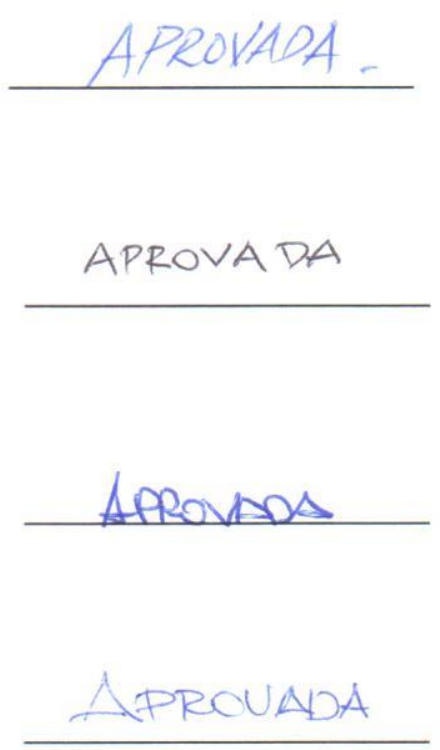

Coordenadora e Presidente da Comissão de Pós-Graduação do Programa de PósGraduação em Arquitetura e Urbanismo: Profa. Dra. Cibele Saliba Rizek. 

À minha família, minha base. 

À professora Akemi Ino, por ter me orientado neste doutorado, participando ativamente nesta pesquisa, estimulando as discussões e incentivando novas possibilidades de aplicações sociais com sistemas construtivos em madeira.

Ao grupo de pesquisa em Habitação e Sustentabilidade (Habis) da Universidade de São Paulo (USP/São Carlos), em especial aos professores Akemi Ino, João Marcos de Almeida Lopes e Lúcia Zanin Shimbo e aos colegas de pesquisa, por momentos de aprendizado em conjunto sobre um tema que nos envolve em desejos e forças para transformar o social.

Ao Programa de Pós-Graduação em Arquitetura e Urbanismo do IAU/USP, incluindo docentes, pelo conhecimento compartilhado, e técnicos administrativos, pelo suporte nas questões institucionais.

Aos professores integrantes da banca de defesa desta tese, Ângela do Valle, Margarete R. F. Gonçalves, Ivan M. R. do Valle, Lúcia Z. Shimbo e Akemi Ino, pelas contribuições específicas para esta pesquisa e outras futuras.

Ao Instituto Federal de Educação, Ciência e Tecnologia de Santa Catarina (IFSC), em especial aos colegas do Departamento Acadêmico de Construção Civil, por permitirem meu afastamento da docência para a finalização desta pesquisa.

Ao Grupo Interdisciplinar de Estudos da Madeira (GIEM) da Universidade Federal de Santa Catarina (UFSC), em especial à professora Poliana Dias de Moraes, pelo conhecimento específico transmitido durante meu mestrado, pois esta base foi essencial para a continuidade da pesquisa sobre o sistema plataforma em madeira no contexto brasileiro.

Às empresas construtoras e aos agentes institucionais envolvidos nesta pesquisa, pelo acesso a dados específicos sobre o wood frame no Brasil, em especial às empresas Tecverde e Roberto Ferreira. Destes, saliento a atenção e as contribuições dadas pela Engenheira Ambiental e Mestre em Construção Civil Carla R. Monich Soldera e pelo Engenheiro Industrial Madeireiro Ramon Pollnow.

À professora doutora Margarete R. F. Gonçalves, da Universidade Federal de Pelotas (UFPel), por sua colaboração com dados essenciais sobre o sistema construtivo Morar Melhor e suas aplicações em habitações sociais estruturadas em madeira executadas no Rio Grande do Sul.

Às colegas da Pós IAU/USP, Kamila, Jane e Rosana, que me acompanharam desde o início desta etapa.

Às colegas do IFSC, Uaçaí, Anelise e Beatriz, pelo companheirismo e pelo apoio necessário para finalizar este processo.

À minha família, meu vínculo afetivo, que sempre me apoia num sentindo mais amplo e me orienta nas minhas decisões. 

ESPÍNDOLA, L. R. O wood frame na produção de habitação social no Brasil. 2017. 331 p. Tese (Doutorado - Programa de Pós-Graduação em Arquitetura e Urbanismo) - Instituto de Arquitetura e Urbanismo, Universidade de São Paulo, São Carlos, 2017.

A inovação tecnológica é resultante de um processo social, movido por agentes e necessidades selecionadas. A tecnologia é um instrumento útil e dirigido por interessados que influenciam decisões sobre o processo produtivo. É importante compreender como ocorre este processo de inovação na indústria da construção civil sob este aspecto teórico. Raramente, a questão sobre a seletividade das inovações é esboçada por pesquisadores da área. Portanto, é necessário adotar uma visão sistêmica, delineando os agentes articuladores e as necessidades elencadas para efetivação das mudanças. Para aprofundar este tema, selecionou-se o caso da implementação do sistema wood frame no Brasil a partir do ano de 2010. No histórico geral do país, desde a segunda metade do século $X X$, a indústria da construção em madeira foi pouco disseminada e apresentou poucas inovações tecnológicas. Mas, em 2009, o setor madeireiro se mobilizou mediante a denominada Comissão Casa Inteligente para transformar e incrementar sua produção. Como resultado desta ação conjunta, em 2012, o sistema construtivo leve em madeira denominado wood frame foi introduzido no programa habitacional Minha Casa Minha Vida (PMCMV) financiado por agentes públicos. Para compreender esta mudança no cenário brasileiro, esta tese tem como objetivo analisar como ocorreu esta introdução do sistema inovador wood frame na produção de habitação no Brasil. Para isso, sob a visão sistêmica, esta pesquisa busca responder o que motivou esta transformação técnica, quais agentes participaram deste processo, como se articularam para promover o wood frame e quais resultados obtiveram. Esta análise contribui para demonstrar como as articulações entre setor produtivo, Estado e instituições de ensino e pesquisa podem ser eficazes para promover as mudanças técnicas no setor de construções.

Palavras-chave: construção leve em madeira, habitação social, inovação tecnológica, sistema nacional de avaliação técnica. 

ESPINDOLA, L. R. The wood light framing on the Brazilian social housing production. 2017. 331 p. Thesis (Doctoral) - Institute of Architecture and Urbanism, University of São Paulo, São Carlos, 2017.

Technological innovation is the result of a social process guided by agents and selected needs. Technology is an instrument directed by the interested who influence decisions about the production process. It is important to comprehend how this innovation process occurs in the civil construction industry with this point of view. The issue about the selectivity of innovations is rarely outlined by researchers in this area. Therefore, it is necessary to understand how the process of technological innovation occurs under a systemic vision, outlining its agents and their selected needs to implement the changes. On this basis, for this research was selected the case of implementation of wood light frame construction in Brazil in the year of 2010. In the history of Brazil, since mid-XX century, the wood construction industry wasn't very disseminated and have presented few technological transformations. However recently, since 2009 , the timber sector has been mobilizing through a committee to transform and increase its production. As a result of this joint action, in 2012, the wood light frame construction was introduced in the social housing program entitled Minha Casa Minha Vida (MCMV) funded by public agents. To understand this change in the scenario of wood construction in Brazil, this thesis aims to analyze how the introduction of the innovative wood frame system occurred in the production of social housing. For this, this research analyzes what motivated this technological change, which agents participated on this process, how they articulated and what results they outcome. This analysis contributes to demonstrate how the articulations between productive sector, state and educational institutions can be effective in promoting technical changes in the construction sector.

Keywords: wood light frame, social housing, technological innovation, national system of technical evaluation. 



\section{LISTA DE FIGURAS}

Figura 1: Exemplo de edificação em wood frame nos países norte-americanos.................................. 37

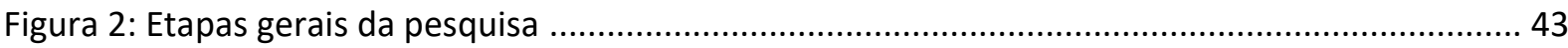

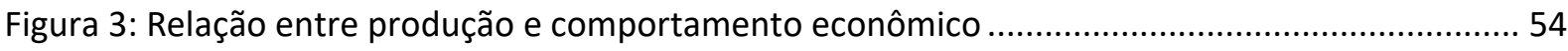

Figura 4: Oscilações econômicas e a introdução de "novas combinações" de produção ...................... 55

Figura 5: Principais fases do processo de desenvolvimento de uma inovação .................................... 66

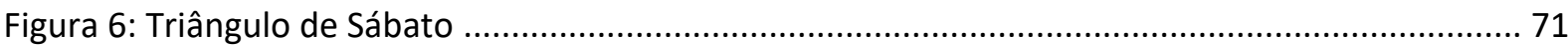

Figura 7: Modelos estatista e laissez-faire das relações governo-universidade-indústria .................... 73

Figura 8: Cadeia produtiva da construção - etapas produtivas, comércio e serviços ........................... 79

Figura 9: Cadeia produtiva da construção - fluxos e interferências ................................................... 80

Figura 10: Fluxograma com etapas de desenvolvimento para produtos inovadores na construção ... 82

Figura 11: Estrutura geral do Sistema Nacional de Avaliações Técnicas (SINAT) ................................. 94

Figura 12: Procedimentos para elaboração e aprovação da Diretriz SINAT ......................................... 96

Figura 13: Procedimentos para elaboração e aprovação do DATec ................................................... 97

Figura 14: Procedimento para aprovação de viabilidade de sistemas inovadores na CEF .................. 98

Figura 15: Produção das tramas estruturais e montagem da edificação............................................. 100

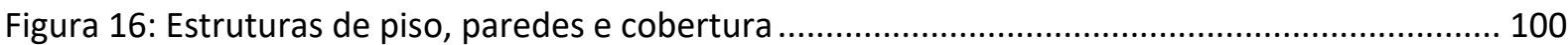

Figura 17: Diferentes composições de trama estrutural para paredes .............................................. 101

Figura 18: Exemplos de construções enxaimel com montantes próximos entre si ............................ 102

Figura 19: Diferentes materiais de preenchimento das paredes ..................................................... 103

Figura 20: Construções enxaimel com alterações no comprimento dos montantes .......................... 104

Figura 21: Estrutura principal do sistema construtivo braced-frame ............................................... 105

Figura 22: Estrutura principal do sistema construtivo balloon frame ….......................................... 107

Figura 23: Estrutura principal do sistema construtivo platform frame ........................................... 108

Figura 24: Corte com detalhes da fundação em radier .................................................................. 118

Figura 25: Plataforma de piso estruturada com vigas/barrotes em madeira .................................... 118

Figura 26: Plataforma de piso estruturada com vigas I e chapas delgadas ...................................... 119

Figura 27: Estrutura de parede externa com chapa estrutural e peça de travamento ...................... 119

Figura 28: Chapas estruturais no sentido horizontal ou vertical ...................................................... 120

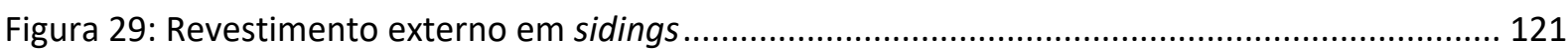

Figura 30: Revestimento externo em tijolos cerâmicos e em estuque ................................................. 121

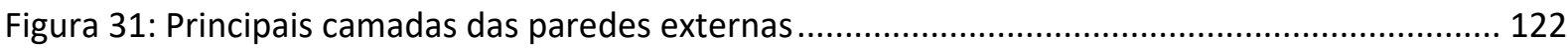

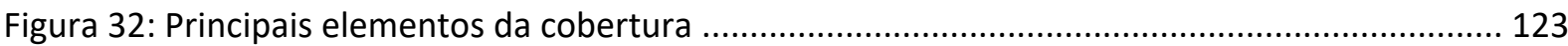


Figura 33: Cobertura com beiral aberto e forrado 123

Figura 34: Processo de montagem da estrutura do sistema balloon frame ...................................... 125

Figura 35: Estrutura de parede do sistema balloon frame erguida manualmente ............................ 125

Figura 36: Processo de montagem da estrutura do sistema platform frame .................................... 126

Figura 37: Método de produção no canteiro - stick-built .................................................................. 127

Figura 38: Modelos de residências oferecidas por catálogos americanos e canadenses ................... 128

Figura 39: Descrição em inglês do método kits pré-cortados da empresa Aladdin Homes................ 128

Figura 40: União dos painéis de parede pequenos ou grandes no canteiro ........................................ 129

Figura 41: Instalação das unidades modulares tridimensionais no canteiro ...................................... 130

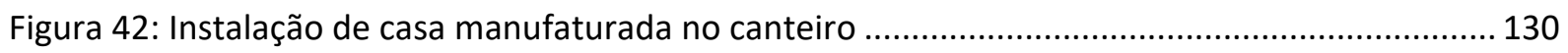

Figura 43: Resumo dos métodos de produção do sistema entramado leve em madeira ................... 131

Figura 44: Linha do tempo com principais períodos das construções populares em madeira no Brasil

Figura 45: Exemplo de construções do período indígena com madeira e palha ................................. 134

Figura 46: Construções estruturadas em madeira no período de colonização portuguesa ................ 135

Figura 47: Construções estruturadas em madeira dos imigrantes alemães e italianos....................... 136

Figura 48: Construções estruturadas em madeira dos imigrantes poloneses e ucranianos................ 137

Figura 49: Construções estruturadas em madeira dos imigrantes japoneses no Vale do Ribeira, SP 138

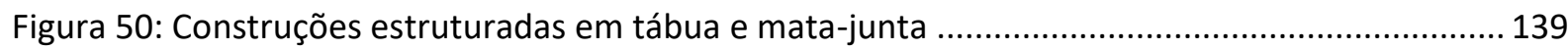

Figura 51: Construções em tábua e mata-junta em meados de 2010 nas regiões sul e norte ............ 140

Figura 52: Construções em kits pré-fabricados com tábuas empilhadas e encaixadas em montantes

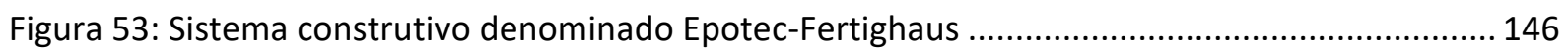

Figura 54: Sistema construtivo wood frame desenvolvido pela empresa Battistella .......................... 147

Figura 55: Construção em wood frame desenvolvido pela empresa Madezatti................................. 149

Figura 56: Sistema construtivo US Home desenvolvido pela empresa Malacon em 2001 ................. 150

Figura 57: Linha do tempo com as principais construções em wood frame no Brasil desde 1976 .... 151

Figura 58: Protótipo Stella-UFSC executado pela UFSC em parceria com a empresa Battistella ....... 154

Figura 59: Projeto Educação em Madeira executado pela UNESP em 2006 ...................................... 155

Figura 60: Estudo de caso com habitação térrea fechada com placas cimentícias em 2006 .............. 156

Figura 61: Protótipo construído pela UFPR em parceria com a COHAB-SC e empresa Lavrasul S.A. . 157

Figura 62: Casa construída com sistema em madeira e revestida com chapa mineralizada Erkulit... 162

Figura 63: Principais segmentos de produtos madeireiros oriundos de florestas plantadas ............. 174

Figura 64: Cadeia de produção generalizada das construções em wood frame .................................. 186

Figura 65: Principais atividades para a formação da Comissão Casa Inteligente em 2009................. 187 
Figura 66: Casa modelo Slim da empresa Tecverde construída em 2010 198

Figura 67: Planta baixa base da casa modelo Slim da empresa Tecverde 198

Figura 68: Principais etapas da montagem da casa Slim no canteiro 199

Figura 69: Modelo tridimensional e construção finalizada do Escritório Verde da UTFPR 200

Figura 70: Produção na fábrica e no canteiro dos elementos do Escritório Verde 201

Figura 71: Núcleo SENAI de Sustentabilidade construído em parceria com Tecverde 202

Figura 72: Produção no canteiro do Núcleo SENAI de Sustentabilidade em 2012 202

Figura 73: Materiais constituintes do painel de parede do Núcleo SENAI 203

Figura 74: Treinamento da empresa alemã Baumeister \& Sapper para produção na fábrica. 211

Figura 75: Definições de projeto para construções em madeira no programa alemão SEMA 212

Figura 76: Composição dos painéis de parede da Tecverde em 2012 213

Figura 77: Estoque dos principais materiais recebidos 214

Figura 78: Leitura do projeto de produção, marcações conforme medidas e corte das peças 214

Figura 79: Montagem do entramado em madeira sobre mesa com hastes pneumáticas 215

Figura 80: Posicionamento e fixação das chapas OSB sobre o entramado 215

Figura 81: Fixação da membrana hidrófuga e da placa cimentícia 216

Figura 82: Painel erguido por ponte rolante e estocado para transporte até o canteiro 216

Figura 83: Exemplos de casas com projetos arquitetônicos padronizados da Tecverde. 217

Figura 84: Projeto da casa Vila do escritório Arquea construída em wood frame..... 217

Figura 85: Montagem da casa Vila com painéis pré-fabricados produzidos pela Tecverde. 218

Figura 86: Construção da casa Vila finalizada 218

Figura 87: Casas de alto padrão construídas pela empresa Tecverde 219

Figura 88: Composição da parede externa de áreas secas conforme dados do DATec 20 221

Figura 89: Protótipo de casa popular construída pela empresa Tecverde em Curitiba, Paraná ........ 222

Figura 90: Publicação do DATec no 20 para o sistema construtivo leve em madeira da Tecverde .... 224

Figura 91: Localização do residencial Haragano no município de Pelotas, RS

Figura 92: Protótipo construído em 2010 com sistema Morar Melhor 235

Figura 93: Resumo do processo para implementação do residencial Haragano... 238

Figura 94: Localização do residencial Haragano na zona urbana de Pelotas 238

Figura 95: Implantação do residencial Haragano 239

Figura 96: Vista geral do residencial Haragano 239

Figura 97: Áreas verdes e de lazer com estares, playground e quiosques com churrasqueira 239

Figura 98: Casa térrea (a) e sobrados geminados (b) 240

Figura 99: Planta baixa da habitação térrea 240

Figura 100: Planta baixa da habitação com dois pavimentos 
Figura 101: Composição das paredes do sistema Morar Melhor original..

Figura 102: Projeto do protótipo da habitação popular com sistema Morar Melhor original

Figura 103: Construção do protótipo da habitação popular com sistema Morar Melhor original ..... 243

Figura 104: Construções com o sistema Morar Melhor original nos municípios de Pelotas e Rio Grande, no Rio Grande do Sul 245

Figura 105: Protótipo do sistema Morar Melhor com algumas alterações de componentes 245

Figura 106: Modelo tridimensional da habitação térrea do residencial Haragano 246

Figura 107: Modelo tridimensional do sobrado do residencial Haragano 247

Figura 108: Camadas principais da fundação radier 248

Figura 109: Impermeabilização com tinta asfáltica sobre a laje da fundação, sob as paredes térreas 248

Figura 110: Peças constituintes do entramado da parede 249

Figura 111: Constituição generalizada das camadas dos painéis de parede 250

Figura 112: Constituição do painel térreo 01 do sobrado do residencial Haragano... 251

Figura 113: Constituição do painel térreo 02 do sobrado do residencial Haragano. 251

Figura 114: Constituição do painel térreo 03 do sobrado do residencial Haragano. 252

Figura 115: Constituição do painel térreo 04 do sobrado do residencial Haragano. 252

Figura 116: Constituição do painel térreo 05 do sobrado do residencial Haragano... 252

Figura 117: Constituição do painel térreo 06 do sobrado do residencial Haragano. 253

Figura 118: Principais estruturas dos painéis de parede do pavimento superior do sobrado............ 253

Figura 119: Composição dos painéis do entrepiso do sobrado. 254

Figura 120: Composição do subsistema de cobertura da UH da extremidade das geminações ......... 255

Figura 121: Localização dos principais fornecedores de insumos para o wood frame do Haragano . 258

Figura 122: Processo de produção da madeira serrada aplainada aplicada no wood frame 259

Figura 123: Localização da fábrica de componentes do sistema wood frame no bairro Laranjal, Pelotas 261

Figura 124: Planta da fábrica com layout e fluxos da produção dos elementos em wood frame ...... 262

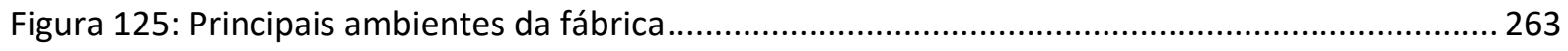

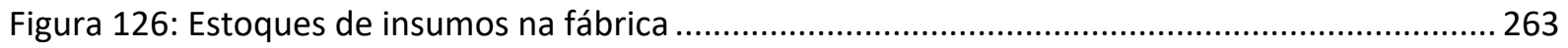

Figura 127: Conferência da qualidade das peças em madeira no início da produção ......................... 265

Figura 128: Carregamento da madeira até estação de corte.......................................................... 265

Figura 129: Estações de corte e furação das peças conforme projeto de produção ............................. 266

Figura 130: Bancadas de corte das chapas OSB e placas cimentícias ................................................ 266

Figura 131: Peças do entrepiso cortadas e montagem do painel .................................................... 267

Figura 132: Visão geral da mesa de montagem do painel de parede .............................................. 267 
Figura 133: Etapas da montagem do painel de parede

Figura 134: Ponte rolante e estoque de painéis de piso e de parede pré-fabricados

Figura 136: Limpeza da fábrica e separação dos resíduos para descarte

Figura 137: Fundação em radier impermeabilizada com tinta asfáltica

Figura 138: Painéis de parede abertos instalados sobre a fundação.

Figura 139: Cadeia de produção dos painéis de parede do sistema wood frame na fábrica e no canteiro

Figura 140: Placas cimentícias com junta aparente e acabamento com textura acrílica 274

Figura 141: Corte e fechamento das paredes com OSB e gesso acartonado

Figura 142: Vedação com gesso acartonado RU e instalação do azulejo cerâmico na cozinha

Figura 143: Instalação das janelas com folga na abertura do entramado 275

Figura 144: Montagem do painel do entrepiso sobre paredes térreas 276

Figura 145: Execução da cobertura com treliças metálicas pré-fabricadas e telhas cerâmicas 276

Figura 146: Instalações elétrica e hidrossanitária 277

Figura 147: Escada metálica e acabamentos finais de piso e de forro 277

Figura 148: Infraestrutura sendo executada em novembro de 2012 278

Figura 149: Sobrados geminados finalizados 278

Figura 149: Variações dos materiais externos do painel de parede da fachada 288

Figura 150: Produção de edificação no canteiro executada por construtores autônomos 289

Figura 151: Produção de painéis abertos na fábrica 290

Figura 152: Casa projetada e construída com painéis abertos em Erechim, Rio Grande do Sul 291

Figura 154: Produção de painéis fechados na fábrica da empresa Tetti em Capão Bonito, São Paulo 292

Figura 155: Produção de painéis fechados na fábrica da empresa Ecos Haus em Curitiba, Paraná... 293 Figura 156: Produção de painéis fechados na fábrica da empresa Tecverde em Araucária, Paraná . 294 Figura 156: Principais resultados da Comissão Casa Inteligente entre 2009 e 2013 299 

Tabela 1: Habitações populares em madeira construídas no Brasil entre 1943 e 2006 142

Tabela 2: Construção de protótipos de habitações populares em madeira no Brasil entre 1990 e 2006 143

Tabela 3: Pesquisas sobre wood frame no Brasil entre os anos de 1979 e 2010 153

Tabela 4: Publicações sobre wood frame em revistas da construção civil entre 2001 e 2008 158

Tabela 5: Orientações da GIDUR/PO para o financiamento de construções convencionais em madeira 165

Tabela 6: Variação cambial nominal do real em relação ao dólar em 2008 171

Tabela 7: Proposta da Comissão Casa Inteligente para a qualificação profissional em wood frame 193

Tabela 8: Divulgação do wood frame em revistas do setor da construção entre 2009 e 2013 196

Tabela 9: Palestras sobre o sistema wood frame em eventos gerais entre os anos de 2009 e 2012. 197

Tabela 10: Exemplo de requisitos para controle de qualidade dos principais materiais constituintes do sistema wood frame conforme Diretriz SINAT 005 de 2011 207

Tabela 11: Instituições de pesquisa e ensaios técnicos realizados para obtenção do DATec 20 223

Tabela 12: Empreendimentos, construtoras e unidades habitacionais na Faixa 1 - FAR do PMCMV em Pelotas 230

Tabela 13: Unidades habitacionais contratadas e concluídas nas Faixas 2 e 3 do PMCMV em Pelotas 230

Tabela 14: Principais diferenças entres os sistemas Morar Melhor e Morar Melhor Aprimorado .... 256

Tabela 15: Elementos do Res. Haragano produzidos na fábrica e no canteiro 260

Tabela 16: Meta de produção para a fabricação das UHs do Residencial Haragano. 269

Tabela 17: Exemplos de manutenções periódicas descritas no Manual do Usuário do Haragano .... 282

Tabela 18: Empresas brasileiras que atuam com wood frame em 2016 286

Tabela 19: Habitações construídas com wood frame no PMCMV desde 2012 a 2015 297

Tabela 20: Participantes da segunda fase de atividades da Comissão Casa Inteligente em 2014 ..... 300

Tabela 21: Palestras sobre o wood frame em eventos entre 2014 e 2016. 301

Tabela 22: Divulgação do wood frame em revistas do setor da construção entre 2013 e 2016. 302

Tabela 23: Participantes da reunião da Comissão Casa Inteligente em julho de 2015 304 

Gráfico 1: Quantidade de residências brasileiras conforme material da parede externa .................... 39

Gráfico 2: Porcentagem de residências em madeira por regiões brasileiras...................................... 39

Gráfico 3: Variação cambial do real em relação ao dólar americano desde 1991 até 2015 ............... 171

Gráfico 4: Variação cambial nominal do real em relação ao dólar nos meses de 2008 ..................... 171

Gráfico 5: Consumo de toras pelos principais segmentos madeireiros em 2008.............................. 175

Gráfico 6: Consumo de toras de pinus pelos principais segmentos de produtos florestais em 2008175

Gráfico 7: Produção e exportação brasileira de madeira serrada de coníferas comparadas ao volume importado pelos EUA nos períodos de 1992 a 2014 ...................................................................... 178

Gráfico 8: Consumo de toras de madeira de floresta plantada pelos principais segmentos madeireiros 



\section{LISTA DE SIGLAS}

\begin{tabular}{|c|c|}
\hline AF\&PA & American Forest \& Paper Association \\
\hline AWC & American Wood Council \\
\hline ASHSB & Architect's Small House Service Bureau \\
\hline CCA & Arseniato de Cobre Cromatado \\
\hline $\mathrm{ABIMCl}$ & Associação Brasileira da Indústria de Madeira Processada Mecanicamente \\
\hline ABRAMAT & Associação Brasileira da Indústria de Materiais de Construção \\
\hline ABNT & Associação Brasileira de Normas Técnicas \\
\hline ABRAF & Associação Brasileira de Produtores de Florestas Plantadas \\
\hline DRYWALL & Associação Brasileira do Drywall \\
\hline AsBEA-PR & Associação Brasileira dos Escritórios de Arquitetura do Paraná \\
\hline APRE & Associação Paranaense de Empresas de Base Florestal \\
\hline BNH & Banco Nacional da Habitação \\
\hline BNDES & Banco Nacional do Desenvolvimento \\
\hline CCB & Borato de Cobre Cromatado \\
\hline $\mathrm{BCIT}$ & British Columbia Institute of Technology \\
\hline CEF & Caixa Econômica Federal \\
\hline CBIC & Câmara Brasileira da Indústria da Construção \\
\hline CWC & Canadian Wood Council \\
\hline CETHAC & $\begin{array}{l}\text { Centro de Estudos e Pesquisas para a Racionalização da Habitação, da } \\
\text { Construção e do Desenvolvimento Urbano }\end{array}$ \\
\hline CEFET/Pelotas & Centro Federal de Educação Tecnológica de Pelotas \\
\hline CETEC - Lins & Centro Tecnológico - Fundação Paulista de Tecnologia e Educação \\
\hline CNC & Comando Numérico Computadorizado \\
\hline CURSAN & Companhia Cubatense de Urbanização e Saneamento \\
\hline $\mathrm{COHAB}$ & Companhias de Habitação do Estado \\
\hline CCFGTS & Conselho Curador do Fundo de Garantia do Tempo de Serviço \\
\hline CREA & Conselho Regional de Engenharia e Agronomia \\
\hline CUB & Custo Unitário Básico \\
\hline DECONCIC & Departamento da Indústria da Construção \\
\hline DOU & Diário Oficial da União \\
\hline DATec & Documento de Avaliação Técnica \\
\hline EGP & Edge Glued Panels \\
\hline EBRAMEM & Encontro Brasileiro em Madeiras e em Estruturas de Madeira \\
\hline EESC/USP & Escola de Engenharia de São Carlos \\
\hline FIESP & Federação das Indústrias do Estado de São Paulo \\
\hline FIEP & Federação das Indústrias do Estado do Paraná \\
\hline FINEP & Financiadora de Estudos e Projetos \\
\hline FPL & Forest Products Laboratory \\
\hline CIENTEC & Fundação de Ciência e Tecnologia \\
\hline CIENTEC & Fundação de Ciência e Tecnologia \\
\hline FUPEF & Fundação de Pesquisas Florestais do Paraná \\
\hline FJP & Fundação João Pinheiro \\
\hline
\end{tabular}




\begin{tabular}{|c|c|}
\hline FAR & Fundo de Arrendamento Residencial \\
\hline GIDUR/PO & Gerência de Desenvolvimento Urbano da CEF de Porto Alegre \\
\hline GHAB & Grupo de Estudos da Habitação \\
\hline HABIS & Grupo de Pesquisa em Habitação e Sustentabilidade \\
\hline LIGNO & Grupo Desenvolvimento de Produtos Lignocelulósicos \\
\hline GIEM & Grupo Interdisciplinar de Estudos da Madeira \\
\hline ITA & Instituição Técnica Avaliadora \\
\hline IBGE & Instituto Brasileiro de Geografia e Estatística \\
\hline INTEC/PUC & Instituto de Pesquisa e Assessoria Tecnológica da PUC \\
\hline IPT & Instituto de Pesquisa Tecnológica \\
\hline ITEP & Instituto de Tecnologia de Pernambuco \\
\hline INTEC & Instituto de Tecnologia do Paraná \\
\hline LACTEC & Instituto de Tecnologia para o Desenvolvimento \\
\hline IFBQ & Instituto Falcão Bauer da Qualidade \\
\hline IBC & International Building Code \\
\hline IRC & International Residential Code \\
\hline LENC & Laboratório de Engenharia e Consultoria Ltda \\
\hline LaMEM & Laboratório de Madeiras e Estruturas de Madeiras \\
\hline LVL & Laminated Veneer Lumber \\
\hline MPSConst & Métodos, Processos e Sistemas Construtivos \\
\hline MCidades & Ministério das Cidades \\
\hline NAHB & National Association of Home Builders \\
\hline NORIE & Núcleo Orientado para a Inovação da Edificação \\
\hline OCDE & Organização para Cooperação e Desenvolvimento Econômico \\
\hline OSB & Oriented Strand Board \\
\hline$P \& D$ & Pesquisa e desenvolvimento \\
\hline $\mathrm{PNH}$ & Plano Nacional de Habitação \\
\hline PMVA & Produto de Maior Valor Agregado \\
\hline PBQP-H & Programa Brasileiro da Qualidade e Produtividade do Habitat \\
\hline QUALIHAB & Programa da Qualidade da Construção Habitacional do Estado de São Paulo \\
\hline PROTECH & $\begin{array}{l}\text { Programa de Difusão de Tecnologia para a Construção de Habitação de Baixo } \\
\text { Custo }\end{array}$ \\
\hline HABITARE & Programa de Tecnologia de Habitação \\
\hline PMCMV & Programa Minha Casa Minha Vida \\
\hline PRONATH & Programa Nacional de Habitação \\
\hline PIT & Projeto Inovação Tecnológica na Construção \\
\hline RTA & Relatório Técnico de Avaliação \\
\hline $\mathrm{RU}$ & Resistente à Umidade \\
\hline SJSS & Secretaria de Justiça Social e Segurança \\
\hline SNH & Secretaria Nacional da Habitação \\
\hline SENAI-PR & Serviço Nacional de Aprendizagem Industrial do Estado do Paraná \\
\hline SINDUSCON & Sindicato da Indústria da Construção Civil \\
\hline SIMADI & Sindicato da Indústria da Madeira de Imbituva \\
\hline SFH & Sistema Financeiro da Habitação \\
\hline SINAT & Sistema Nacional de Avaliações Técnicas \\
\hline
\end{tabular}




\begin{tabular}{|l|l|}
\hline SPA & Southern Pine Association \\
\hline ST & Standard \\
\hline CA-B & Tebuconazole e Cobre \\
\hline TECOMAT & Tecnologia da Construção e Materiais Ltda \\
\hline TESIS & Tecnologia de Sistemas em Engenharia Ltda \\
\hline APA & The Engineered Wood Association \\
\hline UHs & Unidades Habitacionais \\
\hline USDA & United States Department of Agriculture \\
\hline UCPel & Universidade Católica de Pelotas \\
\hline UNU & Universidade das Nações Unidas \\
\hline USP & Universidade de São Paulo \\
\hline UNISINOS & Universidade do Vale do Rio dos Sinos \\
\hline UEL & Universidade Estadual de Londrina \\
\hline UNESP & Universidade Estadual Paulista Júlio de Mesquita \\
\hline UFPel & Universidade Federal de Pelotas \\
\hline UFSC & Universidade Federal de Santa Catarina \\
\hline UFSM & Universidade Federal de Santa Maria \\
\hline UFSCar & Universidade Federal de São Carlos \\
\hline UFPA & Universidade Federal do Pará \\
\hline UFPR & Universidade Federal do Paraná \\
\hline FURG & Universidade Federal do Rio Grande \\
\hline UTFPR & Universidade Tecnológica Federal do Paraná \\
\hline WWPA & Western Wood Products Association \\
\hline WFCM & Wood Frame Construction Manual \\
\hline & \\
\hline
\end{tabular}



INTRODUÇÃO

1 PROCESSO DE INOVAÇÃO - MUDANÇAS TÉCNICAS NA PRODUÇÃO...............................53

1.1 Mudanças no processo de produção para o desenvolvimento econômico...............53

1.2 Caracterização das "novas combinações" de produção............................................58

1.3 Determinação de necessidades para seleção da inovação ......................................61

1.4 Procedimentos para o desenvolvimento de inovação tecnológica............................65

1.5 Agentes determinantes no processo de inovação ..................................................68

2 O PROCESSO DE INOVAÇÃO TECNOLÓGICA NA CONSTRUÇÃO CIVIL ..........................75

2.1 Caracterização da inovação na cadeia da construção civil .................................... 75

2.2 Etapas no desenvolvimento de produtos e processos inovadores ...........................81

2.3 Agentes no processo de inovação da construção do Brasil...................................... 85

2.4 Determinação das necessidades e dos paradigmas tecnológicos na construção ....88

2.5 SINAT: política pública para a implantação de inovação tecnológica na produção de

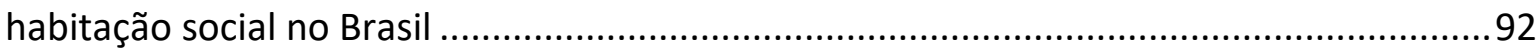

3 REFERÊNCIAS GERAIS SOBRE O SISTEMA CONSTRUTIVO WOOD FRAME ....................99

3.1 Histórico dos sistemas leves estruturados em madeira ............................................99

3.2 Propagação do light wood frame no território norte-americano ............................108

3.2.1 Agro industrialização e mecanização da produção ......................................... 109

3.2.2 Centro de distribuição de madeira processada mecanicamente......................111

3.2.3 Expansão territorial e crescimento populacional na região centro-oeste ........112

3.2.4 Padronizações de produtos e manuais técnicos para construção ....................114

3.3 Principais detalhes técnico construtivos ..........................................................117

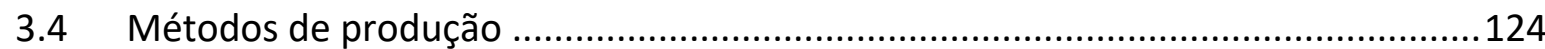




\section{PRIMEIRO PERÍODO DE PRODUÇÃO DO WOOD FRAME NO BRASIL - ENTRE AS DÉCADAS}

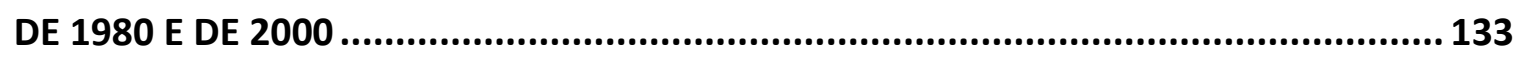

4.1 Sistemas construtivos em madeira populares no Brasil .................................... 133

4.2 Edificações construídas com wood frame no Brasil desde meados de 1980 até o início

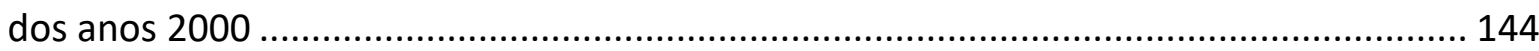

4.3 Principais pesquisas acadêmicas e publicações sobre o wood frame no Brasil até o início de 2010 152

4.4 O contexto do século XX para a difusão das construções em madeira no Brasil ... 159

5 AÇÕES PARA O DESENVOLVIMENTO DO WOOD FRAME NO BRASIL A PARTIR DO ANO DE 2010 169

5.1 Motivações para a transformação do setor de construções em madeira ............... 169

5.1.1 Contexto econômico - crise mundial de 2008 ............................................... 169

5.1.2 Situação do setor florestal brasileiro frente ao contexto econômico .............. 172

5.1.3 Lançamento do PMCMV aliado ao SINAT .................................................... 179

5.1.4 Parceria entre SENAI-PR e Estado Alemão para transferência de tecnologia. 180

5.2 Agentes na promoção do wood frame no Brasil: Comissão Casa Inteligente ......... 182

5.3 Estratégias da Comissão Casa Inteligente para implementar o wood frame .......... 188

5.4 Resultados gerais das ações conjuntas da Comissão Casa Inteligente ................... 195

5.4.1 Divulgação do sistema construtivo wood frame no Brasil.............................. 195

5.4.2 Primeiras construções referências executadas por integrantes da Comissão e

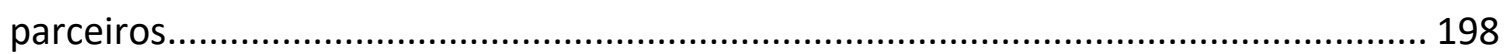

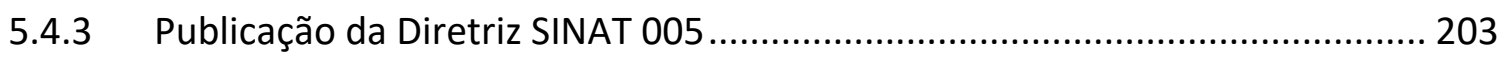

5.5 Consolidação empresarial: o caso da empresa Tecverde ................................... 209

6 RESIDENCIAL HARAGANO - INTRODUÇÃO DO WOOD FRAME NO PROGRAMA MINHA

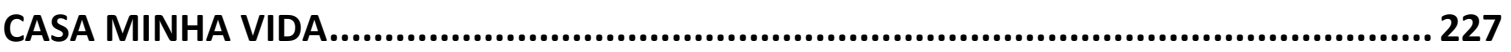

6.1 Agentes da produção no processo de implementação do Haragano ...................... 231

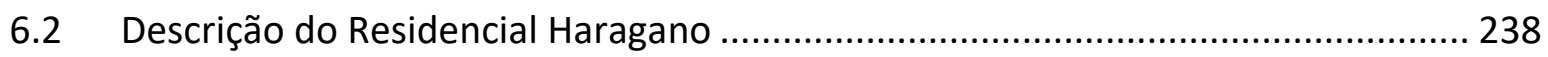


6.3 Sistema construtivo das habitações sociais do Haragano

6.3.1 Sistema construtivo Morar Melhor .............................................................. 241

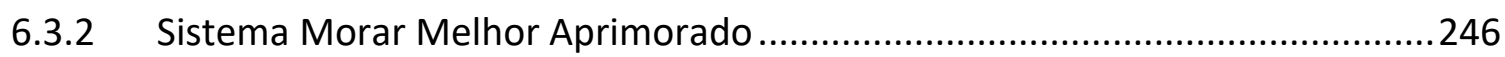

6.4 Produção das habitações em wood frame na fábrica e no canteiro ........................257

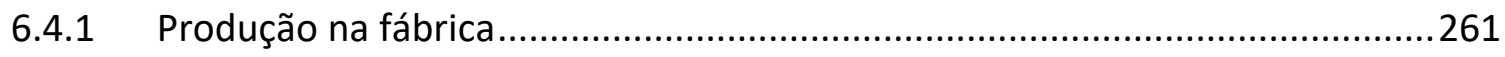

6.4.2 Produção e montagem no canteiro-de-obras ................................................2 272

6.5 Orientações sobre o sistema inovador para os moradores do residencial ..............281

6.6 Avaliação pós-ocupação e ajustes técnicos realizados..........................................283

7 DIFUSÃO DO SISTEMA WOOD FRAME NO BRASIL APÓS A PUBLICAÇÃO DA DIRETRIZ

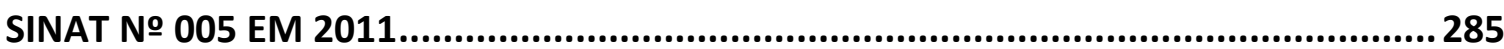

7.1 Caracterização da produção do wood frame no Brasil após 2011 ...........................285

7.2 Produção de habitações em wood frame após a diretriz sinat № 005/2011 ..........295

7.3 Novas articulações da Comissão Casa Inteligente após 2013 .................................299

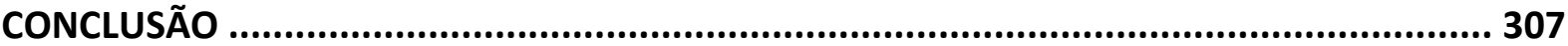

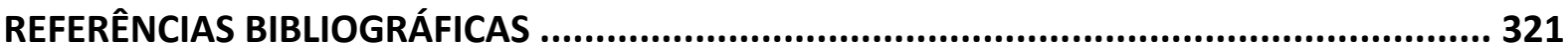


A inovação passa a ser o mais importante componente das estratégias de desenvolvimento (CASSIOLATO; LASTRES, 2005, p. 37).

A inovação, conforme será delineada neste trabalho, está associada conceitualmente a transformações no processo produtivo. Estas mudanças tecnológicas estão fortemente vinculadas ao desenvolvimento econômico de uma sociedade. Tal atribuição entre inovação e desenvolvimento tem como base importantes teorias econômicas pioneiras. Inicialmente, Adam Smith (1996) discorreu sobre como as transformações nos modos de produção, que aprofundam a divisão de trabalho e aumentam a produtividade, tais como a manufatura, afetam a atividade econômica.

Mas, "é com Karl Marx e, posteriormente, com Joseph Schumpeter, que as inovações tecnológicas ganhariam o status de epicentro da transformação econômica capitalista". Ambos filósofos se dedicaram em analisar o funcionamento do sistema capitalista. Nestas análises, incluíram perspectivas sobre a dinâmica do processo produtivo centrado no avanço tecnológico como mecanismo para obtenção de lucro e acúmulo de capital. Nas suas observações, o progresso tecnológico é central, porém não é o único determinante nas transformações do sistema (MARX, 2002; SCHUMPETER, 1961, 1982; PEREIRA; LOPES, 2015, p. 1, 3).

No entanto, ressalta-se que, Marx e Schumpeter apresentaram visões diferenciadas sobre este sistema capitalista. Enquanto Marx elaborou uma crítica, Schumpeter ressaltou, na maior parte de seus trabalhos publicados, a importância dos efeitos das inovações no comportamento dinâmico, na evolução do capitalismo. Entretanto, apesar de certas diferenças conceituais ${ }^{1}$, Schumpeter apresentou os pensamentos de Marx como influência nos seus estudos (MARX, 2002; SCHUMPETER, 1961; PEREIRA; LOPES, 2015).

Por exemplo, na visão schumpeteriana², o progresso técnico é movido pelo "desejo" do lucro. Para o autor, "a inovação representa uma redução do custo produtivo [poupança de trabalho em Marx], fundamental para a obtenção de lucro em um cenário concorrencial" (PEREIRA; LOPES, 2015, p. 4). Tanto para Schumpeter como para Marx, a tecnologia é tida

\footnotetext{
${ }^{1}$ O próprio economista e filósofo Joseph Schumpeter elabora seu posicionamento, ora em concordância, ora em crítica, sobre o trabalho de Karl Marx. Para aprofundar este tema, ver SCHUMPETER, 1961.

${ }^{2}$ Ou seja, na visão desenvolvida por Schumpeter.
} 
como mecanismo para acumulação de riqueza. Nas colocações de ambos autores, a concentração de capital é tanto um objetivo como um resultado da dinâmica de inovação.

[...] além disso, tanto para Marx como para Schumpeter, a inovação é fruto de um processo social. A inovação não possui caráter neutro ou mesmo natural, pois é resultante de um processo intencional, movido por objetivos concretos (PEREIRA; LOPES, 2015, p. 4).

Ter essa noção da inovação como resultante de um processo social, movido por agentes e necessidades selecionadas, é imprescindível para compreender como ocorre esse processo. Conforme colocam Cassiolato e Lastres (2005, p. 38), as mudanças tecnológicas “afetam e também são afetadas pela estrutura produtiva, social, política e institucional de cada nação, sendo que cada uma delas apresenta suas especificidades".

Portanto, além de técnica e material, a tecnologia é social e, por isso, "não se limita a uma questão de engenharia produtiva" (PEREIRA; LOPES, 2015, p. 5). O processo de desenvolvimento de novas tecnologias não está restrito às etapas científicas focadas no produto. Por ser um processo social, a tecnologia é fundamentalmente dependente de condições econômicas e políticas, incluindo intenções e interesses dos envolvidos. Sob este aspecto, é importante destacar o conceito de tecnologia:

[...] a tecnologia é compreendida como o processo social no qual a técnica em si (isto é, o aparato técnico da indústria, dos transportes e da comunicação) representa apenas um fator entre outros. [...]

A tecnologia como modo de produção, como totalidade de instrumentos, dispositivos e invenções que caracterizam a era das máquinas é assim ao mesmo tempo um modo de organizar e perpetuar (ou mudar) relações sociais, uma manifestação de padrões de pensamento e comportamento dominantes, um instrumento de controle e dominação (MARCUSE, 1997, p. 113).

Há intenções e interesses por trás das decisões tecnológicas, pois "o poder tecnológico leva à concentração do poder econômico". Nesse sentido, o aparato produtivo - "as instituições, os dispositivos, as organizações da indústria na sua situação social predominante" - assume a direção da tecnologia, pois esta passa a ser um instrumento de dominação do sistema. É diferente de uma dominação física, opressora e exploradora; a tecnologia assume um novo caráter de dominação: o racional. "Esta racionalidade estabelece padrões de julgamento e promove atitudes que tornam os homens prontos a aceitar e até introjetar os ditames do aparato" (MARCUSE, 1997, p. 116 nota, 117). Ou seja, as necessidades de novas tecnologias são subjetivamente impostas pelo interesse deste aparato produtivo, e o sistema 
passa a assumir estas necessidades como se fossem suas, incluindo a ciência, enquanto possível criadora e desenvolvedora deste produto, e os consumidores finais.

Assim, a tecnologia passa a ser um instrumento útil, dirigido por interessados que influenciam as decisões sobre o processo produtivo. Conforme afirma Vianna (1989, p. 39), “a tecnologia está comprometida com a estrutura de poder, na medida em que é, ao mesmo tempo, instrumento e justificativa". Dessa forma, os padrões das mudanças tecnológicas são diretamente selecionados pelo aparato. Portanto, a necessidade de invenção iguala-se à necessidade incondicional de manter e expandir esse aparato. Mediante esse mecanismo racional e instrumental, a inovação passa a atuar a serviço dos negócios e não da indústria. Todos se submetem para alimentar o aparato (MARCUSE, 1997).

Nesse sentido, o processo e a efetivação das mudanças tecnológicas enfrentam limites e resistências de acordo com o ambiente em que se insere. O autor Dosi (1984 apud Castro, 1999, p. 25), referindo-se aos fatores e atores que afetam as possibilidades dessas mudanças, amplia esta explanação: "As condições de surgimento de uma inovação têm limites conjunturais e sofrem resistência de acordo com os interesses que venham a contrariar".

Para que os eventos técnicos ocorram há uma relação entre um conjunto de fatores. Além da conjuntura econômica somada ou regida pela ação política, destaca-se o grau de interesse de envolvidos, incluindo pesquisadores científicos, agentes promotores, financiadores públicos ou privados, indústria de insumos, construtoras e, por fim, caso tal mudança atinja o mercado, clientes. Pelli (1989 apud CASTRO, 1999) confirma que o processo de alterações da condição tecnológica faz parte de uma "uma estratégia tecnológica condicionadora das características dos produtos, materiais, procedimentos e interesses desenvolvidos por grupos e instituições envolvidas na atividade".

Portanto, compreender esses fatores condicionadores e tentar incluí-los nas análises de processos de inovação é importante para tentar esboçar o motivo pelo qual determinadas soluções técnicas são selecionadas em certos contextos históricos, inclusive na indústria da construção civil. Sob este critério, esta tese propõe analisar o processo de inovação, inicialmente, num quadro geral da construção civil e, posteriormente, no caso específico da implantação do sistema construtivo em madeira denominado wood frame, considerado inovador para o contexto brasileiro.

Apesar da significância econômica da indústria da construção, há uma percepção de que este setor absorve de forma lenta a difusão de inovações e suas empresas são 
conservadoras neste aspecto (MIOZZO; DEWICK, 2004). Por exemplo, ao longo de seu histórico, o Brasil apresenta pouca variação de serviços, sistemas e métodos de construção no seu mercado. Nesse contexto, algumas transformações técnicas são implementadas enquanto outras são impedidas. Mesmo que muitas pesquisas científicas proponham novas tecnologias que visam o desenvolvimento deste setor, poucas destas são efetivamente implementadas pela indústria.

Para compreender este fator, a área da construção carece de estudos que analisam a ocorrência do processo da inovação considerando seu sistema constituinte. Em geral, é natural assumir a empresa e/ou a ciência como entidades únicas na inovação e, por isso, os estudos desconsideram a rede de agentes que atua e influencia neste processo.

De fato, há uma importante articulação que deve ser analisada, abrangendo a atuação do estado, da cadeia de produção e das instituições de ensino e pesquisa em determinado contexto social. Esta articulação influencia e dirige este processo de produção, incluindo a seleção das tecnologias aplicadas no mercado.

Mas, esta questão sobre a seletividade das inovações raramente é esboçada por pesquisadores da área. Alguns autores procuraram apontar o contexto e as motivações que impediram a efetivação de transformações técnicas na construção brasileira, como a industrialização (VARGAS, 1979; BRUNA, 1976; FARAH, 1996; MARICATO, 1983). Outros, como Castro (1999) e Rezende (2003) abordaram especificamente o tema da inovação tecnológica na construção esboçando alguns aspectos da visão da teoria econômica sobre este processo.

Entretanto, desde então, as pesquisas sobre inovação da construção, geralmente, têm como enfoque o bem/produto final e sua materialidade. Por isso, este trabalho visa demonstrar que, além da importância dos aspectos técnicos, a efetivação de uma inovação depende essencialmente de ações articuladas entre agentes que integram este contexto social. Para realizar esta análise, é necessário compreender como ocorre o processo da inovação tecnológica sob uma visão sistêmica, delineando os agentes articuladores e as necessidades elencadas para a implementação das mudanças. Ter tal visão sistêmica do processo auxilia na compreensão de que os padrões de bens e serviços ofertados são influenciados e regulados por arranjos institucionais, por mecanismos de coordenação econômica (MIOZZO; DEWICK, 2004).

E, para aprofundar esta análise, esta tese terá como foco principal um caso específico de inovação tecnológica no setor de construção em madeira. Desde o ano de 2009, este setor 
vem se mobilizando para transformar e incrementar sua produção, em especial, com o engajamento para introduzir o sistema construtivo wood frame no Brasil.

Conforme será delineado no decorrer deste trabalho, o wood frame não é original e tradicional do Brasil, e, por isso, é considerado inovador neste território. Estes sistemas com entramados leves em madeira são comumente aplicados em países norte-americanos (Figura 1), escandinavos e centro-europeus. Nestes locais, sua propagação efetiva é motivada por vantagens apresentadas em seus diferentes métodos de construção, os quais implicam em técnicas racionalizadas, rapidez na execução e pouca mão-de-obra envolvida. O contínuo desenvolvimento tecnológico sobre este sistema vem incrementando seu modo de produção em níveis mais industrializados e reajustando sua composição com materiais adequados aos critérios de desempenho das edificações, tais como confortos térmico e acústico,

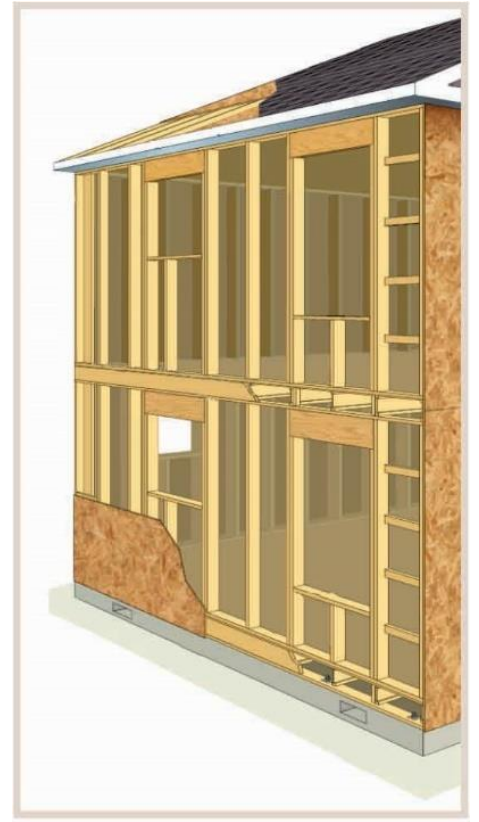

Figura 1: Exemplo de edificação em wood frame nos países norte-americanos Fonte: adaptado de APA, 2012. eficiência energética, entre outros.

Porém, em contrapartida, no Brasil, apesar do seu potencial florestal, as tecnologias construtivas em madeira permaneceram estagnadas por um longo período. Mas ocorreram exceções. Mesmo que poucos, alguns períodos históricos foram marcantes para a cultura brasileira de construção em madeira. Por exemplo, inicialmente, na origem do território, as construções indígenas, sem influências de colonizadores externos, foram representativas com estruturas artesanais em madeira. Na sequência, os colonizadores portugueses trouxeram suas experiências e influências, tais como a estrutura denominada gaiola pombalina, e adaptaram-nas na construção da colônia brasileira. Mais à frente, na primeira metade do século XX, em especial nas regiões sul e sudeste, os imigrantes centro-europeus e japoneses produziram suas habitações em madeira desenvolvendo técnicas a partir de seu conhecimento prévio deste material. No entanto, com o tempo, esta cultura local se perdeu nas diversas regiões do país.

Desde então, no histórico geral do Brasil, a indústria da construção em madeira foi pouco disseminada e apresentou poucas transformações tecnológicas. Desde a segunda 
metade do século XX, os sistemas construtivos comerciais em madeira predominantes podem ser resumidos em dois: primeiro, tábuas e mata-juntas e, segundo, tábuas horizontais empilhadas e encaixadas em montantes ${ }^{3}$.

Ainda, neste histórico, observa-se que a percepção popular quanto às construções em madeira no Brasil é geralmente negativa. Está cercada por conceitos concebidos a partir de más técnicas aplicadas. Isto deve-se a fatores como: profissionais, como engenheiros e arquitetos, que desconhecem as propriedades da madeira; ausência de projeto com detalhes apropriados para elementos em madeira; desinformação sobre a seleção das espécies para determinados usos; erros na execução por falta de capacitação da mão-de-obra; e baixo desenvolvimento tecnológico dos produtos ofertados (BITTENCOURT, 1995)

Com isso, em meados das décadas de 1970 e 1990, a participação de pesquisadores científicos com intuito de aprimorar a utilização da madeira para a construção foi intensificada nas universidades. Entre estas pesquisas, pode-se relatar trabalhos referentes a estruturas e características físico-mecânicas da madeira (HELLMEISTER, 1971; LAHR, 1983), projeto arquitetônico de habitações em madeira (BITTENCOURT, 1995), durabilidade destas construções (BENEVENTE, 1995), utilização de espécie de florestas plantadas para edificações racionalizadas (INO, 1991). Mas, grande parte das pesquisas específicas sobre o aprimoramento de sistemas e componentes construtivos não foi aplicada pela indústria de construções em madeira. O setor permaneceu com as mesmas condições tecnológicas e a disseminação entre a população brasileira continuou pequena.

Os dados do censo demográfico publicado pelo Instituto Brasileiro de Geografia e Estatística (IBGE, 2010) demonstram valores que comprovam a baixa aplicação das construções em madeira entre a população. Tal classificação foi elaborada conforme o material utilizado para as paredes externas das residências, o qual variava entre durável ou não-durável. Dentre os materiais duráveis foram destacados: alvenaria, taipa revestida e madeira aparelhada4; e, os materiais não-duráveis eram: taipa não revestida, madeira aproveitada ${ }^{4}$, palha ou similares.

\footnotetext{
${ }^{3}$ Este último sistema construtivo também é popularmente reconhecido como "Casema" - nome da empresa que teve grande participação na execução de construções com kits pré-fabricados em madeira.

${ }^{4}$ Observa-se que são considerados dois tipos de paredes externas em madeira: aproveitada e aparelhada. Nesta definição, madeira aparelhada refere-se àquela "preparada" para a construção, provavelmente, trata-se de peças beneficiadas. E, a madeira aproveitada é aquela proveniente de embalagens, tapumes, andaimes e outros, talvez, referindo-se ao reaproveitamento de pallets e chapas compostas de madeira (IBGE, 2010).
} 
Sob este critério de dados, conforme o IBGE (2010), dentre um total de aproximadamente 57,5 milhões de edificações destinadas à moradia, apenas $7 \%$ são construídas em madeira, enquanto 90\% são em alvenaria, conforme demonstra o Gráfico 1. Sendo que esta pequena porcentagem de habitações em madeira concentra-se, especialmente, nas regiões sul e norte do país que totalizam $86 \%$ das edificações em madeira, conforme indica o Gráfico 2. Observa-se nestes dados um quadro negativo que identificou a utilização pontual de construções em madeira em meio a uma tradição firmada em edificações estruturadas em concreto e vedadas em alvenaria.

Gráfico 1: Quantidade de residências brasileiras conforme material da parede externa

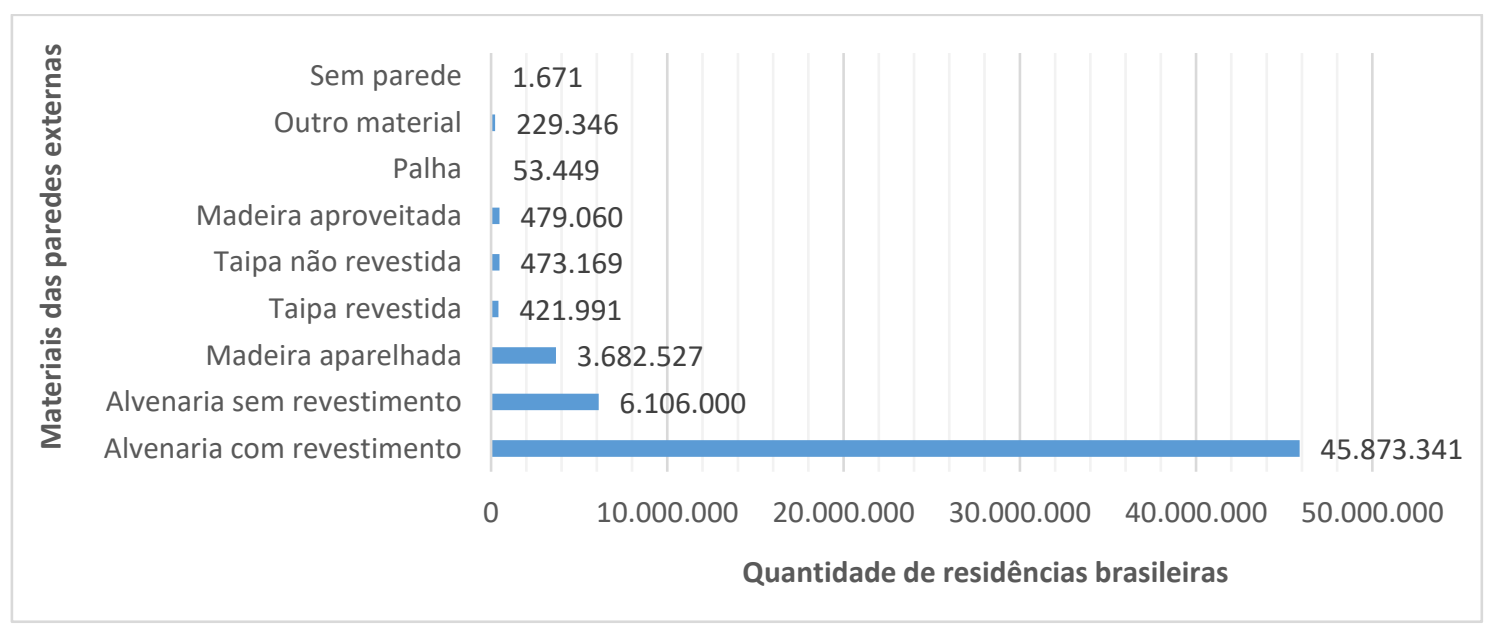

Fonte: autora conforme dados do IBGE, 2010.

Gráfico 2: Porcentagem de residências em madeira por regiões brasileiras

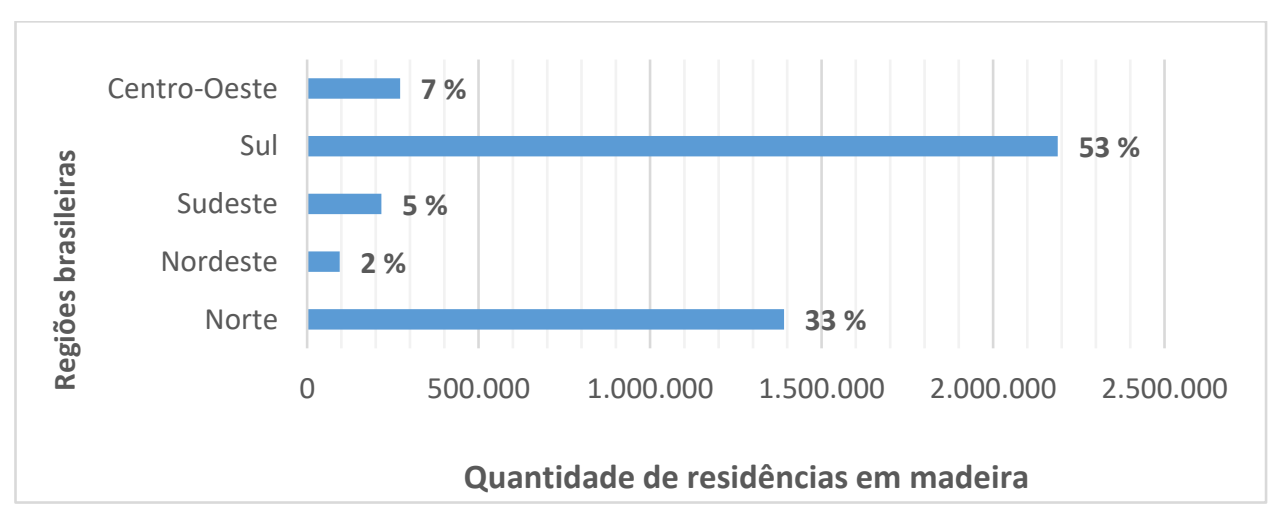

Fonte: autora conforme dados do IBGE, 2010.

Com intuito de alterar este cenário, além das pesquisas científicas anteriores citadas, outros estudos acadêmicos desenvolveram avaliações e propostas sobre os sistemas construtivos leves em madeira, incluindo o wood frame. Seus resultados, em geral, 
identificaram potencialidades de viabilização destes sistemas leves no contexto brasileiro, tais como disponibilidade de madeira proveniente de florestas plantadas e construção racionalizada com menor tempo e custo de produção. No entanto, até o ano 2009, apesar das vantagens técnicas apresentadas, a disseminação destas tecnologias no Brasil ocorria em eventos pontuais com construções isoladas.

Mas, desde o ano de 2010, vem ocorrendo uma alteração significativa neste cenário. Neste período, um grupo atuante da indústria madeireira e do setor de construção organizouse na denominada Comissão Casa Inteligente com intuito de promover a aplicação do sistema wood frame no país. Para isto, seus integrantes definiram suas necessidades de produção e articularam ações para efetivar esta difusão. E, logo, este grupo obteve importantes resultados, como as publicações de documentos técnicos específicos sobre wood frame no Brasil, sendo estes aprovados oficialmente pelo Ministério das Cidades (MCidades), no âmbito da Secretaria Nacional da Habitação (SNH), do Programa Brasileiro da Qualidade e Produtividade do Habitat (PBQP-H) e do Sistema Nacional de Avaliações Técnicas (SINAT) (Brasil, 2011, 2013). Outro resultado importante foi a inserção deste sistema inovador em madeira no programa de habitação social Minha Casa Minha Vida (PMCMV), com a execução do primeiro conjunto habitacional - Residencial Haragano -, financiado pela Caixa Econômica Federal (CEF).

Desde então, novas empresas construtoras passaram a atuar com este sistema inovador em madeira, estimulando a produção com wood frame no país. Por exemplo, uma destas empresas, desde sua abertura em 2009 até o ano de 2016, estimou ter construído, aproximadamente, $85.000 \mathrm{~m}^{2}$ com wood frame. Sendo assim, mesmo que em fase inicial, acredita-se que esta produção vem proporcionando desenvolvimento tecnológico ao setor de construção em madeira do país.

Entretanto, ao observar esta transformação específica no setor de construção em madeira, questiona-se por que e como ocorreu este processo de inovação, sendo que nos períodos anteriores este setor estava praticamente estagnado tecnologicamente. Para obter essas respostas, é necessário avaliar este processo de produção sob uma visão sistêmica, considerando os agentes atuantes, as articulações entre os mesmos, suas motivações, os fatores facilitadores, as dificuldades enfrentadas e os resultados obtidos.

Esta análise sistêmica é importante para compreender o fenômeno da seletividade de determinada tecnologia implementada em um mercado. Em geral, no histórico brasileiro das 
construções, algumas mudanças técnicas ocorrem enquanto outras são impedidas. Portanto, surgem questões sobre por que e como ocorrem estes processos de inovação neste setor. Sendo assim, esta pesquisa se propõe a investigar, interpretar e explicar os motivos e as relações dinâmicas que interferem nesses cenários, como o caso específico da implementação do sistema construtivo inovador wood frame no Brasil a partir do ano de 2010. Esta análise visa contribuir para o contexto geral da construção civil e, principalmente, para o setor das construções em madeira, com intuito de ampliar as investigações sobre a disseminação deste e outros sistemas inovadores no país.

\section{QUESTÕES E HIPÓTESE}

Com base neste breve contexto apontado anteriormente, este trabalho tem como proposta responder as seguintes questões de pesquisa:

\section{Questão geral:}

- Como o sistema inovador em madeira wood frame foi inserido em programa nacional de habitação social financiado por agentes públicos?

\section{Questões específicas:}

- O que motivou a transformação tecnológica no setor de construção em madeira nesse período específico?

- Quais agentes participaram nessa conjuntura para promover a aplicação nacional do wood frame e quais foram suas estratégias estabelecidas para este fim?

- Como ocorreram os processos de regulamentação do sistema inovador wood frame no SINAT e de viabilização do financiamento pela CEF para o PMCMV?

- Que resultados foram alcançados nesse processo de inovação tecnológica após a publicação da Diretriz SINAT no 005 / 2011?

\section{Hipóteses:}

A crise econômica mundial em 2008 reduziu as exportações do setor de produtos florestais no Brasil e propiciou a aplicação desta matéria-prima excedente no mercado 
nacional. Assim, este setor passou a visar as possibilidades de direcionar esta madeira para a indústria da construção civil tendo em vista a abertura do PMCMV em 2009, o qual aumentaria a produção de habitação no país e consumo de insumos. Entretanto, a introdução do wood frame neste programa habitacional somente foi possível com a articulação entre agentes da cadeia de produção do setor de construções em madeira, do estado e das instituições de ensino e pesquisa. Estes agentes objetivaram estabelecer diretrizes normativas mediante o programa SINAT/ PBQP-H para viabilizar o financiamento deste sistema inovador em madeira por meio de agentes públicos.

\section{OBJETIVOS}

O objetivo geral desta pesquisa é analisar como ocorreu a introdução do sistema construtivo inovador wood frame na produção de habitação no Brasil a partir de 2010.

Os objetivos específicos são:

a) Avaliar o que motivou as ações para desenvolver tecnologicamente o setor de construção em madeira no período específico de 2010.

b) Delinear quais agentes participaram neste processo de inovação do wood frame e que estratégias eles estabeleceram para efetivar essa implementação no país.

c) Descrever os processos de regulamentação do sistema inovador wood frame no SINAT e de viabilização do financiamento pela CEF para o PMCMV, caracterizando, em especial, o processo de produção do Residencial Haragano, primeiro empreendimento em wood frame neste programa habitacional.

d) Apontar os principais resultados obtidos mediante esta ação conjunta, caracterizando a difusão do wood frame no Brasil após a publicação da Diretriz SINAT no 005 em 2011.

\section{MÉTODO}

Conforme o contexto delineado inicialmente, a proposta desta pesquisa visa compreender com maior profundidade o fenômeno da inovação tecnológica no setor da construção civil, com ênfase para o caso específico das construções em madeira do tipo wood 
frame. Para este fim, as questões e os objetivos desta tese abordam aspectos referentes a quem, por que e como este processo ocorreu. Neste sentido, esta tese é caracterizada por uma abordagem qualitativa, onde preocupa-se "com aspectos da realidade que não podem ser quantificados, centrando-se na compreensão e explicação da dinâmica das relações sociais" (GERHARDT; SILVEIRA, 2009, p. 32). Assim, com uma análise pormenorizada do cenário específico da introdução do sistema wood frame em 2010 no Brasil, esta pesquisa propõe-se a explicar os fatos que contemplam este fenômeno para dar base e contribuições para conceituações similares no setor da construção civil do país.

Os principais procedimentos adotados para alcançar os objetivos desta pesquisa são ilustrados sinteticamente na Figura 2 e descritos na sequência.

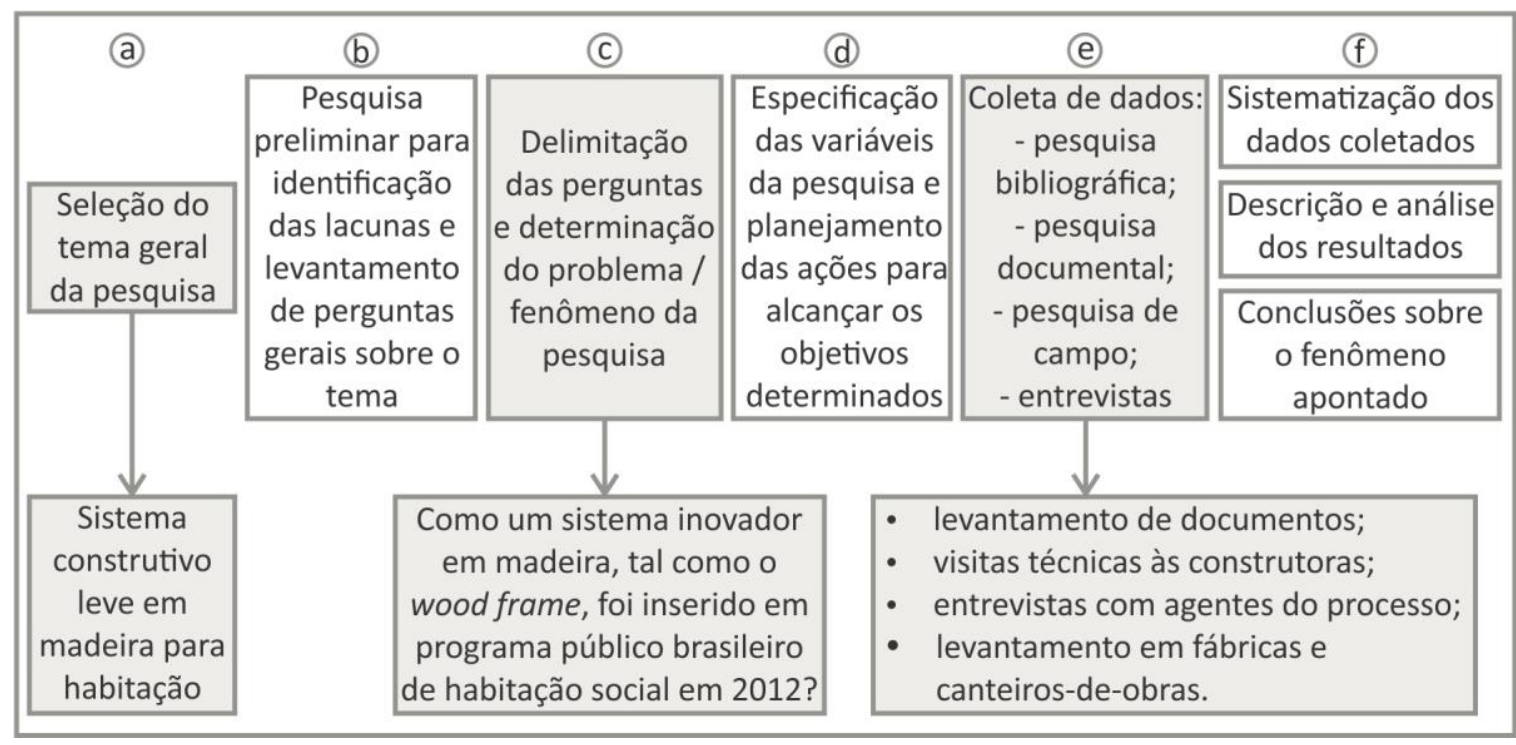

Figura 2: Etapas gerais da pesquisa

Fonte: autora.

\section{a) Seleção do tema geral da pesquisa}

O tema geral - sistema construtivo leve em madeira para habitação - foi selecionado com a intenção de dar continuidade ao trabalho realizado pela autora durante sua pesquisa de mestrado. Concluída no primeiro trimestre de 2010, esta dissertação sugeriu a execução de habitações sociais compostas com painéis de parede coordenados modularmente, adotando os detalhes técnicos construtivos do sistema plataforma em madeira ${ }^{5}$ para todos os

\footnotetext{
${ }^{5}$ Conforme será detalhado nos capítulos 3 e 4 desta tese, existem diferentes tipos de sistemas com estruturas leves em madeira. Destes, o sistema plataforma em madeira é um dos tipos mais comuns de light wood frame.
} 
subsistemas constituintes da edificação projetada (ESPÍNDOLA, 2010). Com base nas conclusões desta dissertação e de outros autores relevantes ao tema, como Krambeck (2006), Campos (2006), Laroca (2007) e Velloso (2010), observou-se a necessidade de ampliar os estudos sobre esse sistema construtivo, direcionando as propostas já realizadas para a prática construtiva no contexto brasileiro.

\section{b) Identificação das lacunas relevantes ao tema}

No primeiro momento da pesquisa, a motivação de aprofundar a temática dos sistemas leves em madeira apoiava-se na questão da sustentabilidade, nos eixos ambiental e social, conforme as necessidades apontadas no setor habitacional do Brasil somadas às possibilidades de desenvolvimento do setor de construções em madeira do país com o uso de técnicas racionalizadas aplicando espécies oriundas de florestas plantadas.

Neste período inicial, as justificativas da pesquisa tinham como base principal as informações teóricas e as experiências práticas relatadas nas fontes bibliográficas nacionais específicas sobre este tema. Em geral, estes documentos publicados até o ano de 2010 forneceram diretrizes de projeto e levantavam as seguintes necessidades sobre o sistema wood frame:

- agir em conjunto com as empresas fabricantes de elementos e componentes constituintes, visando produtos padronizados, seguindo as conformidades dimensionais e aprimorando a compatibilização entre os diferentes subsistemas da edificação;

- monitorar o processo de produção da construção, incluindo a necessidade de respeitar a precisão na execução da obra;

- avaliar as possibilidades de pré-fabricação, visando minimizar os erros e diminuir os custos envolvidos no processo de produção;

- capacitar os profissionais técnicos e treinar a mão-de-obra, mediante a divulgação de cartilhas e manuais técnicos e o oferecimento de unidades curriculares em cursos de engenharia e arquitetura;

- ampliar o investimento em pesquisas para realização de ensaios técnicos experimentais e de avaliações pós-ocupação conforme os requisitos de desempenho do Brasil;

- realizar estudos sobre planejamento, quantitativo, orçamento e custos de obra;

- elaborar documentos para ampliar o conhecimento e diminuir o receio popular quanto ao sistema, como o manual do usuário;

- avaliar os requisitos técnicos para obter o financiamento das edificações em agências de fomento. 
Observou-se que estas lacunas, em geral, demonstravam preocupações para aprimorar o sistema wood frame conforme o contexto brasileiro e incentivar sua aplicação na produção de habitações, a qual não era ocorrente até o início do ano de 2010 . Sendo assim, esta tese iniciou sua proposta com base nestas necessidades levantadas, objetivando avaliar as possibilidades de produção dos componentes do sistema em fábrica e no canteiro-deobras, como uma contribuição prática que possibilitaria alavancar o setor.

Entretanto, com o aprofundamento dos estudos, entre os anos de 2012 e 2013, a investigação sobre o tema se deparou com uma aparente e repentina transição do cenário da indústria da construção em madeira no Brasil. Conforme já descrito brevemente, neste período, este setor passou a introduzir o sistema wood frame na produção de habitações, com ênfase no PMCMV, financiado por agentes públicos. Sendo assim, este fato levantou novas questões especificamente sobre a decorrência do processo de produção deste sistema inovador em madeira no país (Figura 2 - c).

\section{c) Determinação do fenômeno da pesquisa}

Frente às diferentes lacunas levantadas, determinou-se priorizar as questões referentes ao processo de inovação do sistema construtivo wood frame a partir do ano de 2010 no Brasil. Conforme as justificativas já explanadas no início deste trabalho, para o momento específico desta pesquisa, considerou-se que compreender a implementação de uma inovação tecnológica em madeira no país era mais relevante que a elaboração de novas propostas técnicas para o sistema construtivo em questão. Julgou-se como prioridade analisar as dinâmicas desse fenômeno de inovação do wood frame, pois estes dados fornecem suporte para futuras pesquisas sobre a materialidade e o aprimoramento desta tecnologia construtiva, assim como também de outras que se interessam em aplicar seus resultados na prática social ou no mercado, observando a interação entre os agentes das diferentes esferas como instituições de ensino e de pesquisa, Estado e setor produtivo.

\section{d) Especificação das variáveis da pesquisa}

As principais variáveis constituintes do fenômeno do processo de inovação tecnológica do sistema wood frame no Brasil foram classificadas conforme as questões selecionadas para esta tese, assim definidas: 
- Por que: contextos político, social e econômico, em especial do setor produtivo madeireiro, que afetaram as decisões para introduzir o sistema wood frame no ano de 2010 no Brasil.

- Quem: agentes das esferas do Estado, do setor produtivo e de instituições de ensino e pesquisa que participaram deste processo de inovação específico;

- Como: ações e estratégias dos agentes integrantes e articulações entre os mesmos para implementação do sistema wood frame no mercado nacional;

- O que: resultantes do processo de inovação, tais como produtos e métodos construtivos aplicados, ampliação do setor produtivo e empreendimentos habitacionais produzidos, em especial os inclusos no PMCMV, como o pioneiro Residencial Haragano.

\section{e) Procedimentos e coleta de dados}

Em geral, os procedimentos adotados para o levantamento de dados deste diagnóstico específico compreenderam: pesquisa bibliográfica, pesquisa documental, entrevistas semiestruturadas e abertas e visitas técnicas.

Inicialmente, para a formulação da base teórica sobre a relação entre as mudanças técnicas na produção e o comportamento econômico, foram pesquisados autores referências sobre o tema, como: Schumpeter $(1961,1982)$, Dosi $(1982,2006)$, Cassiolato e Lastres (2005), Sábato e Botana (1975) e Etzkowitz e Leydesdorff (2000). Sob o ponto de vista destas teorias econômicas, procurou-se abranger os seguintes questionamentos referentes ao processo de inovação: por que, como, quando, para quem e por quem as inovações são implementadas. Esta linha de raciocínio foi seguida em toda a formulação da tese, tanto na questão geral da construção civil, quanto no caso específico da produção do wood frame.

Assim, para compreender como o processo das inovações tecnológicas vem ocorrendo na indústria da construção brasileira, foram analisadas as formulações de pesquisadores nacionais, incluindo, por exemplo, Bruna (1972), Maricato (1983), Castro (1999), Vianna (1989), Sabbatini (1989), Amorim (1995), Cardoso (2013a, 2013b).

Na sequência, para introduzir o caso selecionado do sistema construtivo wood frame, um levantamento bibliográfico foi realizado para compor seu histórico inicial de produção no contexto norte-americano na primeira metade do século XIX, com base em autores como: Field (1942), Jackson (1985), Page e Walker (1991), Cavanagh (1997), e Monteyne (2004). 
Entrando na análise da produção brasileira com o wood frame, fontes bibliográficas nacionais, em especial a publicação de Zenha (1998), forneceram dados sobre as primeiras construções realizadas com este sistema em madeira entre as décadas de 1980 e 2000.

Após, para coletar os dados específicos sobre a implementação do wood frame na produção de habitação no Brasil a partir do ano de 2010, o levantamento foi realizado sobre três temáticas principais: (1) Comissão Casa Inteligente, (2) Residencial Haragano e (3) difusão do sistema construtivo no Brasil.

(1) Comissão Casa Inteligente:

Para analisar a constituição, as motivações e as ações da Comissão Casa Inteligente, entrevistas semi-estruturadas foram realizadas com integrantes diretos deste processo, como: empresas produtoras de insumos, empresas construtoras, empresas consultoras, agentes de financiamento, associações representativas e instituições de ensino e de pesquisa.

Nos primeiros contatos, nos anos de 2012 e 2013, tal investigação foi dificultada por alguns motivos. Por exemplo, por ser um processo em andamento, novos dados apareciam gradativamente e surgiam novas questões sobre o processo, sendo necessário reestruturar as entrevistas para novos levantamentos.

Mas, com o passar do tempo, estas informações se tornaram mais evidentes quando foram publicamente divulgadas mediante entrevistas realizadas com as instituições envolvidas, incluindo o Serviço Nacional de Aprendizagem Industrial do Estado do Paraná (SENAI-PR), a Federação das Indústrias do Estado do Paraná (FIEP), o Sindicato da Indústria da Construção Civil do Paraná (SINDUSCON-PR), a Associação Paranaense de Empresas de Base Florestal (APRE) e a Associação Brasileira da Indústria de Madeira Processada Mecanicamente $(A B I M C I)$. Além destas publicações, também foram disponibilizados resumos e pautas das principais reuniões da Comissão Casa Inteligente. Assim, com base nas entrevistas, nos documentos e nas publicações da mídia eletrônica, foi possível confirmar e cruzar as informações levantadas sobre este processo.

(2) Residencial Haragano:

Em paralelo, para o levantamento de dados sobre o processo de produção do Residencial Haragano, foram realizadas entrevistas semi-estruturadas e abertas com os principais agentes deste processo, incluindo a Gerência de Desenvolvimento Urbano da CEF de Porto Alegre (GIDUR/PO), a construtora Roberto Ferreira, a empresa Tecverde e a 
professora pesquisadora Margarete R. F. Gonçalves da Universidade Federal de Pelotas (UFPel).

Também, em novembro de 2012, no município de Pelotas no Rio Grande do Sul, visitas técnicas foram realizadas na fábrica da empresa Roberto Ferreira, enquanto os elementos de parede e de piso eram montados, e no canteiro-de-obras, onde as unidades habitacionais eram executadas. Nestas visitas, foram coletados dados sobre o projeto arquitetônico e as tecnologias construtivas aplicadas, incluindo seus elementos constituintes e os métodos de construção do residencial. Estas informações foram complementadas com dados publicados em revistas científicas e em artigos acadêmicos.

(3) Difusão do wood frame no Brasil:

Por fim, para avaliar a difusão do wood frame no território brasileiro desde 2012 até 2016, foram realizadas entrevistas e visitas técnicas nas seguintes empresas das regiões sul e sudeste: Shintech, em Sorocaba, São Paulo; Tetti, em Capão Bonito, São Paulo; Stamade, em São Carlos, São Paulo; Tecverde, em Pinhais e em Araucária, Paraná; EcosHaus, em Curitiba, Paraná; Kürten, em Curitiba, Paraná; Roberto Ferreira, em Pelotas, Rio Grande do Sul; e construtores autônomos, em Florianópolis, Santa Catarina. Para complementar este cenário, dados de outras empresas foram pesquisados em sites da internet e em artigos acadêmicos. Nestes levantamentos, foram constatados os principais componentes constituintes e métodos de construção aplicados.

Em geral, no início dos levantamentos, os envolvidos consideravam muitos dados como restritos para publicações. Pois, por se tratar de uma produção inovadora no Brasil, havia certo receio de tornar públicas as informações particulares, em especial das empresas atuantes. Assim, esta foi uma lacuna enfrentada nesta pesquisa, onde as informações coletadas pareciam desencontradas ou incompletas. Mas, gradualmente, muitas empresas e associações representativas passaram a divulgar seus dados em meios eletrônicos e redes sociais, facilitando o acesso a dados relevantes para a formulação desta tese.

\section{f) Sistematização dos dados coletados e análise dos resultados}

Visando a análise sistêmica do processo de inovação do wood frame no Brasil, os dados levantados foram sistematizados por períodos históricos, agentes integrantes, ações tomadas, técnicas e tecnologias aplicadas. Além de textos descritivos e explicativos, foram elaborados 
registros fotográficos, gráficos, quadros, linhas do tempo e ilustrações simuladas. Por fim, com este cenário detalhado, esta pesquisa objetivou descrever e explicar com maior profundidade os fatores que determinaram ou que contribuíram para a ocorrência do fenômeno delimitado (GERHARDT; SILVEIRA, 2009).

\section{ESTRUTURA DA TESE}

Esta tese está estruturada em sete capítulos. Os objetivos de cada capítulo são resumidos a seguir.

\section{Capítulo 1 - Processo de inovação - mudanças técnicas na produção}

Com base nas teorias de Schumpeter $(1961,1982)$, este primeiro capítulo apresenta a temática da inovação, apontando como é importante e estreita a relação entre as transformações nos processos produtivos e o comportamento do sistema econômico. A partir dessas colocações, pretende-se responder questões gerais sobre a ocorrência da inovação tecnológica, tais como: por que inovar, como são caracterizadas as mudanças de produção, quais as necessidades na seleção da inovação, como ocorre esse processo e, por fim, quem participa desta função especial.

\section{Capítulo 2 - O processo da inovação tecnológica na construção civil brasileira}

Este capítulo tem como objetivo apresentar como vem ocorrendo o processo de mudanças técnicas na construção civil brasileira. Para isso, inicialmente, caracterizam-se quais aspectos podem ser inovados na indústria da construção civil. Na sequência, apresenta-se um modelo teórico com as etapas de desenvolvimento descritas para produtos e processos construtivos inovadores. E, por fim, são elencados os principais agentes e fatores institucionais que vem sendo determinantes para a seleção das necessidades e dos paradigmas tecnológicos na construção brasileira. E, também, salienta como o programa SINAT/PBQP-H vem possibilitando a introdução de sistemas construtivos inovadores no PMCMV.

\section{Capítulo 3 - Referências gerais sobre o sistema construtivo wood frame}

Este capítulo apresenta uma introdução e uma visão geral sobre o sistema construtivo wood frame, apontando seu contexto histórico e suas origens na América do Norte, assim 
como seus principais detalhes técnicos construtivos e métodos de produção. Estes pontos abordados têm o intuito de fornecer uma base teórica para os capítulos seguintes que avaliam a apropriação do wood frame para o contexto brasileiro.

Capítulo 4 - Primeiro período de produção do wood frame no Brasil - entre as décadas de 1980 e de 2000

Este capítulo tem como objetivo apresentar o primeiro período de produção do wood frame no território brasileiro, que ocorreu entre as décadas de 1980 e de 2000 . Estes dados esclarecem que a prática com este sistema leve em madeira foi introduzida no Brasil no final do século XX. Assim, são colocadas informações levantadas sobre as empresas construtoras no Brasil que produziam com o wood frame naquele período. E, também, são apontadas algumas ações tomadas naquele contexto para disseminar este sistema no país, tais como a realização de pesquisas acadêmicas e as publicações para divulgação deste sistema.

Capítulo 5 - Ações para o desenvolvimento do wood frame no Brasil em meados de 2010

A partir de meados de 2010, o setor de construção em madeira iniciou uma transformação impulsionada por ações conjuntas para promover a produção do sistema wood frame no Brasil, mediante a denominada Comissão Casa Inteligente. Os agentes envolvidos no processo desta inovação estabeleceram estratégias a fim de consolidar a aplicação deste sistema construtivo. Portanto, com base neste cenário de mobilização, o capítulo cinco tem como objetivo delinear as questões sobre este processo: o que motivou tal movimento para utilização deste sistema construtivo nesta data específica, quem atuou direta e indiretamente neste processo, o que foi selecionado pelo grupo atuante como necessidade para produção, quais procedimentos e estratégias adotados para alcançar esta proposta e quais foram os resultados apresentados.

Capítulo 6 - Residencial Haragano - Introdução do wood frame no programa Minha

\section{Casa Minha Vida}

Este capítulo apresenta a caracterização do processo de produção do Residencial Haragano, primeiro empreendimento do PMCMV que adota o sistema construtivo inovador wood frame. Assim, os seguintes fatores são detalhados: quem foram os agentes deste 
processo, qual sistema construtivo selecionado, quais detalhes arquitetônicos das residências de um e dois pavimentos, como ocorreu sua execução em fábrica e no canteiro, que orientações os moradores receberam sobre a manutenção do sistema inovador e como ocorre o acompanhamento de avaliação pós-ocupação pelos responsáveis técnicos.

\section{Capítulo 7 - Difusão do wood frame no Brasil após a publicação da Diretriz SINAT no}

\section{5 em 2011}

Após os resultados das primeiras ações da Comissão Casa Inteligente apresentados nos capítulos anteriores, observa-se que a produção do wood frame vem sendo difundida gradualmente no Brasil. Para analisar esta difusão após esta nova conjuntura do setor, este capítulo procura caracterizar a produção deste sistema no Brasil entre os anos de 2012 e 2016, apontando um quantitativo de construtores envolvidos e suas principais soluções tecnológicas adotadas, como materiais constituintes e métodos de execução. Também, procura-se examinar a quem, em geral, esta produção de edificações em wood frame vem sendo destinada. E, por fim, este capítulo encerra discorrendo sobre como a Comissão Casa Inteligente age para dar continuidade à promoção deste sistema no Brasil. 


\section{PROCESSO DE INOVAÇÃO - MUDANÇAS TÉCNICAS NA PRODUÇÃO}

O sistema construtivo wood frame, introduzido recentemente no Brasil, é considerado inovador nesse contexto. Para compreender a dinâmica no processo de inserção deste sistema em madeira no território brasileiro, antes, faz-se necessário elaborar uma explanação com foco mais amplo sobre o que está envolvido nos processos de inovação, em especial, na indústria da construção civil. Pois, assim, quando a questão sobre o wood frame for delineada posteriormente neste trabalho, os agentes envolvidos, suas atuações, as relações entre os mesmos e a produção resultante poderão ser caracterizados com maior critério.

Portanto, este primeiro capítulo apresenta a temática da inovação, apontando como é importante e estreita a relação entre as transformações nos processos produtivos e o comportamento do sistema econômico. A partir dessas colocações, pretende-se responder questões gerais sobre a ocorrência da inovação tecnológica, tais como: por que inovar, como são caracterizadas as mudanças de produção, quais as necessidades na seleção da inovação, como ocorre esse processo e, por fim, quem participa desta função especial. Esses assuntos discutidos têm como enfoque o campo de produção das edificações no Brasil, o qual será detalhado no segundo capítulo.

\subsection{MUDANÇAS NO PROCESSO DE PRODUÇÃO PARA O DESENVOLVIMENTO ECONÔMICO}

A temática da inovação tecnológica não é recente. Para compreender sua origem, a abordagem aqui apresentada tem como base as principais teorias do economista austríaco Schumpeter (1961, 1982), elaboradas em meados da década de 1910. Suas reflexões apontam como as mudanças no processo produtivo são consideradas fundamentais para o desenvolvimento do sistema econômico, e, consequentemente, para a transformação social pertinente a estes.

Conforme a exposição de Schumpeter (1982), o comportamento econômico é dirigido para o consumo, ou seja, para a aquisição de bens que devem satisfazer as necessidades do consumidor. Dessa forma, tais necessidades, assim como as demandas e as condições externas dadas, são fatores decisivos no processo econômico. E, como consequência, a 
produção de bens segue estas necessidades e "é, por assim dizer, puxada por elas", tornandose um problema econômico (Figura 3).

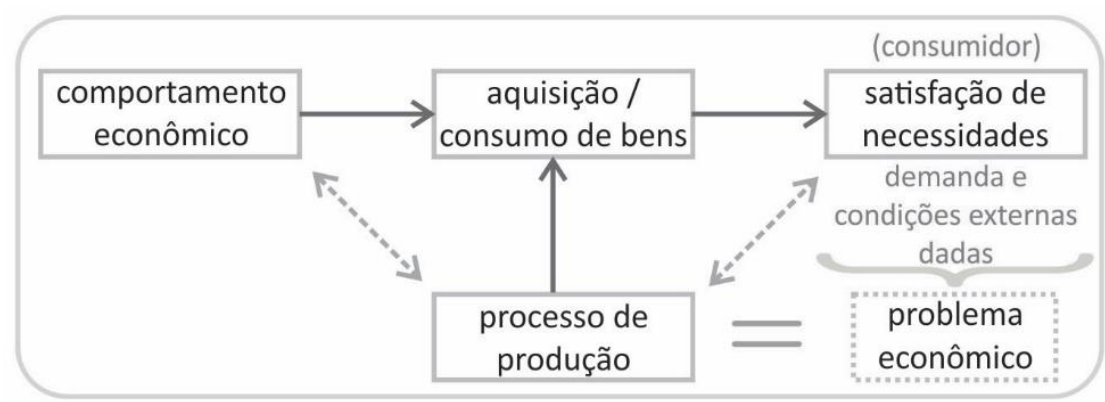

Figura 3: Relação entre produção e comportamento econômico Fonte: elaborado pela autora conforme dados de Schumpeter, 1982.

Em um âmbito geral, "produzir significa combinar as forças e coisas ao nosso alcance. Todos os métodos de produção significam algumas dessas combinações técnicas". Assim, o processo de produção é caracterizado mediante o conceito de "combinações de forças produtivas". Ou seja, o processo de produção combina meios de produção, modos de produção, força de trabalho; no qual, "os resultados dessas combinações são os produtos" (SCHUMPETER, 1982, p. 16).

A principal tese schumpeteriana afirma que a mediação entre processo de produção e comportamento econômico pode promover o desenvolvimento do sistema. $E$, para isso, são necessárias mudanças que causem rupturas no fluxo circular fechado da vida econômica. Tal fluxo econômico fechado é descrito como aquele que tende ao equilíbrio contínuo, apresentando oscilações insignificantes na sua estrutura. Nesta situação estacionária, não ocorrem variações ou desenvolvimento. Então, a atividade do indivíduo é governada pelos períodos econômicos precedentes, os quais "emaranharam-no numa rede de conexões econômicas e sociais da qual ele não pode livrar-se facilmente" (SCHUMPETER, 1982, p. 11). Neste equilíbrio, as técnicas de produção e as preferências dos consumidores são consideradas imutáveis. "A produção se caracteriza por uma atividade de pura rotina: as empresas produzem sempre os mesmos tipos e quantidades de bens; os fatores são combinados sempre da mesma forma" (MORICOCHI; GONÇALVES, 1994, p. 30).

Em contrapartida, para que haja desenvolvimento econômico, é necessário descontinuar os canais deste fluxo fechado, causando mudanças que perturbem seu equilíbrio. E, na tese shcumpeteriana, são as transformações na produção, mediante a 
realização de "novas combinações", que proporcionam a variação econômica e o desenvolvimento do sistema. Assim, a introdução de novos processos de produção é descrita como "o impulso fundamental que põe e mantém em funcionamento a máquina capitalista" (SCHUMPETER, 1961, p. 105).

Esse organismo econômico capitalista oscila em "um movimento em forma de onda que alterna períodos de prosperidade e de depressão", no qual "todo boom é seguido por uma depressão, toda depressão por um boom" (SCHUMPETER, 1982, p. 142). E, o aparecimento das novas combinações de produção - posteriormente denominadas inovações - está diretamente relacionado a tais "flutuações econômicas", observadas na Figura 4.

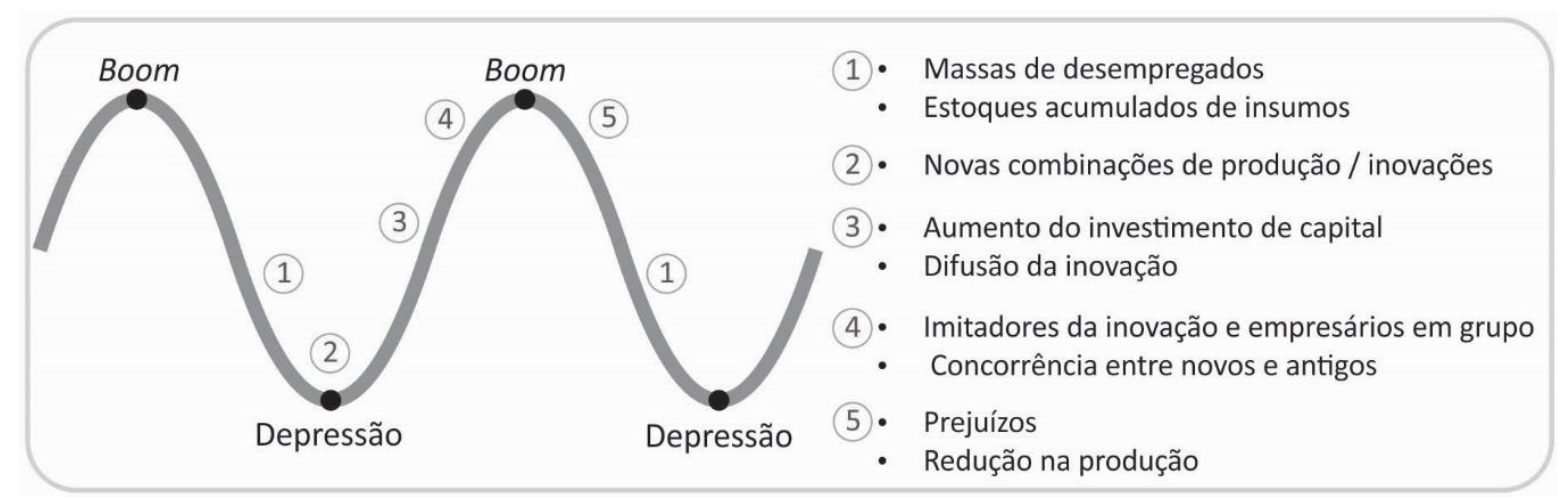

Figura 4: Oscilações econômicas e a introdução de "novas combinações" de produção Fonte: elaborado pela autora conforme dados de Schumpeter, 1982.

Dentro destas oscilações no comportamento econômico, o período de crise parece propício para a introdução de inovações. Neste momento, "há geralmente massas de desempregados, estoque acumulados de matéria-prima, máquinas, edifícios, etc., oferecidos abaixo do custo de produção" (SCHUMPETER, 1982, p. 149). E, as atividades inovadoras são empreendidas na expectativa de algum retorno econômico para quem as realiza (DOSI , 2006). Assim, tal condição das forças produtivas nesse período de depressão econômica pode facilitar o aparecimento das novas combinações de produção.

Mas, para iniciar esse processo de inovação, o "empresário" - denominação de Schumpeter para aquele que lidera e realiza tal função especial - deve possuir os meios produtivos para realocá-los nas novas combinações. Se não os possuir, o mesmo precisa ter capital, ou seja, o poder da compra para adquiri-los. Empresas já estabelecidas talvez já possuem estes meios ou podem obtê-los com o lucro advindo de produções anteriores. Se 
este não for o caso, o que geralmente ocorre, para a realização das novas combinações de produção, deve-se recorrer condicionalmente ao crédito como financiamento desses meios.

\begin{abstract}
"Através do crédito, os empresários obtêm acesso à corrente social dos bens antes que tenham adquirido o direito normal a ela. [...] A concessão do crédito opera nesse sentido como uma ordem para o sistema econômico se acomodar aos propósitos do empresário, como um comando sobre os bens de que necessita: significa confiar-lhe forças produtivas" (SCHUMPETER, 1982, p. 74).
\end{abstract}

O financiamento de crédito é necessário para viabilizar o processo de inovação. Tal vinculação entre novas combinações de meios de produção e crédito constitui-se no fenômeno fundamental do desenvolvimento econômico. Portanto, o sistema bancário assume o papel de conceder tal crédito ao "empresário", se colocando "entre os que desejam formar combinações novas e os possuidores dos meios produtivos" (SCHUMPETER, 1982, p. 74).

Na sequência, com a formação das novas combinações de produção, atinge-se uma época de expansão e prosperidade na onda do ciclo econômico, com aumento do investimento de capital e indústrias produtoras estimuladas. Com a difusão do novo produto no mercado e boa reação do consumidor, o negócio poderá render um excedente sobre os custos, com uma diferença positiva entre receitas e despesas. Visando esse lucro, outros "empresários" tornam-se imitadores desta inovação e também se introduzem no mercado.

Nesse período, ocorre elevação na demanda por trabalhador, o que proporciona maior renda para o mesmo e o possibilita a aumentar a demanda pelos bens de consumo, elevando, consequentemente, os preços gerais. Proporcional ao desenvolvimento em questão, "[...] o processo capitalista eleva progressivamente, não por coincidência, mas em virtude do seu próprio mecanismo, o padrão de vida das massas", considerando principalmente os artigos de consumo em massa. "Os problemas de fornecimento de mercadoria à massa" são "resolvidos", um após o outro (SCHUMPETER, 1982, 1961, p. 87).

Porém, o dinamismo econômico diminui conforme as conquistas das novas combinações são difundidas e se firmam, levando ao fim do boom econômico. Pois, após o "empresário" pioneiro realizar sua inovação, seus imitadores aparecem, não de forma contínua, mas em grupos, causando problemas referentes à absorção destes no sistema econômico. Inicialmente, o aparecimento destes grupos estimula as indústrias produtoras de meios de produção, pois, na disputa por tais meios, elevam a concorrência e os níveis de 
competitividade. Mas logo, a oferta de bens finais produzidos aumenta, o que leva os empresários a elevar seus padrões e seus custos para permanecer nesta concorrência, mas diminuem seus preços e, consequentemente, seus lucros. Também, os novos produtos passam a concorrer com os antigos já consolidados. E, conforme os consumidores vão se posicionando em favor dos novos, os antigos sentem-se obrigados a fazer transformações e elevar seus custos para permanecer no mercado, reduzindo assim suas receitas (SCHUMPETER, 1982).

E, após o boom, logo se segue novamente o período de recessão e depressão, com perturbações, prejuízos, desemprego, decréscimo na renda do trabalhador, baixo consumo de bens e redução nas produções. Estes ciclos, assim como seus fenômenos e efeitos, constituem um "processo de rejuvenescimento intermitente da maquinaria econômica", onde o "motor do capitalismo" se alimenta das oportunidades abertas aos novos empreendimentos e investimentos. A inovação passa a ser uma função do processo capitalista (SCHUMPETER, 1961, p. 87, 142). Assim, este autor procura demonstrar que o desenvolvimento econômico está fortemente atrelado à introdução de novas combinações produtivas.

Desde então, com maior ênfase a partir da segunda metade do século $X X$, nas elaborações de autores neoschumpeterianos, a denominação "novas combinações" produtivas segue, geralmente, substituída pela expressão inovação tecnológica. No entanto, mesmo sob outra nomenclatura, mantém-se a inovação como indicativo de crescimento econômico e geração de riqueza (UTTERBACK, 1996). Sobre isso, Cassiolato e Lastres (2007, p. 154) afirmam:

O crescimento da economia é visto como um processo dinâmico que depende tanto da geração e uso das inovações, quanto dos processos de difusão das mesmas. Os avanços - produtivos, tecnológicos, organizacionais, institucionais, etc. - resultantes de processos inovativos são tomados como fator básico na formação dos padrões de transformação da economia e de seu desenvolvimento no longo prazo.

Assim, os estímulos para promover a inovação nos diversos setores de produção se apoiam nesse objetivo do desenvolvimento econômico. Dessa forma, conclui-se que a motivação geral dada para se inovar é sua interferência positiva na dinâmica do comportamento econômico. No setor da construção, este ponto de vista é similar, quando os incentivos também estão pautados nessa condicionante. A introdução de novas combinações de produção pode contribuir para a expansão do setor. No entanto, mesmo com este 
posicionamento positivo, quando comparada a outros setores, observa-se no seu contexto histórico que indústria da construção brasileira encontrou algumas barreiras para inserir novas combinações, conforme será delineado no capítulo seguinte.

Mas o que seriam estas "novas combinações" de produção ou inovações que apresentam tamanha influência no comportamento econômico? O item seguinte busca responder esta questão ao elencar casos propostos por Schumpeter que se tornaram base conceitual da inovação tecnológica para os diversos setores econômicos, incluindo a indústria da construção.

\subsection{CARACTERIZAÇÃO DAS “NOVAS COMBINAÇÕES” DE PRODUÇÃO}

De forma geral, realizar "novas combinações" significa modificar o modo de produção por ofertar os meios produtivos existentes no sistema econômico de forma diferente das recorrentes. Estas novas combinações de produção são caracterizadas em cinco casos transcritos a seguir (SCHUMPETER, 1982, p. 48):

(1) Introdução de um novo bem - ou seja, um bem com que os consumidores ainda não estiverem familiarizados - ou de uma nova qualidade de um bem;

(2) Introdução de um novo método de produção, ou seja, um método que ainda não tenha sido testado pela experiência no ramo próprio da indústria de transformação, que de modo algum precisa ser baseada numa descoberta cientificamente nova, e pode consistir também em nova maneira de manejar comercialmente uma mercadoria;

(3) Abertura de um novo mercado, ou seja, de um mercado em que o ramo particular da indústria de transformação do país em questão não tenha ainda entrado, quer esse mercado tenha existido antes, quer não;

(4) Conquista de uma nova fonte de oferta de matérias-primas ou de bens semimanufaturados, mais uma vez independentemente do fato de que essa fonte já existia ou teve que ser criada;

(5) Estabelecimento de uma nova organização de qualquer indústria, como a criação de uma posição de monopólio (por exemplo, pela trustificação) ou a fragmentação de uma posição de monopólio.

Em suma, pelo autor, as novas combinações, ou seja, as inovações englobam: novos bens de consumo, novos métodos de produção, novos mercados, novas fontes de oferta de matéria-prima ou novos insumos e novas formas de organizações industriais e empresariais. Conforme já destacado anteriormente, estas novas combinações aqui caracterizadas dão impulso ao funcionamento da máquina capitalista (SCHUMPETER, 1961). 
Quando estas combinações são qualificadas como "novas", isso não indica que necessariamente precisam ser invenções. Os processos de inovações são diferentes dos de invenções. Enquanto as invenções têm como preceito uma descoberta ou uma criação de algo completamente inexistente, a inovação ocorre a partir de dados já existentes no sistema, tais como experiências, conhecimentos e tecnologias acumulados no decorrer do tempo. Conforme Utterback (1996), as inovações surgem a partir de capacidades antigas. Por exemplo, um produto inovador pode ser resultante de uma síntese de várias tecnologias já existentes, as quais combinadas e reunidas criam algo novo que é implementado no mercado.

Ainda complementando este raciocínio, Rogers $(1995$, p. 11) afirma que "uma inovação é uma ideia, uma prática ou um objeto que é percebido como novo por um indivíduo ou por outra unidade de adoção". Portanto, o adjetivo "novo" pode ser referente a um bem que o consumidor desconhece ou está pouco familiarizado. Também, pode ser um método de produção ainda não aplicado pela indústria de determinado setor, ou um mercado ainda não aberto em um local, ou um rearranjo nas estruturas e organizações de empresas e indústrias. Mas, cabe observar, que para algo ser considerado inovação, este deve chegar na fase de implementação no mercado.

No decorrer dos anos, os discursos sobre inovação se tornaram mais populares. Geralmente, as definições são mais resumidas e simplificadas, como a encontrada na Lei de incentivo à inovação e à pesquisa científica e tecnológica no ambiente produtivo do Brasil (BRASIL, Lei no 10.793, 2004), a qual afirma que inovação é a "introdução de novidade ou aperfeiçoamento no ambiente produtivo ou social que resulte em novos produtos, processos ou serviços".

Não raro, as atribuições mais atuais sobre inovação têm como base os conceitos elaborados a partir da década de 1960, quando a Organização para Cooperação e Desenvolvimento Econômico (OCDE) foi instituída oficialmente com objetivo de promover políticas relacionadas à expansão e estabilidade econômica mundial. Ao longo dos anos, a OCDE vem sendo integrada por especialistas de 30 países industrializados, incluindo norteamericanos, europeus, asiáticos, escandinavos, entre outros. Desde então, foram publicados manuais metodológicos sobre o conceito de Ciência e Tecnologia, sendo os principais: Manual de Frascati, sobre investigação e desenvolvimento; Manual de Oslo, sobre inovação; e Manual de Camberra, sobre balança tecnológica de pagamentos e patentes (OCDE, 2007). 
O Manual de Oslo é resultante de pesquisas e experiências práticas constatadas pelos países integrantes desta organização, tendo como objetivo refinar conceitos, definições e metodologias sobre inovação. Em 1992, a OCDE, em conjunto com o Fundo Nórdico para o Desenvolvimento Industrial, publicou a primeira edição deste manual, destacando a importância do crescimento da economia mundial impulsionado por atividades de inovação. Incialmente, o enfoque era dado à inovação tecnológica de produto e processo. Posteriormente, em 1997, a OCDE e o Gabinete Estatístico das Comunidades Europeias (Eurostat) publicaram sua segunda edição. Nesta, o tema expandiu e, além dos bens, o setor de serviços foi inserido entre os produtos inovadores. Por último, em 2005, a terceira edição do manual discutiu a inclusão de questões de inovações consideradas não-tecnológicas, como inovação de marketing e inovação organizacional (OCDE, 2006).

Por fim, concluiu-se que, a partir das apreensões nestes períodos, inovação pode ser conceituada da seguinte forma:

Uma inovação é a implementação de um produto - bem ou serviço - novo ou significativamente melhorado, ou um processo, ou um novo método de marketing, ou um novo método organizacional nas práticas de negócios, na organização do local de trabalho ou nas relações externas (OCDE, 2006, p. $55)$.

Esta definição da OCDE (2006) procura ser mais abrangente ao especificar quatro tipos de inovação:

(a) Inovação de produto: refere-se à introdução de novos bens e serviços ou ao aperfeiçoamento significativo nas características técnicas e funcionais de bens e serviços existentes;

(b) Inovação de processo: é a implementação de um método novo ou significativamente melhorado de produção ou de distribuição;

(c) Inovação de marketing: envolve mudanças significativas no design do produto ou em sua embalagem, no posicionamento do produto, em sua promoção ou na fixação de preços;

(d) Inovação organizacional: é a implementação de um novo método organizacional nas práticas de negócios da empresa, na organização do seu local de trabalho ou em suas relações externas. 
Esta caracterização delineada para as inovações tecnológicas, tendo a origem conceitual nas teorias econômicas de Schumpeter, são adotadas por diversos setores econômicos, incluindo o da construção civil, como será abordado no capítulo seguinte.

\subsection{DETERMINAÇÃO DE NECESSIDADES PARA SELEÇÃO DA INOVAÇÃO}

A determinação das necessidades é um fator importante a ser examinado no processo de inovação. No início deste capítulo (Figura 3), apresentou-se que as necessidades são satisfeitas pelo consumo de bens produzidos e, portanto, são fatores decisivos no sistema econômico. Como consequência, o processo de produção de bens é "puxado" por estas necessidades, pois "o indivíduo produz diretamente para o consumo" (SCHUMPETER, 1982, p. 14). Assim, a produção, ao ser direcionada por tais necessidades, além de ser um problema tecnológico, torna-se também um problema econômico. Portanto, no raciocínio elaborado por Schumpeter (1982), a necessidade está vinculada ao consumo e é determinante nas combinações da produção. O mesmo procede para as novas combinações de produção inovações.

Então, como são determinadas as necessidades que "puxam" as novas combinações de produção? Essa questão já foi levantada por Dosi (1982, p. 148), quando o autor apontou as seguintes perguntas: por que certos desenvolvimentos tecnológicos emergem ao invés de outros? Existe uma ordem no processo de geração de novas tecnologias e no progresso técnico após? Existe alguma regularidade nos relacionamentos funcionais entre os vastos fatores econômico, social, institucional e científico, os quais são prováveis influências no processo de inovação?

No ímpeto de responder estas questões, inicialmente, até meados da década de 1960, apresentavam-se duas teorias sobre a determinação das necessidades de inovação, sendo estas: a teoria do impulso pela tecnologia - technology-push ou science-push - e a teoria da indução pela demanda - demand-pull (DOSI, 1982).

$\mathrm{Na}$ teoria do impulso pela tecnologia, definia-se que a ciência assumia o direcionamento das mudanças técnicas. Esta teoria adotava uma visão unidirecional e linear, apresentando a seguinte sequência: pesquisa básica, pesquisa aplicada, desenvolvimento experimental, produção e mercado. Assim, nestes termos, a necessidade para inovação era 
resultante de novos conhecimentos adquiridos em pesquisas e aplicados por cientistas e engenheiros.

Por sua vez, a teoria da indução pela demanda apontava as forças do mercado como determinantes no processo de inovação. As unidades produtoras do mercado supostamente reconhecem as necessidades, e, assim, "tomam medidas para satisfazê-las através das suas atividades tecnológicas" (MOWERY; ROSENBERG, 1979 apud DOSI, 2006, p. 31). Conforme esta teoria, no mercado existem bens finais que satisfazem as necessidades dos consumidores ou usuários, os quais expressam as suas preferências através de padrões de demanda. Essa demanda é determinada pelas dimensões de utilidade conferidas pelo consumidor/usuário, revelando quais bens ou características satisfazem mais suas preferências. Os produtores do mercado monitoram quais utilidades apresentam maior peso para os consumidores e a inovação parte deste ponto. Assim, essa teoria sustenta que o mercado está "puxando" a atividade de inovação conforme a demanda dos consumidores (DOSI, 1982).

Estas proposições avançaram conforme o tempo e as experiências implicavam em ajustes nos seus conceitos. Entretanto, algumas críticas importantes foram levantadas sobre estas duas teorias. Por exemplo, na teoria da demanda, mesmo que o consumidor esteja atrelado ao processo de produção, as necessidades para seleção de inovações não surgem espontaneamente nos consumidores, fazendo com que o aparato produtivo se modifique sob sua pressão.

Essas mudanças [...] aparecem na esfera da vida industrial e comercial, não na esfera das necessidades dos consumidores de produtos finais.

[...] razão pela qual desprezaremos qualquer espontaneidade das necessidades dos consumidores que possa existir de fato, e admitiremos que os gostos são "dados".

[...] é o produtor que, via de regra, inicia a mudança econômica, e os consumidores são educados por ele, se necessário; são, por assim dizer, ensinados a querer coisas novas, ou coisas que diferem em um aspecto ou outro daquelas que tinham o hábito de usar" (SCHUMPETER, 1982, p. 48).

Sendo assim, a determinação das novas necessidades para iniciar o processo de inovação não cabe aos consumidores, pois estes indivíduos assumem pensamentos que lhes são impostos. Eles aprendem a gostar e a desejar novos produtos que passam a suprir suas aparentes necessidades. Conforme Marcuse (1978), estas necessidades podem ser caracterizadas como "falsas", uma vez que são determinadas por forças externas em 
interesses sociais particulares. Ainda, o autor Dosi $(1982,2006)$ aponta as limitações de definir demandas por funções utilidade, pois o conceito de utilidade pode ser relativo.

Mas, mesmo com essas fragilidades, há o reconhecimento de que a força do mercado é importante para a determinação do sucesso das inovações. O mercado, sob a visão da demanda, assume o papel de dispositivo de seleção final. Mas, ele não é o único fator determinante e, talvez, nem o principal.

No processo de inovação, deve-se considerar a importância dos fatores econômicos como modeladores da direção da mudança técnica (DOSI, 1982, 2006). E essa é a principal crítica apontada sobre a teoria da tecnologia que colocava a ciência como fonte autônoma da inovação, sem interferência dos fatores econômicos durante esta determinação. Conforme a teoria, a questão da economia apareceria apenas no final da linha unidirecional ciênciatecnologia-produção a fim de viabilizar e a consolidar a inovação. Conforme Gushi (1999, p. 15), nesta teoria, "a lógica econômica seria a de apenas concretizar a incorporação desses desenvolvimentos, pelo menos no curto prazo".

Portanto, esta desconsideração da influência econômica sobre o direcionamento do processo de inovação é uma grande fragilidade na teoria do impulso pela tecnologia. A ciência e a tecnologia não podem ser consideradas neutras ou exógenas na seleção das necessidades para inovação, pois estão sob efeitos de forças econômicas. Por exemplo, Rosenberg (2006) questiona em que termos a ciência pode ser considerada uma força exógena, sem ser submetida a fatores econômicos, enquanto há evidências de que a própria ciência é moldada por estímulos econômicos e pode ser direcionada para gerar maiores contribuições econômicas.

Nesse sentido, o autor Dosi (2006, p. 36) afirma que não é possível aceitar a visão de progresso técnico "dada por Deus, pelos cientistas e pelos engenheiros", parafraseando a economista Joan Robinson. Pois, não se pode desconsiderar a importância dos fatores econômicos no processo de direcionamento das atividades de inovação, haja vista a "complexa estrutura de retroalimentação entre o ambiente econômico e as direções das mudanças tecnológicas".

De forma geral, todo o processo de produção, incluindo a determinação das necessidades para inovação, é veementemente determinado pela lógica desse sistema econômico. Toda produção envolve selecionar possibilidades e renúncias. O papel da tecnologia envolve a busca de soluções para problemas e necessidades. E, estas decisões e 
ponderações estão subordinadas ao comportamento econômico existente. Assim, se estas estão em conformidade aos fatores econômicos, então são levadas à prática e são produzidas no sentido tecnológico. O contrário também ocorre, algumas necessidades selecionadas podem ser impedidas pelo sistema (SCHUMPETER, 1982).

Deste modo, além da determinação da necessidade geral que "puxa" a inovação, durante cada etapa deste processo, seguindo a corrente ciência-tecnologia-produção, ocorrem seleções de paradigmas e trajetórias tecnológicas. Esta seletividade vai aumentando com o passar dos níveis desta corrente. Em um primeiro nível de seleção, a ciência busca resoluções para problemas/necessidades determinados e estabelece um paradigma científico, ou seja, um padrão de solução para esse problema com base no conhecimento científico. Em outro nível, a tecnologia, de forma similar à ciência, é definida pelo conhecimento prático e teórico-aplicado sobre o processo produtivo. Com esse conhecimento tecnológico, procura-se resoluções técnicas para o problema e define-se um paradigma tecnológico - um modelo, padrão de solução tecnológica. Por fim, a produção é a tecnologia "incorporada em dispositivos e equipamentos", onde novamente se seleciona elementos, componentes, métodos produtivos. Assim, é definida a trajetória tecnológica para a necessidade determinada (DOSI, 1982, 2006).

Nesse processo, há diversas possiblidades ou paradigmas tecnológicos, e, em consequência, há diferentes trajetórias, isto é, direções tecnológicas para a resolução do problema. Por isso, a questão ainda permanece: por que um paradigma é selecionado dentre vários excluídos? Como ele foi "preferido" dentre outros paradigmas?

Algumas variáveis influenciam nas decisões do desenvolvimento tecnológico, como o histórico tecnológico e o campo de especialização das organizações envolvidas no P\&D (DOSI, 1982). Mas, conforme já mencionado, a direção tecnológica não é determinada de forma exclusiva e autônoma pela ciência.

[...] essas trajetórias tecnológicas de modo algum são exclusivamente "dadas pelos engenheiros"; [...] elas constituem o resultado final da complexa interação entre alguns fatores econômicos fundamentais (busca de novas oportunidades de lucro e de novos mercados, tendências de economia de custo e automação etc.), junto com poderosos fatores institucionais (os interesses e as estruturas das empresas existentes, os efeitos dos órgãos governamentais, os padrões do conflito social etc.) (DOSI, 2006, p. 290).

Novamente, os indicadores econômicos funcionam como dispositivos direcionais entre possíveis escolhas tecnológicas. "A seleção é feita a cada nível, desde a pesquisa até os 
esforços tecnológicos relativos à produção, entre as possíveis "trajetórias", com base em certos critérios evidentes e amplos, como exequibilidade, negociabilidade, rentabilidade" (DOSI, 2006, p. 48). Por exemplo, no critério da potencial rentabilidade, uma seleção ocorre considerando os custos envolvidos na nova tecnologia. Entre estes, os custos referentes a mão-de-obra, em certos setores, são elevados. Portanto, para economizar com a mão-deobra, o paradigma e sua trajetória selecionam inovações que incorporem a mecanização da produção, reduzindo a mão-de-obra e garantindo o lucro.

Ainda, é importante ressaltar que, aliados às forças econômicas, os fatores institucional e social também atuam como dispositivos seletivos dos paradigmas tecnológicos. São fatores poderosos nesta seletividade, onde estão presentes, por exemplo, os interesses das empresas já existentes e estruturadas, os efeitos das ações dos órgãos governamentais e os padrões do conflito social (DOSI, 2006). Ou seja, dentro da lógica do sistema econômico, a necessidade, "mãe das invenções", está fortemente vinculada à necessidade de manter e expandir o aparato de produção, isto é, instituições, dispositivos e organizações da indústria. No fim, pode-se dizer que a "invenção é a mãe da necessidade" (MARCUSE, 1997, p. 119).

Portanto, pode-se concluir que a tecnologia não é autônoma. "A tecnologia é moldada por fatores sociais. A tecnologia é um produto da sociedade e é influenciada por normas e valores do sistema social" (ROGERS, 1995, p. 139). Desta forma, o progresso tecnológico não é neutro. A necessidade passa a ser determinada pela racionalidade tecnológica, com a padronização dos pensamentos sob o controle do aparato produtivo, sob contextos econômicos, políticos e sociais.

\subsection{PROCEDIMENTOS PARA O DESENVOLVIMENTO DE INOVAÇÃO TECNOLÓGICA}

As atividades de inovação tecnológica são o conjunto de etapas científicas, tecnológicas, organizativas, financeiras e comerciais, incluindo os investimentos em novos conhecimentos, que levam ou que tentam levar à implementação de produtos e de processos novos ou melhorados. (OCDE, 2007)

Conforme os diferentes segmentos da indústria, as atividades do processo de desenvolvimento de inovação assumem certas especificidades. Este item apontará de forma resumida as etapas gerais do modelo descrito por Rogers (1995) para inovação de um produto 
genérico. Além deste, outros autores aprimoraram este modelo, especialmente na área da engenharia de produção.

Para Rogers (1995), o processo de desenvolvimento de uma inovação tecnológica consiste em seis fases principais: (1) reconhecimento de uma necessidade ou de um problema, (2) pesquisa, (3) desenvolvimento, (4) comercialização, (5) difusão e adoção, e, por fim, (6) suas consequências (Figura 5). Observa-se que essas fases nem sempre ocorrem nesta sequência linear ou nesta ordem específica. E cada etapa pode ser decomposta em diferentes atividades.

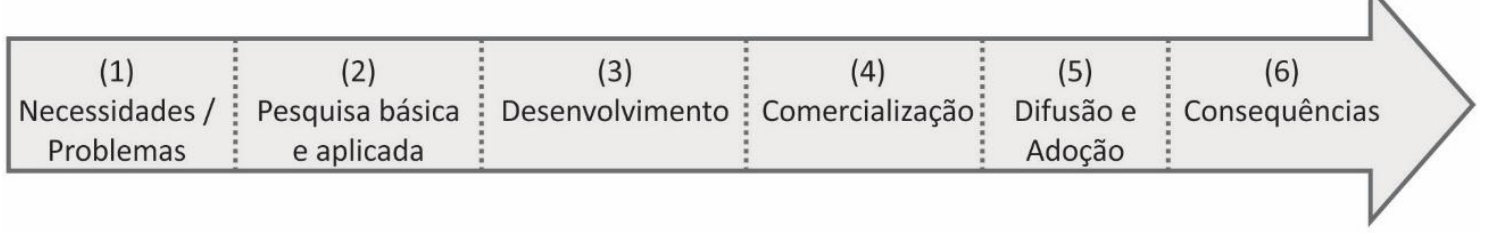

Figura 5: Principais fases do processo de desenvolvimento de uma inovação Fonte: Rogers, 1995.

A primeira fase é iniciada com o reconhecimento de um problema ou de uma necessidade. Conforme já discutido no item anterior deste capítulo, alguns autores acreditam que as forças do mercado são predominantes nesta etapa. Enquanto outros, incluindo Rogers (1995), afirmam que as necessidades podem ser constatadas em pesquisas científicas sobre problemas urgentes presentes na sociedade ou pressupostos problemas futuros. Ambos fatores são importantes para diagnosticar necessidades, porém não são exclusivos na determinação da seleção da necessidade. Novamente, ressalta-se a importância da atuação das forças econômicas, institucionais e sociais sobre tal determinação.

Após a fase de reconhecimento da necessidade selecionada, atividades de pesquisa e desenvolvimento (P\&D) são estimuladas para buscar soluções e resoluções tecnológicas. Assim, na segunda etapa, a necessidade elencada passa a ser investigada com maior profundidade mediante pesquisas básicas e aplicadas para ampliar o conhecimento sobre os fatos. As pesquisas básicas referem-se a investigações iniciais que ainda não apresentam o objetivo de aplicar o conhecimento para solução de problemas práticos. Em contrapartida, as pesquisas aplicadas consistem em investigações científicas que têm como objetivo solucionálos de forma prática. Assim, em geral, afirma-se que a inovação pode ser resultante da 
sequência de pesquisa básica, seguida pela pesquisa aplicada, que leva ao desenvolvimento, próxima etapa deste processo. Nesse conceito, aponta-se a íntima relação entre pesquisa e desenvolvimento, que são distintas nas funções, porém, interdependentes (ROGERS, 1995).

Antes de iniciar os projetos de desenvolvimento, alguns estudos são realizados, incluindo: análise da necessidade e existência econômica; identificação e formulação técnica do problema; análise das exequibilidades física, econômica e financeira (ASIMOW, 1962 apud SABBATINI, 1989).

Na sequência, a etapa de desenvolvimento da inovação é definida como "o processo de colocar uma nova ideia de uma forma que é esperada para satisfazer as necessidades do público com potencial de adoção" (ROGERS, 1995, p. 137). Esta fase ocorre com base nas pesquisas anteriormente realizadas, que levantaram dados como, por exemplo, requisitos de desempenho técnico, materiais e componentes, métodos de produção, patentes existentes, normas e regulamentos, políticas públicas.

No desenvolvimento da inovação de um produto, são realizadas atividades como projetos para o produto e para a sua respectiva produção. Por exemplo, em um projeto preliminar são realizados: seleção da concepção experimental, formulação analítica, estabelecimento de parâmetros de produto, ajustamento dos parâmetros, otimização e estabelecimento da solução, previsão do desempenho do sistema, avaliação da concepção, simplificação de solução. E, no projeto detalhado, apontam-se estas tarefas: desenvolvimento das concepções gerais, projeto geral de subsistemas, componentes e partes, projeto montagem, construção de protótipos, testes de protótipos, analise e previsão de desempenho, reprojeto (ASIMOW, 1962 apud SABBATINI, 1989, p. 100).

Com os projetos finalizados, sua materialização ocorre principalmente na fase de comercialização. Para Rogers (1995), esta fase engloba atividades de produção, fabricação, embalagem, marketing e distribuição.

Finalizando o processo da inovação, Rogers (1995) inclui a fase de difusão e adoção. Neste caso, a difusão não significa apenas a disseminação da inovação proposta, mas referese à comunicação que ocorre entre agentes e sociedade sobre o novo bem/produto. Além da persuasão sobre o cliente para que adote a inovação, a comunicação, quando visa trocas de informação, pode fornecer dados para possíveis aprimoramentos da inovação. A difusão é considerada muito importante pelo autor, pois, reflete diretamente na fase final que corresponde às consequências desta inovação, a qual pode ser adotada ou rejeitada pela 
população. A partir deste resultado, mudanças relativas à inovação podem ocorrer no indivíduo e na sociedade, que estão entre uns dos responsáveis para a perpetuação da inovação.

Tal processo de desenvolvimento da inovação é um processo dinâmico. No seu estágio inicial, a inovação está num estado fluido, onde incertezas de objetivos e de técnicas fazem com que ocorram frequentes mudanças importantes tanto no processo de produção, quanto no produto. Os custos nesta fase inicial ainda permitem tal flexibilidade. Em um estágio posterior, transitório, as mudanças não ocorrem mais com tanta facilidade quanto anteriormente. Pois, com o projeto do produto definido e instituído no mercado, também chamado de projeto dominante, e com a produção bem delineada, os custos das mudanças podem ser onerosos. Por fim, a dinâmica do processo de inovação finaliza ou minimiza quando os produtos já estão padronizados, altamente definidos e consolidados. Como os vínculos entre produto e processo de produção se tornam cada vez mais estreitos e interdependentes, qualquer mudança em ambos afeta o outro, implicando em dificuldades técnicas e elevação nos custos (UTTERBACK, 1996).

Esta dinâmica é importante na introdução de determinada inovação tecnológica no mercado, pois permite alterações e correções para garantir seu aprimoramento, visando qualidade e eficiência. Mas, deve ser feita no princípio da disseminação da inovação, para não ter custos muito elevados quando já está consolidada e para não criar preconceitos populares diante de questões duvidosas para o consumidor final.

\subsection{AGENTES DETERMINANTES NO PROCESSO DE INOVAÇÃO}

Na teoria de Schumpeter (1982), um primeiro agente na realização de novas combinações é quem o autor chama de "empresários", ou seja, são os indivíduos cuja função é realizá-las. Nesta definição, ser um empresário não significa uma profissão, nem uma condição duradoura.

[...] alguém só é um empresário quando efetivamente "levar a cabo novas combinações", e perde esse caráter assim que tiver montado o seu negócio, quando dedicar-se a dirigi-lo, como outras pessoas dirigem seus negócios.

[...] Portanto, finalmente, os empresários são um tipo especial e o seu comportamento um problema especial, a força motriz de um grande número de fenômenos significativos (SCHUMPETER, 1982, p. 56, 58). 
Para Schumpeter $(1982$, p. 56) realizar novas combinações na produção "é um processo especial", pois não é uma tarefa simples e fácil, e, por isso, passa a ser objeto de um "tipo especial de "função"”, exercida pelo "empresário". O autor esclarece porque considera esta função especial. Enquanto está no fluxo circular fechado da economia, o indivíduo está habituado a agir pronta e racionalmente. Não requer esforço continuar no estado de equilíbrio deste fluxo; suas aptidões e experiências bastam.

É assim porque todo conhecimento e todo hábito, uma vez adquirido, incorporam-se tão firmemente em nós como um terrapleno ferroviário na terra. Não requerem ser continuamente renovados e conscientemente reproduzidos, mas afundam no estrato do subconsciente. São transmitidos normalmente, quase sem conflitos, pela herança, pelo ensino, pela educação, pela pressão do ambiente. Tudo que pensamos, sentimos ou fazemos muito torna-se frequentemente automático, e nossa vida consciente fica livre desse esforço (SCHUMPETER, 1982, p. 60).

Entretanto, sair da rotina para realizar novas combinações requer um enorme esforço, pois está contra ou fora da corrente do fluxo normal. Além das fronteiras da rotina, o indivíduo enfrenta obstáculos, incógnitas. Muitas pessoas veem quando novas possiblidades se apresentam, mas não as enfrentam. Aquele que assume esse processo especial tem a função especial de líder, "um gênero especial de conduta" (SCHUMPETER, 1982, p. 61). Este encontra inúmeras dificuldades no processo de inovação. Entre estas, o autor aponta três pontos principais: estar fora dos canais habituais, a psique do homem de negócios e a reação do meio ambiente social.

Primeiro, estar fora dos canais habituais deixa o indivíduo desprovido de regras de conduta e de dados para as tomadas de decisões. Assim, ele está exposto às incertezas e está propenso a cometer erros em maior grau. Deve, por isso, examinar exaustivamente os efeitos prós e contras da inovação proposta. Isso requer um conhecimento intelectual especializado profundo e meticuloso (SCHUMPETER, 1982).

Segundo, a psique do indivíduo que assume a inovação o deixa relutante em realizar tal tarefa especial. Pois, seus pensamentos voltam repetidamente aos hábitos arraigados que não requerem esforço.

É, portanto, necessário uma força de vontade nova e de outra espécie para arrancar, dentre o trabalho e a lida com as ocupações diárias, oportunidade e tempo para conceber e elaborar a combinação nova e resolver olhá-la como uma possibilidade real e não meramente como um sonho. Essa liberdade mental pressupõe um grande excedente de força sobre a demanda cotidiana e é algo peculiar e raro por natureza (SCHUMPETER, 1982, p. 61). 
Por fim, terceiro, a reação do ambiente social exerce pressão sobre o indivíduo. Qualquer desvio do costume social causa estranhamento, desperta oposição e é condenado. Pode se manifestar com impedimentos legais ou políticos. Porém, mesmo quando as oposições não estão materializadas, estas estão presentes e trazem consequências negativas nos procedimentos de realizar cooperações necessárias para executar o projeto e de conquistar os consumidores. Portanto, o líder é o indivíduo que transpassa tais estranhamentos e assume o caminho especial para inovação (SCHUMPETER, 1982).

No entanto, apesar de Schumpeter denominar um indivíduo como responsável pelo processo de inovação, ressalta-se que este caminho para novas combinações não é trilhado só. No seu parecer, a empresa é a agente central nesse processo, mas está inclusa em um ambiente institucional e sob suas influências.

Os estudiosos desse tema, que analisavam a estrutura do mercado e sua influência prioritária sobre as inovações industriais, com o tempo, reconheceram que era necessário ter habilidades, treinamento e conhecimento sobre ciência e engenharia para efetivar as inovações. Nesse sentido, concluíram que o P\&D para a indústria era importante, visando sua competitividade no mercado (DOSI et al., 1988). Como consequência, em especial nos países desenvolvidos, muitos centros de ciência e tecnologia foram instalados dentro e fora das indústrias.

Mas, gradualmente, com novas experiências efetivadas, os teóricos foram percebendo que a problematização sobre o processo da inovação é ainda mais complexa e vai além das forças do mercado e da ciência. Portanto, no início da década de 1970, sua compreensão foi aprimorada, quando passaram a entender que as inovações são resultantes de um conjunto de atividades interligadas, de "um processo de aprendizado interativo, não-linear, cumulativo, específico da localidade e conformado institucionalmente" (CASSIOLATO; LASTRES, 2007, 2005, p. 35). E, para a realização destas atividades, além da empresa e das instituições de pesquisa, outros agentes estão presentes neste processo.

A partir desse novo entendimento do processo de inovação, em meados da década de 1980, foi adotada a visão de "sistemas de inovação", introduzida na coletânea acadêmica intitulada Technical Change and Economic Theory, de Dosi et al. (1988), com destaque aos autores Christopher Freeman, Bengt-Ake Lundvall e Richard Nelson. Em geral, esta visão sistêmica vem abordando as possíveis relações econômicas, políticas e sociais entre a empresa e demais organizações para promover as inovações (CASSIOLATO; LASTRES, 2005). Assim, o 
sistema de inovação compreende "um conjunto de instituições distintas que contribuem para o desenvolvimento da capacidade de inovação e aprendizado de um país, região ou localidade" (CASSIOLATO; LASTRES, 2003, p.24).

Essa abordagem sistêmica é importante para compreender que, apesar da empresa geralmente ser o ponto central, todo o processo de inovação depende de articulações entre um conjunto de agentes de diversas esferas, incluindo empresas produtoras, empresas fornecedoras, empresas consultoras, instituições de ensino e de pesquisa, instituições financeiras, agentes reguladores, organizações governamentais, conforme constatam os autores Cassiolato e Lastres (2003, p. 24):

[...] o desempenho inovativo de uma economia como um todo depende não apenas do desempenho de organizações específicas, como empresas e organizações de pesquisa, mas também de como elas interagem entre si e com o setor governamental, na produção, distribuição e uso de conhecimentos, em prol da competitividade, crescimento econômico e bem estar social.

Portanto, para viabilizar as inovações é necessário criar condições organizacionais e institucionais compatíveis, onde a empresa passa a interagir dinamicamente com os demais agentes deste sistema. Mas, esta relação varia muito conforme país, região ou local, dependendo das bases social, cultural, política e econômica.

Neste aspecto, ao analisar o cenário do desenvolvimento tecnológico na América Latina, os autores Sábato e Botana (1975) apontam a articulação entre as seguintes esferas: infraestrutura científico-tecnológica, estrutura produtiva e instituições governamentais. Em um modelo que ficou conhecido como "Triângulo de Sábato" esta relação é esboçada com a ligação entre infraestrutura científico-tecnológica e estrutura produtiva na base e o governo no vértice superior deste triângulo (Figura 6).

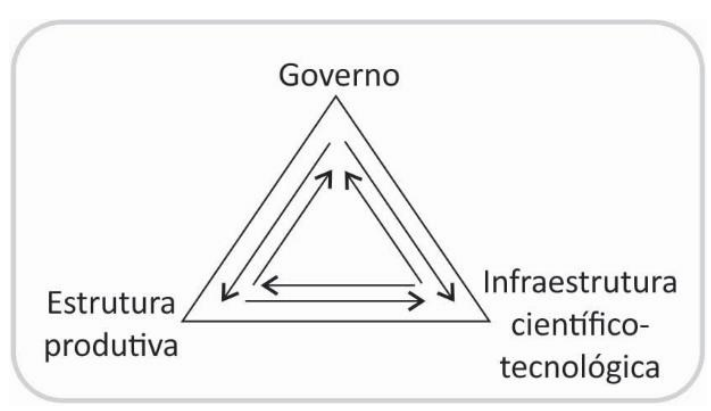

Figura 6: Triângulo de Sábato

Fonte: adaptado de Sábato e Botana, 1975. 
$O$ vértice da infraestrutura científico-tecnológica representa o sistema educacional que forma cientistas, tecnólogos, assistentes, operários, administradores, e também os centros de P\&D, incluindo, por exemplo, os laboratórios das universidades e dos institutos de pesquisa, que incorporam conhecimento para novos sistemas de produção. O objetivo destas instituições é planejar, promover, coordenar e estimular a pesquisa. Para isso, são regidas por mecanismos jurídico-administrativos e necessitam de recursos financeiros para o cumprimento das atividades programadas (SÁBATO; BOTANA, 1975).

Por sua vez, o vértice da estrutura produtiva corresponde ao conjunto de setores produtivos que provêm bens e serviços à sociedade. E, por fim, o vértice do governo compreende o conjunto de instituições que tem como objetivo formular políticas e mobilizar recursos para os demais vértices. Também, estabelece processos legislativo e administrativo sobre os mesmos. Ainda, pode formular princípios e estratégias para fixar metas que estimulam e impulsionam a inovação. E, mediante decisões políticas, designam recursos e elaboram programações para a ciência e tecnologia para este fim (SÁBATO; BOTANA, 1975).

As organizações e instituições são categorizadas nesses vértices conforme suas funções. Cada vértice é o centro de convergência de diversas instituições, unidades de decisão e de produção e realização de atividades. Por isso, as relações entre os diferentes vértices apresentam diferentes dimensões. Este triângulo se estabelece pela ocorrência de três tipos de relações principais: primeiro, dentro de cada vértice - intra-relações; segundo, entre vértices - inter-relações; e terceiro, entre os três vértices - extra-relações. Estas variam conforme seus agentes e seus fluxos de demanda. Estas articulações são caracterizadas conforme os diferentes setores econômicos de determinado local (SÁBATO; BOTANA, 1975).

Além do Triângulo de Sábato, outros modelos passaram a reconhecer a importância destas relações entre indústria-governo-universidade. Entre estes, o mais disseminado foi estabelecido por Leydesdorff e Etzkowitz em meados da década de 1990 denominado "Hélice Tríplice". Neste modelo, a hélice tríplice é uma plataforma para as interações entre diferentes organizações com finalidade de promover a inovação. A hélice é composta por diversos espirais que representam as relações dinâmicas entre as esferas. E, cada uma destas três esferas institucionais tem sua missão, seu papel, os quais em determinadas relações podem se sobrepor em diferentes graus. Em resumo, nos papéis primários atribuídos, a indústria é o lócus da produção, o governo é a fonte de regulamentação e relações contratuais e a 
universidade é a geradora de conhecimento, fonte de investigações críticas, tecnologia e empreendedorismo (ETZKOWITZ; LEYDESDORFF, 2000, ETZKOWITZ, 2009).

Neste caso, acredita-se que estas esferas institucionais fomentam a cooperação para inovação. Assim, "a interação entre universidade, indústria e governo é a chave para a inovação e o crescimento em uma economia baseada no conhecimento". Mas, dependendo do regime local, a esfera que assume o papel central desta hélice pode alterar. Por exemplo, em um regime laissez-faire, a indústria é a força impulsionadora deste processo de inovação; enquanto, em um regime estatista, é o governo que assume o papel de liderança neste processo. Entretanto, nas sociedades baseadas em conhecimento, a universidade ou outras instituições produtoras de conhecimento apresentam o papel chave desta hélice, tendo a responsabilidade de transferir a tecnologia. Esta última abordagem é a adotada na visão da hélice tríplice (Figura 7) (ETZKOWITZ; LEYDESDORFF, 2000, ETZKOWITZ, 2009).

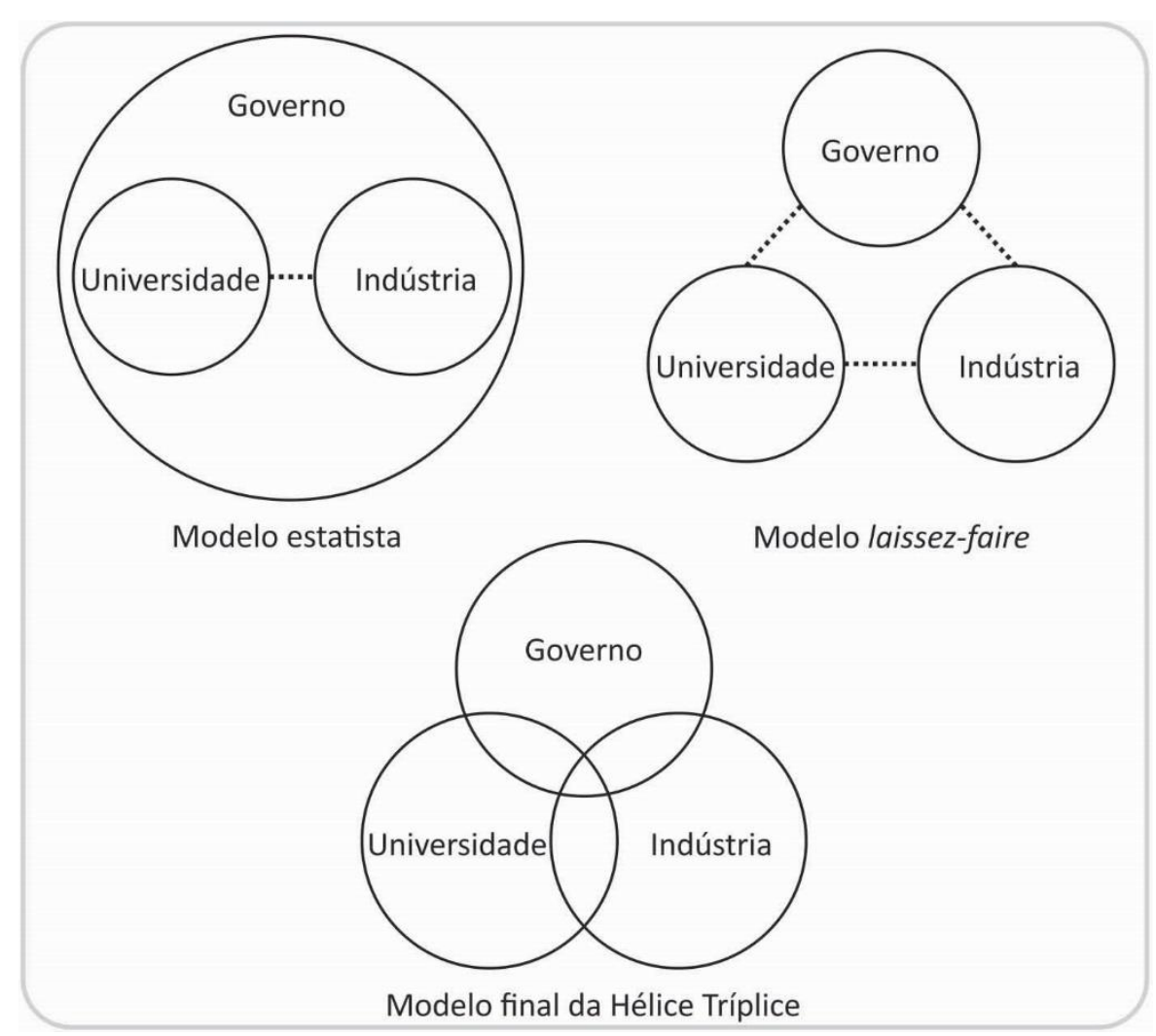

Figura 7: Modelos estatista e laissez-faire das relações governo-universidade-indústria Fonte: Etzkowitz, 2009.

Novamente, salienta-se que estas abordagens dependem dos contextos político, econômico, cultural e social. Sobre o cenário brasileiro, algumas análises apontam como vem 
ocorrendo, em geral, o comportamento destas relações entre indústria-governo-universidade para promover as inovações tecnológicas e o desenvolvimento econômico do país (NEGRI; KUBOTA, 2008).

No entanto, as pesquisas brasileiras do setor da construção civil carecem desta análise sistêmica, especialmente avaliando quem são seus agentes inerentes e como estes interagem entre si para promover a inovação tecnológica destas indústrias. Questiona-se o motivo que fundamenta a aplicação de um produto ou um método inovador neste setor - por que uns são plenamente efetivados no mercado enquanto outros não. Nesse sentido, a fundamentação apresentada neste primeiro capítulo poderá auxiliar nesta análise de determinações das mudanças técnicas na indústria da construção civil brasileira.

Seguindo esta fundamentação aqui explanada, nos capítulos seguintes, espera-se esboçar sobre a ocorrência do processo de produção e mudanças técnicas neste setor, onde o comportamento econômico e as influências institucionais determinam as necessidades e os paradigmas tecnológicos. 


\section{O PROCESSO DE INOVAÇÃO TECNOLÓGICA NA CONSTRUÇÃO CIVIL}

Este capítulo tem como objetivo apresentar como vem ocorrendo o processo de mudanças técnicas na construção civil brasileira. Assim, com base nas abordagens das teorias econômicas apontadas no capítulo anterior, procura-se aplicar uma visão mais sistêmica para analisar a produção deste setor, em especial, nos processos de inovações direcionados às habitações. Para isso, inicialmente, caracterizam-se quais aspectos podem ser inovados na indústria da construção civil. Na sequência, apresenta-se um modelo teórico com as etapas de desenvolvimento descritas para produtos e processos construtivos inovadores. E, por fim, são elencados os principais agentes e fatores institucionais que vem sendo determinantes para a seleção das necessidades e dos paradigmas tecnológicos na construção brasileira.

\subsection{CARACTERIZAÇÃO DA INOVAÇÃO NA CADEIA DA CONSTRUÇÃO CIVIL}

A inovação tecnológica na indústria da construção de edifícios é definida por Sabbatini (1989) como a incorporação de um "novo" componente, elemento, sistema ou método construtivo que representa avanços significativos em termos de desempenho, qualidade ou custo. Conforme já esclarecido previamente, o adjetivo novo não necessariamente significa uma invenção ou uma criação de algo completamente inexistente. Mas o "novo" indica algo que é desconhecido na percepção do usuário ou consumidor final, ou que é aplicado para outro fim, ou que é aplicado em um contexto diferente.

Entretanto, além de produtos e de métodos construtivos definidos por Sabbatini (1989), outros fatores podem ser inovados na indústria da construção. No capítulo anterior, o Manual de Oslo, baseado nas premissas de Schumpeter, categorizou as inovações referentes a produto, processo, organização ou marketing. Com base neste manual, a Câmara Brasileira da Indústria da Construção (CBIC) assumiu uma definição similar para seu setor salientando quatro possibilidades de inovação, definidos a seguir (MONTEIRO FILHA et al., 2010):

(a) inovações de produto: referem-se ao produto edifício ou a um ou mais de seus subsistemas, componentes ou materiais;

(b) inovações de processo: são aquelas que inovam o processo de produção dos edifícios; 
(c) inovações organizacionais: são as que afetam a organização das empresas e seus processos que não estão diretamente relacionados à produção;

(d) inovações de marketing: novas formas de relacionamento com os clientes, promoção dos produtos, comunicação com o mercado.

Ainda, o Banco Nacional do Desenvolvimento (BNDES) amplia estas categorias elencadas, acrescentando como estes podem ser realizados (MONTEIRO FILHA et al, 2010):

(a) A inovação no produto edificação visa agregar requisitos de desempenho ao mesmo, mediante novos materiais, componentes ou sistemas construtivos ou por inovações de projetos;

(b) Revoluções ou mudanças incrementais no processo de produção são decorrentes de inovações de materiais, componentes ou subsistemas construtivos, de equipamentos e ferramentas ou de fornecimento de materiais;

(c) Inovações na organização das empresas, geralmente, estão relacionadas aos seus processos internos, como administrativo ou atendimento ao cliente. Estas mudanças organizacionais podem ocorrer com a implantação de softwares, novos arranjos de trabalho com fornecedores, novas formas de prestação de serviços;

(d) Nas inovações de marketing podem ser elaboradas novas formas para visualização de especificações e projetos, novos métodos para visualização dos produtos, a fim de promovê-los no mercado.

Percebe-se nestas especificações do CBIC e do BNDES que, além da edificação como produto alvo, a indústria da construção agrega outros setores e atividades, os quais poderiam ser considerados com mais minúcia na questão das novas combinações produtivas. No entanto, em estudos gerais sobre o assunto, pode ser difícil explicitar ou enquadrar com precisão cada categoria de inovação, haja vista a amplitude e o grau de complexidade do setor da construção civil.

A Construção Civil engloba agentes e atividades ligados à indústria de materiais, componentes e sistemas; comércio atacadista e varejista a ela relacionado; setores de serviços técnicos especializados de projeto e engenharia consultiva; construção de edifícios e obras de infraestrutura; setores de serviços financeiros, imobiliários, de manutenção e de reforma, demolições e reconstruções; e setores de serviços laboratoriais, pesquisa e desenvolvimento e capacitação profissional (CARDOSO, 2013a, p. 8).

Com tamanhas especificidades, identificar e mensurar quais necessidades de transformações produtivas nesta indústria pode ser considerada uma tarefa árdua. Dentro de 
um macro setor, questiona-se o que poderia ser inovado na construção civil. Para obter essa resposta, desmembrar a indústria da construção em uma visão sistêmica dos seus setores pode ser interessante para compreender onde e como se inserem suas atividades, tanto no seu aspecto geral, quanto em casos específicos, como, por exemplo, o setor de construção em madeira.

Tal necessidade de decompor conceitualmente os segmentos da indústria da construção no Brasil ocorreu em meados da década de 1980 (MARTUCCI, 1990). Neste período, a crise econômica do país atingia a construção civil, reduzindo seus investimentos e desacelerando o setor. Essa situação indicava a necessidade de transformações ou inovações que propulsionassem seu desenvolvimento tecnológico. Assim, na busca por este crescimento econômico, a visualização do setor sob aspectos das atividades de produção possibilitaria novas análises para compreender sua situação a fim de promover possíveis mudanças além das proposições específicas para os bens finais.

Atualmente, esta estrutura setorial da indústria da construção está modelada como cadeia produtiva. Os modelos mais reconhecidos desta cadeia foram desenvolvidos pelo Departamento da Indústria da Construção (DECONCIC) da Federação das Indústrias do Estado de São Paulo (FIESP) e pela Associação Brasileira da Indústria de Materiais de Construção (ABRAMAT), com objetivo de diagnosticar entraves e melhorar a competitividade do setor (FIESP, 2016, ABRAMAT, 2011).

Em geral, a cadeia produtiva adotada pelos diversos setores industriais refere-se a um "conjunto de etapas consecutivas pelas quais passam e vão sendo transformados e transferidos os diversos insumos, em ciclos de produção, distribuição e comercialização de bens e serviços" (CASSIOLATO; LASTRES, 2003, p. 5). De forma similar, o conceito para cadeia produtiva da construção é assim descrito:

Por trás de um edifício pronto, há um complexo processo de produção, que envolve elos da indústria da construção, da indústria de materiais, do comércio, dos serviços e da indústria de equipamentos. O conjunto desses elos é chamado de cadeia produtiva (ABRAMAT, 2011, p. 56).

Sobre a contribuição do enfoque da cadeia produtiva, Castro e Lima (2003, p. 5) mencionam como esta organização é útil para análise e compreensão dos macroprocessos de produção, examinando seu desempenho, levantando gargalos e oportunidades ainda não exploradas nos processos produtivos. 
De forma similar, uma análise prospectiva da cadeia de produção da construção tem como intuito: modelar seu sistema industrial composto por elos e segmentos interligados, analisar seu comportamento e desempenho, identificar fatores críticos e necessidades, identificar demandas tecnológicas como orientação para busca de inovações e demandas não tecnológicas, tais como oportunidades, ameaças e ações possíveis para melhoria de seu futuro desempenho (CARDOSO; ABIKO; GONÇALVES, 2002).

A cadeia da construção no Brasil apresenta a seguinte sequência de etapas produtivas: extração da matéria-prima, transformação e produção de materiais, componentes e sistemas construtivos, comercialização e prestação de serviços diretos e, por fim, construção dos bens finais comercializados para o consumidor. Em paralelo, foram acrescentadas quatro áreas transversais: engenharia e arquitetura, serviços técnicos especializados, máquinas e equipamentos e normalização e certificação (FIESP, 2016).

O mapeamento geral desta cadeia pode ser observado na Figura 8 ao apresentar os seus principais elos, segmentos e suas interligações. Primeiro, a matéria-prima é extraída. $\mathrm{Na}$ sequência, é transformada em materiais, componentes e, em alguns casos, sistemas construtivos, como pré-moldados, pré-fabricados. Estes produtos intermediários são comercializados em varejo por lojas de materiais de pequeno e médio porte, em atacado ou diretamente às construtoras. A construção/montagem é realizada por construtoras ou por autogestão e autoconstrução, ou seja, por "iniciativa das próprias famílias, que contratam a mão de obra e/ou realizam pessoalmente os serviços necessários". Nesse ínterim, ocorrem operações de intermediação financeira da produção e da comercialização por meio de agentes de serviços bancários e de financiamento. Por fim, os bens finais - edificações, construção pesada e montagem industrial - chegam ao consumidor ou usuário.

Conforme destacado pela Federação das Indústrias do Estado de São Paulo (FIESP, 2016), durante todo esse processo produtivo, outras atividades de suporte e serviços podem ser elencadas, tais como:

- Setor de máquinas e equipamentos: "compreende a fabricação, comercialização, locação, instalação e manutenção de máquinas, equipamentos e ferramentas para atividades industriais, de extração mineral, construção, transporte e elevação de cargas";

- Serviços de engenharia e arquitetura: elaboração, coordenação e gestão de projetos e prestação de consultoria em todas atividades do processo; 
- Serviços de mão-de-obra: refere-se principalmente aos trabalhadores envolvidos nas atividades de execução dos setores de extração, produção na indústria, processo de construção/montagem no canteiro e serviços especializados;

- Serviços técnicos especializados: "envolvem atividades de preparação de terreno, demolição, manutenção, instalações, reformas, etc., e são responsáveis por auxiliar no processo construtivo e expandir o ciclo de vida das edificações";

- Normalização, certificação e gestão da qualidade: empresas e entidades especializadas em normalização, auditoria e certificações, para garantir qualidade e eficiência aos produtos e serviços.

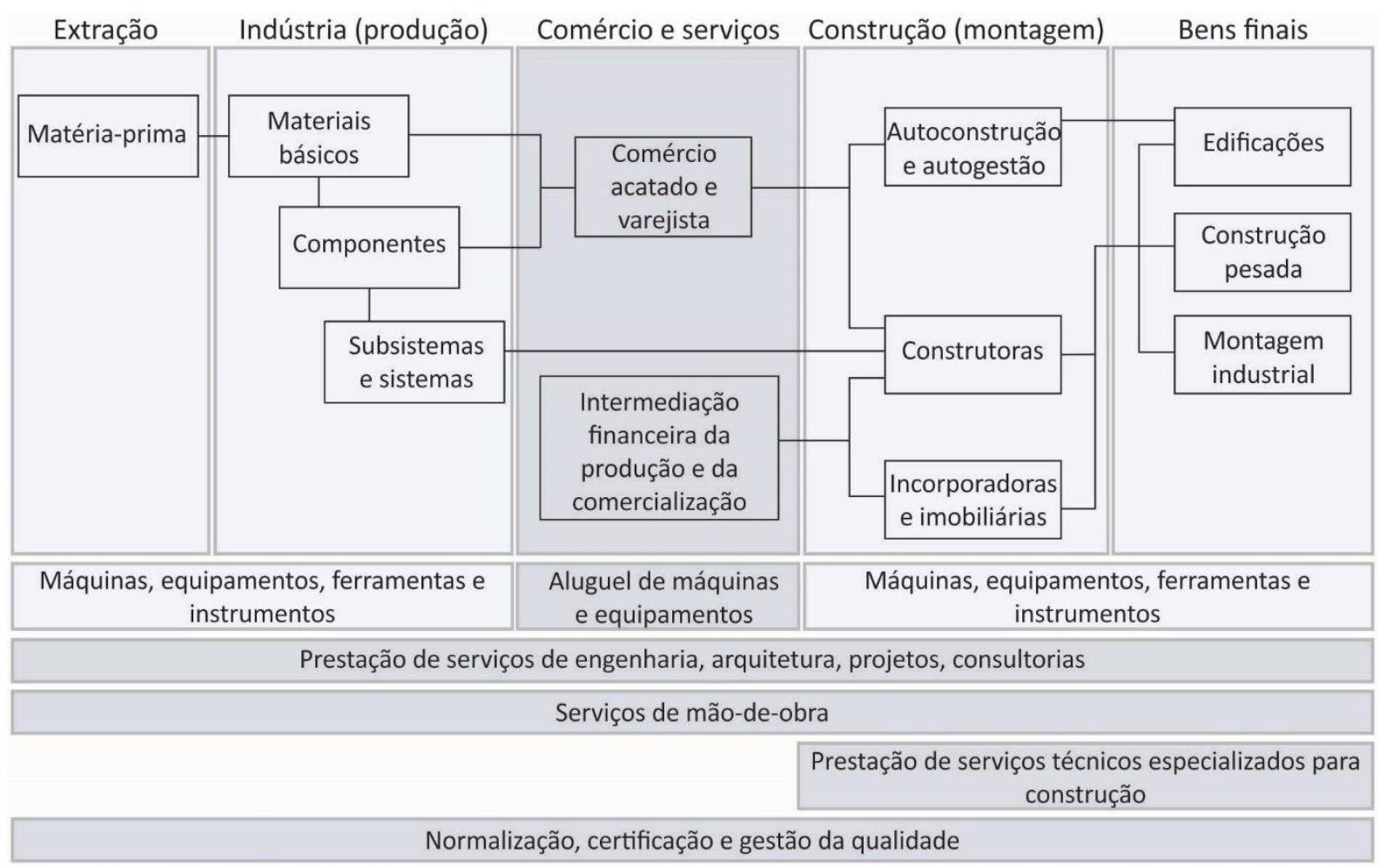

Figura 8: Cadeia produtiva da construção - etapas produtivas, comércio e serviços

Fonte: elaborado pela autora conforme dados de ABRAMAT (2011) e FIESP (2016).

Com estes dados apresentados, o desenho da cadeia busca auxiliar nas análises das situações ocorrentes e nos levantamentos de dados que possibilitam demarcar e propor intervenções para o desenvolvimento tecnológico deste setor, não apenas na produção de insumos ou nas atividades de construção do bem final, mas também nos demais elos relacionados a estes. Também, é significativo avaliar as articulações existentes entres tais operações e entre os elos, como as transações e os fluxos de material e de capital demarcados na Figura 9. 
Nestas articulações, também devem ser considerados os agentes que não estão diretamente presentes nos elos da cadeia de produção, mas que exercem influência sobre os mesmos, inclusive sobre suas necessidades produtivas. Castro e Lima (2003) classificam dois ambientes externos que estão relacionados à cadeia, são estes: ambiente institucional, o qual inclui instituições de normas, leis, políticas e programas institucionais, e ambiente organizacional, incluindo associações de representação, agentes de certificação, centros de ensino, pesquisa e desenvolvimento, centros de capacitação e treinamento (Figura 9). A atuação destas instituições e organizações influenciam na seleção dos paradigmas e na determinação das trajetórias tecnológicas de acordo com contextos econômicos, políticos e sociais, conforme será observado nos itens posteriores deste trabalho.

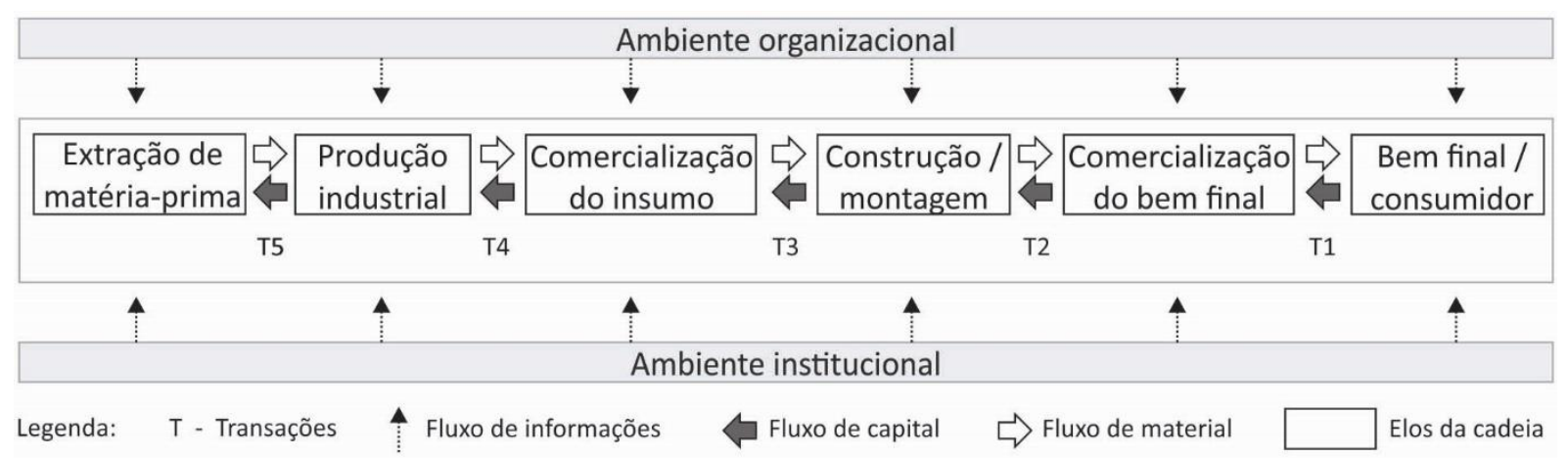

Figura 9: Cadeia produtiva da construção - fluxos e interferências

Fonte: adaptado de Castro e Lima (2003) e Haga (2008).

Por fim, conforme buscou-se delinear neste item, as "novas combinações" produtivas na construção civil compreendem mudanças técnicas em toda a cadeia de produção, incluindo produtos finais ou intermediários, processos de produção, serviços técnicos, atividades de comercialização, organização estrutural das empresas envolvidas. E, para identificar o que poderia ser inovado em determinado segmento da indústria da construção, é preciso analisar seu processo produtivo, decompondo o setor em uma sucessão de atividades até chegar ao bem final - demarcando seus elos, fluxos e transações e identificando seus agentes internos e externos. Este procedimento pode auxiliar para apontar transformações necessárias que possibilitariam melhorar seu desempenho tecnológico.

Após identificar tais possibilidades de transformações, alguns autores propõem métodos para desenvolver e efetivar estas inovações, em especial para bens e processos do setor de edificações, conforme o item seguinte discorrerá. 


\subsection{ETAPAS NO DESENVOLVIMENTO DE PRODUTOS E PROCESSOS INOVADORES}

O processo de inovação tecnológica ocorre através de uma sucessão de estágios. No capítulo anterior, foi demonstrado um processo generalizado para inovação de um produto, incluindo as etapas de: reconhecimento de necessidade, pesquisa básica e aplicada, desenvolvimento, comercialização e difusão. Em uma sequência similar, aplicando ao setor da construção, Sabbatini (1989) propôs um método com uma sequência de eventos e atividades para o processo de desenvolvimento de produtos e processos construtivos inovadores.

A proposta deste autor estava focada na visão de desenvolvimento do setor mediante a racionalização e a industrialização. Naquele período, em meados da década de 1980, estes fatores eram apontados como necessidade para aprimorar os aspectos de desempenho das construções. Desde então, esta temática do desempenho das edificações e de suas partes constituintes permanece entre as necessidades de mudanças técnicas elencadas neste setor e, por isso, este modelo proposto por Sabbatini (1989) mantém sua relevância neste tema, conforme descrito a seguir.

Para a inovação e o desenvolvimento de Métodos, Processos e Sistemas Construtivos (MPSConst), Sabbatini (1989) propôs um plano de ação, como uma estratégia para enfrentar determinado problema. Este plano é dividido em fases, as quais são subdivididas em etapas. Quatro fases principais estão organizadas de acordo com as seguintes funções operacionais:

I. Concepção - coleta e seleção de informações, criação de modelos;

II. Verificação - produção e experimentação do modelo criado na fase anterior;

III. Descrição - consolidação da tecnologia desenvolvida ainda em carácter de pesquisa experimental;

IV. Comercialização - introdução e manutenção do MPSConst no mercado, primeiro em escala piloto e, posteriormente, em maior escala, efetivando sua disseminação.

Estas quatro fases são subdivididas em 12 etapas, conforme ilustrado na Figura 10 e descritas em resumo a seguir (SABBATINI, 1989). 


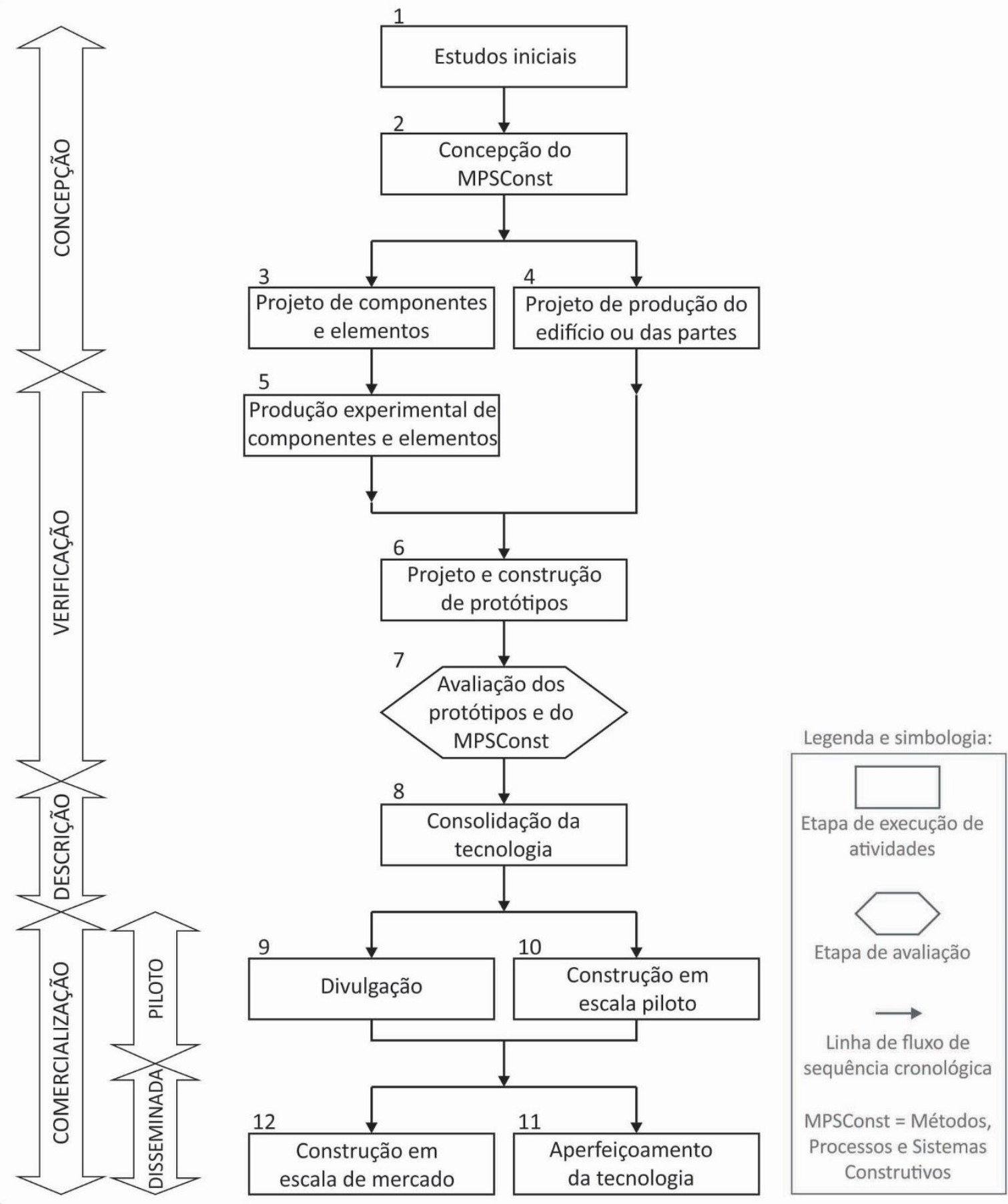

Figura 10: Fluxograma com as etapas de desenvolvimento para produtos inovadores na construção

Fonte: Sabbatini, 1989.

Inicialmente, na fase de concepção, estão inseridas as etapas enumeradas de um a cinco. A primeira destas corresponde aos estudos iniciais, quando são coletadas informações derivadas do mercado, do estado da arte, de fatores de produção e de fatores ambientais. Com isso, identifica-se a necessidade a ser atendida, em especial com base nas forças do 
mercado ${ }^{6}$. Para satisfazer esta necessidade, formula-se um problema tecnicamente, ou seja, aponta-se qual MPSConst será desenvolvido, delineando um conjunto de soluções exequíveis e analisando as viabilidades técnico-econômico-financeira para este fim. Um banco de dados com este conjunto de informações fica disponível para as decisões da próxima etapa.

Na etapa dois, de concepção do MPSConst, as diversas alternativas propostas na fase anterior são analisadas e uma destas soluções é selecionada para o desenvolvimento, identificando seus elementos e componentes ou técnicas e métodos construtivos. Com base nestes dados, o projeto preliminar é elaborado, detalhando as características materiais, funcionais e formais.

Nas etapas três e quatro, os projetos de componentes e elementos e/ou de produção do edifício ou de suas partes são formulados, analisados, sintetizados, caracterizados e avaliados em procedimentos mais exigentes e refinados. Nestas avaliações podem ser empregados métodos como: "maquetes e outros modelos icônicos, modelos matemáticos, simulações digitais, etc." (SABBATINI, 1989, p. 135). Aqui se encerra a fase de concepção.

Na sequência, a etapa cinco dá início à fase de verificação. Nesta etapa, ocorre a produção experimental dos componentes e elementos propostos em três níveis principais, sendo estes: primeiro, produção de caráter exploratório para avaliar sua produtibilidade; segundo, produção em escala piloto com número de exemplares adequados para caracterizar e avaliar seu desempenho técnico pré-estabelecido; e, terceiro, produção em maior escala, suficientes para construção de protótipos.

Na etapa seis, são projetados e construídos protótipos, ou seja, modelos físicos em escala real que permitem a avaliação efetiva da exequibilidade da proposta de inovação. Esta execução permite observar problemas que não foram identificados nas atividades anteriores. Esta análise, descrita na etapa 7, deve ser realizada durante e após a construção do protótipo, apontando modificações que necessitam ser feitas no projeto, realimentando as etapas anteriores deste processo.

\footnotetext{
${ }^{6}$ Para Sabbatini (1989, p. 127), “o mercado é o cenário natural para o reconhecimento de uma necessidade. Esta pode se tornar evidente por uma solicitação ou sugestão efetiva de organismos do mercado. [...] Em suma, normalmente, a necessidade surge por ação das forças de mercado". No entanto, como observado no capítulo anterior, e como será mencionado no item seguinte, em uma visão sistêmica, as necessidades para produção são geralmente determinadas por organismos institucionais e contextos econômico, político e social, em especial, visando manter o controle do aparato produtivo.
} 
A etapa 8 está na fase de descrição e compreende as atividades para a consolidação da tecnologia, ou seja, de preparação para a sua disseminação no ambiente do mercado. "É nessa etapa que deve ser projetada e planejada, de forma precisa e minuciosa, a fase seguinte, de comercialização" (SABBATINI, 1989, p. 117). Esta é uma etapa ampla e complexa, que inclui a elaboração de: projeto e planejamento para a produção de componentes e elementos; planejamento da divulgação e da distribuição; projeto e planejamento do consumo; planejamento para revitalização da tecnologia e da retirada do mercado.

$\mathrm{Na}$ sequência, na fase de comercialização, a etapa 9 consiste na divulgação da tecnologia inovadora nos meios técnico e comercial. Isto inclui: "palestras, conferências, seminários, publicação de trabalhos técnicos, apresentação de trabalhos em simpósios e congressos, promoção de simpósios, edição de livros e manuais técnicos, demonstrações em campo e laboratoriais, entrevistas técnicas, etc." (SABBATINI, 1989, p. 118). Nestas atividades, o autor salienta a importância da participação dos pesquisadores e desenvolvedores da tecnologia inovadora, não só pelo seu conhecimento específico deste processo, mas também por proporcionar uma troca de informações direta do produtor com o mercado, resultando em possíveis aperfeiçoamentos da recente inovação.

Além dos aperfeiçoamentos resultantes da comunicação com o consumidor / usuário final, outras correções podem ser observadas nas atividades da etapa 10. Nesta, a construção em escala piloto, ou seja, as primeiras produções, ainda em menor escala, permitem a análise e a detecção de possíveis deficiências que não foram observadas anteriormente. $E$, em tempo hábil, deve-se efetuar as devidas correções.

Este aperfeiçoamento da tecnologia, enquadrado na etapa 11, é importante para evitar resultados negativos na disseminação. O processo de inovação é dinâmico e deve estar aberto para os ajustes e aperfeiçoamentos da tecnologia em questão. Para isso, sugere-se "criar um mecanismo que promova o aperfeiçoamento constante do MPSConst, em consonância com sua disseminação no mercado. Este mecanismo é a manutenção do processo de desenvolvimento tecnológico em atividade no transcorrer da vida útil do MPSConst" (SABBATINI, 1989, p. 119). Dessa forma, procura-se não afetar a percepção geral sobre seu desempenho técnico.

Após estes maiores ajustes, a inovação tecnológica está pronta para a produção em maior escala. Assim, encerrando este processo de desenvolvimento, a etapa 12 consiste na construção em escala de mercado e na disseminação efetiva da inovação. 
Em geral, durante todo este processo, observa-se que a direção dos fluxos é cíclica e não unidirecional, pois informações de etapas posteriores são importantes para retornar e realimentar as etapas anteriores, a fim de garantir o desempenho técnico e a eficiência do produto ou processo inovador proposto.

Entretanto, as decisões tomadas nestas etapas descritas não dependem apenas dos pesquisadores ou dos produtores que atuam diretamente no processo de desenvolvimento da inovação. O paradigma tecnológico, ou seja, o padrão de solução tecnológica adotado, assim como a trajetória tecnológica, que se refere a seleção da tecnologia em cada etapa desse caminho, dependem de outros agentes e contextos sociais.

\subsection{AGENTES NO PROCESSO DE INOVAÇÃO DA CONSTRUÇÃO DO BRASIL}

Neste item, procura-se abordar os três agentes principais que participam do processo de inovação na indústria da construção civil brasileira: setor produtivo, instituições de ensino e pesquisa e órgãos governamentais. Na sequência, serão descritas suas principais funções e atuações neste processo. E, por fim, será analisado como vem ocorrendo a interação entre governo-indústria-universidade para promover as inovações tecnológicas no setor da construção brasileira.

Conforme observado no início deste capítulo, os agentes do setor produtivo da construção civil correspondem àqueles que exercem as diversas atividades nesta cadeia de produção. Portanto, estes agentes são os produtores de bens finais - edifícios; produtores de bens intermediários - materiais, componentes, elementos e sistemas construtivos; produtores de matérias-primas básicas; comerciantes e distribuidores de materiais; fornecedores de ferramentas e equipamentos; profissionais técnicos especializados em projeto, consultoria, controle tecnológico e gestão de qualidade; e, fornecedores de serviços de execução de subsistemas e sistemas construtivos (MONTEIRO FILHA et al., 2010). Destes, as empresas construtoras e os empreendedores públicos e privados são considerados o centro desta produção (CARDOSO, 2013b).

As empresas realizam mudanças técnicas visando expandir ou consolidar sua atuação no mercado, com estratégias para aumentar seu lucro e sua competitividade. E, no Brasil, estas transformações concentram-se mais em produtos iniciais da cadeia do que em processos construtivos. Neste campo, destacam-se os grandes produtores e fornecedores de materiais 
e de componentes para a construção, como por exemplo, empresas multinacionais de oligopólios de produtos como tinta, gesso, cimento. Estas empresas de produtos, que atuam em grande escala, passam a investir em pesquisa e desenvolvimento, em geral, em procedimentos autônomos ou em parceria com centros de pesquisa (AMORIM, 1995).

Por sua vez, outro agente importante no processo de inovação na indústria da construção são os "setores de serviços laboratoriais, pesquisa e desenvolvimento e capacitação profissional" (CARDOSO, 2013a, p. 8). Além de formar profissionais que atuarão nesta indústria da construção, estas instituições executam pesquisas específicas visando o desenvolvimento deste setor.

Estas instituições de pesquisa da área de tecnologia da construção vêm se consolidando, em especial, concentradas nas regiões sul e sudeste do Brasil. Em levantamento realizado por Cardoso (2013b), 41 centros de pesquisa de programas de pós-graduação de mestrado e doutorado foram constatados atuando em linhas de pesquisa, tais como: desenvolvimento sustentável; qualidade do projeto, desempenho e avaliação pós-ocupação; conforto ambiental e eficiência energética; gestão e economia da construção; engenharia urbana e gestão habitacional; sistemas e processos construtivos; materiais de construção; patologia e durabilidade das construções; inovação tecnológica; reaproveitamento de resíduos na construção; tecnologia da informação e comunicação; e tecnologia de sistemas prediais. Neste levantamento foi diagnosticado que estas "linhas de pesquisa investigadas tratam de problemas concretos da indústria da construção e são de interesse para os agentes públicos e privados da cadeia produtiva" (CARDOSO, 2013b, p. 22).

Por fim, além do setor produtivo e das instituições de pesquisa, o Estado é um terceiro agente que atua no processo de inovação. Sua função e sua atuação neste processo da construção brasileira é caracterizada por: contratar obras públicas, financiar empreendimentos habitacionais, fornecer subsídios para as empresas produtoras e construtoras, elaborar legislações e regulações que regem a oferta de serviços desta indústria e apoiar a infraestrutura de universidades e institutos de pesquisa (AMORIM, 1995, CARDOSO, 2013b).

Mas os resultados dos processos de inovação tecnológicas na indústria da construção não são sempre positivos, pois há dificuldades para efetivá-las. A visão sistêmica de atuação conjunta e de interpendência das esferas governo-indústria-universidade para promover a inovação não vêm ocorrendo no setor da construção civil do país. Constata-se um 
distanciamento entre estes agentes. E, este fato é motivado pelos aspectos levantados por Cardoso (2013a, p. 25) transcritos a seguir:

- falta de familiaridade dos agentes do mercado e do setor público com a linguagem utilizada na academia;

- dificuldade de integração entre as comunidades acadêmica e empresarial e acadêmica e administração pública;

- pouco peso que associações de classe e entidades setoriais têm no trato das relações entre academia e mercado;

- agentes do mercado não sabem como chegar aos institutos de pesquisa e às universidades com demandas concretas, nem onde procurar e como estabelecer parcerias;

- institutos de pesquisa e universidades são pouco ativos na busca da aproximação com os agentes do mercado e do setor público;

- falta parceria entre academia e agentes dos setores privado e público para o desenvolvimento de produtos e transferência tecnológica;

- impressão do mercado de que a academia está à frente dos seus problemas e à margem de suas reais necessidades;

- falta de ações setoriais claras para captação das necessidades e demandas das empresas públicas e privadas para o direcionamento de pesquisas.

Ainda, além destes entraves do sistema, outros específicos são apresentados e ampliados por Cardoso (2013a), Monteiro Filha et al. (2010) e Rezende, Barros e Abiko (2002). Com base nestes diagnósticos, verifica-se que, em geral, não há coordenação e alinhamento das iniciativas nos ambientes acadêmico, empresarial e governamental para promover o desenvolvimento tecnológico da indústria brasileira de construção. A falta de integração entre estas esferas não corresponde aos modelos de sistema de inovação universidade-empresagoverno propostos no Triângulo de Sábato e na Hélice Tríplice, apresentados no capítulo anterior. Esse é um dos motivos pelo qual se explica por que algumas inovações propostas pela academia não são aplicadas na indústria ou no mercado brasileiro.

Ainda, outro fator importante para esta questão está relacionado às influências dos contextos político, econômico e social, onde algumas decisões são tomadas, principalmente entre as esferas governo-indústria, visando as necessidades impostas pelas forças econômicas e pelo aparato produtivo deste setor. O item seguinte discorre sobre este aspecto, colocando um exemplo de como a trajetória tecnológica na construção brasileira foi direcionada, em especial para o caso da produção industrializada de habitação social no período do Plano Nacional de Habitação (PNH) e do Banco Nacional de Habitação (BNH). 


\subsection{DETERMINAÇÃO DAS NECESSIDADES E DOS PARADIGMAS TECNOLÓGICOS NA CONSTRUÇÃO BRASILEIRA}

Para alguns autores brasileiros, como Sabbatini (1989, p. 127) anteriormente citado, as necessidades de mudanças técnicas para o setor da construção brasileira surgem "por ação das forças de mercado". Ele afirma que, para o caso específico da construção, predomina a teoria denominada demand pull, onde a demanda e os organismos do mercado são essenciais para a realização das inovações tecnológicas deste setor.

Por sua vez, Castro (1999, p. 23) apresenta a mesma visão de descrita por Dosi (1982), na qual as inovações são resultantes "do interesse de uma empresa que, em uma conjuntura econômica favorável, vai buscar num estoque de descobertas científicas aplicáveis a oportunidade de desenvolver e investir num novo mercado". Aqui, coloca-se em pauta as ações de pesquisa e desenvolvimento como base para o investimento da empresa nas mudanças técnicas.

De forma similar, para Amorim (1995), a empresa é "o palco dos processos de renovação", pois "é o ponto de passagem obrigatório das transformações" antes de se efetivar no mercado. Segundo este autor, o processo de inovações tecnológicas resulta da associação da ciência - technology push - e da demanda - demand pull. Mas, no seu ver, são as empresas que determinam a necessidade e conduzem o processo da inovação. Porém, elas não atuam exclusivamente, já que estão sujeitas às influências políticas e econômicas.

Portanto, conforme observado anteriormente, adotando a empresa no centro deste processo de inovação, muitas necessidades reais da indústria da construção brasileira são identificadas na avaliação desse setor produtivo, visualizando as atividades, os agentes, os elos e os fluxos desta cadeia de produção. Mas, é importante alterar a visão que se tem da cadeia produtiva como uma simples sequência de operações de transformações de seus bens até resultar no produto final. É apropriado agregar o seguinte raciocínio de Morvan (1988 apud SIMONI; HOEFLICH, 2007, p. 17) para a cadeia produtiva:

A articulação de cada operação é largamente influenciada pela fronteira de possibilidades ditadas pela tecnologia em curso e é definida pelas estratégias dos agentes que buscam a máxima valorização de seu capital. As relações entre os agentes são de interdependência ou complementaridade e são determinadas por forças hierárquicas. 
É necessário perceber que nas atividades produtivas e nos elos entre as mesmas há articulações e estratégias guiadas por forças hierárquicas que buscam máxima valorização do seu capital. Nesse aspecto, a tecnologia, enquanto um dos atuais instrumentos predominantes de dominação do sistema capitalista, é útil e dirigida pelos interessados para determinar a ocorrência ou não de modificações dentro de um setor industrial específico, como no caso da construção civil no Brasil.

Assim, a determinação da tecnologia está comprometida com esta estrutura de poder, para manter os interesses do aparato produtivo. As relações entre o Estado e o sistema produtivo dirigente guiam as diretrizes econômicas e tecnológicas. Portanto, o Estado exerce papel fundamental na relação de causa e efeito entre tecnologia e sociedade. A política dá diretrizes e determina o processo de desenvolvimento tecnológico em uma sociedade, refletindo as relações hierárquicas existentes, desenvolvendo uma tecnologia "subjugada ao desejo de conservação do poder e controle sobre a sociedade por parte da minoria dirigente" (ROY; CROSS, 1975 apud VIANNA, 1989, p. 39).

Com base neste entendimento, a seguir será exemplificado, como uma determinada necessidade colocada por alguns do setor da construção brasileira - a industrialização - não foi selecionada como paradigma tecnológico, por causa das condicionantes econômicas e políticas, em meados da década de 1960.

[...] pode-se afirmar, que os maiores obstáculos no caminho da industrialização da construção não são de ordem técnica, na elaboração de projetos, fabricação e montagem dos organismos arquitetônicos, mas de caráter econômico, administrativo e político (BRUNA, 1976, p. 87).

Em 1964, foi iniciado o Plano Nacional de Habitação (PNH) e o Banco Nacional de Habitação (BNH) com objetivo expresso de produzir milhões de moradias para as camadas populares do país. E, logo no início desse período, na metade da década de 1965, visava-se a industrialização da construção, substituindo os métodos tradicionais e artesanais dos canteiros-de-obra. O aumento da produtividade e da racionalização possibilitaria uma contribuição para o problema da habitação social, na tentativa de acelerar o processo construtivo e reduzir custo. E, a construção em massa de habitações poderia ser a oportunidade para implementar esta industrialização no setor, assim como ocorria com outros setores produtivos nacionais, como no ramo automobilístico. Conforme ressalta Castro (1999, p. 33), "sublinhava-se uma meta de industrialização espelhada na indústria auto 
mecânica". Nesse sentido, alguns profissionais técnicos deste setor acreditavam em uma mudança tecnológica no setor, adotando esta necessidade da industrialização e da racionalização da produção.

Entretanto, naquele mesmo período, ocorria uma crise econômica nacional e o setor da construção foi utilizado pelo Estado como um instrumento para adiar esta crise. Foi constatado que o déficit nacional, que constituía uma necessidade real, foi eleito pelo governo como "problema fundamental", justificando a criação de uma conjuntura para produção de habitações sociais. Porém, posteriormente, ao analisar a atuação deste programa social e seus resultados, concluiu-se que este problema "não passou de um artifício político formulado para enfrentar um problema econômico conjuntural" (BOLAFFI, 1979, p. 47). Era uma fórmula que visava conter e reduzir as pressões inflacionárias e conservar o apoio das massas populares por mencionar o problema que estas estavam enfrentando.

O sistema formulado em torno do BNH captava recursos e os repassava para iniciativa privada, e, por fim, também transferiu suas funções para a mesma. A política habitacional, orientada de forma pragmática, atendeu os interesses da indústria da construção, de promotores imobiliários e de agentes financeiros. Logo, a questão da habitação se tornou secundária (BOLAFFI, 1979; MARICATO, 1983). As aplicações dos recursos financeiros foram, progressivamente, retiradas das habitações sociais e concentradas nas habitações de alto e médio custo, ou ainda mais, para obras de infraestrutura (MARICATO, 1978).

O BNH desempenhou funções alheias aos seus objetivos manifestos e não tomou medidas eficientes e práticas no sentido de transformar a produção tecnológica na construção civil. Em geral, foram produzidas construções em série, mas sem ganho em produtividade, com "mil tijolos postos" em loteamentos nas periferias das cidades. Maricato (1983, p. 55) denominou esse fenômeno como "processo industrial de favelamento".

Por medidas econômicas, ressaltava-se a importância da construção civil em absorver a mão-de-obra excedente e desqualificada. Muitos trabalhadores desqualificados chegavam do campo para a cidade e ficavam desempregados. Portanto, a preferência aos meios tradicionais de construção era justificada pela necessidade de criar empregos para estes trabalhadores (BOLAFFI, 1979; MARICATO, 1983). A indústria da construção recebia incentivos periódicos do governo para a absorção dessa mão-de-obra excedente e desempregada do país (BRUNA, 1976). 
Também, para efetivar um novo processo de produção industrializado, a formação de mão-de-obra qualificada era considerada cara e demandaria tempo para esta adaptação, por isso, não interessava o setor produtivo adotar esta inovação. Para eles, pré-fabricar seria menos lucrativo do que manter os meios tradicionais de construção com a mão-de-obra em massa, desqualificada e barata (MARICATO, 1983). Assim, grupos de empreiteiros se opuseram à transformação tecnológica do setor via industrialização, não só pela questão da mão-de-obra, mas também pelas flutuações econômicas acentuadas pela inflação e pelas mudanças políticas (AMORIM, 1992 apud CASTRO, 1999, BRUNA, 1976).

Portanto, apesar da industrialização ter sido apontada como possibilidade de mudança técnica na construção brasileira naquele período, ela não foi determinada como necessidade ou paradigma tecnológico do aparato produtivo dirigente. O discurso político e econômico fez parecer interessante manter a condição artesanal da produção, mesmo que em condições indignas. Tal condição da indústria da construção frente aos trabalhadores foi mantida por uma relação íntima entre Estado e setor produtivo, por meios de incentivos fiscais e outros, visando manter a situação favorável a ambos.

Assim, este caso demonstrou como a seleção de produtos e/ou de métodos construtivos "se curva diante da adequação econômica". Este fator esclarece o motivo pelo qual "métodos que são tecnologicamente inferiores ainda podem ser os que melhor se ajustam às condições econômicas dadas". Pois, os métodos de produção e os quantitativos ou coeficientes desta produção são decididos com base no ponto de vista econômico. Por isso, é possível uma decisão de dar continuidade ao "trabalho manual mais primitivo ao invés das máquinas perfeitas" (SCHUMPETER, 1982, p. 15, 16).

No Brasil, inúmeras propostas de inovação vêm sendo pesquisadas e lançadas com intuito de aprimorar sistemas e processos de produção enraizados na manufatura artesanal e substituí-los por outras organizações de trabalho, outros métodos de produção e outros aspectos técnicos construtivos. No entanto, o setor da construção, enquanto um dos potenciais influentes na economia estatal, em geral, acompanhou os encaminhamentos e comportamentos econômicos, mantendo a condição de suposto "atraso" tecnológico. Pois, conforme Vianna (1989, p. 39), "o desenvolvimento tecnológico, em seu processo histórico, está sempre comprometido com o sistema econômico vigente. São elos inseparáveis". Sendo assim, muitas vezes, o sistema econômico tem se transformado em uma baliza para as mudanças tecnológicas na construção. 


\subsection{SINAT: POLÍTICA PÚBLICA PARA A IMPLANTAÇÃO DE INOVAÇÃO TECNOLÓGICA NA PRODUÇÃO DE HABITAÇÃO SOCIAL NO BRASIL}

No início da década de 1980, no final do período do BNH, as condições econômicas se agravaram e atingiram o setor da construção. Com isso, o discurso político, que antes negava os processos industrializados, passou a salientar a necessidade de melhorar a produtividade das construções, em especial focada na racionalização dos seus produtos intermediários componentes, elementos, subsistemas. A justificativa era pautada na necessidade de diminuir os custos das construções. Com criação de programas governamentais, as empresas construtoras ou produtoras de materiais de construção foram "incentivadas através de financiamentos a buscar acelerar e baratear o processo construtivo e o produto respectivamente" (MARICATO, 1983, p. 152). Nesse período, destacou-se a publicação do Instituto de Pesquisa Tecnológica (IPT) em parceria com o BNH determinando critérios mínimos para avaliação de desempenho de habitações sociais.

Desde a década de 1990, o discurso de transformações técnicas para as construções brasileiras permaneceu focado na necessidade de desempenho e qualidade da construção. Nesta década, programas e incentivos estatais foram instituídos visando este aspecto, como, por exemplo:

- 1991: Programa Nacional de Habitação (PRONATH);

- 1993: Programa de Difusão de Tecnologia para a Construção de Habitação de Baixo Custo (PROTECH);

- 1994: Programa de Tecnologia de Habitação (HABITARE);

- 1996: Programa da Qualidade da Construção Habitacional do Estado de São Paulo (QUALIHAB).

- 1998: Programa Brasileiro de Produtividade e Qualidade do Habitat (PBQP-H).

Destes, destaca-se o PBQP-H. Este programa foi instituído com o objetivo de articular agentes públicos e privados, a fim de fortalecer a capacidade tecnológica e gerencial do setor produtivo nacional, estimulando a implementação de programas de aperfeiçoamento da qualidade e aumento da produtividade das construções. Também, entre suas diretrizes o PBQP-H incentiva a utilização de novas tecnologias para a produção habitacional (PBQP-H, 2016). 
Para promover a inovação tecnológica para as habitações brasileiras, em 13 de agosto de 2007, a portaria no 345 do Ministério das Cidades foi publicada no Diário Oficial da União (DOU) instituindo o Sistema Nacional de Avaliações Técnicas de produtos inovadores (SINAT), no âmbito PBPQ-H, vinculado à Secretaria Nacional de Habitação (SNH) (BRASIL, 2007a, 2007b).

Inicialmente, a atuação do SINAT estava focada para promover exclusivamente ${ }^{7}$ a aplicação de produtos inovadores, ou seja, sistema, subsistema, elemento ou componente construtivo que não apresenta norma brasileira regulamentada pela Associação Brasileira de Normas Técnicas (ABNT) e também que não é tradicionalmente aplicado no território nacional. Além dos produtos, o regimento do SINAT também faz menção à processos de construção inovadores, diferentes dos métodos tradicionais aplicados no canteiro-de-obras. Sob este intuito, os principais objetivos gerais do SINAT foram assim transcritos (BRASIL, 2007a, p. 2, 3):

- estimular o processo de inovação tecnológica no Brasil, aumentar o leque de alternativas tecnológicas para a produção de obras de edifícios e de saneamento, e promover o equilíbrio competitivo nos setores produtivos correlatos;

- reduzir riscos nos processos de tomada de decisão por parte de agentes promotores, incorporadores, construtores, seguradores, financiadores e usuários de produtos e processos de construção inovadores quanto à aptidão técnica ao uso, considerandose fundamentalmente de requisitos de desempenho [...];

- orientar produtores, fabricantes e construtores quanto aos requisitos e critérios de desempenho aplicáveis ao produto ou ao processo, explicitando-os em documentos técnicos definidos no regimento do SINAT;

- favorecer a troca comercial entre países ou blocos comerciais [...].

Analisando estes objetivos observa-se a que esta instituição governamental, com base no reconhecimento de novas possibilidades para as construções no país, criou mecanismos para implementá-las e, com isso, estimular este setor mediante novas relações e competitividade. Por carecerem de documentos técnicos oficializados pela ABNT, o SINAT foi regimentado especificamente para prover medidas que estabelecem regulamentações provisórias para estes produtos inovadores com intuito de propiciar sua aplicação com qualidade e desempenho no cenário da construção brasileira.

\footnotetext{
7 Em 2016, o SINAT passou a ser denominado Sistema Nacional de Avaliação Técnica de Produtos Inovadores e Sistemas Convencionais, conforme a Portaria no 550, de 11 de novembro de 2016 do Ministério das Cidades. Assim, com novo procedimento, o SINAT passou a avaliar e conceder Fichas de Avaliação de Desempenho (FAD) para os sistemas convencionais.
} 
Estes documentos reguladores estabelecem critérios técnicos para avaliar estes produtos e processos inovadores, conforme os requisitos de desempenho estabelecidos nas normas vigentes no país. E, sobretudo, ao aferir esta documentação, a comprovação destes dados técnicos visa reduzir os riscos sobre os agentes promotores, incorporadores, financiadores, seguradores e usuários finais envolvidos nas produções destas inovações.

Neste processo de inovação, o SINAT possibilita a formulação e a publicação de dois documentos principais: (a) Diretriz SINAT e (b) Documento de Avaliação Técnica (DATec). Primeiro, a Diretriz SINAT elenca "requisitos, critérios e métodos para a avaliação técnica de desempenho para produtos e processos inovadores". Por sua vez, o DATec é elaborado com base nos resultados gerais desses procedimentos de avaliação específicos e determina a concessão para o determinado produto e/ou processo inovador (BRASIL, 2007a, p. 3). Para exercer estas funções, o SINAT está estruturado em: comissão nacional, secretaria geral, comitê técnico, grupos especializados e Instituições Técnicas Avaliadoras (ITA's) (Figura 11).

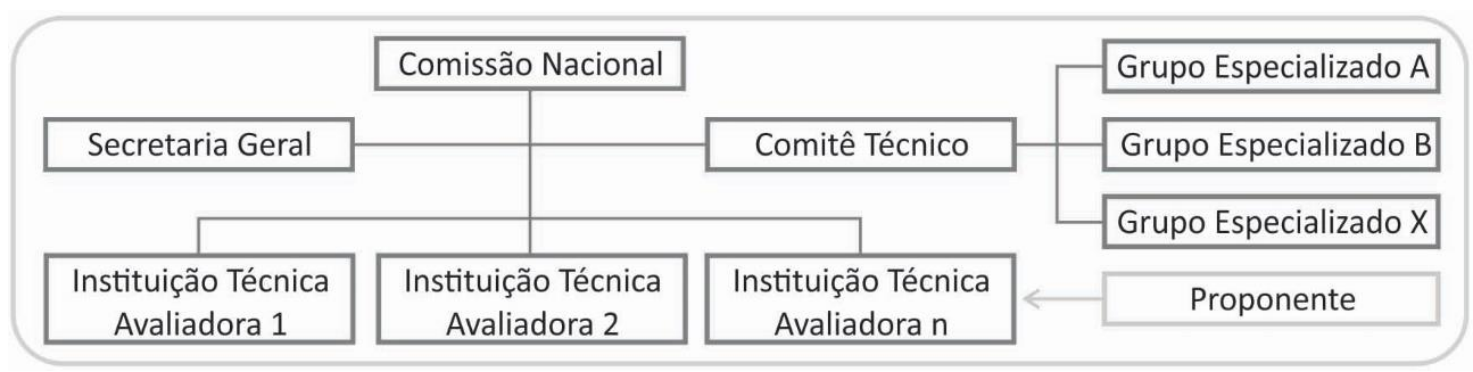

Figura 11: Estrutura geral do Sistema Nacional de Avaliações Técnicas (SINAT)

Fonte: adaptado de Weber, 2011.

A comissão nacional do SINAT é integrada por representantes das seguintes instituições ou entidades: coordenação geral do PBQP-H, entidades promotoras, agentes financiadores públicos, cadeia produtiva da construção civil, instituições de pesquisa e/ou ensino, órgão governamental ligado à inovação tecnológica e entidade representante de usuários e consumidores de produtos da construção civil. A função geral da comissão nacional é fomentar a comunicação entre o meio técnico, o setor produtivo e o SINAT, para analisar as necessidades relativas deste tema referentes à cadeia produtiva, incluindo os consumidores finais. Já, a secretaria geral do SINAT operacionaliza as atividades técnico-administrativas do SINAT (BRASIL, 2007b). 
Por sua vez, o comitê técnico do SINAT, além de assessorar tecnicamente a comissão nacional, tem a função de analisar os documentos técnicos no âmbito do Sistema, especialmente as Diretrizes e os DATec's. Este comitê é integrado por representantes técnicos com experiência e conhecimento sobre produtos inovadores para a construção civil, incluindo: agentes promotores de habitação, empresas construtoras ou consultoras em engenharia, instituições de pesquisa e/ou ensino, Instituições Técnicas Avaliadoras (ITA's) e coordenadores dos grupos especializados do SINAT (BRASIL, 2007b).

Estes grupos especializados dão suporte ao comitê na análise das Diretrizes técnicas e das minutas dos DATec's. Estes grupos são criados a partir das necessidades do Sistema, constituídos a partir de planos estratégicos setoriais conforme determinado setor produtivo ou família de produtos da construção civil (BRASIL, 2007b).

Por fim, as ITA's são institutos e/ou laboratórios de pesquisa ou de ensino e pesquisa com capacidade para realizar ensaios e análises de desempenho de produtos da construção civil. Estas instituições são independentes do SINAT, mas podem ser autorizadas a participar do Sistema após procedimentos de análise da comissão nacional. Dentre as ITA's vinculadas ao SINAT estão: CONCREMAT Engenharia e Tecnologia S/A, Instituto Falcão Bauer da Qualidade (IFBQ), Instituto de Pesquisas Tecnológicas do Estado de São Paulo (IPT), Instituto de Tecnologia de Pernambuco (ITEP), Instituto de Tecnologia para o Desenvolvimento (LACTEC), Laboratório de Engenharia e Consultoria Ltda (LENC), SENAI/Criciúma, Tecnologia da Construção e Materiais Ltda (TECOMAT), Tecnologia de Sistemas em Engenharia Ltda (TESIS) e Universidade do Vale do Rio dos Sinos (UNISINOS) (PBQP-H, 2016).

Para solicitar uma Diretriz SINAT, o proponente, que pode ser uma pessoa física ou jurídica, entra em contato com uma ITA e apresenta o produto inovador que deseja obter a Diretriz SINAT. Com base nesta solicitação, esta ITA contratada analisa o produto proposto e elabora uma minuta de Diretriz SINAT. Este documento apresenta os requisitos de desempenho relativos à segurança, habitabilidade, durabilidade e adequação ambiental e aponta os métodos de avaliação necessários para estes dados com base em normas nacionais e internacionais relativas ao produto. Na sequência, esta Diretriz é encaminhada para o comitê técnico do SINAT que analisa e harmoniza os dados apresentados neste documento. Esta etapa também pode ser auxiliada por grupos especializados, conforme o setor produtivo ou família de produtos apropriados para a proposta. Por fim, a Diretriz é referendada pela comissão nacional do SINAT, publicando-a no portal do PBQP-H (Figura 12) (BRASIL, 2007b). 


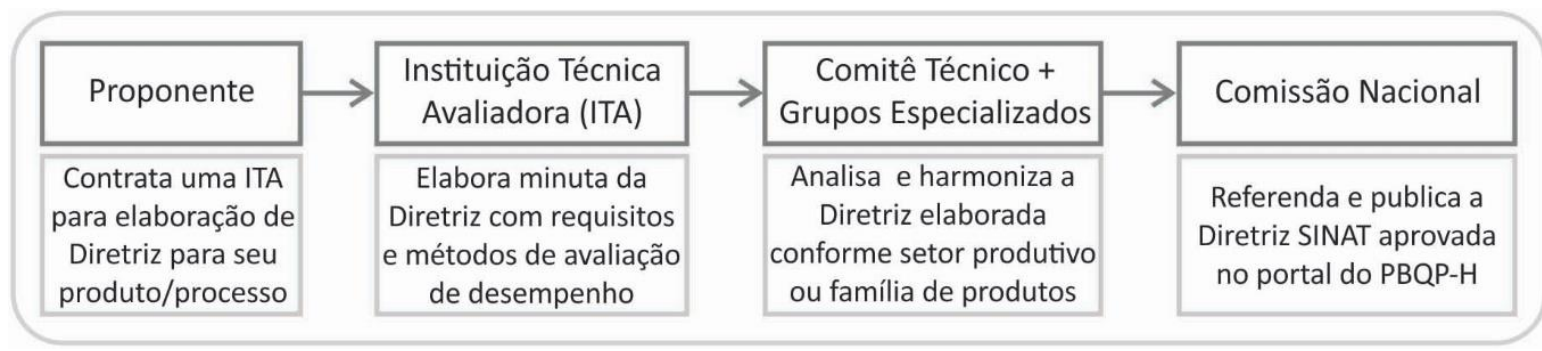

Figura 12: Procedimentos para elaboração e aprovação da Diretriz SINAT

Fonte: autora.

O procedimento para solicitar a concessão de um DATec é semelhante. Primeiro, o proponente, geralmente uma construtora, faz a solicitação à ITA. Na sequência, a ITA analisa se o produto em questão pode ou não participar deste processo, verificando se existe uma Diretriz SINAT correspondente e se o produto já está sendo produzido, a fim de possibilitar auditorias neste processo de produção na fábrica e no canteiro. Em caso positivo, a ITA inicia os procedimentos de ensaios e avaliações técnicas seguindo os critérios impostos na Diretriz SINAT. Os resultados destas análises são descritos em Relatórios Técnicos de Avaliação (RTA's), os quais têm publicação restrita ao proponente. Ainda, a ITA responsável realiza auditorias e inspeções técnicas para conferir as diferentes etapas da produção em questão. Por fim, todas estas informações são resumidas na elaboração da minuta do DATec. Após finalizado, este documento é encaminhado e analisado pelo comitê técnico e grupo especializado da área. E, a comissão nacional do SINAT chancela e publica oficialmente o DATec (Figura 13) (BRASIL, 2007b).

O DATec publicado é provisório, pois tem validade por dois anos. Mas, se o produto apresenta produção continuada ou seriada, ele pode ser renovado sob algumas condicionantes. Primeiro, o produto e o processo devem ter seu controle de qualidade aprovado nos monitoramentos e nas auditorias periódicas da ITA responsável. Também, o produto proposto para renovação não deve apresentar modificações que diminuam o desempenho que havia sido avaliado anteriormente. As possíveis modificações devem ser reavaliadas em ensaios realizados por ITA's e, consequentemente, o DATec deve ser atualizado com estas novas informações (BRASIL, 2007b).

Por fim, o proponente, que solicitou as avaliações técnicas ao SINAT e arcou com os custos destas da avaliação, é o detentor do DATec. Assim, ele “é o responsável pela 
demonstração e garantia da qualidade de seu produto ou processo, pela orientação quanto ao uso adequado e pela assistência técnica" (BRASIL, 2007a, p. 1).

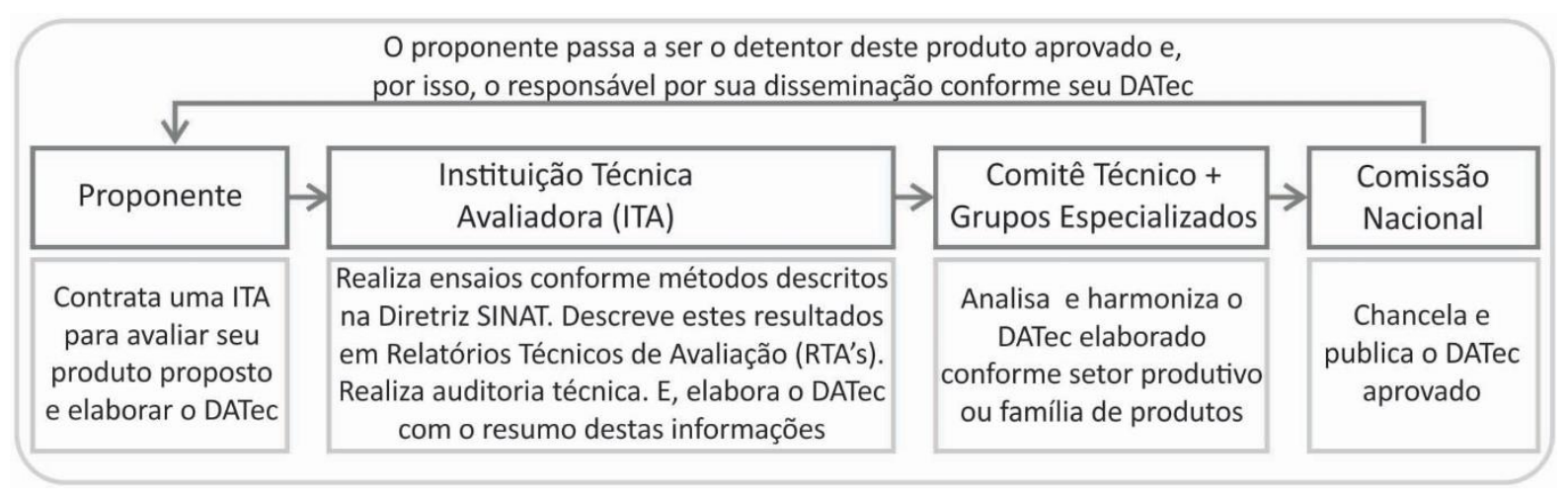

Figura 13: Procedimentos para elaboração e aprovação do DATec

Fonte: autora.

Em 2007, por iniciativa da CBIC, foi instituído o Projeto Inovação Tecnológica na Construção (PIT), abrangendo 10 subprojetos com intuito de promover ações para o desenvolvimento do setor com base na inovação, tendo como coordenador geral o SINDUSCON-SP. O segundo destes subprojetos foi criado com o objetivo específico de viabilizar o SINAT/PBQP-H e foi coordenado pelo representante do CBIC (CBIC, 2010).

Como resultado destes trabalhos, desde 2009 até 2016, foram aprovados e publicados 11 Diretrizes SINAT e 31 DATec's. Destes, a maioria compreende subsistemas construtivos que utilizam diferentes soluções aplicando concreto armado. Outros materiais também foram aprovados, tais como: PVC, gesso, aço e madeira (PBQP-H, 2016).

A aplicação destas inovações aprovadas foi motivada pela operacionalização do PMCMV. A Lei Federal no 11.977, de 7 de julho de 2009, ao instituir o programa habitacional, estabeleceu no artigo 73 que o "uso de novas tecnologias construtivas" seria assegurado nesta produção (BRASIL, 2009). Assim, a CEF, enquanto participante do PBPQ-H e principal agente financiador do PMCMV, passou a aceitar os DATec's emitidos pelo SINAT para o seu processo interno de avaliação e homologação de desempenho para sistemas inovadores.

Neste processo, inicialmente, o proponente do empreendimento residencial encaminha sua solicitação de avaliação técnica do sistema inovador à CEF. Na sequência, a GIDUR da CEF analisa a proposta para este empreendimento e encaminha o roteiro com os procedimentos necessários ao proponente. Por sua vez, conforme requisitado, este proponente apresenta os RTA's e o DATec emitidos pelas ITA's do SINAT. Estes documentos 
são analisados pelos técnicos da GIDUR, que emitem o parecer consubstanciado. Por fim, a Gerência Nacional de Gestão, Padronização e Normas Técnicas (GEPAD) da CEF reúne-se com os técnicos da GIDUR local para a aprovação da viabilidade prévia (Figura 14) (FERNANDES, 2011).

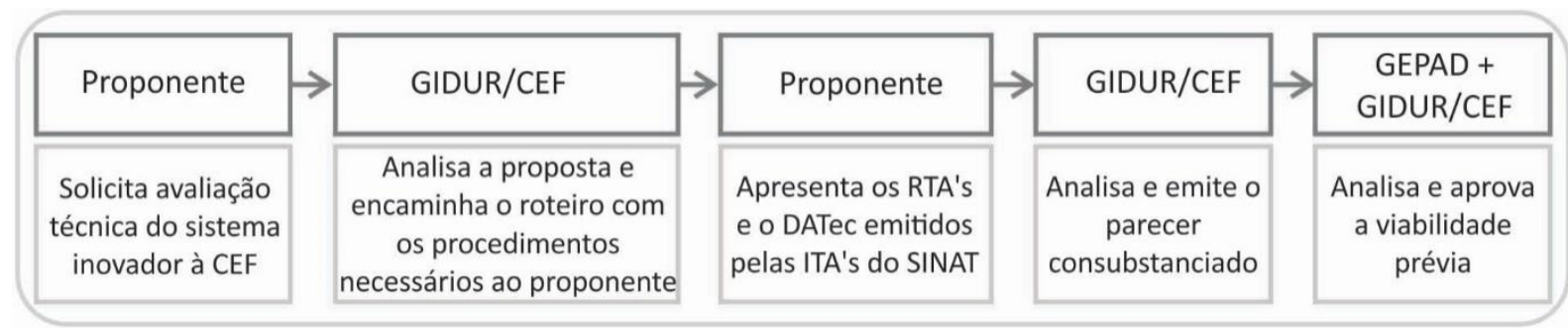

Figura 14: Procedimento para aprovação de viabilidade de sistemas inovadores na CEF

Fonte: elaborado pela autora com base em Fernandes, 2011.

Como resultado, durante a vigência do PMCMV, muitos dos sistemas inovadores homologados pelo SINAT apresentaram seus RTA's emitidos pelas ITA's e receberam viabilidade prévia da CEF. Assim, esses sistemas inovadores vêm sendo aplicados especialmente nas construções de empreendimentos de habitações sociais financiadas pelo governo. Portanto, a instituição do SINAT aliada ao PMCMV vem sendo um fator facilitador para promover os sistemas inovadores no setor da construção neste período.

Entre estes casos de desenvolvimento tecnológico, esta tese destaca as construções executadas com o sistema inovador em madeira denominado wood frame, o qual passou por este processo de avaliação do SINAT e foi introduzido no PMCMV em meados de 2010 a 2012. A escolha deste estudo de caso, conforme já justificada, é motivada pela recente transformação do setor madeireiro após um longo quadro de estagnação tecnológica. Em geral, as construções em madeira vêm enfrentado barreiras que dificultam os processos de financiamento mediante agentes públicos. Mas, uma conjuntura recente integrou agentes do sistema universidade-empresa-governo para promover a efetivação do wood frame no Brasil. Para aprofundar esta análise, os capítulos seguintes apresentarão: as referências gerais deste sistema, quando ocorreu sua primeira produção no Brasil e como ocorreu este processo para a produção de habitação social no PMCMV, mediante o SINAT. 


\section{REFERÊNCIAS GERAIS SOBRE O SISTEMA CONSTRUTIVO WOOD FRAME}

Para aprofundar a discussão sobre a recente produção brasileira utilizando o sistema inovador denominado wood light frame, o presente capítulo apresenta uma introdução e uma visão geral sobre este sistema construtivo. Os itens seguintes apontam o contexto histórico do sistema e suas origens, assim como seus principais detalhes técnicos construtivos e métodos de produção. Estes pontos abordados têm o intuito de fornecer uma base teórica para os capítulos seguintes que avaliam a apropriação do wood frame para o contexto brasileiro.

\subsection{HISTÓRICO DOS SISTEMAS LEVES ESTRUTURADOS EM MADEIRA}

Desde o período medieval até o final do século XVIII, na Europa, em especial nas regiões central e norte, a madeira era abundantemente aplicada como material estrutural na composição de suas edificações. As peças eram trabalhadas por carpinteiros em procedimentos tradicionalmente artesanais. Tais elementos construtivos, na sua maioria com grandes seções quadradas, eram falquejados e entalhados para a montagem das tramas estruturais. Dentre os sistemas em madeira deste período, destacaram-se as construções denominadas enxaimel, sendo estas, nas suas principais origens, conhecidas como: colombage ou construction à pan de bois, em francês (BENOÎT; PARADIS, 2007); fachwerk, em alemão (KOLB, 2008); half-timber ou black-and-white, em inglês (HARRIS, 2013).

Conforme registros do autor Harris (2013) sobre as regiões do Reino Unido, em geral, antes do canteiro-de-obras, as peças em madeira eram preparadas, identificadas e montadas em frames $^{8}$, ou seja, entramados estruturais. Posteriormente, estes frames eram transportados ao terreno, onde eram erguidos e unidos. Esta sequência de produção está resumida na Figura 15. Neste processo, um ou dois trabalhadores conseguiam carregar uma peça como vigas e pilares. Mas a trama estrutural, pelo seu peso, requeria a ação de mais trabalhadores e equipamentos auxiliares para erguer o conjunto.

\footnotetext{
${ }^{8}$ Portanto, com base nesse contexto histórico, assume-se que a atual denominação wood frame refere-se aos quadros estruturais ou entramados de madeira.
} 

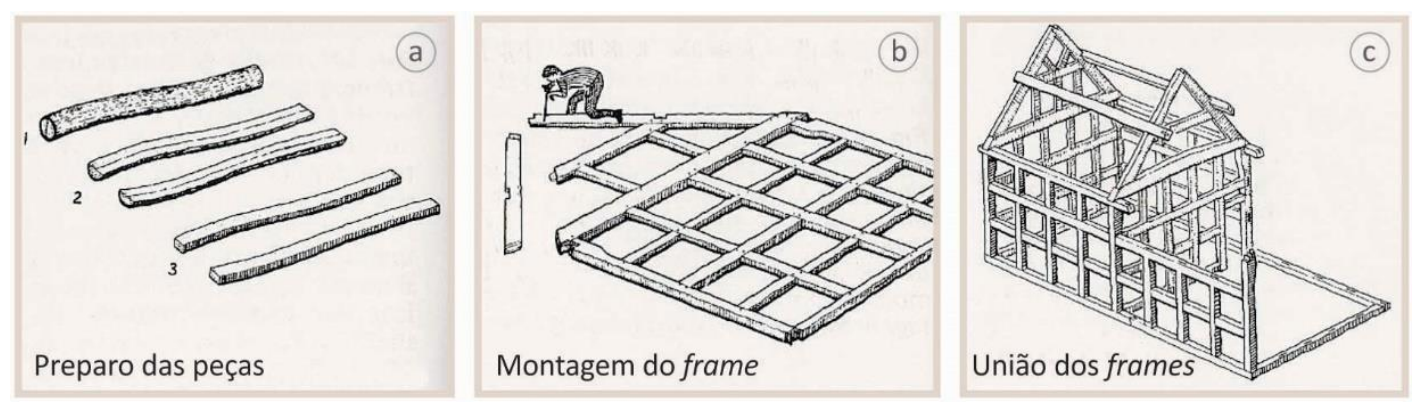

Figura 15: Produção das tramas estruturais e montagem da edificação

Fonte: adaptado de Harris, 2013.

No conjunto da edificação, ilustrada na Figura 16, observam-se frames ou conjuntos estruturais para os subsistemas de piso, parede e cobertura. As construções dos telhados não raro eram compostas por tesouras nas mais variadas formas, adequadas conforme período e função da edificação. Por sua vez, o piso era composto essencialmente por vigas e barrotes e sua base podia ser utilizada durante a construção como plataforma de apoio para as atividades em níveis mais elevados da edificação. Por fim, os painéis de parede podiam ser distinguidos em dois tipos principais: primeiro, a caixa externa da construção - box frame ou wall frame e, segundo, os painéis de parede transversais - cross frame; estes últimos, geralmente, eram aplicados para a divisão dos ambientes internos (HARRIS, 2013).

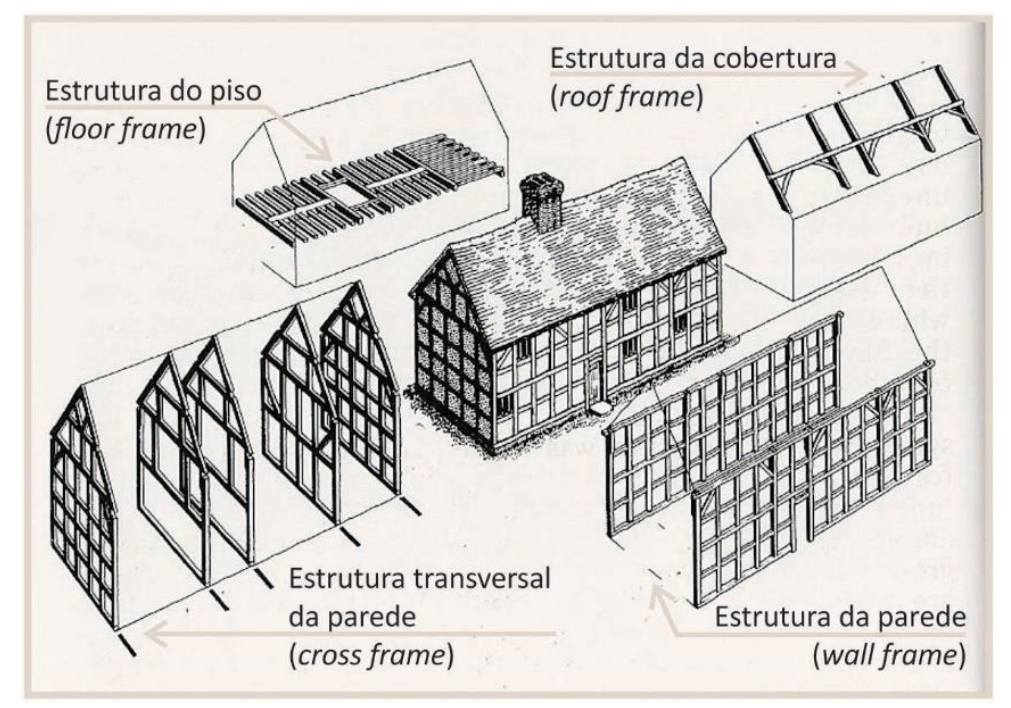

Figura 16: Estruturas de piso, paredes e cobertura Fonte: adaptado de Harris, 2013.

Os desenhos e as composições destes frames variavam, principalmente, os referentes às tramas das paredes externas. A Figura 17 apresenta três modelos principais de paredes 
citados por Harris (2013): (a) estrutura medieval, (b) estrutura em painéis quadrados e (c) estrutura com montantes próximos.

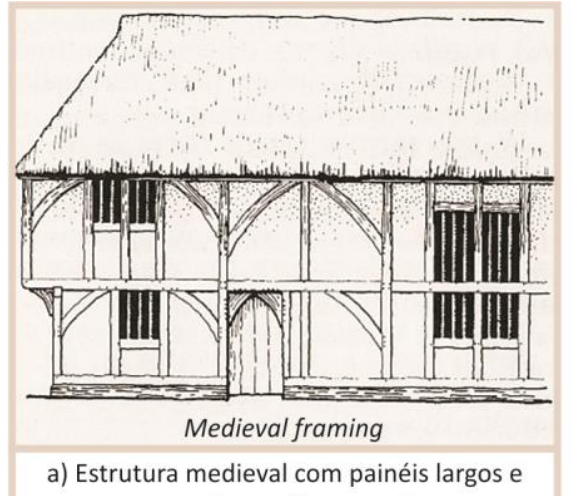
peças diagonais arqueadas

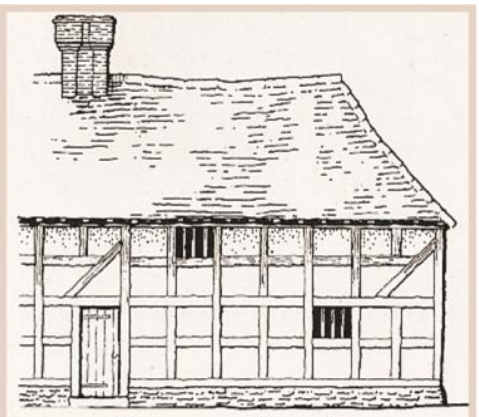

Square panel framing

b) Estrutura em painéis quadrados

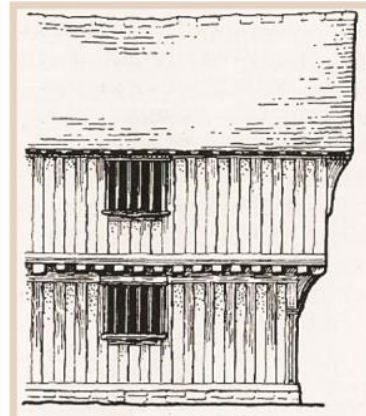

Close studding

c) Estrutura com montantes próximos

Figura 17: Diferentes composições de trama estrutural para paredes Fonte: adaptado de Harris, 2013.

No primeiro modelo, ilustrado na Figura 17a, as construções medievais com estrutura de madeira apresentavam paredes com painéis largos, ou seja, pilares com grande afastamento entre si, sem a presença de montantes ou travessas intermediários. Nestes exemplares, destacavam-se as peças diagonais arqueadas posicionadas entre os pilares e as vigas do quadro estrutural (HARRIS, 2013).

Um segundo modelo se tornou comum no fim do século XV. Este era caracterizado por tramas estruturadas em painéis quadrados, geralmente aplicados para celeiros e casas no campo, ilustrado na Figura 17b. Estes painéis quadrados mediam aproximadamente entre 75 a $90 \mathrm{~cm}$, formados por montantes e travessas de grandes seções quadradas (HARRIS, 2013).

Por fim, no terceiro modelo (Figura 17c), a parede era composta por uma estrutura com montantes bem próximos entre si, com espaçamento variando em média entre $60 \mathrm{~cm}$ ou mais, dependendo da disponibilidade de madeira ou das condições financeiras do proprietário. Quanto maior o uso da madeira, mais destaque tinha a edificação. Por isso, em meados dos séculos XV e XVI, tais construções se tornaram populares entre aqueles com maior status social. Além de ser utilizada em casas e fazendas prósperas, as estruturas com montantes próximos eram aplicadas em construções públicas, como corporações, mercados e igrejas (HARRIS, 2013).

Dentre as regiões que adotavam as estruturas em madeira, este exemplar com montantes próximos tornou-se o mais desejado e mais caro naquele período. Seu custo era 
influenciado tanto pelo material quanto pela mão-de-obra necessária, a qual requeria mais trabalho e tempo pela maior quantidade de peças aplicadas quando comparada aos demais sistemas estruturais. Nesse sentido, o aspecto visual da fachada com montantes pouco espaçados se tornou emblemático. Portanto, para não afetar visualmente tal sequência de padrão linear, a peças diagonais, as quais eram necessárias para contraventar a estrutura, muitas vezes eram fixadas pela face interna dos montantes (Figura 18) (HARRIS, 2013).

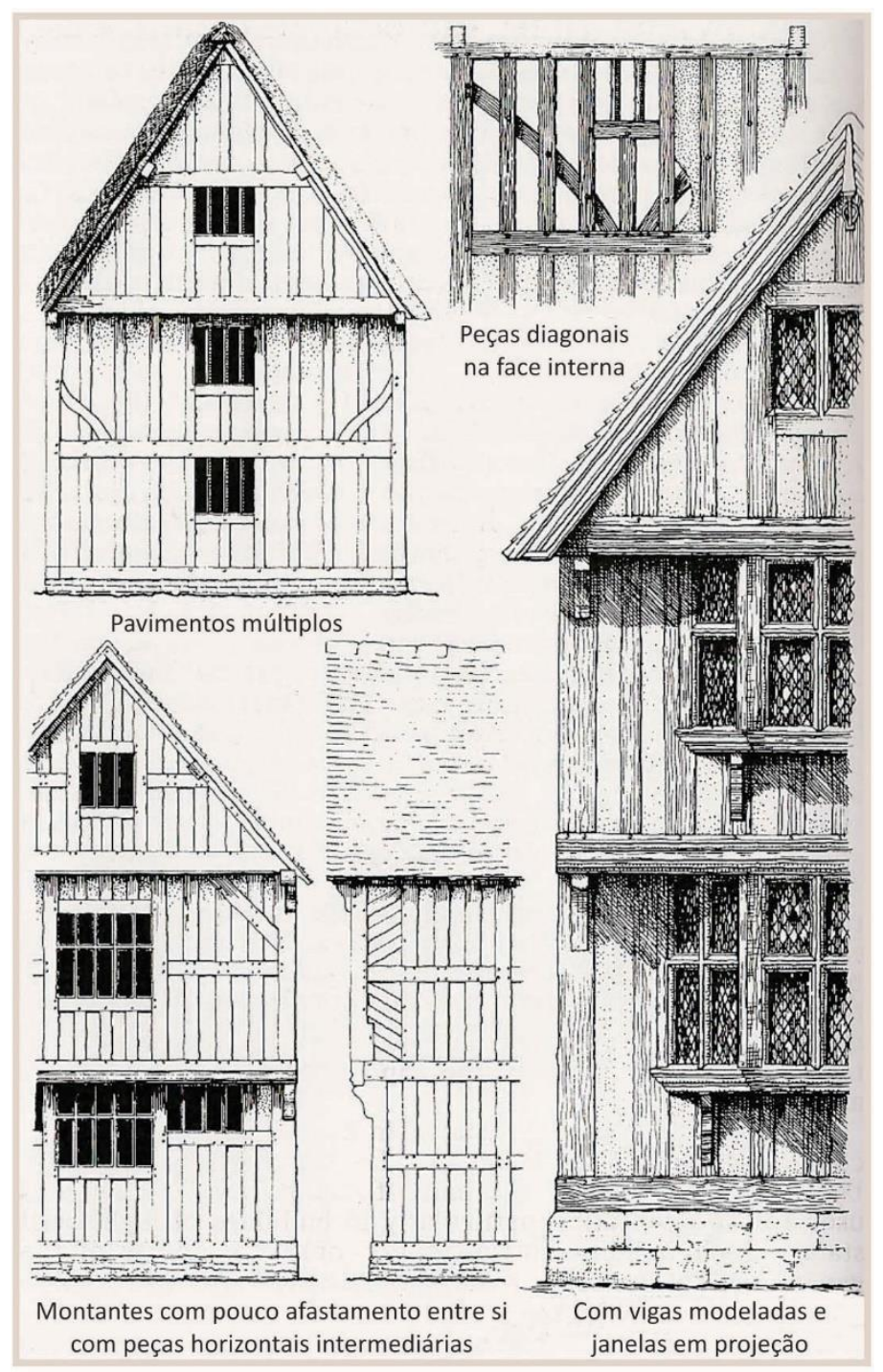

Figura 18: Exemplos de construções enxaimel com montantes próximos entre si Fonte: adaptado de Harris, 2013.

Em todos os três modelos apresentados anteriormente, os espaços vazios entre os entramados de madeira das paredes eram preenchidos por diferentes materiais (Figura 19). Por exemplo, nas estruturas de painéis quadrados, os preenchimentos mais comuns eram 
elaborados de pau-a-pique ou taipa. Nestes, a estrutura de madeira era entalhada com ranhuras ou furos de aproximadamente $2,5 \mathrm{~cm}$ de diâmetro para receber a trama da taipa. $\mathrm{Na}$ vertical, peças mais resistentes, como pequenas tiras de madeira, eram posicionadas com 30 a $45 \mathrm{~cm}$ entre si. Sobre esta base mais forte, hastes ou galhos com pequenos diâmetros de seção eram entrelaçados. Esta trama era preenchida nas faces interna e externa com uma mistura composta de barro, estrume e palha picada. Por fim, essas superfícies recebiam um acabamento a base de cal ou outra pintura disponível. Mas, as peças da estrutura em madeira eram deixadas expostas, sem receber revestimento ${ }^{9}$. Assim, destacava-se o contraste das cores escuras das peças de madeira com a cor esbranquiçada dos materiais de preenchimento, recebendo o nome popular "preto e branco" - black-and-white (HARRIS, 2013).

Por sua vez, nas estruturas com montantes de madeira mais próximos entre si, não havia espaço para a execução da taipa (Figura 19). Assim, ripas com pequeno comprimento eram posicionadas e sobrepostas horizontalmente. Ou, em locais com disponibilidade, lascas de pedra eram aplicadas como preenchimento. Ainda, utilizava-se tijolos, mesmo que em alguns casos não eram indicados pelo seu peso excessivo sobre as estruturas em madeira. Por fim, estes elementos eram cobertos com estuque e pintados com cal (HARRIS, 2013).

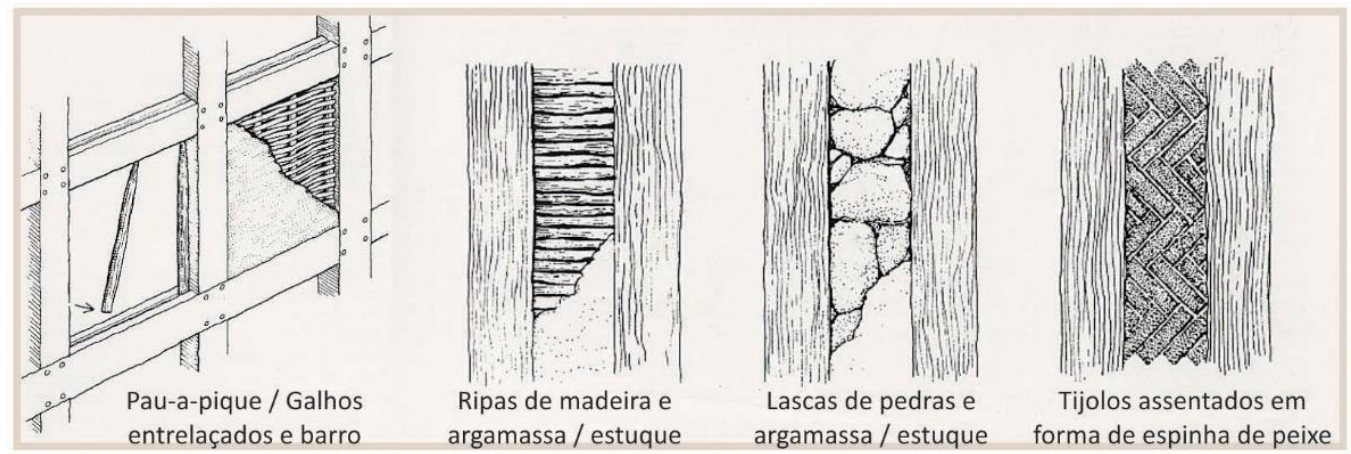

Figura 19: Diferentes materiais de preenchimento das paredes

Fonte: adaptado de Harris, 2013.

Com o tempo, as construções enxaimel passaram por transformações técnicas impelidas por fatores como: diminuição de madeira disponível, consequente aumento no custo deste material naqueles territórios e alterações nos modos de produção e nos materiais

\footnotetext{
${ }^{9}$ Nem sempre se intencionava expor as estruturas de madeira das edificações. Por exemplo, na região de East Anglia, no sudeste da Inglaterra, as construções eram totalmente rebocadas com argamassa. Isso parece ter acontecido em meados dos séculos XVII e XVIII, em geral, quando as estruturas em madeira começaram gradualmente a ceder seu lugar para outros materiais para as paredes, como argamassa e tijolo (HARRIS, 2013).
} 
ofertados provenientes da revolução industrial que se fazia presente. Tais fatores contribuíram para mudanças técnicas como: diminuição da seção das peças de madeira utilizadas nas estruturas; substituição das uniões destas peças, antes elaboradas com entalhes, por outras ligações mais simplificadas, como as pregadas; utilização de outros materiais de vedação; e restrição da aplicação de peças estruturais em madeira na cobertura e no piso das edificações.

Por exemplo, sobre estas mudanças técnicas, os autores Benoît e Paradis (2007) descrevem que as construções europeias em enxaimel, datadas entre os séculos XII e XVI, utilizavam peças falquejadas, com grandes seções retangulares ou quadradas e entalhadas para união das mesmas. Inicialmente, o comprimento das peças equivalia à altura da edificação, indo desde a fundação até a cobertura. O apogeu do estilo enxaimel com peças longas foi na Noruega, no século XII. Porém, com o tempo, o tamanho e o peso das peças dificultavam seu manuseio, além de serem onerosas pela quantidade de material aplicado e de trabalhadores envolvidos na montagem da edificação. Assim, gradualmente, tais construções passaram a utilizar peças curtas, conforme a altura de cada pavimento (Figura 20). Com esta adequação, as execuções eram mais rápidas. Porém, as peças, em geral, ainda eram caracterizadas por grandes seções. Também, se mantinha a necessidade de carpinteiros experientes e habilidosos para realizar entalhes para o encaixe e a união das peças.
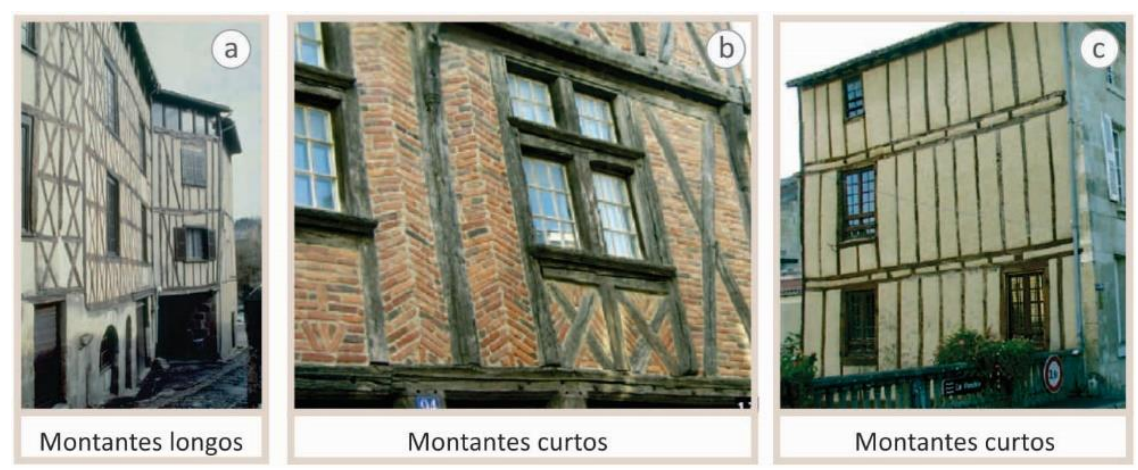

Figura 20: Construções enxaimel com alterações no comprimento dos montantes Fonte: Benoît e Paradis, 2007.

Acredita-se que estas transformações antecederam e foram importantes na conformação dos sistemas com estruturas leves em madeira - light wood frame - iniciados entre os séculos XVIII e XIX, em especial no território norte-americano sob a influência de colonos franceses e ingleses. Neste novo período, destacaram-se os sistemas construtivos 
denominados: braced frame, balloon frame e platform frame, sendo os dois últimos os mais significativos entre os light frames.

As construções do tipo braced frame foram registradas a partir do início de 1800 . Estas eram comuns, por exemplo, na região norte de New England, nos Estados Unidos. Este sistema podia ser considerado uma transição entre as estruturas pesadas e leves de madeira, pois, apresentava elementos com grandes seções, como pilares e vigas ou travessas, misturados com peças mais esbeltas, como os montantes, que eram peças mais esbeltas, sem função estrutural, posicionadas entre os pilares. Peças diagonais - braces, de onde derivou-se a denominação deste sistema - eram fixadas nos cantos do entramado estrutural, entre pilares e travessas, para dar rigidez e estabilidade ao conjunto. Por fim, após a montagem das estruturas das paredes, as vigas de piso eram instaladas sobre as soleiras no térreo e sobre as travessas no entrepiso. Salienta-se que, neste sistema, as peças, ainda eram unidas com ligações entalhadas (Figura 21) (BOCK, 1992).

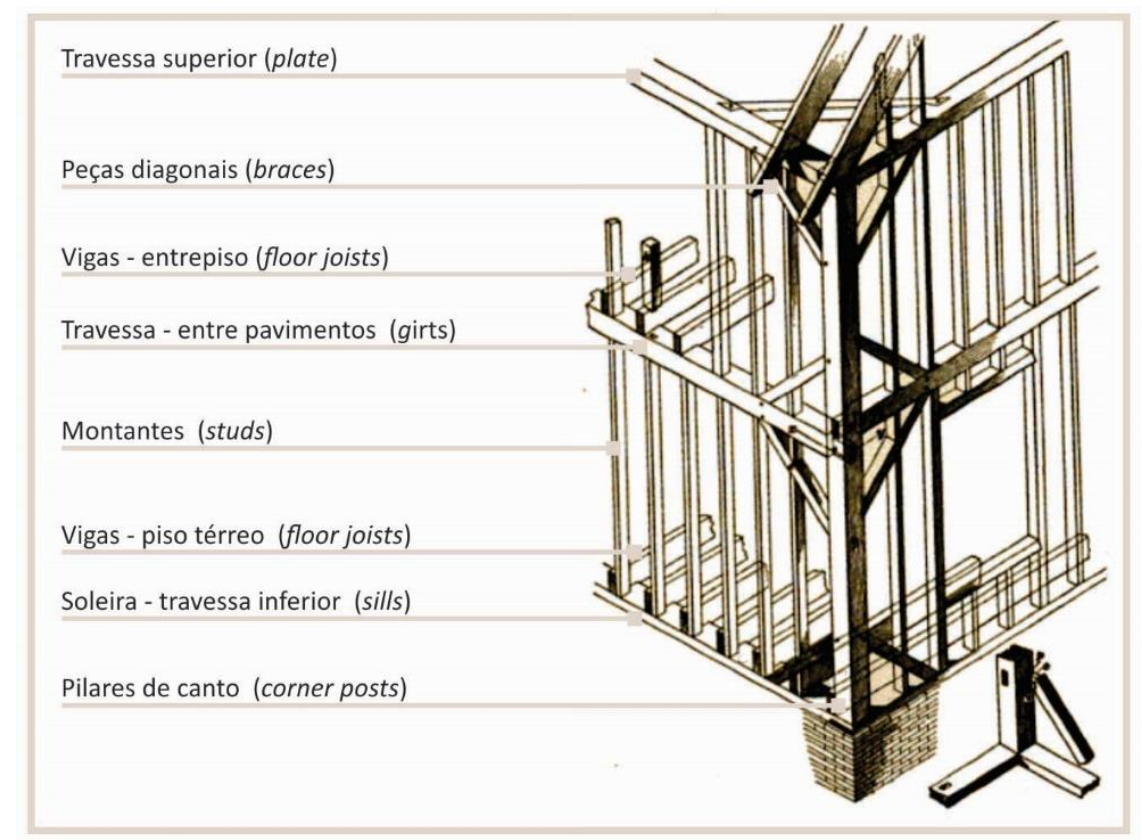

Figura 21: Estrutura principal do sistema construtivo braced-frame Fonte: adaptado de Bock, 1992.

O sistema balão - balloon frame - é considerado o pioneiro entre as estruturas leves em madeira. Afirma-se que sua primeira construção comprovada foi a igreja católica St. Mary em 1832/1833 na cidade de Chicago, nos Estados Unidos. Há uma controvérsia com respeito 
ao seu criador. Autores dividem-se entre Augustine Desdat Taylor e George Washington Snow, com mais evidências apontadas para o segundo (SPRAGUE, 1981).

O real significado do título balloon está envolvido entre mitos e folclores espalhados no tempo. Alguns historiadores acreditam que seu nome pode ser atribuído à leveza da estrutura, esbelteza das peças ou rapidez na sua montagem. Mas, o autor que mais se aproxima de um significado é Ted Cavanagh (1997), o qual conecta esta nomenclatura a um sistema construtivo similar utilizado anteriormente na França chamado poteaux-sur-sole. Sua justificativa tem como base cartas de colonos e imigrantes instalados nos Estados Unidos, datadas do início do século XIX, que se referem a um sistema construtivo característico dos colonizadores como Maison en Boullin, em francês, ou Balloon House, em inglês.

É notável como este sistema sobrepujou as estruturas em madeira anteriores que apresentavam grandes seções unidas com entalhes e sambladuras, as quais foram substituídas por peças serradas com pequenas dimensões padronizadas e unidas com ligações pregadas. Por exemplo, inicialmente, no balloon frame, os montantes do entramado das paredes para edificações com dois pavimentos eram, geralmente, dimensionados com a seção $2 " \times 4 "$ ou 2" × 6" e com comprimento contínuo conforme a altura da edificação, indo desde a soleira até a travessa superior, sem interrupções. Por serem componentes estruturais, estes eram posicionados com pouco espaçamento entre si, geralmente, de $60 \mathrm{~cm}$. Esta trama poderia ser travada por peças diagonais fixadas nos montantes ou por vedação de tábuas de madeira também aplicadas no sentido diagonal à estrutura. Por fim, para a composição do entrepiso, uma travessa de madeira era fixada na face interna dos montantes para receber as vigas (Figura 22) (BOCK, 1992).

Os espaçamentos entre os montantes contínuos e sem interrupções constituíam uma vantagem para a passagem das tubulações das instalações, como shafts entre pavimentos. No entanto, em casos de incêndio, estes espaços vazios facilitavam a propagação do fogo para os pavimentos superiores. Assim, a estrutura do sistema balloon frame sofreu algumas alterações. Entre estas, destaca-se a instalação de pequenas peças horizontais fixadas entre os montantes com a função de barrar tal propagação do fogo. 


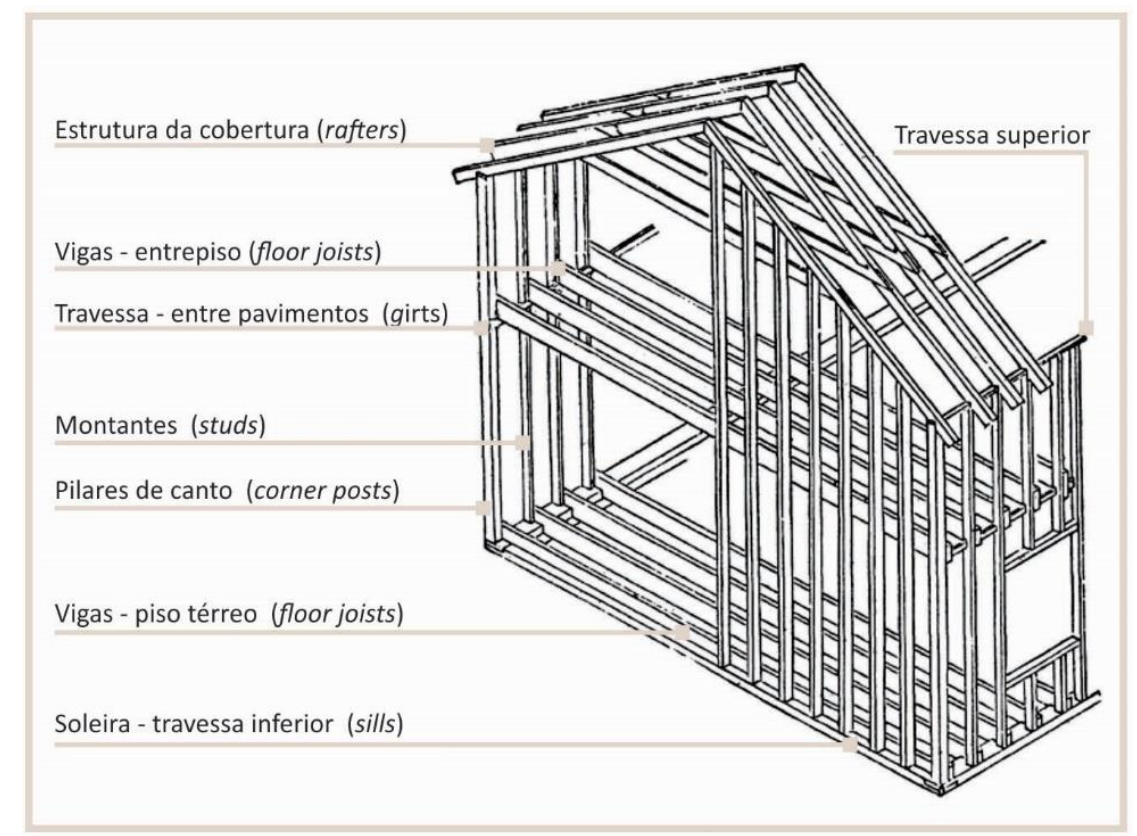

Figura 22: Estrutura principal do sistema construtivo balloon frame Fonte: adaptado de BELL, 1858 apud JENSEN, 1971.

Já na primeira metade do século XX, o sistema plataforma - platform frame praticamente substituiu seu antecessor balloon frame. A maior diferença entre estes dois sistemas era a composição estrutural, onde, no sistema plataforma, os montantes das paredes apresentavam comprimento delimitado conforme a altura de cada pavimento. Além de curtos, estes montantes, geralmente, possuíam a seção de $2^{\prime \prime} \times 4^{\prime \prime}$, equivalentes a aproximadamente $5 \mathrm{~cm} \times 10 \mathrm{~cm}$, para edificações de dois pavimentos. $E$, por isso, sua denominação em alguns locais refletia esta característica, sendo assim, também era conhecido como two by four, ou dois por quatro. Ainda, outra denominação comum era western frame, referindo-se à região oeste dos Estados Unidos, onde os sistemas leves em madeira foram abundantemente aplicados no período de expansão territorial deste país.

Conforme ilustra a Figura 23, o sistema plataforma era constituído, basicamente, por uma estrutura de piso térreo sobre a fundação de concreto. Sobre o piso, eram instalados os painéis de parede estruturados por: (a) travessa ou barra inferior, (b) montantes, sendo espaçados a cada 30, 40 ou $60 \mathrm{~cm}$, conforme a carga suportada pelo painel, e (c) travessa ou barra superior. Na parte superior dos painéis de parede, uma segunda travessa superior era fixada, a qual unia os painéis entre si, dando maior resistência para toda estrutura. No princípio, barras na diagonal eram instaladas nos montantes para dar rigidez ao painel de parede. Posteriormente, com a mesma função, estas diagonais foram substituídas por chapas 
de compensado ou chapas OSB - Oriented Strand Board. Na sequência, a estrutura do entrepiso era posicionada sobre as travessas duplas das paredes térreas. $E$, por fim, sobre esta plataforma do entrepiso, as paredes do segundo pavimento eram fixadas. A denominação do platform frame deriva desta sequência de montagem das estruturas de parede sobre plataformas de piso.

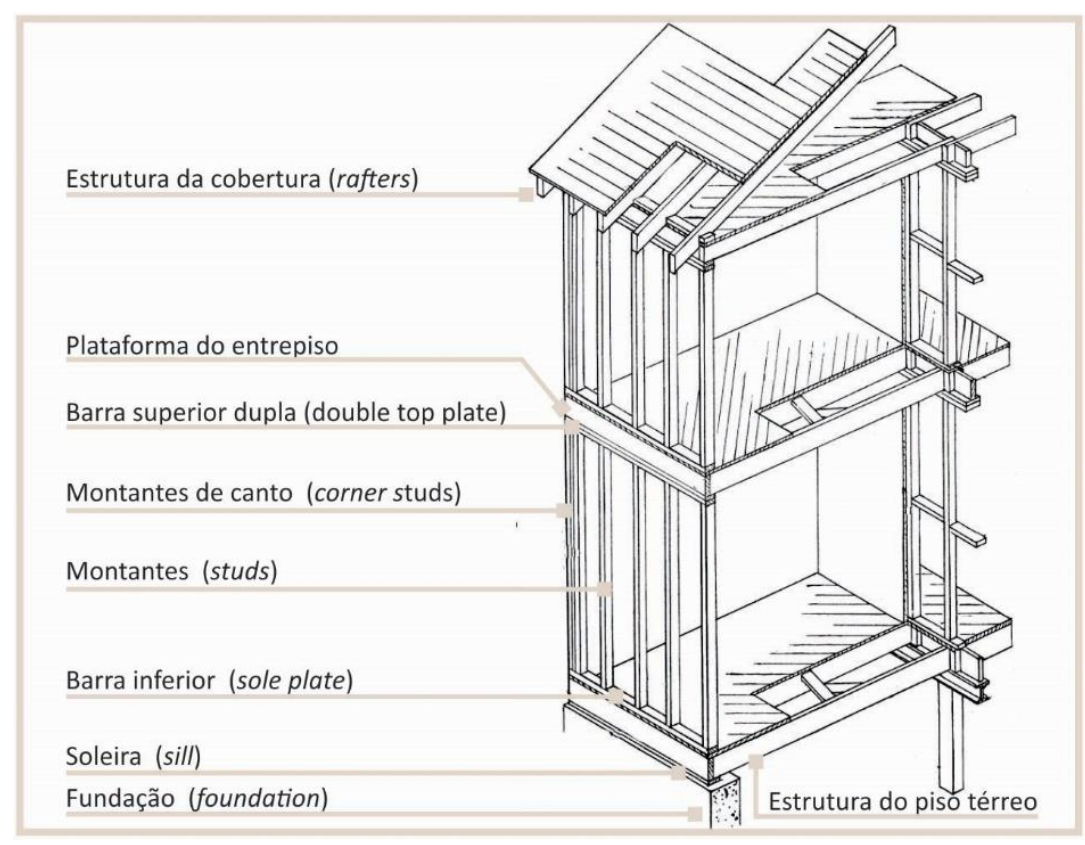

Figura 23: Estrutura principal do sistema construtivo platform frame Fonte: adaptado de HOLTMAN, 1921 apud MONTEYNE, 2004.

Estes sistemas leves, essencialmente caracterizados por peças de madeira serrada, padronizadas, com pequenas seções e unidas por ligações pregadas, tiveram propagação e aceitação popular em diversos países, tendo como destaque a América do Norte. O item seguinte apontará alguns fatores que favoreceram a consolidação destes sistemas, em especial no território dos Estados Unidos.

\subsection{PROPAGAÇÃO DO LIGHT WOOD FRAME NO TERRITÓRIO NORTE-AMERICANO}

Acredita-se que o sistema balloon frame, pioneiro entre os sistemas leves em madeira, teve seu desenvolvimento atrelado às práticas das construções dos antigos colonizadores nas fazendas de New England, na região leste dos EUA, apesar de ser primeiramente reconhecido em registros históricos da cidade de Chicago, no centro-oeste. Rapidamente, este sistema se 
tornava a forma predominante de construção tanto em Chicago quanto nas áreas vizinhas. Relatos de 1834 comprovam que o número dessas edificações aumentava de forma espantosa em pouco tempo, onde dezenas se transformavam em algumas centenas (TAKASE, 1981).

Tal propagação acelerada foi possibilitada mediante necessidades sociais específicas naquele contexto histórico. Os subitens seguintes procuram destacar três fatores que favoreceram esta inovação das construções em madeira no século XIX nos EUA: primeiro, a agro industrialização e a mecanização da produção, que resultaram em componentes como pregos em série e madeira serrada; segundo, a disponibilidade abundante de material, sendo a cidade de Chicago um centro comercial com localização estratégia na distribuição de madeira; e, terceiro, a expansão territorial norte-americana para a região centro-oeste, com crescimento populacional acelerado e necessidade de construções rápidas e com baixo custo. Por fim, no século XX, após a consolidação das construções em madeira neste território, seus componentes foram aprimorados e padronizados resultando em novos sistemas e métodos de produção.

\subsubsection{Agro industrialização e mecanização da produção}

No início do século XIX, os Estados Unidos era um território com economia e atividade essencialmente agrícola. Dois terços dos trabalhadores americanos estavam empregados nesta área. Assim, as prioridades do governo refletiam os interesses da agricultura e seu desenvolvimento industrial estava inicialmente focado neste setor (HIRSCHMAN; MOGFORD, 2009; PAGE; WALKER, 1991).

A extração e o processamento de recursos naturais destacavam-se entre as principais atividades industriais. Portanto, o complexo de indústrias produzia máquinas, ferramentas e suprimentos para acelerar o processamento da matéria-prima agrícola. Nesse contexto, a produções de ferro e, posteriormente, de aço foram importantes para a invenção de maquinários mecanizados (PAGE; WALKER, 1991). Esta transformação tecnológica na produção foi primordial para o avanço das composições das construções tradicionais em madeira dos colonos norte-americanos. Dois componentes resultantes desta produção industrial foram destacados: pregos produzidos mecanicamente e madeira serrada.

No período colonial norte-americano, os pregos eram feitos artesanalmente à mão e seus preços eram controlados pela colonizadora britânica, a maior produtora naquele 
momento. As leis da colônia britânica permitiam apenas a existência de indústrias primárias, nas quais os pregos artesanais eram comercializados por preços muito elevados (FIELD, 1942). Portanto, sob a falta de acesso ao componente, as construções em madeira nos EUA mantinham a tradição das ligações entalhadas, trabalhadas manualmente por carpinteiros com muita habilidade, como pôde ser observado no sistema do tipo braced frame, apresentado no item anterior.

Mas, com o fortalecimento das agroindústrias no continente americano, pressões internas foram feitas para acelerar e baratear a produção de pregos. Assim, no final do século XVIII, foram criadas máquinas de fazer pregos com processos mecânicos e sequenciais. Com maior disponibilidade do produto, seu preço foi reduzido drasticamente, tornando-se popularmente acessível (FIELD, 1942). Como consequência, as construções em madeira puderam substituir as conexões elaboradas com pinos, entalhes e encaixes por ligações simples com pregos. Isso significava a substituição de carpinteiros com saber-fazer artesanal específico por trabalhadores sem conhecimentos ou habilidades com pré-requisitos necessários.

Outra importante transformação nestas construções foi a introdução de madeira serrada com seções menores e padronizadas. Antes, as peças em madeira eram grandes e trabalhadas artesanalmente, com machado, enxó, serra braçal. Mas, com o surgimento das primeiras serrarias, os colonizadores substituíram suas ferramentas manuais por utilitários mecanizados, diminuindo tempo e esforço de trabalho.

No século XVII, as primeiras serrarias eram movidas por rodas d'água e, por isso, localizavam-se, principalmente, junto às florestas no litoral e às quedas de águas de rios. Gradualmente, expandiram para o interior, seguindo o avanço das fronteiras rumo ao meiooeste e o recuo das florestas. Em meados de 1790, foram computadas cerca de 150 a 200 serrarias nestes locais. Posteriormente, surgiram as serras movidas a vapor. Estas foram registradas em 1832 na cidade de Chicago e também, provavelmente, nas florestas de Michigan e do país vizinho Canadá. Estas serras podiam cortar os elementos em madeira em seções menores e padronizadas, aproveitando mais da tora da árvore extraída (FIELD, 1942).

Em meados de 1850, na região centro-oeste dos EUA, além da exploração direta da madeira serrada e beneficiada, produziam-se dormentes, caixilhos, portas, barris, caixas, móveis, elementos para carruagens. Melhorias foram constantemente feitas, tanto na qualidade dos produtos como nos meios de produção. Aço substituiu o ferro, motores a vapor 
operavam as máquinas, as quais se tornam maiores, diversificadas, afiadas e calibradas. Em 1860, o processamento de madeira liderava as inovações mecânicas, com as serra-fita, serramúltipla, serra-circular, lixadeiras, plainas e máquinas alimentadas mecanicamente (PAGE; WALKER, 1991).

Em 1870, dois grandes segmentos industriais se concentravam na região centro-oeste: alimento processado e madeira serrada e produtos derivados. A cidade de Chicago destacouse dentre os centros industriais e comerciais madeireiros entre os anos de 1830 e 1870 . As serrarias e os produtos em madeira estavam entre as cinco maiores indústrias no topo do ranking nacional na transição para o século XX. A indústria moveleira e indústria de construção de casas cresceram em conjunto com as serrarias. Em meados de 1870 e 1880, as inovações mecânicas das serrarias contribuíram para aumentar a produtividade do setor que influenciou diretamente na revolução da construção civil americana, com o desenvolvimento de sistemas leves em madeira (PAGE; WALKER, 1991).

\subsubsection{Centro de distribuição de madeira processada mecanicamente}

Em 1833, a cidade de Chicago, localizada estrategicamente, iniciou uma nova era comercial com a importação de madeira. Inicialmente, a madeira era proveniente das florestas de Michigan e, posteriormente, do Canadá, regiões vizinhas. Além do transporte por ferrovias, diversas embarcações carregadas com madeira eram levadas pelos rios, canais e lagos. Em 1839, Chicago se tornou um centro de distribuição de madeira para a região centrooeste dos EUA. Neste ano, relata-se que George Snow, aclamado como um dos criadores do sistema balloon frame, abriu o primeiro pátio de distribuição de madeira processada mecanicamente (FIELD, 1942).

Durante este período, o preço da madeira em Chicago era baixo em relação a outras regiões, inclusive com valor expressivamente inferior quando comparado aos locais fornecedores de toras. $\mathrm{E}$, mesmo com o crescimento rápido deste negócio, a demanda muitas vezes excedia a oferta, a qual era principalmente destinada para a construção de edificações, haja vista o aumento populacional nesta cidade com grandes indústrias (FIELD, 1942). 
3.2.3 Expansão territorial e crescimento populacional na região centro-oeste

No início do século XIX, com meios de transporte traçados, a expansão territorial seguia rumo à região centro-oeste dos EUA. Tal crescimento acompanhou o processo da "agro industrialização" americana, com uma combinação de agentes agrícolas, ferrovias e indústrias pesadas, culminando, posteriormente, em uma das zonas industriais pioneiras do mundo (PAGE; WALKER, 1991). Nesta região, a localização da cidade de Chicago era privilegiada, acessada por canais, rios e ferrovias. Assim, a cidade se transformou em um grande centro industrial e também em um importante centro de vendas de terras, correspondendo ao crescimento populacional naquele período (FIELD, 1942).

No ano de 1833, havia aproximadamente 15 habitações em Chicago, com uma população estimada de 200 a 300 pessoas. Um ano após, este número havia subido para 600 habitações. Além da oportunidade industrial, o crescimento populacional também era estimulado pelo incremento dos meios de transporte. Em 1837, havia pouco mais de 4.000 habitantes; enquanto, em 1850, com a ligação ferroviária entre as cidades de Chicago e Nova Iorque, a população somou mais de 20.000. Em 1860, Chicago apresentava mais de 200.000 habitantes, chegando a ultrapassar o marco de 1.000.000 no ano de 1890 (MARRYAT, 1883; FIELD, 1942).

No início, os preços das terras eram reduzidos. Porém, sob o domínio de especuladores, estes valores chegaram a ter aumento de $100 \%$ por dia durante um período de cinco anos, quando comparados aos valores iniciais (FIELD, 1942). Com o crescimento vertiginoso, o déficit habitacional impulsionou a aplicação de alguma solução construtiva rápida e com baixo custo.

Como apresentado anteriormente, na década de 1830, Chicago e as regiões vizinhas se destacaram pela produção e comércio de madeira processada mecanicamente. Peças menores e padronizadas com preços acessíveis favoreceram a seleção do material para as construções destes novos colonizadores. Ainda, estes apropriaram-se da disponibilidade de pregos produzidos sequencialmente em máquinas para criar detalhamentos construtivos mais fáceis de executar. Como resultado dessas inovações tecnológicas, o sistema balloon frame apresentou características vantajosas para este período de construção em massa de residências, tais como simplicidade, facilidade e rapidez na montagem da estrutura, além de custo reduzido quando comparado aos sistemas tradicionais. 
"Junto com a leveza e a simplicidade, vieram a rapidez e a facilidade de montagem. Significava que um homem e um rapaz podiam agora obter com facilidade os mesmos resultados que vinte homens conseguiam com o método antigo de estrutura em madeira". 0 construtor também assumia o papel do arquiteto, enquanto o lema adotado era: "Todo homem seu próprio arquiteto" (WOODWARD, 1869 apud FIELD, 1942, p. 7).

Os escritores também confirmaram que a popularidade do novo sistema entre os colonos devia-se principalmente ao grande apelo: preço. Estimava-se que o balloon frame era $40 \%$ mais barato do que as estruturas tradicionais com encaixes e pinos de madeira. Ainda, complementavam que existia a possibilidade de subtrair o custo de um trabalhador especializado, com a seguinte afirmação: "Se você mesmo construir com balloon frame... ele custa o preço do material e qualquer valor que você colocar pelo seu próprio tempo" (WOODWARD, 1869 apud FIELD, 1942, p. 8).

Assim, o balloon frame, pioneiro dentre as construções leves em madeira, se consolidava como um sistema que qualquer trabalhador poderia executar. Era comum trabalhadores urbanos construírem suas próprias casas. Os imigrantes mal pagos enfrentavam taxas mais altas para adquirir uma casa própria do que os americanos nativos brancos. Portanto, os imigrantes pregavam e montavam suas casas sozinhos, enquanto a elite local empregava construtores profissionais e carpinteiros especializados para erguer suas residências mais elaboradas (JACKSON, 1985).

Outra prática que contribuiu para a propagação do balloon frame neste e em outros territórios foi o desenvolvimento de kits prontos para a construção de casas, sendo estas condicionadas por modelos de projetos arquitetônicos delimitados pelas empresas. Os elementos constituintes eram pré-cortados, enumerados e embalados para serem entregues por qualquer ferrovia do país. Em 1872, componentes pré-fabricados como janelas e portas foram introduzidos, completando os kits. Deste modo, reduzia-se as tarefas do construtor, limitando seu trabalho à montagem da edificação seguindo instruções e recomendações do projeto (JACKSON, 1985).

Sobre este aspecto, Greeley (1872 apud FIELD, 1942, p. 24) escreveu: “Com a aplicação de máquinas, o trabalho de construir uma casa foi grandemente reduzido, e as pradarias do oeste estão cheias de casas que lhe foram enviadas prontas, e as variações de peças numeradas para que pudessem ser montadas por qualquer um". 
Ainda, neste mesmo período, revistas e livros incluíam projetos com plantas, elevações e detalhes de casas para as pessoas replicarem por si só. Algumas dessas publicações pioneiras foram as seguintes: The Architecture of Country House, em 1850, de Andrew Jackson Downing; Houses for the people, em 1855, de Gervase Wheeler; Villas and cottages, em 1857, de Calvert Vaux; Country Seats, em 1866, de Henry Hudson Holly. Estes autores persuadiam os clientes a construírem com o sistema balloon, afirmando que o mesmo, apesar de leve, era estável e resistente. Estes livros portfólios, denominados pattern books, apelavam, geralmente, para leitores que não eram profissionais da construção e que achavam difícil imaginar a casa a partir dos seus detalhes, encontrados nos guias. Reforçavam a ideia de que o preço do arquiteto era um item luxuoso e desnecessário no orçamento familiar. Especificações detalhadas para a execução, assim como estimativa precisa de custo, eram inclusos nestes livros (JACKSON, 1985).

Por fim, mediante estes aspectos sociais presentes, até o fim do século XIX, o balloon frame consolidou-se como um sistema construtivo popular no território norte-americano. Este invento superou em diversos aspectos as práticas que eram comuns nas construções da Europa naquele período. E isso fez com que aflorasse o senso e o orgulho americano de modernidade. Estimava-se que cerca de $60 \%$ a $80 \%$ de todas casas nos EUA eram construídas com este modelo, tornando-se um fenômeno nesta sociedade (FIELD, 1942). De acordo com o historiador Kingston Heath (1996 apud JOHNSON, 2007), "o balloon frame foi produto da Revolução Industrial Americana". E, logo, tornou-se o ator principal na realização sonho americano da construção da casa própria nos subúrbios americanos (JACKSON, 1985).

\subsubsection{Padronizações de produtos e manuais técnicos para construção}

Já no século $X X$, os componentes foram aprimorados e novos sistemas leves com estrutura de madeira foram desenvolvidos, sendo o sistema plataforma o modelo mais popular na construção de residências. O início deste século foi marcado por ações para normalizar e padronizar produtos e processos, e isto não foi diferente para o caso dos elementos em madeira para as construções. Nesse sentido, em 1910, inserido no Departamento de Agricultura dos Estados Unidos (USDA), foi instituído o Laboratório de Produtos Florestais - Forest Products Laboratory (FPL) - dedicado a testar e avaliar o 
comportamento de elementos constituintes do sistema wood frame (SHERWOOD, STROH, 1989; MONTEYNE, 2004).

$\mathrm{Na}$ década de 1920, instituições de normas e padronizações, departamentos governamentais, comitês relacionados à economia na construção, agentes imobiliários e associações da indústria da construção mobilizaram-se para nacionalizar e padronizar os componentes e os processos das construções. Como resultado, em 1923, foi formado o Architect's Small House Service Bureau (ASHSB), refletindo tal necessidade de criar padrões para a construção de residências racionalizadas e com menor custo. Para a elaboração de catálogos que divulgariam estas ações, esta associação tinha como parceiros a Southern Pine Association (SPA) e a empresa Weyerhaeuser Forest Products, ambas do setor florestal e madeireiro (MONTEYNE, 2004). Portanto, a maioria destas publicações demonstravam especificações para os sistemas leves em madeira, o que constituiu um benefício para sua promoção popular.

Também, neste período, foi intensificado o uso de propagandas para incentivar o uso de produtos em madeira. Em 1928, em uma campanha conhecida como 4-Square, a empresa Weyerhaeuser divulgou conteúdos para o público em geral e para indústrias, anunciando sua linha de produtos com madeira selecionada e processada a fim de resultar em peças com as quatro faces bem lisas e com cortes precisos de topo. Cerca de 6 milhões deste artigo foram publicados por mês em revistas de construção, relatando sobre "a história da madeira garantida", referindo-se à confiabilidade do produto. Com base nesta experiência positiva, em 1932, a Associação Nacional de Produtores de Madeira Serrada - National Lumber Manufacturers Association - formou uma organização subsidiária devotada inteiramente para elaborar promoções e propagandas com intuito de ampliar o uso da madeira (MONTEYNE, 2004).

Durante a segunda metade do século $X X$, centenas de conselhos e associações representantes da indústria de produtos madeireiros se reafirmaram nos países norteamericanos e reorientaram seus objetivos para, além do marketing, enfatizar a tecnologia. Além da madeira serrada, diversos produtos derivados direcionados para a construção de edificações vêm sendo representados, tais como: chapas de compensado, chapas OSB, chapas de materiais compósitos, vigas I compostas, madeira laminada colada, madeira microlaminada ou laminated veneer lumber (LVL), entre outros. 
Ao longo do tempo, muitas dessas associações alteraram denominações, migaram suas metas ou se fundiram. Atualmente, são consideradas importantes referências nacionais e regionais: Canadian Wood Council (CWC), American Wood Council (AWC), The Engineered Wood Association, derivada da antiga American Plywood Association (APA), American Forest \& Paper Association (AF\&PA) e Western Wood Products Association (WWPA).

Em geral, estas associações vêm fornecendo uma estrutura organizacional para empresas e indústrias associadas trabalharem em conjunto em questões políticas visando o fortalecimento da aplicação da madeira na construção. Dentre suas principais atividades, incluem-se a realização de testes de qualidade e o estabelecimento de padrões para os produtos madeireiros comercializados. Tais dados, geralmente, são divulgados em relatórios e tabelas numéricas e, em formato resumido, podem estar estampados nos produtos finais das empresas associadas aferindo sua certificação. E, por fim, para o público de construtores e projetistas, publicam-se guias e manuais que detalham tecnicamente a utilização desses produtos na construção conforme cada região específica.

O primeiro manual com informações completas e detalhadas para as construções em wood frame do tipo plataforma foi o U.S. Department of Agriculture Handbook № 73, intitulado "Wood-frame house construction", escrito pelos cientistas O.C. Heyer e L.O. Anderson, publicado em 1955 pelo FPL e USDA. Este manual se tornou popular e foi adotado rapidamente pelo público em geral, incluindo os construtores e as instituições educacionais, principalmente. Conforme novas tecnologias eram disponibilizadas para este sistema construtivo, este manual era revisado e editado, incluindo, a partir da década de 1980, a participação do National Research Center subsidiário do National Association of Home Builders (NAHB) (SHERWOOD, STROH, 1989). Ainda, mais tarde, outro importante exemplo destas publicações influentes foi o Wood Frame Construction Manual (WFCM), originalmente publicado por AWC e AF\&PA em 1996, revisado periodicamente com base nos dados do International Residential Code (IRC) em vigor.

Portanto, a constante publicação de livros, guias, catálogos e manuais com detalhes específicos dos elementos constituintes padronizados e dos procedimentos para cada etapa da construção também pode ser considerada uma influência sobre a cultura dos sistemas leves em madeira nos países norte-americanos no século XX. De forma simplificada, por meio de ilustrações, tabelas e textos explicativos, estes materiais detalham o passo-a-passo da obra executada no canteiro. Geralmente, o foco é dado para edificações unifamiliares de até 2 
pavimentos. Assim, a apropriação popular manteve a tradição das construções em madeira para as residências nestes locais.

No entanto, além da América do Norte, os sistemas leves se tornaram proeminentes em outros países com tradição de construções em madeira, como, por exemplo, em regiões da Europa central e nórdica, assim como também no Japão e na Austrália. A composição destes sistemas wood light frame pode ser muito variada, conforme o contexto de aplicação. Mesmo com tais oscilações, o sistema plataforma, em geral, apresenta um padrão básico de estruturação, como será resumido no item seguinte.

\subsection{PRINCIPAIS DETALHES TÉCNICO CONSTRUTIVOS}

Foram selecionados alguns dos principais detalhes técnicos do sistema plataforma em madeira, com objetivo de descrever, em resumo, seus principais subsistemas: fundação, plataforma de piso, paredes e cobertura.

A fundação, em geral, pode ser executava em radier - laje de concreto armado. E, algumas prevenções devem ser tomadas para evitar que a umidade do solo passe pela fundação e chegue até a estrutura de madeira. Por exemplo, deve-se minimizar o acúmulo de água no solo em contato direto com a fundação. Para isso, recomenda-se colocar um solo menos permeável na camada superior e um aterro granular na sua camada inferior. Ainda, neste aterro, pode-se instalar uma manta geotêxtil e um cano com pequenas perfurações para auxiliar na drenagem deste solo. Também, antes da concretagem, sob a fundação, é necessário regularizar o solo e aplicar primer, manta asfáltica e filme de polietileno. Por fim, com a fundação finalizada, deve-se impermeabilizar a superfície superior com material betuminoso antes da ancoragem da soleira ou guia de madeira. Sugere-se executar o piso externo com material impermeável e com inclinação na direção oposta à parede. E, é necessário respeitar um afastamento mínimo entre o piso acabado e a estrutura de madeira, conforme ilustrado na Figura 24, a qual demonstra distâncias do código de obras americano, indicados por APA (2016). 


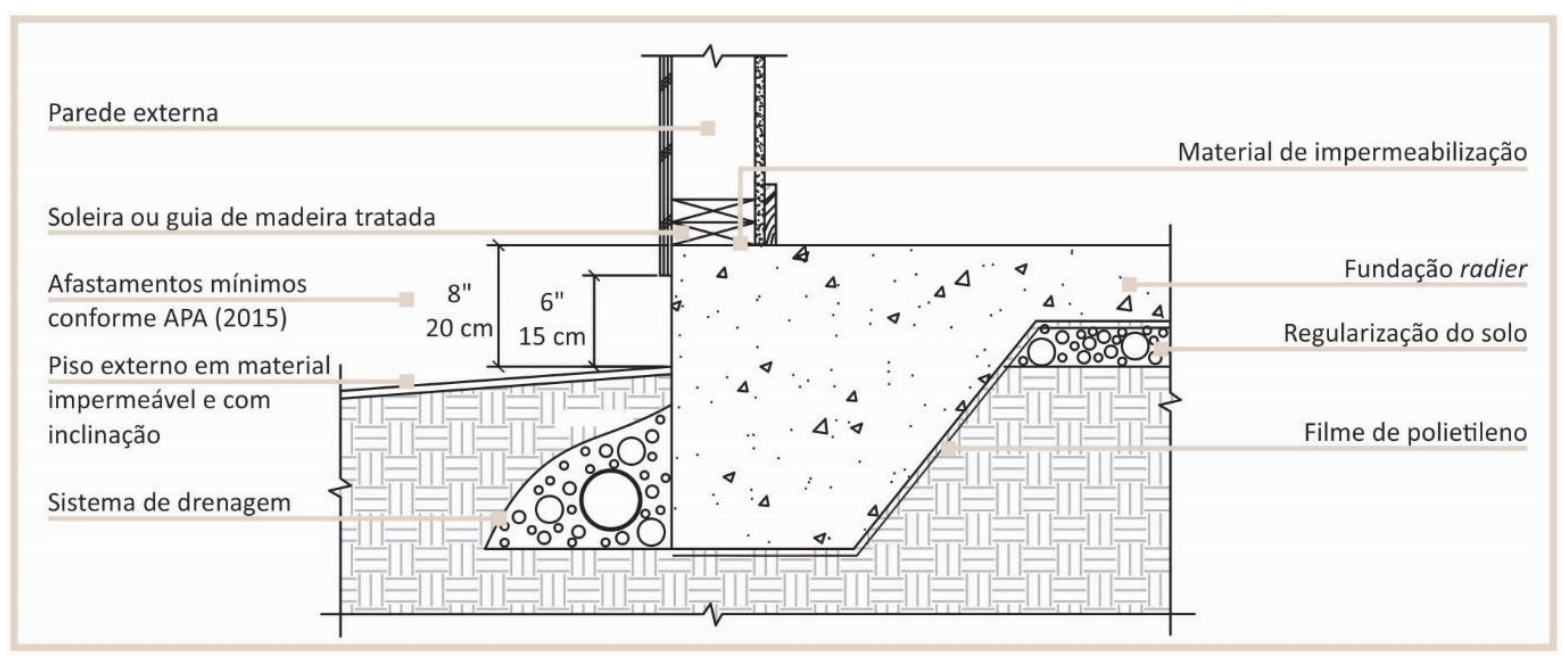

Figura 24: Corte com detalhes da fundação em radier

Fonte: adaptado de APA, 2015.

O procedimento é similar com fundações constituídas por viga-baldrame de blocos de concreto ou por sapata corrida de concreto. No entanto, uma plataforma de piso pode substituir a laje de concreto. Tal plataforma é constituída por uma estrutura de vigas/barrotes de madeira (Figura 25) ou vigas I compostas por madeira e OSB (Figura 26). Sobre estas, são colocadas chapas delgadas estruturais de madeira, compensado ou OSB, posicionadas perpendicularmente às vigas. Estas chapas, geralmente, são fixadas com pregos, mas acrescentar cola pode reforçar a rigidez estrutural. Ainda, para a rigidez, recomenda-se a instalação de bloqueadores na estrutura sob a união entre as chapas (APA, 2016).

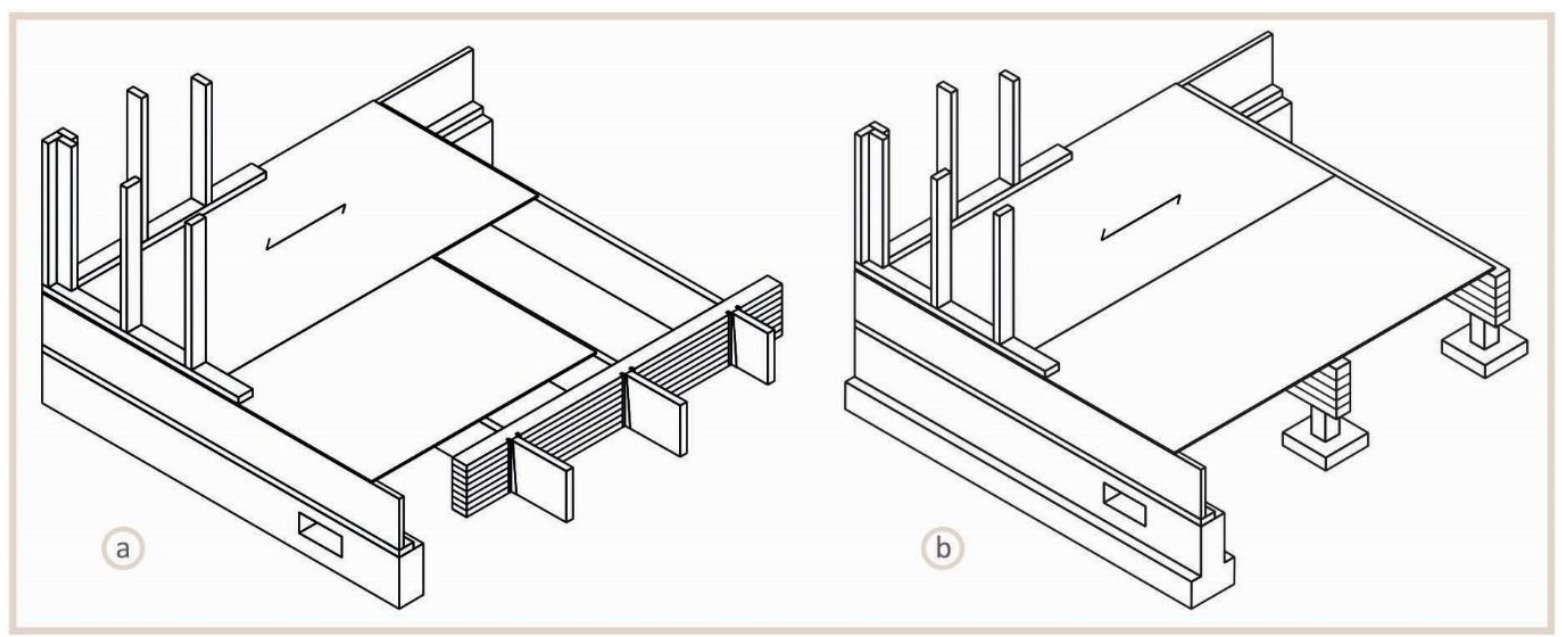

Figura 25: Plataforma de piso estruturada com vigas/barrotes em madeira Fonte: adaptado de APA, 2015. 


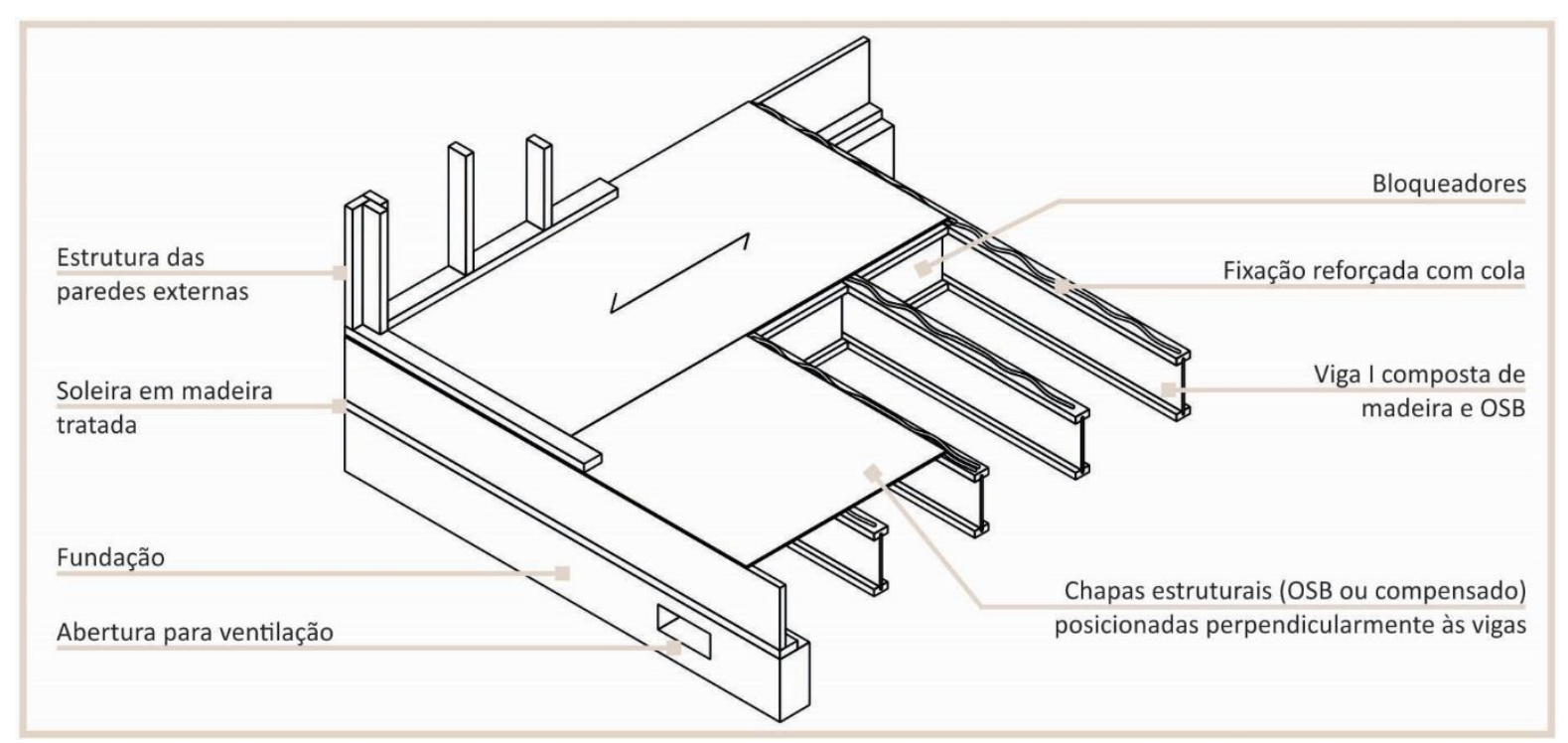

Figura 26: Plataforma de piso estruturada com vigas I e chapas delgadas

Fonte: adaptado de APA, 2015.

Sobre a fundação radier ou sobre a plataforma de piso em madeira, são instaladas as paredes da edificação. O frame ou entramado em madeira da parede externa é constituído por barra inferior, montantes e barra superior. Travamentos podem ser instalados entre os montantes ou na diagonal da estrutura geral. Ainda, chapas estruturais, como OSB ou compensado, dão contraventamento e rigidez para o conjunto estrutural (APA, 2016).

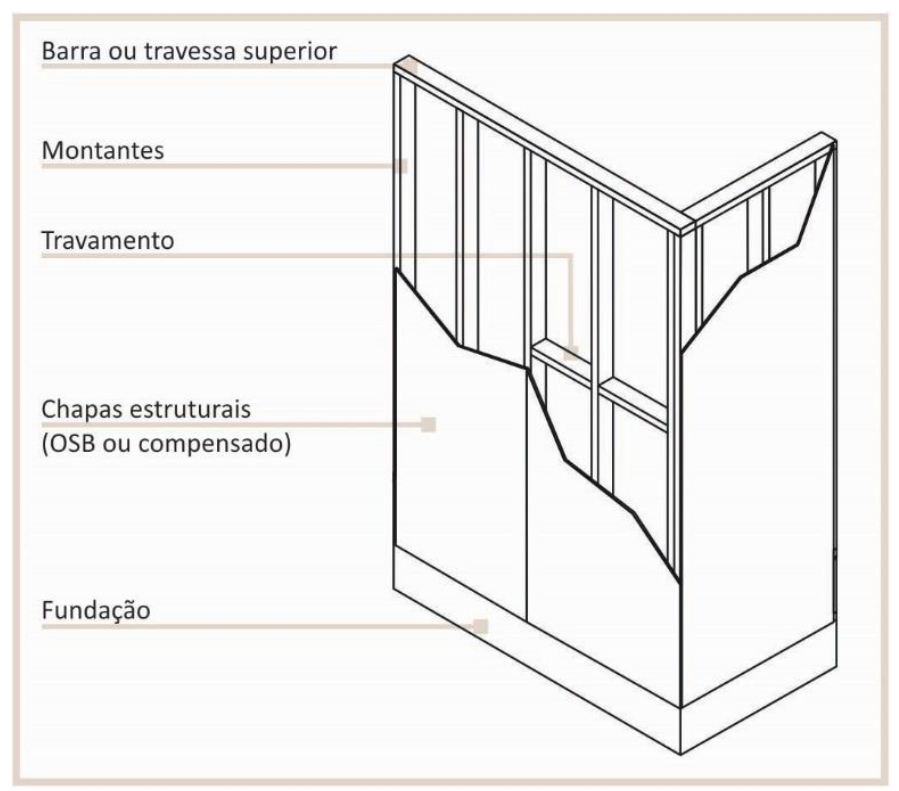

Figura 27: Estrutura de parede externa com chapa estrutural e peça de travamento Fonte: adaptado de APA, 2015. 
Estas chapas estruturais podem ser aplicadas no sentido vertical, seguindo a orientação dos montantes, ou no sentido horizontal, transversal aos montantes, conforme ilustra a Figura 28 (APA, 2016). Esta última opção dá maior estabilidade à estrutura; assim como, também, a instalação de chapas tanto na superfície interna quanto externa do entramado.

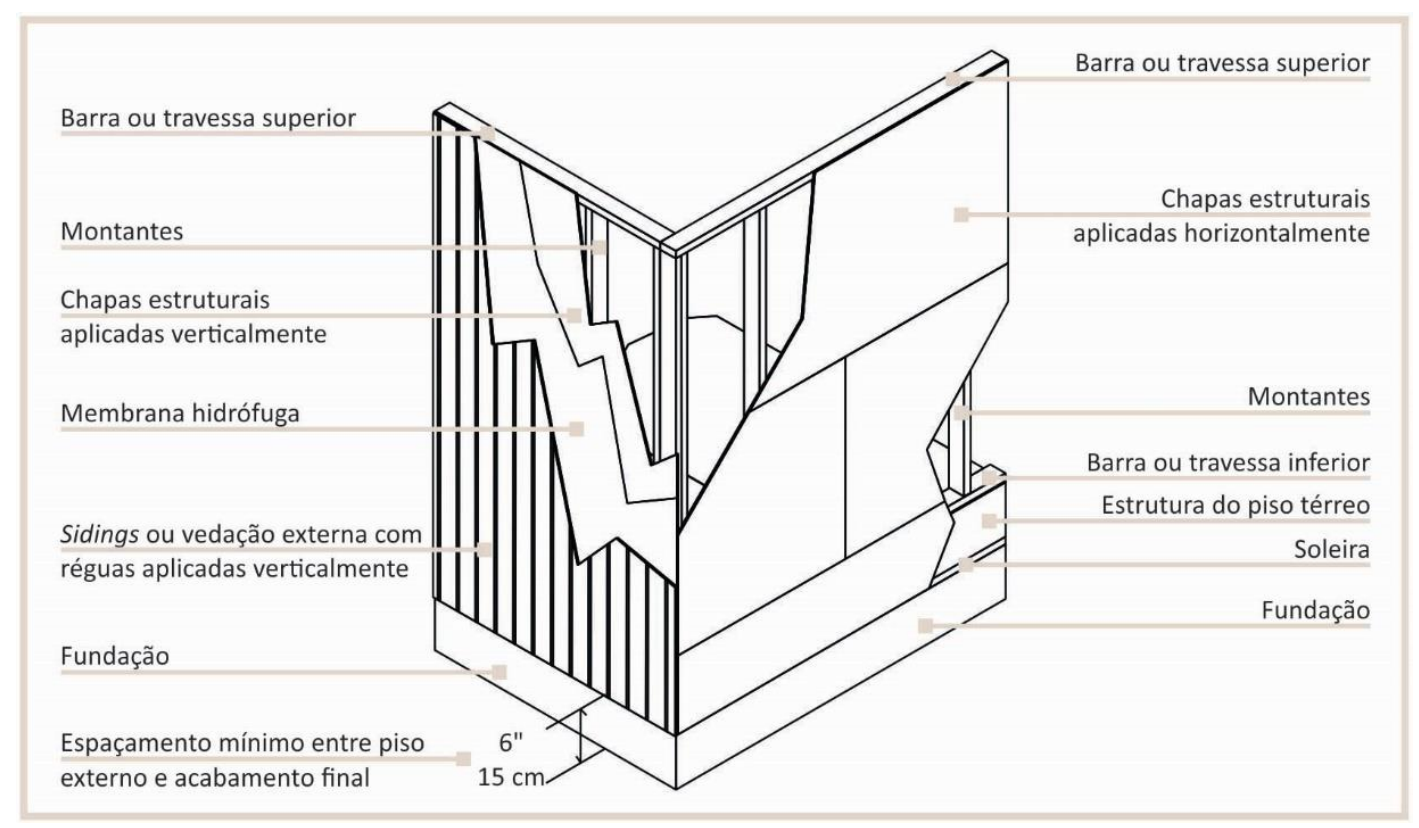

Figura 28: Chapas estruturais no sentido horizontal ou vertical Fonte: adaptado de APA, 2015.

Entretanto, como pode ser observado na ilustração anterior, esta estrutura em madeira não fica aparente, pois outros materiais compõem as camadas internas, intermediárias e externas das paredes. Estas composições podem ser variadas, conforme as necessidades do contexto onde serão aplicadas. As mais comuns estão elencadas brevemente a seguir.

Nas camadas externas, após a chapa estrutural de OSB ou compensado, em geral, são aplicados a membrana hidrófuga, que evita a entrada de água e permite a saída da umidade ou vapor internos, e o acabamento final. Este pode ser em: sidings ou réguas de madeira ou de PVC aplicados horizontal ou verticalmente (Figura 29); tijolos cerâmicos (Figura 30a); estuque (Figura 30b); entre outros (APA, 2016; CMHC, 2013). 


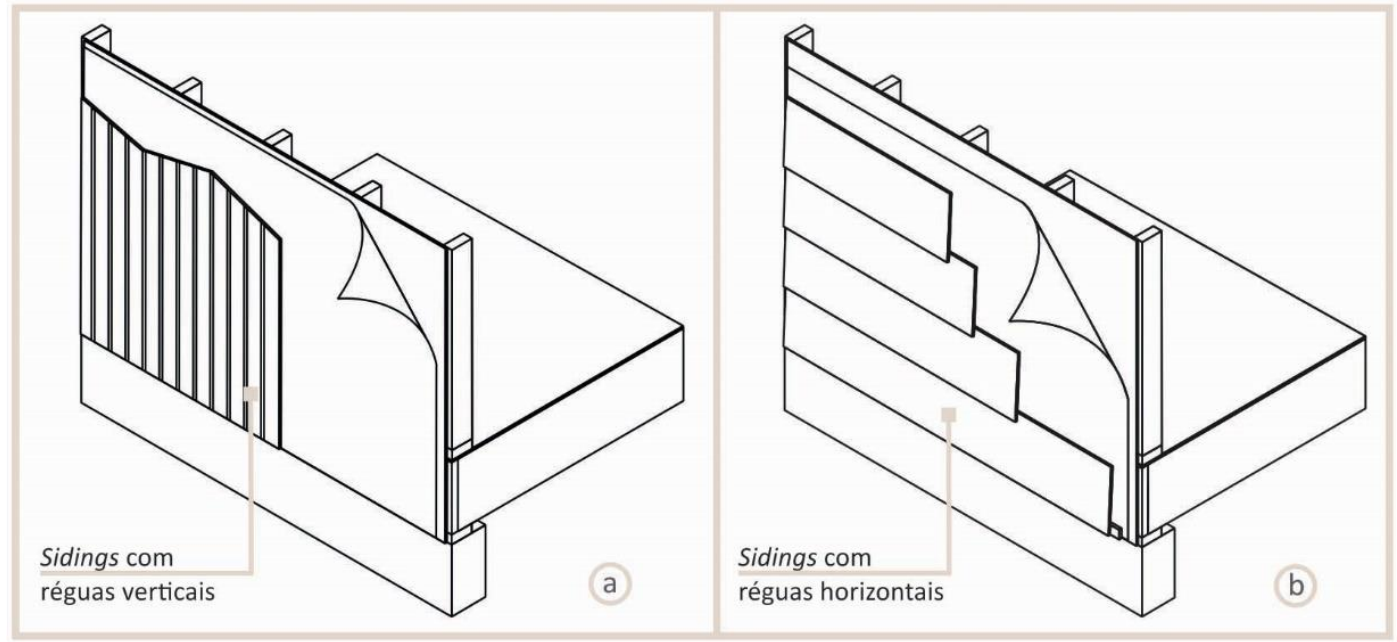

Figura 29: Revestimento externo em sidings

Fonte: adaptado de APA, 2015.

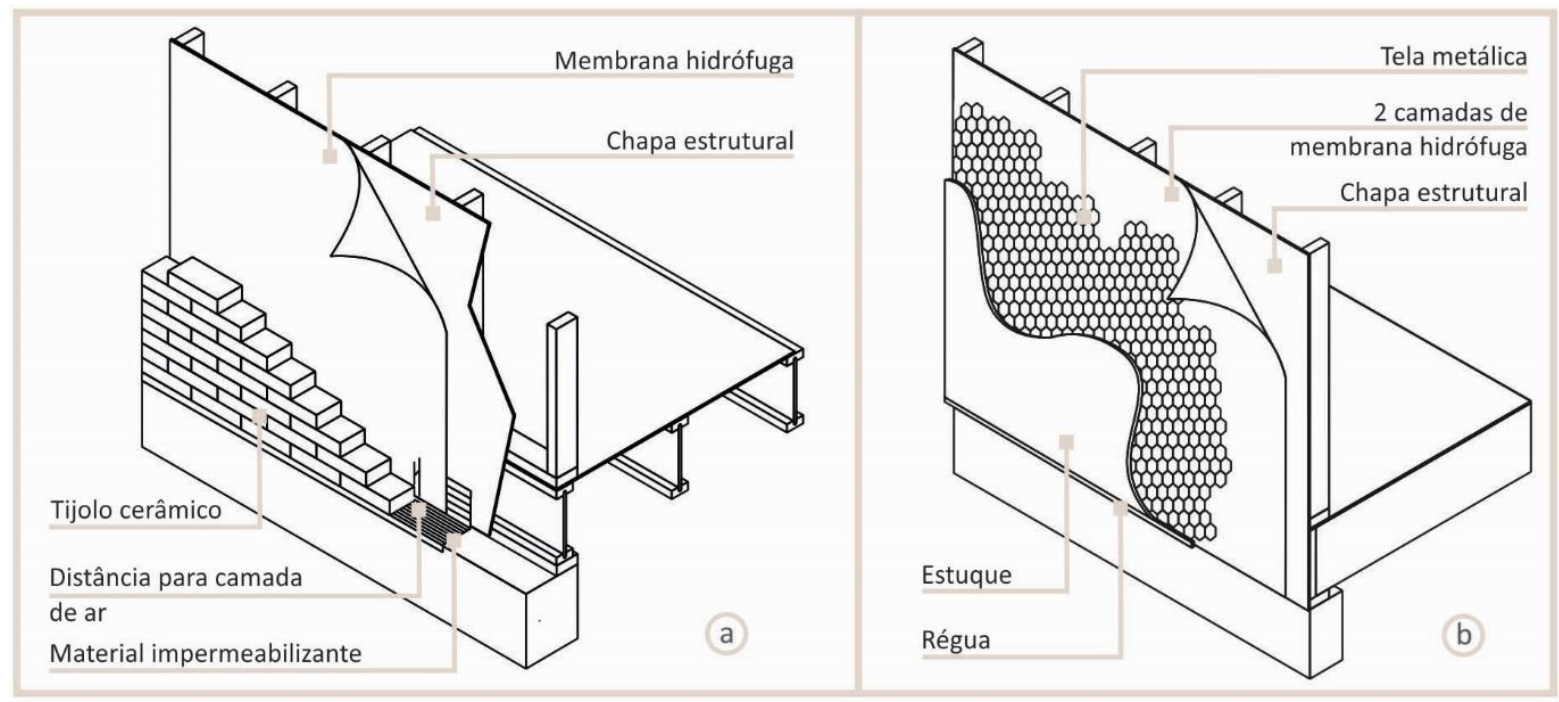

Figura 30: Revestimento externo em tijolos cerâmicos e em estuque

Fonte: adaptado de APA, 2015.

Interno ao entramado estrutural, nos espaços vazios entre os montantes e barras, são colocados materiais para isolamento térmico e acústico (Figura 31). As especificações para este material são atribuídas conforme o clima, a orientação solar e outras variáveis ambientais da região em que a edificação está localizada. Os materiais mais comumente aplicados são fibra de vidro e lã mineral, como a lã de rocha. Mas, atualmente, estão disponíveis outras opções como: Iãs naturais de ovelha, de algodão ou de palha; fibra plástica derivada do reaproveitamento de garrafas PET; fibra de celulose, produzida com papéis reciclados; entre outras. 
Na superfície interna da parede, é aplicada a chapa de gesso acartonado (Figura 31). Esta pode ser fixada diretamente no entramado de madeira ou, então, como é mais comum, é fixada sobre outra chapa estrutural de OSB ou compensado. Em climas mais frios, onde o ambiente interno é aquecido, são colocadas membranas de barreiras para vapor na face interna da parede, pois este impede a passagem da umidade para o interior da mesma. Porém, em climas quentes, a membrana é colocada na superfície mais aquecida, que é a externa. Neste caso, uma membrana hidrófuga é mais apropriada, pois, conforme mencionado anteriormente, ela permite a saída do vapor e da umidade existente dentro da parede, mas impede a entrada de água que pode passar pelo acabamento externo (CMHC, 2013).

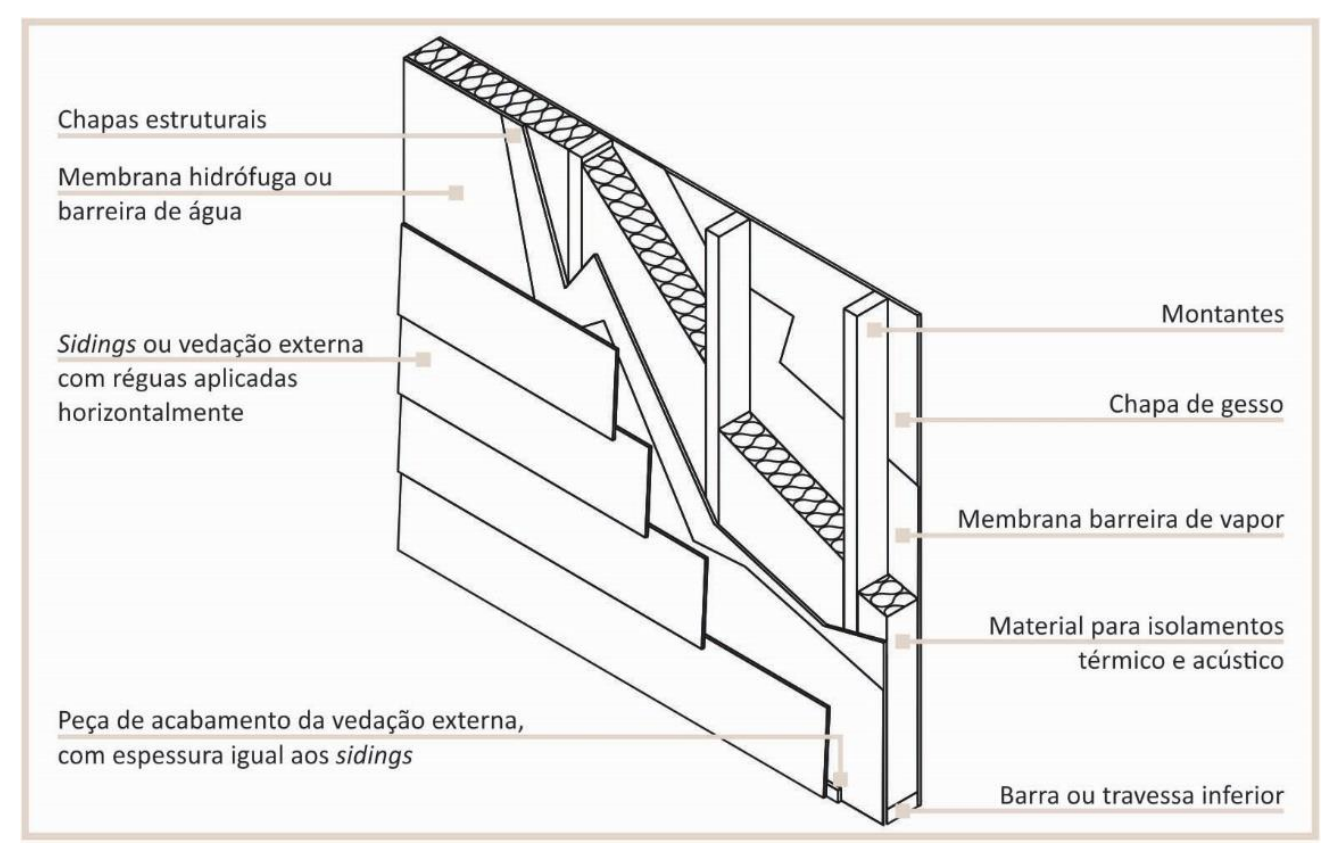

Figura 31: Principais camadas das paredes externas Fonte: adaptado de APA, 2015.

Sobre as paredes térreas, situa-se o entrepiso. Ele é composto por uma plataforma com elementos de madeira, como ilustrado anteriormente nas figuras Figura 25 e Figura 26. Sobre este entrepiso, são fixadas as paredes do segundo pavimento e, sobre estas, a estrutura da cobertura.

A cobertura pode ser plana ou inclinada. Esta segunda opção está ilustrada na Figura 32, onde, geralmente, são utilizadas treliças estruturais pré-fabricadas, com peças com seções pequenas unidas por chapas metálicas estampadas. Sobre estas treliças, são fixadas chapas estruturais de OSB ou de compensado, as quais são unidas por encaixe do tipo macho e fêmea 
ou por conectores metálicos. Sobre as chapas, são aplicados a membrana hidrófuga e a telha selecionada, sendo as shingles - telhas planas asfálticas ou de madeira - as mais comuns nos países norte-americanos. Sob os telhados, no ambiente interno, pode-se colocar materiais isolantes termo-acústico e vedar com forro em gesso acartonado. Na área externa, o beiral pode ser aberto ou forrado com chapas estruturais, deixando pequenas aberturas para circulação de ar e ventilação (Figura 33). As peças estruturais expostas devem ser cobertas e protegidas por uma tabeira, metálica ou de madeira tratada quimicamente (CMHC, 2013).

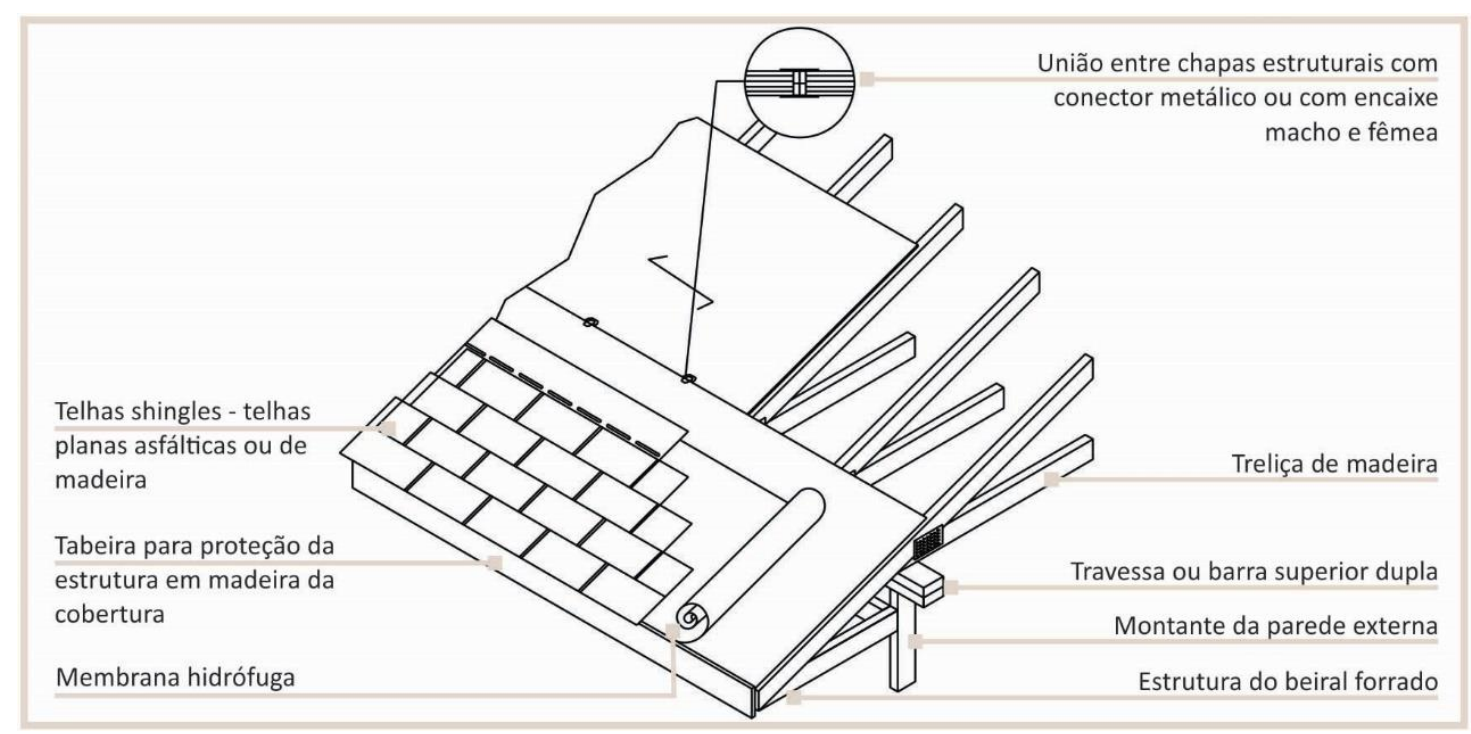

Figura 32: Principais elementos da cobertura

Fonte: adaptado de APA, 2015.

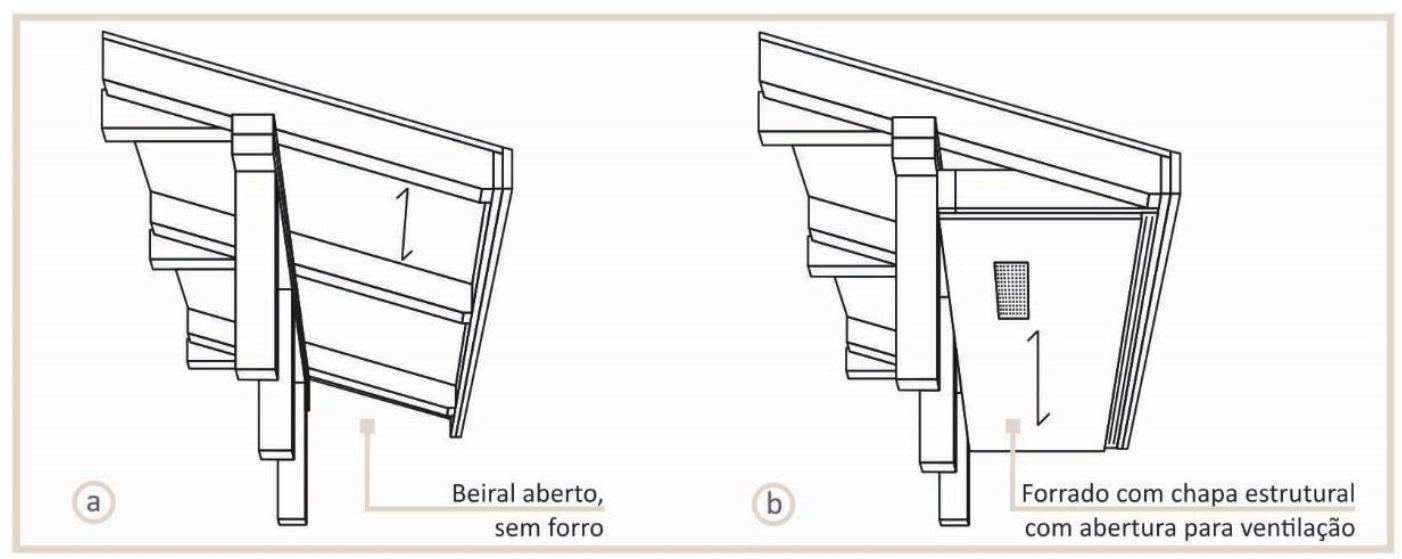

Figura 33: Cobertura com beiral aberto e forrado

Fonte: adaptado de APA, 2015. 
Para maior detalhamento dos elementos constituintes deste sistema leve, o International Building Code (IBC) (ICC, 2015), direcionado para os EUA e Canadá, fornece especificações para construções em madeira no capítulo 23 , com foco para construções convencionais do tipo light-frame na seção 2308. Ainda, na seção 2309, este código indica a aplicação dos dados divulgados no Wood Frame Construction Manual (WFCM) para edificações residenciais para uma ou duas famílias, em classificações de menor risco (AWC, 2014). E, nos países europeus, a norma utilizada para a definição destes elementos é o Eurocode 5-Design of timber structures (EN, 2004).

\subsection{MÉTODOS DE PRODUÇÃO}

Conforme apontado nos subitens anteriores, inicialmente, o sistema ballon frame, registrado como um dos pioneiros dentre as estruturas leves, era executado por carpinteiros com experiência nas construções em madeira mais tradicionais. Com a necessidade de construção em massa e com o preço mais elevado da mão-de-obra, foram desenvolvidos manuais que instruíam as pessoas a montarem sua própria residência. As peças eram trabalhadas nas serrarias, com as bitolas necessárias, e, na sequência, transportadas até o canteiro-de-obras, onde seriam unidas e erguidas.

O autor O'Brien (2010) resume as etapas de construção da estrutura principal do sistema balloon frame em oito passos principais, observados na Figura 34 descrita a seguir. Primeiro, as soleiras eram fixadas sobre a fundação e, sobre estas, eram erguidos pilares de canto, geralmente, com seção quadrada e com comprimento contínuo conforme a altura dos dois pavimentos. Ainda, eram colocadas peças diagonais que davam estabilidade e contraventamento para estes pilares. Segundo, travessas superiores eram pregadas, unindo os pilares. Terceiro, montantes, com a mesma altura contínua dos pilares de canto, eram posicionados com espaçamentos regulares e fixados com pregos na soleira e na travessa. Quarto, alguns montantes eram recortados conforme as peças diagonais. Quinto, os montantes eram recortados para a aplicação da travessa intermediária. Sexto, sobre esta travessa intermediária eram colocadas as vigas do entrepiso. Sétimo, sobre a soleira eram colocadas as vigas do piso térreo. Oitavo, os elementos da cobertura eram preparados para sua instalação. 


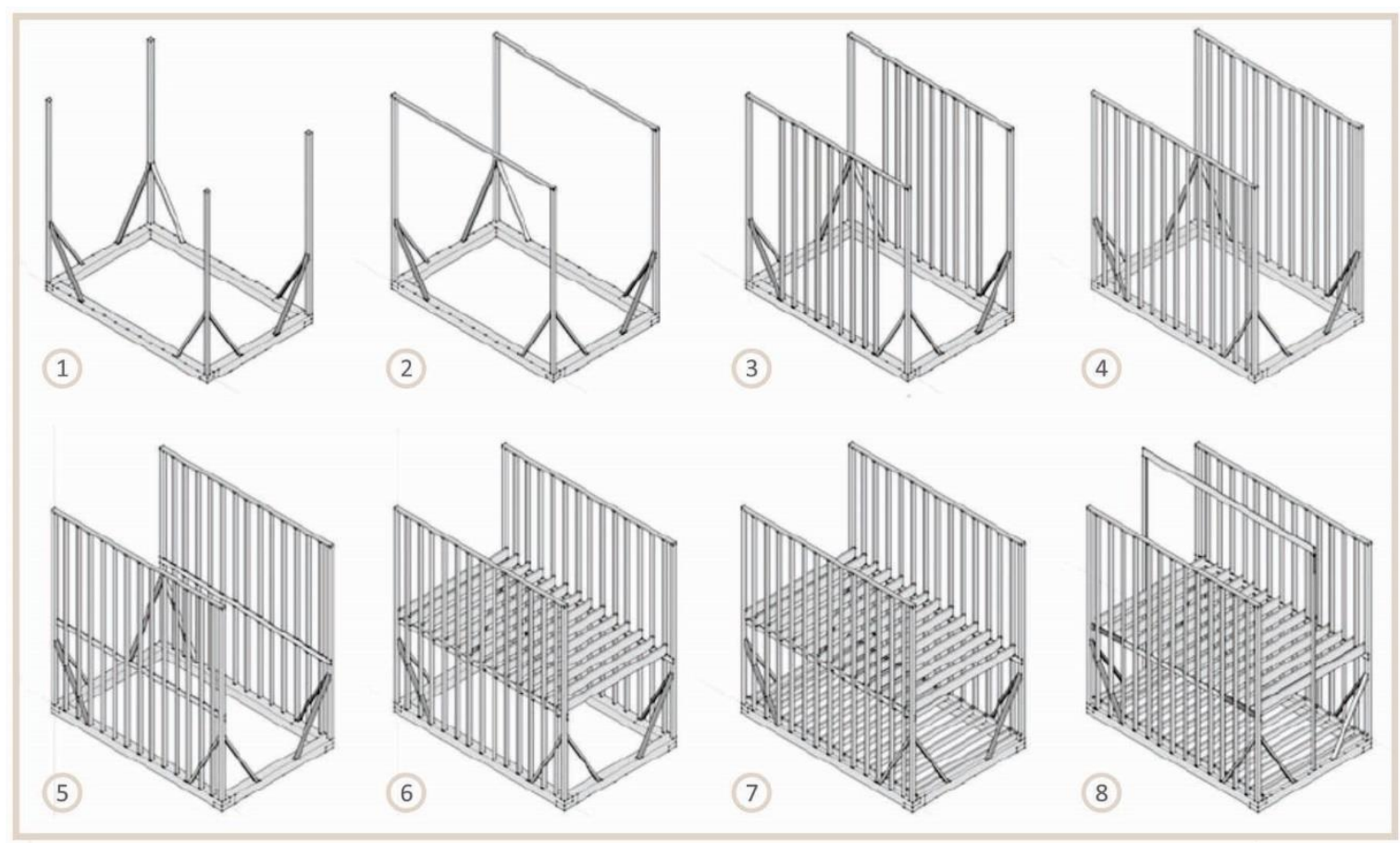

Figura 34: Processo de montagem da estrutura do sistema balloon frame Fonte: O'Brien, 2010.

Outra opção de montagem do balloon frame está ilustrada na Figura 35. Esta demonstra que, após a finalização do piso térreo, sobre o mesmo, a estrutura da parede era unida no chão e erguida, geralmente, manualmente para sua posição onde seria fixada. A dimensão dos painéis exigia a força de muitos trabalhadores nesse processo. E, este foi um dos motivos que levou à simplificação do sistema, encurtando a altura dos painéis de parede conforme o pé-direito de cada pavimento da edificação, dando origem ao sistema plataforma.

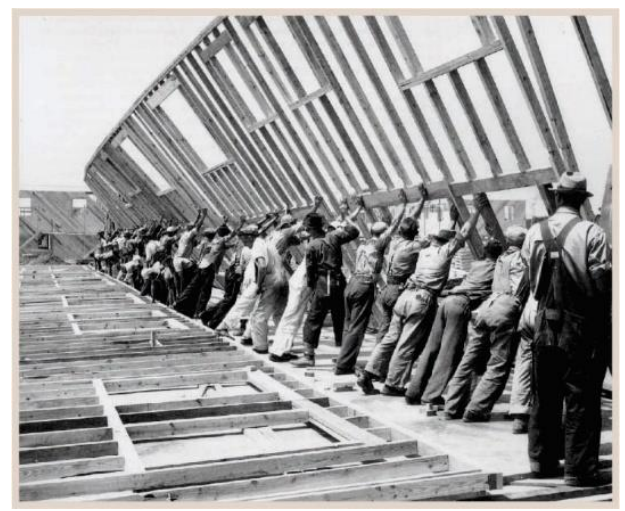

Figura 35: Estrutura de parede do sistema balloon frame erguida manualmente Fonte: Peter, 1989 apud Kucker, 2002. 
As sequências para execução da estrutura do sistema plataforma em madeira são similares ao seu antecessor. Novamente, o autor O’Brien (2010) sintetiza esses passos, descritos a seguir conforme a Figura 36. Primeiro, sobre a fundação, são instaladas soleiras, vigas e chapas estruturais que compõem o piso térreo. Sobre esta plataforma de piso, os painéis estruturais das paredes são montados sobre piso; e sua estrutura contém travessas inferior e superior, montantes e barra diagonal. Na sequência, estes painéis são erguidos e posicionados, sendo sustentados temporariamente por escoras. No segundo passo ilustrado, todos os painéis de parede do térreo são fixados, incluindo os montantes de canto. Terceiro, barras duplas superiores são fixadas sobre as paredes, unindo todos painéis e montantes de canto. Nos quarto e quinto passos, a estrutura do entrepiso é executada sobre as paredes térreas. Por fim, nos passos seis à oito, as estruturas das paredes do segundo pavimento são montadas, erguidas e posicionadas sobre o entrepiso, conforme ocorreu com as paredes térreas.

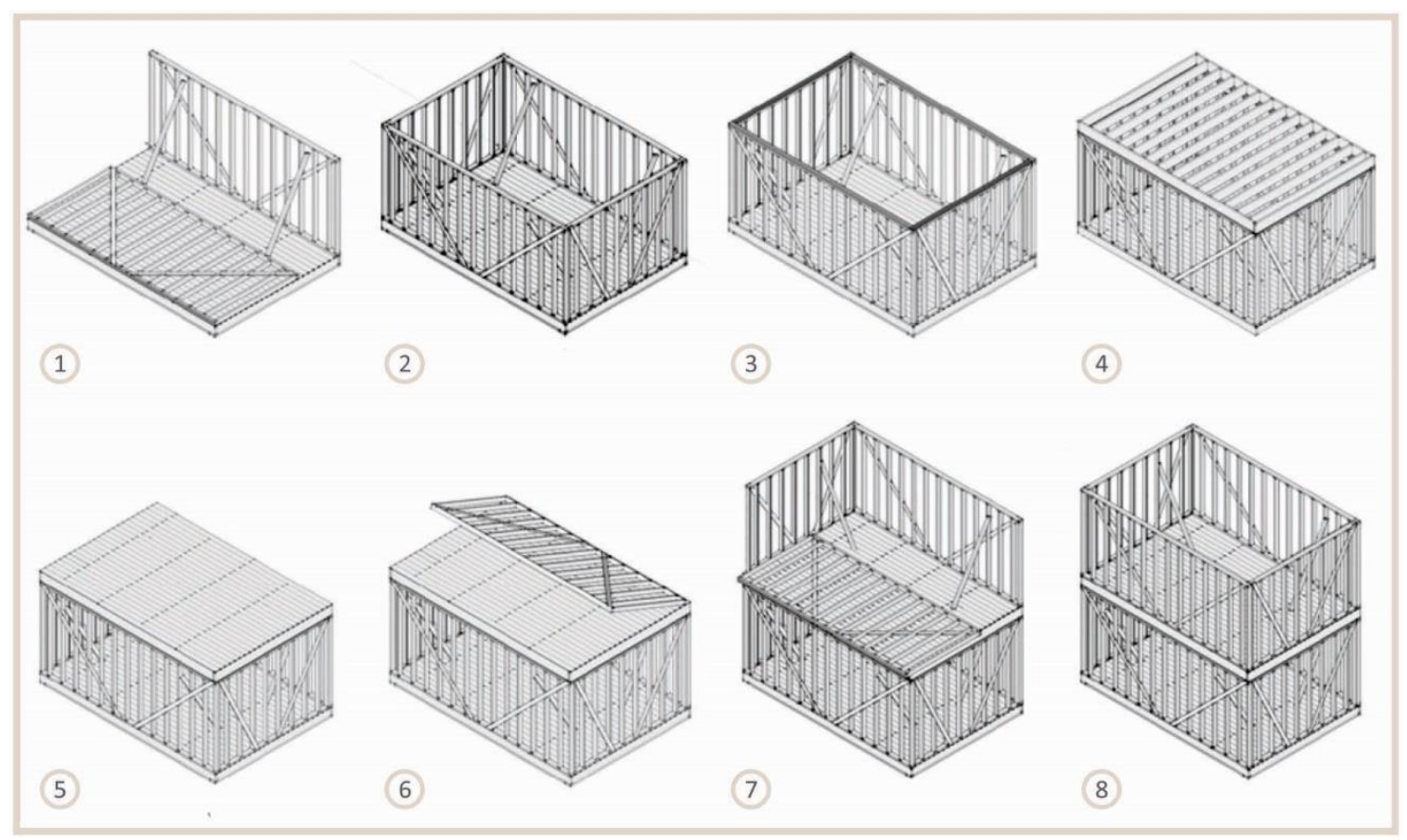

Figura 36: Processo de montagem da estrutura do sistema platform frame Fonte: O’Brien, 2010.

Essa descrição detalhada demonstra um processo de produção mais artesanal, pois seu nível de industrialização é baixo, quase nulo. Neste caso, em geral, o processo industrial se concentra na elaboração dos componentes constituintes, tais como: peças de madeira 
serrada e beneficiada, chapas estruturais de madeira, conectores, portas e janelas. Esses componentes individuais serão transformados em elementos compostos e subsistemas durante a execução da edificação no canteiro-de-obras. Por exemplo, as peças em madeira maciça são processadas na serraria onde são beneficiadas com bitolas específicas mediante procedimentos industriais mecanizados. Mas, são transportadas e chegam ao canteiro-deobra como componentes individuais. No canteiro, são cortadas no comprimento desejado, unidas e fixadas uma a uma, manualmente com martelos ou pregadeiras pneumáticas, resultando na estrutura dos painéis de parede. Por isso, muitas vezes esse método de produção pode ser denominado stick-built, referindo-se à construção com palitos, ou seja, peças de madeira com pequenas seções. Esta construção é, portanto, classificada por ser um método de produção ocorrente no canteiro - on-site ou site-built (Figura 37). Este vem sendo o método predominante de construção dos sistemas leves em madeira no território dos EUA, conforme relata (O'BRIEN; WAKEFIELD; BELIVEAU, 2000).

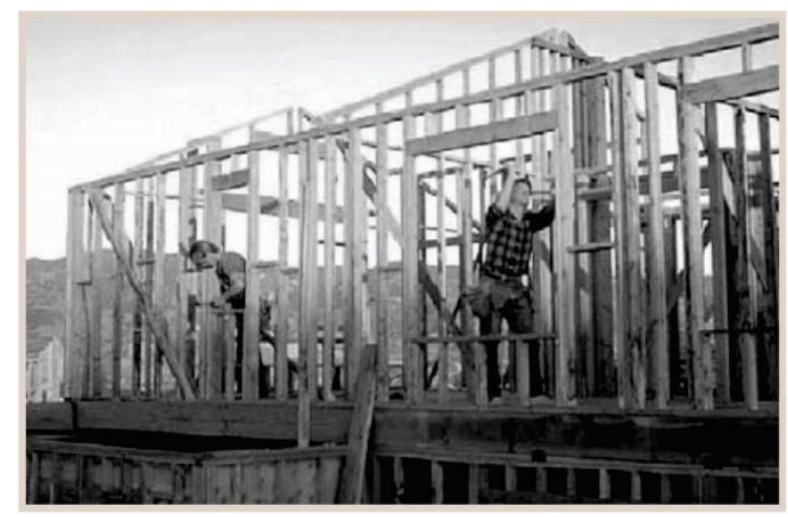

Figura 37: Método de produção no canteiro - stick-built Fonte: Topping et al., 2015.

No fim do século XIX e início do século $X X$, foram desenvolvidos métodos para a construção em massa de residências. Neste período, destacaram-se as vendas de kits précortados - pre-cut kits-, encomendados diretamente de catálogos de companhias americanas e canadenses (Figura 38). Assim como o stick-built, o processo de união dos componentes era realizado completamente no canteiro. Mas, neste caso, selecionava-se a edificação desejada no catálogo e todas suas peças já vinham cortadas nas dimensões exatas do projeto, junto com conectores necessários e esquadrias prontas (Figura 39). Todos os componentes, desde estrutura em madeira até acabamentos finais, eram embalados e numerados 
individualmente. No canteiro-de-obras, apenas era necessário montar estas peças, acompanhadas por um manual de instruções. Por isso, esses métodos tornaram-se conhecidos como kits faça você mesmo - Do It Yourself (DYS). Assim, este foi considerado um dos primeiros métodos pré-fabricados dos sistemas leves em madeira, com atividades dividas entre fábrica e canteiro (O'BRIEN; WAKEFIELD; BELIVEAU, 2000; WARZECHA, 2015).
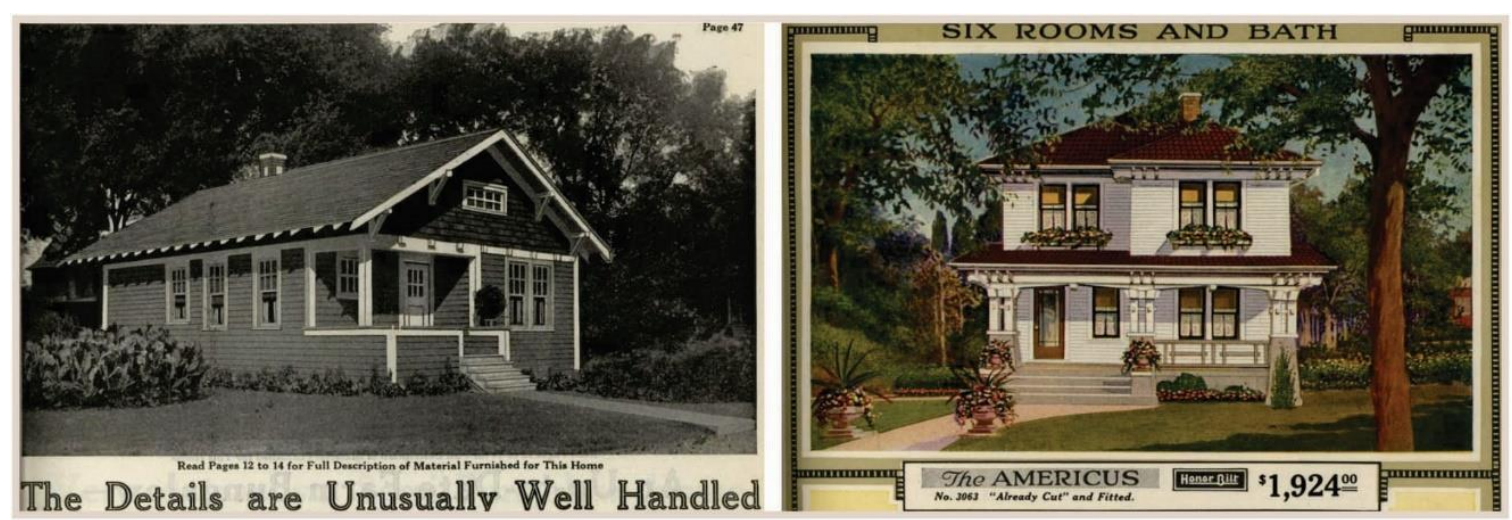

Figura 38: Modelos de residências oferecidas por catálogos americanos e canadenses Fonte: Warzecha, 2015.

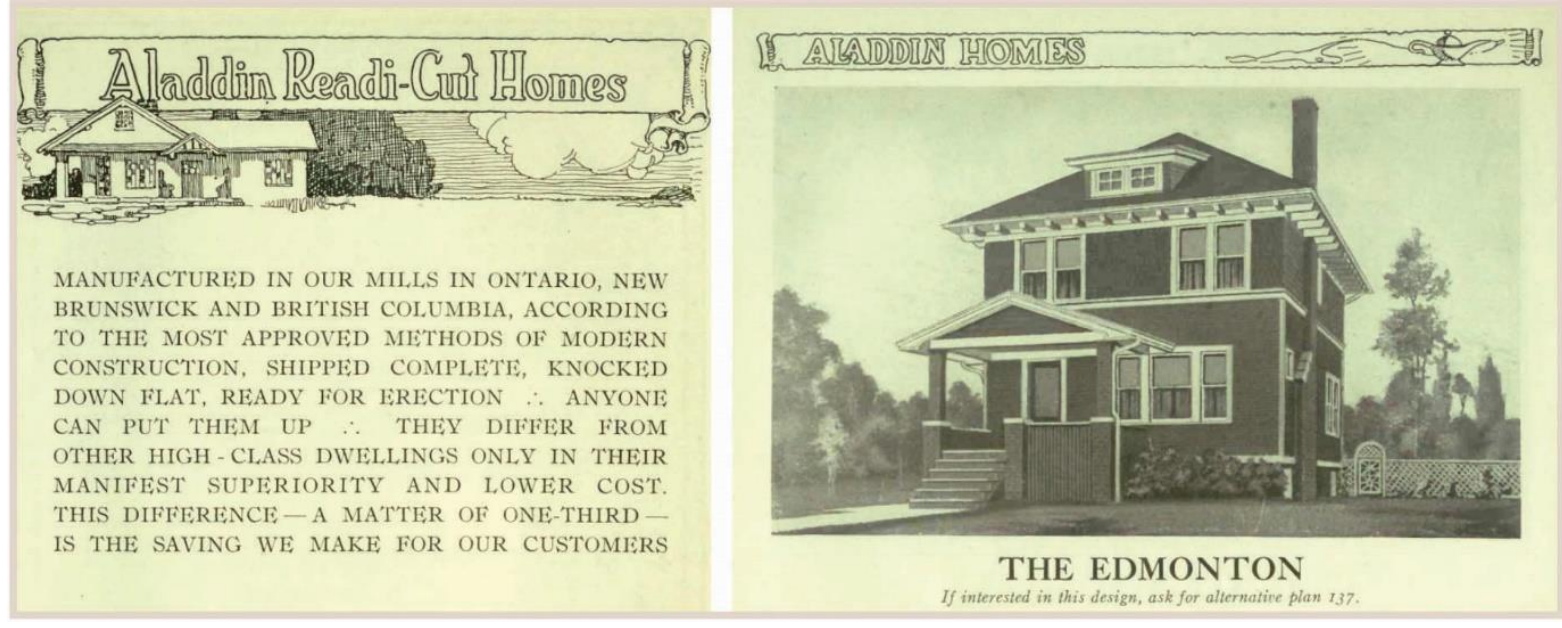

Figura 39: Descrição em inglês do método kits pré-cortados da empresa Aladdin Homes Fonte: Warzecha, 2015.

Entretanto, a partir das décadas de 1920 e 1930, as atividades de produção começaram a aumentar na fábrica e o nível de industrialização dos elementos foi elevado, diminuindo as atividades necessárias no canteiro-de-obras. Sendo assim, atualmente, os principais métodos de pré-fabricação utilizados para os sistemas leves em madeira dividem-se entre semi e totalmente industrializados; e estes são: sistemas panelizados, sistemas com módulos 
tridimensionais e sistema com residência manufaturada (O'BRIEN; WAKEFIELD; BELIVEAU, 2000).

No sistema panelizado, painéis de parede e de piso são montados sequencialmente na fábrica com diversas possiblidades de mecanização na produção e, posteriormente são transportados ao canteiro-de-obras para serem unidos. Os painéis de parede, na maioria das vezes, possuem 2,40 $\mathrm{m}$ de altura, mas seu comprimento pode variar. Painéis pequenos têm entre $2,4 \mathrm{~m}$ à 3,6 $\mathrm{m}$ de comprimento e podem ser erguidos e posicionados por dois ou três trabalhadores; enquanto painéis com maior comprimento, com máximo de 9,6 $\mathrm{m}$ de comprimento, necessitam ser erguidos por gruas (Figura 40) (PALMER, 2000).

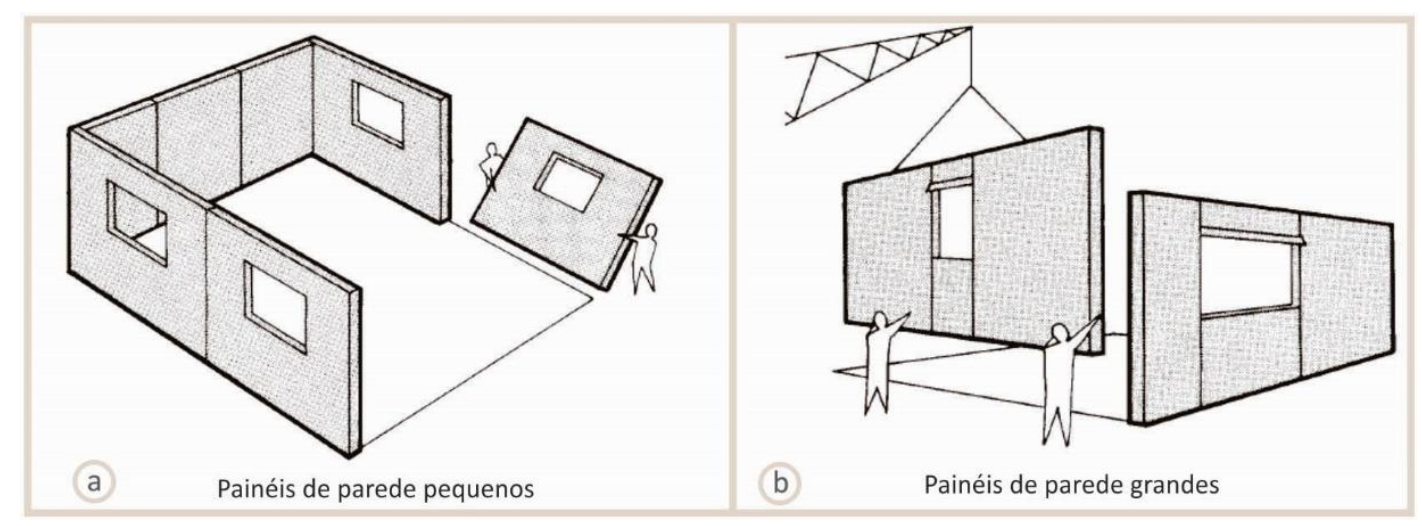

Figura 40: União dos painéis de parede pequenos ou grandes no canteiro Fonte: Palmer, 2000.

Ainda, estes painéis de parede podem ser pré-fabricados abertos ou fechados. $\mathrm{Na}$ produção em fábrica, os painéis abertos têm o entramado em madeira fechado com a chapa estrutural OSB ou compensado em uma das suas superfícies, interna ou externa. No canteiro, este painel é finalizado com membrana hidrófuga, material isolante termo-acústico, chapa de gesso acartonado, acabamentos finais interno e externo e instalações elétrica e hidráulica. Em contrapartida, o painel fechado é totalmente executado em fábrica, sendo transportado para o canteiro com as camadas internas e externas pré-fabricadas. No canteiro, são posicionados e unidos sobre a fundação ou sobre a plataforma de piso (O'BRIEN; WAKEFIELD; BELIVEAU, 2000; PALMER, 2000).

$\mathrm{Na}$ produção de unidades modulares tridimensionais, ambientes completos, geralmente com painéis de parede fechados e plataforma de piso, são produzidos e unidos na fábrica e transportados ao canteiro para serem montados com auxílio de gruas. Neste 
método, reduz-se ainda mais o tempo de montagem no canteiro. Porém, a precisão é ainda maior para evitar erros que não podem ser corrigidos na etapa das atividades desenvolvidas no canteiro (O'BRIEN; WAKEFIELD; BELIVEAU, 2000).

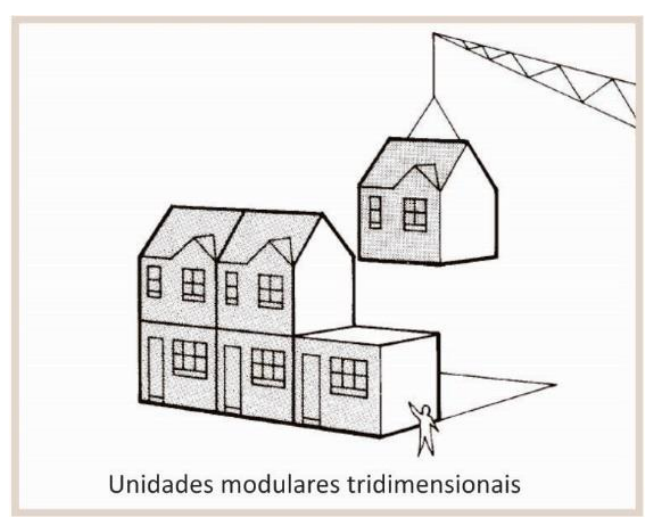

Figura 41: Instalação das unidades modulares tridimensionais no canteiro Fonte: Palmer, 2000.

Por fim, a produção de casas manufaturadas - manufactured homes - consiste na produção total da edificação residencial em fábrica. Inicialmente, em meados de 1950, estas também eram denominadas como casas móveis - mobile homes. Pois, são construídas, geralmente, sobre chassis metálicos, utilizando as técnicas convencionais do sistema plataforma para paredes e cobertura. E, após a finalização destas unidades completas na fábrica, são transportadas sobre rodas ao canteiro e transferidas e instaladas sobre a fundação (O'BRIEN; WAKEFIELD; BELIVEAU, 2000).

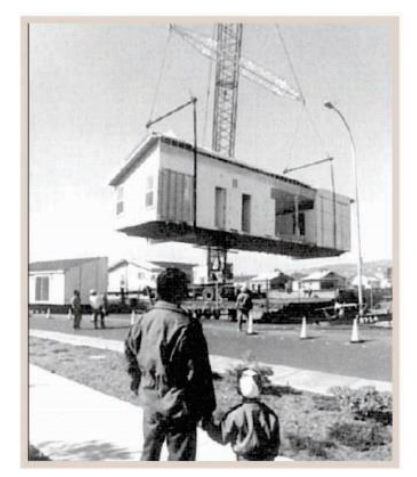

Figura 42: Instalação de casa manufaturada no canteiro Fonte: O'Brien; Wakefield; Beliveau, 2000. 
Portanto, conclui-se que a constituição técnica do sistema plataforma é a mais aplicada para as construções com entramados leves em madeira, variando os materiais aplicados nas suas camadas de parede. E, os principais métodos de produção, classificados em ordem crescente de nível de industrialização e pré-fabricação, são os seguintes: stick-built no canteiro, construção panelizada em fábrica, construção com unidades modulares e construção totalmente manufaturada (Figura 43).

\begin{tabular}{|c|c|c|c|}
\hline \multicolumn{4}{|c|}{ Sistema leve com entramado em madeira (Wood Light Frame) } \\
\hline \multicolumn{4}{|c|}{ Principais técnicas convencionais: sistema plataforma (Platform Frame) } \\
\hline \multicolumn{4}{|c|}{ Principais métodos de produção: } \\
\hline $\begin{array}{l}\text { Construção no canteiro } \\
\text { (Stick-built ou Stud-frame) }\end{array}$ & $\begin{array}{c}\text { Construção com painéis } \\
\text { pré-fabricados } \\
\text { (Panelized ou Panel } \\
\text { construction) }\end{array}$ & $\begin{array}{l}\text { Construção com unidades } \\
\text { modulares tridimensionais } \\
\text { (Modular construction) }\end{array}$ & $\begin{array}{c}\text { Construção manufaturada } \\
\text { (Manufactured housing ou } \\
\text { Mobile homes) }\end{array}$ \\
\hline - & Nível de industri & ção e pré-fabricação & \\
\hline
\end{tabular}

Figura 43: Resumo dos métodos de produção do sistema entramado leve em madeira Fonte: autora.

Destes, atualmente, destaca-se no mercado a produção com painéis pré-fabricados. Estima-se que aproximadamente $90 \%$ das residências com um ou dois pavimentos de países como EUA, Canadá e Escandinávia utilizam este método de construção. Na região central da Europa, este mercado é crescente. Por exemplo, em 1985, o primeiro catálogo deste sistema foi publicado na Alemanha pela federação de carpinteiros - Federation of German Master Carpenters - como auxílio para projetistas e construtores. E, em 1988, na Suíça, um catálogo semelhante foi publicado com intuito de encorajar este tipo de construção. Assim, há cerca de três décadas, o sistema panelizado estruturado com montantes e travessas de madeira ${ }^{10}$ se tornou popular e estabelecido nos mercados destes locais. E, o campo de utilização vem se expandindo. Já existem edifícios com multi-pavimentos construídos nos EUA, Canadá, Escandinávia, Suíças e em outros países vizinhos (KOLB, 2008).

Em geral, os autores deste tema observam que esta difusão do sistema wood frame, em especial com o método panelizado, é positiva e crescente nestes países tendo em vista as

\footnotetext{
10 No entanto, a composição das construções panelizadas da Europa central apresenta algumas diferenças quando comparada os sistemas originais norte-americanos, pois as características foram adequadas para as condições desses países. Para mais detalhes sobre este sistema alemão, ver o autor Kolb (2008).
} 
vantagens que consideram sobre este processo construtivo. Por exemplo, Sanchez (1995) lista alguns fatores que atraem muitos produtores aos sistemas leves entramados em madeira, tais como:

- Seus elementos construtivos, como painéis de parede, de piso e de cobertura, podem ser produzidos com diferentes graus de industrialização, na fábrica, no canteiro de obras ou parcialmente em ambos locais;

- O processo construtivo, em geral, é racionalizado ao aplicar elementos que estão conforme os preceitos da coordenação modular, reduzindo o desperdício de material aplicado;

- Os elementos podem ser padronizados e pré-fabricados mediante processos mecanizados sequenciais, assim, esta execução é mais rápida na fábrica e na montagem no canteiro, diminuindo o custo envolvido com a mão-de-obra nesta produção;

- O sistema permite a flexibilidade do projeto arquitetônico e da conformação espacial dos ambientes, inclusive para modificações futuras necessárias para seus usuários;

- A união entre seus componentes constituintes é simples, sem encaixes especiais, bastando a aplicação de pregos, parafusos ou grampos, melhorando a produtividade;

- Os espaços vazios entre as peças em madeira do entramado permitem a fácil instalação de materiais elétricos, hidráulicos e isolantes térmicos e acústicos;

- O peso reduzido da estrutura traz economia na execução das fundações;

- A obra é seca e limpa em todas as etapas da produção na fábrica e no canteiro.

Procurando estes potenciais, na segunda metade do século $X X$, este sistema construtivo leve em madeira vem sendo notado em diversos outros países além dos anteriormente mencionados. Por exemplo, na América do Sul, o Chile apresenta exemplares com tecnologias similares produzidos com métodos industrializados e componentes manufaturados no próprio país. Em contrapartida, neste mesmo período, no Brasil, mesmo com o potencial florestal nacional, este sistema teve pouco destaque na produção de edificações em madeira, conforme descrito a seguir. 


\section{PRIMEIRO PERÍODO DE PRODUÇÃO DO WOOD FRAME NO BRASIL - ENTRE AS DÉCADAS DE 1980 E DE 2000}

Este capítulo apresenta o primeiro período de produção do wood frame no território brasileiro, que ocorreu entre meados das décadas de 1980 e de 2000. Estes dados têm como intuito esclarecer que a prática com este sistema leve em madeira foi introduzida no Brasil no final do século XX. Porém, na década de 2000, aquela produção reduziu consideravelmente e o sistema não se efetivou no mercado nacional.

Sob este aspecto, inicialmente, este capítulo elenca de forma sucinta as principais práticas construtivas populares em madeira no Brasil, demonstrando que os sistemas do tipo wood frame não eram utilizados tradicionalmente nesta base histórica. Na sequência, destacam-se algumas empresas construtoras no Brasil que produziam utilizando o sistema wood frame entre meados das décadas de 1980 e de 2000. Abrangendo o final deste período, apontam-se as principais ações tomadas para disseminar este sistema no país, tais como a realização de pesquisas acadêmicas e a publicação e divulgação deste sistema. Por fim, para compreender os motivos pelos quais esta primeira implementação do wood frame não se efetivou na indústria da construção, procura-se levantar alguns fatores que possivelmente foram limitantes neste processo de produção.

\subsection{SISTEMAS CONSTRUTIVOS EM MADEIRA POPULARES NO BRASIL}

Na constituição das diversas civilizações, conforme a disponibilidade, a madeira era comumente utilizada na construção das primeiras edificações. Na condição natural de troncos e galhos, a madeira era selecionada e transformada de forma rudimentar, compondo sistemas de estrutura e de vedação para paredes e coberturas, sendo combinada com outros materiais elementares como terra, palha e pedra. Com o decorrer do tempo, os componentes e as técnicas das construções em madeira, assim como seus instrumentos de trabalho, foram gradualmente aprimorados conforme culturas e regiões.

Para contextualizar a representatividade das construções em madeira no Brasil, apresenta-se a seguir uma linha do tempo que aponta, de forma sucinta, quatro períodos históricos que destacam ocorrências e ausências das técnicas construtivas em madeira no 
país. A delimitação de tais momentos foi elaborada especificamente para a situação das construções em madeira tendo como base os relatos de autores considerados referências neste tema. Conforme ilustrado na Figura 44, os períodos foram nomeados nesta sequência: (1) indígena, (2) colonização portuguesa, (3) imigração de centro-europeus e japoneses, (4) pós-imigração.

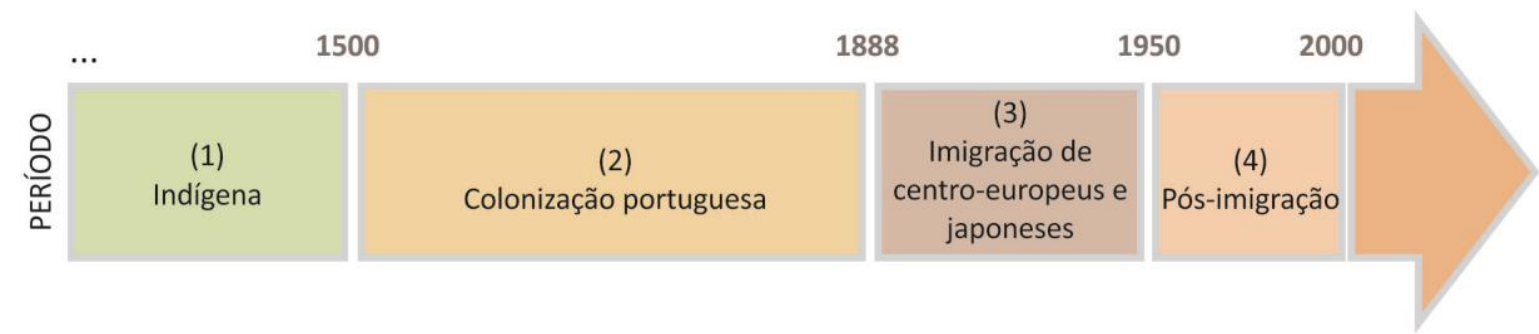

Figura 44: Linha do tempo com principais períodos das construções populares em madeira no Brasil Fonte: autora.

No Brasil, as construções rudimentares em madeira remetem-se ao período indígena que antecede a colonização portuguesa. Conforme descrito por Weimer (2005), os indígenas nativos construíam suas edificações aplicando materiais disponíveis localmente por meio de técnicas essencialmente manuais, geralmente entrelaçando madeira com palha e terra (Figura 45). Este era um processo comum utilizado por diferentes tribos em todo o território, ainda sem a influência das técnicas estrangeiras.

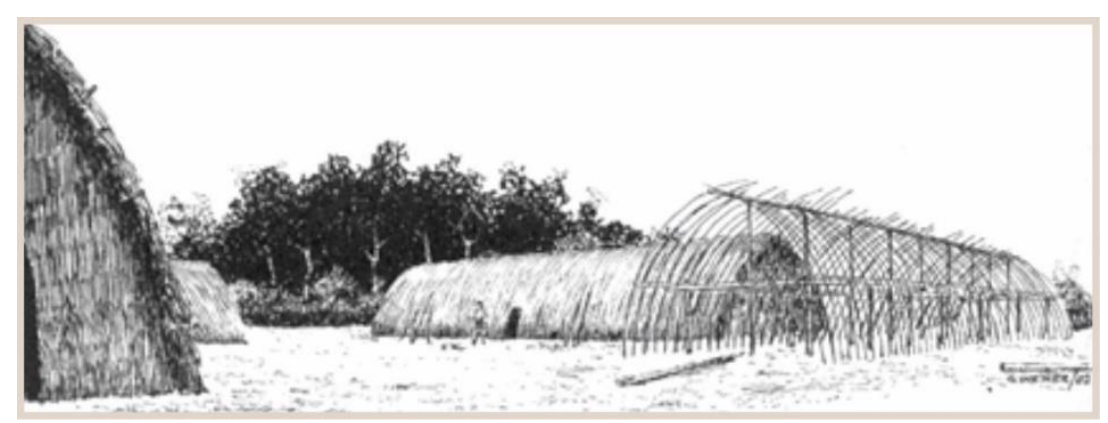

Figura 45: Exemplo de construções do período indígena com madeira e palha Fonte: Weimer, 1983.

A madeira era o material predominante nas construções indígenas até a chegada dos colonos portugueses. Sob o domínio desta primeira colonização, as construções eram produzidas por escravos. A seleção dos materiais aplicados diferenciava as classes sociais. Edificações em terra e adobe eram destinadas à população pobre, enquanto as construções 
em pedra, técnica de tradição portuguesa, eram reservadas para os grupos mais destacados. Madeira também era material de uma população desprivilegiada, executada com técnicas precárias que consentiram uma imagem negativa do material mantida até o presente (REIS FILHO, 2006).

Neste período da colonização portuguesa, destacaram-se as composições com fundação de pedras, paredes de tijolos e argamassa, esquadrias, assoalhos, forros e estrutura do telhado em madeira e cobertura vedada com telhas cerâmicas. Apesar da presença de detalhes em madeira mais aprimorados, este material usualmente não predominava na edificação. A população mediante preconceito e resistência evitava o uso da madeira nas paredes das construções (REIS FILHO, 2006).

Entretanto, ainda na colonização portuguesa, em meados do século XVIII, algumas construções da região sudeste brasileira, como por exemplo as localizadas nas fazendas dos estados de São Paulo e Minas Gerais, utilizavam um sistema construtivo que aplicava a madeira na sua estrutura principal. Nestas edificações, sobre a fundação executada em pedras, apoiava-se o baldrame em madeira e o piso estruturado com vigas-mestras e barrotes. Na sequência, a parede era estruturada com cunhais e esteios encaixados nos baldrames. Para reforçar esta estrutura, peças na diagonal eram colocadas entre os cunhais e os esteios. Para as aberturas das janelas, eram utilizados verga e peitoril. Por fim, os frechais eram colocados na parte superior da parede para amarrar toda esta estrutura. Todas estas peças em madeira eram unidas por meio de encaixes e sambladuras. E, o vazio desta estrutura era vedado com tijolos e argamassa ou com taipa. Geralmente, a estrutura em madeira não era aparente, pois era coberta com estuque (Figura 46) (CRUZ, 2008).

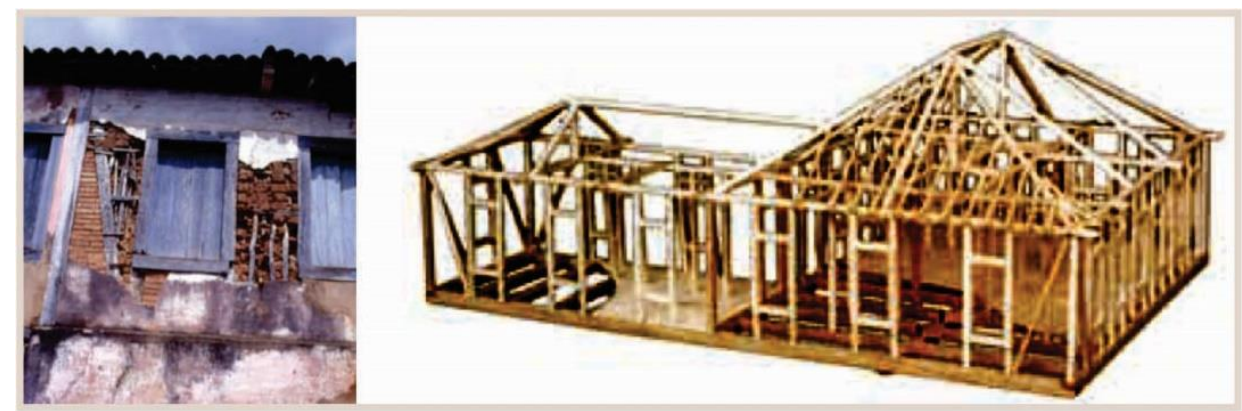

Figura 46: Construções estruturadas em madeira no período de colonização portuguesa Fonte: Cruz, 2008. 
No final do século XIX, com a abolição da escravatura, a chegada de imigrantes centroeuropeus e asiáticos trouxe novos processos e técnicas de construção. Este momento foi especialmente importante para a consolidação da arquitetura popular em madeira no Brasil. Estas construções se destacaram, principalmente, com a colonização de imigrantes germânicos, italianos, poloneses, ucranianos e japoneses. Neste período, diferentes técnicas em madeira foram aplicadas no território brasileiro adotando os materiais locais. Em geral, tais construções demonstraram o saber-fazer do trabalhador que se apropriava do material desde sua extração até a execução dos detalhes das edificações.

Estabelecidos principalmente na região sul do país, nos estados do Rio Grande do Sul, Paraná e Santa Catarina, os imigrantes da Europa central foram gradativamente transformando suas técnicas construtivas conforme a percepção concernente ao comportamento da madeira no Brasil e a necessidade de ocupação dos moradores.

Por exemplo, os imigrantes alemães aplicavam sua técnica tradicional popularmente conhecida como enxaimel. Para compor as paredes, as peças em madeira eram falquejadas em seções retangulares, entalhadas e encaixadas entre si. Os montantes eram apoiados sobre fundações de pedra e peças diagonais proporcionavam rigidez à trama estrutural (Figura 47a) (WEIMER, 1983).

Por sua vez, as construções permanentes dos imigrantes italianos, geralmente, possuíam fundação de pedra, paredes estruturadas com pilares e vigas de madeira de pequenas seções, vedadas e contraventadas com tábuas pregadas verticalmente (Figura 47b) (POSENATO, 1983).
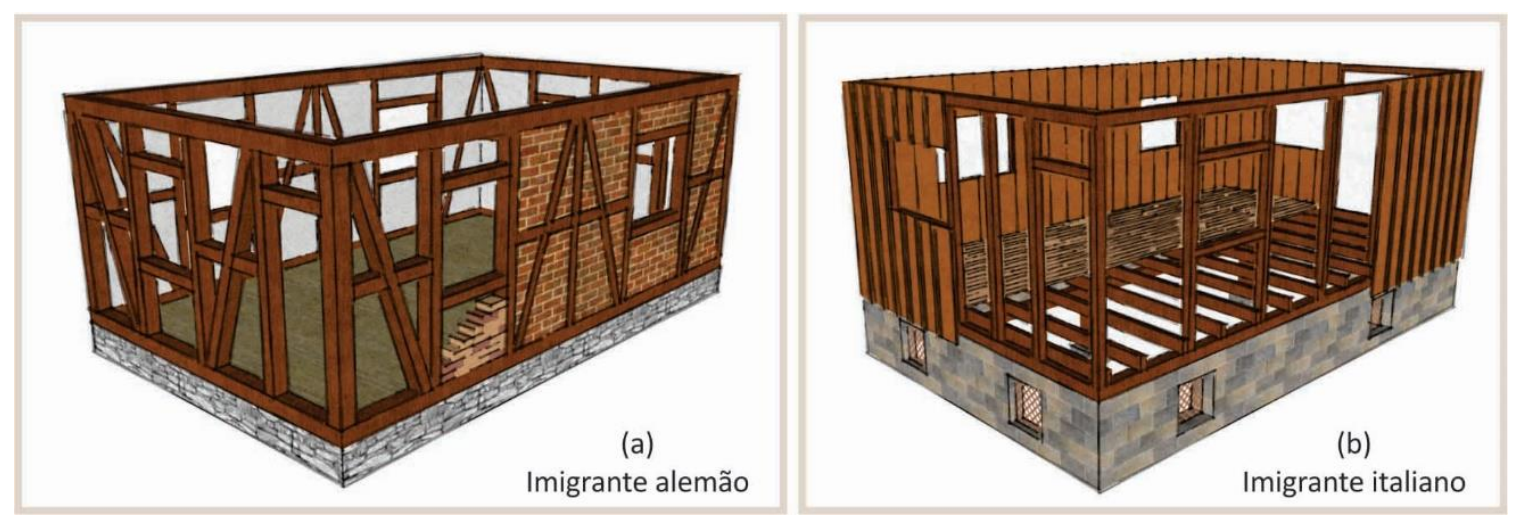

Figura 47: Construções estruturadas em madeira dos imigrantes alemães (a) e italianos (b) Fonte: autora. 
Os imigrantes poloneses e ucranianos, inicialmente, estruturavam suas construções com troncos de madeira falquejados em seções redondas ou retangulares, sobrepostos horizontalmente e encaixados com entalhes (Figura 48a) (WEIMER, 2005). Posteriormente, adequando às condições climáticas do Brasil e com a propagação de serrarias na região paranaense, as edificações definitivas destes imigrantes eram constituídas por paredes com estrutura de pilar e viga de pequenas seções retangulares e vedadas com tábuas serradas de madeira pregadas verticalmente. Lambrequins de madeira eram aplicados nos beirais da cobertura (Figura 48b) (LAROCCA JÚNIOR et al., 2008). Estas últimas peças, além de proporcionarem identidade às residências, tinham como função proteger os elementos estruturais da cobertura contra a ação das intempéries, atuando como pingadeiras.

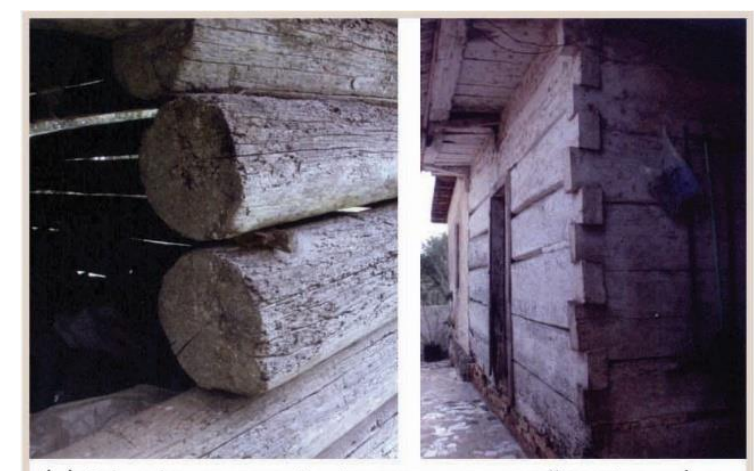

(a) Primeiro momento: troncos com seção retangular ou redonda, sobrepostos e encaixados

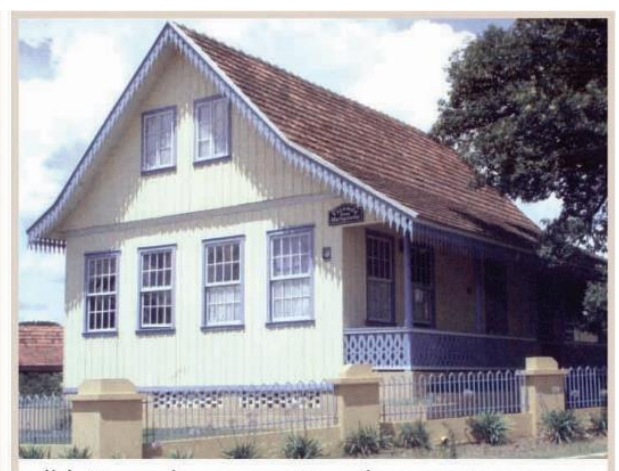

(b) Segundo momento: pilares e vigas com pequenas seções, vedados com tábuas

Figura 48: Construções estruturadas em madeira dos imigrantes poloneses e ucranianos Fonte: Larocca Júnior et al., 2008.

Ainda neste período de imigrações, os japoneses instalaram-se próximos às colônias agrícolas localizadas principalmente no estado de São Paulo. Posteriormente, também se se instalaram em outras regiões, tais como Paraná e Pará. As técnicas construtivas aplicadas nas colônias japonesas variavam conforme a região, porém, em geral, ressaltavam a utilização da madeira conforme a tradição do seu país. Por exemplo, na cidade de Registro em São Paulo, as construções destes imigrantes apresentavam o piso de madeira elevado do solo e apoiado sobre fundações de pedra ou alvenaria de tijolos. As paredes eram estruturadas por esteios e vigas de madeira de maior seção, unidas por meio de sambladuras. Os vazios desta estrutura eram vedados com taipa de mão ou taipa de sopapo, na qual uma malha composta por lâminas de bambu na horizontal e na vertical era coberta com camadas feitas, essencialmente, de argila e fibras de palha de arroz (Figura 49) (GONÇALVES, 2008; HIJIOKA et al., 2013). 
Entretanto, outras composições arquitetônicas dos imigrantes japoneses substituíam esta vedação de taipa por tábuas serradas horizontalmente, conforme a descrição de Numazawa (2009) referente à colônia na cidade de Tomé-Açú em Pará.

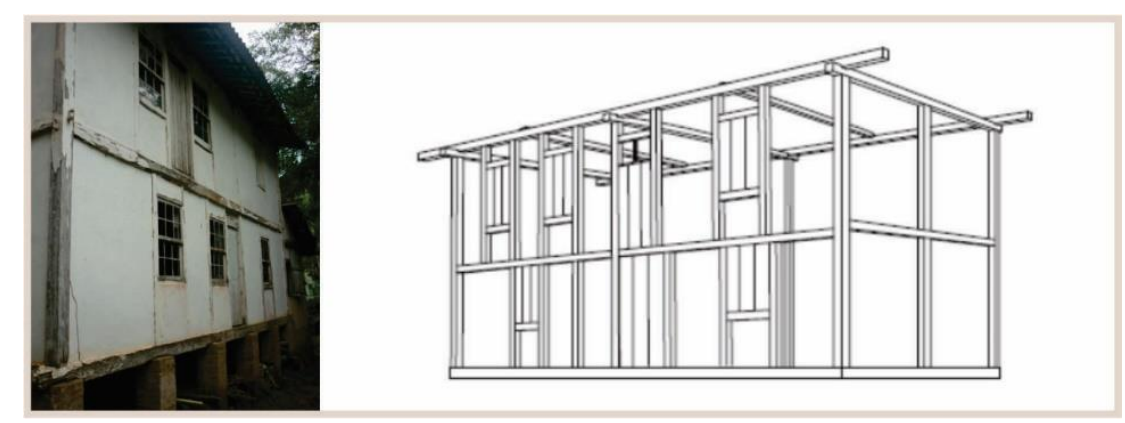

Figura 49: Construções estruturadas em madeira dos imigrantes japoneses no Vale do Ribeira, SP Fonte: Hijioka et al., 2013.

Em paralelo a estes métodos construtivos dos imigrantes, nas primeiras décadas do século $X X$, com a propagação crescente das serrarias instaladas próximas das florestas na região sul brasileira, a madeira, em abundância, apresentava-se como material acessível para as construções nestes locais. As madeiras eram serradas e beneficiadas, transformadas em produtos prontos para serem aplicados nas edificações, os quais, na sua maioria, eram destinados para exportação ou eram comercializados em grandes centros. Mas, também, estes produtos eram aplicados nas construções das residências dos operários das próprias serrarias, assim como nas edificações das novas vilas. Neste período, muitos carpinteiros estavam disponíveis para estas construções, tornando o custo da mão-de-obra acessível. Inclusive, muitos imigrantes, com sua experiência prévia, trabalhavam nas serrarias ou como carpinteiros no canteiro de obras (ZANI, 2005).

O sistema construtivo predominante produzido nestas regiões era caracterizado por uma estrutura de piso com barrotes e assoalho de madeira. Sobre este piso, as paredes eram constituídas por uma estrutura de entramado com esteios e linhas inferior e superior do quadro. Esta estrutura era vedada externamente com tábuas pregadas no sentido vertical e com sarrafos de pequena seção fixados externamente entre as juntas destas tábuas (ZANI, 2005). Sendo assim, este sistema construtivo foi popularmente denominado tábua e matajunta (Figura 50). 


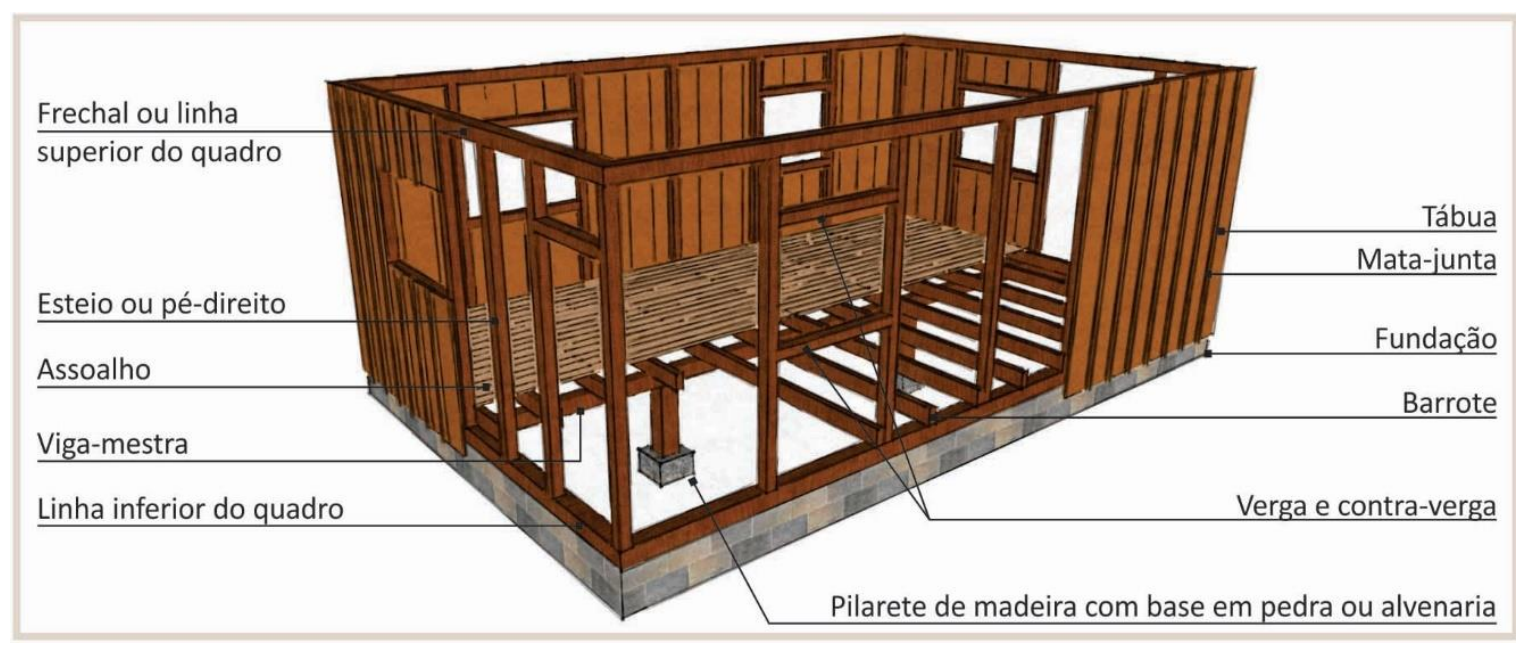

Figura 50: Construções estruturadas em tábua e mata-junta

Fonte: autora

Com suas vantagens de produção, tais como apresentar componentes em madeira com seções padronizadas e simplicidade de execução com peças unidas com pregos, este sistema construtivo passou a ser o mais aplicado nas regiões enquanto material e mão-deobra eram acessíveis. Entretanto, a exploração descontrolada das florestas nativas trouxe efeitos negativos para o setor madeireiro. E, na segunda metade do século $X X$, com a matériaprima escassa, as serrarias reduziram suas produções ou fecharam suas instalações. Consequentemente, o custo da madeira aumentou, assim como o da mão-de-obra, com a ausência de carpinteiros qualificados (ZANI, 2005).

Desde então, o sistema de tábua e mata-junta permaneceu como o mais popular dentre as soluções construtivas que utilizam madeira de floresta plantada no Brasil. Além da grande difusão na região sul, este sistema, com algumas variações, é também amplamente aplicado na região norte brasileira, onde a população, por abundância de material, utiliza as espécies de madeira nativas disponíveis localmente para a construção de suas edificações (Figura 51). Em geral, este sistema vem sendo utilizado para autoconstruções de habitações, para suprir a necessidade urgente de abrigo de determinada população. Assim, desenvolvese uma percepção de que a madeira é material destinado para uso temporário, até a família ter condições de trocá-la por uma construção permanente em alvenaria. 

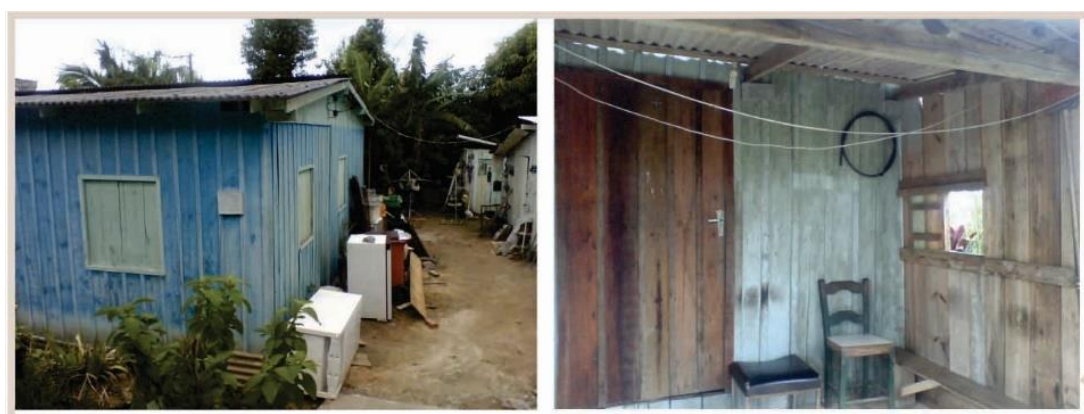

Habitação popular em madeira na região sul brasileira
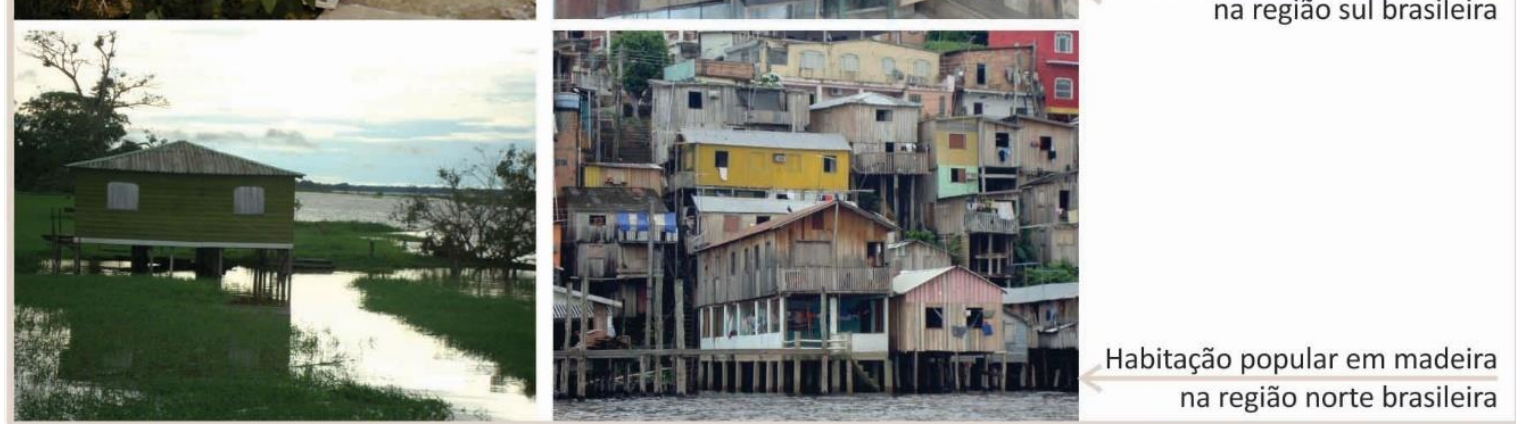

Figura 51: Construções em tábua e mata-junta em meados de 2010 nas regiões sul e norte Fonte: autora

Por fim, desde a segunda metade do século XX, outros sistemas em madeira vêm sendo utilizados no território brasileiro. Entre estes, destaca-se o sistema comercializado constituído por kits de componentes pré-fabricados em madeira, incluindo tábuas com entalhes machofêmea sobrepostas horizontalmente e encaixadas em montantes recortados (Figura 52). Após um projeto preliminar da edificação, estas peças são usinadas em fábricas e, na sequência, são transportadas ao canteiro para serem montadas conforme o projeto.
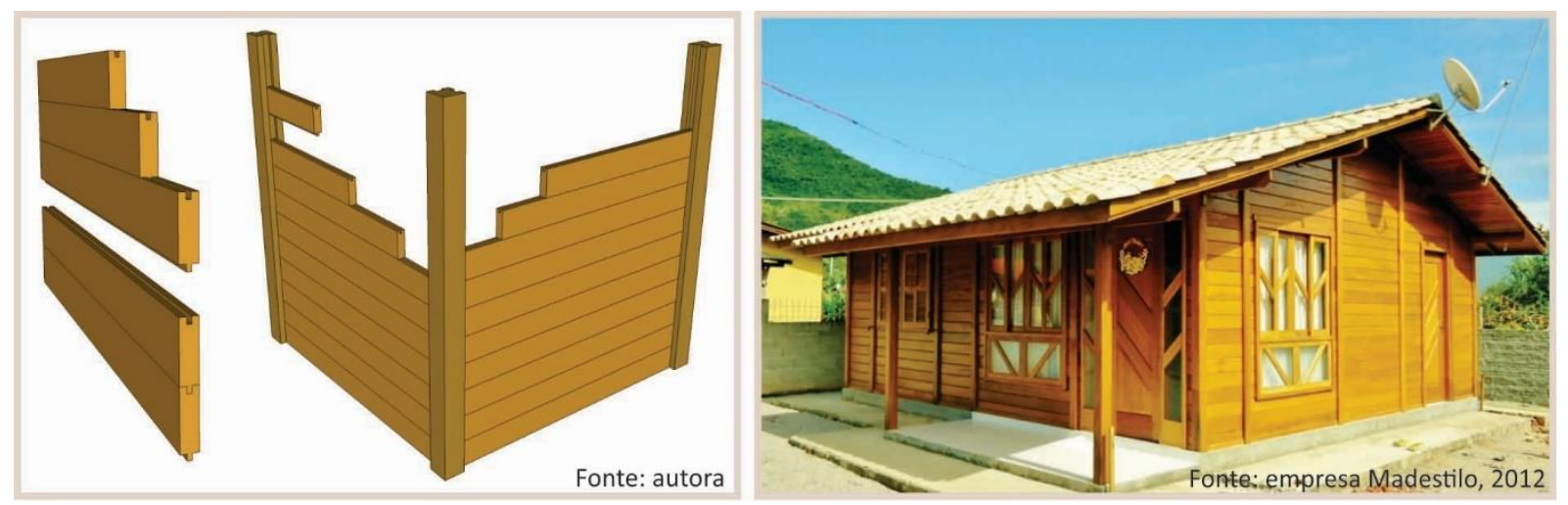

Figura 52: Construções em kits pré-fabricados com tábuas empilhadas e encaixadas em montantes Fonte: autora, arquivo da empresa Madestilo, 2012

Este sistema é produzido, em geral, com madeiras de espécies nativas, e, portanto, com custos maiores quando comparados às espécies oriundas de florestas plantadas. Neste 
sentido, não é tão popular quanto o sistema construtivo descrito anteriormente. Usualmente, são aplicados em construções de médio e alto padrão, em construções de veraneio, em regiões litorâneas, ou de campo, em regiões serranas. Mas, muitas empresas fornecem kits para habitações com áreas reduzidas, com um ou dois dormitórios distribuídos em um pavimento térreo. E, geralmente, os fatores que atraem as famílias que adquirem estas habitações são vantagens como projeto arquitetônico padronizado, rapidez na execução e preço fechado, ou seja, sem alterações durante a construção.

Além destes sistemas já conhecidos popularmente, em paralelo, alguns escritórios de arquitetura e de engenharia especializados em projetos com madeira vêm aplicando outras tecnologias com este material, como por exemplo: sistema estrutural pilar-viga em madeira vedado com diversos materiais, sistema de vedação com painéis constituídos por peças em madeira e sistema estrutural composto por peças em madeira laminada colada. Mas, estas práticas construtivas ocorrem em casos específicos, caracterizando-se em uma disseminação pontual. E, raramente, são experiências que se tornam conhecidas pela população em geral ou por profissionais graduados nas áreas da construção civil.

Sobre esta situação, os autores Dias e Ino (2008) procuraram realizar um levantamento para identificar e registrar as principais construções de habitações populares em madeira executadas no país desde os anos de 1943 até 2006 com base em dados coletados em produções acadêmicas e científicas relevantes ao tema ${ }^{11}$. A partir destes dados, a Tabela 1 apresenta uma seleção de construções populares em madeira, citando: período, sistema construtivo, autor, local e quantidade de unidades implantadas. Nesta listagem, observa-se que estas construções foram executadas com quatro diferentes tipos de sistemas construtivos: pilar-viga, montantes e tábuas encaixadas, painel e entramado.

Sobre estas construções listadas, nota-se a predominância da atuação das prefeituras dos municípios aliadas às Companhias de Habitação do Estado (COHAB). Também, destaca-se a atuação do Instituto de Pesquisas Tecnológicas (IPT) com pesquisas relativas ao tema das construções em madeira, as quais resultaram em importantes empreendimentos, tais como 0 conjunto construído no município de Campos do Jordão, em São Paulo, em 1987, com 133 unidades habitacionais utilizando painéis de parede estruturados com madeira de pinus

\footnotetext{
11 Outras construções de habitações populares em madeira que ocorreram neste mesmo período podem não estar relatadas neste levantamento de Dias e Ino (2008) por dificuldades de acesso às informações e às referências dos diversos estados brasileiros, necessitando de uma revisão e atualização dos dados.
} 
oriundo de florestas plantadas com incentivos fiscais. Ainda, instituições de ensino, como o Grupo de Pesquisa em Habitação e Sustentabilidade (HABIS), inicialmente denominado GHAB, participaram em alguns destes processos, com destaque à produção do conjunto Pedra 90, com 360 unidades habitacionais construídas em Marcelândia, Mato Grosso, com reaproveitamento de serrarias locais. Por fim, alguns engenheiros e arquitetos, assim como empresas construtoras, também contribuíram com suas produções neste período listado. Entre estas, destacam-se as empresas Battistella e EPOTEC, as quais, por produzirem elementos pré-fabricados com o sistema wood frame com método panelizado, serão mais detalhadas na sequência deste trabalho (Tabela 1 ).

Tabela 1: Habitações populares em madeira construídas no Brasil entre 1943 e 2006

\begin{tabular}{|c|c|c|c|c|c|}
\hline Ano & Denominação & $\begin{array}{c}\text { Sistema } \\
\text { Construtivo } \\
\end{array}$ & Autor & Local & $\begin{array}{c}\text { Unidades } \\
\text { construídas }\end{array}$ \\
\hline 1943 & Abrigos SEMTA & Pilar-viga & Álvaro Vital Brasil & $\mathrm{MA}, \mathrm{CE}, \mathrm{PI}$ & - \\
\hline 1955 & Vila Serra do Navio & Pilar-viga & Oswaldo Bratke & $\begin{array}{c}\text { Serra do Navio, } \\
\text { AP }\end{array}$ & - \\
\hline 1976 & EPOTEC - Fertighaus & Painel & Koelle, F.; Koelle, D. & $\begin{array}{c}\text { Salto Santiago, } \\
\text { PR }\end{array}$ & 102 \\
\hline 1982 & Coroado & Painel & IPT / SHAM & Manaus, AM & 40 \\
\hline 1982 & CASEMA & $\begin{array}{c}\text { Montantes e } \\
\text { tábuas } \\
\text { encaixadas }\end{array}$ & $\begin{array}{l}\text { Casema Ind. Com. } \\
\text { Ltda. }\end{array}$ & - & - \\
\hline 1987 & Conjunto habitacional & Pilar-viga & IPT & $\begin{array}{l}\text { Campos do } \\
\text { Jordão, SP }\end{array}$ & 133 \\
\hline 1987 & Habitação popular & Painel & Metello, H.S & Cuiabá, MT & 50 \\
\hline 1987 & Conjunto habitacional & - & COHAB-AC & Rio Branco, $\mathrm{AC}$ & 40 \\
\hline 1988 & Conjunto habitacional & - & COHAB-AC & Rio Branco, AC & 203 \\
\hline 1988 & EPOTEC - Fertighaus & Painel & F. Koelle e D. Koelle & Aracruz, ES & 23 \\
\hline 1989 & Conjunto habitacional & - & COHAB-AC & Rio Branco, AC & 423 \\
\hline 1989 & Conjunto habitacional & Painel & LBA & Rio Branco, $\mathrm{AC}$ & 200 \\
\hline 1991 & Unidade Experimental & Painel & FUNTAC & Rio Branco, $\mathrm{AC}$ & 07 \\
\hline 1991 & Alojamentos & Pilar-viga & $\begin{array}{c}\text { Companhia Vale do } \\
\text { Rio Doce }\end{array}$ & Linhares, ES & - \\
\hline 1992 & $\begin{array}{c}\text { Unidades } \\
\text { habitacionais }\end{array}$ & Entramado & $\begin{array}{l}\text { Empr. Mun. Habit. } \\
\text { Popular }\end{array}$ & Santo André, SP & 96 \\
\hline 1993 & Stella & Painel & Batistella & Itá, SC & 100 \\
\hline 1993 & $\begin{array}{c}\text { Unidades } \\
\text { Habitacionais }\end{array}$ & - & $\begin{array}{c}\text { COHAB - Pref. } \\
\text { Caxias do Sul }\end{array}$ & $\begin{array}{c}\text { Caxias do Sul, } \\
200 \\
\end{array}$ & 200 \\
\hline 1994 & Vila Tecnológica & - & COHAB-Curitiba & Curitiba, PR & 18 \\
\hline 1995 & Vila Tecnológica & - & COHAB-RP & $\begin{array}{c}\text { Ribeirão Preto, } \\
\text { SP }\end{array}$ & 14 \\
\hline 1995 & $\begin{array}{c}\text { Conjunto habitacional } \\
\text { Pedra } 90 \\
\end{array}$ & Painel & $\begin{array}{c}\text { GHAB/ Pref. } \\
\text { Cuiabá/ PRODECAP }\end{array}$ & $\begin{array}{c}\text { Marcelândia, } \\
\text { MT } \\
\end{array}$ & 360 \\
\hline 2006 & $\begin{array}{c}\text { Assentamento Sepé- } \\
\text { Tiarajú }\end{array}$ & Pilar-viga & $\begin{array}{c}\text { Habis/EESC-USP/ } \\
\text { UFSCar }\end{array}$ & Serra Azul, SP & 09 \\
\hline
\end{tabular}

Fonte: Dias e Ino, 2008. 
Além destas habitações populares, desde 1990, se intensificaram as pesquisas visando a transformação e o desenvolvimento tecnológico da indústria de construção em madeira no Brasil. Nestes processos, foram construídos protótipos e unidades experimentais nas diversas regiões brasileiras, em geral, como resultados de pesquisas em instituições de ensino, como Universidade de São Paulo (USP), Universidade Federal de Santa Catarina (UFSC), Universidade Federal do Pará (UFPA), Universidade Federal de São Carlos (UFSCar) e Universidade Estadual de Londrina (UEL).

A Tabela 2 lista as principais experiências nacionais na construção de protótipos utilizando diferentes soluções tecnológicas em madeira, como tijolo em madeira, painel, pilarviga, entramado e plataforma. Destas construções, o protótipo Stella-UFSC será detalhado na sequência deste trabalho, pois destacou-se na promoção do sistema wood frame com parecerias em conjunto a empresas atuantes neste setor.

Tabela 2: Construção de protótipos de habitações populares em madeira no Brasil entre 1990 e 2006

\begin{tabular}{|c|c|c|c|c|c|}
\hline Ano & Denominação & $\begin{array}{c}\text { Sistema } \\
\text { Construtivo }\end{array}$ & Autor & Local & $\begin{array}{l}\text { Unidades } \\
\text { construídas }\end{array}$ \\
\hline 1990 & $\begin{array}{c}\text { Protótipo unidade } \\
\text { habitacional }\end{array}$ & $\begin{array}{c}\text { Tijolo } \\
\text { madeira }\end{array}$ & Conceição, P.N. & Cuiabá, MT & 01 \\
\hline 1993 & $\begin{array}{c}\text { Projeto } \\
\text { "Morar/Conscientizar" }\end{array}$ & Painel & $\begin{array}{l}\text { GHab / Pref. } \\
\text { Cuiabá / } \\
\text { SMADES }\end{array}$ & Cuiabá, MT & 02 \\
\hline 1993 & $\begin{array}{l}\text { Protótipo Sistema } \\
\text { 2"x4" }\end{array}$ & Entramado & $\begin{array}{l}\text { IPT / Aracruz / } \\
\text { PONCE, R. }\end{array}$ & $?$ & 01 \\
\hline 1996 & Casa do Horto & Pilar-viga & $\begin{array}{l}\text { GHab/EESC- } \\
\text { USP/UFSCar }\end{array}$ & São Carlos, SP & 01 \\
\hline 1997 & $\begin{array}{c}\text { Protótipo - Unidade } \\
001 \\
\end{array}$ & Pilar-viga & $\begin{array}{l}\text { GHab/EESC- } \\
\text { USP/UFSCar }\end{array}$ & São Carlos, SP & 01 \\
\hline 1997 & $\begin{array}{c}\text { Protótipo - Unidade } \\
002 \\
\end{array}$ & Pilar-viga & $\begin{array}{l}\text { GHab/EESC- } \\
\text { USP/UFSCar }\end{array}$ & São Carlos, SP & 01 \\
\hline 2000 & $\begin{array}{l}\text { Protótipo unidade } \\
\text { habitacional }\end{array}$ & Entramado & $\begin{array}{l}\text { Moura, J.D.; } \\
\text { Barnabé, M. F. } \\
\text { / Fund. Kellogg }\end{array}$ & Londrina, PR & 01 \\
\hline 2002 & $\begin{array}{c}\text { Protótipo unidade } \\
\text { habitacional }\end{array}$ & Painel & UFPA & Belém, PA & 01 \\
\hline 2002 & $\begin{array}{l}\text { Protótipo habitação } \\
\text { popular: Stella - UFSC }\end{array}$ & Plataforma & $\begin{array}{l}\text { Battistella / } \\
\text { GIEM - UFSC }\end{array}$ & Florianópolis, SC & 01 \\
\hline 2004 & $\begin{array}{c}\text { Protótipo habitação } \\
\text { de emergência: } \\
\text { Mutante }\end{array}$ & Painel & Lata / UEL & Londrina, PR & 01 \\
\hline 2005 & $\begin{array}{c}\text { Protótipo habitação } \\
\text { de emergência }\end{array}$ & Painel & $\begin{array}{l}\text { Habis/EESC- } \\
\text { USP/UFSCar }\end{array}$ & Serra Azul, SP & 01 \\
\hline
\end{tabular}

Fonte: Dias e Ino, 2008. 
Portanto, com estas informações apresentadas sobre o contexto geral das construções em madeira no país, observa-se que, ocorreram iniciativas para implementar novas tecnologias neste setor, em especial, direcionadas para a habitação popular. Dentre estas, este trabalho destaca a seguir o sistema construtivo wood frame, o qual, na segunda metade do século XX, foi aplicado por algumas empresas construtoras brasileiras e, desde então, vem sendo analisado e proposto em pesquisas acadêmicas brasileiras.

\subsection{EDIFICAÇÕES CONSTRUÍDAS COM WOOD FRAME NO BRASIL DESDE MEADOS DE 1980 ATÉ O INÍCIO DOS ANOS 2000}

Conforme introduzido no capítulo anterior, o sistema leve entramado em madeira, denominado wood frame, é originário dos países norte-americanos, centro europeus e escandinavos, reconhecido desde as primeiras décadas do século XIX. Mas, como observado há pouco, na colonização brasileira, em especial nas instalações dos imigrantes centro europeus, esta técnica de construção não foi adotada neste território.

É difícil datar quando ocorreu a primeira construção aplicando o wood frame no Brasil, pois além da falta de documentos e de registros sobre estas construções, as nomenclaturas adotadas variam entre regiões e épocas, dificultando esta análise. Dentre as denominações mais comuns encontradas no Brasil estão: sistema $2 " \times 4$ ", sistema plataforma em madeira, sistema com estrutura leve em madeira, sistema com entramado leve em madeira e wood frame - sendo esta última a denominação mais recente. Também, existem dúvidas sobre se determinadas soluções adotadas para elementos em madeira no país, como painéis de parede, podem ou não ser enquadradas neste sistema específico. Assim, neste trabalho, assume-se que o sistema wood frame brasileiro é aquele que se assemelha às composições originais desenhadas no capítulo anterior, com entramado constituído por montantes e travessas inferior e superior, contraventados por chapas OSB ou compensado.

Sendo assim, com base neste critério, este item visa analisar um primeiro processo de produção do wood frame no Brasil, considerando as experiências práticas que foram efetuadas por algumas empresas construtoras a partir da segunda metade do século XX até o início do século XXI.

Conforme dados coletados, os primeiros relatos de construções com este sistema fazem referência à quatro empresas, sendo estas: EPOTEC Paraná Indústria e Comércio de 
Casas Pré-Fabricadas, Battistella Indústria e Comércio Ltda, empresa Madezatti e construtora Malacon. A seguir, estas quatro são descritas brevemente, sendo que a fonte dos dados apresentados sobre as duas primeiras empresas - EPOTEC e Battistella - tem como base o Catálogo de Processos e Sistemas Construtivos para Habitação promovido pelo IPT e coordenado por Zenha (1998).

A empresa EPOTEC Paraná Indústria e Comércio de Casas Pré-Fabricadas Ltda estava localizada no município de Piraquara, próximo à Curitiba, no estado do Paraná. O seu sistema construtivo era denominado Epotec-Fertighaus (Figura 53), inventado por Friedrich A. H. Koelle e Detlev E. F. Koelle. Suas paredes externas e internas eram constituídas por painéis modulados com $125 \mathrm{~cm}$ de largura e com $250 \mathrm{~cm}, 275 \mathrm{~cm}$ ou $300 \mathrm{~cm}$ de altura. Peças de madeira tratada ${ }^{12}$ com seção transversal de $5 \mathrm{~cm} \times 5 \mathrm{~cm}$ formavam uma grelha ${ }^{13}$ e os vazios entre as peças eram preenchidos com materiais isolantes, como lã de rocha, lã de vidro, espuma de poliuretano ou isopor. Esta estrutura era fechada, em ambas as faces, com chapas duras derivadas de madeira - Hardboard - e revestidas interna e externamente com argamassa epóxica e impermeabilizadas com resinas epóxi. As juntas entre painéis podiam ser dissimuladas, com peças de encaixe parafusadas na lateral dos painéis, ou aparentes, com perfil de PVC rígido, sendo esta última solução prevista para paredes desmontáveis (ZENHA, 1998).

Ainda, para um segundo pavimento, a estrutura do entrepiso era formada por peças de madeira tratada e chapas duras de madeira. E a cobertura era estruturada por treliças planas de madeira pré-fabricadas, fechada com telhas cerâmicas ou de fibrocimento (ZENHA, 1998).

Entre os anos de 1972 e 1994, este sistema construtivo foi avaliado tecnicamente pelas instituições: IPT, Instituto de Tecnologia do Paraná (INTEC), COHAB de Curitiba, Companhia Cubatense de Urbanização e Saneamento (CURSAN), Escola de Engenharia de São Carlos (EESC / USP) e Centro Tecnológico - Fundação Paulista de Tecnologia e Educação (CETEC - Lins). Os requisitos avaliados foram os seguintes: desempenho estrutural, estanqueidade à água, segurança ao fogo, desempenho térmico e durabilidade (ZENHA, 1998).

\footnotetext{
${ }^{12}$ Esta empresa também utilizava perfis metálicos na estrutura dos painéis de parede.

${ }^{13}$ Ao descrever a estrutura do painel de parede como grelha, esta fonte não deixa claro se este sistema EpotecFertighaus realmente pode ser classificado como wood frame. Mas as ilustrações usadas nesta descrição levam a crer que era um sistema bem similar, inclusive com as camadas de materiais aplicados.
} 
Estas edificações eram comercializadas mediante venda direta ou empreitada global, fornecimento de kits, fornecimento para mutirões e construção parcial semi-acabada. E, estimava-se que uma edificação de $66 \mathrm{~m}^{2}$ era construída em cinco semanas, incluindo duas semanas para montagem das paredes (ZENHA, 1998).

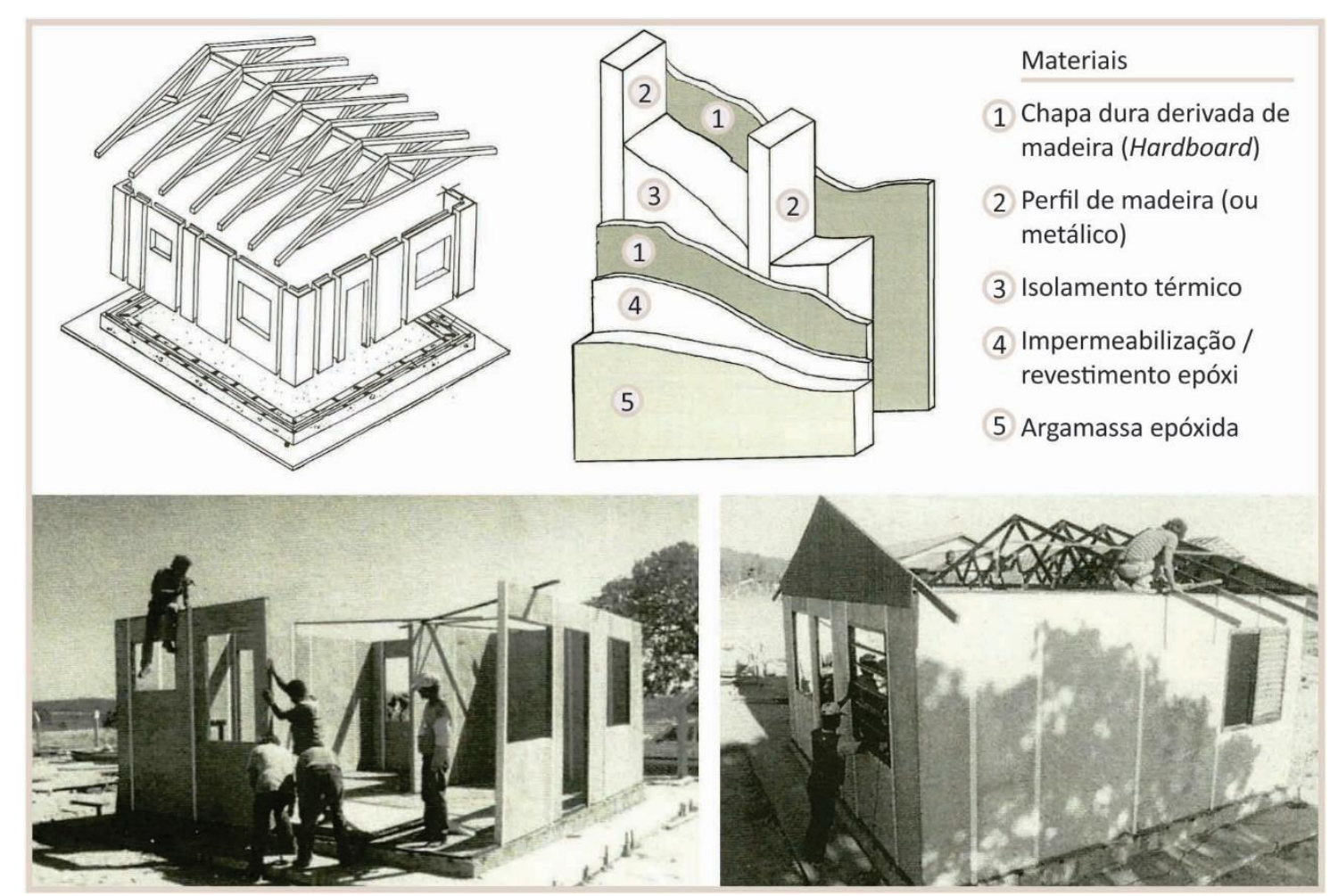

Figura 53: Sistema construtivo denominado Epotec-Fertighaus

Fonte: Zenha, 1998.

A segunda empresa era a Battistella Indústria e Comércio Ltda., com escritório localizado no município de Curitiba, no Paraná, e unidade de produção no município de Lages, Santa Catarina, a qual desenvolveu o sistema construtivo Stella (Figura 54). Este era composto por painéis com dimensões modulares de $122 \mathrm{~cm} \times 244 \mathrm{~cm}$ e com espessuras de $15 \mathrm{~cm}$ para paredes externas e $10 \mathrm{~cm}$ para paredes internas. Além desta dimensão de $244 \mathrm{~cm}$, a altura do painel poderia ser também de $274 \mathrm{~cm}$ e $305 \mathrm{~cm}$. Este painel era composto por um entramado de montantes e travessas com madeira oriunda de floresta plantada e tratada em autoclave com produto preservativo. Estas peças em madeira eram unidas com pregos anelados e fechadas com chapas de madeira de compensado sarrafeado, com $15 \mathrm{~mm}$ de espessura, fixadas com pregos anelados neste entramado. A união entre os painéis de madeira era vedada com perfis de PVC (ZENHA, 1998). 
Esta construção permitia até dois pavimentos. Então, sobre os painéis de parede térreos, a estrutura de piso para o segundo pavimento era executada com treliças planas de madeira espaçadas a cada $61 \mathrm{~cm}$. E, sobre estas, eram aplicadas as chapas de madeira de compensado, com $30 \mathrm{~mm}$ de espessura (ZENHA, 1998).

Por fim, a cobertura deste sistema construtivo era estruturada com tesouras de madeira pré-fabricadas, posicionadas com espaçamentos de $122 \mathrm{~cm}$ entre si, permitindo um vão livre máximo de 12,20 m. Para fechar externamente esta estrutura, eram colocadas telhas de fibrocimento ou cerâmicas. E sob estas, eram aplicadas as chapas de madeira e uma manta de espuma de polietileno como isolante térmico e acústico (ZENHA, 1998).
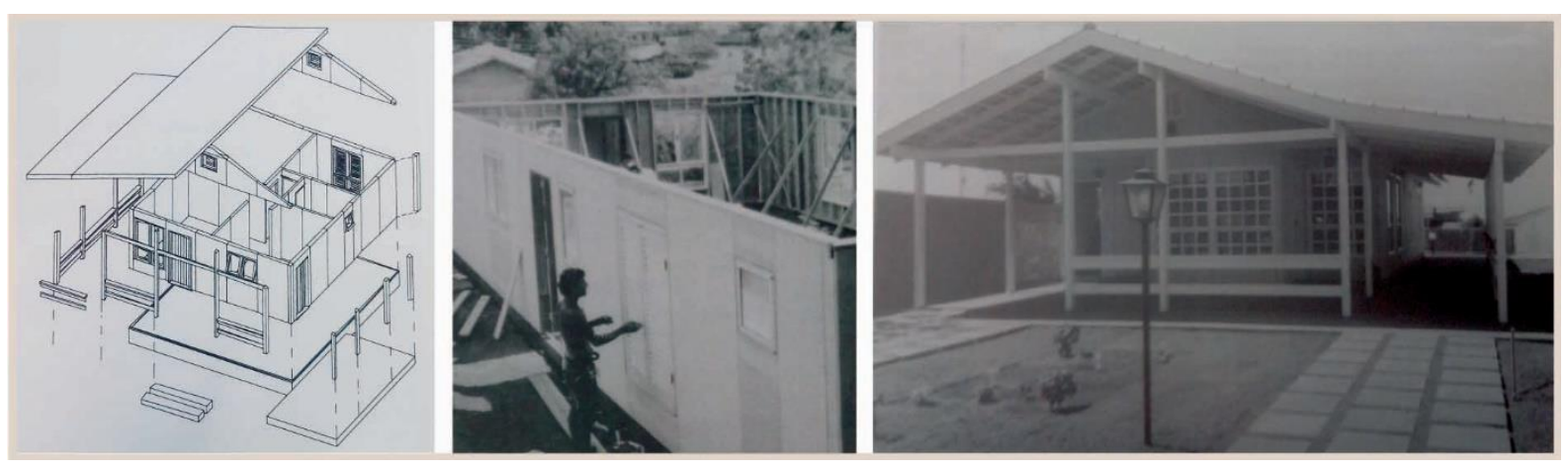

Figura 54: Sistema construtivo wood frame desenvolvido pela empresa Battistella Fonte: Zenha, 1998.

Entre os anos de 1988 e 1994, este sistema construtivo foi avaliado tecnicamente pelas instituições: Instituto de Pesquisas Tecnológicas do Estado de São Paulo (IPT), Fundação de Pesquisas Florestais do Paraná (FUPEF), Universidade Federal de Santa Catarina (UFSC), Instituto de Pesquisa e Assessoria Tecnológica da PUC (INTEC/PUC) e Fundação de Ciência e Tecnologia (CIENTEC). Os requisitos avaliados foram os seguintes: desempenho estrutural, estanqueidade à água e desempenho térmico (ZENHA, 1998).

Estimava-se que uma edificação de $50 \mathrm{~m}^{2}$ era construída em dez dias, desde a fundação até acabamentos finais, incluindo as paredes pré-fabricadas, que eram montadas em três dias. A empresa apresentava um modelo de negócio que comercializava o sistema Stella por meio de: venda direta ou empreitada, fornecimento de kits, fornecimento para mutirões e fornecimento de componentes avulsos de madeira. E, por fim, após a venda, a empresa prestava assistência técnica com possíveis realizações de manutenções, reposições ou 
substituições de peças em garantia, conforme descritas em um certificado de garantia inserido no contrato (ZENHA, 1998).

As principais aplicações do sistema Stella foram os seguintes empreendimentos:

- 1986 - construção de 22 unidades institucionais públicas para a Prefeitura Municipal de Rio Grande, no Rio Grande do Sul;

- 1990 - construção de 02 unidades escolares, com área total de $4.427 \mathrm{~m}^{2}$, para as Escolas Municipais Cirne Lima e João Palma da Silva, do município de Canoas, Rio Grande do Sul;

- 1993 - construção de 100 unidades habitacionais, com área total de $8.994 \mathrm{~m}^{2}$, para a Vila Residencial de Itá, das Centrais Elétricas do Sul do Brasil (ELETROSUL), em Itá, Santa Catarina;

- 1994 - construção de 79 unidades institucionais particulares, com área total de 4.427 $\mathrm{m}^{2}$, para a empresa PROFAC Engenharia e Comércio, no estado de São Paulo;

- 1995 - 01 unidade escolar, com 751 m²$^{2}$, para a Escola de Medicina da Fundação do $A B C$, em Santo André, São Paulo.

A terceira empresa, Madezatti, foi fundada em 1948 como indústria extrativista de madeira. Localizada em Caxias do Sul, no Rio Grande do Sul, em 1958, iniciou sua produção de habitações populares em madeira. Em 1967, iniciou a comercialização de casas financiadas pelo Sistema Financeiro da Habitação (SFH) mediante o Banco Nacional da Habitação (BNH) atendendo mutuários das diversas classes sociais. Mas, sua produção se intensificou com a ocorrência de grandes obras na década de 1970, momento de crescimento do país. Neste período, a empresa atuou na produção de edificações para os canteiros de obra e para as vilas de operários, como por exemplo para construções de hidrelétricas nos estados do Paraná, Pará e Goiás (MADEZATTI, 2016).

Sendo assim, desde este período atuou na construção de habitações de baixa, médio e alto padrões, alojamentos, escolas, hospitais, supermercados e igrejas destinados para o Brasil e outros países como Angola, Arábia Saudita, Argélia, Argentina, Uruguai, Bolívia, Estados Unidos, Nigéria, Tanzânia, Venezuela e Antártida. Portanto, produzindo e montando aproximadamente $25.000 \mathrm{~m}^{2}$ por mês, nas décadas de 1970 e 1980, a Madezatti foi considerada a maior empresa de pré-fabricado na América Latina (MADEZATTI, 2016).

A autora Canto (1996) afirma que a empresa construía com dois sistemas básicos, sendo estes: painéis portantes e ossatura de madeira. Conforme esta referência, há evidências de que a empresa ainda atuava com o sistema entramado em 1996. Por exemplo, conforme a Figura 55, nota-se que o sistema caracterizado por painéis estruturados com travessas e 
montantes, fechados com chapas derivadas de madeira. Estes painéis eram pré-fabricados e montados no canteiro sobre a fundação de concreto.
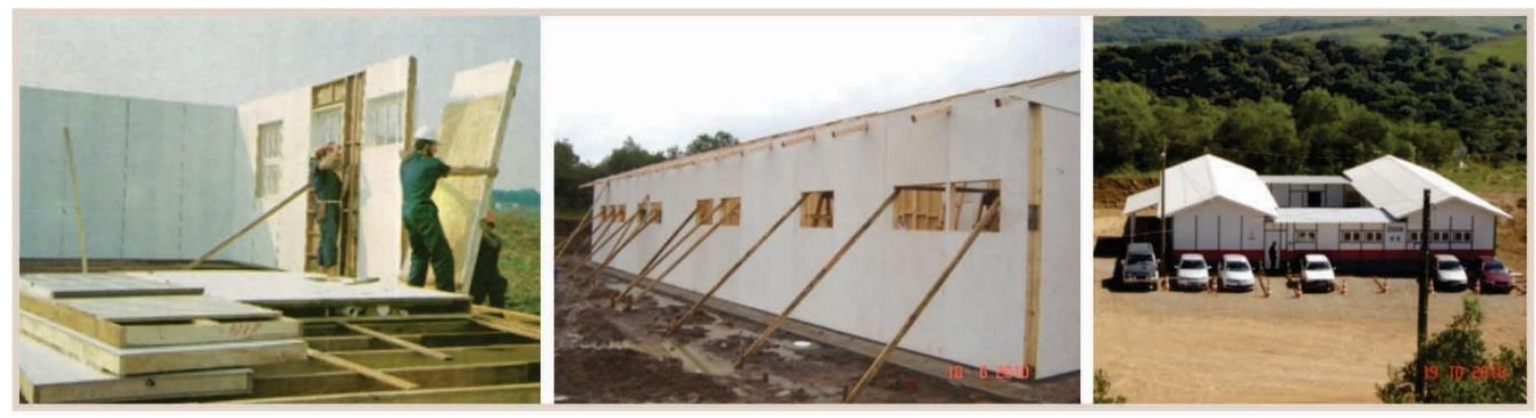

Figura 55: Construção em wood frame desenvolvido pela empresa Madezatti

Fonte: Madezatti, 2016.

Por fim, a quarta empresa iniciou seus trabalhos com o sistema wood frame em meados de 2000. A construtora Malacon, localizada em Curitiba, no Paraná, era dirigida pelo engenheiro Maurício Trindade Malafaia, com o denominado sistema US Home, referenciando a origem norte-americana desta tecnologia construtiva. A sua fundação era executada com radier com $10 \mathrm{~cm}$ de altura e baldrames com $15 \mathrm{~cm}$ de altura e $30 \mathrm{~cm}$ de largura, concretados sobre uma lona vinílica para barrar a transmissão da umidade do solo (NAKAMURA, 2009; TÉCHNE, 2002).

Na sequência, as suas paredes eram constituídas por entramados com montantes e travessas em madeira de araucária tratadas em autoclave com arseniato de cobre cromatado (CCA), com barreiras de fogo entre os montantes. Esta estrutura era contraventada com chapas $\mathrm{OSB}^{14}$ ou compensado, fixadas na face externa do entramado. Após, papelão alcatroado era grampeado sobre as chapas de OSB ou compensado para envelopá-las e proteger esta estrutura contra a umidade. Por fim, a estrutura das paredes era fechada internamente com chapa de gesso acartonado e acabada externamente com sidings em madeira ou em PVC e com tijolos cerâmicos (NAKAMURA, 2009; TÉCHNE, 2002).

O entrepiso, ou plataforma de piso para o segundo pavimento, era constituído por vigas I de madeira serrada e OSB, cobertas por chapas OSB e compensado, sobre as quais os

\footnotetext{
${ }^{14}$ Observa-se que, neste período, as chapas OSB ainda não eram produzidas no Brasil, portanto, eram importadas e fornecidas pela empresa chilena Masisa, com fábrica localizada em Ponta Grossa, no Paraná.
} 
acabamentos de piso finais eram aplicados. E, a estrutura da cobertura era constituída por treliças pré-fabricadas em madeira e telhas onduladas de fibrocimento.

Em 2001, a empresa Malacon construiu um empreendimento de habitação popular o Condomínio Porto Primavera. Localizado no bairro de Vila Hauer, em Curitiba, este residencial era composto por oito unidades habitacionais, totalizando $440 \mathrm{~m}^{2}$ de área construída. Cada unidade possuía $50 \mathrm{~m}^{2}$, incluindo dois dormitórios, sala, cozinha, banheiro e área de serviço. Após a execução da fundação em radier, a estrutura da parede de cada sobrado foi erguida e montada em quatro dias (NAKAMURA, 2009; TÉCHNE, 2002).

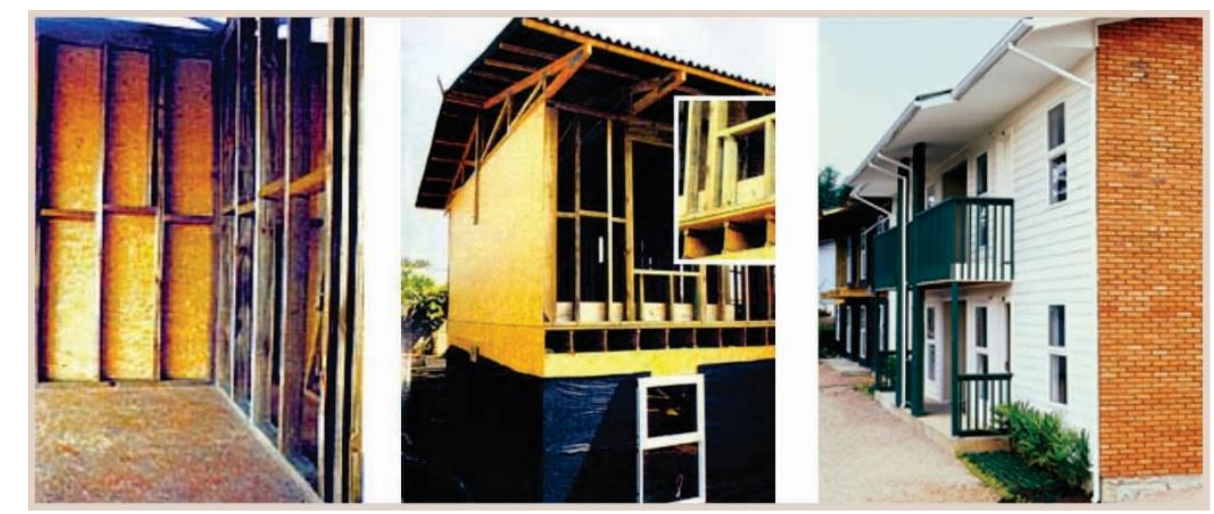

Figura 56: Sistema construtivo US Home desenvolvido pela empresa Malacon em 2001 Fonte: Téchne, 2002.

Estas unidades foram construídas visando um público com renda mais baixa. Inicialmente, a proposta da empresa não era vender as unidades, mas, sim, alugá-las. Pois, segundo o relato do diretor da empresa, para vender as habitações construídas em madeira, haja vista o preconceito popular referente ao material, a procura seria pequena e, por isso, o preço deveria ser significativamente reduzido. Assim, com as habitações alugadas, a empresa se responsabilizaria por realizar vistorias periódicas nestas edificações (TÉCHNE, 2002).

Além destas quatro empresas encontradas nas pesquisas bibliográficas, também há registros sobre a construção de uma residência com dois pavimentos realizada pelo engenheiro brasileiro Carlos Alves e o construtor norte-americano Alfred Lee Edgar, no município de Viamão, no Rio Grande do Sul, entre dezembro de 2000 e março de 2001 (MOLINA; CALIL JÚNIOR, 2010). O sistema wood frame adotado seguiu os padrões e as composições norte-americanas, com entramado em madeira, chapas OSB importadas pela Masisa e chapas de gesso acartonado. 
Portanto, com esses registros, é possível observar que as construções em wood frame no Brasil ocorreram desde o fim da década de 1970. Inicialmente, as produções das empresas EPOTEC e Battistella foram destinadas principalmente para a construção de vilas e alojamentos para a execução de obras de infraestrutura, como linhas de metrôs e hidroelétricas. Destas, na década de 1990, a empresa Battistela teve mais destaque na produção de habitações, as quais eram destinadas para uma classe com renda mais alta. Após, em meados de 2000, a construtora Malacon e o engenheiro Carlos Alves tomaram iniciativa em promover este sistema construtivo no país com a execução de algumas unidades habitacionais (Figura 57).

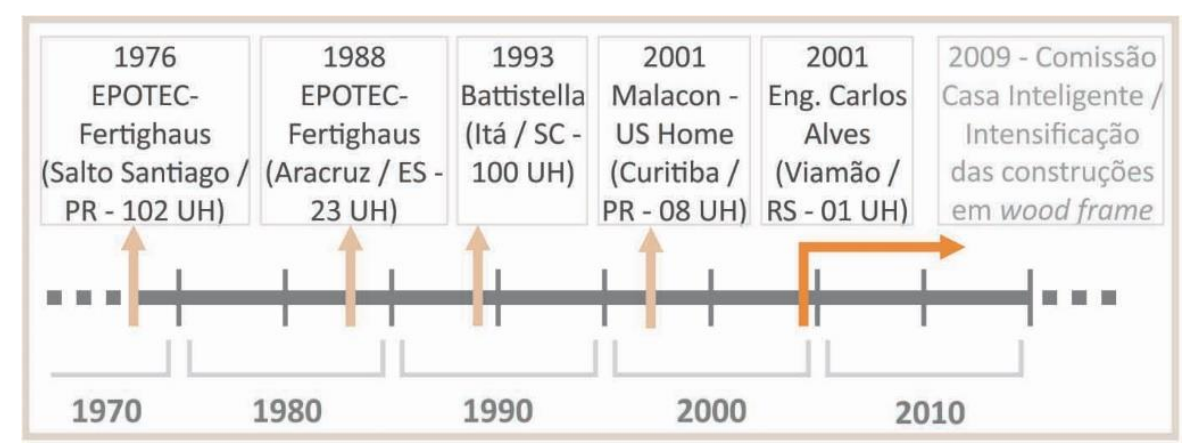

Figura 57: Linha do tempo com as principais construções em wood frame no Brasil desde 1976

Fonte: autora

Mas, logo após este primeiro período de produções, há dificuldade para encontrar registros sobre construções com o wood frame no Brasil na década de 2000. As empresas que antes produziam com esse sistema construtivo alteraram ou encerraram a suas atividades. Por exemplo, a empresa Battistella passou a atuar nos serviços de logística, beneficiamento e comercialização de produtos e serviços da área de cultivos florestais. Por sua vez, a empresa EPOTEC, enquanto atuava, deu maior ênfase ao sistema leve em aço - steel frame - nas suas construções. O mesmo ocorreu com o engenheiro Carlos Alves, do Rio Grande do Sul, que atualmente trabalha com projetos em steel frame. A empresa Madezatti passou ter maior enfoque na produção de componentes para a construção civil e para a indústria moveleira, destinados ao mercado externo. E, não há mais relatos da atuação da empresa Malacon com seu sistema US Home de Curitiba.

Assim, observa-se que, apesar das primeiras iniciativas, não ocorreu a efetivação da difusão do wood frame para produção de habitações no Brasil naquele período. Com base 
neste cenário, a década de 2000 é marcada por uma concentração das primeiras pesquisas acadêmicas sobre o tema, as quais visavam a promoção deste sistema no território nacional, conforme o item seguinte abordará.

\subsection{PRINCIPAIS PESQUISAS ACADÊMICAS E PUBLICAÇÕES SOBRE O WOOD FRAME NO BRASIL ATÉ O INÍCIO DE 2010}

Acredita-se que a primeira pesquisa que divulgou o sistema construtivo wood frame no Brasil foi publicada em 1979 no documento de dissertação de mestrado elaborado pela autora Carolina Palermo, apresentado à Universidade de São Paulo (USP). Este trabalho intitulado "Utilização da Madeira na Construção da Habitação" tinha como referência principal os detalhes construtivos deste sistema leve descritos no manual de construção "Wood-frame house construction" do autor americano L.O. Anderson, de 1970. Esta primeira publicação serviu como base para as próximas pesquisas desenvolvidas no Brasil sobre este tema.

Nas duas décadas seguintes, além da segunda publicação da autora Palermo, não foram encontrados outros registros acadêmicos sobre as possibilidades de aplicação deste sistema construtivo no Brasil. Entretanto, a partir do ano 2000, as pesquisas sobre o wood frame começaram a se intensificar, tendo como objetivo promover e difundir este sistema na indústria nacional.

A Tabela 3 traz um breve levantamento de pesquisas realizadas por acadêmicos desde 1979 até o primeiro semestre de 2010, quando começa a ocorrer nova transformação na produção deste setor, conforme o capítulo seguinte delineará.

$E$, na sequência, são destacadas quatro destas pesquisas listadas, as quais resultaram em construções de protótipos ou unidades experimentais, sendo estas: sistema Stella-UFSC; Projeto Educação em Madeira; habitação térrea com sistema plataforma e placas cimentícias; e habitação social para avaliação de desempenho termo-acústico. 
Tabela 3: Pesquisas sobre wood frame no Brasil entre os anos de 1979 e 2010

\begin{tabular}{|c|c|c|c|}
\hline Pesquisador & Instituição & Ano & Título \\
\hline Palermo, C.P. & USP & 1979 & Utilização da madeira na construção da habitação \\
\hline Palermo, C.P. & Metz & 1991 & $\begin{array}{l}\text { Système ouvert de construction en bois pour la Maison populaire, } \\
\text { applique a une systematique autoconstructive, comme une } \\
\text { reponse a la demande d'habitations dans la region sudbresilienne }\end{array}$ \\
\hline $\begin{array}{l}\text { Hilgenber Neto, M. } \\
\text { F. }\end{array}$ & UFPR & 2004 & $\begin{array}{l}\text { Estudo de viabilidade técnico/econômica da casa de madeira } \\
\text { popular no Estado do Paraná }\end{array}$ \\
\hline Santos, A.C. & UFSC & 2005 & $\begin{array}{l}\text { Pisos em sistema leve de madeira sob ação de carregamento } \\
\text { monotônico em seu plano. }\end{array}$ \\
\hline Dias, G.L. & UFSC & 2005 & $\begin{array}{l}\text { Estudo experimental de paredes estruturais de sistema leve em } \\
\text { madeira (sistema plataforma) submetidas a força horizontal em } \\
\text { seu plano }\end{array}$ \\
\hline $\begin{array}{l}\text { Palermo, C.P.; } \\
\text { Szücs, C.A.; Barth, } \\
\text { F.; Souza, M.E.F. } \\
\end{array}$ & $\begin{array}{l}\text { UFSC / } \\
\text { Battistella }\end{array}$ & 2006 & $\begin{array}{l}\text { Sistema STELLA-UFSC: avaliação e desenvolvimento de sistema } \\
\text { construtivo em madeira de reflorestamento voltado para } \\
\text { programas de habitação social (Coletânea Habitare }\end{array}$ \\
\hline Krambeck, T.I. & UFSC & 2006 & $\begin{array}{l}\text { Revisão de sistema construtivo em madeira de floresta plantada } \\
\text { para habilitação popular }\end{array}$ \\
\hline Stamato, G.C. & UNESP & 2006 & Projeto Educação em Madeira - Itapeva, SP \\
\hline Campos, R.J.A. & UEL & 2006 & $\begin{array}{l}\text { Diretrizes de projeto para produção de habitações térreas com } \\
\text { estrutura tipo plataforma e fechamento com placas cimentícias }\end{array}$ \\
\hline Laroca, C. & UFPR & 2007 & $\begin{array}{l}\text { Desenvolvimento de protótipo de habitação social em madeira de } \\
\text { reflorestamento e avaliação do desempenho termo-acústico }\end{array}$ \\
\hline Souza, A.F.P. & UFSC & 2010 & $\begin{array}{l}\text { A Sustentabilidade no uso da madeira de floresta plantada na } \\
\text { construção civil }\end{array}$ \\
\hline Espíndola, L.R. & UFSC & 2010 & $\begin{array}{l}\text { Habitação de interesse social em madeira conforme os princípios } \\
\text { de coordenação modular e conectividade }\end{array}$ \\
\hline Velloso, J.G. & UFSC & 2010 & Diretrizes para construções em madeira no sistema plataforma \\
\hline
\end{tabular}

Fonte: autora.

Em 2002, a professora Carolina Palermo iniciou a coordenação de um projeto de pesquisa com tema: "Sistema STELLA-UFSC: avaliação e desenvolvimento de sistema construtivo em madeira de reflorestamento voltado para programas de habitação social". Este projeto da Universidade Federal de Santa Catarina (UFSC) foi realizado em parceria com a empresa Battistella, de Lages, Santa Catarina, com apoio da Financiadora de Estudos e Projetos (FINEP), no Programa de Tecnologia de Habitação (HABITARE). Esta pesquisa foi realizada por integrantes do Grupo de Estudos da Habitação (GHab-UFSC) e do Grupo Interdisciplinar de Estudos da Madeira (GIEM-UFSC) (SZÜCS et al., 2006).

Até então, a empresa Battistella estava produzindo habitações para população de renda mais alta, com a denominada Stella Casa Pronta. Mas, a empresa estava interessada em ampliar seu público alvo. Com isso, o objetivo desta pesquisa era transformar a produção desta empresa, diminuindo os custos envolvidos neste processo, sem perder a qualidade, para atender habitações mais populares, inseridas em programas sociais públicos. O principal 
resultado alcançado nesta parceria foi a concepção do projeto da habitação chamada StellaUFSC e as experiências adquiridas na construção do seu protótipo no departamento de Engenharia Civil da UFSC, que foi inaugurado em agosto de 2003 (SZÜCS et al., 2006).

A habitação Stella-UFSC foi projetada e construída com área de $47 \mathrm{~m}^{2}$, incluindo copa, cozinha e sala de estar no pavimento térreo e quarto e banheiro no pavimento superior. 0 sistema construtivo denominado sistema plataforma adotou painéis modulados constituídos por montantes e travessas em madeira de pinus com seção de $3 \mathrm{~cm} \times 12 \mathrm{~cm}$ e pé-direito com $244 \mathrm{~cm}$. A parede da edificação era dupla com $15 \mathrm{~cm}$ de espessura, incluindo uma câmara de ar com $12 \mathrm{~cm}$ de espessura. Na face interna, as paredes eram fechadas com chapas de compensado e, na face externa, eram fechadas com sidings de madeira. Sobre a parede térrea, o entrepiso foi estruturado com vigas maciças de madeira serrada, vigas de madeira laminada colada e vigas I com alma de chapas sarrafeadas; e, sobre as vigas, foram fixadas chapas de compensado. E, a cobertura foi estruturada com treliças de madeira e fechada com telhas de madeira, produzidas pela empresa (Figura 58) (SZÜCS et al., 2006; HABITARE, 2004).
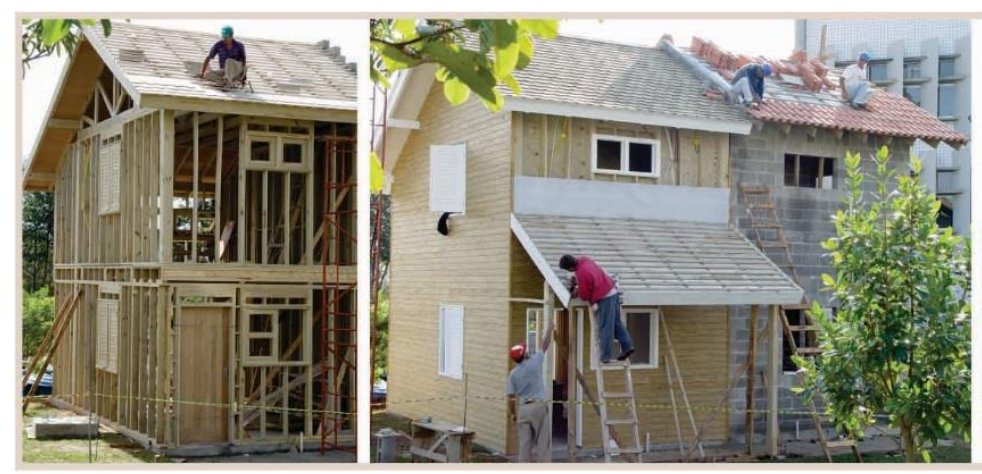

Figura 58: Protótipo Stella-UFSC executado pela UFSC em parceria com a empresa Battistella Fonte: arquivo do GIEM/UFSC, 2004.

Uma segunda referência importante de pesquisa com o sistema wood frame na década de 2000 foi o "Projeto Educação em Madeira". Este projeto teve início em 2007, sob coordenação do então professor Guilherme Corrêa Stamato, da Universidade Estadual Paulista Júlio de Mesquita (UNESP), Itapeva, São Paulo. Esta proposta tinha como objetivo construir salas de aula para promover este sistema construtivo por meio do ensino prático e da vivência dos alunos do curso de Engenharia Florestal desta universidade. Após a concepção do projeto, buscou-se estabelecer parcerias com empresas fornecedoras e produtoras dos materiais utilizados. Por fim, esta pesquisa apresentou como resultado principal a construção 
de duas salas de aula, com áreas de $76 \mathrm{~m}^{2}$ cada, localizadas na UNESP de Itapeva (STAMATO; OLIVEIRA JUNIOR, 2008).

As paredes das salas de aula foram compostas por painéis fabricados por alunos da instituição, em local coberto no próprio campus da UNESP, onde os elementos ficaram armazenados até a montagem sobre a fundação de concreto. Estes painéis de parede eram constituídos por um entramado com montantes e travessas de madeira de pinus tratado com CCA, com seções de $4 \mathrm{~cm} \times 9 \mathrm{~cm}$. Entre os vazios da estrutura foi aplicado uma lã isolante termo acústica. Na face externa deste entramado, chapas OSB foram fixadas e cobertas com uma membrana hidrófuga para proteção contra umidade. O fechamento interno dos painéis foi realizado com chapas de gesso acartonado. E, o acabamento externo variou entre sidings de madeira e estuco. Por fim, a cobertura foi estruturada com treliças em madeira e chapas OSB, fechadas com telha cerâmica e forrada com gesso acartonado (Figura 59) (STAMATO; OLIVEIRA JUNIOR, 2008).
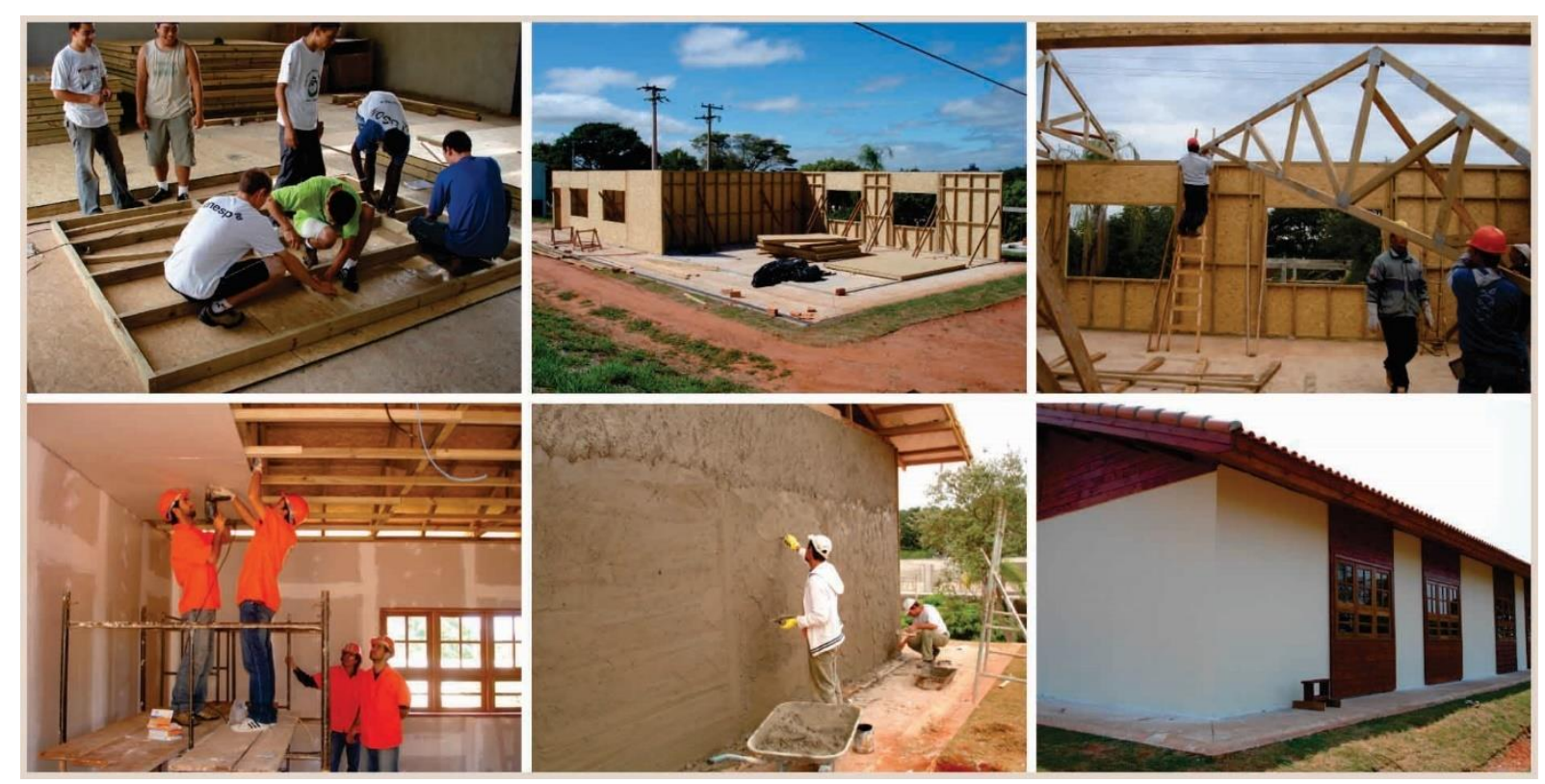

Figura 59: Projeto Educação em Madeira executado pela UNESP em 2006

Fonte: Stamato e Oliveira Júnior, 2008.

A terceira pesquisa a ser destacada foi realizada por Campos (2006) durante seu mestrado desenvolvido na Universidade Estadual de Londrina (UEL). O objetivo de sua análise era propor a utilização de placas cimentícias, como produto industrializado, para o fechamento externo das paredes do sistema wood frame, como já realizado em muitos outros 
países. Para averiguar isto, o autor levantou diretrizes de projeto com base em um estudo de caso de uma habitação térrea construída com esta tecnologia (Figura 60).

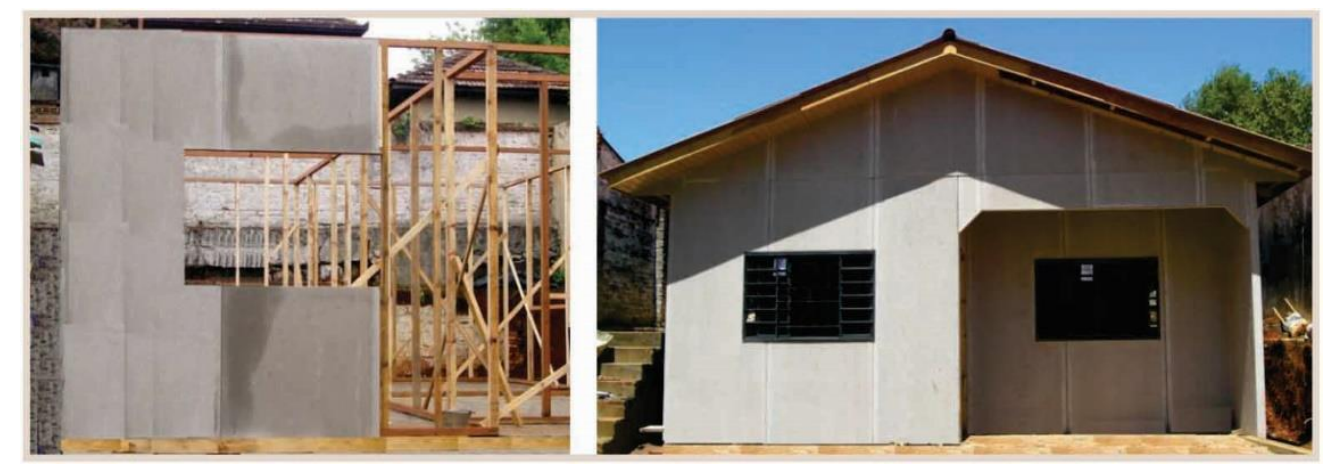

Figura 60: Estudo de caso com habitação térrea fechada com placas cimentícias em 2006 Fonte: Campos, 2006.

Por sua vez, a pesquisa de Laroca realizada na Universidade Federal do Paraná (UFPR) foi importante, pois foi implementada mediante parceria realizada com um agente estatal promotor de habitações sociais. A Companhia de Habitação do Estado de Santa Catarina (COHAB-SC) estava interessada em incluir habitações com sistemas pré-fabricados com madeira de florestas plantadas nos programas sociais. Sob a perspectivas de comercializar estas residências, alguns empresários do setor se interessaram em participar desta proposta. Com isso, a empresa Lavrasul, produtora de chapa de compensado e de peças serradas beneficiadas, estabeleceu parceria para a construção de um protótipo de habitação aplicando o sistema wood frame (LAROCA, 2007).

O protótipo foi constituído em Canoinhas, Santa Catarina, onde a empresa estava localizada. As paredes da habitação foram constituídas por painéis modulares compostos por entramado em madeira de pinus, fechado com chapas de compensado, fornecidos pela empresa. Estes painéis foram produzidos em mesas de montagem com gabaritos e transportados para o canteiro onde foram fixados na fundação de concreto. Com base nesta produção, a autora realizou análises de todo o processo construtivo, desde o recebimento e controle de qualidade das peças de madeira até a montagem final no canteiro (Figura 61) (LAROCA, 2007). 

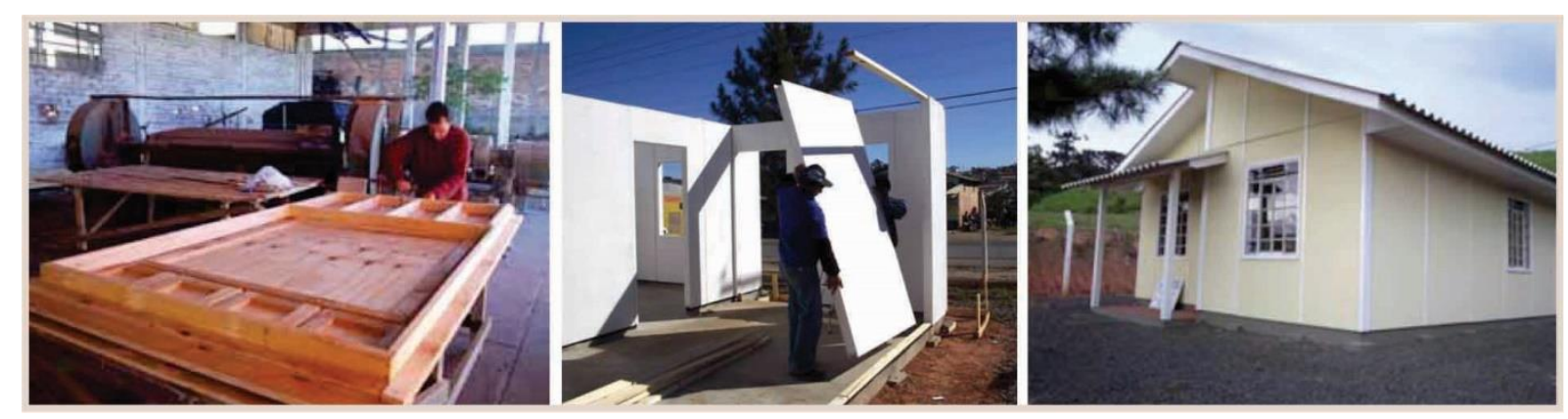

Figura 61: Protótipo construído pela UFPR em parceria com a COHAB-SC e empresa Lavrasul S.A. Fonte: Laroca, 2007.

Além destas quatro experiências destacadas, neste mesmo período da década de 2000, muitas outras pesquisas foram realizadas sobre materiais, componentes e elementos constituintes do sistema wood frame, identificando potencialidades e lacunas aprofundadas em análises específicas. Ensaios laboratoriais, simulações e proposições teóricas foram realizados em especial nos estados de Santa Catarina, Paraná e São Paulo, em grupos de pesquisa, como: Grupo Interdisciplinar de Estudos da Madeira (GIEM/UFSC), Laboratório de Madeiras e Estruturas de Madeiras (LaMEM/USP), grupo Desenvolvimento de Produtos Lignocelulósicos (LIGNO/UNESP), Grupo de Pesquisa em Habitação e Sustentabilidade (HABIS/ USP) e Instituto de Pesquisa e Tecnologia (IPT). Muitos dos resultados foram divulgados em artigos de eventos científicos, em especial nos anais do Encontro Brasileiro em Madeiras e em Estruturas de Madeira (EBRAMEM).

Em paralelo, a partir do ano 2000, as pesquisas acadêmicas e as produções das empresas construtoras resultaram na divulgação do sistema wood frame por meio de artigos publicados em revistas na área da construção civil, tais como da editora PINI (Tabela 4).

Os artigos destas revistas apontaram as principais características gerais do sistema wood frame e elencaram suas vantagens com base nas experiências históricas dos países norte-americanos. Também, utilizando o exemplo de construções brasileiras de meados de 2000, os autores apresentaram o passo a passo da execução destas edificações e estimativas de custo. Além desta editora, outras revistas e jornais de circulação popular também citavam sobre estas possibilidades de inovação no setor das construções em madeira no Brasil. 
Tabela 4: Publicações sobre wood frame em revistas da construção civil entre 2001 e 2008

\begin{tabular}{||l|c|c||}
\hline Revista / editora & Data & Tema \\
\hline \hline PiniWeb & 06/novembro/2001 & Feira destaca vantagens da obra seca \\
\hline Téchne / Pini & Ed. 59- Fevereiro/2002 & Popular com tecnologia \\
\hline PiniWeb & $11 /$ abril/2002 & Orçamento real \\
\hline PiniWeb & $11 /$ abril/2002 & Passo a passo da execução do light wood frame \\
\hline Téchne / Pini & Ed. 69-Dezembro/2002 & Do bloco ao painel \\
\hline Téchne / Pini & Ed. 69-Dezembro/2002 & Casa com frame de madeira e paredes de OSB \\
\hline Téchne / Pini & Ed. 69-Dezembro/2002 & Revolução industrial \\
\hline Téchne / Pini & Ed. $140-$ Novembro/2008 & $\begin{array}{c}\text { Light wood frame - construções com estrutura leve de } \\
\text { madeira }\end{array}$ \\
\hline
\end{tabular}

Fonte: autora com base em PINI, 2016.

Por fim, as pesquisas e as publicações acadêmicas deste período foram importantes, pois deram um primeiro embasamento técnico sobre o wood frame e demonstraram as adequações e possibilidades de aplicação no contexto brasileiro. Já que o sistema não estava incluso no currículo das escolas de engenharia civil e de arquitetura, as experimentações práticas, em especial as que envolveram alunos de graduação e pós-graduação, foram primordiais para inculcar nestes profissionais o desejo de construir e de promover esta nova tecnologia com madeira de florestas plantadas no Brasil.

Mas, a divulgação sobre o wood frame, em geral, ainda permanecia mais restrita aos profissionais da área da construção civil, concentradas entre os anos de 2001 e 2002. Assim, o conhecimento popular sobre o sistema ainda era baixo. E, nos anos seguintes, apesar dos resultados positivos demonstrados, o sistema não foi difundido no setor de construções de habitações no país.

Sobre este fato, não foi realizado um diagnóstico específico com os agentes envolvidos no contexto de produção daquele período com objetivo de levantar e compreender quais fatores dificultaram a propagação do wood frame desde meados dos anos 2000 . Mas, neste caso, pode-se observar o contexto geral do período anterior e apontar alguns aspectos que facilitaram ou não o desenvolvimento do setor de construções em madeira no Brasil naquele momento, conforme o item seguinte deste trabalho procura considerar. Pois, muitos destes aspectos constatados por autores sobre o processo de produção do século XX ainda são relevantes para as questões atuais. 


\subsection{O CONTEXTO DO SÉCULO XX PARA A DIFUSÃO DAS CONSTRUÇÕES EM MADEIRA NO BRASIL}

No início do século XX, na região sul do Brasil, próximo às florestas locais, foram instaladas as primeiras serrarias. E, logo, a quantidade de serrarias em operação cresceu rapidamente. Por exemplo, segundo o levantamento de Zani (2005), no estado do Paraná, em 1920 existiam 174 serrarias em operação, em 1949 contabilizavam 687 serrarias e em 1962 eram 859 serrarias. Em geral, este crescimento ocorreu atrelado à economia de exploração madeireira voltada para o mercado externo.

Também, outro importante fator que influenciou no crescimento destas atividades madeireiras foi a construção das estradas de ferro que ligariam os estados de São Paulo, Paraná, Santa Catarina e Rio Grande do Sul. Por exemplo, na transição entre os séculos XIX e XX, foi iniciada a obra da grande ferrovia São Paulo - Rio Grande. Assim, no início do século XX, a norte-americana Brazil Railway Company foi contratada pelo governo brasileiro para esta construção (CLARO; SANTOS, 1991).

A partir de 1910, subsidiada a esta empresa, a Lumber and Colonization Company, caracterizada por atuar nas atividades madeireiras e de colonização, começou suas atividades no Brasil por adquirir as áreas próximas às instalações desta ferrovia em construção. Além da especulação imobiliária, a Lumber Co passou a explorar estas terras com florestas de araucárias e instalar serrarias, inicialmente localizadas nos estados de Santa Catarina e Paraná. Com equipamentos industrializados e avançados para aquele período, a empresa trouxe trabalhadores especializados dos EUA e contratou outros trabalhadores locais com altos salários para todo processo de produção, que incluía desde a extração da matéria-prima de troncos até a fabricação de componentes em madeira para construção de edificações, os quais principalmente destinados à exportação (CARVALHO; NODARI, 2008).

A primeira e maior serraria da Lumber Co. estava localizada em Três Barras, Santa Catarina. Nesta região, com técnicas de beneficiamento mais desenvolvidas, eram produzidos kits para construções de casas, incluindo: vigas, barrotes, tábuas de fechamento, divisórias, forros, assoalhos, esquadrias, madeiramento para cobertura e vistas. Estes kits eram destinados à exportação. Entretanto, parte desta produção ficava na região, onde eram construídas casas de maior padrão utilizando estes mesmos componentes. Também, a empresa Lumber Co. construiu habitações populares em vilas destinadas para os 
trabalhadores envolvidos na construção das ferrovias, adotando uma estrutura mais simplificada para estas edificações, compostas por peças de pequena seção vedadas externamente com tábuas verticais (CLARO; SANTOS, 1991).

O registro destas e outras vilas ferroviárias construídas essencialmente com sistemas em madeira pode ser observado, por exemplo, em documentos da Rede Viação Paraná e Santa Catarina (RVPSC). Naquele período, o principal sistema construtivo adotado foi de tábua e mata-junta, também denominado "casa de araucária", referindo-se à espécie utilizada. Estes projetos foram desenhados e executados pela RVPSC, com tipologias e ambientes conforme os cargos dos trabalhadores e funcionários da vila (BATISTA, 2011).

Ainda, além das atividades da Lumber Co, muitas outras serrarias estavam atuando nestas regiões dos estados de Santa Catarina e Paraná, ampliando a indústria madeireira que se colocava entre as atividades econômicas mais importantes destes locais. Um dos resultados deste momento de expansão pode ser observado nos valores nacionais de exportação de madeira de pinho de araucária, os quais, desde a década 1910 até a década de 1940, aumentaram significativamente, passando de 481.974 toneladas para 3.766 .140 toneladas (CARVALHO; NODARI, 2008).

Além da demanda externa, há evidências de que parte da produção destas serrarias também era disponibilizada localmente. Portanto, conforme já mencionado no início deste capítulo, a primeira metade do século XX foi propícia para as construções em madeira nestas regiões brasileiras, com fatores facilitadores neste processo de produção, destacando (BATISTA, 2011):

- a grande quantidade de matéria-prima disponível localmente e o consequente preço acessível do material no mercado;

- a simplicidade do sistema construtivo adotado, sendo o tábua e mata-junta o mais popular;

- as possiblidades de variação tipológica com este sistema construtivo;

- a disponibilidade de mão-de-obra especializada, incluindo os imigrantes da Europa Central;

- a produção em série nas serrarias, com fornecimento de kits pré-cortados para serem montados com facilidade e rapidez no canteiro de obras.

Mas, na segunda metade do século $X X$, a produção das habitações populares em madeira foi reduzida drasticamente nestas regiões brasileiras. Além da diminuição de matéria- 
prima, com grande parte das florestas de araucária desmatadas, outros fatores foram influentes nesta situação.

Por exemplo, neste mesmo período, iniciou-se o movimento moderno, que fortaleceu a utilização de concreto nas composições da arquitetura brasileira. E, mediante os contextos político e econômico vigentes, em um processo de produção orientado por agentes diretos e indiretos, o concreto foi selecionado como tecnologia principal para as construções brasileiras. Assim, desde a metade do século XX, o concreto, por sua hegemonia, foi considerado natural e inquestionável, privilegiado nos currículos acadêmicos e popularizado. Portanto, outras técnicas construtivas, incluindo as de madeira, foram subjugadas, enquanto o concreto era institucionalizado (SANTOS, 2008).

Como resultado, desde então, as estruturas em concreto armado se estabeleceram culturalmente como material mais seguro e eficiente que os demais sistemas, $E$, as habitações assim construídas foram popularmente denominadas como "casa de material". Naquele período do modernismo, construir com vedação em alvenaria e estrutura em concreto armado significava progresso e ascensão social. E, sob este novo quadro, as novas construções em madeira foram reduzidas. As famílias que tinham condições financeiras passaram a reconstruir suas residências utilizando alvenaria e concreto. E, para a população que não possuía recursos para uma nova construção, foram disponibilizadas soluções que repaginavam as antigas edificações em madeira para apresentarem o aspecto visual de uma "casa de material".

Neste último caso, para dar uma aparência de "material" à construção já edificada em madeira, uma das soluções propostas na década de 1960 chamava-se Erkulit, de autoria do austríaco Peter Petschel. Esta prática consistia em revestir as paredes de tábua e mata-junta com chapas de fibras mineralizadas. Na sequência, nas juntas entre chapas, uma tela plástica era aplicada para evitar rachaduras futuras. Após, sobre as chapas eram executados o chapisco e o reboco. Por fim, para o acabamento final, massa e tinta eram aplicadas (Figura 62) (BATISTA, 2011).

Sobre esta nova técnica, a propaganda do mercado clamava: "Mude sua casa sem mudar de endereço. Com chapas Erkulit sua casa de madeira se transformará em uma linda residência em material". Como resultado, desde meados de 1960 até 2000, esta empresa revestiu aproximadamente 20 mil casas em madeira na cidade de Curitiba e regiões próximas, do Paraná (BATISTA, 2011, p. 78). 


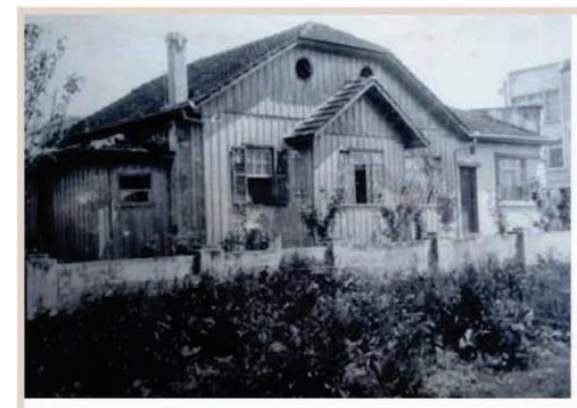

Casa original construída em madeira com sistema tábua e mata-junta

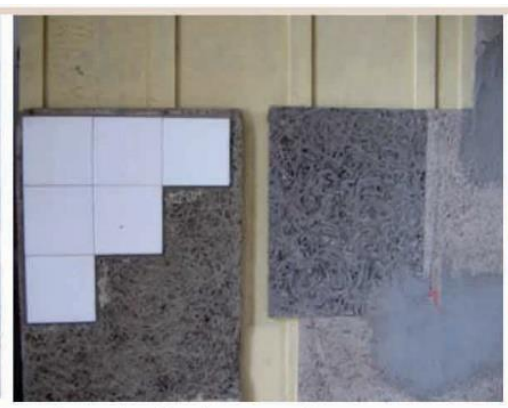

Tecnologia de revestimento com chapas mineralizadas - Erkulit

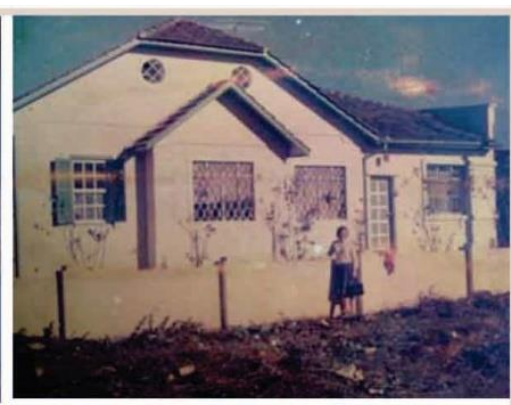

Casa construída em madeira revestida com tecnologia Erkulit

Figura 62: Casa construída com sistema em madeira e revestida com chapa mineralizada Erkulit Fonte: acerco da empresa Erkulit (1972) apud Batista (2007).

A naturalização do concreto armado contribuiu para a negação dos sistemas construtivos em madeira - um sentimento negativo já existente no Brasil desde as colonizações portuguesas. Com o passar do tempo, a cultura popular desenvolveu um preconceito quanto à confiabilidade da madeira enquanto material principal para suas construções. Mas, conforme Ino (1991), além das questões culturais, este preconceito também ocorreu motivado pelo desconhecimento da tecnologia da madeira. Tanto os usuários, quanto os profissionais da construção civil, vem fundamentando seus pré-conceitos baseados em experiências mal sucedidas, que denegriram a imagem deste material. Em geral, os diversos maus exemplos destas construções em madeira revelaram o baixo nível tecnológico deste setor brasileiro neste período, assim como a falta de interesse para superar esta deficiência.

Sobre tais condições tecnológicas ocorrentes na segunda metade do século $X X$, a autora Bittencourt (1995) elaborou uma análise com base em dois levantamentos realizados nesta época, especialmente focados nas atuações da região sul brasileira. O primeiro levantamento foi promovido pelo BNH, através do Centro de Estudos e Pesquisas para a Racionalização da Habitação, da Construção e do Desenvolvimento Urbano (CETHAC), incluindo dados sobre produção, extração, consumo, comercialização, beneficiamento, publicados em 1979 no relatório intitulado "Madeira na construção habitacional". E, o segundo levantamento, com dados similares, foi financiado pela PROMOTECH no estado de Santa Catarina, publicado por Voinson em 1986. 
Conforme estes relatórios, observou-se que, na primeira metade do século XX, o setor foi caracterizado por sistemas de corte mecânico tradicional, restringindo-se ao desdobro da madeira (VOINSON, 1986 apud BITTENCOURT, 1995). E, na segunda metade do século XX, a indústria madeireira já se apresentava como destaque no setor primário da economia brasileira, com potencial de produtos florestais destinados ao mercado externo. Mas, apesar desta significância, os equipamentos aplicados pela indústria nacional para transformação da madeira não apresentavam um nível tecnológico semelhante a este setor no âmbito internacional (CETHAC, 1979 apud BITTENCOURT, 1995).

Por exemplo, para usinar madeiras de densidades médias e baixas, as serrarias brasileiras predominantemente aplicavam processos rudimentares e manuais combinados com serras-fita e serras-circulares. Estas máquinas, que eram suficientes para o ciclo dos pinheiros nativos do sul do país, não foram atualizadas para o processamento de espécies de madeira nativas com maior densidade e de outras madeiras provenientes de florestas plantadas, como o pinus e o eucalipto, caracterizados por toras com pequenos diâmetros. Portanto, em geral, a técnica de corte era limitada e não resultava em produtos com bitolas em conformidade aos limites de tolerâncias exigidos, em especial pelo mercado de exportação (CETHAC, 1979 apud BITTENCOURT, 1995). Ainda, sobre esta constatação o CETHAC descreveu em seu relatório:

Nos anos 80, início da fase do aproveitamento das florestas cultivadas, a indústria de transformação da madeira continuou a enfrentar a falta de equipamentos nacionais adequados, comprometendo o resultado econômico dos grandes investimentos realizados no setor de reflorestamento (CETHAC, 1979 apud BITTENCOURT, 1995, p. 26).

Em contrapartida, na segunda metade do século XX, os outros setores da cadeia de produtos florestais no Brasil estavam se desenvolvendo tecnologicamente, na sua maioria sob demanda do mercado externo, incluindo entre estes: pasta química e celulose para papel, laminação para compensados e produtos manufaturados, como madeira aplainada, lambris, molduras (CETHAC, 1979 apud BITTENCOURT, 1995). Em função das demandas externas, estas indústrias começaram a se reequipar para atender os padrões internacionais de qualidade. Por exemplo, em meados da década de 1970, os fabricantes de manufaturados de madeira que atendiam o mercado externo começaram a importar equipamentos, modernizando e racionalizando sua linha de produção, desde a secagem artificial da madeira até a classificação e a embalagem adequada dos produtos (BITTENCOURT, 1995). 
Assim, esses dados demonstraram que, no geral, o desenvolvimento tecnológico do setor madeireiro vem acompanhando principalmente a demanda do mercado externo. $E$, apesar das potencialidades provenientes de florestas plantadas disponíveis no país desde meados dos anos 1980, a cadeia de produção de construções em madeira não apresentou um avanço. Pois, no Brasil não existe uma base industrial-tecnológica consolidada que dá suporte para a aplicação da madeira em larga escala neste setor e que garanta a qualidade em todo o seu processo, desde a matéria-prima até o produto final - edificação. Portanto, "a falta de tecnologia apropriada ao processo construtivo tem gerado o uso inadequado da madeira" (BITTENCOURT, 1995, p. 04).

Aliado às deficiências deste processo de produção, decorrente da estagnação da indústria de construção em madeira no país, não há demanda de mão-de-obra especializada ou de profissionais qualificados para atuar nesta área. Sem a exigência destes trabalhadores específicos para suprir o mercado, o sistema educacional deixa de considerar relevante a inclusão de conteúdos programáticos que priorizem a madeira (BITTENCOURT, 1995). E, com o desconhecimento técnico do material, as práticas errôneas se replicam no contexto brasileiro, denegrindo as potencialidades da madeira com construções e componentes constituintes com baixa qualidade.

Estas práticas negativas, além de aumentarem o preconceito popular, afetam também os critérios estabelecidos para o financiamento destas obras, fator preponderante para a difusão das construções em madeira. Nesse sentido, com base na demanda existente, os agentes financiadores estabelecem orientações e exigem comprovações de desempenho para avaliar se o financiamento é viabilizado ou não para determinada edificação.

Por exemplo, a Caixa Econômica Federal (CEF), principal instituição financiadora no Brasil atualmente, vem estabelecendo procedimentos para o financiamento de habitações em madeira, os quais podem variar entre os diversos estados brasileiros, levando em conta os seus aspectos locais, culturais, tecnológicos, de logística e de mercado. A Tabela 5 apresenta em resumo as orientações da Gerência de Desenvolvimento Urbano e Rural de Porto Alegre (GIDUR/PO) da CEF para o financiamento de habitações térreas ou sobrados que aplicam sistemas construtivos convencionais em madeira (ESPÍNDOLA; INO, 2014). 
Tabela 5: Orientações da GIDUR/PO para o financiamento de construções convencionais em madeira

\begin{tabular}{|l|c|c|c||}
\hline Casas térreas e sobrados & A construir & Novo & Usado \\
\hline \hline Prazo máximo & 15 anos & 15 anos & 15 anos \\
\hline $\begin{array}{l}\text { Valor limite para financiamento } \\
\text { (com áreas molháveis em alvenaria) }\end{array}$ & $100 \%$ & $100 \%$ & $100 \%$ \\
\hline $\begin{array}{l}\text { Valor limite para financiamento } \\
\text { (sem áreas molháveis em alvenaria) }\end{array}$ & $80 \%$ & $80 \%$ & $80 \%$ \\
\hline Termo de ciência & Sim & Sim & Sim \\
\hline Termo de responsabilidade do responsável técnico & Sim & Sim & Não \\
\hline Termo do fornecedor & Sim* & Sim* & Não \\
\hline Vistoria sem patologia CAIXA & Não & Sim & Sim \\
\hline ART de cálculo estrutural & Sim & Não & Não \\
\hline Comprovação de desempenho (RTA) & Não & Não & Não \\
\hline Manual do proprietário - manutenção & Sim & Sim & Não \\
\hline *Comprovação de utilização de madeira extraída de floresta com manejo controlado. & \\
\hline
\end{tabular}

Fonte: autora com base em entrevista realizada com GIDUR/PO da CEF em 2012.

Quando aprovado, o prazo máximo do financiamento é limitado ao tempo de garantia informado no laudo, podendo ser menor ou maior que 15 anos. Este limite é estipulado conforme os dados apresentados na Tabela 5 e outra informações mais específicas mais sobre o desempenho técnico e a durabilidade da construção em madeira em questão.

Portanto, além destas orientações gerais estabelecidas para todo território nacional listadas na Tabela 5, para garantir que o produto final apresente melhor desempenho e maior durabilidade, a GIDUR/PO acrescentou outros aspectos que devem ser respeitados nos processos de financiamento das habitações individuais para os casos situados no estado do Rio Grande do Sul. Dentre estes fatores exigidos estão:

- comprovação legal da origem da madeira, indicando os procedimentos de secagem, desdobramento, beneficiamento e imunização da mesma;

- especificação da espécie de madeira e dos tipos de tratamento e de imunização aplicados;

- utilização da espécie Pinus elliotii é restrita aos elementos de forros e de divisórias internas;

- utilização de espécies de madeira de alta densidade para assoalhos, esquadrias e paredes externas, incluindo lambris;

- execução obrigatória de paredes externas duplas, inserindo material isolante no interior destas, a fim de garantir seu desempenho térmico e acústico - exceto nos casos de paredes compostas por peças com espessura de 02 polegadas ou 5 $\mathrm{cm}$, aproximadamente;

- proteção efetiva à penetração de umidade nas paredes externas utilizando produtos específicos para esta função; 
- execução da cobertura com estrutura reforçada, beirais avantajados e fechamento com telhas cerâmicas ou de concreto.

Dentre estas condicionantes, destaca-se que a questão da durabilidade do componente ou da construção está atrelada à seleção da espécie de madeira utilizada. Para os principais elementos da edificação, especialmente os expostos às intempéries, priorizamse espécies mais densas. E as espécies de baixa densidade, como o pinus, são restritas a elementos não estruturais, como os forros e as divisórias internas. O receio quanto à aplicação destas últimas espécies refere-se a sua suscetibilidade frente à umidade e à ação de insetos xilófagos. Portanto, faz-se necessária a comprovação de tratamento para imunização destas peças. Ainda, outras medidas técnicas também visam a durabilidade e a vida útil da edificação, como proteção das paredes de fachadas e da estrutura da cobertura exposta nos beirais (ESPÍNDOLA, INO, 2014).

Mas, apesar dessas possibilidades de financiamento que se apresentam para habitações em madeira em alguns estados, muitos desses pedidos são indeferidos, barrando a difusão destas construções no mercado. Os agentes financeiros assumem uma postura mais rígida quando analisam processos que aplicam este material nos sistemas construtivos. Por exemplo, para a GIDUR/PO da CEF, o financiamento dessas habitações é frequentemente inviabilizado, pois, em geral, as construções em madeira no país não atendem os critérios estabelecidos de desempenho e são ofertadas com baixa qualidade. Sobre esta postura conservadora da CEF, os responsáveis da GIDUR/PO ainda complementam:

Entendemos que, em princípio, a oferta de edificações em madeira no mercado da construção civil tem se caracterizado por produtos com baixa tecnologia, ausência de controle de qualidade dos diversos componentes, ausência de certificação de origem da madeira e processo de beneficiamento deficiente, gerando edificações de baixo desempenho e durabilidade, salvo algumas exceções, o que explica a postura conservadora da CAIXA em relação a estas tipologias (entrevista com CEF/GIDUR/PO, 2012).

Além das práticas errôneas consequentes do desconhecimento técnico do material, estas ofertas de produtos com baixa qualidade refletem as deficiências que perpassam por toda a cadeia de produção das habitações em madeira, incluindo equipamentos, serviços, processos, pessoal, matéria-prima. Portanto, análises mais aprofundadas sobre esta cadeia necessitam ser realizadas para diagnosticar e aprimorar cada um destes aspectos em todo seu ciclo, incluindo: o plantio e o manejo florestal, as transformações nas serrarias, os processos de tratamento químico e de secagem, a manufatura nas indústrias de componentes 
construtivos, a elaboração dos projetos das habitações, a execução na fábrica e a montagem no canteiro, a manutenção periódica pelo usuário, a desmontagem e desconstrução.

Em especial, para a implementação e a difusão de novas tecnologias construtivas em madeira, as especificidades da cadeia precisam ser coerentes com as necessidades de cada sistema, assim como também o sistema deve estar adequado ao contexto em que se apresenta. Nesse sentido, a autora Bittencourt (1995, p. 07) destacou que é necessário reconhecer que "um sistema construtivo em madeira requer uma nova prática técnica, refletindo nas formas e nos produtos da prática arquitetônica e rompendo com os sistemas convencionais em alvenaria e tradicionais em madeira".

Com base nesses aspectos, para iniciar uma nova fase de produção com o sistema wood frame no Brasil e para reverter a situação presente de estagnação tecnológica das habitações em madeira do país, desde meados de 2009, empresas do setor madeireiro reuniram-se com pesquisadores, construtores, fornecedores e consultores para estabelecer critérios para efetivar esta difusão. Conforme os capítulos seguintes abordarão, a formação e as ações desta conjuntura incluindo vários agentes da cadeia de produção madeireira tem trouxeram resultados positivos e diferentes do primeiro período de produção com o sistema wood frame no Brasil. 


\section{AÇÕES PARA O DESENVOLVIMENTO DO WOOD FRAME NO BRASIL A PARTIR DO ANO DE 2010}

Conforme delineado no capítulo anterior, o desenvolvimento das construções em madeira no Brasil estava praticamente estagnado até o início de 2010. As inovações das edificações em madeira ocorriam de forma pontual no contexto brasileiro.

Entretanto, a partir de 2010, o setor iniciou uma transformação positiva impulsionada por ações conjuntas para desenvolver o sistema construtivo wood frame no Brasil. Os agentes envolvidos no processo desta inovação estabeleceram estratégias a fim de consolidar a aplicação deste sistema construtivo. E, logo nos anos seguintes, obtiveram resultados que confirmavam a eficiência deste sistema ao ser adequado ao contexto brasileiro e que possibilitaram a sua propagação inicial neste território.

Portanto, com base neste cenário de mobilização e de engajamento para promover a produção do sistema wood frame no contexto brasileiro, este capítulo tem como objetivo delinear as questões sobre este processo: o que motivou tal movimento para utilização deste sistema construtivo nesta data específica, quem atuou direta e indiretamente neste processo, - que foi selecionado pelo grupo atuante como necessidade para produção, quais procedimentos e estratégias adotados para alcançar esta proposta e quais foram os resultados apresentados. A seguir, os itens deste capítulo apresentarão estas informações.

\subsection{MOTIVAÇÕES PARA A TRANSFORMAÇÃO DO SETOR DE CONSTRUÇÕES EM MADEIRA}

Para compreender as necessidades que motivaram a transformação do setor madeireiro, este item apresenta: (1) o contexto econômico no período em questão; (2) a situação do setor florestal frente a este contexto; (3) o lançamento do PMCMV aliado ao SINAT; e (4) a parceria entre o SENAI-PR e o Estado alemão para transferência de tecnologia.

\subsubsection{Contexto econômico - crise mundial de 2008}

Em 2007, a crise financeira estava se agravando nos Estados Unidos, evidenciada primeiramente por problemas no seu setor imobiliário. Nesse período, a estrutura do sistema financeiro americano, decorrente de conjunturas econômicas anteriores, se encontrava 
instável e frágil. Desde a década de 1980, a renda real dos trabalhadores estava estagnada e, com uma poupança reduzida, eles acumulavam dívidas. Subsidiárias financeiras e outras instituições proviam créditos para estes trabalhadores, incluindo os créditos imobiliários para que estes mantivessem o consumo em geral e os lucros empresariais (MILAN, 2013).

Bolhas financeiras sustentaram a demanda nas últimas décadas, evitando que a superprodução tivesse seus efeitos sentidos com mais força (MILAN, 2013, p. 136).

Quando as taxas de juros de curto prazo foram reajustadas a partir de 2004, o nível de inadimplência aumentou substancialmente, incluindo as hipotecas sub-preferenciais. Os títulos lastreados nestas hipotecas e em outros empréstimos se desvalorizaram, gerando perdas bilionárias para bancos e investidores alavancados ao redor do mundo (MILAN, 2013, p. 116).

Portanto, em 2006, a deflação na bolha imobiliária norte-americana aumentou. Os mutuários deixaram de pagar suas hipotecas. As dívidas das famílias estavam maiores que o valor do ativo financiado. "Esta deflação gerou reflexo nos produtos financeiros alavancados e derivados destas operações de crédito". Muitos investidores e especuladores não previram o risco e não conseguiram ajustar suas carteiras ou o fizeram de forma a aumentar a instabilidade financeira. Em meados de 2007, após perdas no mercado, esta bolha que sustentava o setor imobiliário estourou e desencadeou perdas para todo o sistema (MILAN, 2013, p. 125).

O sistema de créditos foi congelado, levando ao fechamento e à falência de bancos e instituições financeiras afins. "Cerca de 400 bancos faliram desde 2008, enquanto outros foram socorridos ou parcialmente nacionalizados pelo governo, com os contribuintes tendo de arcar com parte dos custos deste socorro [...]". No último trimestre de 2008, com a falência do banco americano Lehman Brothers, os reflexos da crise financeira se alastraram para o sistema internacional, agravando o cenário econômico mundial (MILAN, 2013, p. 126).

Uma das consequências desta crise internacional foi a variação cambial, fator que impactou diretamente as atividades de comércio internacional. Por exemplo, no Brasil, como se observa no Gráfico 3, desde 1994, ano do estabelecimento do real, até o ano de 2003, ocorreu uma desvalorização da moeda brasileira frente ao dólar americano, elevando a taxa de câmbio nominal. Em contrapartida, nos anos seguintes, entre 2003 a 2007, ocorreu uma valorização do real em relação ao dólar, reduzindo a taxa de câmbio (IPEA, 2016).

Porém, no último trimestre de 2008, momento em que as instituições financeiras sentiram as consequências da crise internacional, a moeda brasileira rapidamente 
desvalorizou diante o dólar, conforme é detalhado na Tabela 6 e no Gráfico 4. Neste curto período, desde agosto a dezembro de 2008, a moeda oscilou de $R \$ 1,61$ a $R \$ 2,39$, desvalorizando aproximadamente $48 \%$. Essa tendência de depreciação cambial seguiu no início de 2009. Mas, com algumas medidas do governo brasileiro, logo após, em 2010 e 2011, o valor do real equiparado ao dólar americano sofreu uma leve queda. Entretanto, nos anos seguintes, a partir de 2012, o real continuou em depreciação (IPEA, 2016).

Gráfico 3: Variação cambial do real em relação ao dólar americano desde 1991 até 2015

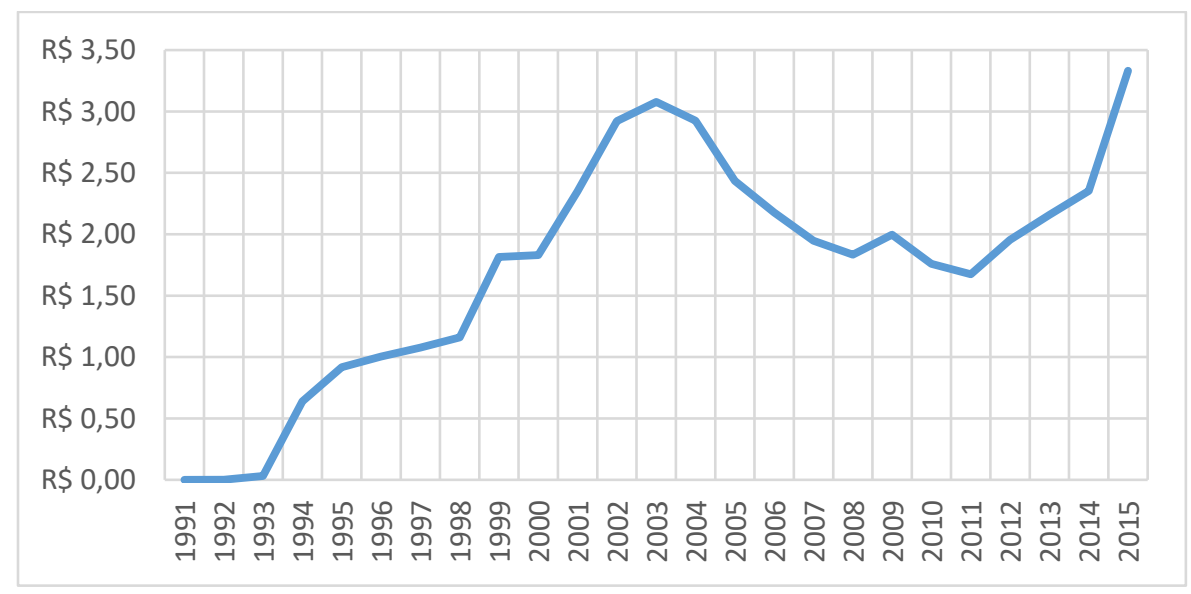

Fonte: elaborado pela autora com base em dados do IPEA, 2016.

Tabela 6: Variação cambial nominal do real em relação ao dólar em 2008

\begin{tabular}{|l|c||}
\hline Ano.mês & $\begin{array}{c}\text { Câmbio médio } \\
\text { mensal - Ano 2008 }\end{array}$ \\
\hline \hline 2008.01 & $R \$ 1,7739$ \\
\hline 2008.02 & $R \$ 1,7273$ \\
\hline 2008.03 & $R \$ 1,7072$ \\
\hline 2008.04 & $R \$ 1,6885$ \\
\hline 2008.05 & $R \$ 1,6601$ \\
\hline 2008.06 & $R \$ 1,6185$ \\
\hline 2008.07 & $R \$ 1,5910$ \\
\hline 2008.08 & $R \$ 1,6119$ \\
\hline 2008.09 & $R \$ 1,7992$ \\
\hline 2008.10 & $R \$ 2,1725$ \\
\hline 2008.11 & $R \$ 2,2659$ \\
\hline 2008.12 & $R \$ 2,3940$ \\
\hline
\end{tabular}

Fonte: elaborado pela autora com base em dados do IPEA, 2016
Gráfico 4: Variação cambial nominal do real em relação ao dólar nos meses de 2008

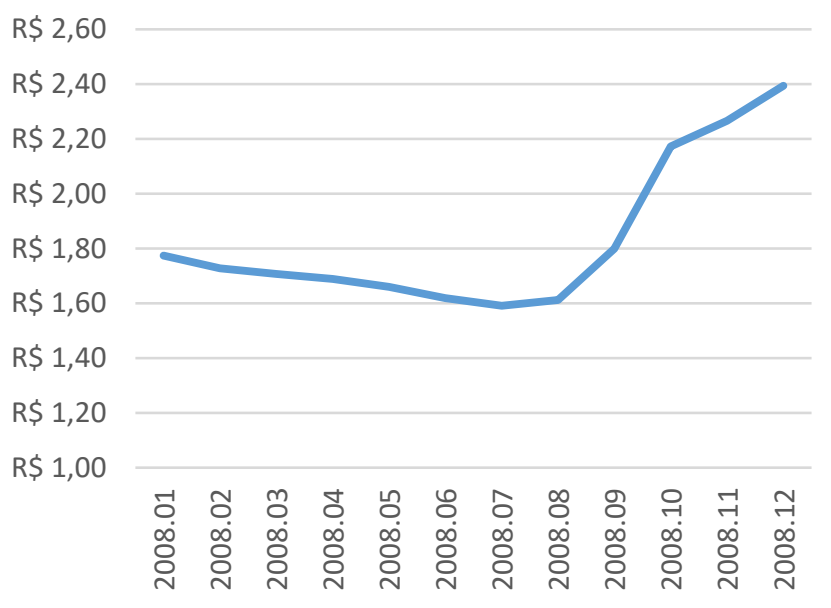

Fonte: elaborado pela autora com base em dados do IPEA, 2016 
Além de observar a variação cambial nominal, a qual faz a relação entre as moedas nacional e estrangeira, é necessário perceber o câmbio real, o qual correlaciona os preços do produto nacional e estrangeiro. Nesse sentido, em uma explicação resumida, quando a taxa de câmbio real está valorizada, seu produto se torna mais caro no comércio internacional. Em contrapartida, quando está desvalorizada, este produto fica mais barato e mais competitivo neste comércio, sendo mais visado para as exportações (TONETO JÚNIOR, 2013).

Desse modo, a partir do ano de 2002, com a desvalorização da taxa de câmbio real somada ao crescimento econômico mundial, ocorreu um crescimento nas exportações dos produtos brasileiros. Este mercado externo estava mais concentrado nos produtos de origem de atividades agrícolas e extrativistas, com indústrias de baixa intensidade tecnológica e fortemente ligadas à agropecuária e aos recursos naturais do Brasil, como: couro, celulose, madeira e siderurgia. Assim, de 2002 a 2008, o país apresentou um crescimento econômico como consequência das exportações e dos superávits comerciais (TONETO JÚNIOR, 2013).

Porém, conforme já observado, em 2008, com a crise mundial, a taxa de câmbio brasileira sofreu uma depreciação muito rápida e afetou diretamente muitos setores que tinham suas principais atividades direcionadas para exportação.

[...] essa rápida e desordenada desvalorização do câmbio provocou efeitos desestabilizadores sobre a economia brasileira. Diversas empresas do setor produtivo, principalmente as empresas exportadoras, amargaram prejuízos bastante significativos com a desvalorização do real (OREIRO; BASILIO, 2009, p. 146).

Dentre estes setores, a produção florestal brasileira, que historicamente tem grande parcela dos seus produtos destinados para a exportação, foi diretamente afetada, conforme delineado a seguir.

\subsubsection{Situação do setor florestal brasileiro frente ao contexto econômico de 2008}

No último trimestre de 2008, os efeitos do agravamento da crise econômica mundial atingiram o setor madeireiro do Brasil. Os segmentos integrados ao cultivo de pinus e eucalipto tiveram seus investimentos reduzidos, com estimativa de agravamento para o ano de 2009. As variações cambiais referentes ao dólar americano influenciaram diretamente este setor que destina maior parte dos seus bens produzidos ao mercado externo. 
Portanto, a seguir serão analisados alguns dados referentes à produção, exportação e consumo dos segmentos da cadeia de produtos madeireiros de florestas plantadas, especialmente entre os anos de 2007 e 2009, período que abrangeu a crise dos EUA, a qual logo afetou a economia internacional e as relações comerciais. Estes dados visam compreender o comportamento do setor madeireiro no Brasil frente às mudanças econômicas e o consequente impulso que incentivou o redirecionamento de aplicação da matéria-prima de madeira para a indústria da construção de edificações.

A cadeia de produtos madeireiros oriundos de florestas plantadas se inicia na silvicultura, sendo os gêneros, como pinus e eucalipto, os mais comuns no Brasil. Após plantio, cultivo e colheita, obtém-se a madeira em tora como matéria-prima florestal para a geração de produtos. Conforme o resultado final desejado, esta tora passa por diferentes processos mecânicos industriais podendo ter um ou mais níveis de transformação. Quanto maior o nível de processamento, maior valor se agrega ao produto.

Os principais segmentos de produtos florestais madeireiros são: (1) celulose e polpa para indústria de papel, papel-cartão e afins, (2) lenha como insumo energético, (3) carvão vegetal para indústria siderúrgica na produção de ferro-gusa, ferro-liga e aço, (4) serrados e produtos derivados com maior valor agregado, (5) painéis compensados, (6) painéis reconstituídos de fibras e de partículas (Figura 63). Destes, os itens 4, 5 e 6 podem ter a cadeia de construção como destino final, tanto para componentes da edificação, quanto para seu mobiliário.

No decorrer dos anos, a produção de celulose e polpa vem sendo destinada principalmente para o mercado externo. Já as produções de carvão vegetal e de lenha tem maior consumo no mercado interno. No entanto, o uso desse carvão está diretamente ligado à produção da siderurgia, com ferro-gusa e aço, que são materiais destinados para exportação. Por sua vez, os painéis reconstituídos, principalmente de MDF e MDP, são destinados à indústria moveleira nacional. E, por fim, os produtores de serrados têm como demanda principal o mercado doméstico em função de empresas de reprocessamento da madeira serrada para transformá-la em produtos de maior valor agregado (PMVA), que são principalmente destinados ao mercado externo (ABRAF, 2006, 2007). 


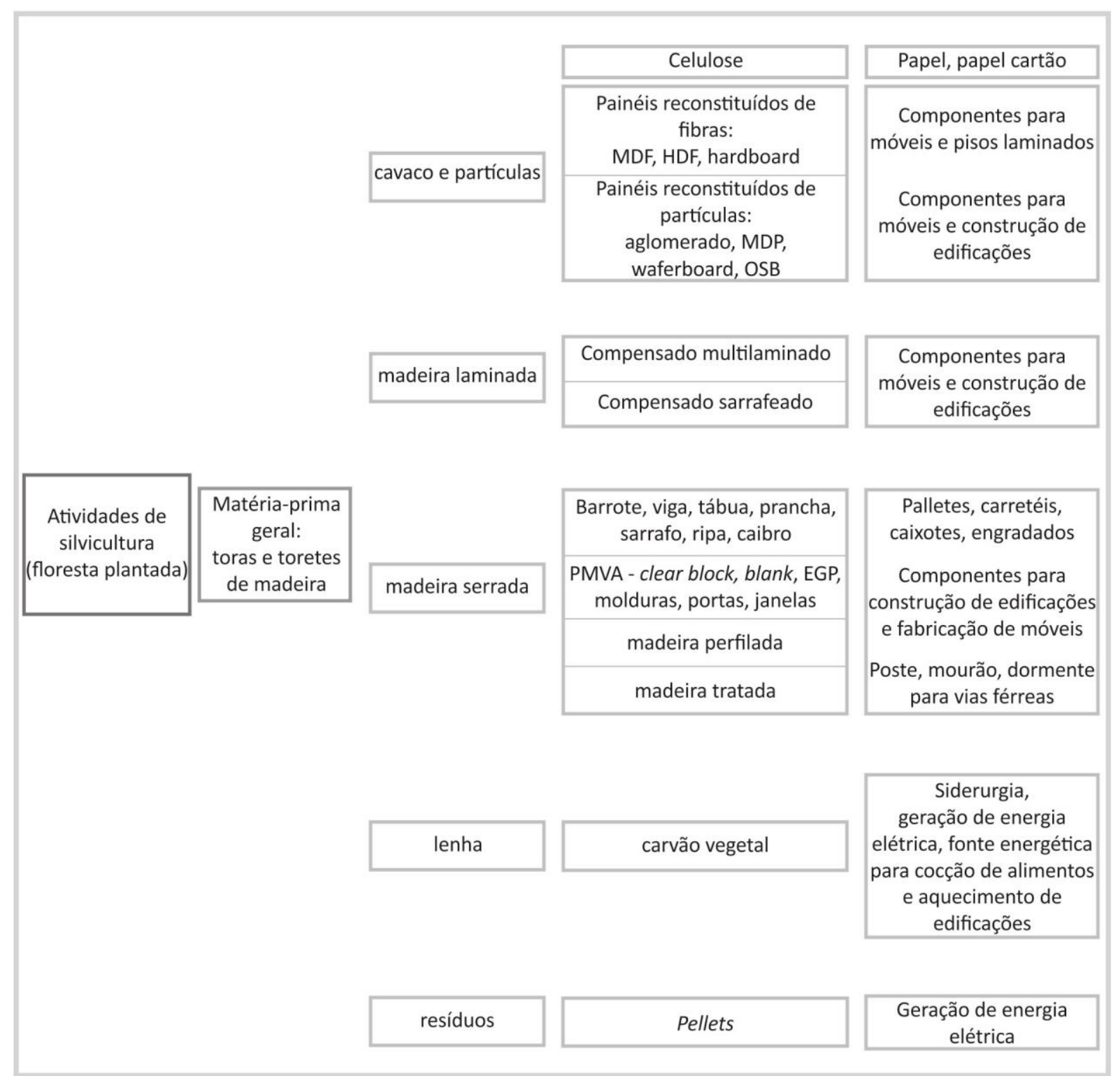

Figura 63: Principais segmentos de produtos madeireiros oriundos de florestas plantadas Fonte: elaborado pela autora com base em ABRAF, 2009, 2010.

Sobre o consumo de toras de pinus e eucalipto, em $\mathrm{m}^{3}$, o Gráfico 5 apresenta a classificação em porcentagem dos principais produtores madeireiros em 2008. O segmento mais expressivo em consumo de toras foi o de celulose e papel, que representou $34 \%$ do total. O segundo mais expressivo neste ano foi o grupo composto por serrados, compensado e PMVA, tais como molduras, portas, janelas, pisos e Edge Glued Panels (EGP), totalizando 24\% das toras consumidas. Os setores de lenha e carvão vegetal também foram significativos, com $23 \%$ e $14 \%$, respectivamente. Por último, com menor expressividade no consumo de toras, os painéis reconstituídos representaram $5 \%$ do total (ABRAF, 2009). 
Gráfico 5: Consumo de toras pelos principais segmentos madeireiros em 2008

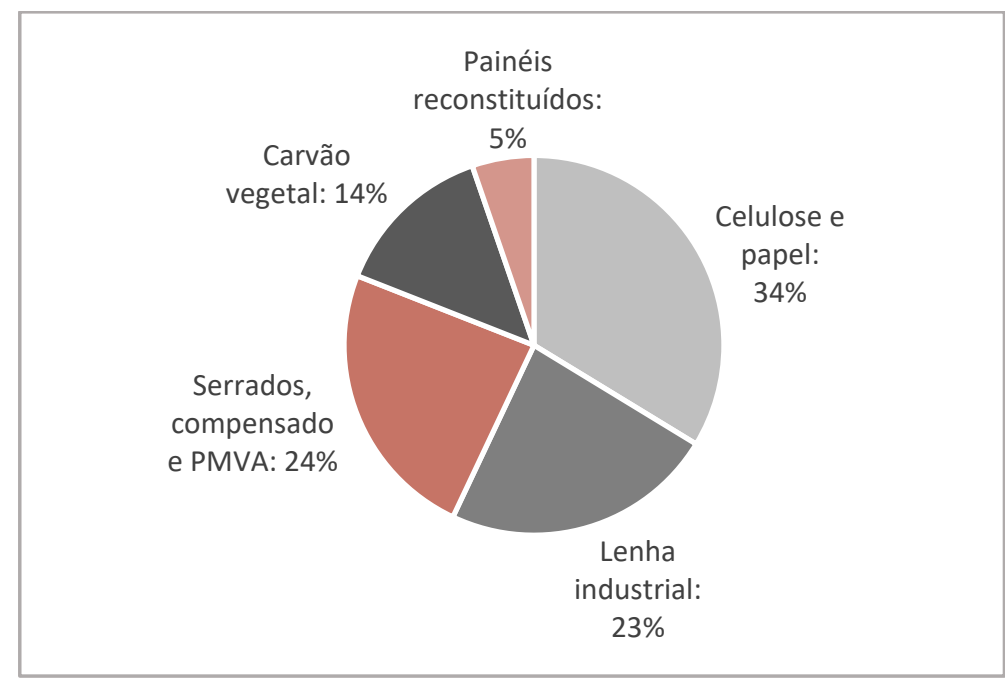

Fonte: elaborado pela autora com base em ABRAF, 2009, 2010.

Com base nestas estatísticas da Associação Brasileira de Produtores de Florestas Plantadas (ABRAF, 2009), no decorrer dos anos, o consumo de madeira de florestas plantadas de eucalipto vem sendo destinado principalmente para os segmentos de celulose, lenha e carvão vegetal. E, pouco se utiliza desta espécie para produção de serrados e painéis. Por exemplo, em 2008, apenas $3,7 \%$ de eucalipto foi destinado para produtos serrados e derivados. Em contrapartida, conforme o Gráfico 6 apresenta, as plantações de pinus vêm atendendo sobretudo o setor de serrados e PMVA, com 49,94\% do total. O consumo de pinus para painéis reconstituídos e compensados também são significativos, com 9,90\% e 10,11\%, respectivamente.

Gráfico 6: Consumo de toras de pinus pelos principais segmentos de produtos florestais em 2008

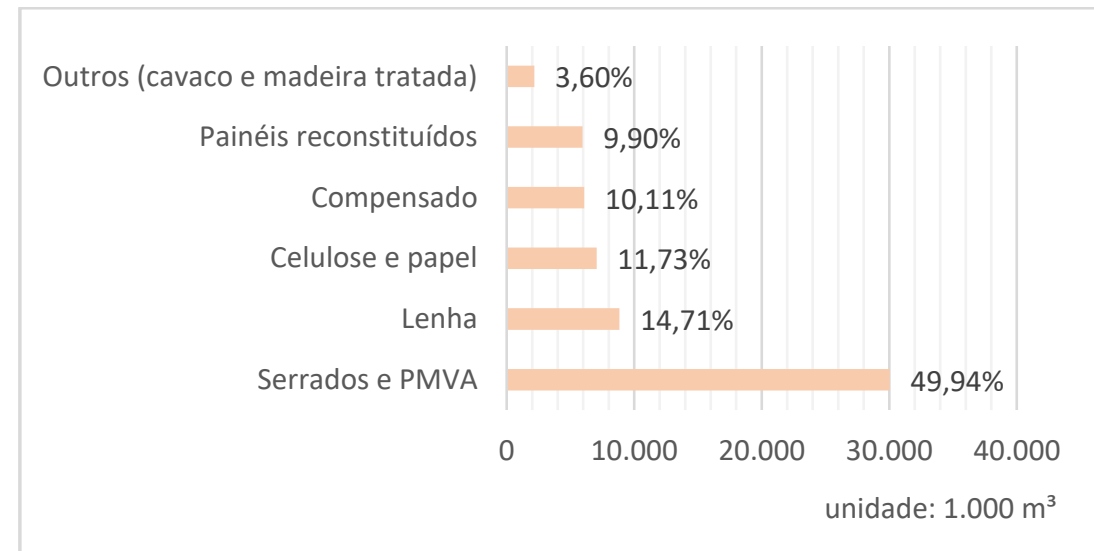

Fonte: elaborado pela autora com base em ABRAF, 2009. 
Entre 2006 e 2007, a demanda por matéria-prima destes vários segmentos industriais era crescente. As indústrias de base florestal estavam expandindo, em especial os setores de celulose e papel, siderurgia a carvão vegetal e painéis reconstituídos. Destes, a produção dos painéis reconstituídos foi um destaque, com aumento de mais de $25 \%$ nos últimos 6 anos, sendo destinados para produção de móveis. E, como consequência, neste período, o consumo de toras cresceu devido aos principais consumidores: celulose, carvão e serrados (ABRAF, 2007).

No entanto, como exceção, a produção de compensados de pinus estava diminuindo e inclusive algumas fábricas fecharam no Brasil. Isto ocorreu por dois fatores principais: primeiro, outros produtos estavam tomando seu mercado, como os painéis reconstituídos, e segundo, o seu valor de exportação estava apresentando queda desde 2004. Além da variação cambial que se tornou desfavorável para este produto, as suas exportações reduziram, já que sua demanda principal reduziu. O EUA era seu principal consumidor externo e o segmento de construção civil deste país estava em recesso.

Portanto, em um balanço geral, até 2008 , as produções das indústrias de base florestal estavam impulsionadas pelo aumento das demandas internas e externas, assim como pela elevação dos preços das principais commodities. Também, a expansão do crédito interno estimulou a venda de bens duráveis, que afetou positivamente o consumo de móveis e painéis reconstituídos. Entretanto, no último trimestre de 2008, com a desaceleração da economia, este cenário mudou.

"[...] a redução de crédito no mercado mundial diminuiu a demanda por commodities agrícolas e industriais de diversas regiões produtoras, inclusive do Brasil. Entre elas citam-se o ferro gusa, aço, celulose, papéis de imprimir e escrever e embalagens, painéis de madeira e móveis" (ABRAF, 2009, p. 34).

Os créditos foram restritos, afetando o mercado doméstico, incluindo as áreas de celulose, siderurgia, mineração, construção civil, açúcar e álcool. Com estas condições econômicas, ocorreu um decréscimo de investimentos no setor de produtos florestais, em especial nos recursos destinados ao setor industrial. Por exemplo, conforme os dados de 2006, as empresas vinculadas à ABRAF investiram um total de $R \$ 4,8$ bilhões em florestas e indústrias, sendo que o setor das indústrias obteve $71 \%$ deste valor total. Em 2007, este valor de investimento teve um crescimento chegando a $R \$$ 6,13 bilhões e as perspectivas de investimentos futuros estavam positivas apontando cerca de $\mathrm{R} \$ 20$ bilhões para os anos 
seguintes. Entretanto, em 2008, com a crise, estes valores caíram e o investimento totalizou $\mathrm{R} \$$ 4,25 bilhões, sendo apenas 48\% destinado para a indústria. Em 2009, a redução foi ainda maior, contabilizando $\mathrm{R} \$ 2,08$ bilhões, equivalente a $53 \%$ do investimento do ano anterior. $E$, deste valor, o segmento industrial foi o mais afetado, diminuindo $83 \%$ dos seus investimentos em relação ao ano de 2008 (ABRAF, 2007, 2008, 2009, 2010).

A crise também refletiu no consumo e, como consequência, nas produções destes segmentos florestais. Com a redução de consumo no mercado externo, os estoques permaneceram elevados, o que levou à diminuição dos preços dos commodities e, assim, a produção passou a ser reduzida. A "valorização do dólar não compensou a queda dos volumes exportados" (ABRAF, 2009, p. 35).

Um dos setores mais afetados da produção florestal foi o carvão vegetal, pois é utilizado na siderurgia para produção de gusa, matéria-prima para o aço, que é destinada principalmente à exportação. Assim como o carvão, a celulose também apresentou queda nos preços - em agosto de 2008 sua tonelada equivalia a US\$ 810,00 e no fim de 2008 reduziu para US\$530,00 (ABRAF, 2009).

Por sua vez, o consumo dos painéis de madeira reconstituída ainda permaneceu alto no último trimestre de 2008, pois este período é normalmente caracterizado pela alta demanda de móveis. No entanto, no início de 2009, os pedidos dos mercados interno e externo reduziram em relação ao mesmo período do ano anterior, com queda de $30 \%$ das exportações e de $20 \%$ do comércio doméstico, como consequência da retração na demanda de móveis (ABRAF, 2009, 2010).

O consumo de compensados, que é dependente do mercado externo, foi ainda mais reduzido, se tornando mais destinado ao consumo interno. Por fim, os produtos de madeira sólida e PMVA, que são produzidos nacionalmente, mas destinados à exportação, tiveram uma queda expressiva na demanda internacional. Pois, ainda que a produção primaria de serrados visasse o mercado interno brasileiro, a aplicação principal destas produções é destinada aos PMVA, que atendem com maior ênfase o mercado externo. Assim, a produção de madeira serrada de pinus também foi afetada (ABRAF, 2009, 2010). Esta queda na exportação de madeira serrada de florestas plantadas, em especial a consumida pelos EUA, pode ser observada no Gráfico 7. 
Gráfico 7: Produção e exportação brasileira de madeira serrada de coníferas comparadas ao volume importado pelos EUA nos períodos de 1992 a 2014

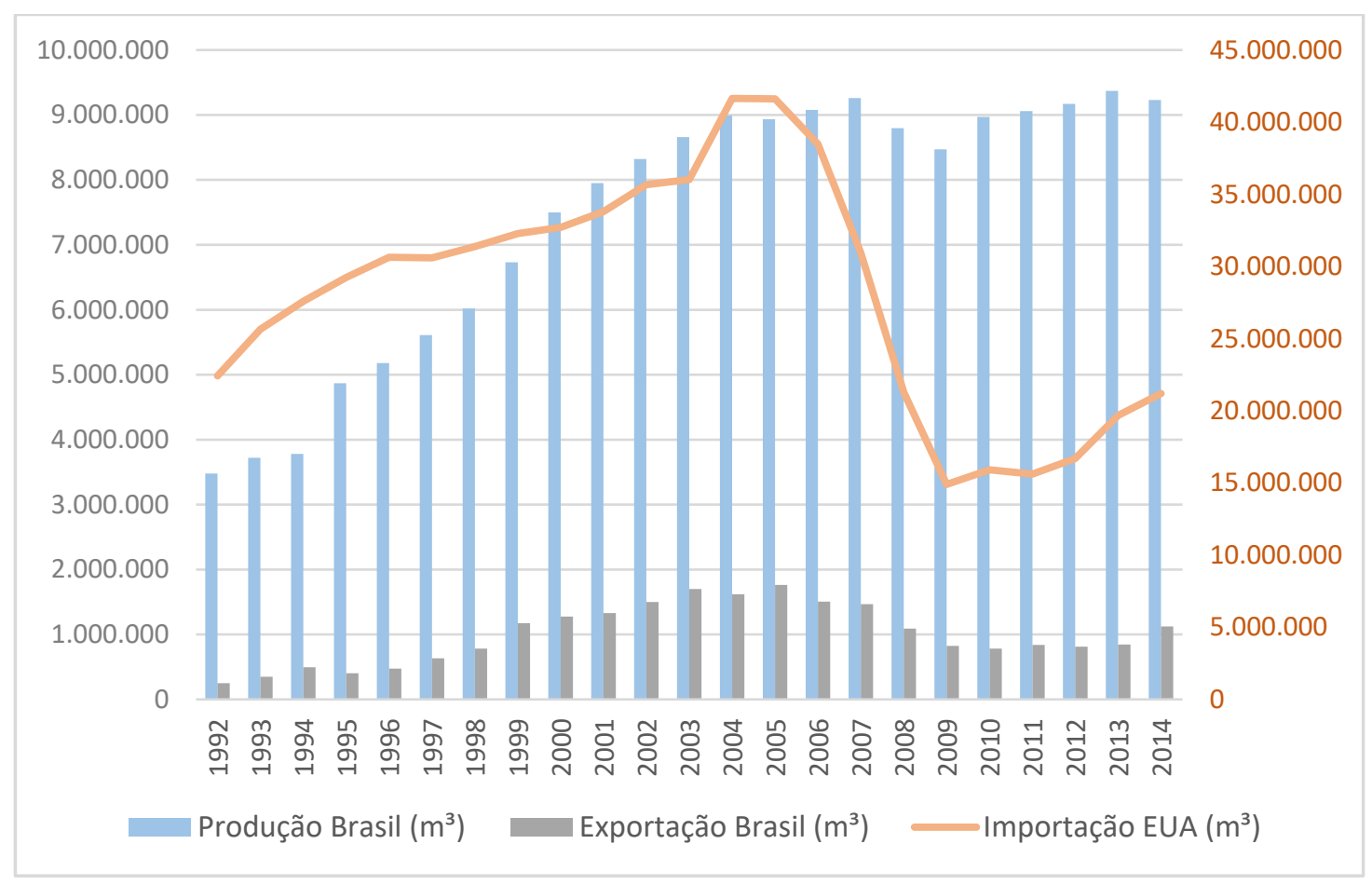

Fonte: elaborado pela autora com base em FAO, 2016.

A redução destas produções impactou diretamente no consumo da matéria-prima toras de madeira (Gráfico 8). De 2007 para 2008, os diversos segmentos do setor florestal apresentaram crescimento no consumo de toras, conforme se observa no Gráfico 8. Entretanto, em 2009, em especial os segmentos de serrados, compensados e PMVA apresentaram uma queda drástica no consumo de toras de pinus (ABRAF, 2010).

Gráfico 8: Consumo de toras de madeira de floresta plantada pelos principais segmentos madeireiros

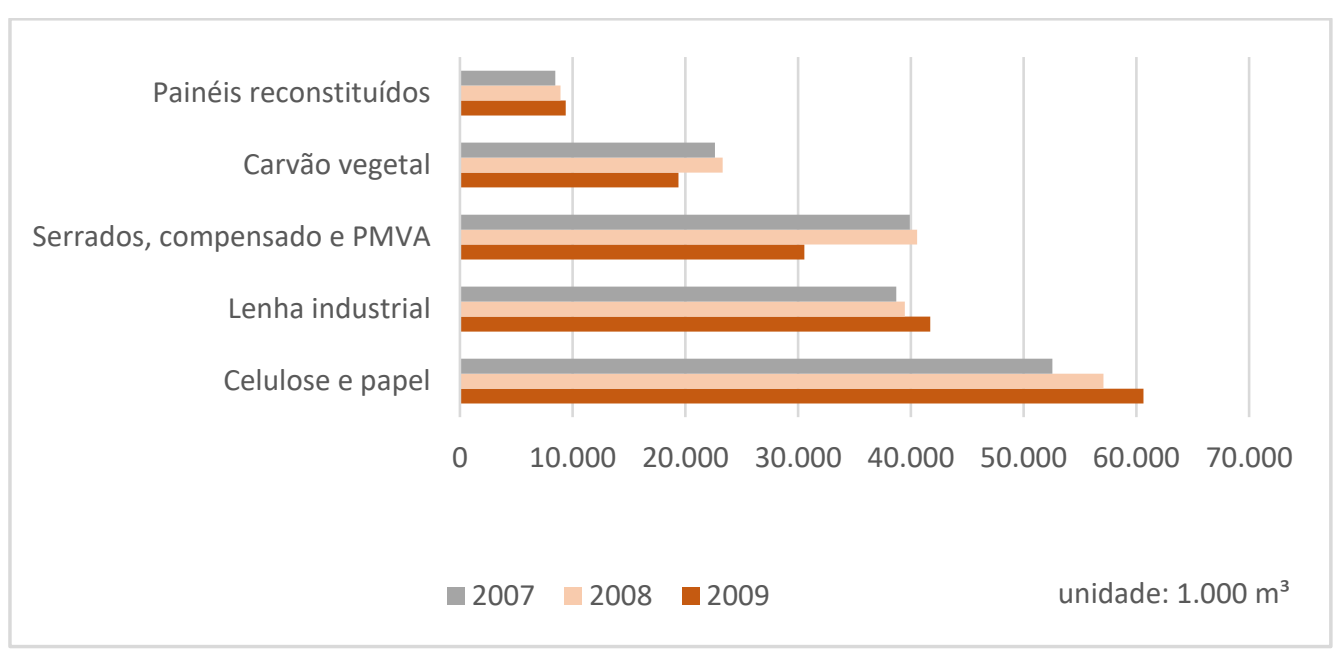

Fonte: elaborado pela autora com base em $\operatorname{ABRAF}(2009,2010)$. 
Por fim, os efeitos da crise resultaram na redução das exportações, na queda das produções, na fusão de empresas de painéis, no fechamento de empresas do setor de madeira processada mecanicamente e demissão de trabalhadores empregados nestas indústrias. Até novembro de 2008, a Associação Brasileira da Indústria de Madeira Processada Mecanicamente (ABIMCI) estimava que o setor madeireiro do país já havia demitido cerca de 100 mil funcionários, tendo um total de 2 milhões de empregados nestes segmentos. Os setores mais prejudicados foram de madeira serrada, portas, compensados, PMVA. E, do Estado do Paraná, a cidade de Sengés foi a mais afetada, já que sua produção era concentrada para o mercado norte-americano (BERTOLDI, 2008).

Assim, as florestas cultivadas e suas toras de madeira, que haviam sido anteriormente produzidas de acordo com a expectativa de crescimento do mercado, acabaram ficando estocadas por causa desta crise que assolou o setor e reduziu os segmentos de produções florestais. Assim como, com a redução dos PMVA para exportação, sua matéria-prima principal - a madeira serrada - ficou sem destino comercial certo e excedeu no estoque do mercado interno. Portanto, para a recuperação destes setores, era necessário reaplicar as toras e as madeiras serradas de pinus para outros produtos comerciais.

\subsubsection{Lançamento do PMCMV aliado ao SINAT}

Em paralelo à necessidade do setor florestal, em 2009, o PMCMV foi lançado, criando uma expectativa de crescimento do setor da construção civil no Brasil, pois esperava-se a produção de mais de 1 milhão de residências populares. Isso significava que a indústria moveleira nacional poderia ter um aumento na sua demanda interna tendo em vista este novo cenário nacional. E, também, os produtores de madeira serrada de pinus, que estavam com estoques ociosos, concluíram que aplicar o seu produto na construção civil poderia ser um avanço para movimentar comercialmente o setor madeireiro. Assim, estas indústrias "reorientaram suas produções ao mercado nacional, favorecido pelo aumento do consumo em alguns setores da economia, entre eles o da construção civil" (ABRAF, 2010, p. 93).

Como alternativa, as empresas deste setor têm buscado se adaptar e suprir a demanda por produtos de madeira do mercado interno da construção civil, apesar deste representar um nicho de produtos específicos. Segundo a $A B I M C l$, ainda assim o crescimento acelerado observado nos últimos dois anos por este segmento é a válvula de escape para o setor de madeira sólida, 
o qual já sofreu perdas significativas devido à valorização do real ante o dólar até o início da crise financeira (ABRAF, 2009, p. 37).

Portanto, reorientar a aplicação da produção de serrados de pinus para produtos da construção civil tornou-se uma alternativa para estas indústrias. Mas, em geral, historicamente, o nicho de destes produtos em madeira para as habitações era muito restrito à esquadrias e acabamentos de piso, forro e molduras. Por isso, era necessário ampliar as possibilidades destas aplicações.

Alavancar a produção de construções em madeira no Brasil seria um resultado muito positivo para a indústria madeireira, conforme comentou o empresário presidente do Sindicato da Indústria da Madeira de Imbituva (SIMADI) e coordenador do Conselho Setorial da Indústria da Madeira da Federação das Indústrias do Estado do Paraná (FIEP):

A utilização da madeira para a construção de residências é um sonho do setor. Temos uma gama de produtos para oferecer e precisamos provar tecnicamente a viabilidade deles. É um dos caminhos que o setor precisa trilhar (FIEP, 2012).

Nesse sentido, neste mesmo período, aliado ao PMCMV, o SINAT ${ }^{15}$, enquanto política pública inserida no MCidades desde 2007, se tornou um facilitador para implementar tecnologias construtivas consideradas inovadoras neste programa habitacional. O SINAT instituiu procedimentos de avaliação de diretrizes técnicas para os sistemas considerados não tradicionais no contexto brasileiro, ou não normatizados. Assim, seria possível provar a viabilidade de sistemas construtivos inovadores em madeira, conforme anseio do setor madeireiro e da construção civil. E, após a deliberação deste processo, tais construções executadas poderiam ser financiadas por agentes públicos, como a CEF, e inseridas no PMCMV.

\subsubsection{Parceria entre SENAI-PR e Estado Alemão para transferência de tecnologia}

Um quarto fator elencado como facilitador neste processo de implementação do sistema wood frame no Brasil foi a parceria reafirmada com a Alemanha para possibilitar a transferência da sua tecnologia específica para esta construção em madeira.

\footnotetext{
${ }^{15}$ A descrição pormenorizada dos procedimentos do SINAT está no capítulo 2, item 2.5 , desta tese.
} 
Desde 1983, há aproximadamente três décadas, o SENAI do Estado do Paraná havia estabelecido um acordo para cooperação internacional com o Ministério das Finanças e Economia do Estado Baden-Württemberg da Alemanha com o seguinte objetivo:

[...] promover a cooperação entre organizações, transferência de tecnologia e metodologias educacionais, em especial na estruturação dos Institutos SENAI de Tecnologia e unidades operacionais. Também prevê visitas mútuas de delegações técnicas, eventos de informação e ações de formação continuada sobre temas inovadores, em todos os segmentos de atuação do SENAI no Paraná (SENAI-PR, 2016).

Esta relação de cooperação tem se demonstrado importante para possibilitar o desenvolvimento tecnológico do Brasil, pois este Estado alemão vem se destacando em diversas áreas, incluindo os setores madeireiro e moveleiro.

Inicialmente, esta relação comercial entre Brasil e Alemanha estava focada, em especial, no segmento de máquinas e ferramentas para o processamento da madeira. Também, missões técnico-empresarias na Alemanha e no Brasil foram organizadas para conhecer as tecnologias alemãs do setor de móveis e para oportunizar a abertura do mercado alemão às indústrias brasileiras deste setor. Um dos resultados dessas missões foi a criação do Centro de Informação da Madeira, Móveis e Meio Ambiente em 2005, localizado em Curitiba, no SENAI-PR.

Posteriormente, no período da crise econômica mundial em 2008, o estado alemão tinha interesse em ampliar suas parcerias para exportar suas tecnologias, incluindo também maquinários avançados específicos para a construção civil em madeira. Dessa forma, em 2009, o SENAI-PR atuou como indutor de novas tecnologias, por apoiar e aproximar empresas brasileiras e alemãs para o desenvolvimento de projetos inovadores como o sistema construtivo wood frame (SENAI-PR, 2013; MADEIRA TOTAL, 2006).

Esta parceria em conjunto com a motivação do setor florestal brasileiro foi muito importante para a formação inicial de uma comissão constituída por agentes interessados em transformar o setor de construção em madeira no Brasil. Esta comissão que passou a ser denominada Casa Inteligente será descrita a seguir. 


\subsection{AGENTES NA PROMOÇÃO DO WOOD FRAME NO BRASIL: COMISSÃO CASA INTELIGENTE}

No início do ano de 2009, alguns empresários e construtores brasileiros também se mostraram interessados em iniciar a produção de edificações utilizando o sistema construtivo wood frame e, por isso, procuraram sindicatos representantes da indústria da construção e das indústrias madeireiras. Assim, buscaram aliar os interesses das empresas de construção às necessidades que o setor madeireiro enfrentava diante da crise econômica internacional. Na sequência, esses agentes se organizaram em conjunto para desenvolver estratégias com objetivo de introduzir o sistema wood frame com maior ênfase no setor brasileiro.

Primeiramente, em junho de 2009, o SENAI-PR em parceria com o Ministério das Finanças e Economia do Estado Baden-Württemberg da Alemanha promoveram uma viagem técnico-empresarial para este país com objetivo de ampliar o conhecimento dos brasileiros sobre as construções em madeira, em especial, as compostas por sistemas leves, como o wood frame, e avaliar questões estratégicas para a sua aplicação no contexto brasileiro, em especial no estado do Paraná.

[...] o objetivo era apresentar ao Brasil um sistema construtivo utilizado em vários países da Europa e para o qual as empresas alemãs produzem componentes e máquinas. "Nesse sentido, o nosso país é visto como um mercado promissor não só por seu enorme déficit habitacional, mas também pelas condições favoráveis de fornecimento de matéria-prima e por ser um mercado carente de soluções sustentáveis", comenta Caio Bonatto, sóciodiretor da Tecverde que também participou da viagem (TECHNÉ, 2009).

Nesta viagem para a Alemanha, estavam presentes 19 brasileiros, entre estes, representantes do SENAI das cidades de Curitiba, Caxias do Sul e Rio de Janeiro, além de outros empresários e técnicos do setor, incluindo construtores interessados na produção do wood frame no Brasil, tais como a empresa paranaense Tecverde ${ }^{16}$.

A excursão organizada pelo ministério de Baden-Württemberg incluiu programações para demonstrar a aplicação da tecnologia alemã para a construção em madeira. Além de assistir uma palestra sobre eficiência energética, o grupo visitou uma feira de construção sustentável, um centro de ensino sobre práticas construtivas, uma empresa de esquadrias -

\footnotetext{
${ }^{16}$ No fim deste capítulo, será apresentado como a empresa Tecverde, que iniciou suas atividades em meados de 2009, cresceu neste período de organização e estabelecimento de estratégias para o setor de construção em madeira. Para este fato, além do estabelecimento das relações com a cadeia de produção do sistema wood frame no Brasil, foi importante a atuação em conjunto efetuada pelos diversos agentes que passaram a compor a Comissão Casa Inteligente.
} 
Kneer-Südfenster -, uma empresa de maquinários para fabricação de componentes para construções em madeira - Weinmann - e duas empresas construtoras clientes desta última Weberhaus e Friedrichson.

Dentre as visitas técnicas programadas, notou-se o interesse da transferência da tecnologia alemã para o Brasil, em especial dos maquinários produzidos pela empresa Weinmann que possibilitariam a expansão das construtoras brasileiras em wood frame e o consequente desenvolvimento do setor madeireiro no país. Sobre esta possibilidade de relação comercial, o assessor da presidência da Federação das Indústrias do Estado do Paraná (FIEP) afirmou: “A Alemanha queria vender sua tecnologia, seu maquinário, e o setor madeireiro do Brasil precisava ganhar mercado" (FIEP, 2014).

Ao que tudo indica, a estratégia alemã surtiu efeito. Um exemplo é a experiência da própria Tecverde, que decidiu instalar até o final deste ano [2009] a sua primeira fábrica de painéis depois de firmar parcerias para desenvolvimento de matéria-prima, componentes, engenharia e projeto. "Implantada no Paraná, a fábrica terá capacidade para produzir anualmente 44 casas de $70 \mathrm{~m}^{2}$ a $280 \mathrm{~m}^{2}$ destinadas ao mercado de médio a alto padrão", adianta Bonatto [sócio-diretor da empresa Tecverde] (TECHNÉ, 2009).

Assim, a parceria firmada entre o SENAI-PR e o estado alemão foi um fator facilitador neste estágio inicial do processo de implementação do sistema wood frame no Brasil, com métodos de produção industrializados. Posteriormente, maquinários foram importados ao Brasil e, também, plantas de fábricas foram projetadas conforme as experiências práticas das empresas alemãs, inclusive o layout da fábrica do Residencial Haragano, descrito no capítulo seguinte.

Ainda, logo após a vigem à Alemanha, para continuar o processo de reconhecimento e de embasamento técnico preliminar do sistema construtivo wood frame e dos seus métodos de produção, em julho de 2009, alguns empresários do setor de construção participaram de uma viagem técnica ao British Columbia Institute of Technology (BCIT) para conhecer o cenário e a tradição das construções em madeira no Canadá.

Após estas viagens à Alemanha e ao Canadá, estes empresários se mobilizaram, mediante o SENAI-PR e a Federação das Indústrias do Estado do Paraná (FIEP), para criar um grupo de interessados do setor para promover a aplicação deste sistema leve em madeira no Brasil.

[...] empresários que individualmente já trabalhavam com a construção em madeira, retornaram ao Brasil determinados a implantar o wood frame da 
forma mais fundamentada, organizando frentes de trabalho para discutir a divulgação do sistema construtivo e sua padronização, de acordo com a realidade nacional de clima e mercado (TECHNÉ, 2009).

Em um primeiro momento, este grupo foi denominado "Wood Frame no Brasil Sistema de Construção Sustentável”. Na primeira reunião oficial deste grupo, no dia primeiro de setembro de 2009, relatou-se a presença de 55 pessoas pertencentes à 43 instituições, dos estados brasileiros de São Paulo, Paraná, Santa Catarina e Rio Grande do Sul e do estado sudoeste da Alemanha, Baden-Württemberg. Na ata desta reunião, foram listados os seguintes presentes (BUETTNER, 2009):

- fornecedor de equipamentos para fabricação de elementos para construções estruturadas em madeira - Weinmann-Homag;

- consultor de equipamentos do setor madeireiro - Moosmayer Technology;

- consultor legal - Pauls Advocacia;

- consultor de projeto e estruturas em madeira - Stamade Projeto e Consultoria em Madeira;

- empresa de certificação de construções sustentáveis - SCOBRA;

- empresas de engenharia e construtoras, tais como: Concretize Engenharia, Opus Prime, Caribea, Shintech, Tecverde;

- construtor carpinteiro: Friedl Zimmerei;

- produtores e fornecedores de madeira serrada e de madeira tratada, tais como: Berneck, Battistella, Arauco, Sólida Brasil, Madezatti, Perennial Woods, TW Brazil, Preservam, Madebampi;

- produtores e fornecedores dos demais insumos para a cadeia de produção de construção leve em madeira, como: acabamentos e revestimentos, sistemas de cobertura, chapas de gesso acartonado, chapas de madeira compensada, chapas OSB, membrana hidrófuga, produtos para preservação da madeira, materiais isolantes térmico e acústico; de empresas como: Multiplac, Rossi Coberturas e Revestimentos, Onduline, Saint-Gobain, Caribea Indústria Madeireira, LP Building Products, Montana Química, Rock Fibras;

- associações representantes de setores empresariais, como Associação Paranaense de Empresas de Base Florestal (APRE), Associação Brasileira da Indústria de Madeira Processada Mecanicamente $(\mathrm{ABIMCl})$, Associação Brasileira dos Escritórios de Arquitetura do Paraná (AsBEA-PR) e Associação Brasileira do Drywall (DRYWALL);

- órgãos reguladores, como Conselho Regional de Engenharia e Agronomia do Paraná e de Santa Catarina (CREA-PR e CREA-SC);

- agente regulador e financiador - Caixa Econômica Federal (CEF); 
- instituições de ensino e de pesquisa, como o Universidade Federal de Santa Catarina (UFSC), Universidade Estadual Paulista do campus Itapeva (UNESP), Universidade Positivo, SENAI-PR e Instituto de Pesquisa Tecnológica (IPT).

Observa-se que, o grupo procurou reunir e abranger diversos agentes das esferas empresariais, estatais e institucionais do setor da construção civil, direcionando o foco para o sistema wood frame. Este fato era importante tendo em vista que este sistema era considerado inovador no Brasil, pois sua disseminação era pontual e quase desconhecida popularmente. E, por isso, ainda não se havia organizado um encontro com os possíveis atores desta produção.

Conforme a listagem, dentre os presentes nesta primeira reunião, a maior representatividade era de empresas que, por suas características, poderiam constituir a cadeia de produção deste sistema construtivo selecionado (Figura 64). Estas empresas produziam ou eram representantes comerciais dos principais insumos constituintes do wood frame, tais como: madeira serrada, madeira tratada, chapas estruturais derivadas de madeira, membrana hidrófuga, lã de rocha, chapa de gesso acartonado.

Também, estavam ali empresas do setor de serviços que possibilitariam a aquisição de equipamentos, maquinários, ferramentas e instrumentos para a produção dos elementos das edificações na fábrica e/ou no canteiro-de-obras, inclusive maquinários para produção industrial de edificações em madeira que ainda não ocorria no contexto brasileiro.

$\mathrm{Na}$ sequência desta cadeia de produção, estavam presentes algumas empresas construtoras. Dentre estas, três se destacaram, porque apresentavam experiências prévias com sistemas construtivos leves estruturados em madeira, sendo estas: Caribea, Shintech e Tecverde. Em paralelo, no setor de serviços, estava a empresa Stamade, atuando como consultora de projetos e de estruturas em madeira. Ressalta-se a importância desta consultoria, pois, antes da ação como empresário, o engenheiro civil Guilherme Correa Stamato tinha adquirido conhecimentos teóricos e práticos deste sistema por atuar como pesquisador e docente, vinculado à Universidade de São Paulo no campus São Carlos e à Universidade Estadual Paulista no campus Itapeva, respectivamente.

Também, entre os presentes, estavam as associações e os sindicatos que representariam os interesses dessas respectivas empresas de insumos e das construtoras. Estas entidades poderiam facilitar a mediação nas relações comerciais conforme as necessidades desta produção conjunta, em especial referente à fatores legais. 


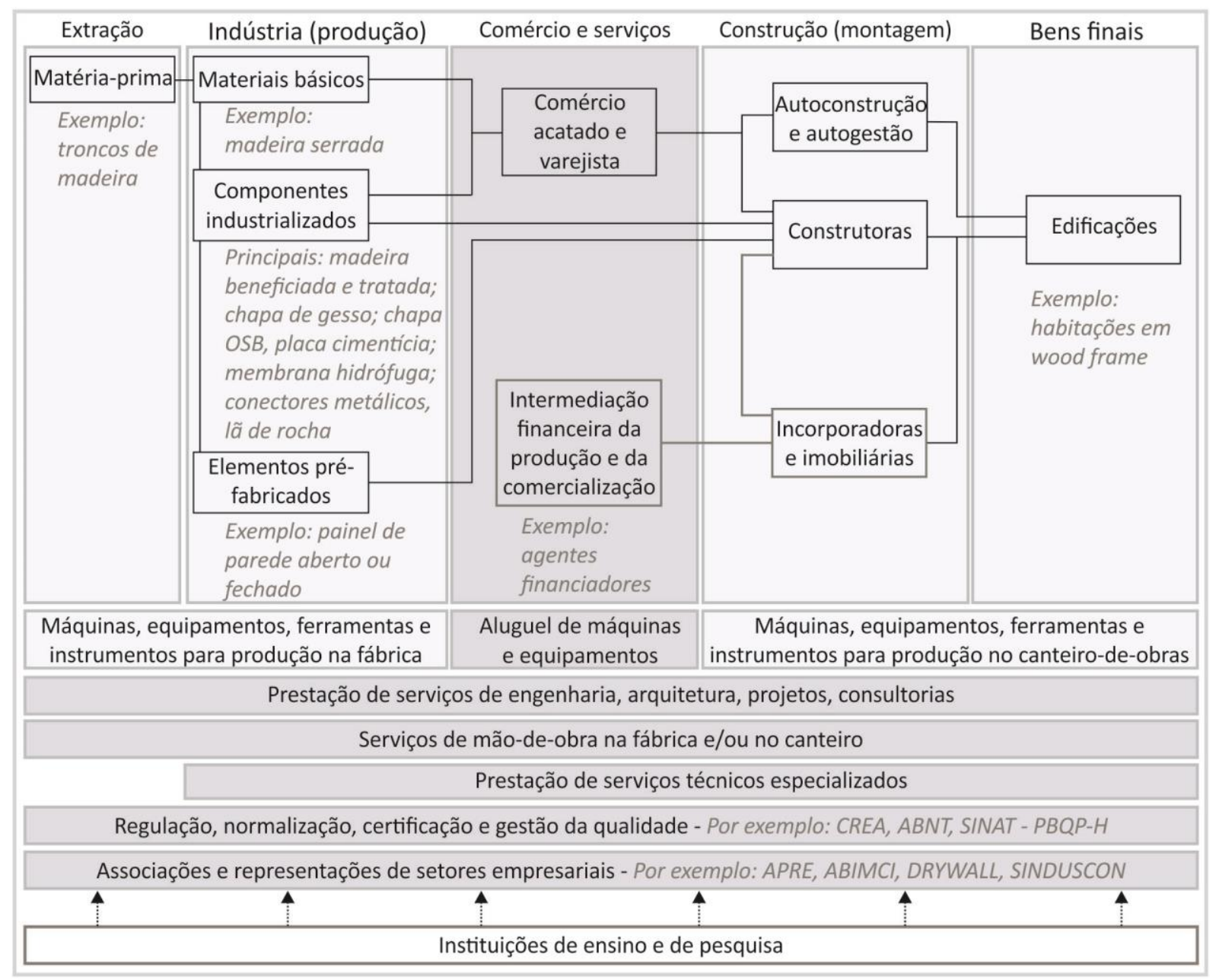

Figura 64: Cadeia de produção generalizada das construções em wood frame

Fonte: autora.

À parte desta cadeia, mas com relações diretas com a mesma, estavam presentes instituições de ensino e pesquisa com intuito de agregar o conhecimento sobre a construção em madeira mediante pesquisas acadêmicas e de transmitir este conhecimento para futuros engenheiros, arquitetos e técnicos da construção civil. Destas instituições, destacava-se o Grupo Interdisciplinar de Estudos da Madeira (GIEM) da UFSC, o qual vem pesquisando sobre este tema específico desde meados da década de 1990. E, também, outro destaque era o SENAI-PR, que vem possibilitando as parcerias entre as empresas brasileiras e alemãs para promover a inovação no setor madeireiro nacional, inclusive para dar treinamento para mãode-obra local.

Por fim, para que as edificações produzidas com sistema em madeira fossem efetivadas no mercado ou em programas de habitações sociais, era necessária a atuação de 
agentes estatais financiadores, como a CEF. E, nesse papel, a CEF estava presente nesta reunião para esclarecer como sistemas inovadores, como o wood frame, poderiam ser financiados se regularizados conforme as normas brasileiras de desempenho vigentes. Para isto, também era importante a participação do IPT, o qual contribuiu relatando sobre a realização de testes e ensaios para conferir a viabilidade técnica dos componentes constituintes e de toda a edificação.

Ainda no início deste processo de implementação do wood frame no Brasil, na sua terceira reunião, por questões administrativas de estruturação e representatividade, este grupo foi oficializado como câmara setorial integrante dos Conselhos Setoriais da Construção Civil e da Indústria de Base Florestal da FIEP. Dessa forma, a partir de quatro de novembro de 2009, o grupo foi denominado "Comissão Casa Inteligente" (Figura 65). Desde então, esta comissão vem sendo coordenada pelo engenheiro Euclésio Finatti, diretor do Sindicato da Indústria da Construção Civil do Paraná (SINDUSCON-PR).

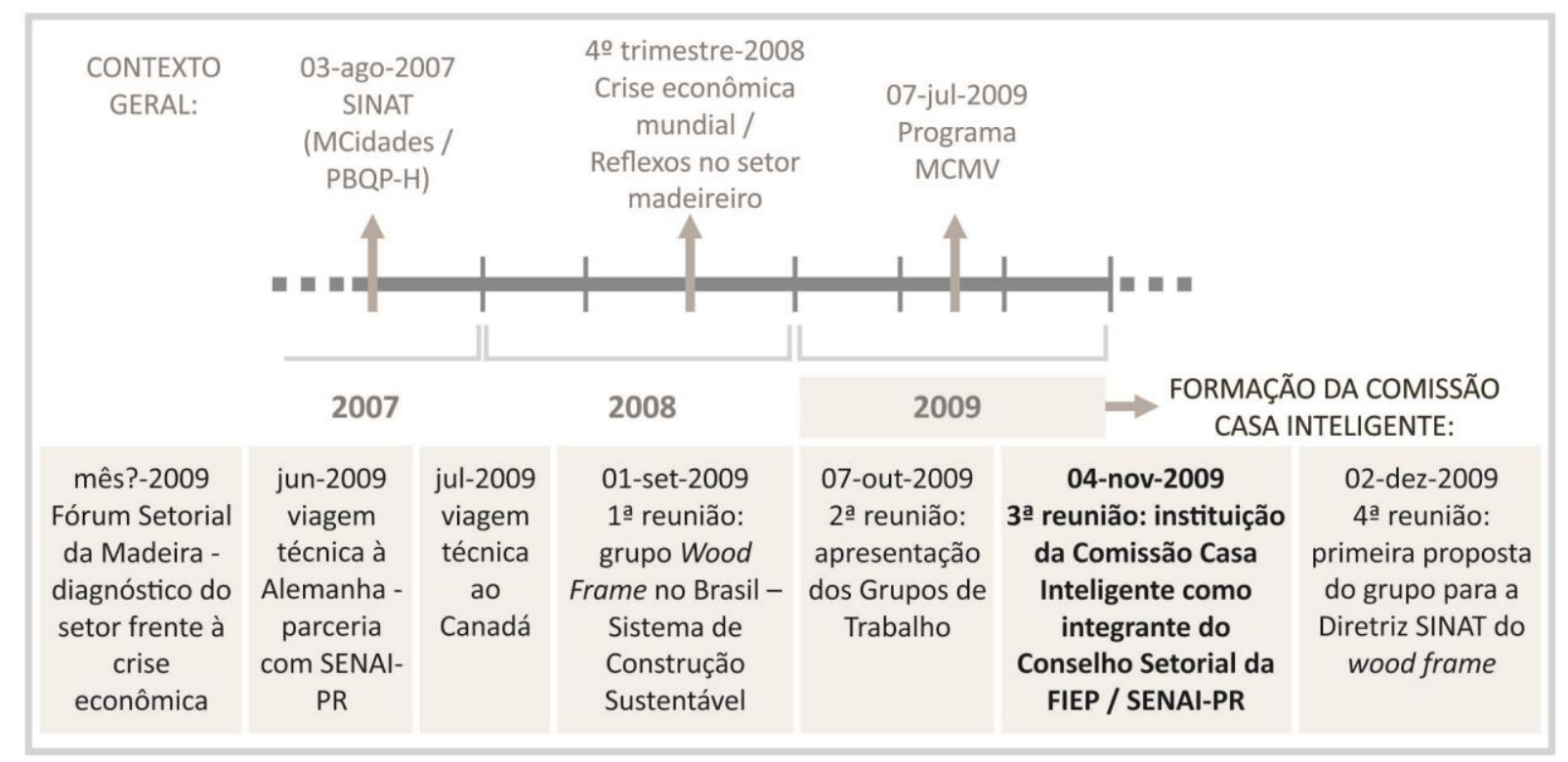

Figura 65: Principais atividades para a formação da Comissão Casa Inteligente em 2009 Fonte: autora.

Nas reuniões e nos procedimentos seguintes, alguns destes participantes iniciais se desligaram, enquanto outros se vincularam ao processo. Mas, cabe salientar, como os itens seguintes deste trabalho discorrerão, que a atuação conjunta desses agentes da Comissão Casa Inteligente foi primordial para a efetiva introdução wood frame no contexto brasileiro. Para isso, a comissão estabeleceu seus principais objetivos para esta primeira etapa e delineou 
estratégias para alcançá-los. Por fim, desde 2010, os resultados dessa conjuntura vêm se tornado evidentes no contexto geral da cadeia produtiva e em casos específicos de determinadas empresas. Conforme os itens seguintes abordarão estes fatores, os agentes envolvidos e seus papéis desempenhados neste processo serão mais esclarecidos.

\subsection{ESTRATÉGIAS DA COMISSÃO CASA INTELIGENTE PARA IMPLEMENTAR O WOOD FRAME}

Inicialmente, de acordo com o relato da primeira reunião do grupo (BUETTNER, 2009), a Comissão Casa Inteligente tinha como objetivo elaborar uma proposta para implantação de um sistema construtivo que aplicasse os preceitos de sustentabilidade, levantando diretrizes para este projeto.

Sobre as possibilidades de tecnologias de construção sustentável, a empresa Tecverde, que tinha participado das viagens técnico-empresarial à Alemanha e ao Canadá, apresentou ao grupo reunido o sistema wood frame e suas vantagens, focando nas possibilidades de industrialização dos seus elementos constituintes. A empresa apontou a necessidade de desenvolvimento e aprimoramento das tecnologias de construção do Brasil, que historicamente são caracterizadas por métodos artesanais. E, com a produção industrializada do wood frame adequada ao contexto brasileiro, em geral, poderia se agregar racionalização, produtividade e qualidade ao sistema.

Também sobre este aspecto da industrialização como um preceito de sustentabilidade, Uli Böhmerle, integrante do Centro de Informação da Madeira do SENAI-PR e perito integrado do Centro Internacional de Migração e Desenvolvimento do Ministério da Economia de BadenWürttemberg, ressaltou a oportunidade de acesso à tecnologia avançada alemã de equipamentos para produção de componentes para construções leves em madeira, como as ofertadas pela empresa Weinmann.

Com base nestes aspectos salientados, o grupo aprovou a seleção do sistema construtivo wood frame para a proposta de implementação no Brasil. E, na sequência, por meio de atividades dinâmicas, estes participantes enumeraram seus desejos e suas expectativas para este projeto, apresentando palavras e expressões-chave que podem ser resumidas nestes cinco aspectos principais: sustentabilidade ambiental, aplicação da madeira na construção, déficit habitacional, financiamento da construção e desempenho técnico. 
Quando o grupo abordou a sustentabilidade da construção, se referia, principalmente, ao quesito ambiental. E, para isso, um passo seria aprimorar a qualidade dos elementos e a eficiência do processo construtivo. Também, para construções sustentáveis preponderava-se a seleção de materiais locais, não-tóxicos, duráveis, renováveis, reciclados, reutilizáveis, com baixa energia incorporada, com mínimo de resíduo, compondo sistemas facilmente montados e desmontados, com manual de manutenção visando sua vida útil (CIB, 1999).

Assim, a aplicação de madeira proveniente de florestas plantadas neste sistema construtivo era uma proposta vinculada aos preceitos de sustentabilidade. Pois, entende-se que a madeira é um material natural e renovável, especialmente quando proveniente de florestas corretamente manejadas, permitindo a perpetuação das espécies e mantendo o equilíbrio ambiental. Em resumo, a aplicação da madeira nesta construção pode ser viável por apresentar fatores como: ampla disponibilidade de material, captura e estoca dióxido de carbono $\left(\mathrm{CO}_{2}\right)$, não requer aditivos poluentes para sua fabricação sendo um produto natural, seu processamento consome pouca energia, permite desmontagem e reutilização e aplica os princípios de construção enxuta (KOLB, 2008).

Entretanto, apesar destas vantagens, o grupo também compreendia que o receio popular em utilizar a madeira nas habitações brasileiras poderia se tornar uma barreira neste processo de implementação do wood frame. Portanto, seria necessário realizar um trabalho de conscientização e de divulgação de informação sobre este sistema, inclusive utilizando estratégias de marketing para lhe dar melhor visibilidade a fim de transformar positivamente a percepção da população em geral.

Outra estratégia para disseminar o wood frame no Brasil seria selecionar em qual mercado este sistema seria aplicado naquele primeiro momento, levando em consideração o contexto socioeconômico presente.

Iniciamos todas as discussões inerentes aos desafios do novo processo construtivo, avaliando os vieses técnico, político, cultural e financeiro. Não se tratava apenas de transferir tecnologia, mas de estudar o mercado e adaptá-la ao máximo à realidade do Brasil, diz Euclésio Finatti, coordenador da comissão e diretor técnico do SINDUSCON-PR (ENIC, 2014).

Assim, o grupo concluiu que abranger o discurso do déficit habitacional no Brasil naquele período de 2009 era oportuno. Pois, naquele mesmo ano, o Governo Federal havia lançado um programa nacional para construções de habitações sociais com intuito de diminuir o déficit elevado do país. O PMCMV poderia ser a oportunidade para aplicar este sistema 
construtivo em madeira proposto pelo grupo. E, inicialmente, a maior demanda deste programa habitacional estava focada principalmente para as populações de baixa renda ${ }^{17}$. Portanto, se poderia construir empreendimentos em maior escala, o que seria um aspecto facilitador para aplicar elementos construtivos mais padronizado para produções repetitivas com determinado grau de industrialização.

Entretanto, para poder participar do PMCMV, o sistema wood frame precisaria ser aprovado e financiado por agentes públicos como a CEF. E, até aquele momento, o histórico de aprovação de financiamentos para construções em madeira no país não era muito favorável. Pois, conforme descrito no capítulo anterior, entre os principais questionamentos para as construções em madeira em geral, mencionava-se o baixo nível de tecnologia aplicado, o processo deficiente de beneficiamento das peças em madeira e a ausência de controle de qualidade dos produtos ofertados, os quais resultavam em edificações de baixo desempenho e durabilidade.

Assim, era necessário demonstrar o desempenho técnico do wood frame adaptado ao contexto brasileiro. Mas, como o mesmo não tem norma técnica no país, é considerado um sistema inovador pelos preceitos do SINAT mediante o PBQP-H. E, por isso, o sistema e seus elementos constituintes necessitavam passar por um processo de avaliação técnica para possibilitar sua concessão de viabilidade prévia e de financiamento pela CEF. Esta avaliação deveria considerar os critérios da norma de desempenho vigente, com aspectos como resistência estrutural, segurança contra incêndio, estanqueidade à água, desempenho térmico, desempenho acústico, durabilidade e manutenabilidade. Os ensaios técnicos precisavam ser realizados e atestados por instituições de pesquisa credenciadas ao SINAT, tais como o IPT.

Com base nestas condições gerais que delimitariam o processo de implantação do wood frame no Brasil, os objetivos de ação da Comissão Casa Inteligente começaram a ser gradualmente esclarecidos e se tornar mais específicos conforme os trabalhos do grupo avançavam. Estes objetivos estavam centrados na definição de diretrizes de desempenho para o sistema construtivo wood frame, ainda não consolidado no Brasil, a fim de obter sua

\footnotetext{
17 Isto não queria dizer que todas empresas construtoras ali presentes neste primeiro momento estavam interessadas em atuar com o wood frame no setor de habitações populares. Posteriormente, com a proposta estabelecida para habitações sociais mediante procedimentos do PMCMV e do SINAT, algumas empresas construtoras se distanciaram da Comissão Casa Inteligente.
} 
homologação no SINAT e possibilitar seu financiamento pela CEF. Este objetivo foi comentado por integrantes desta comissão nos seguintes relatos:

O grupo discute o desenvolvimento de meios que facilitem a adequação técnica da construção em wood frame à realidade brasileira (APRE, 2016).

O engenheiro Euclésio Finatti, diretor do Sindicato da Indústria da Construção Civil do Paraná (SINDUSCON-PR) e coordenador da Comissão Casa Inteligente - instalada pela FIEP -, afirma que o grupo trabalha para que a tecnologia possa ser utilizada por quem busca financiamentos públicos para a construção de residências. Com o aumento da procura pela tecnologia, seria aberta uma nova oportunidade de negócio para a indústria madeireira (FIEP, 2012).

Entre os principais objetivos da comissão, que tem se reunido frequentemente em Curitiba, está a homologação do wood frame segundo o SINAT (Sistema Nacional de Avaliações Técnicas) para liberação de financiamento junto à Caixa Econômica Federal no primeiro semestre de 2010 (TECHNÉ, 2009).

Para o andamento destas proposições, inicialmente, a Comissão Casa Inteligente organizou-se em grupos de trabalho divididos nos seguintes cinco eixos temáticos: (1) associação, (2) marketing, (3) qualificação profissional, (4) matéria-prima e normatização e (5) financiamento. Os resultados destes grupos de trabalho foram apresentados periodicamente em reuniões realizadas na FIEP, localizada na cidade de Curitiba.

O grupo de trabalho denominado associação foi coordenado pelo professor Orlando Ribeiro, da Universidade Positivo do Paraná. O objetivo deste grupo era apresentar soluções para formação de uma entidade de associação que representaria a Comissão Casa Inteligente e se responsabilizaria pelos seus trabalhos. Logo na segunda reunião da comissão, em outubro de 2009, foi apresentada a proposta de implantar uma Câmara Setorial na FIEP, a qual teria o mesmo papel de uma associação, porém sem o custo implicado com ônus administrativos. Portanto, foi decidido que a Comissão Casa Inteligente integraria os Conselhos Setoriais da Construção Civil e da Indústria de Base Florestal da FIEP. Com esta questão oficializada e encerrada em novembro de 2009, o grupo temático associação foi suprimido do processo com seu objetivo cumprido.

O grupo de trabalho de marketing era inicialmente coordenado por Caio Bonatto da empresa Tecverde, tendo como objetivo geral divulgar e disseminar as características do sistema wood frame para públicos diversos, incluindo consumidores em potencial, profissionais técnicos e estudantes do setor da construção e agentes financiadores. $O$ intuito 
deste grupo era minimizar o estigma negativo da aplicação da madeira na construção civil brasileira e, gradualmente, transformar os preconceitos instalados na cultura popular.

[...] o grupo espera quebrar preconceitos de instituições reguladoras e do público consumidor e dissociar a construção em madeira do estigma de só se poder construir com esse sistema casas de veraneio, com baixa tecnologia e pouca versatilidade (TECHNÉ, 2009).

Em geral, as ações gerais propostas e encaminhadas pelo grupo de marketing consistia em procurar meios para a divulgação técnica e a promoção de aplicação do wood frame, incluindo apresentações em seminários técnicos, participação em eventos científicos realizando palestras e mini cursos, reuniões específicas com possíveis instituições visando obras públicas, formação de parcerias com institutos e Organizações Não Governamentais (ONGs) voltadas ao tema da sustentabilidade e do setor florestal, publicação de artigos científicos em revistas nacionais de alta circulação e qualificação na área da engenharia civil e arquitetura. Estas apresentações eram divididas para os diversos integrantes da Comissão Casa Inteligente interessados nesta responsabilidade.

Em muitas dessas ocasiões, o discurso do marketing salientava a qualidade da edificação por aspectos como o grau de tecnologia agregado e a sustentabilidade. Pois, como no wood frame a madeira é um componente constituinte que não fica aparente na edificação, então, em alguns momentos, na promoção deste sistema construtivo, a madeira ficava em segundo plano.

\footnotetext{
"Na verdade, nós não estamos falando de casas de madeira, e sim de casas de alta tecnologia e sustentáveis, produzidas sob os mais rigorosos controles de qualidade e com todas as vantagens intrínsecas ao sistema wood frame, como velocidade, flexibilidade, conforto térmico e acústico, preço, sustentabilidade", ressalta Caio Bonatto (TECHNÉ, 2009).
}

Entretanto, em eventos específicos do setor madeireiro ou da construção civil, era necessário ampliar o conhecimento técnico sobre a madeira como material eficiente para as edificações brasileiras, demonstrando suas diversas possibilidades de aplicação e desmistificando as suas propriedades, em especial sobre fatores referentes à durabilidade e ao desempenho ao fogo.

Ainda mais, além da informação divulgada como marketing, era necessário aprofundar o conhecimento técnico em diferentes níveis teóricos e práticos sobre o sistema wood frame e seus métodos de produção para introduzi-lo com qualidade no contexto brasileiro. Em especial, era um requisito ter trabalhadores qualificados e com conhecimento específico 
sobre o novo sistema construtivo. Para isso, os diversos trabalhadores do setor da construção civil precisariam receber capacitação, treinamento e qualificação profissional.

Por isso, o terceiro grupo de trabalho da Comissão Casa Inteligente visava o treinamento de profissionais técnicos e da mão-de-obra. Este grupo, coordenado por Uli Böhmerle, do SENAI-PR, estabeleceu algumas áreas profissionais que tinha a expectativa de contemplar neste primeiro momento. A primeira proposta deste grupo para formação profissional consistia em cursos de três diferentes níveis: médio profissionalizante, superior de tecnologia e pós-graduação. Os cursos poderiam ser respectivamente ofertados por escolas profissionalizantes, como o SENAI, ou por universidades e institutos de educação superior e tecnológica (Tabela 7).

Tabela 7: Proposta da Comissão Casa Inteligente para a qualificação profissional em wood frame

\begin{tabular}{|c|c|c|c|c|}
\hline Curso & Nível & $\begin{array}{c}\text { Instituição de } \\
\text { ensino }\end{array}$ & Formação & Tema \\
\hline \multirow{3}{*}{ Profissionalizante } & \multirow{3}{*}{ Médio } & \multirow{3}{*}{$\begin{array}{l}\text { SENAI, escolas } \\
\text { profissionalizantes }\end{array}$} & Básica & Carpintaria e marcenaria \\
\hline & & & Avançada & $\begin{array}{c}\text { Sistema wood frame - construção } \\
\text { e processo fabril }\end{array}$ \\
\hline & & & $\begin{array}{l}\text { Básica e } \\
\text { avançada }\end{array}$ & $\begin{array}{c}\text { Acabamentos - instalações, } \\
\text { sistemas, equipamentos, } \\
\text { tecnologias }\end{array}$ \\
\hline \multirow{2}{*}{ Tecnologia } & \multirow{2}{*}{$\begin{array}{l}\text { Superior - } \\
\text { Tecnólogo }\end{array}$} & \multirow{2}{*}{$\begin{array}{l}\text { Universidades e } \\
\text { Institutos de } \\
\text { Educação Superior } \\
\text { e Tecnológica }\end{array}$} & $\begin{array}{c}\text { Mestre de } \\
\text { obras }\end{array}$ & Construção - canteiro, montagem \\
\hline & & & $\begin{array}{l}\text { Engenharia de } \\
\text { Produção }\end{array}$ & Processo fabril - indústria \\
\hline \multirow{3}{*}{ Pós-graduação } & \multirow{3}{*}{ Superior } & \multirow{3}{*}{ Universidades } & $\begin{array}{l}\text { Especialização } \\
\text { lato sensu }\end{array}$ & Engenharia e arquitetura \\
\hline & & & MBA & Administração de negócios \\
\hline & & & $\begin{array}{l}\text { Mestrado e } \\
\text { doutorado } \\
\text { stricto sensu }\end{array}$ & Engenharia e arquitetura \\
\hline
\end{tabular}

Fonte: elaborado pela autora com base em dados coletados em FIEP (2011).

Outra sugestão foi a formação de um centro de capacitação de mão-de-obra especializado para este sistema para trabalhos na fábrica e no canteiro-de-obras, conforme comentou o engenheiro Euclésio Finatti, diretor do SINDUSCON-PR e coordenador da Comissão Casa Inteligente:

Nesse caso, tanto os funcionários das fábricas quanto engenheiros, arquitetos e o pessoal responsável pela instalação das estruturas nos terrenos precisam ter treinamento específico para lidar com esse tipo de material (BORTOLIN, 2010). 
Para a realização destes cursos, seriam realizadas parcerias com empresas com experiência prévia neste sistema construtivo em madeira, tal como a Weinmann. E, também, se pensava na possiblidade de trazer trabalhadores experientes do estado alemão de BadenWürttemberg para ministrar nos cursos para carpinteiros ofertados no SENAI-PR. Assim, estimava-se que a qualidade da execução nas várias etapas da construção prezaria as características originais do sistema construtivo wood frame, evitando a sua disseminação errônea e a consequente má impressão na população brasileira.

Por sua vez, o quarto grupo o quarto grupo de trabalho era coordenado por Carlos Roberto de Luca, da Associação DRYWALL, unificando dois eixos: matéria-prima, coordenado por Graça Berneck, da empresa Berneck, e normatização, coordenado por Guilherme Stamato, da empresa Stamade.

Sobre o eixo matéria-prima, o grupo tinha como objetivo levantar as especificações do sistema wood frame para o Brasil, considerando as matérias-primas necessárias e o seu quantitativo estimado. Também, era necessário levantar dados sobre os produtores destes insumos para ter uma visão geral desta cadeia de produção no país. Para isso, a Associação Paranaense de Empresas de Base Florestal (APRE) e a Associação Brasileira de Indústria de Madeira Processada Mecanicamente (ABIMCI) realizaram um levantamento das seguintes empresas: associadas de base florestal, preservadores de madeira, produtoras de compensado de pinus, produtoras de compensado de madeira tropical, fornecedoras de madeira serrada, produtoras de portas de madeira, produtoras de janelas, molduras e batentes, produtoras de pisos de madeira, produtoras de lãs isolantes. Ainda, sugeriu-se a consulta em associações específicas para levantar os materiais gerais, como, por exemplo, os que constituem os sistemas de cobertura, os fechamentos de parede e forro em Drywall e os vidros para esquadrias.

Em paralelo, o grupo de normatização, levantou quais documentos normativos nacionais e internacionais se aplicavam às construções em wood frame. Com base nessas normas técnicas, o objetivo deste grupo era propor diretrizes técnicas para este sistema adequando-o ao contexto brasileiro. Estas diretrizes seriam delineadas conforme as especificações do SINAT. E isto incluía a participação do IPT nesta etapa, em especial para a realização de ensaios técnicos exigidos na norma de desempenho vigente. Assim, o grupo de normatização realizou uma estimativa de orçamento para os procedimentos de oficialização da Diretriz SINAT para o wood frame. E, com isso, foi realizada uma enquete para saber quais 
integrantes da Comissão Casa Inteligente e outros novos interessados do setor empresarial iriam participar desta etapa, realizando os pagamentos estipulados para este fim.

O quinto e último grupo integrante da Comissão Casa Inteligente era denominado financiamento e coordenado por Rubens Campos, da empresa LP. Este grupo tinha os mesmos objetivos do grupo normatização, porém com intuito de ampliar as alternativas de financiamento das edificações para outras opções além do PMCMV. Por exemplo, com normas da ABNT para o wood frame, o seu financiamento seria possível para casas de todas faixas de renda, incluindo edificações para população de maior renda, as quais não eram o foco do PMCMV nas propostas iniciais do Governo Federal.

Desde setembro de 2009 a janeiro de 2010, foram realizadas reuniões mensais para apresentar os resultados parciais de cada grupo. Na sequência, as reuniões ficaram mais esporádicas conforme as atividades se tornaram mais práticas a fim de cumprir o objetivo geral da Comissão Casa Inteligente e implantar o wood frame no Brasil. No entanto, mesmo que todos os grupos tenham obtido resultados parciais, os esforços conjuntos transpareceram em especial no grupo de normatização com a promoção do wood frame mediante a publicação da Diretriz SINAT, conforme apresentado na sequência.

\subsection{RESULTADOS GERAIS DAS AÇÕES CONJUNTAS DA COMISSÃO CASA INTELIGENTE}

Este item apresenta os resultados da Comissão Casa inteligente em um primeiro momento de atuação que abrange o período desde sua formação no segundo semestre de 2009 até o ano de 2013, quando foi concluída a execução do primeiro empreendimento social construído com wood frame no Brasil. Os principais resultados estão organizados pelas seguintes ações desta comissão: divulgação e marketing sobre o sistema e sobre a comissão, construção dos primeiros modelos em wood frame, e, por fim, publicação da Diretriz SINAT.

\subsubsection{Divulgação do sistema construtivo wood frame no Brasil}

Conforme a Comissão Casa Inteligente avançava seus trabalhos, a divulgação de informações sobre o sistema construtivo wood frame se tornou mais frequente por meios eletrônicos em entrevistas de jornais locais, especialmente no estado paranaense. Muitas dessas entrevistas eram realizadas com os coordenadores dos grupos de trabalho ou com o 
coordenador geral desta comissão - Euclésio Finatti, do SINDUSCON-PR. As informações divulgadas eram sucintas, porém necessárias e importantes para este primeiro momento de exposição do sistema para a população brasileira. As principais entrevistas foram inclusive utilizadas como base de pesquisa para este trabalho e estão citadas nas referências bibliográficas, pois forneciam informações sobre o processo de mobilização inicial da Comissão Casa Inteligente, seus integrantes, seus objetivos e suas principais ações. Também, a inclusão de empresas construtoras em redes sociais populares, onde relatavam com frequência suas atividades neste setor, foi preponderante para uma nova forma de visualização mais informal sobre o sistema, porém com detalhes diferenciados de marketing.

Outro meio de divulgação, que era um dos planos da Comissão Casa Inteligente, vem ocorrendo em revistas impressas e digitais. Estas revistas são das diversas áreas de conhecimento, como administração, produção industrial, florestal, madeireira e construção civil. Na Tabela 8, foram selecionadas as principais matérias publicadas por uma editora de ampla divulgação nacional no setor da construção. Os artigos destas revistas ou deste site iniciaram com informações sobre os procedimentos da Comissão Casa Inteligente e, posteriormente, divulgaram as primeiras execuções deste grupo com dados mais técnicos do wood frame, inclusive com detalhes importantes da execução e do orçamento do Residencial Haragano, primeiro empreendimento social no Brasil construído com este sistema.

Tabela 8: Divulgação do wood frame em revistas do setor da construção entre 2009 e 2013

\begin{tabular}{|c|c|c|}
\hline Revista & Edição / Data & Título do artigo \\
\hline Téchne / Pini & Ed. 148 - Julho/2009 & Light wood frame \\
\hline PiniWeb & 09/Setembro/2009 & $\begin{array}{l}\text { Grupo de trabalho quer homologar construção em Light } \\
\text { Wood Frame na Caixa }\end{array}$ \\
\hline Téchne / Pini & Ed. 151 - Outubro/2009 & $\begin{array}{c}\text { Pronta entrega } \\
\end{array}$ \\
\hline Téchne / Pini & Ed. 161 - Agosto/2010 & $\begin{array}{l}\text { Wood frame - construções com perfis e chapas de } \\
\text { madeira }\end{array}$ \\
\hline Téchne / Pini & Ed. 171 - Junho/2011 & $\begin{array}{l}\text { Análise do desempenho estrutural de módulos de wood } \\
\text { frame }\end{array}$ \\
\hline PiniWeb & 18/Outubro/2011 & $\begin{array}{l}\text { Especialistas apresentam sistemas construtivos } \\
\text { residenciais }\end{array}$ \\
\hline PiniWeb & 22/Agosto/2012 & $\begin{array}{l}\text { Governo do Paraná vai construir conjunto habitacional } \\
\text { com wood frame }\end{array}$ \\
\hline PiniWeb & 19/Dezembro/2012 & $\begin{array}{l}\text { Rede iVerde monta protótipo de moradia popular em } \\
\text { wood frame }\end{array}$ \\
\hline Equipe de Obra / Pini & Ed. 62 - Agosto/2013 & Habitação popular em madeira \\
\hline $\begin{array}{l}\text { Construção Mercado / } \\
\text { Pini }\end{array}$ & $\begin{array}{c}\text { Ed. } 146- \\
\text { Setembro/2013 }\end{array}$ & MCMV de madeira - Orçamento popular \\
\hline
\end{tabular}


Os integrantes da Comissão Casa Inteligente também focaram seus esforços para participar em eventos diversos que abordavam temas como sustentabilidade, indústria madeireira, construção civil, tecnologias inovadoras, empreendedorismo. Geralmente, estas primeiras palestras foram ministradas por Euclésio Finatti, representante do SINDUSCON-PR e coordenador desta comissão, e por Caio Bonatto, representante da empresa Tecverde e coordenador do grupo de trabalho sobre marketing (Tabela 9).

Tabela 9: Palestras sobre o sistema wood frame em eventos gerais entre os anos de 2009 e 2012

\begin{tabular}{||l|c|c|c||}
\hline Evento & Data / Local & Palestrante (s) & Tema \\
\hline \hline $\begin{array}{l}\text { Feira Internacional da } \\
\text { Indústria da Madeira - } \\
\text { FEMADE 2010 }\end{array}$ & $\begin{array}{c}24-28 \text { maio 2010 / } \\
\text { EXPOTRADE, } \\
\text { Pinhais, PR }\end{array}$ & $\begin{array}{c}\text { Euclésio Finatti (SINDUSCON- } \\
\text { PR) / Daniel Araújo (Saint } \\
\text { Gobain - Brasilit) }\end{array}$ & $\begin{array}{c}\text { Uso da madeira na } \\
\text { construção civil }\end{array}$ \\
\hline $\begin{array}{l}\text { Realização Greensun e } \\
\text { Tecverde }\end{array}$ & $\begin{array}{c}8 \text { agosto 2011 / } \\
\text { SENAI, Londrina, PR }\end{array}$ & Caio Bonatto (Tecverde) & $\begin{array}{c}\text { Construções sustentáveis } \\
\text { em wood frame }\end{array}$ \\
\hline ConstruTech - Pini & 18 outubro 2011 & Lucas B. Maceno (Tecverde) & $\begin{array}{c}\text { Resistência do wood } \\
\text { frame ao fogo }\end{array}$ \\
\hline $\begin{array}{l}\text { III Fórum da } \\
\text { sustentabilidade ADEMI- } \\
\text { BA }\end{array}$ & $\begin{array}{c}18 \text { julho 2012 / } \\
\text { Salvador, BA }\end{array}$ & Caio Bonatto (Tecverde) & $\begin{array}{c}\text { Empreendedorismo } \\
\text { sustentável na construção } \\
\text { civil }\end{array}$ \\
\hline Papo verde na FNAC & $\begin{array}{c}11 \text { setembro de } \\
2012 \text { / Shopping } \\
\text { Barigui, Curitiba, PR }\end{array}$ & Caio Bonatto (Tecverde) & $\begin{array}{c}\text { Cases da empresa } \\
\text { Tecverde }\end{array}$ \\
\hline
\end{tabular}

Fonte: elaborado pela autora com base em dados coletados.

Por fim, neste primeiro momento de atuação da Comissão Casa Inteligente, a divulgação do wood frame mediante entrevistas, artigos eletrônicos, revistas impressas e palestras parecia estar crescendo. Inclusive, alguns dos integrantes da comissão estavam planejando a criação de um evento específico para a cadeia de produção de construções em madeira, o qual, em 2014, passou a ser denominado Simpósio Madeira e Construção.

Ainda, foi observado que estas divulgações e a consequente visualização deste sistema no cenário brasileiro passaram a ter mais impulso após a realização das primeiras construções modelos com wood frame executadas por integrantes da Comissão Casa Inteligente e parceiros em meados de 2010, conforme será detalhado a seguir. 
5.4.2 Primeiras construções referências executadas por integrantes da Comissão e parceiros

Este item apresentará brevemente três construções referências que foram executadas por integrantes da Comissão Casa Inteligente em parceria com outros agentes da cadeia de produção do wood frame do Brasil, incluindo a ação de instituições de ensino e pesquisa. São estas as construções: primeira casa modelo da empresa Tecverde em 2010, laboratório de pesquisa Escritório Verde da Universidade Tecnológica Federal do Paraná (UTFPR) em 2011 e Núcleo SENAI de Sustentabilidade em 2012.

A primeira casa modelo, denominada Slim, foi projetada pelo escritório de arquitetura Bacoccini e executada pela empresa Tecverde, no início de 2010 (Figura 66). No seu projeto base, esta residência de dois pavimentos totalizava uma área de $118 \mathrm{~m}^{2}$, aproximadamente, conforme a Figura 67. No entanto, seu projeto era modular e flexível, permitindo o acréscimo de ambientes com opções de combinações extras.
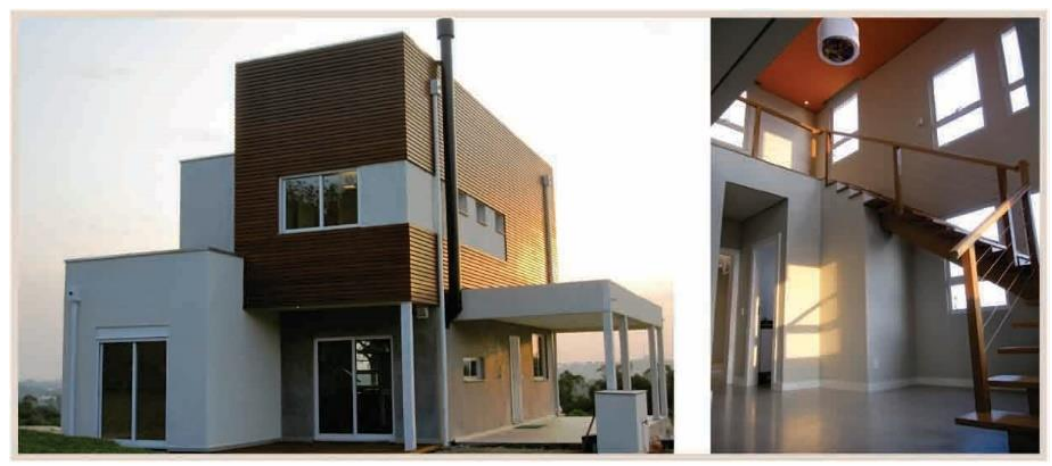

Figura 66: Casa modelo Slim da empresa Tecverde construída em 2010 Fonte: banco de dados empresa Tecverde, 2010.

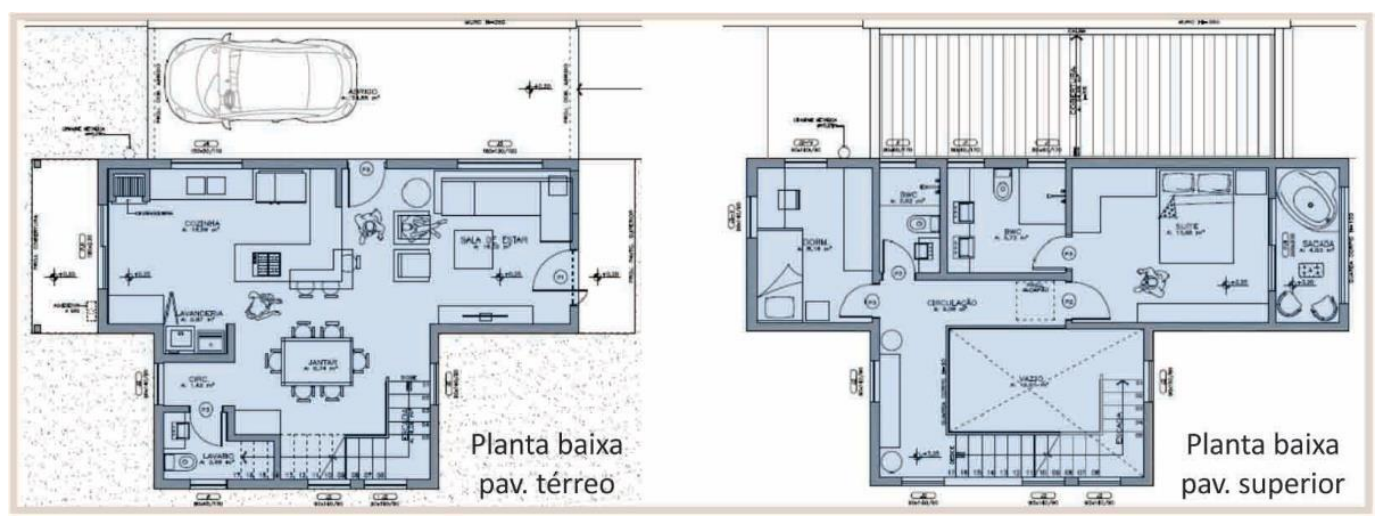

Figura 67: Planta baixa base da casa modelo Slim da empresa Tecverde Fonte: banco de dados empresa Tecverde, 2010. 
A edificação foi construída com o sistema wood frame, constituído por painéis de parede estruturados com madeira de pinus tratado com CCA, isolante térmico e acústico, chapas OSB, membrana hidrófuga. Internamente foi vedada com chapa de gesso acartonado e externamente sua vedação variava entre placas cimentícias ou siding vinílico, tipo de réguas em PCV (AECWEB, 2010). Após um período de treinamento para produção, os painéis de parede e de piso dessa edificação foram executados na fábrica da empresa Tecverde, em Pinhais, no Paraná. Após finalizados e transportados ao canteiro-de-obras, estes painéis foram montados e fixados sobre uma fundação em radier. E, no canteiro, as instalações hidráulicas e elétrica e os acabamentos finais foram executados. Esta casa, considerada de alto padrão, foi construída num total aproximado de 3 meses (Figura 68).

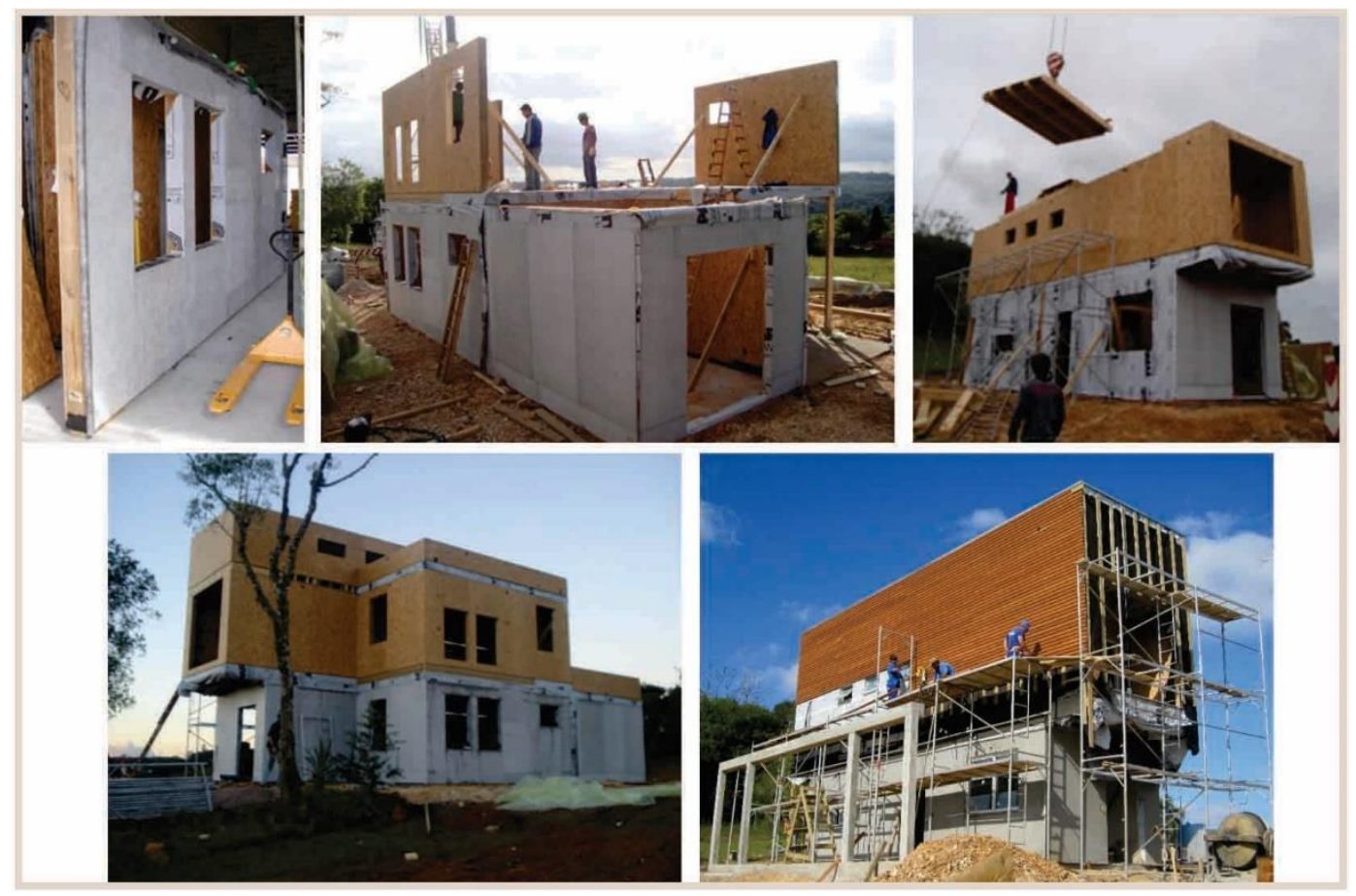

Figura 68: Principais etapas da montagem da casa Slim no canteiro Fonte: AECWEB, 2010.

Como resultado de reconhecimento, em 2010, a Casa Modelo Slim foi classificada entre os três finalistas da categoria Materiais de Construção do Prêmio Planeta Casa. Por fim, esta primeira edificação executada pela empesa Tecverde, integrante da Comissão Casa Inteligente, demonstrou a interação entre a cadeia de produção que estava atuando nessa conjuntura. 
Uma segunda construção que se tornou referência neste período foi o Escritório Verde, iniciado em fevereiro de 2011. Esta edificação, instalada na UTFPR, em Curitiba, foi pensada como um escritório comercial sustentável e centro de pesquisa neste tema. O Escritório Verde foi projetado pelo professor Eloy Casagrande Júnior, da UTFPR (Figura 69). O projeto foi executado mediante parceria com aproximadamente 40 empresa fornecedoras de produtos, materiais e tecnologias. Dentre estas empresas parceiras destacam-se três integrantes da Comissão Casa Inteligente: a Berneck, que forneceu madeira de pinus autoclavado; a LP, que forneceu diversos insumos como chapa OSB, membrana hidrófuga, sidings, decowall ${ }^{18}$ e vigas I; e a Tecverde, que executou os painéis de parede (ESCRITÓRIO VERDE, 2016).

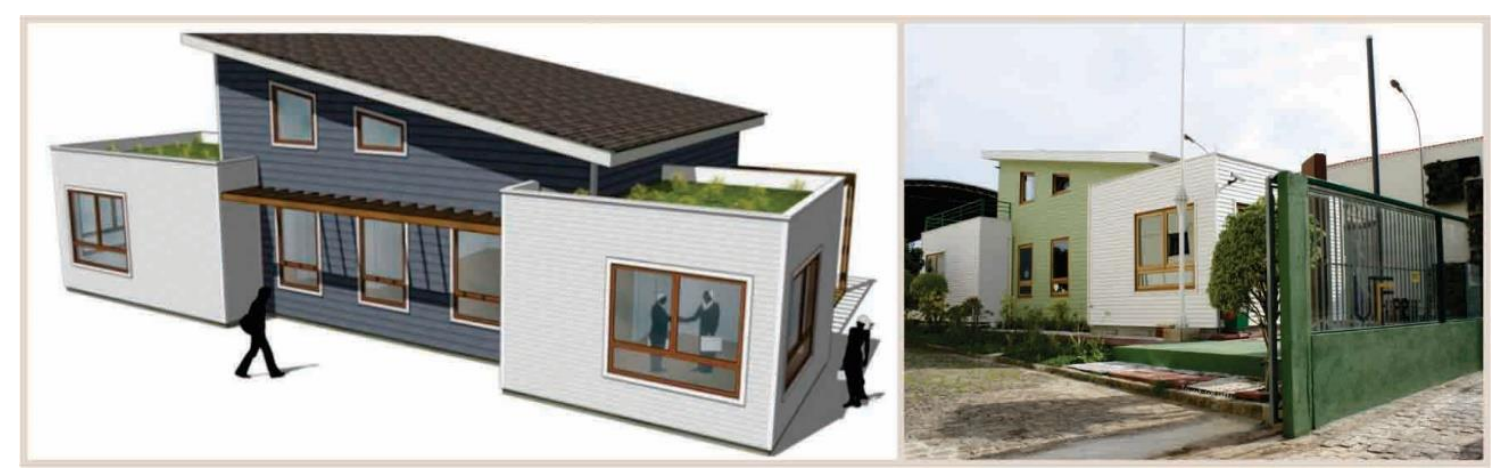

Figura 69: Modelo tridimensional e construção finalizada do Escritório Verde da UTFPR Fonte: Escritório Verde, 2016.

O sistema construtivo adotado para as paredes foi o wood frame, com painéis préfabricados constituídos por entramado de pinus, isolante em lã de pet, manta de borracha de pneu reciclado para isolamento acústico e chapa OSB. Estes painéis foram produzidos na fábrica da Tecverde em 12 dias. Depois foram transportados ao canteiro, onde foram montados em 5 dias. $\mathrm{O}$ acabamento final externo destes painéis foi executado com sidings vinílicos e o acabamento interno com placa cimentícia e painel decowall (Figura 70) (ESCRITÓRIO VERDE, 2016).

Além dessa solução, outras tecnologias visando a sustentabilidade estavam presentes nesta edificação, tais como: telhado verde, coleta e uso de água da chuva, painéis fotovoltaicos para gerar energia, painéis termodinâmicos para aquecimento de água e sistema

\footnotetext{
${ }^{18}$ Revestimento decorativo de uso interno produzido pela empresa LP Building Products, localizada em Ponta Grossa, Paraná. É constituído por uma chapa OSB, produzida com resinas resistentes e revestida na face de acabamento com uma lâmina de madeira.
} 
de calefação, iluminação natural, iluminação artificial com lâmpadas LED, piso elevado e carpete em material reciclado (ESCRITÓRIO VERDE, 2016).

Como resultado, o Escritório Verde foi aprovado pela Universidade das Nações Unidas (UNU), da ONU, como Centro Regional de Integração Expertise de Educação para o Desenvolvimento Sustentável (CRIE Curitiba), com objetivo de promover a educação para a sustentabilidade.
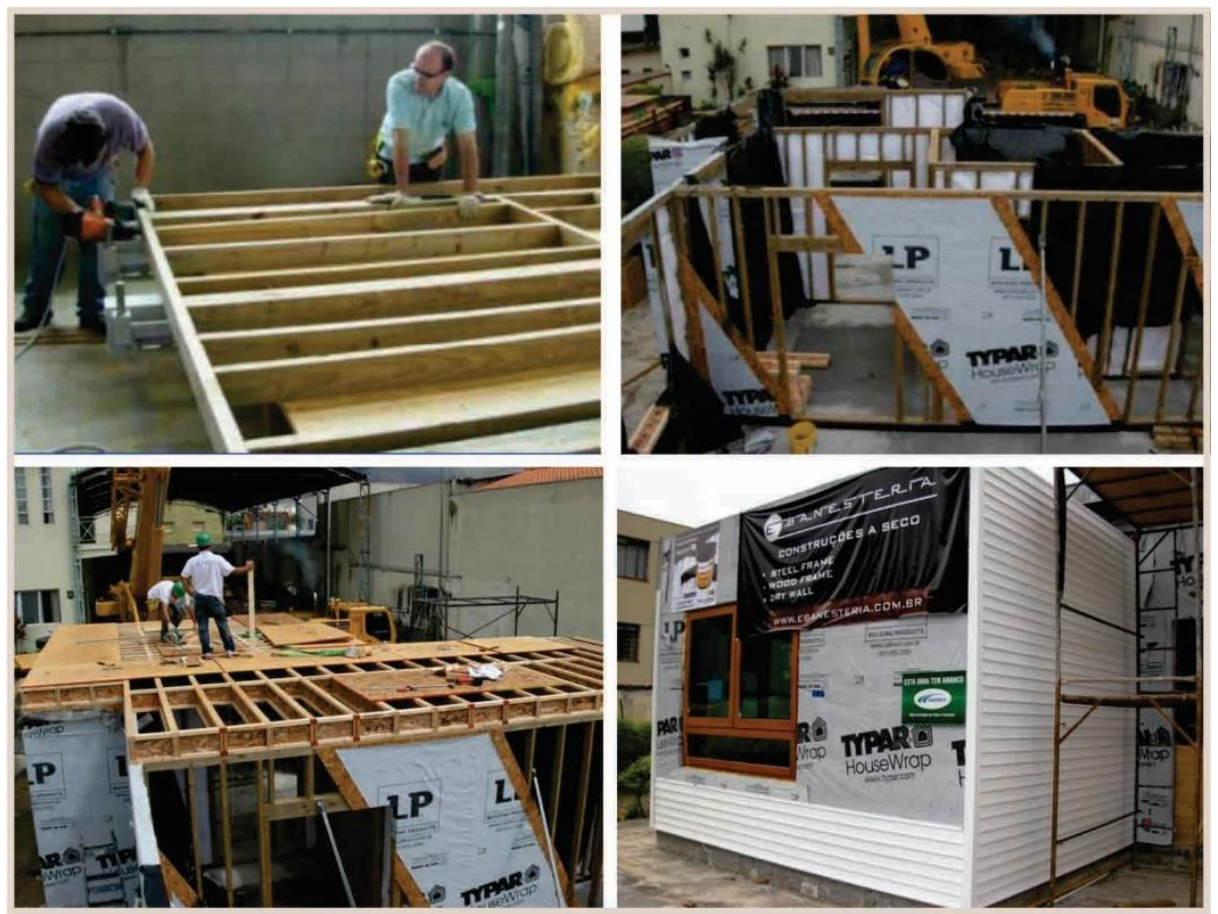

Figura 70: Produção na fábrica e no canteiro dos elementos do Escritório Verde

Fonte: Escritório Verde, 2016.

Por fim, a terceira construção modelo deste primeiro momento de atuação da Comissão Casa Inteligente é o Núcleo de Sustentabilidade do SENAI, localizado na unidade SENAI da Cidade Industrial de Curitiba. É um espaço projetado para realização de pesquisas de inovação sobre tecnologias ambientais, incluindo o tema da construção de baixo consumo energético.

A ideia para o Núcleo surgiu de um projeto elaborado pela principal empresa parceira, a Tecverde, com o objetivo de popularizar o sistema construtivo a seco, o wood frame, um método de construção que gera benefícios ambientais, reduzindo consideravelmente resíduos da construção e emissões de $\mathrm{CO}_{2}$ (CHIESSE et al., 2013, p. 19). 
Assim, em 2012, a partir da iniciativa com o SENAI-PR, o Núcleo foi projetado pelo escritório Studio ArqBox e foi concebido mediante várias empresas parceiras (Figura 71). Destes, destacou-se a Tecverde na produção dos painéis de parede e de piso na fábrica e na montagem da edificação no canteiro (Figura 72). Seu projeto contemplava aspectos como: aproveitamento da luz e da ventilação naturais, iluminação artificial com lâmpadas LED, geração de energia fotovoltaica, tintas inibidoras da propagação de incêndio, teto verde, reaproveitamento da água da chuva (CHIESSE et al., 2013).
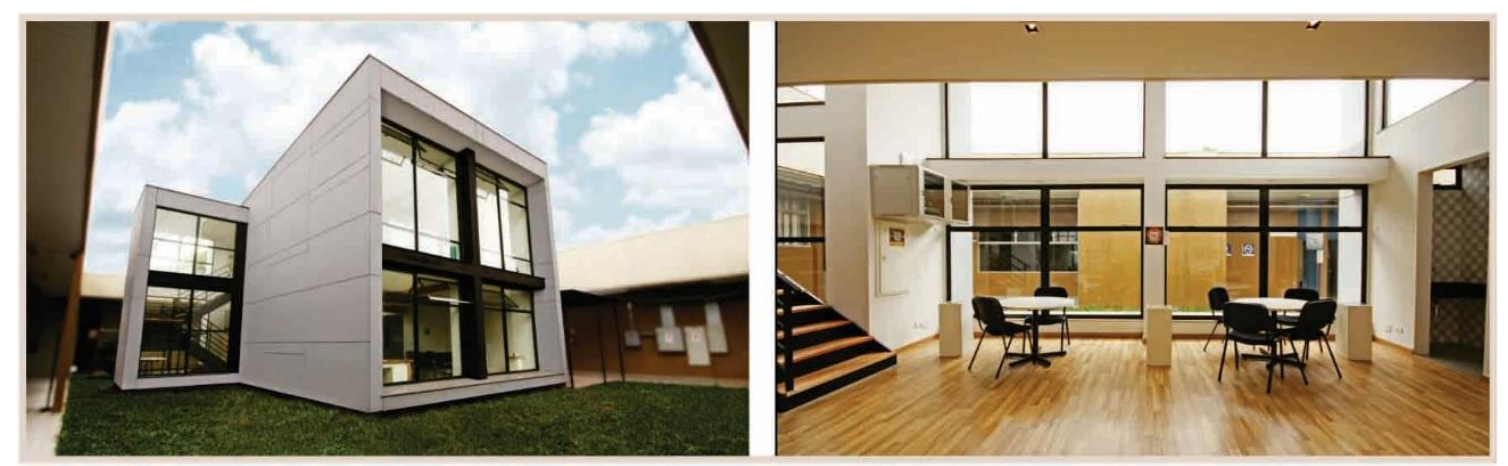

Figura 71: Núcleo SENAI de Sustentabilidade construído em parceria com Tecverde Fonte: Archdaily, 2013.
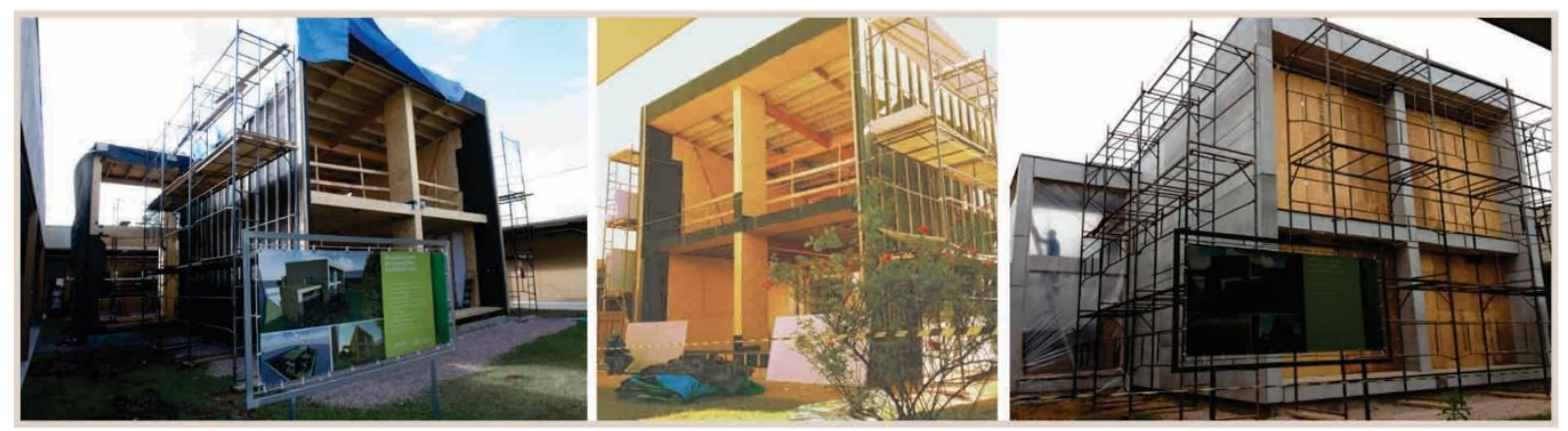

Figura 72: Produção no canteiro do Núcleo SENAI de Sustentabilidade em 2012 Fonte: Tecverde, 2013.

Esta edificação de dois pavimentos, com área de $180 \mathrm{~m}^{2}$, aproximadamente, era constituída por uma estrutura do tipo wood frame. Seus painéis de parede eram compostos pelos seguintes materiais, nesta sequência: gesso acartonado para vedação interna, chapa OSB, entramado de madeira, isolante em lã de Pet, chapa OSB, membrana hidrófuga, ripas para circulação interna de ar e vedação externa com placa cimentícia (Figura 73).

Como resultado, este projeto elaborado pelo SENAI em parceria com diversas empresas, que visava a educação e a inovação de tecnologias sustentáveis para construção, 
foi nomeado e premiado na categoria Community Engagement: Mobilising Local Innovations for Sustainable Development do prêmio Regional Centres of Expertise - RCE Awards de 2014.

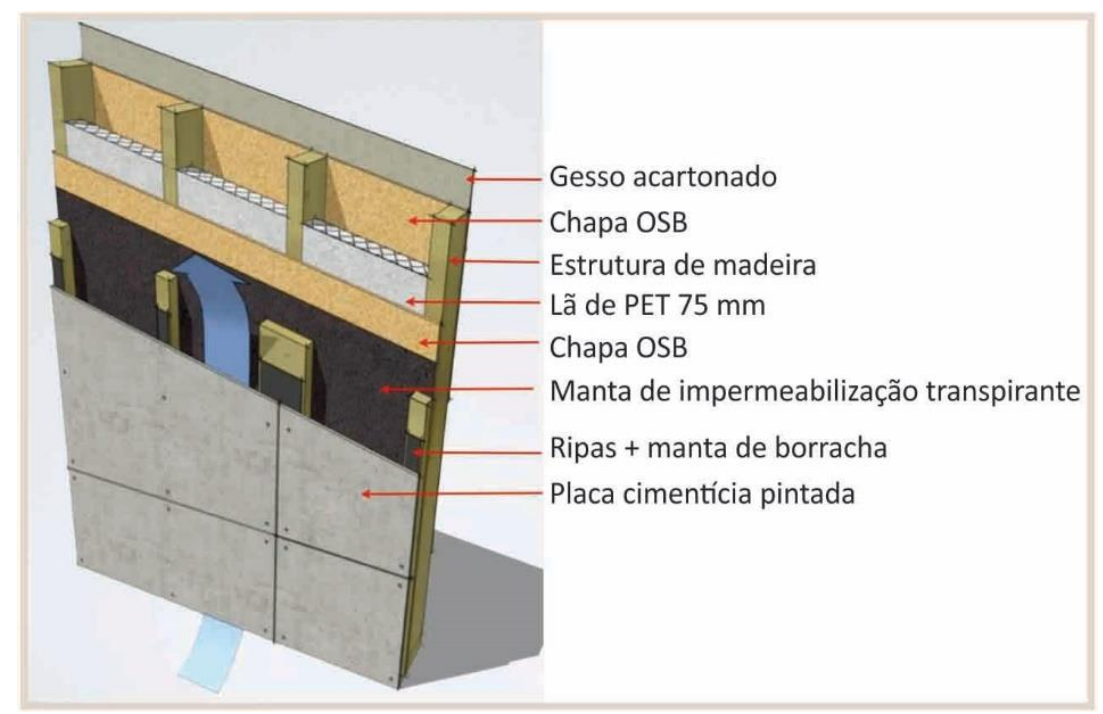

Figura 73: Materiais constituintes do painel de parede do Núcleo SENAI Fonte: Archdaily, 2013.

Além destas construções em wood frame, outras foram executadas neste período de 2009 a 2013. Entretanto, como resultado das ações conjuntas da Comissão Casa Inteligente, estas três construções atuaram como modelo e referência neste primeiro momento, dando maior visibilidade a este sistema construtivo ainda desconhecido no cenário brasileiro. Também, estes resultados demonstraram como as instituições de ensino e de pesquisa atuaram nesse processo como parceiras de produtores e de fornecedores de insumo para consolidar projetos que visam futuras pesquisas sobre o wood frame e outros temas associados ao desempenho deste sistema adequado ao contexto brasileiro. Por fim, a cadeia de produção se mostrou articulada neste processo de produção. Este foi um fator essencial para consolidar estas primeiras experiências e dar base para as futuras atividades deste setor.

\subsubsection{Publicação da Diretriz SINAT no 005 / 2011}

Conforme já mencionado, pelo regimento do SINAT, inserido no PBQP-H do MCidades, o sistema wood frame é considerado inovador, pois não possui normas técnicas específicas no Brasil e não é aplicado tradicionalmente neste território. E, por isso, para ser contemplado em agências de financiamento público, necessita apresentar diretrizes e documentos de 
avaliação técnica que delineiam os critérios de desempenho do sistema em questão. Com base neste contexto, um dos principais objetivos iniciais da Comissão Casa Inteligente foi agir em conjunto para viabilizar a aprovação desta diretriz SINAT para o wood frame.

Entretanto, antes de redigirem a proposta para a diretriz SINAT do sistema wood frame, alguns integrantes da Comissão Casa Inteligente que já haviam participado deste mesmo processo, porém, para outro sistema, o steel frame, contribuíram com sua experiência prévia neste assunto. Entre estes estavam a empresa LP Building Products e o representante da associação DRYWALL. O sistema leve tipo steel framing consistia em estruturas com perfis leves de aço conformados a frio, fechadas com chapas delgadas, como gesso acartonado e OSB. E, sua Diretriz SINAT no 003 foi aprovada em abril de 2010 pelo MCidades.

Assim, no final de 2009, estes integrantes que participaram do processo anterior do steel frame e que agora estavam presentes na Comissão Casa Inteligente forneceram ao grupo de normatização do wood frame algumas informações pertinentes sobre o processo de aprovação de uma diretriz SINAT e, também, encaminharam documentos elaborados com a participação direta do IPT, tal como a diretriz do steel frame, que estava em processo de aprovação. Este exemplo poderia ser um auxílio e uma base para os próximos passos do grupo normatização neste processo de elaboração da diretriz SINAT para o wood frame.

Seguindo este exemplo e os encaminhamentos fornecidos pelo PBQP-H e MCidades, O grupo de trabalho normatização, coordenado por Guilherme Stamato, esboçou uma primeira proposta de modelo para a diretriz SINAT do wood frame e a apresentou na quarta reunião mensal da comissão, realizada em dezembro de 2009. Este texto inicial foi elaborado como um referencial para o processo, haja vista que esta discussão técnica sobre o wood frame deveria ocorrer em conjunto com o IPT, o qual, no seu papel de Instituição Técnica Avaliadora (ITA), daria encaminhamento nos procedimentos de ensaios e especificações técnicas para a redação da diretriz SINAT.

Em geral, este documento daria referências e diretrizes para a avaliação técnica do sistema wood frame, incluindo seus requisitos e critérios de desempenho, bem como os métodos que deveriam ser adotados para estas avaliações técnicas. Entretanto, antes do contato e da oficialização do procedimento com o IPT, a Comissão Casa Inteligente deveria analisar e decidir questões de interesse dos seus integrantes que, posteriormente, estariam redigidas no documento final da diretriz SINAT. Por exemplo, o grupo precisava confirmar aspectos conforme o interesse das empresas participantes, em especial das construtoras, tais 
como: o objeto da diretriz, ou seja, a caracterização geral do sistema wood frame; e, o campo de aplicação, que delimitaria a tipologia da edificação e sua classificação de uso.

Sobre estes aspectos, o primeiro modelo apresentado pelo grupo normatização descreveu de forma geral que o objeto alvo desta diretriz era composto por elementos estruturais em madeira fixados a chapas de travamento, resultando em componentes de parede ou piso com capacidade estrutural para resistir às ações aplicadas à edificação. E, esta diretriz contemplaria edificações térreas ou de dois pavimentos ou de até cinco pavimentos, de uso habitacional (FIEP, 2011).

Após delinearem estes e outros fatores principais referentes ao modelo da diretriz para o wood frame, o grupo iria oficializar este processo com o IPT. Para formalizar a diretriz SINAT mediante o MCidades, estimou-se um custo de aproximadamente $R \$ 50.000,00$. E, para realizar este pagamento, o grupo realizou um levantamento de quais empresas e profissionais liberais com fins lucrativos desejariam permanecer ou não nas reuniões e discussões da Comissão Casa Inteligente a partir deste período. Portanto, ainda em dezembro de 2009, cada empresa deveria expressar seu interesse neste processo de cotização da diretriz SINAT do wood frame e se comprometer com o pagamento de uma taxa no valor de $\mathrm{R} \$ 1.000,00$. Este critério também era válido para empresas que demonstrassem interesse de ingressar neste processo no futuro, as quais passariam a ser analisadas pela comissão. Por fim, até o fim de 2009, aproximadamente 25 empresas estavam participando desta cotização para a diretriz SINAT, sendo estimados: 01 associação de insumo produzido para construção civil, 01 sindicato representante da indústria da construção, 10 empresas construtoras ou prestadoras de serviços para construção civil, 01 empresa fornecedora de maquinário para construções em madeira, 08 empresas do setor florestal, empresas fornecedoras de madeira serrada e empresas de tratamento da madeira, 04 empresas de insumos gerais da cadeia de produção do wood frame. Nos meses seguintes, outras chamadas foram realizadas ao grupo para complementar o valor total deste processo.

Na sequência, o grupo de normatização da Comissão Casa Inteligente ficou encarregado pelos contatos com o IPT durante o processo de deliberação da diretriz SINAT. Como resultado desse processo, em setembro de 2011, a Diretriz SINAT no 005 para "Sistema leves tipo Light Wood framing" foi publicada oficialmente pelo MCidades (BRASIL, 2011).

Em geral, esta diretriz apresenta as seguintes informações sobre este sistema construtivo: objeto, aplicação, restrições de uso, terminologia, documentos técnicos 
complementares, caracterização dos principais materiais e componentes que formam este sistema, os requisitos e critérios de desempenho conforme as normas técnicas pertinentes, os métodos de avaliação a serem adotados para cada requisito anterior especificado e, por fim, dados sobre o controle da qualidade na montagem dos elementos constituintes e da unidade habitacional. Algumas destas principais informações estão resumidas a seguir conforme a redação da Diretriz no 005 (BRASIL, 2011).

O objeto, ou seja, o sistema construtivo contemplado por esta diretriz é assim descrito:

Sistemas construtivos cuja principal característica é ser estruturado por peças de madeira maciça serrada com fechamentos em chapas delgadas (Sistemas Leves tipo Light Wood Frame). Os sistemas construtivos objetos dessa diretriz referem-se a estruturas, paredes (vedação vertical externa ou interna), pisos e coberturas formados pelos componentes descritos a seguir [...] (BRASIL, 2011).

A aplicação desta Diretriz é restrita para unidades habitacionais unifamiliares térreas e sobrados, isolados e geminados. Este fato divergia da intenção inicial de alguns integrantes da Comissão Casa Inteligente, a qual foi apresentada no primeiro modelo desta diretriz, onde se citava a expectativa de atender também edificações com até 5 pavimentos.

Nas restrições de uso, a Diretriz estabelece que a madeira empregada nos componentes deste sistema deve ser de origem legal, proveniente de florestas plantadas ou nativas com manejo florestal aprovado pelo IBAMA. E, nas suas características, a madeira aplicada em peças estruturais, como por exemplo as peças constituintes dos entramados dos painéis de parede, deve ser altamente resistente ao ataque de insetos xilófagos ou deve ser tratada com preservantes químicos como o CCA, Borato de Cobre Cromatado (CCB) ou Tebuconazole e Cobre (CA-B). As peças sem função estrutural, não necessitam ter este tratamento. $E$, outras restrições de uso dão indicativos de soluções construtivas que devem ser seguidas para evitar o contato dos elementos constituintes em madeira com a umidade.

Após a definição da terminologia e dos principais documentos normativos nacionais e internacionais que são pertinentes ao sistema wood frame, são detalhadas as principais características técnicas para os seguintes componentes constituintes: peças em madeira serrada, chapas OSB, chapas em madeira compensada, placas cimentícias, chapas de gesso para drywall, siding de PVC, componentes de revestimento, selantes para preenchimento de juntas aparentes, massa para preenchimento de juntas dissimuladas, fita ou tela para junta 
dissimulada, materiais de isolamento acústico, materiais de isolamento térmico, barreiras impermeáveis e componentes de fixação metálicos.

Os requisitos e critérios de desempenho, assim como os métodos de avaliação destes dados, consideraram a ABNT NBR15.575 ${ }^{19}$ e outras normas vigentes pertinentes, salientando os fatores: desempenho estrutural, segurança contra incêndio, estanqueidade à água, desempenho térmico, desempenho acústico, durabilidade e manutenabilidade.

Por fim, a Diretriz no 005 considera que a produção dos elementos constituintes do wood frame pode ocorrer em unidades industriais e/ou no canteiro-de-obras. E, para estas etapas deve-se aplicar um controle de qualidade no recebimento de todos materiais e nas diversas etapas da montagem, pois auditorias técnicas serão realizadas pela ITA nestas fases da produção. A diretriz fornece detalhes para inspeção dos materiais recebidos, incluindo requisitos, método de avaliação e frequência da inspeção. A Tabela 10 exemplifica alguns destes dados. E, para a montagem, cada obra deve ter seu procedimento de execução, incluindo planejamento de armazenamento e proteção dos materiais recebidos. Após finalizada a montagem, é necessário inspecionar a qualidade da edificação como um todo.

Tabela 10: Exemplo de requisitos para controle de qualidade dos principais materiais constituintes do sistema wood frame conforme Diretriz SINAT 005 de 2011

\begin{tabular}{|c|c|}
\hline Material & Requisitos para controle de qualidade \\
\hline \multirow{7}{*}{ Peças estruturais de madeira } & Procedência legal \\
\hline & Classificação visual \\
\hline & Conferência de dimensões e tolerâncias conforme projeto \\
\hline & Proteção contra organismos xilófagos \\
\hline & Proporção de nós na seção transversal da peça \\
\hline & Deformações \\
\hline & Teor de umidade \\
\hline \multirow{3}{*}{ Placas cimentícias } & Aspecto da superfície, ausência de ondulações \\
\hline & Tolerâncias geométricas \\
\hline & Resistência mecânica, absorção de água e variação hidroscópica \\
\hline \multirow{3}{*}{ Chapas de gesso para drywall } & Aspecto da superfície, ausência de ondulações e de manchas \\
\hline & Tolerâncias geométricas \\
\hline & Resistência mecânica e absorção de água \\
\hline \multirow{3}{*}{ Chapas de madeira reconstituída } & Tolerâncias geométricas \\
\hline & Aspecto da superfície, uniformidade \\
\hline & Teor de umidade \\
\hline
\end{tabular}

Fonte: elaborado pela autora com base em Brasil, 2011.

\footnotetext{
${ }^{19}$ Naquele momento, desde a formulação da Diretriz SINAT no 005 até sua publicação em 2011, a Norma de Desempenho ABNT NBR 15.575 estava em consulta pública, sendo esta publicada em julho de 2013. Portanto, a vigência da Norma de Desempenho é posterior à publicação da primeira Diretriz SINAT no 005. Assim para cumprir a norma, alguns dados da Diretriz no 005 foram alterados na sua primeira revisão publicada em 2016.
} 
Portanto, em geral, esta diretriz fornece uma base para a próxima etapa que consiste em um proponente contratar ITAs para a realização dos métodos de avaliação conforme as referências normativas delineadas. Quando uma ITA realiza estes ensaios e analisa estes dados técnicos, emite os Relatórios Técnicos de Avaliação (RTAs) que são necessários para a publicação de um possível Documento de Avaliação Técnica (DATec), exigido pela CEF para o financiamento de edificações, em especial as inclusas no PMCMV.

Assim, a Comissão Casa Inteligente concluiu que a aprovação desta diretriz SINAT para o wood frame mediante o MCidades possibilitaria um avanço no setor dessas construções no Brasil. E, na reunião desta comissão, realizada em setembro de 2011 , levantou-se a questão sobre os próximos passos para propor um DATec que possibilitasse este financiamento da CEF. Existia uma dúvida inicial no grupo sobre quem seria o proponente e, consequentemente, o detentor deste DATec. Pois, conforme o regimento do SINAT (BRASIL, 2007b), um proponente pode ser uma "pessoa física ou jurídica que solicita a avaliação técnica do produto no SINAT" e este passa a ser o detentor do DATec deste produto.

Naquele momento, as associações APRE e DRYWALL se disponibilizaram para esta função, caso a proposta partisse da comissão em conjunto, como havia ocorrido para o processo da Diretriz SINAT 005. Uma segunda proposta colocada pelo grupo foi a criação de uma associação específica para a Comissão Casa Inteligente executar um DATec. Mas, neste processo, a empresa Tecverde, que estava avançando rapidamente nas suas realizações com wood frame, já havia determinado que, conforme suas necessidades, estava em meios de propor seu DATec com uma solução tecnológica própria. E, assim, se solicitado, a empresa disponibilizaria informações pertinentes sobre este novo processo para a Comissão Casa Inteligente.

Sob este cenário, observa-se que a Comissão Casa Inteligente, desde sua formação em 2009 até a publicação da Diretriz SINAT no 005 em 2011, contribuiu para agilizar procedimentos necessários constatados pelo setor para implantar o wood frame no Brasil, em especial para sua introdução no mercado por meio de agências de financiamento. Um dos principais resultados foi a participação ativa das empresas envolvidas nesta cadeia de produção, inclusive com a atuação paralela de parcerias com instituições de ensino, como a UTFPR e o SENAI-PR na construção dos primeiros modelos em wood frame. 
Esta primeira relação estabelecida entre os agentes da cadeia de produção deste setor possibilitou novos avanços, em especial para empresas construtoras. Neste período de transformação do cenário das construções em madeira, algumas empresas nacionais estavam construindo com o sistema wood frame. Entre estas, destacou-se a empresa Tecverde, a qual era integrante e participante ativa da Comissão Casa Inteligente. Diferente das demais, esta empresa foi criada especificamente para produzir com o wood frame e foi a primeira no território nacional a aplicar métodos de construção industrializados para este sistema. $O$ item seguinte abordará como a ação da Comissão Casa Inteligente contribuiu positivamente para a consolidação de empresas construtoras, focalizando o caso da empresa Tecverde.

\subsection{CONSOLIDAÇÃO EMPRESARIAL: O CASO DA EMPRESA TECVERDE}

Em 2009, a empresa Tecverde foi formada inicialmente por Caio Bonatto, Carlos Roberto Justus e Lucas Maceno, enquanto eram colegas da Universidade Federal do Paraná (UFPR) e tinham 23 anos em média.

Caio Bonatto, sócio-diretor da empresa, cresceu visitando seu pai construtor nos canteiros-de-obras. E, após cursar o primeiro ano da graduação em engenharia civil, em 2004, ele trancou o curso e viajou para Nova Zelândia. Seu objetivo era conhecer a produção da indústria da construção neste outro país, haja vista que, na sua percepção, o setor brasileiro estava estagnado, ofertando construções com baixa qualidade, custos elevados e prazos longos. Durante este um ano na Nova Zelândia, ele obteve conhecimento de construções mais sustentáveis que aplicavam sistemas e elementos industrializados. Seus colegas, Beto Justos e Lucas Maceno também tiveram uma experiência similar quando fizeram intercâmbio nos EUA e no Canadá, respectivamente (GOL, 2015).

Com base nestas experiências de sistemas e métodos de produção industrializada conhecidos no exterior, em 2007 e 2008, estes estudantes de engenharia civil pesquisaram mais a fundo sobre quais possíveis tecnologias poderiam ser adaptadas ao contexto brasileiro e produzi-las comercialmente. Assim, eles selecionaram o sistema wood frame para esta finalidade e iniciaram suas primeiras propostas de adequação do sistema à realidade brasileira considerando os materiais e a mão-de-obra disponíveis. Com base nestes estudos propositivos, no final de 2009, ainda como estudantes de graduação, eles fundaram a empresa Tecverde visando produzir construções sustentáveis e industrializadas (TECVERDE, 2015). 
Entretanto, para fundar a empresa, eles necessitavam de recursos financeiros e de parcerias com empresas de insumos que poderiam integrar uma possível cadeia de produção do wood frame no Brasil. Também, precisavam adquirir tecnologia mecanizada para a produção industrial dos elementos constituintes do wood frame. Assim, eles recorreram à Federação das Indústrias do Paraná (FIEP) com este objetivo. E, conforme já foi descrito anteriormente, em julho de 2009, mediante a FIEP e o SENAI-PR, eles participaram de uma missão técnica à Alemanha para conhecer empresas do setor de construção em madeira e suas tecnologias aplicadas. E, como resultado, com o convênio estabelecido com o Ministério da Economia do Estado de Baden-Württemberg, foi possível transferir essa tecnologia específica para a produção, incluindo maquinários ofertados pela empresa alemã Weinmann.

E, para obter seus recursos financeiros iniciais, a empresa Tecverde optou por se inscrever em um investimento-anjo ${ }^{20}$. Ou seja, como empresa recém-formada com alto potencial de crescimento, a Tecverde poderia receber investimentos de "anjos", que seriam pessoas experientes, como empresários, executivos e profissionais liberais, que optam por investir seu capital próprio nas proposições inovadoras de novas empresas. Dessa forma, mediante investidores-anjo, a Tecverde recebeu aproximadamente $\mathrm{R} \$ 350$ mil. Além disso, a empresa também se inscreveu no edital do Programa Prime ${ }^{21}$ da Financiadora de Estudos e Projetos (FINEP). Este programa foi criado no início de 2009, com objetivo de fornecer condições financeiras favoráveis para que empresas recém-formadas com potencial possam desenvolver e consolidar seus empreendimentos. E, por ser selecionada neste programa da FINEP, a Tecverde recebeu o aporte de R\$ 120 mil (GOL, 2015).

Com base nestas contribuições financeiras iniciais e nas parcerias estratégicas com fornecedores de insumos e de equipamentos, no ano de 2010, a empresa Tecverde iniciou sua

\footnotetext{
${ }^{20} \mathrm{O}$ Investimento-Anjo é o investimento efetuado por pessoas físicas com seu capital próprio em empresas nascentes com alto potencial de crescimento - as startups - apresentando as seguintes características: (1) é efetuado por profissionais experientes - empresários, executivos e profissionais liberais -, que agregam valor para o empreendedor com seus conhecimentos, experiência e rede de relacionamentos além dos recursos financeiros, por isto é conhecido como smart-money, (2) tem normalmente uma participação minoritária no negócio, (3) não tem posição executiva na empresa, mas apoiam o empreendedor atuando como um mentor/conselheiro (ANJOS DO BRASIL, 2016).

${ }^{21}$ O programa Prime - Primeira Empresa Inovadora entrou em operação no ano de 2009, com objetivo de criar condições financeiras favoráveis para que empresas nascentes de alto valor agregado possam consolidar com sucesso a fase inicial de desenvolvimento dos seus empreendimentos. Neste programa, cada empreendimento contemplado faz jus a recursos de Subvenção Econômica de $\mathrm{R} \$ 120$ mil para custear recursos humanos qualificados e serviços de consultoria especializada em estudos de mercado, serviços jurídicos, financeiro, certificação e custos, entre outros, durante 12 meses (FINEP, 2016).
} 
produção. Neste ano, a estrutura organizacional da empresa já contabilizava mais três sócios, Diogo Lovato e Maria Paula Roco Nascimento, também do curso de engenharia civil da UFPR, e Pedro Virmond Moreira, do curso de arquitetura da UFPR. Este último sócio, atual diretor de engenharia de produto da Tecverde, em 2010, recebeu treinamento de duas empresas alemãs Baumeister \& Sapper Engineering Ltd e SEMA Software (TECVERDE, 2015).

A primeira destas empresas - Baumeister \& Sapper Engineering Ltd - tem experiência na indústria de construção pré-fabricada e atua nas áreas de soluções inovadoras, prestação de serviços, consultoria e treinamento para construções industrializadas em wood frame. Por exemplo, em parceria com a empresa de maquinários Weinmann, planeja e projeta layouts de fábrica conforme capacidade de produção, procedimentos operacionais manuais e mecanizados e logística dos materiais. Também, tem profissionais que adequam esboços de projetos arquitetônicos já aprovados pelo cliente para projetos detalhados, incluindo todos os componentes constituintes com suas especificações considerando as cargas influentes nos mesmos. E, com base nestes detalhes desenhados em programas computadorizados, elabora os projetos para a produção de elementos de piso, parede e cobertura na fábrica, com dimensões exatas especificadas para serem inseridas nas máquinas controladas por comando numérico computadorizado (CNC). Ainda mais, esta empresa fornece treinamento operacional para os trabalhadores da produção conforme a planta da fábrica projetada, considerando, por exemplo, linhas de produção, divisões dos empregados nas estações de trabalho e controle de qualidade em cada etapa (Figura 74) (BAUMEISTER-SAPPER, 2016).
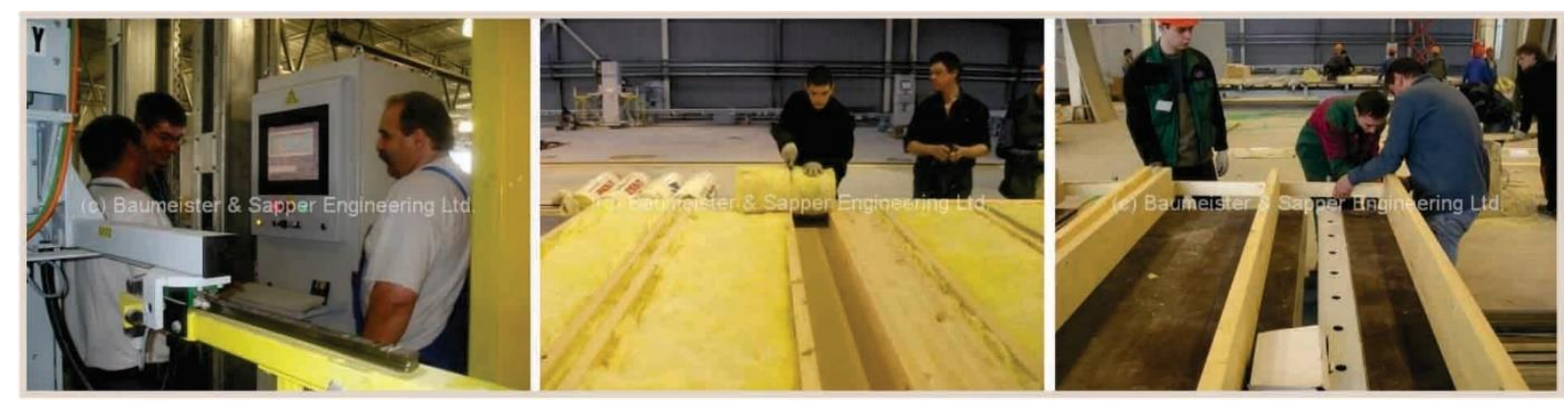

Figura 74: Treinamento da empresa alemã Baumeister \& Sapper para produção na fábrica Fonte: Baumeister-Sapper, 2016.

A segunda empresa alemã - SEMA Software - produz um dos softwares mais utilizados para a construções em madeira, disponibilizado em 11 idiomas. Após selecionar o sistema construtivo e modelar geometricamente a edificação em três dimensões, o programa permite 
analisar os dados estruturais e a distribuição das cargas em cada componente. Conforme a necessidade, o programa é flexível e permite alterações nestes dados e nos componentes. Por fim, com a conclusão do projeto, o programa gera os detalhes dos componentes constituintes, com projetos para produção cujos dados numéricos podem ser utilizados nas máquinas de processamento e usinagem dos elementos pré-fabricados em madeira. Também, gera planilhas com o quantitativo dos materiais utilizados (Figura 75) (SEMA-SOFT, 2016).

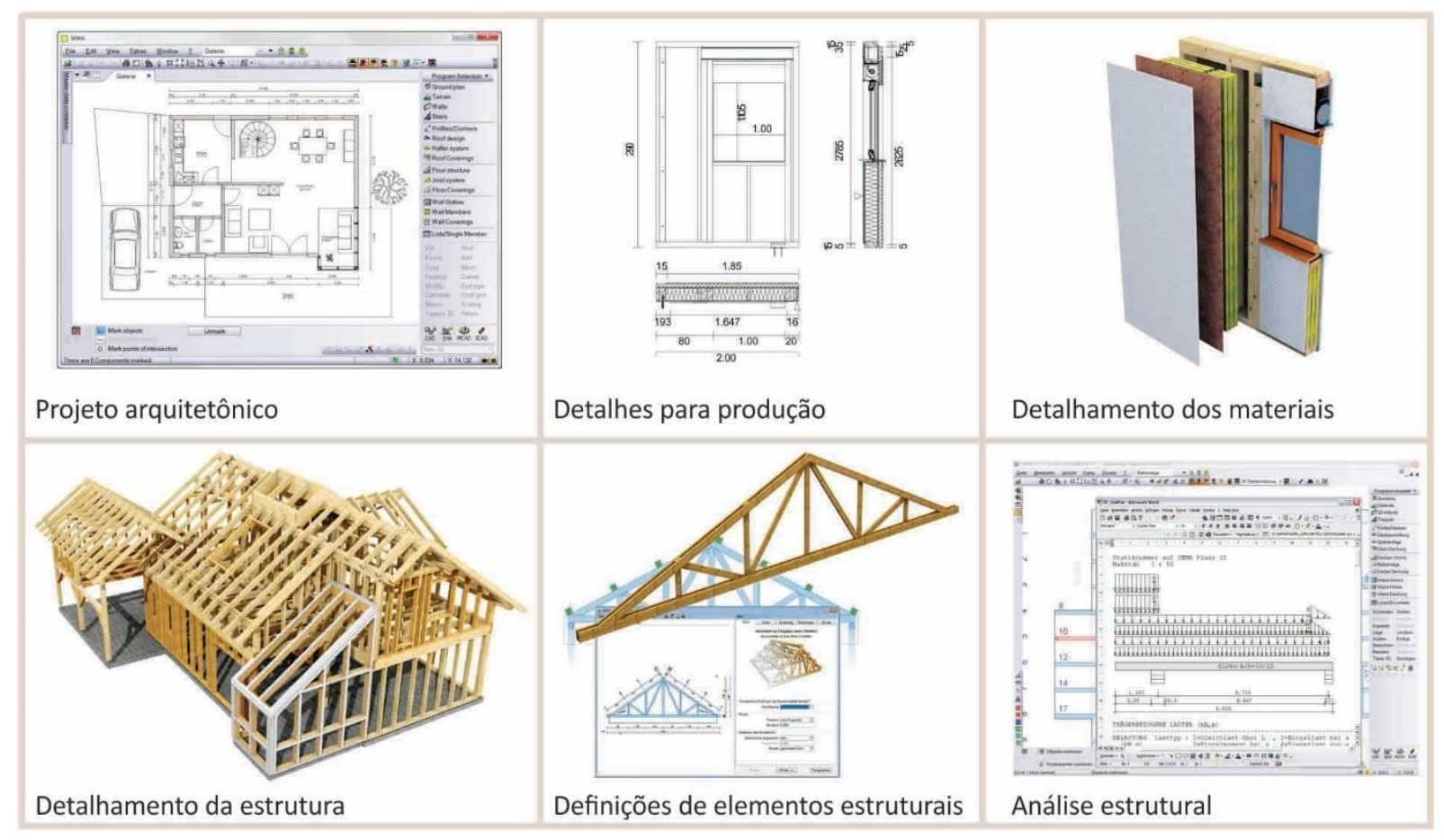

Figura 75: Definições de projeto para construções em madeira no programa alemão SEMA

Fonte: adaptado de SEMA-SOFT, 2016.

Portanto, as informações obtidas nos treinamentos ocorrentes nestas duas empresas alemãs foram necessárias para a Tecverde iniciar sua produção, pois, no Brasil, atualmente, os cursos de engenharia civil e arquitetura não abordam o sistema wood frame no seu conteúdo curricular, já que o foco nestas instituições de ensino são construções em alvenaria estruturadas em concreto. Assim, com base nestes treinamentos, o arquiteto da empresa Pedro Moreira constatou que, para a empresa, era necessário adotar uma representação arquitetônica conforme o sistema wood frame, o que era uma dificuldade por causa da cultura de desenho e projeto arquitetônico no Brasil.

[...] os projetos arquitetônicos necessitam ser pensados à luz do sistema construtivo a ser aplicado. Essa questão se apresentou como desafio no Brasil, um local onde a cultura arquitetônica e as soluções técnicas são voltadas para a aplicação da alvenaria e concreto (ABDI, 2015, p. 178). 
Além do treinamento, em 2010, a Tecverde recebeu assessoramento da empresa alemã Weinmann para montar sua primeira fábrica. Localizada no município de Pinhais, região metropolitana de Curitiba, no Paraná, a fábrica apresentava seu layout em uma área de 400 $\mathrm{m}^{2}$, com capacidade para produção de 4 casas por mês, com áreas de $150 \mathrm{~m}^{2}$ cada. Ali, uma equipe de seis trabalhadores se dividia em estações de trabalho para produzir, principalmente, painéis abertos de parede, em uma produtividade contabilizada em $80 \mathrm{~m}^{2} / \mathrm{dia}$ (ABDI, 2015).

Em geral, estes painéis abertos eram constituídos por um entramado formado por montantes e travessas de madeira de pinus beneficiado e tratado com CCA. Este entramado era preenchido com isolante em lã de pet ou lã de vidro. Na sua face externa, esta estrutura em madeira era contraventada com chapas OSB, protegidas com membranas hidrófugas. Sobre estas membranas, as placas cimentícias eram fixadas. A face interna deste painel permanecia aberta para o mesmo ser completado no canteiro, onde receberia as instalações elétricas e hidráulicas e, por fim, era fechado com chapas OSB e de gesso acartonado (Figura 76). Por serem caracterizados como abertos, estes painéis apresentavam algumas vantagens para a montagem no canteiro, como a sua fixação facilitada e no prumo sobre a fundação em radier ou sobre o entrepiso do segundo pavimento e a fixação entre painéis de parede. Também, como a empresa não era especializada na execução dos projetos complementares, no princípio de sua atuação, era mais ágil instalar os materiais elétricos e hidrossanitários no próprio canteiro. De forma geral, a utilização de painéis abertos diminuía a ocorrência de erros na etapa da montagem.

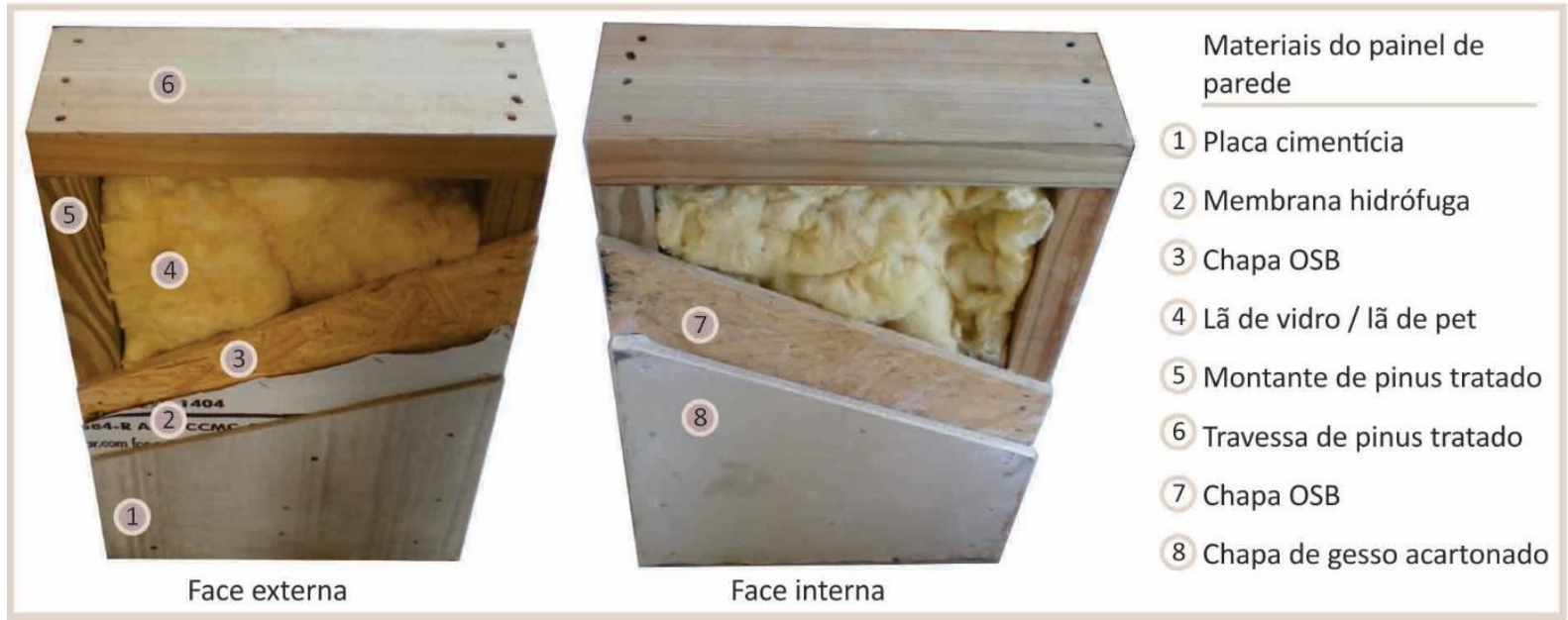

Figura 76: Composição dos painéis de parede da Tecverde em 2012

Fonte: autora. 
No início do fluxo de produção, o material recebido era estocado no interior da fábrica (Figura 77). Antes das usinagens dos componentes, os materiais passavam por um controle de qualidade visual. A madeira serrada de pinus de florestas plantadas já vinha tratada com CCA e beneficiada na bitola especificada no projeto. Assim, era estocada próximo de uma estação de corte, onde as peças eram medidas, marcadas e cortadas com uma serra circular na dimensão de projeto (Figura 78).
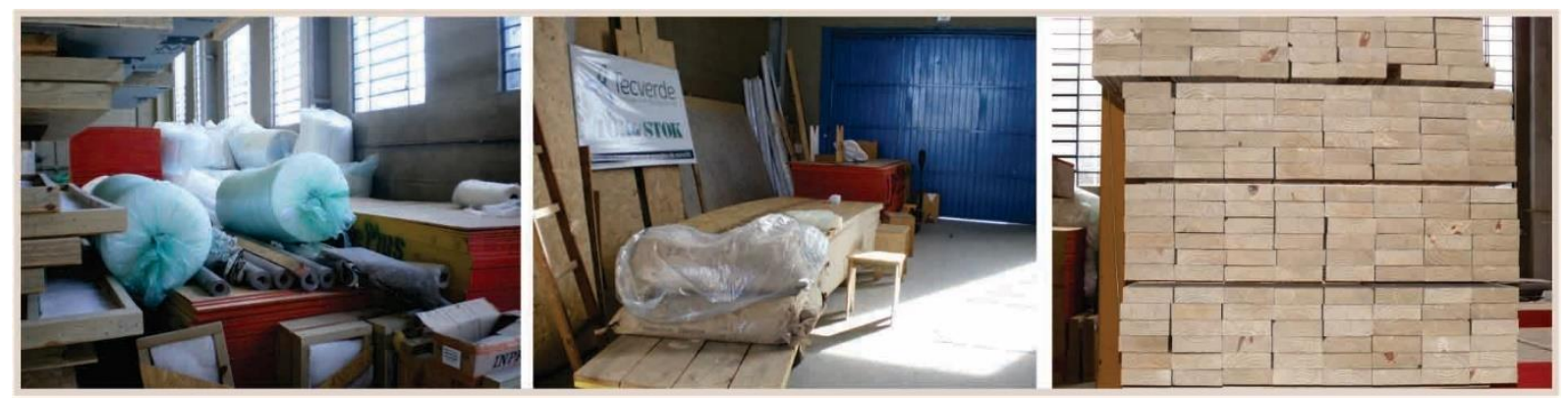

Figura 77: Estoque dos principais materiais recebidos

Fonte: autora.
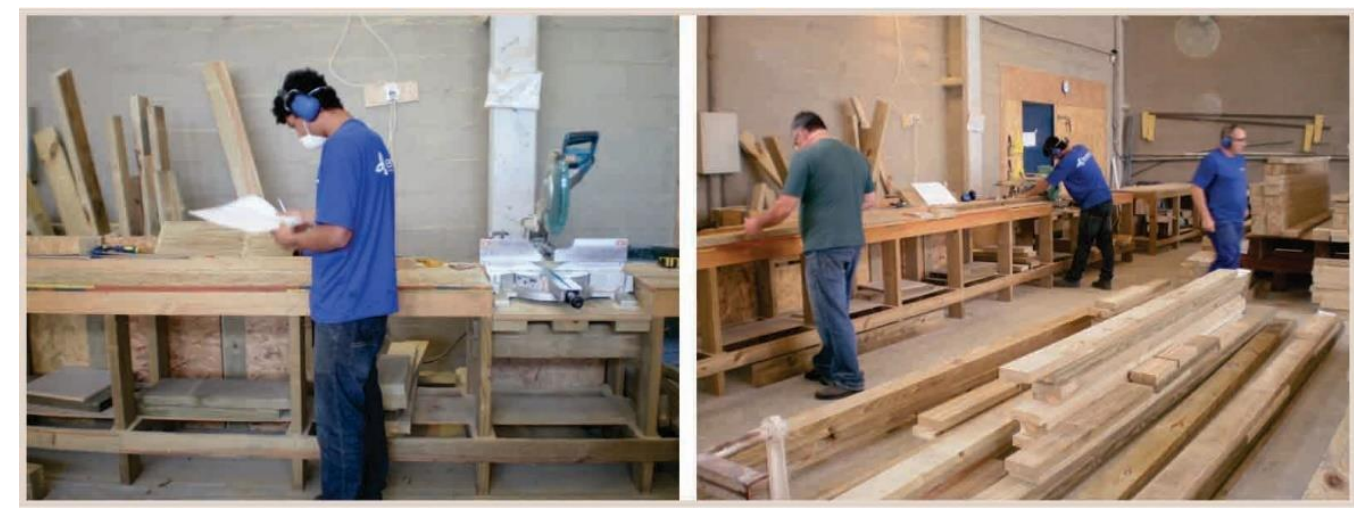

Figura 78: Leitura do projeto de produção, marcações conforme medidas e corte das peças Fonte: autora.

Na sequência, a madeira cortada era colocada próximo à mesa de montagem dos painéis de parede. Nesta mesa, os trabalhadores posicionavam os montantes e as travessas conforme indicava o projeto de produção do painel de parede. Esta mesa de trabalho era pneumática, onde hastes podiam ser movidas para fixar a altura do painel de parede e dar mais segurança na hora de montar a sua estrutura. Após conferir as medidas e os esquadros, os trabalhadores fixavam as peças em madeira com pregadeiras pneumáticas (Figura 79). 

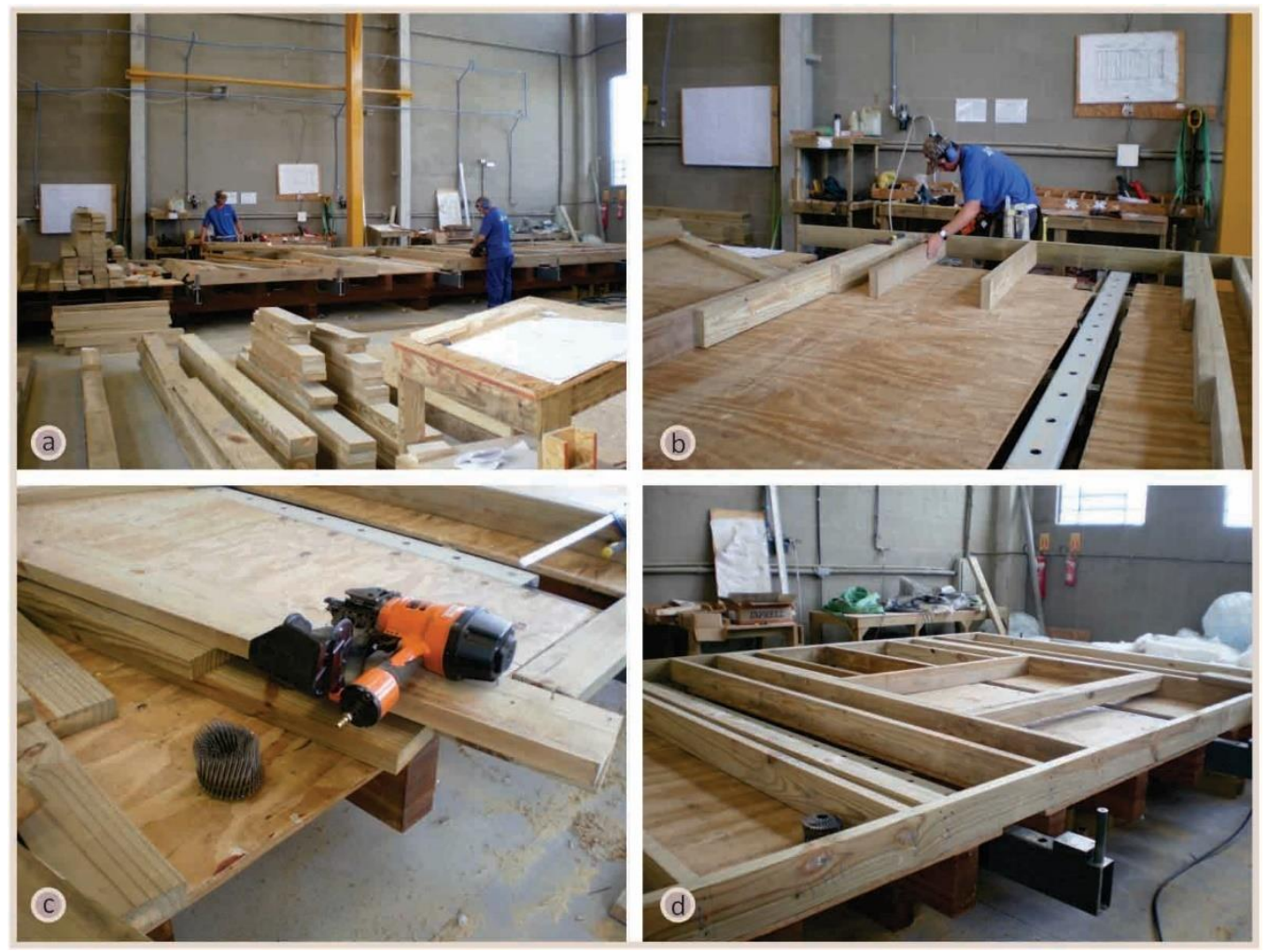

Figura 79: Montagem do entramado em madeira sobre mesa com hastes pneumáticas Fonte: autora.

Nesta mesma mesa de montagem, as furações eram executadas nas peças do entramado para possibilitar a passagem de tubulações ou eletrodutos. Na sequência, com o entramado em madeira finalizado, os trabalhadores posicionavam as chapas OSB e as fixavam com pregadeiras pneumáticas (Figura 80). Sobre a chapa OSB, instalavam as membranas hidrófugas e fixavam as placas cimentícias sobre as mesmas (Figura 81).
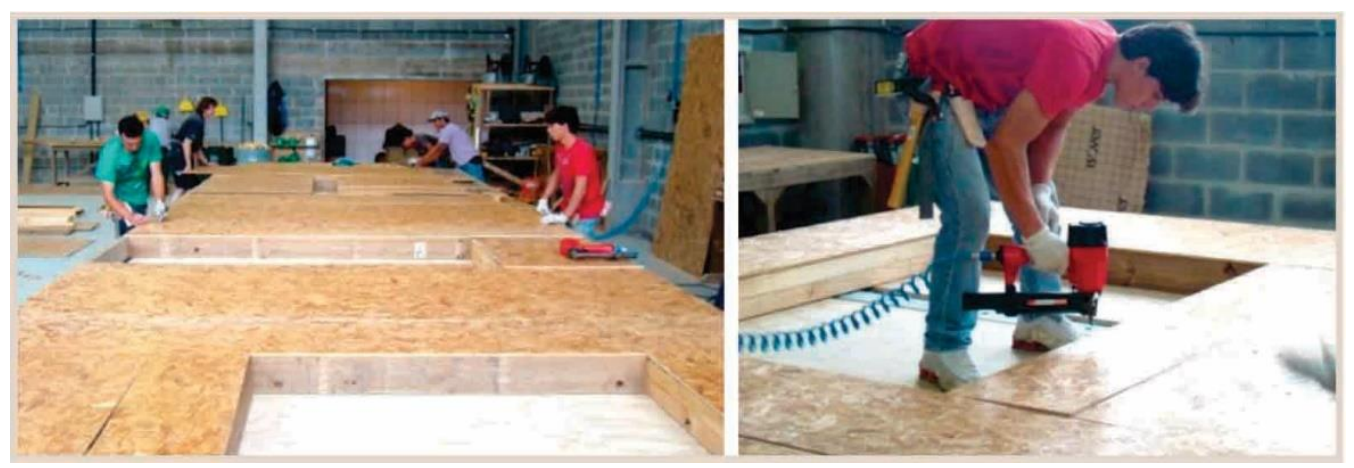

Figura 80: Posicionamento e fixação das chapas OSB sobre o entramado

Fonte: Tecverde, 2013. 


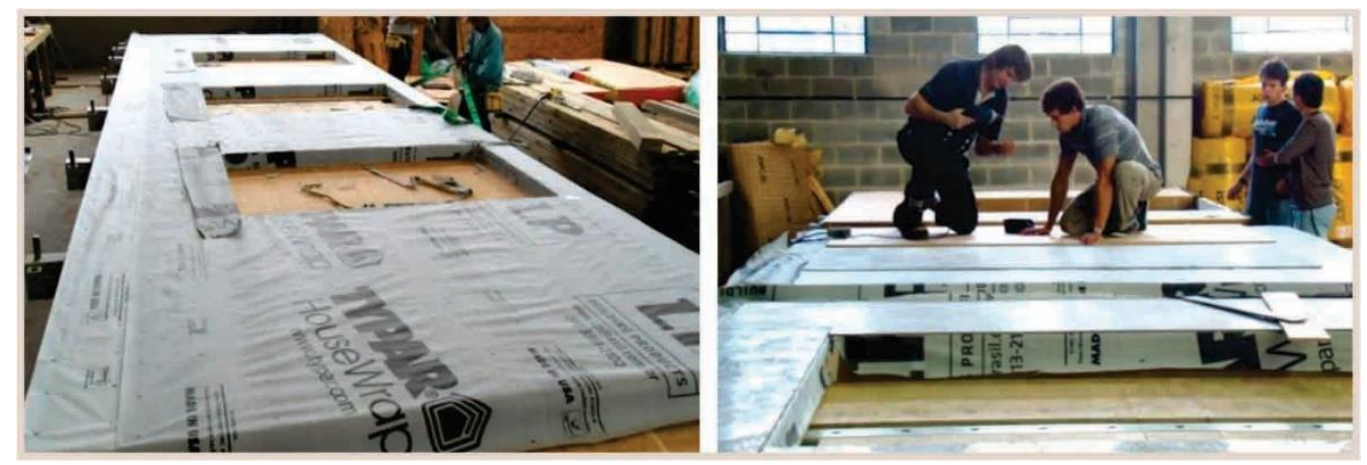

Figura 81: Fixação da membrana hidrófuga e da placa cimentícia

Fonte: Tecverde, 2013.

Com auxílio da ponte rolante, este painel era erguido e virado sobre a mesa de montagem, para ser preenchido com lã de isolamento térmico e acústico. Por fim, o painel aberto finalizado era erguido e estocados na fábrica, aguardando o seu transporte até o canteiro.

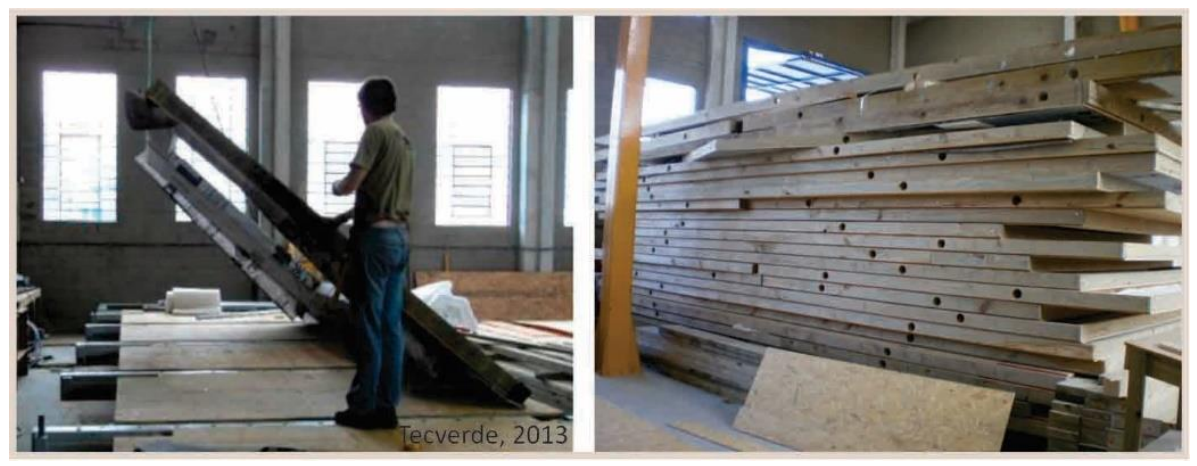

Figura 82: Painel erguido por ponte rolante e estocado para transporte até o canteiro Fonte: Tecverde, 2013 / autora.

Conforme foi colocado no item anterior, a primeira construção da empresa Tecverde ocorreu no primeiro semestre de 2010, após parcerias de relacionamento com empresas desta cadeia de produção, possibilitadas pela conjuntura da Comissão Casa Inteligente, da qual a empresa era integrante desde sua formação. Esta primeira construção foi a casa modelo Slim, que foi temporariamente aberta ao público para visitação e conhecimento do wood frame (Figura 66).

Neste primeiro momento de atuação da empresa, o modelo de negócios estava centrado na construção de casas de médio e alto padrão com modelos arquitetônicos prontos. Esta decisão de adotar projetos arquitetônicos padronizados foi tomada visando a eficiência 
da produção na fábrica. Pois, quanto menos variedades de elementos produzidos, maior seria a repetição das tarefas e menores seriam o tempo e o custo desta produção. Para a inserção desta tecnologia no mercado brasileiro, a empresa disponibilizou um portfólio com aproximadamente 30 modelos de casas e de configurações espaciais (Figura 83).

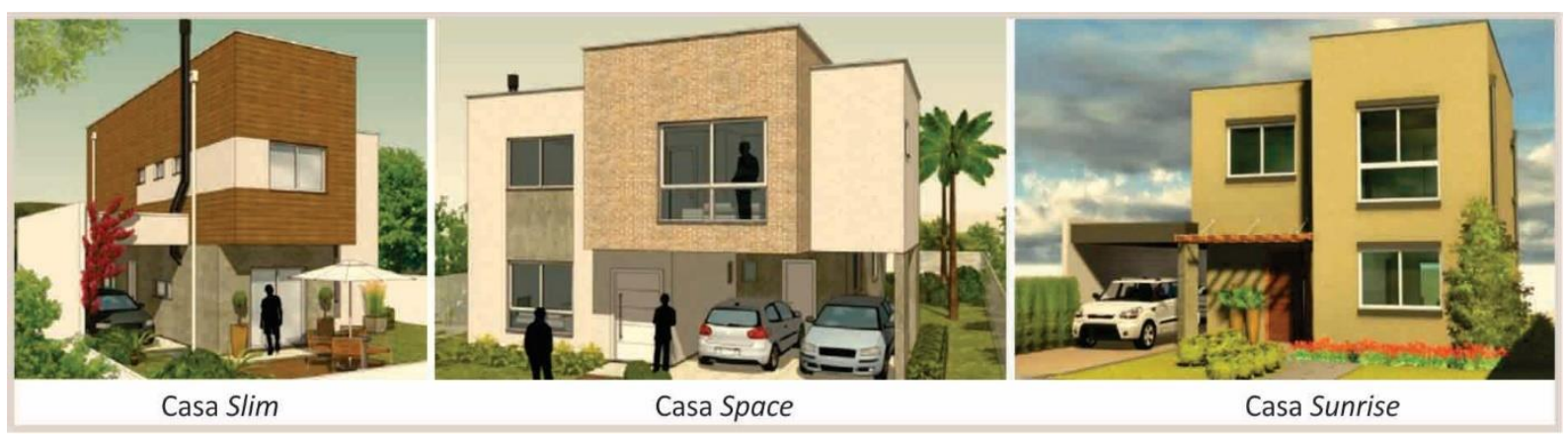

Figura 83: Exemplos de casas com projetos arquitetônicos padronizados da Tecverde Fonte: Banco de dados da Tecverde, 2012.

Além dos projetos padronizados, a empresa realizava parceria com outros escritórios de arquitetura para o desenvolvimento e a execução de projetos personalizados. Entre estes, destacou-se a casa Vila projetada em 2011 pelos arquitetos Fernando Caldeira de Lacerda, Pedro Amin Tavares e Bernardo Richter da Arquea Arquitetos. Esta casa de 207 m², localizada em São José dos Pinhais, no Paraná, foi estruturada com o sistema wood frame, produzido pela empresa Tecverde, utilizando materiais de fabricantes como: Alucom, Knauf, Lyptus do Brasil, Rothoblaas, TW Brasil. Após finalizada, em 2012, esta construção foi reconhecida publicamente recebendo menção honrosa no Prêmio Planeta Casa da Editora Abril (Figuras Figura 84 à Figura 86) (ARCHDAILY, 2014).

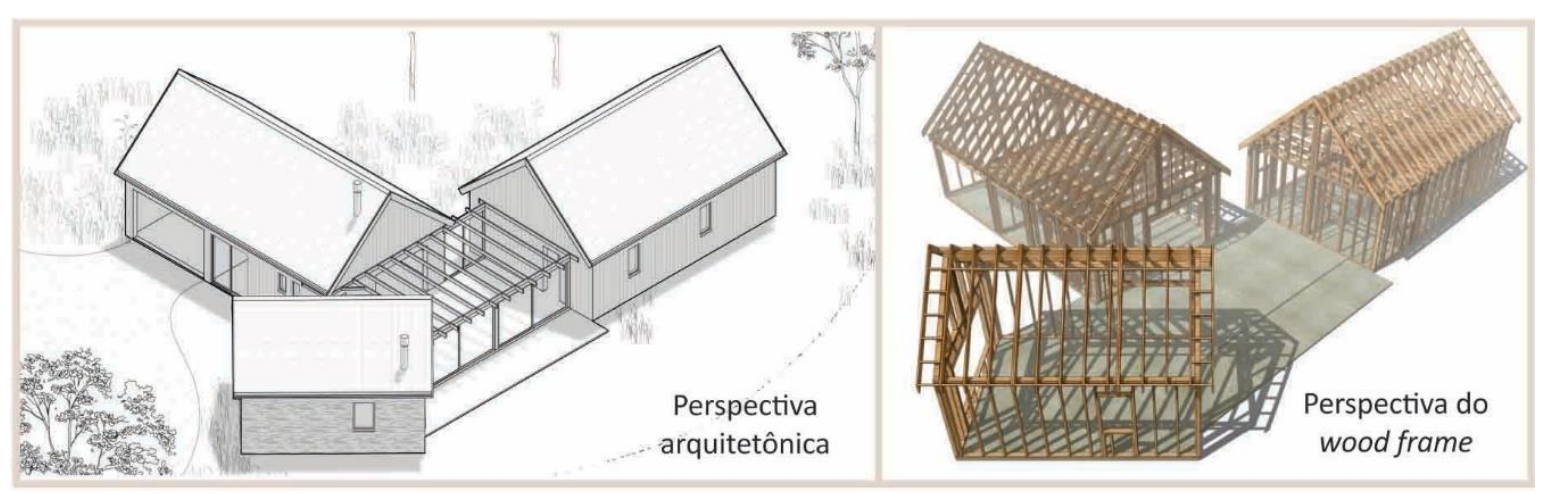

Figura 84: Projeto da casa Vila do escritório Arquea construída em wood frame Fonte: Archdaily, 2014. 


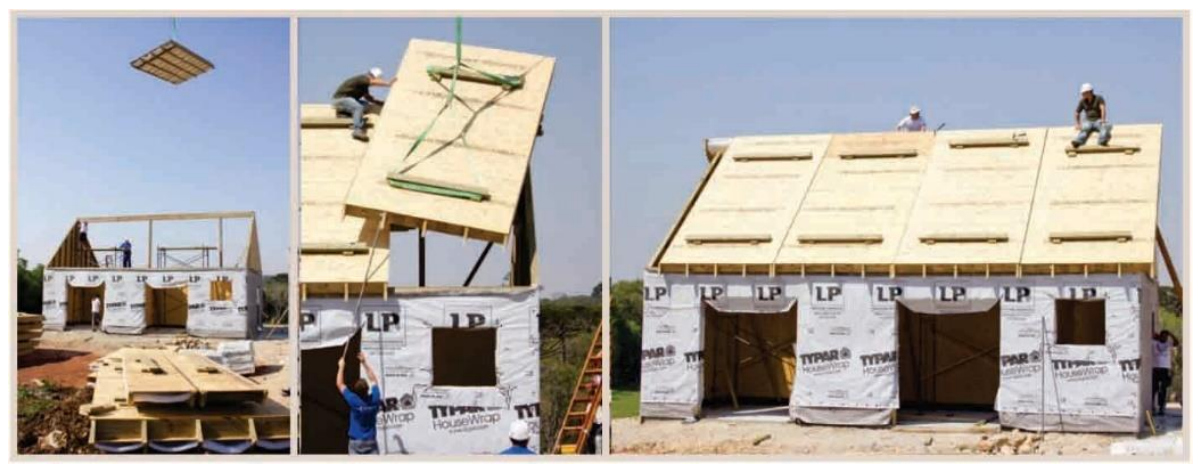

Figura 85: Montagem da casa Vila com painéis pré-fabricados produzidos pela Tecverde Fonte: Archdaily, 2014.
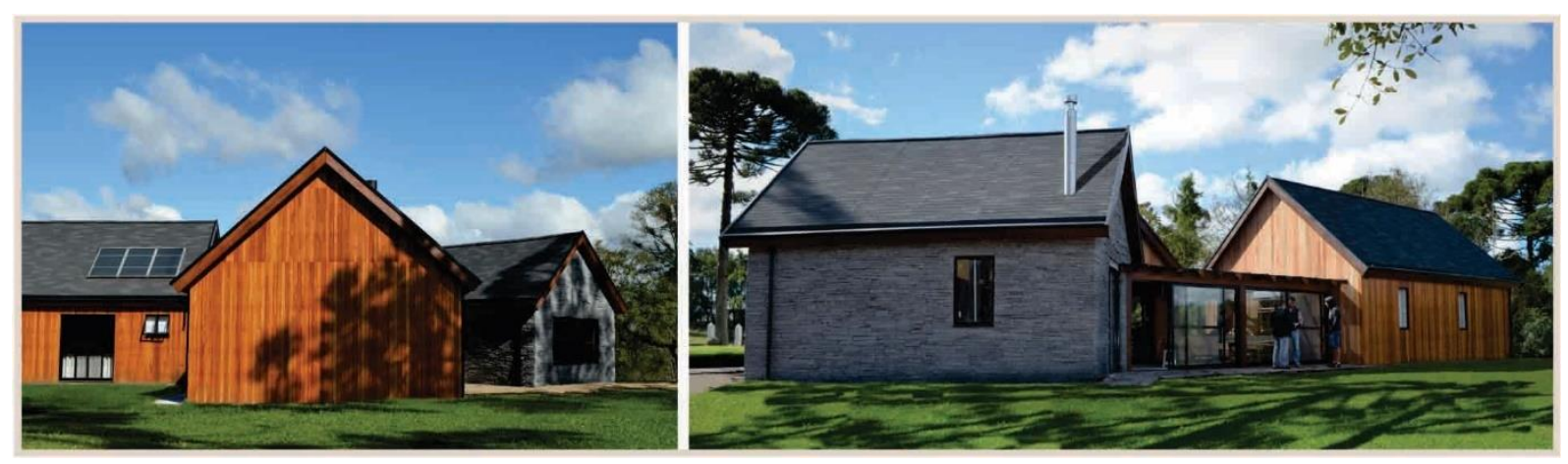

Figura 86: Construção da casa Vila finalizada

Fonte: Archdaily, 2014.

No entanto, em 2010, no primeiro ano de produção, a empresa Tecverde vendeu apenas três residências. Os empreendedores relatam que esta dificuldade inicial ocorreu principalmente pois enfrentaram barreiras para financiar suas edificações estruturadas em madeira e, assim, a população diante deste fato agiu com receio.

"Os bancos brasileiros não financiavam casas pré-fabricadas, o que gerava desconfiança dos possíveis compradores", conta Bonatto. "O primeiro ano foi muito difícil: vendemos apenas três unidades" (PINHO, 2012).

Mas, visando alterar esta condição de falta de financiamento para as construções em wood frame, neste mesmo período de 2010, a Comissão Casa Inteligente em conjunto com o IPT estava elaborando análises sobre o sistema wood frame para a publicação do documento da diretriz SINAT. E, dentre os critérios de desempenho desta diretriz, salientava-se a questão da durabilidade da edificação conforme as normas brasileiras. Também, em paralelo, a empresa Tecverde, enquanto aprimorava seu sistema, desenvolveu alguns testes e soluções tecnológicas para aumentar a durabilidade desta construção, como a utilização de mantas 
asfálticas de impermeabilização na base dos painéis de parede, que evitam a passagem da umidade do solo e da fundação de concreto para estes componentes em madeira.

Logo na sequência, no fim de 2010, o banco Santander liberou o financiamento para as construções em wood frame da empresa Tecverde. Sobre este processo, Lucas Maceno, um dos sócios diretores da empresa comentou em uma entrevista:

"Nós tínhamos um produto interessante, mas não uma boa condição de
pagamento. Foi aí que em um evento, o sócio Caio Bonatto sentou, por
acaso, ao lado do superintendente de negócios sustentáveis do Banco
Santander e explicou que o wood frame não é uma simples construção em
madeira e sim um sistema construtivo avançado e tão seguro e durável
quanto às demais construções", relata. Depois disso, o banco resolveu
apostar no projeto e juntos conseguiram alterar a regulamentação nacional
de financiamento de casas que usam madeira em suas estruturas
(ENDEAVOR, 2012).

Assim, sob esta nova perspectiva, com a possibilidade de obter financiamento de até 30 anos, a Tecverde passou a oferecer aos clientes condições de negócio semelhantes a outros sistemas tradicionais financiados. E este fato permitiu seu ingresso efetivo no mercado imobiliário brasileiro. Isso resultou no aumento imediato na produção de casas de médio e alto padrões (Figura 87) e, assim, seu faturamento foi de aproximadamente $R \$ 3$ milhões em 2011 e de R\$ 5 milhões em 2012 (PINHO, 2012; ENDEAVOR, 2012).

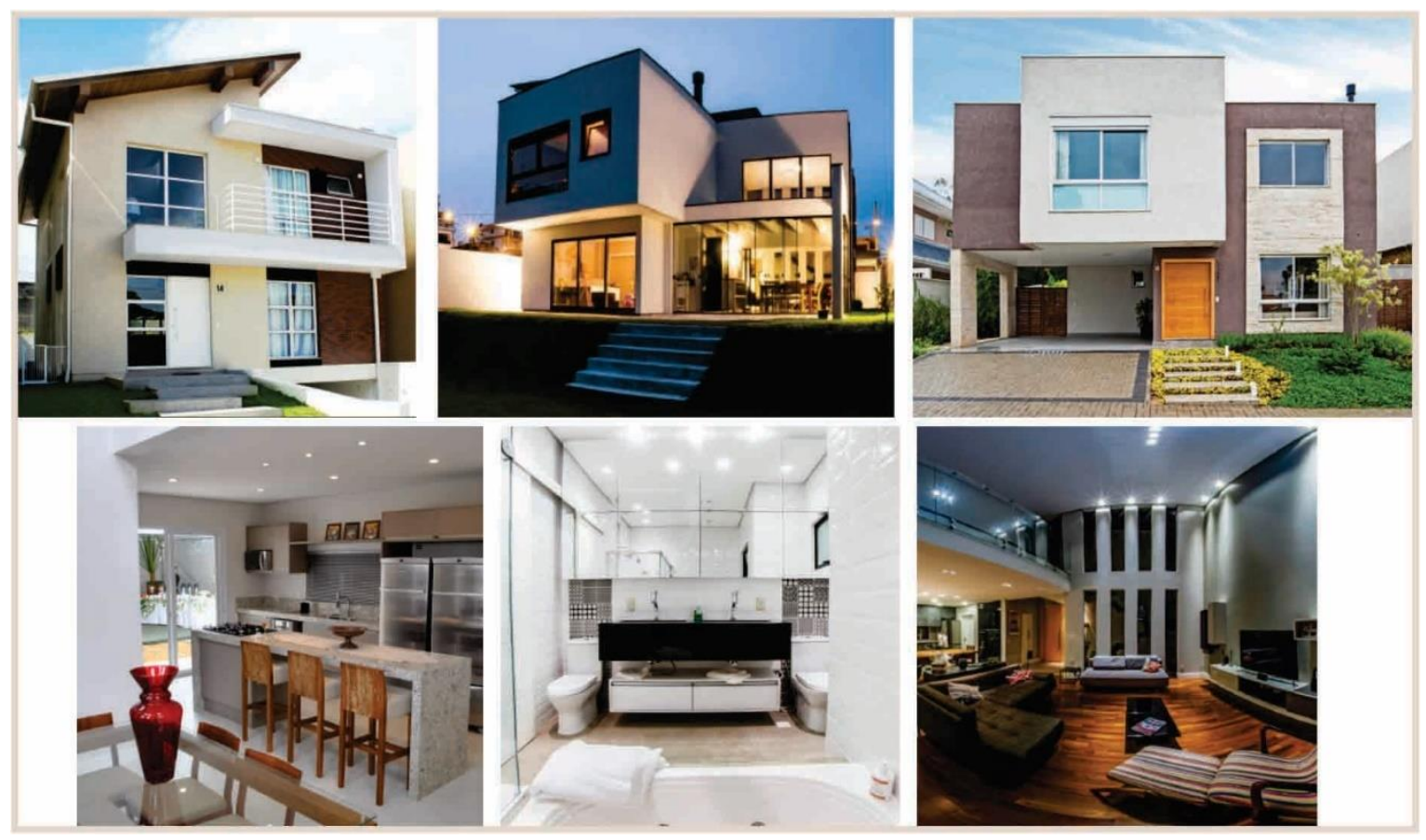

Figura 87: Casas de alto padrão construídas pela empresa Tecverde Fonte: Tecverde, 2015. 
Logo, o crescimento acelerado na produção também resultou no aumento e nas transformações da estrutura organizacional da empresa. Constatou-se que, em julho de 2012, a empresa dividia seus funcionários em três setores principais: 10 pessoas no escritório, incluindo engenheiros civil, mecânico, de produção, industrial madeireiro, arquitetos, especialistas em venda e marketing; 07 trabalhadores na produção na fábrica; e 06 trabalhadores para montagem no canteiro-do-obras. Os engenheiros e arquitetos vêm se especializando periodicamente com empresas parceiras na Alemanha, no Canadá, nos EUA e no Chile. E, os estagiários e trabalhadores da fábrica e da montagem no canteiro foram treinados, em geral, por estes profissionais especializados ou parceiros, como o SENAI-PR. Ainda, a Tecverde tem parcerias com consultores, como a empresa Stamade, que lhe presta serviços, principalmente, referentes ao cálculo estrutural dos elementos das edificações.

Para continuar ampliando sua produção, em 2011 e 2012, após a publicação oficial da Diretriz SINAT no 005, a empresa Tecverde iniciou os procedimentos para obtenção de um Documento de Avaliação Técnica (DATec) próprio que possibilitaria o financiamento de suas edificações em agências públicas como a CEF, inclusive inserindo o sistema wood frame na produção de habitações sociais do PMCMV em vigência. Isso significaria um aumento significativo para sua produção tendo em vista que os empreendimentos sociais deste programa estavam, geralmente, sendo construídos em larga escala.

Para o processo de homologação do DATec no 20, primeiro, a Tecverde elaborou e determinou os detalhes do sistema construtivo proposto denominado "Tecverde - Sistema leve em madeira" destinado para unidades unifamiliares térreas isoladas ou geminadas. Nesta caracterização, especificou-se em especial as paredes do sistema com seus materiais constituintes. A seguir, descreve-se de forma resumida a composição das paredes externas de áreas secas, com base no documento oficial publicado (BRASIL, 2013).

As paredes externas são compostas por um entramado constituído de peças de madeira serrada e tratada com CCA em autoclave, com seção de $38 \mathrm{~mm} \times 89 \mathrm{~mm}$, fixadas entre si com pregos anelados. O espaçamento entre os montantes do entramado é determinado por cálculo estrutural, sendo $60 \mathrm{~cm}$ o espaçamento máximo permitido. Na face externa deste entramado, chapas OSB estruturais com 9,5 mm de espessura são alinhadas com grampos galvanizados e fixadas com pregos anelados. A base da parede recebe uma manta asfáltica impermeabilizante até $20 \mathrm{~cm}$ de altura. Na sequência, a membrana hidrófuga 
é fixada sobre a chapa OSB com grampos galvanizados. Por fim, as placas cimentícias com 8 $\mathrm{mm}$ de espessura são fixadas e as juntas destas placas recebem tratamento aparente, com selante a base de poliuretano e uma demão de textura acrílica. Na face interna, o entramado em madeira é fechado com chapas de gesso acartonado com 12,5 mm de espessura, fixados com parafusos de rosca soberba (Figura 88) (BRASIL, 2013).

No acabamento entre o painel de parede e o piso, um cordão de polietileno e selante de poliuretano são aplicados para vedar a fresta de encontro destes dois elementos construtivos (Figura 88). Ainda, na interface entre parede e piso de áreas secas é feita uma impermeabilização aplicando argamassa polimérica flexível até $25 \mathrm{~cm}$ de altura, e nas áreas molhadas, como o box, este material é aplicado até $150 \mathrm{~cm}$ de altura (BRASIL, 2013).

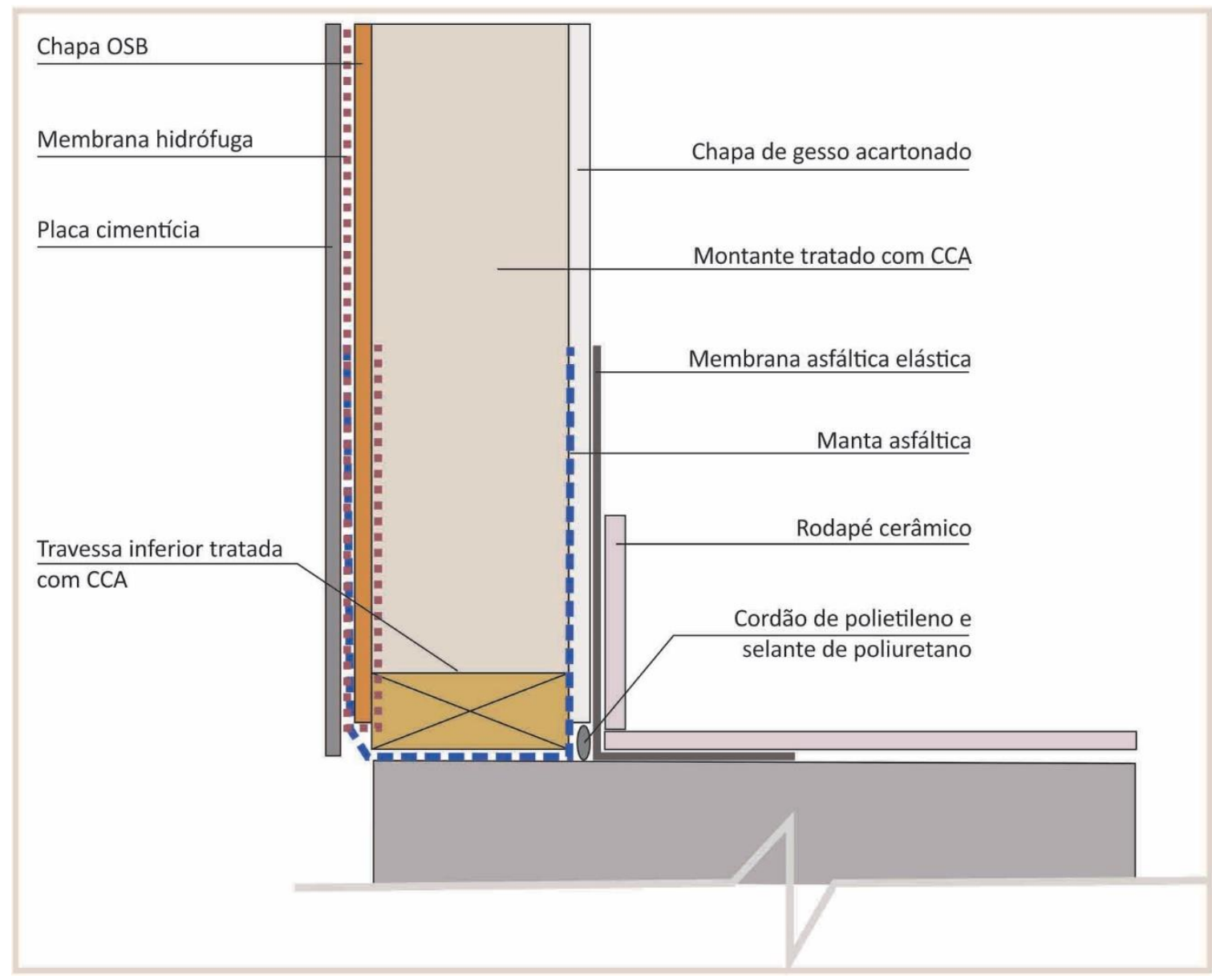

Figura 88: Composição da parede externa de áreas secas conforme dados do DATec 20 Fonte: autora com base em Brasil, 2013.

Além destes detalhes para paredes externas de áreas secas, o DATec no 20 ainda apresenta as caracterizações dos componentes para: paredes externas de áreas molháveis e 
molhadas; paredes de geminação, isto é, paredes de divisão entre unidades habitacionais distintas; interface entre parede e oitão interno na divisão das unidades geminadas; interface entre paredes e esquadrias; interface com tubulações hidráulicas e elétricas, reforço das paredes para fixação de peças suspensas.

Outras informações apresentadas no DATec no 20 são referentes ao processo de produção dos painéis de parede na fábrica e sua montagem no canteiro. Nesta produção, um sistema de qualidade foi desenvolvido pela Tecverde, onde os materiais recebidos e os elementos produzidos na fábrica devem ser inspecionados e identificados para sua rastreabilidade futura.

Por fim para homologação deste sistema proposto, a empresa Tecverde contratou ITA's, que seguindo as referências da Diretriz SINAT 005 para o wood frame, realizaram as seguintes avaliações técnicas principais: desempenho estrutural, estanqueidade à água, desempenho térmico, desempenho acústico, durabilidade e manutenabilidade, segurança ao fogo. Os ensaios realizados e as fichas técnicas apresentadas estão descritos na Tabela 11, conforme as ITA's que executaram esses procedimentos.

Ainda, para realizar alguns destes ensaios, em meados de 2012, a empresa construiu um protótipo de uma unidade habitacional térrea na cidade de Curitiba, como projeto similar aos especificados pela CEF para residências populares da Faixa 1 do PMCMV (Figura 89).

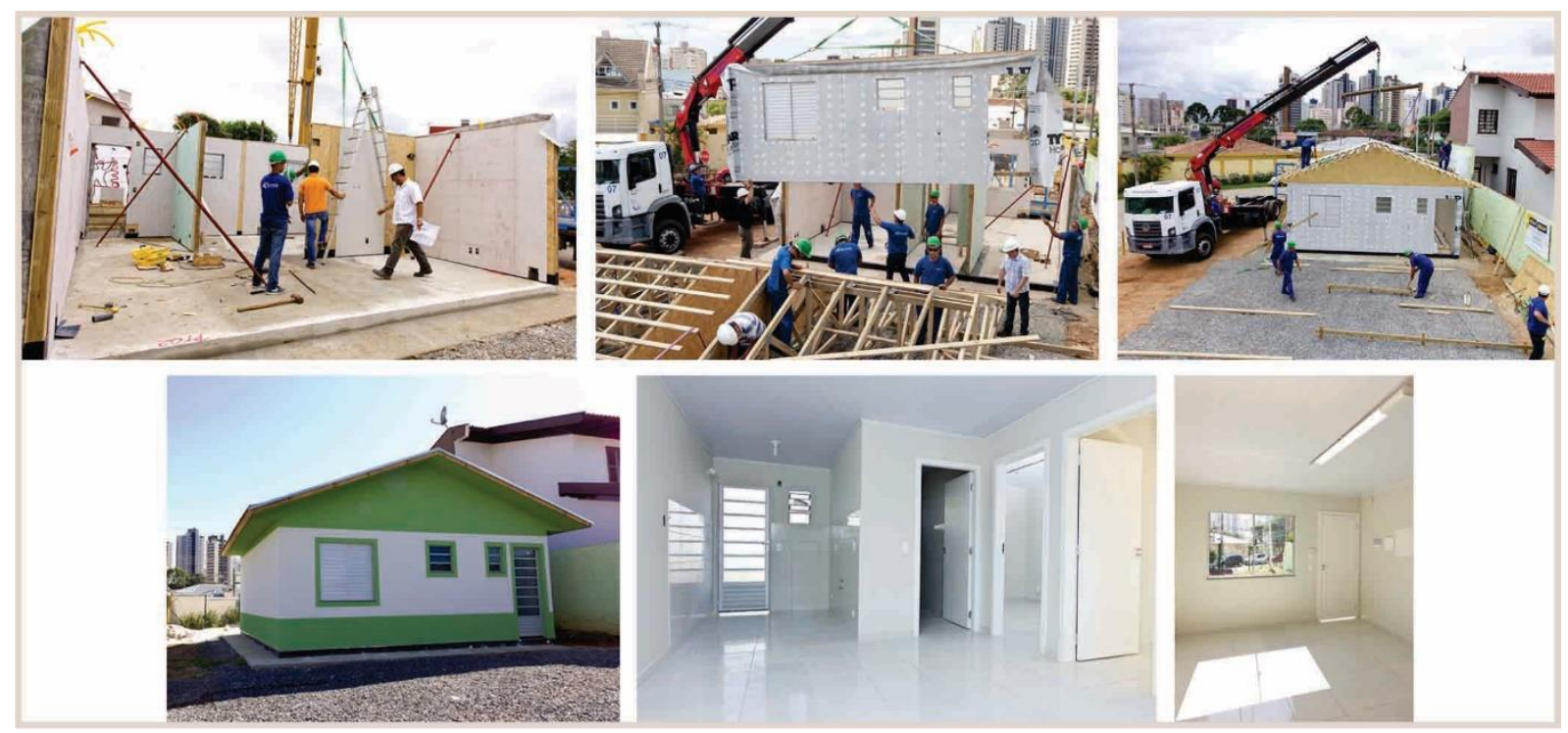

Figura 89: Protótipo de casa popular construída pela empresa Tecverde em Curitiba, Paraná Fonte: Brasil, 2013; Tecverde, 2015. 
Tabela 11: Instituições de pesquisa e ensaios técnicos realizados para obtenção do DATec 20

\begin{tabular}{|c|c|}
\hline Instituição & Ensaio técnico \\
\hline \multirow{8}{*}{$\begin{array}{l}\text { Instituto Falcão Bauer de Qualidade } \\
\text { (IFBQ) - São Paulo, SP }\end{array}$} & Relatório Técnico de Avaliação (RTA) \\
\hline & Inspeção de campo \\
\hline & Resistência à compressão \\
\hline & Impactos de corpo mole e de corpo duro \\
\hline & Solicitações transmitidas por portas para as paredes \\
\hline & Resistência a solicitações de cargas de peças suspensas \\
\hline & Estanqueidade na interface parede/janela \\
\hline & Estanqueidade e choque térmico da parede de fachada \\
\hline \multirow{2}{*}{ Institutos LACTEC - Curitiba, PR } & $\begin{array}{l}\text { Resistência a solicitações de cargas de peças suspensas - } \\
\text { rede de dormir }\end{array}$ \\
\hline & Névoa salina neutra em componentes de fixação metálicos \\
\hline \multirow{12}{*}{$\begin{array}{l}\text { Instituto de Pesquisa Tecnológica (IPT) - } \\
\text { São Paulo, SP }\end{array}$} & $\begin{array}{l}\text { Avaliação de desempenho térmico de casa térrea isolada } \\
\text { nas oito Zonas Bioclimáticas Brasileiras }\end{array}$ \\
\hline & Resistência ao fogo em parede com função estrutural \\
\hline & Índice de propagação superficial de chama - chapa de OSB \\
\hline & Densidade óptica específica de fumaça - chapa de OSB \\
\hline & Índice de propagação superficial de chama - réguas de PVC \\
\hline & Incombustibilidade da lã de escória e vidro \\
\hline & Incombustibilidade da lã de rocha basáltica \\
\hline & $\begin{array}{l}\text { Resistência ao ataque de cupins de madeira seca em } \\
\text { painéis de OSB }\end{array}$ \\
\hline & Ensaios em chapas de OSB \\
\hline & Isolação sonora da lã de escória e vidro \\
\hline & Condutividade térmica da lã de escória e vidro \\
\hline & Permeabilidade ao vapor de água da barreira impermeável \\
\hline \multirow{2}{*}{$\begin{array}{l}\text { Laboratório de Materiais de Construção } \\
\text { Civil da Universidade Federal de Santa } \\
\text { Maria (UFSM) - Santa Maria, RS }\end{array}$} & Isolação sonora de fachada \\
\hline & Isolação sonora de paredes geminadas entre dormitórios \\
\hline \multirow{2}{*}{$\begin{array}{l}\text { Laboratório Ciências da Madeira da } \\
\text { Universidade Federal de Pelotas (UFPel) } \\
\text { - Pelotas, RS }\end{array}$} & Identificação de espécie da Madeira \\
\hline & Compressão da madeira \\
\hline $\begin{array}{l}\text { Empresa Montana Química S.A. - São } \\
\text { Paulo, SP }\end{array}$ & Retenção e Penetração de CCA \\
\hline $\begin{array}{l}\text { Laboratório de ensaios técnicos do } \\
\text { SENAI-PR - São José dos Pinhais, PR }\end{array}$ & $\begin{array}{l}\text { Densidade básica e aparente e flexão da madeira maciça } \\
\text { Pinus }\end{array}$ \\
\hline \multirow{2}{*}{$\begin{array}{l}\text { Laboratório de Ensaios de Referência } \\
\text { (LabER) }\end{array}$} & Certificação de placas cimentícias planas \\
\hline & $\begin{array}{l}\text { Envelhecimento acelerado por imersão/secagem de placas } \\
\text { cimentícias planas }\end{array}$ \\
\hline Empresa Rock Fibras & Ficha técnica de isolantes térmicos e acústicos \\
\hline Empresa Kanuf & $\begin{array}{l}\text { Ficha técnica de chapas de gesso acartonado Standard e } \\
\text { Resistente à Umidade }\end{array}$ \\
\hline Empresa / marca Typar & Ficha técnica da barreira impermeável \\
\hline Empresa / marca Drykomanta & Ficha técnica da manta impermeabilizante \\
\hline $\begin{array}{l}\text { Empresa / marca Monopol PU } 25 \text { - } \\
\text { Viapol }\end{array}$ & Ficha técnica do selante para preenchimento de juntas \\
\hline
\end{tabular}

Fonte: elaborado pela autora com base em Brasil, 2013.

Por fim, com base nos dados técnicos apresentados pelas instituições em cada ensaio, o Instituto Falcão Bauer de Qualidade (IFBQ) foi o responsável para elaborar o Relatório 
Técnico de Avaliação para o sistema construtivo Tecverde. Na sequência, foram realizadas auditorias e o DATec elaborado foi encaminhado para ser avaliado por colegiados do SINAT, no âmbito do PBQP-H do MCidades. Após aprovado, em outubro de 2013 o DATec no 20 proposto pela empresa Tecverde foi emitido (Figura 90) (BRASIL, 2013).

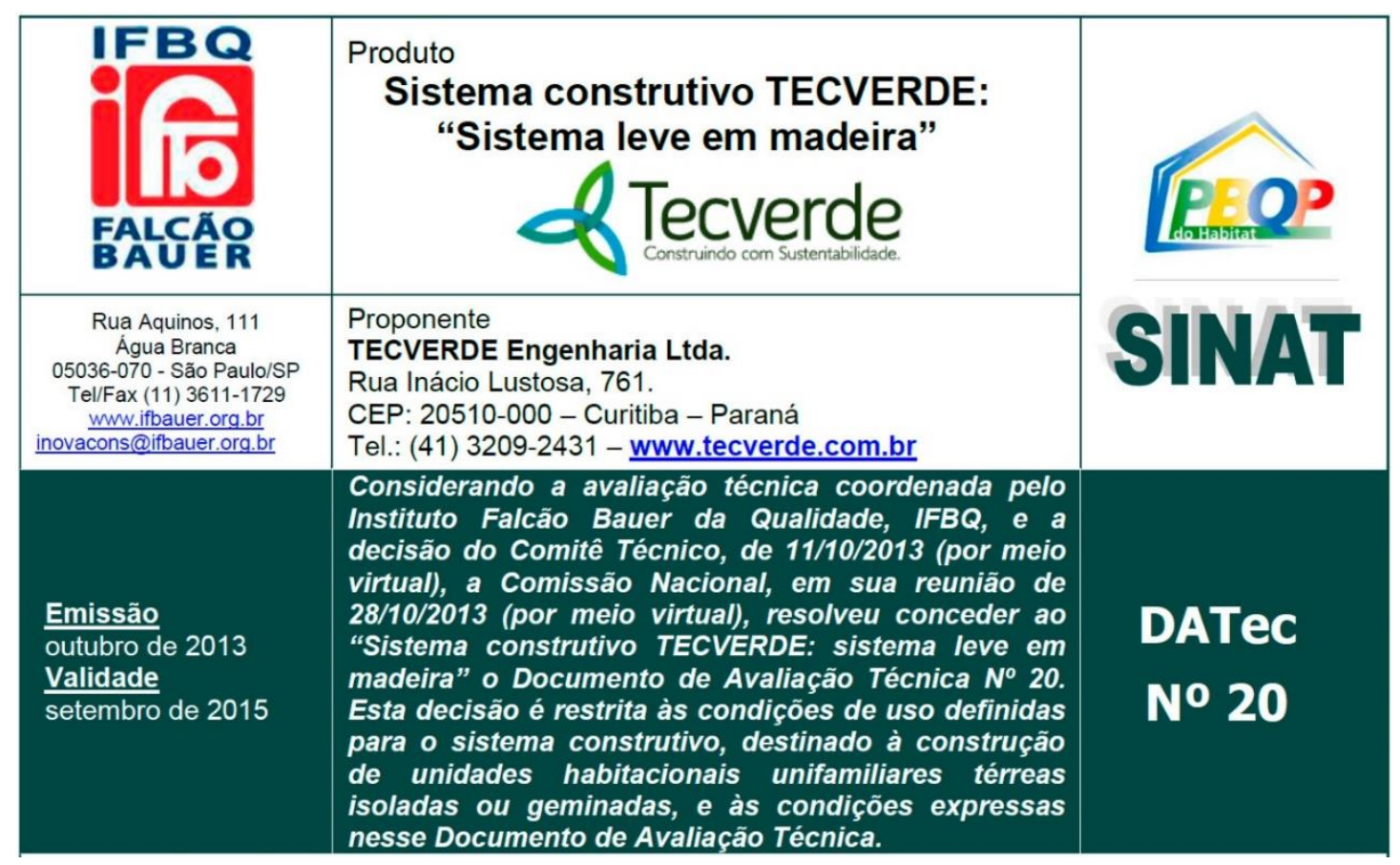

Figura 90: Publicação do DATec no 20 para o sistema construtivo leve em madeira da Tecverde Fonte: Brasil, 2013.

Como proponente deste sistema homologado, a empresa Tecverde passou a ser a responsável pela qualidade do produto aprovado. Assim, quando executado nestes preceitos, a empresa deve seguir as especificações e normas técnicas descritas no DATec vigente, a fim de garantir as condições de qualidade e de desempenho conforme especificações das avaliações técnicas realizadas pelo SINAT. Como detentora da tecnologia, a empresa tem a responsabilidade de controlar a aplicação deste sistema construtivo específico (BRASIL, 2013).

Sob esta nova perspectiva, a empresa Tecverde pretendeu atuar com um novo modelo de negócios, o qual, por um primeiro momento, passou a ser denominado Rede iVerde e, depois, Rede Tecverde 22 . A proposta da Tecverde era de cessão e de licenciamento do seu

\footnotetext{
${ }^{22}$ Atualmente, em 2016, apesar da empresa Tecverde continuar focada em parcerias com outras construtoras brasileiras interessadas em produzir com seu sistema construtivo wood frame homologado, o modelo de negócios da empresa é diferente deste primeiro proposto pela Rede iVerde. Este modelo da Rede iVerde / Tecverde com esses objetivos deliberados em meados de 2012 logo deixou de existir.
} 
produto homologado wood frame para que a outra empresa fosse possibilitada de executar obras financiadas a partir deste DATec no 20. Além da transferência de conhecimento e do suporte prestado ao construtor interessado em executar com o sistema inovador, a empresa, enquanto detentora e responsável pela tecnologia mediante o SINAT, deveria monitorar a utilização da tecnologia, sendo corresponsável pelas obras (REDE TECVERDE, 2014).

Inicialmente, em meados de 2012, este negócio era pensado para a produção de habitações populares para o PMCMV e seus procedimentos eram assim descritos pela Rede Tecverde: (1) o construtor interessado contatava a Rede com um empreendimento habitacional em análise ou aprovado, (2) em conjunto desenvolviam os projetos arquitetônicos e os orçamentos estimados, (3) o contrato de licenciamento da tecnologia era fechado, (4) implantava-se a fábrica para o construtor ou ele comprava painéis pré-fabricados por outras empresas, (5) a rede fornecia o treinamento da equipe, (6) a produção era iniciada com apoio na gestão técnico-operacional da fábrica e (7) a Rede prestava suporte de engenharia e de monitoramento de qualidade (REDE TECVERDE, 2014).

Neste processo, a Tecverde não seria necessariamente a responsável direta pelos empreendimentos solicitados ao PMCMV. Enquanto as demais construtoras viabilizariam o empreendimento social mediante os órgãos responsáveis, como prefeitura e CEF, a Tecverde seria corresponsável pela execução destas obras, pois, assim, exercia o controle de qualidade do seu produto homologado, conforme as exigências do DATec no 20 e do SINAT.

Ainda, em meados de 2011, em data anterior ao processo do DATec $\mathrm{n}$ 을 20, a empresa Tecverde estabeleceu sua primeira parceria com uma construtora na execução de um empreendimento com 280 unidades habitacionais inserido no PMCMV. A construtora Roberto Ferreira, que estava viabilizando a construção do Residencial Haragano no PMCMV, entrou em contato com a Tecverde, a qual passou a atuar como consultora técnica neste processo de produção. Como resultado, o Residencial Haragano se destacou como o primeiro empreendimento social construído com o sistema wood frame no Brasil, financiado por agentes públicos. Devido à importância desta ocorrência, esse processo de produção é caracterizado no capítulo seguinte. 


\section{RESIDENCIAL HARAGANO - INTRODUÇÃO DO WOOD FRAME NO PROGRAMA MINHA CASA MINHA VIDA}

O residencial Haragano, primeiro empreendimento social constituído com sistema estruturado com peças leves em madeira - wood light frame, inserido no programa MCMV faixa 1, ou seja, destinado para famílias com renda máxima de 3 salários mínimos (s.m.). 0 residencial está localizado na zona urbana da cidade de Pelotas, situada na mesorregião sudeste do Rio Grande do Sul (RS), na margem da Lagoa dos Patos, de acordo com as ilustrações da Figura 91.

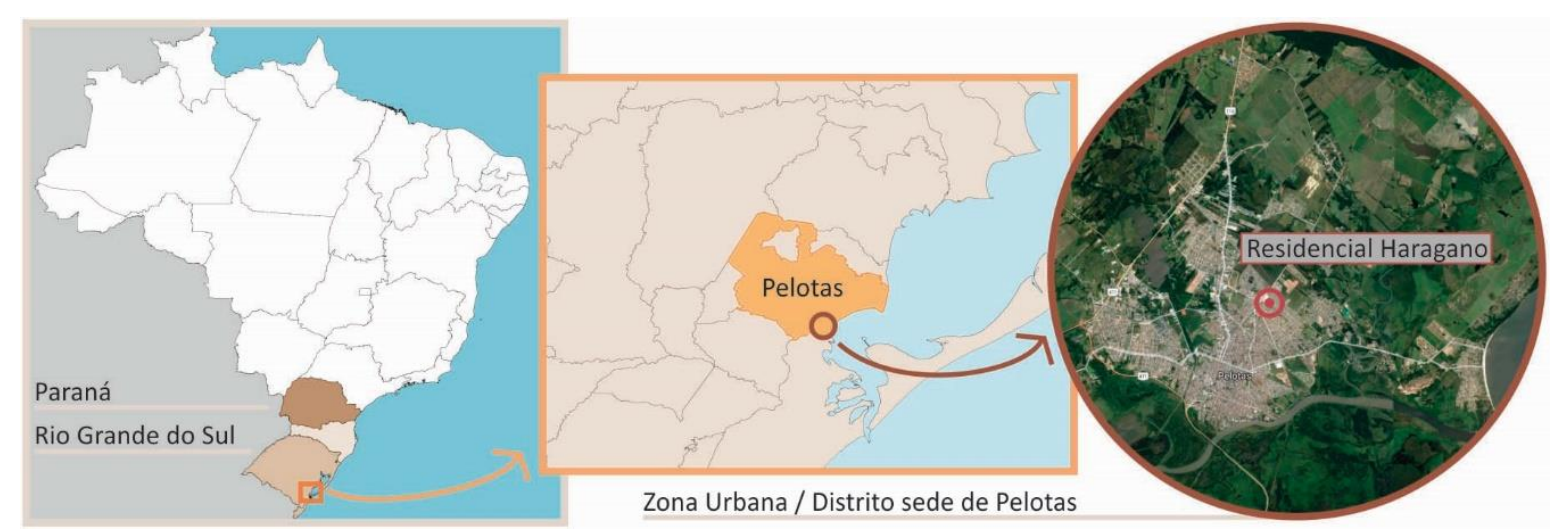

Figura 91: Localização do residencial Haragano no município de Pelotas, RS Fonte: elaborado pela autora com base em mapas base do IBGE (2010) e GoogleMaps (2016).

Conforme os dados apresentados no censo demográfico publicado pelo IBGE em 2010, Pelotas apresentava 328.275 habitantes, portanto era considerado o terceiro município mais populoso de RS, contabilizado após as cidades de Porto Alegre e Caxias do Sul. Neste período, a cidade apresentava um total aproximado de 114.000 domicílios particulares permanentes ${ }^{23}$ (IBGE, 2010). Ainda, a Fundação João Pinheiro (FJP) calculou que a região metropolitana de Pelotas apresentava um déficit habitacional absoluto de 17.019 residências (FJP, 2013).

Com base nestes dados estatísticos e outros critérios de seleção estabelecidos pelo Ministério das Cidades (MCidades), Pelotas, estava entre as cidades contempladas para a

\footnotetext{
${ }^{23}$ Interessante observar que do total das residências particulares permanentes, estimou-se que $94,99 \%$ eram construídas com alvenaria, 4,84\% eram construções com madeira aproveitada ou aparelhada e os $0,17 \%$ restantes, com outros materiais (IBGE, 2010). Esses valores fornecem uma breve evidência de como a tradição das construções com paredes estruturadas em madeira, trazidas pelos imigrantes centro-europeus, não está mais presente na cultura local. Assim, a prática comum de vedação e estrutura das residências atuais em Pelotas é com alvenaria cerâmica e concreto.
} 
primeira fase do programa habitacional nacional MCMV, iniciado no ano de 2009. Este fato foi confirmado pela Superintendência Regional Extremo Sul da CEF do Rio Grande do Sul em uma reunião realizada no mês de abril de 2009 com representantes do município, da indústria da construção e da Gerência de Desenvolvimento Urbano da CEF em Porto Alegre (GIDUR/PO) (DIÁRIO POPULAR, 2009).

Para o Sindicato da Indústria da Construção e Mobiliário de Pelotas e Região (SINDUSCON-Pelotas), esta notícia era propícia para aquele momento, pois poderia ser a oportunidade de transição para o setor da construção local que vinha enfrentando dificuldades provenientes da crise econômica e financeira. Portanto, após a publicação da Medida Provisória № 456 de 26/03/2009 que instituiu as primeiras resoluções do PMCMV, o SINDUSCON-Pelotas, a CEF e a prefeitura local estabeleceram estratégias de parcerias para consolidar a execução deste programa no município de Pelotas (DIÁRIO POPULAR, 2009).

Primeiramente, a Prefeitura de Pelotas oficializou sua participação no PMCMV ao assinar o termo de adesão mediante a CEF, no dia 22 de abril de 2009. Ainda nesse mês, a Secretaria Municipal de Habitação desta prefeitura fez um levantamento sobre a demanda habitacional do município. E, até o dia 30 de abril, conforme as três faixas salariais estabelecidas pelo PMCMV, o número de famílias interessadas inclusas neste cadastro era contabilizado assim pelo Serviço de Inscrição e Análise de Demanda: 1.792 na Faixa 1, 144 na Faixa 2 e 20 na Faixa 3 (PREFEITURA MUNICIPAL DE PELOTAS, 2009a). A partir dessa data, conforme avançava o PMCMV, novas inscrições de interessados eram agendadas no cadastro de habitação social, em especial para os possíveis beneficiários da Faixa 1.

O SINDUSCON-Pelotas constatou o interesse de 14 empresas construtoras associadas em participar do PMCMV - Faixa 1. Portanto, a CEF reuniu-se com estas empresas e apresentou informações institucionais e técnicas sobre a execução do programa. Ainda, em paralelo, o sindicato, representando tais empresas, manifestou algumas petições para a prefeitura com intuito de estimular a inserção das mesmas no PMCMV. Por exemplo, solicitou - levantamento das áreas que a prefeitura disponibilizaria para construção dos empreendimentos e indicou as necessidades de isenção de impostos e tributos e de desburocratização e agilidade no processo para execução das obras (PREFEITURA MUNICIPAL DE PELOTAS, 2009b).

Neste sentido, a Prefeitura, através da Lei № 5.603 de 03/08/2009, instituiu o programa habitacional municipal denominado "Pelotas Habitação Digna”, a fim de viabilizar a 
construção de habitações populares dentro do programa federal MCMV. Dentre as particularizações desta lei, o poder executivo, mediante a publicação de editais específicos, foi autorizado a doar terrenos de propriedade do município ao Fundo de Arrendamento Residencial (FAR) para a construção de habitações que contemplem a Faixa 1 deste programa social. Ainda, em outro aspecto, esta lei municipal isenta os empreendimentos da Faixa 1 e 2 e reduz em 90\% para os empreendimentos da Faixa 3 os seguintes impostos e taxas:

- Imposto sobre Transmissão de Bens Imóveis - ITBI - sobre a aquisição de imóveis pelo Construtor, pela Caixa Econômica Federal, bem como sobre a aquisição pelo mutuário final.

- Imposto sobre a Propriedade Predial e Territorial Urbano - IPTU durante a execução do Projeto e durante o período em que o Construtor e a Caixa Econômica Federal detiverem a propriedade dos imóveis destinados às edificações, somente até a conclusão das obras de construção das unidades habitacionais.

- Impostos sobre Serviços de Qualquer Natureza - ISSQN - incidente sobre os serviços prestados na consecução das edificações, desde que observadas as obrigações acessórias e formalidades exigidas por norma tributária.

- Taxas incidentes sobre formalidades necessárias à execução e aprovação das obras (PELOTAS, Lei № 5.603, 2009).

Por fim, como resultado, na região metropolitana de Pelotas, desde 2009 até o mês de setembro de 2015, foram contabilizadas as seguintes unidades habitacionais (UHs) contratadas: 294 UHs na Faixa 1 - modalidade Rural; 234 na Faixa 1 - modalidade Entidades; 2.800 UHs na Faixa 1 - modalidade Fundo de Arrendamento Residencial (FAR) (Tabela 12); 6.866 UHs na Faixa 2 - modalidade Conselho Curador do Fundo de Garantia do Tempo de Serviço (CCFGTS) (Tabela 13); e 1.237 UHS na Faixa 3 - modalidade CCFGTS (Tabela 13) (MCidades; SNH, 2015).

Conforme estes dados, até setembro de 2015, cinco empresas de engenharia e construção participaram na execução de dez empreendimentos na Faixa 1 - FAR. Quatro destes 10 empreendimentos ainda não haviam sido concluídos e entregues nesta data. Mas, no fim de dezembro de 2015, a Prefeitura Municipal de Pelotas já havia sorteado os moradores contemplados para estes quatro empreendimentos restantes. 
Tabela 12: Empreendimentos, construtoras e unidades habitacionais na Faixa 1 - FAR do PMCMV em Pelotas

\begin{tabular}{|c|c|c|c|c|}
\hline $\begin{array}{l}\text { Empreendimento } \\
\text { (Data de contrato) }\end{array}$ & Construtora & $\begin{array}{c}\text { Unidades } \\
\text { Habitacionais } \\
\text { contratadas }\end{array}$ & $\begin{array}{c}\text { Unidades } \\
\text { Habitacionais } \\
\text { concluídas }\end{array}$ & $\begin{array}{c}\text { Valor total } \\
\text { contratado } \\
(R \$)\end{array}$ \\
\hline $\begin{array}{l}\text { Res. Eldorado } \\
(25 / 09 / 2009)\end{array}$ & $\begin{array}{c}\text { Roberto Ferreira Comercial e } \\
\text { Construtora LTDA }\end{array}$ & 420 & 420 & 17.976 .000 \\
\hline $\begin{array}{l}\text { Res. Jardins do Obelisco } \\
(14 / 01 / 2010)\end{array}$ & $\begin{array}{c}\text { ZECON - Zechlinski Engenharia } \\
\text { e Construção LTDA }\end{array}$ & 240 & 240 & 10.467 .038 \\
\hline $\begin{array}{l}\text { Res. Fragata } \\
(23 / 02 / 2010)\end{array}$ & Ricardo Ramos Construtora & 340 & 340 & 15.171 .978 \\
\hline $\begin{array}{l}\text { Res. Buenos Aires } \\
(09 / 07 / 2010)\end{array}$ & Labore Engenharia LTDA & 240 & 240 & 10.781 .061 \\
\hline $\begin{array}{l}\text { Res. Montevideo } \\
(09 / 07 / 2010)\end{array}$ & Labore Engenharia LTDA & 240 & 240 & 10.800 .000 \\
\hline $\begin{array}{l}\text { Res. Haragano } \\
(01 / 02 / 2012)\end{array}$ & $\begin{array}{c}\text { Roberto Ferreira Comercial e } \\
\text { Construtora LTDA }\end{array}$ & 280 & 280 & 14.829 .498 \\
\hline $\begin{array}{l}\text { Res. Acácia } \\
(31 / 07 / 2013) \\
\end{array}$ & $\begin{array}{c}\text { ZECON - Zechlinski Engenharia } \\
\text { e Construção LTDA }\end{array}$ & 240 & - & 15.360 .000 \\
\hline $\begin{array}{l}\text { Res. Amazonas } \\
(31 / 07 / 2013) \\
\end{array}$ & $\begin{array}{c}\text { Serial Engenharia e Estruturas } \\
\text { LTDA }\end{array}$ & 280 & - & 17.829 .036 \\
\hline $\begin{array}{l}\text { Res. Azaleia } \\
(31 / 07 / 2013)\end{array}$ & $\begin{array}{c}\text { Serial Engenharia e Estruturas } \\
\text { LTDA }\end{array}$ & 240 & - & 15.282 .030 \\
\hline $\begin{array}{l}\text { Res. Roraima } \\
(31 / 07 / 2013)\end{array}$ & Labore Engenharia LTDA & 280 & - & 17.829 .036 \\
\hline \multicolumn{2}{|r|}{ Total } & 2.800 & 1.760 & 146.325 .676 \\
\hline
\end{tabular}

Fonte: elaborado pela autora com base em MCidades; SNH, 2015 e Prefeitura Municipal de Pelotas, 2013.

Tabela 13: Unidades habitacionais contratadas e concluídas nas Faixas 2 e 3 do PMCMV em Pelotas

\begin{tabular}{||l|c|c|c|c||}
\hline Faixa & Modalidade & $\begin{array}{c}\text { Unidades } \\
\text { Habitacionais } \\
\text { contratadas }\end{array}$ & $\begin{array}{c}\text { Unidades } \\
\text { Habitacionais } \\
\text { concluídas }\end{array}$ & $\begin{array}{c}\text { Valor total } \\
\text { contratado (R\$) }\end{array}$ \\
\hline \hline Faixa 2 & CCFGTS & 6.866 & 5.833 & 527.240 .635 \\
\hline Faixa 3 & CCFGTS & 1.237 & 337 & 52.775 .700 \\
\hline \hline \multicolumn{2}{|c|}{ Total } & 8.103 & 6.170 & 580.016 .336 \\
\hline
\end{tabular}

Fonte: elaborado pela autora com base em MCidades; SNH, 2015.

Destes empreendimentos sociais construídos em Pelotas, grande parte foi edificado com materiais considerados tradicionais, como vedação em alvenaria estruturada com concreto armado. Assim, o Residencial Haragano da construtora local Roberto Ferreira, construído com um sistema inovador estruturado com elementos pré-fabricados em madeira, passou a ter destaque na imprensa local e nacional, a qual, desde então, descreveu com maior frequência os aspectos gerais e diferenciais do sistema aplicado wood frame. Tal repercussão na mídia, em geral, relacionou esta construção com palavras-chave positivas, como: 
sustentabilidade, redução de $\mathrm{CO}_{2}$, redução do prazo total da obra, redução de custos, préfabricação. E, em geral, conforme alguns comentários replicados pela população nestes artigos publicados, observa-se que estes estão instigados a saber mais sobre a aplicação do wood frame nas diversas regiões brasileiras. No entanto, outros comentários demonstram que a desinformação aliada ao constante preconceito popular contra construções em madeira traz uma reação negativa e receosa quanto a este sistema inovador em madeira.

Portanto, é necessário ampliar os estudos e a divulgação da construção com sistema wood frame no Brasil, para que, gradualmente, sua tecnologia seja aprimorada ao contexto das diversas regiões brasileiras e, consequentemente, o conceito popular esclarecido. No entanto, até o momento, não há pesquisas acadêmicas que aprofundam a análise sobre este primeiro empreendimento social construído com tal sistema em madeira. Tanto as especificidades técnicas do sistema quanto o processo desta produção devem ser explanados.

Deste modo, conforme o objetivo de contribuição desta tese, este capítulo apresenta a caracterização do processo de produção do estudo de caso do Residencial Haragano, que adota o sistema construtivo inovador wood frame, detalhando os seguintes fatores: quem foram os agentes deste processo, qual sistema construtivo selecionado, quais detalhes arquitetônicos das residências de um e dois pavimentos, como ocorreu sua execução em fábrica e no canteiro, que orientações os moradores receberam sobre a manutenção do sistema inovador e como ocorreu o acompanhamento de avaliação pós-ocupação pelos responsáveis técnicos.

\subsection{AGENTES DA PRODUÇÃO NO PROCESSO DE IMPLEMENTAÇÃO DO HARAGANO}

Em novembro de 2009, o Governo do Estado do Rio Grande do Sul autorizou a doação do terreno ${ }^{24}$, sem benfeitorias, localizado na zona urbana do município de Pelotas, no loteamento Dunas do bairro Areal, com área de 3,99 ha, para o FAR, sendo assim destinado exclusivamente para construção de unidades residenciais para alienação às famílias com renda mensal de até 3 s.m. no âmbito do PMCMV. Sob posse do FAR, esse recurso passou a ser operacionalizado e gerido pela CEF (ESTADO DO RIO GRANDE DO SUL, Lei № 13.284, 2009).

\footnotetext{
${ }^{24}$ Anteriormente, este terreno era da Companhia de Habitação do Estado do Rio Grande do Sul (COHAB/RS). Mas, com a sua extinção em 1995, passou para posses do Estado do RS.
} 
Na sequência, por meio de edital de licitação para a construção do empreendimento habitacional neste terreno, a empresa Roberto Ferreira Comercial e Construtora LTDA iniciou os procedimentos para a execução do residencial Haragano neste local. Para isso, antes, esta. Com esse objetivo, os principais documentos comprobatórios exigidos pela CEF visaram verificar os seguintes itens (CEF, 2016):

- formalização da proposta da construtora à CEF;

- regularidade da constituição e da direção organizacional da empresa;

- regularidade da responsabilidade técnica;

- regularidade do FGTS perante a CEF;

- certificação de qualificação da construtora no PBQP-H;

- idoneidade nas contratações com o Governo Federal;

- solvência, ou seja, se a mesma conseguirá cumprir as condições contratadas para a construção do empreendimento;

- capacidade da empresa para o volume de obra pretendido, por meio de atestados de qualificação técnica e de realização de obras e de parecer constatando a produção simultânea de mais de 1.000 UHs, considerando todos programas habitacionais operados pela CEF, e portfólio de 500 UHs produzidas no âmbito da CEF ou no mercado e crédito imobiliário emitido pela CEF.

Em suma, ao ser questionado sobre os principais requisitos que uma construtora precisa apresentar para ser aprovada nesta análise de risco feita pela CEF, o superintendente da CEF Extremo Sul respondeu:

[...] nós temos de ter cuidado com a seleção das empresas, pois não adianta contratar serviço e depois a empresa não ter condições de entregar. A firma deve ter saúde financeira comprovada.

[...] Uma construtora deve, basicamente, comprovar a viabilidade do empreendimento que se propõe realizar, deve estar com o empreendimento em dia com a legislação, o mesmo vale para a situação do vendedor do terreno. A análise de risco da construtora precisa ser aprovada pela Caixa e deve haver contratação de seguro que garanta a entrega da unidade pronta ao proponente. Esses são os pontos principais. Sendo aprovados, a empresa torna-se apta (FILHO, 2013).

Portanto, conforme tais fatores solicitados, o histórico da construtora Roberto Ferreira foi importante para sua aprovação na CEF e participação no PMCMV. Afinal, a execução do residencial Haragano não era a primeira construção desta empresa em programas de habitação social. 
Desde sua fundação em $1953^{25}$, a construtora Roberto Ferreira atuou predominantemente no setor habitacional. Entre os anos de 1956 e 1986, período em que operava o SFH/BNH, a empresa construiu um conjunto habitacional com 192 UHs e, em sociedade com a construtora Santa Tecla, construiu outras $1.788 \mathrm{UHs}$, mediante a COHAB/RS. No ano de 1991, construiu 96 UHs em parceria com a CEF no Plano Empresário Popular (PEP). Entre os anos de 1992 e 1996, construiu 744 UHs em parceria com empresa financeira Randon Consórcios sediada em Caxias do Sul, RS. Em 1998, construiu 200 UHs através da Carta de Crédito Associativo da CEF. Por fim, entre 2001 e 2005, durante o PAR, programa habitacional que tinha a CEF como agente executor, a Roberto Ferreira afirma ter construído aproximadamente 1.057 UHs (CHIARELLI, 2014; ROBERTO FERREIRA, 2016).

Sendo assim, a construtora tinha um demonstrativo histórico significativo de sua capacidade de cumprir os contratos de construção de empreendimentos habitacionais com grande volume de produção. E, portanto, em 2009, foi aprovada como credenciada da CEF para participar no PMCMV. Ainda neste ano, no mês de setembro, a empresa Roberto Ferreira assinou um contrato para executar seu primeiro empreendimento no PMCMV, Faixa 1-FAR, denominado Residencial Eldorado, conforme listado na Tabela 12 já apresentada. Suas 420 UHs foram entregues em maio de 2011. No entanto, apesar desta inserção da construtora Roberto Ferreira no PMCMV, cada proposta de execução de empreendimento deveria ser avaliada de forma individual e específica no âmbito da GIDUR da CEF.

Desta forma, em 2011, a construtora Roberto Ferreira iniciou os procedimentos para a execução do seu segundo empreendimento no PMCMV, Faixa 1-FAR - o Residencial Haragano, constituído por 270 sobrados e 10 casas térreas, totalizando 280 UHs. Primeiramente, a empresa apresentou sua proposta, enviando para a GIDUR/PO da CEF documentos primários, contendo identificação, localização, custos preliminares, memorial descritivo e projetos arquitetônicos. Porém, nesta proposta do residencial Haragano enviada à $C E F$, havia um diferencial que era a utilização de um sistema construtivo não-convencional para as edificações no Brasil.

\footnotetext{
25 “Em 1953 a empresa teve sua fundação sob a razão social de Menna Barreto S.A. A partir de 1968, com a entrada do Engenheiro Civil Roberto Ferreira frente à direção do grupo, passou a se chamar Roberto Ferreira Comercial e Construtora Ltda. Na década de 80 a empresa passou a ser dirigida pela nova geração, através de uma natural sucessão familiar, sendo desde então dirigida pelo Engenheiro Civil Ricardo Targa Ferreira" (ROBERTO FERREIRA, 2016).
} 
A construtora Roberto Ferreira, ao longo de seu histórico de produção de edificações residenciais, se propôs a aplicar diferentes soluções tecnológicas nas suas construções, visando a racionalização das mesmas para otimizar, por exemplo, tempo e custos envolvidos nesse processo, tendo como foco principal as habitações populares. Dentre estas tecnologias, a empresa relatou os seguintes produtos: blocos de concreto produzidos no canteiro de obras, alvenaria estrutural com blocos cerâmicos, argamassas industrializadas, esquadrias padronizadas e prontas para instalação na obra, lajes pré-moldadas em fábrica "piloto" da empresa. Também, executou protótipos para experimentação do sistema leve em aço - steel frame (ROBERTO FERREIRA, 2016).

Além destes casos, em meados do ano 2002, a empresa destacou o desenvolvimento e o patenteamento do sistema construtivo denominado Monta Bloco, o qual consistia na utilização de blocos de concreto intertravados e assentados a seco. A viabilidade deste sistema foi analisada e aprovada pela GIDUR/PO da CEF. Assim, foi aplicado na construção de, aproximadamente, 500 casas (ROBERTO FERREIRA, 2016).

Estas inovações ocorreram mediante parcerias da empresa Roberto Ferreira com fornecedores das cadeias de produção em questão e com instituições de ensino e pesquisa da área da construção. Dentre estas instituições, relatou-se: a Universidade Federal de Santa Maria (UFSM), a Fundação de Ciência e Tecnologia (CIENTEC) - vinculada à Secretaria de Desenvolvimento Econômico, Ciência e Tecnologia do Estado do Rio Grande do Sul, a Universidade Federal do Rio Grande (FURG), a Universidade Católica de Pelotas (UCPel), o Núcleo Orientado para a Inovação da Edificação (NORIE) da Universidade Federal do Rio Grande do Sul (UFRGS), o Centro Federal de Educação Tecnológica de Pelotas (CEFET/Pelotas) (ROBERTO FERREIRA, 2016).

Para o caso específico do residencial Haragano, ressalta-se a parceria da empresa Roberto Ferreira com a Universidade Federal de Pelotas (UFPel), em meados de 2010, com objetivo de utilizar o sistema construtivo denominado Morar Melhor ${ }^{26}$. Este sistema foi desenvolvido em projeto coordenado pela professora Margarete Regina Freitas Gonçalves, da Faculdade de Arquitetura e Urbanismo (FAUrb/UFPel), em meados de 2005.

Em suma, a proposta do sistema Morar Melhor consistia em paredes estruturadas com entramados em madeira de eucalipto, vedadas externamente com placas cimentícias e

\footnotetext{
${ }^{26}$ A proposta do Projeto Morar Melhor é detalhada neste trabalho no item 7.3 que abrange o tema sobre o sistema construtivo utilizado no residencial Haragano.
} 
internamente com lambris de pinus. Em 2006, mediante parcerias da UFPel com empresas fornecedoras de insumos, foi construído um protótipo de uma habitação popular para avaliar fatores de desempenho, como qualidade, durabilidade, conforto térmico. Outra análise elaborada foi a de estimativa de custos. A partir destes resultados, em 2007, a viabilidade do sistema Morar Melhor obteve o parecer favorável da GIDUR/PO. Como consequência, com esta homologação, este sistema poderia ser financiado pela CEF na construção de habitações populares térreas (DIÁRIO POPULAR, 2007).

Assim, em 2010, a empresa Roberto Ferreira, interessada em aplicar o sistema homologado Morar Melhor na construção de empreendimentos da Faixa 1 do PMCMV, construiu um protótipo de habitação em parceria com a UFPel e com o engenheiro civil representante de uma empresa fabricante e fornecedora de placas cimentícias (Figura 92).

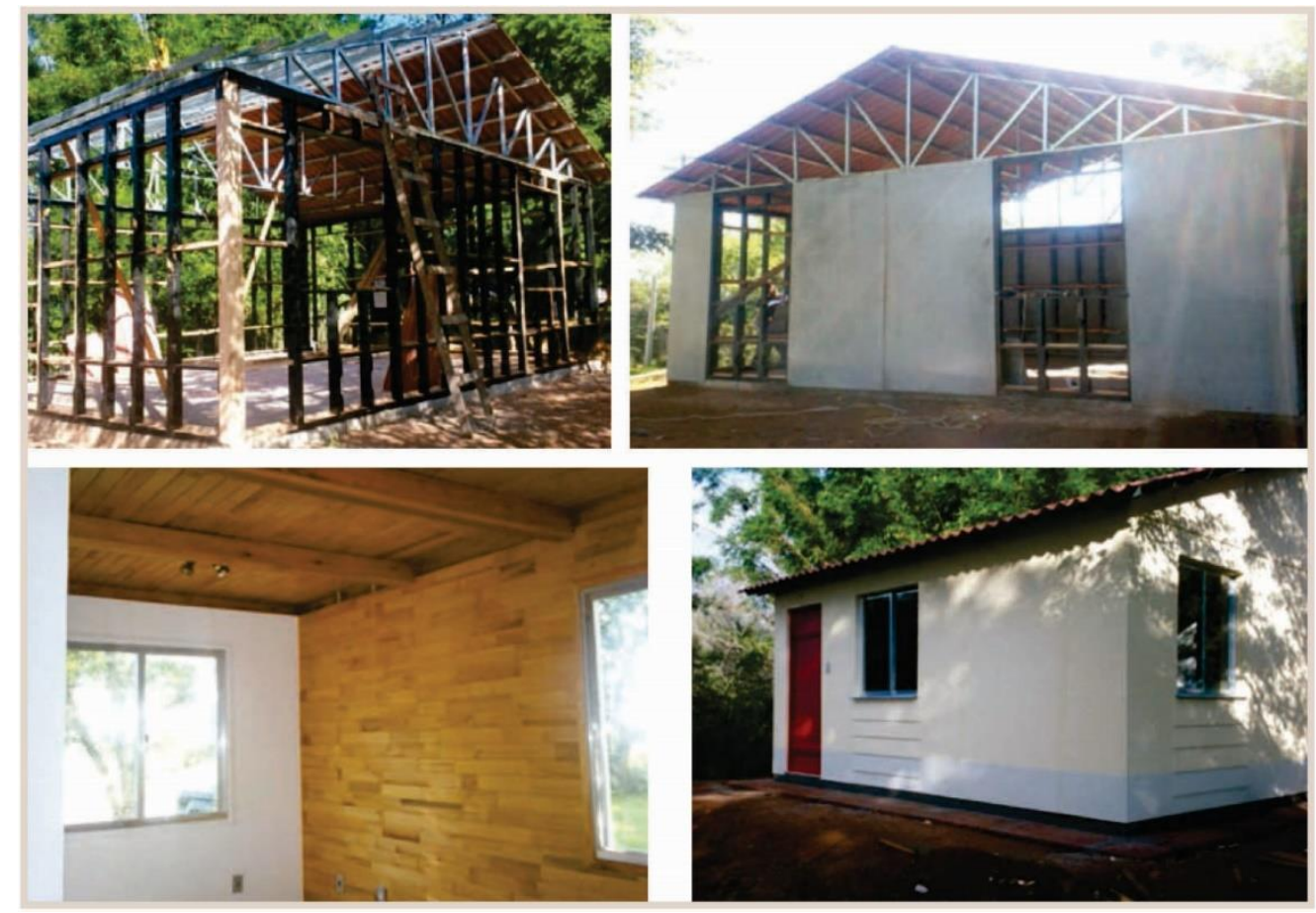

Figura 92: Protótipo construído em 2010 com sistema Morar Melhor Fonte: Roberto Ferreira, 2016.

Em 2011, no âmbito do PMCMV, a empresa Roberto Ferreira encaminhou a documentação do Residencial Haragano propondo a utilização deste sistema construtivo Morar Melhor, já homologado, para a análise de viabilidade prévia feita pela GIDUR/PO. Com a aprovação, em janeiro e fevereiro de 2012, o contrato entre a CEF e a Roberto Ferreira, assim como o contrato entre a empresa e a Prefeitura de Pelotas, foram assinados, liberando 
a execução do empreendimento. Logo na sequência, as obras foram iniciadas com a etapa de implantação, com serviços de terraplanagem.

Porém, antes da execução das edificações, a proposta do sistema Morar Melhor homologado necessitou de alterações significativas na tecnologia da construção. Assim, a empresa Roberto Ferreira optou por selecionar técnicas do sistema wood frame para este residencial. Esta seleção do wood frame como sistema constituinte das unidades do Haragano foi motivada por duas necessidades principais: redução de custos e de tempo gastos na produção (LIMA, 2012; FERREIRA, 2013).

Por exemplo, referente à redução de custo, um orçamento simplificado apontou que uma habitação de $45 \mathrm{~m}^{2}$ construída em wood frame apresentou uma redução de custos de até $10 \%$ quando comparada à mesma habitação construída em alvenaria. Esta economia estimada baseou-se, principalmente, no custo da mão-de-obra, a qual seria reduzida na produção, pois o sistema wood frame analisado utilizaria componentes modulares préfabricados executados em menor tempo (FERREIRA, 2013). Sobre o resultado desta breve comparação, o engenheiro Ricardo Targa Ferreira, sócio-diretor da empresa Roberto Ferreira, afirmou:

\footnotetext{
Comparando os dois sistemas, há um custo de cerca de $10 \%$ maior do wood frame em materiais. Mas a redução de mão de obra chega a 50\% em relação à alvenaria. Esse é o grande ganho do sistema. E ainda diminui o tempo de obra em, no mínimo, um terço. [...]

Não achávamos que teríamos sucesso com a alvenaria estrutural, devido à dificuldade em encontrar profissionais e ao alto custo deles. Por isso, resolvemos fechar a parceria para usar wood frame. Na fase de planejamento, já víamos que o custo do metro quadrado de uma alvenaria revestida já estava ultrapassando em $\mathrm{R} \$ 100$ o metro quadrado do wood frame. Além disso, havia o receio de não entregarmos no prazo (FERREIRA, 2013)
}

Ainda, além da redução de custo com a mão-de-obra envolvida, outra motivação para seleção do wood frame foi o tempo de produção para entregar o residencial dentro do prazo estipulado pelo PMCMV. Havia um cronograma determinado para as etapas da construção até sua conclusão. O cumprimento deste cronograma seria fiscalizado pela CEF como condicionante para repassar à construtora os recursos financeiros contratados. Assim, a produção mediante a pré-fabricação de componentes facilitaria o cumprimento desses prazos. Portanto, a construtora Roberto Ferreira optou por produzir os componentes de 
parede e de entrepiso das habitações em fábrica, o que, por fim, reduziria significativamente a data de entrega das UHs.

Após determinar as mudanças nos detalhes técnicos construtivos e no método de construção do sistema Morar Melhor original, a empresa Roberto Ferreira entregou nova documentação à GIDUR/PO solicitando apreciação da viabilidade do denominado Sistema Construtivo Morar Melhor Aprimorado, o qual implementava técnicas do sistema wood frame.

Para obter novo parecer da CEF sobre este sistema, nova documentação foi-lhe enviada, como: memorial descritivo do sistema construtivo, descrição do processo de préfabricação de elementos de parede e de entrepiso, projeto estrutural e memorial de cálculo, RTA's e documentos complementares de fornecedores com dados técnicos conferindo o desempenho dos componentes desta construção, declaração de procedência da madeira beneficiada, informativo sobre o tratamento químico e a durabilidade dos elementos em madeira serrada e proposta de monitoramento do empreendimento.

Na sequência, a instituição avaliadora considerou estas alterações propostas como adequadas, incluindo a inserção de aprimoramento no processo construtivo, com a préfabricação dos elementos. Também, as alterações na estrutura e nos fechamentos interno e externo dos painéis de parede foram analisadas e consideradas em conformidade com a Diretriz SINAT no 005, específica para o wood frame. Portanto, em concordância, a CEF, através do GIDUR/PO, emitiu parecer favorável à viabilidade prévia do sistema construtivo Morar Melhor Aprimorado, no Rio Grande do Sul.

Ainda, durante a execução das obras do empreendimento Haragano, foram realizados acompanhamentos na produção em fábrica e no canteiro, complementação dos dados técnicos com outros ensaios tecnológicos e emissão de relatórios técnicos mensais à GIDUR/PO para atestar a conformidade do sistema construtivo. Neste processo, a professora Margarete R. F. Gonçalves atuou como supervisora da Roberto Ferreira no acompanhamento do sistema Morar Melhor Aprimorado.

Por fim, o residencial Haragano concluiu suas obras em 2013 e, no ano seguinte, em março de 2014, a Prefeitura de Pelotas e a Secretaria de Justiça Social e Segurança (SJSS), após sorteio dos cadastrados, divulgou os contemplados a morar neste empreendimento. Logo após, a CEF, a construtora Roberto Ferreira e a SJSS de Pelotas realizaram reuniões com estes beneficiados para dar orientações sobre "convívio coletivo, cuidados e manutenção do 
condomínio, legislação do programa Minha Casa Minha Vida e condominial, forma adequada de uso de sua moradia, organização da eleição do síndico, assinatura de contrato e entrega das chaves" (CUNHA, 2014).

Portanto, pode-se concluir que, para a efetivação do primeiro residencial do PMCMV construído com o sistema wood frame, foi necessária uma ação conjunta entre empresas construtoras, empresas fornecedoras dos insumos, assessores técnicos especialistas, instituições de pesquisa e de ensino, sindicato representante das construtoras e órgãos estatais como MCidades, GIDUR/PO da CEF, Prefeitura de Pelotas e Governo do RS (Figura 93).

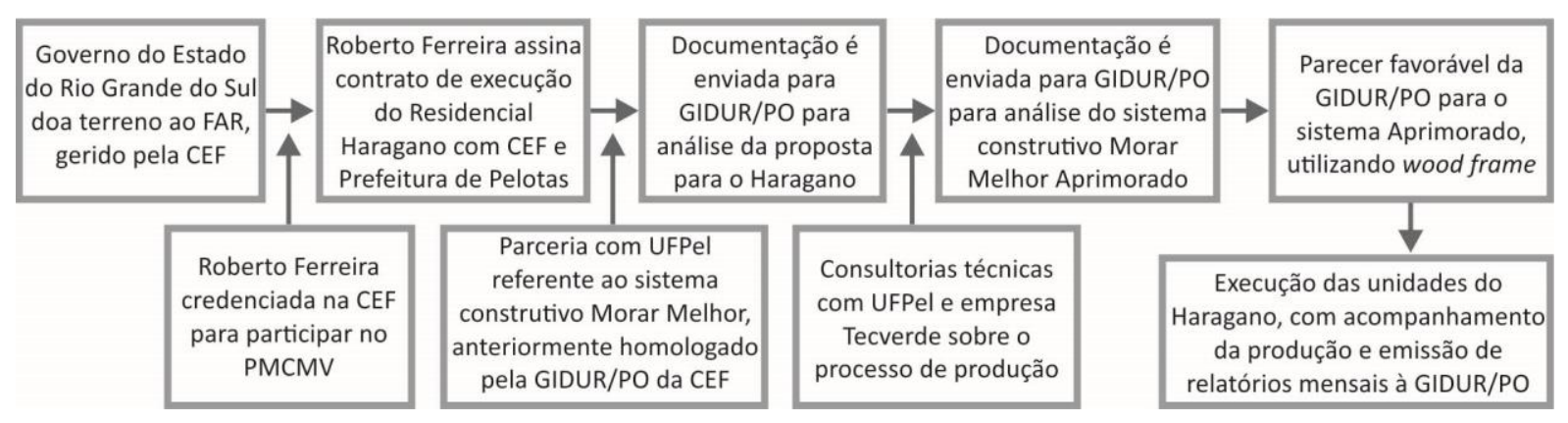

Figura 93: Resumo do processo para implementação do residencial Haragano

Fonte: autora.

\subsection{DESCRIÇÃO DO RESIDENCIAL HARAGANO}

O residencial Haragano está localizado na zona urbana do município de Pelotas, no loteamento Dunas do bairro Areal, com área de 3,99 ha, na rua Sidnei Alves Dias, número 300, situada no prolongamento das ruas 2 e 20 (Figura 94).

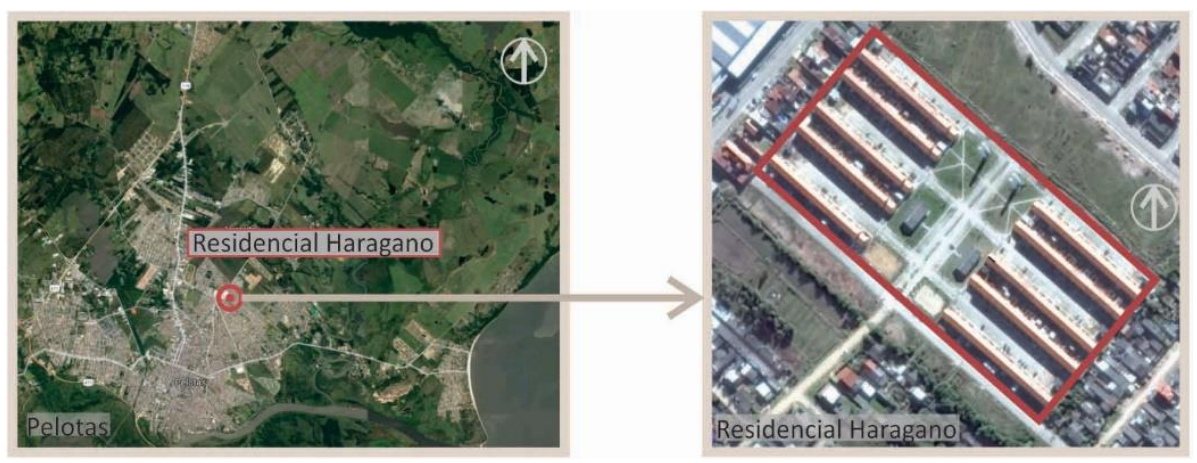

Figura 94: Localização do residencial Haragano na zona urbana de Pelotas

Fonte: elaborado pela autora com base em mapa de GoogleMaps, 2016. 
O Haragano é um empreendimento do PMCMV - Faixa 1/FAR constituído como condomínio residencial, contratado por $\mathrm{R} \$$ 14.829.498,00 (CEF, 2016). A implantação do empreendimento apresenta 280 UHs unifamiliares, sendo 270 residências de dois pavimentos e 10 térreas. Estas unidades estão distribuídas em 10 fitas que contêm os sobrados geminados e uma residência térrea na sua extremidade. As vagas de garagem estão localizadas em frente às UHs. Além das residências, o projeto contempla guarita, áreas verdes e áreas de lazer, como salões de festas, churrasqueiras, quadras esportivas e playgrounds (Figura 95 a Figura 97).
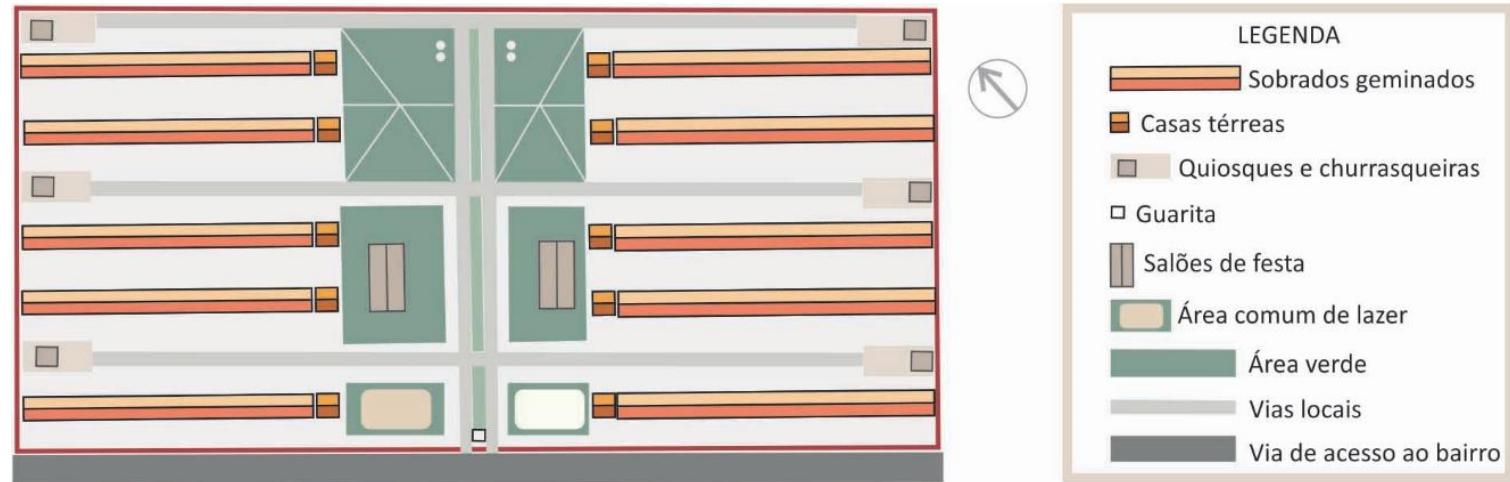

Figura 95: Implantação do residencial Haragano Fonte: autora.

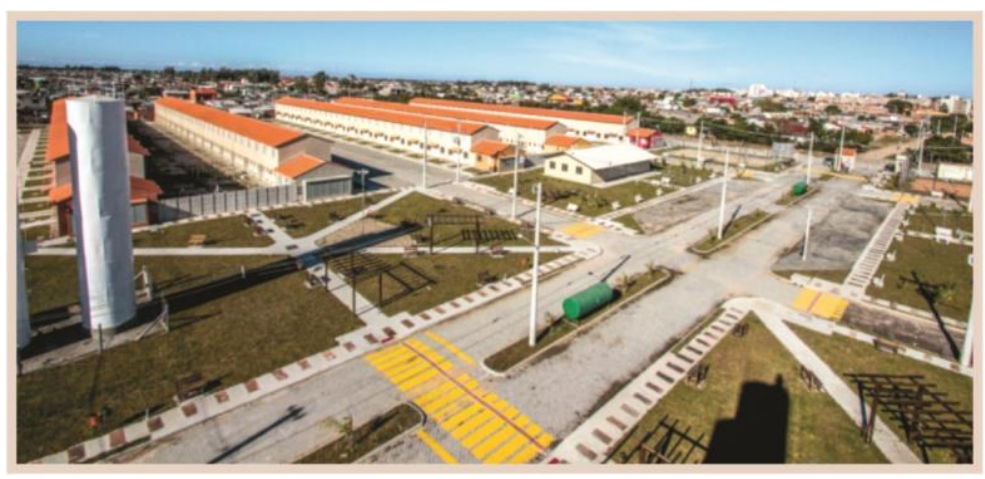

Figura 96: Vista geral do residencial Haragano Fonte: Dockendorff, 2014.
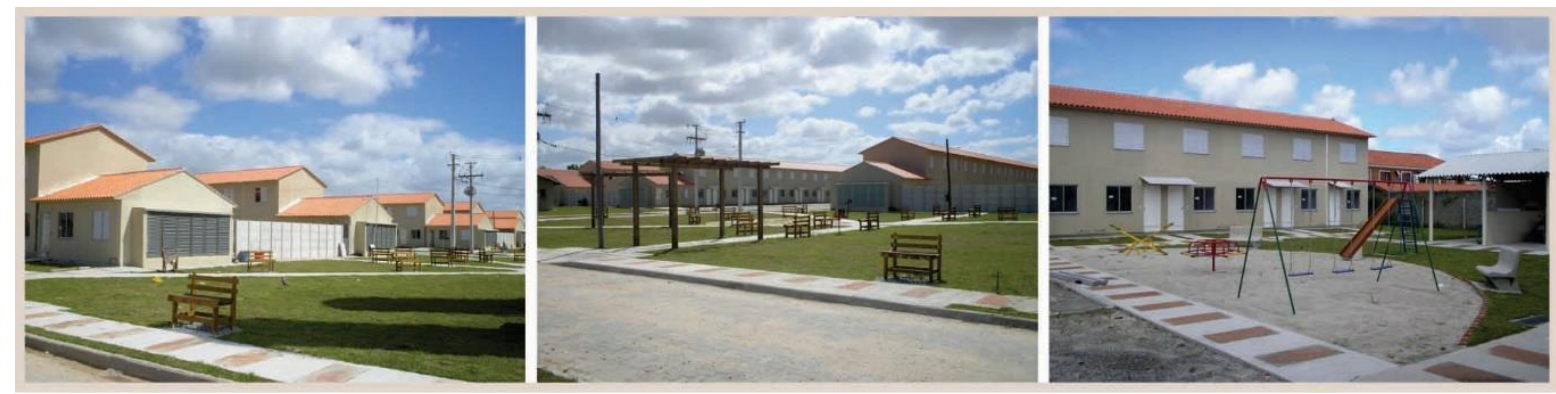

Figura 97: Áreas verdes e de lazer com estares, playground e quiosques com churrasqueira Fonte: arquivo da empresa Tecverde, 2013. 
As residências térreas (Figura 98a) foram projetadas para contemplar pessoas com deficiências e, portanto, são acessadas por rampas externas. Cada casa térrea totaliza, aproximadamente, $42 \mathrm{~m}^{2}$, compreendendo dois dormitórios, sala e cozinha conjugadas, um banheiro e lavanderia externa (Figura 99). E, os sobrados (Figura 98b), com área de, aproximadamente, $47 \mathrm{~m}^{2}$, são constituídos por sala, cozinha e banheiro no pavimento térreo e dois dormitórios no pavimento superior, acessados por escada metálica (Figura 100).
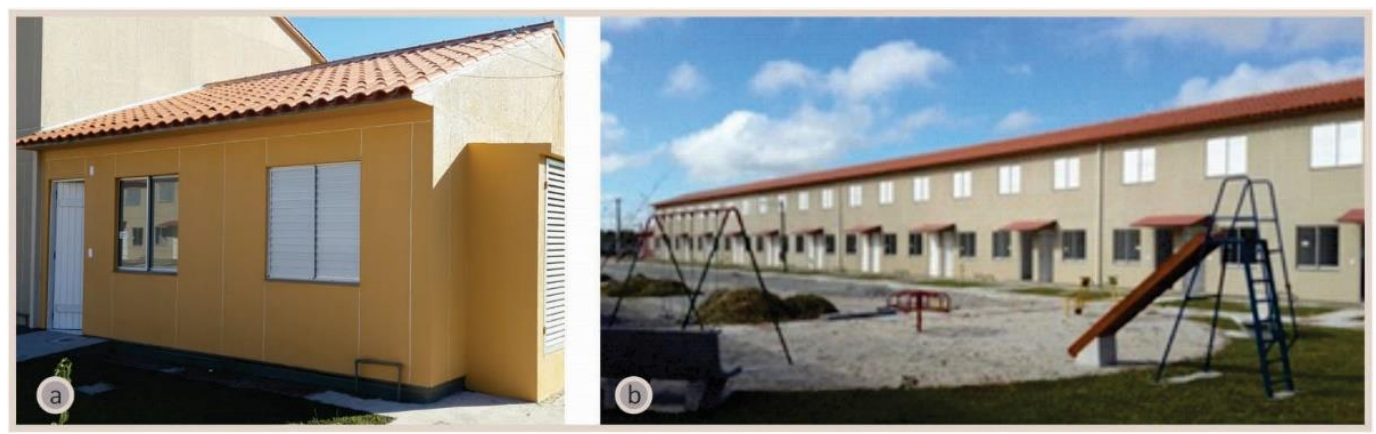

Figura 98: Casa térrea (a) e sobrados geminados (b)

Fonte: arquivo da empresa Tecverde, 2013.

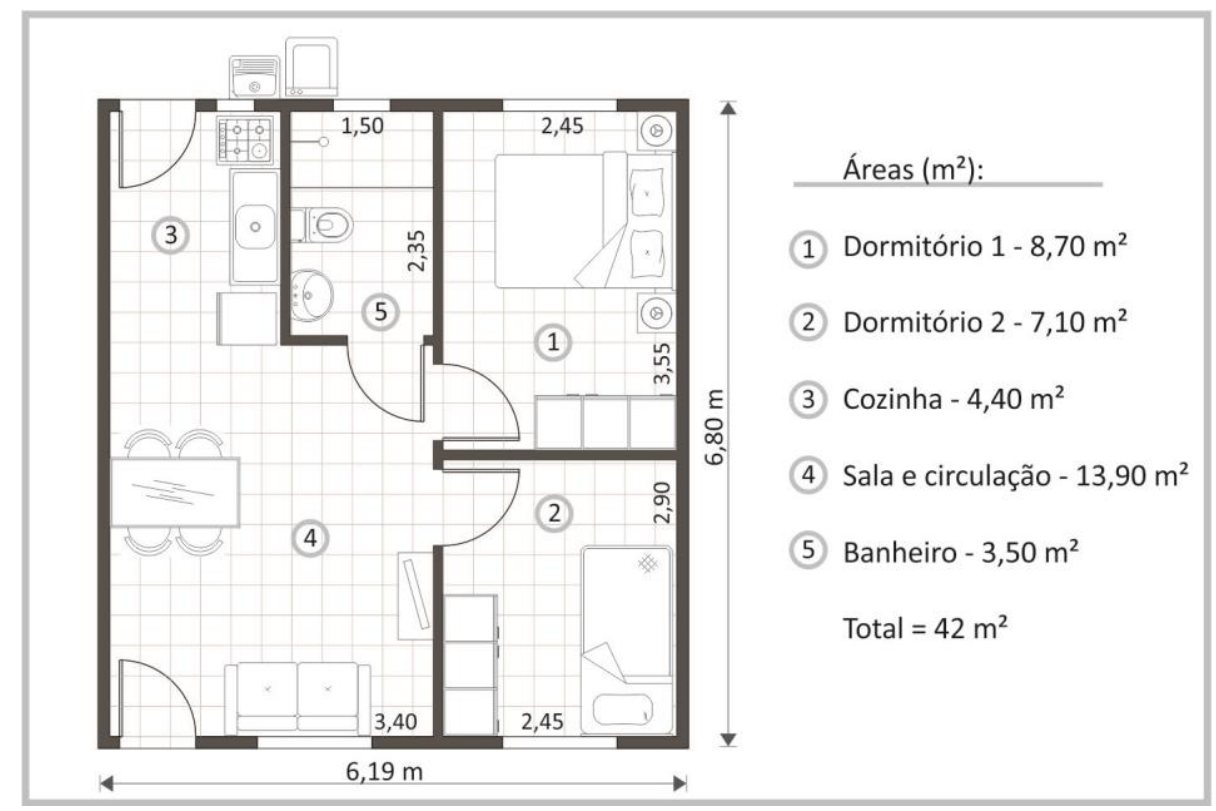

Figura 99: Planta baixa da habitação térrea

Fonte: elaborado pela autora com base em dados da empresa Roberto Ferreira. 


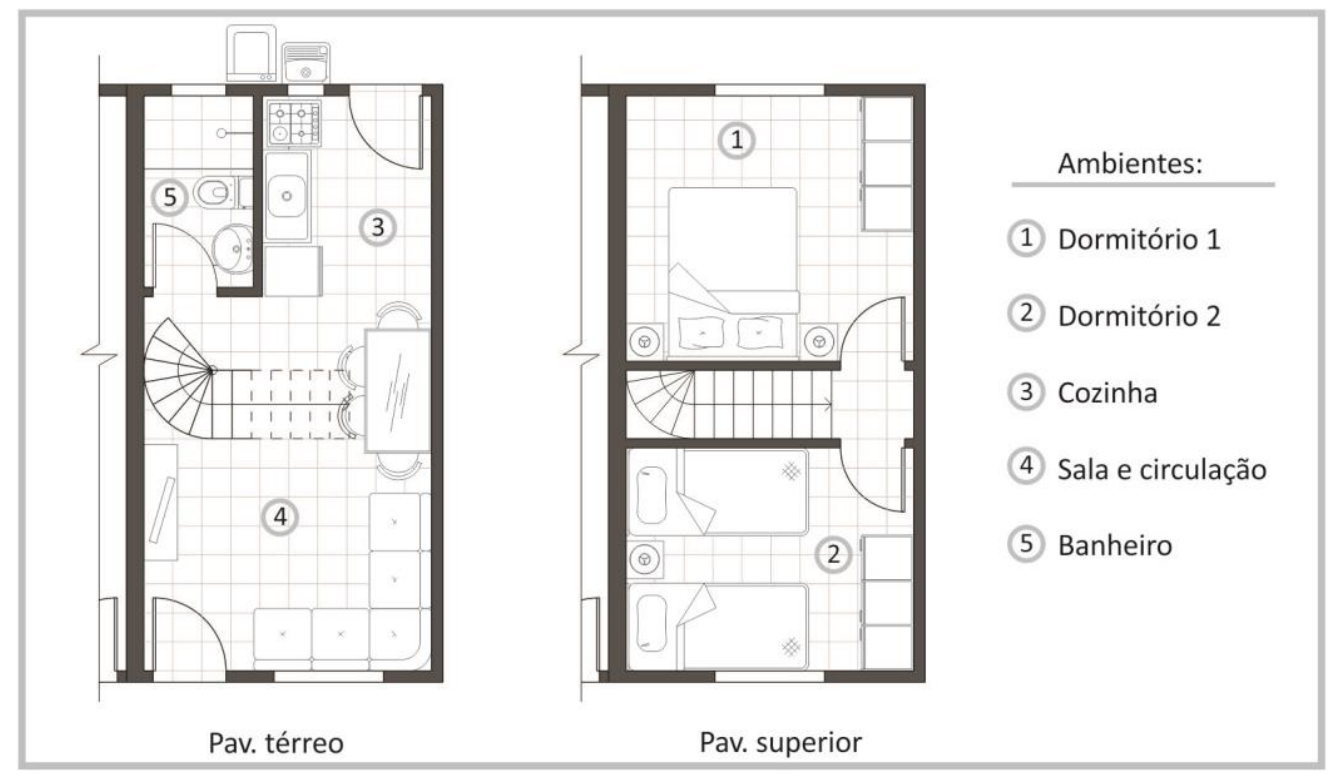

Figura 100: Planta baixa da habitação com dois pavimentos Fonte: elaborado pela autora com base em dados da empresa Roberto Ferreira.

\subsection{SISTEMA CONSTRUTIVO DAS HABITAÇÕES SOCIAIS DO HARAGANO}

Conforme já mencionado, inicialmente, para a construção das UHs do Residencial Haragano, a empresa Roberto Ferreira selecionou o sistema construtivo Morar Melhor, desenvolvido em projeto da UFPel em 2005 e homologado pela CEF em 2007. Posteriormente, em meados de 2011, para ser aplicado no empreendimento Haragano, que exigia produção em larga escala, foi necessário realizar determinadas alterações técnicas neste sistema construtivo, o qual passou a ser denominado Morar Melhor Aprimorado. Estes dois sistemas serão apresentados a seguir, com ênfase ao detalhe técnico construtivo do Haragano.

\subsubsection{Sistema construtivo Morar Melhor}

O sistema construtivo Morar Melhor é resultado de uma atividade de extensão da FAUrb/UFPel constituída pela seguinte equipe: Professora Doutora Margarete Regina Freitas Gonçalves como coordenadora do projeto, Professor Doutor Darci Gatto como colaborador, estudantes de graduação Mateus Gross da Costa e Diego Pereira Abeijon como pesquisadores, e engenheiro civil Auro Oliveira da Fonseca, colaborador externo à comunidade acadêmica. Iniciado em 2005, este projeto de extensão tinha como objetivo transmitir conhecimentos 
sobre modulação, construção a seco e produtos industrializados para habitação social, haja vista a grande demanda existente no Estado do Rio Grande do Sul (GONÇALVES, 2006).

Originalmente, o sistema Morar Melhor, possuía as seguintes características principais:

- fundação com blocos de concreto e laje do piso térreo executada em concreto armado e impermeabilizado com tinta asfáltica nas faixas de posicionamento das paredes;

- paredes estruturadas com entramado de peças serradas em madeira de eucalipto, fechadas externamente com placas cimentícias de $10 \mathrm{~mm}$ de espessura e internamente com lambris de madeira de pinus (Figura 101);

- esquadrias em madeira de eucalipto;

- instalações elétrica e hidrossanitária embutidas nas paredes;

- cobertura estruturada com tesouras em madeira de eucalipto, fechadas com telhas onduladas de fibrocimento sem amianto e forradas com lambris de pinus na mesma inclinação da cobertura;

- acabamento cerâmico no piso;

- acabamento das superfícies externas das paredes das fachadas com produto impermeabilizante e selador de base acrílica e tinta acrílica (Figura 101);

- Oitões fechados com telhas onduladas de fibrocimento pintadas com tinta acrílica.

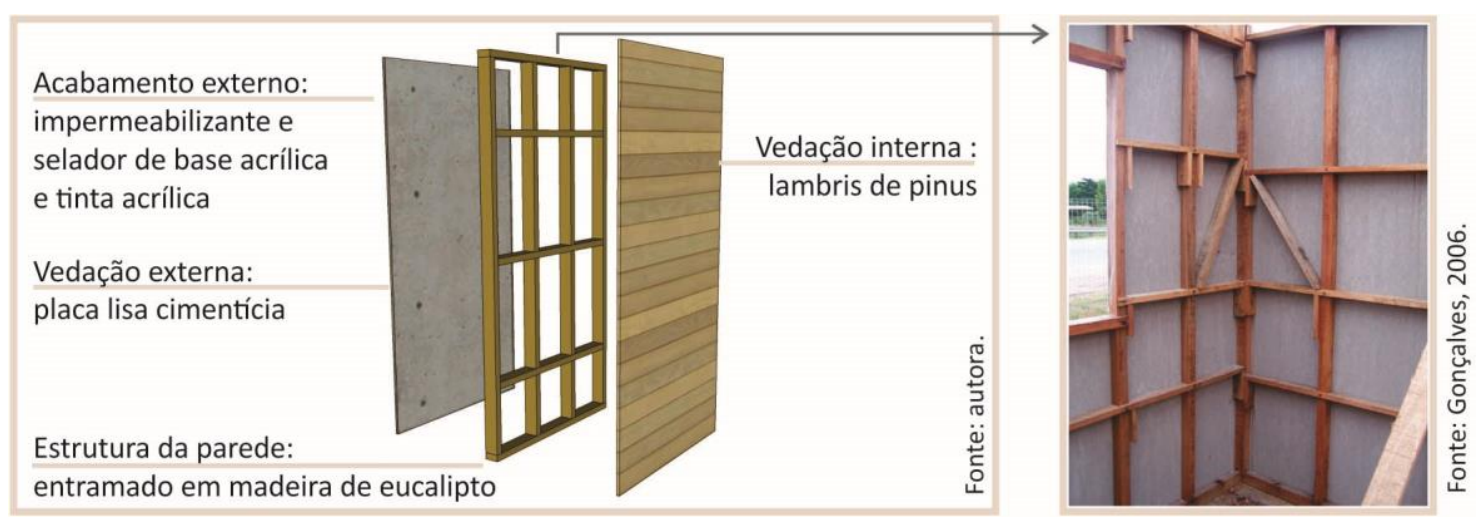

Figura 101: Composição das paredes do sistema Morar Melhor original

Fonte: elaborado pela autora com base em Gonçalves, 2006.

Em 2006, este projeto foi apresentado para avaliação da viabilidade técnica perante a CEF para possibilitar o financiamento de construções populares com este sistema. Para isso, incialmente, um protótipo de habitação foi construído no município de Rio Grande, localizado à $25 \mathrm{~km}$ de distância da região central de Pelotas. Esta casa térrea era constituída por sala, cozinha, banheiro e dois dormitórios, totalizando uma área de $46 \mathrm{~m}^{2}$, aproximadamente (Figura 102) (SILVA; GONÇALVES, 2010). A execução deste protótipo foi realizada em parceria 
com a empresa fornecedora de insumo João Materiais de Construção e outras empresas produtoras (Figura 103).

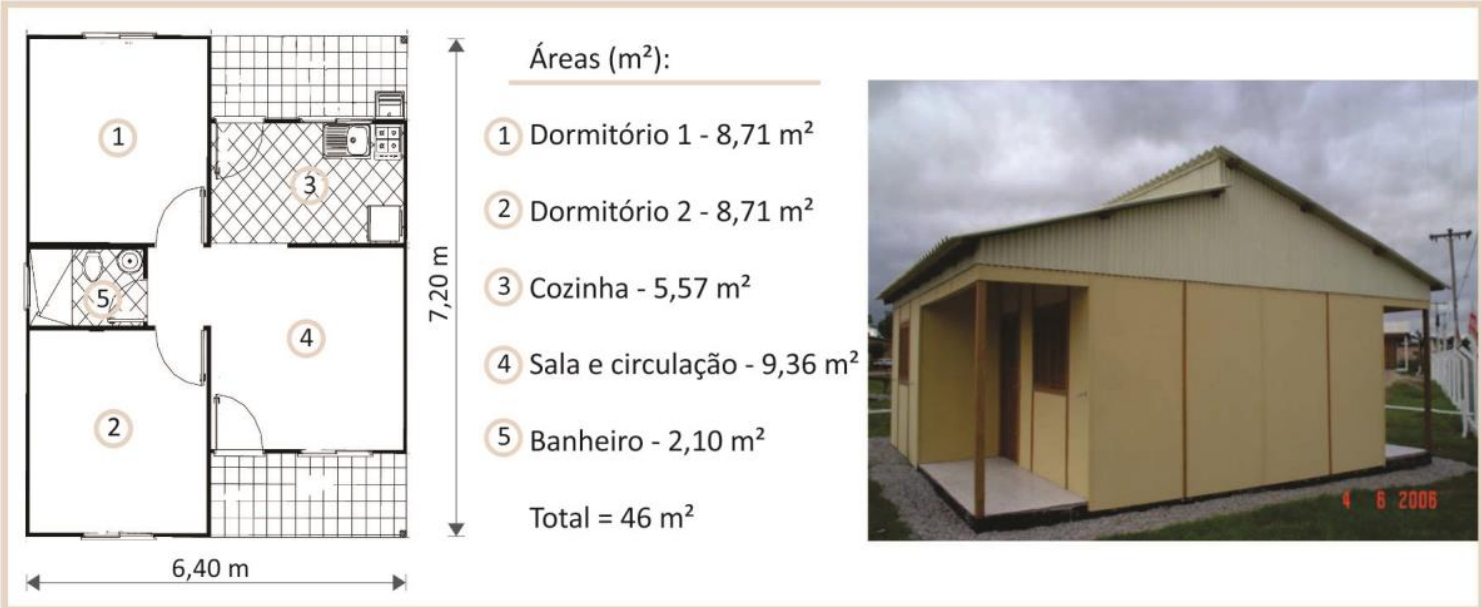

Figura 102: Projeto do protótipo da habitação popular com sistema Morar Melhor original Fonte: adaptado de Silva e Gonçalves, 2010.
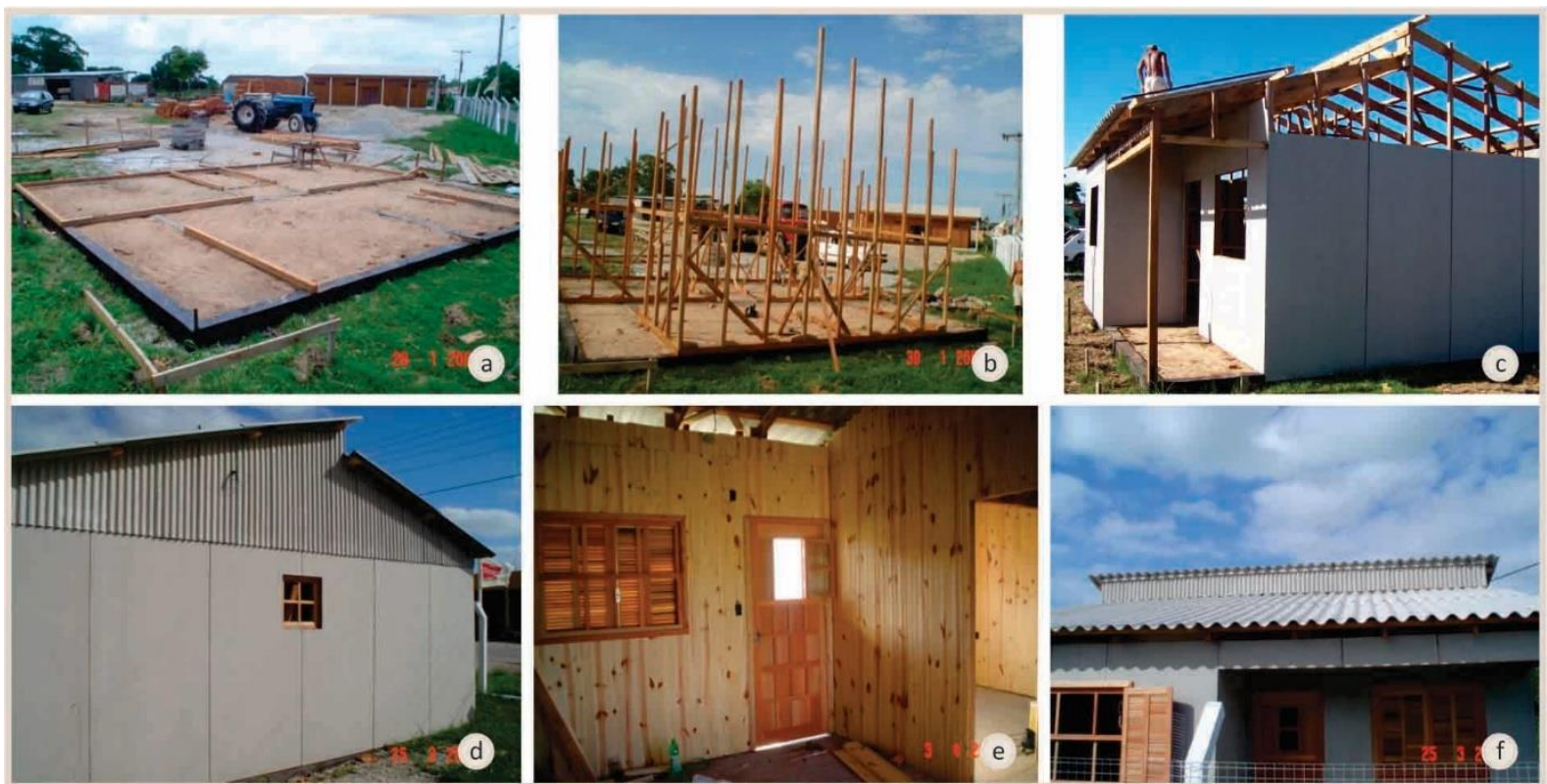

Figura 103: Construção do protótipo da habitação popular com sistema Morar Melhor original Fonte: adaptado de Gonçalves, 2006.

Com base neste protótipo, os documentos apresentados para a análise da CEF foram os seguintes: ficha informativa da inovação tecnológica, projetos arquitetônico, elétrico e hidrossanitário, detalhamento do entramado em madeira modular, memorial descritivo, orçamento, quantitativos de materiais, cronograma de execução da obra, manual de uso e manutenção e planilha com dados aferindo o atendimento às normas brasileiras. Ainda, os 
seguintes aspectos técnicos do sistema construtivo em questão foram analisados (GONÇALVES, 2006):

- avaliação do desempenho da placa cimentícia referente à absorção de água, isolamento sonoro, calor e choque térmico, estanqueidade à água e resistência ao impacto de corpo mole e corpo duro, realizado pelo IPT;

- avaliação das condições de estanqueidade das juntas de dilatação entre placas cimentícias, realizada pela UFSM;

- identificação da madeira utilizada na estrutura das paredes e da cobertura, realizada pela UFPel;

- avaliação da resistência mecânica da madeira de eucalipto usada nas estruturas das paredes e da cobertura, realizada pela UFSM;

- avaliação de conforto térmico e acústico das paredes, realizada pela UFRGS;

- análise da resistência das paredes a impactos de corpo mole, corpo duro e de peças suspensas, realizada pela UFSM;

- análise do desempenho térmico do protótipo, realizado pela UFPel (SILVA; GONÇALVES, 2007, 2008, 2010).

Por fim, este projeto demonstrou vantagens para a construção de habitações populares, com aspectos como: aplicação de madeira de floresta plantada como pinus ou eucalipto, flexibilidade do projeto arquitetônico, permitindo ampliações e adaptações dos ambientes construídos, racionalização com a aplicação de produtos comerciais industrializados, rápida execução no canteiro e fácil manutenção.

Ainda, outro resultado importante foi a redução do custo da construção. A estimativa realizada por Gonçalves (2006) apontou que o custo da habitação construída com o sistema Morar Melhor era inferior quando comparado a uma casa com mesmo padrão com sistemas tradicionais em alvenaria. Esta análise apontou que o valor do metro quadrado deste sistema inovador era cerca de $36 \%$ do Custo Unitário Básico (CUB) do Estado do Rio Grande do Sul naquele período avaliado (DIÁRIO POPULAR, 2007).

Por fim, através da construção de protótipos e análises técnicas, o sistema construtivo Morar Melhor comprovou e obteve sua viabilidade prévia perante a CEF em julho de 2007. E, nos anos seguintes de 2008 a 2010, este sistema foi aplicado em algumas edificações da região dos municípios de Rio Grande e de Pelotas (Figura 104). 


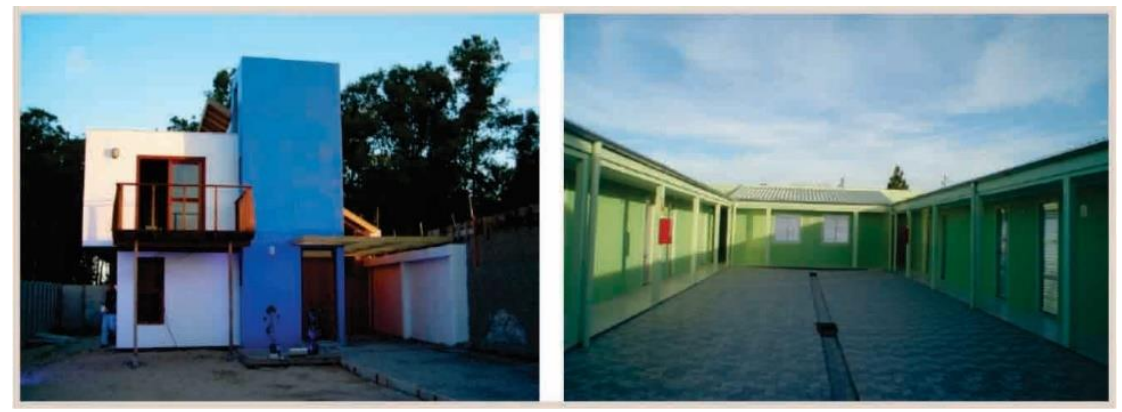

Figura 104: Construções com o sistema Morar Melhor original nos municípios de Pelotas e Rio Grande, no Rio Grande do Sul

Fonte: Gonçalves, 2006.

Em 2011, a empresa Roberto Ferreira iniciou sua parceria com a UFPel e com fornecedores de insumos e, como resultado, construiu um protótipo de habitação popular com o sistema Morar Melhor já homologado pela CEF. No entanto, foram feitas pequenas alterações em relação à composição original. Por exemplo, foram instaladas janelas em alumínio e a vedação interna também foi executada com revestimento cerâmico, conforme ilustra a Figura 105.

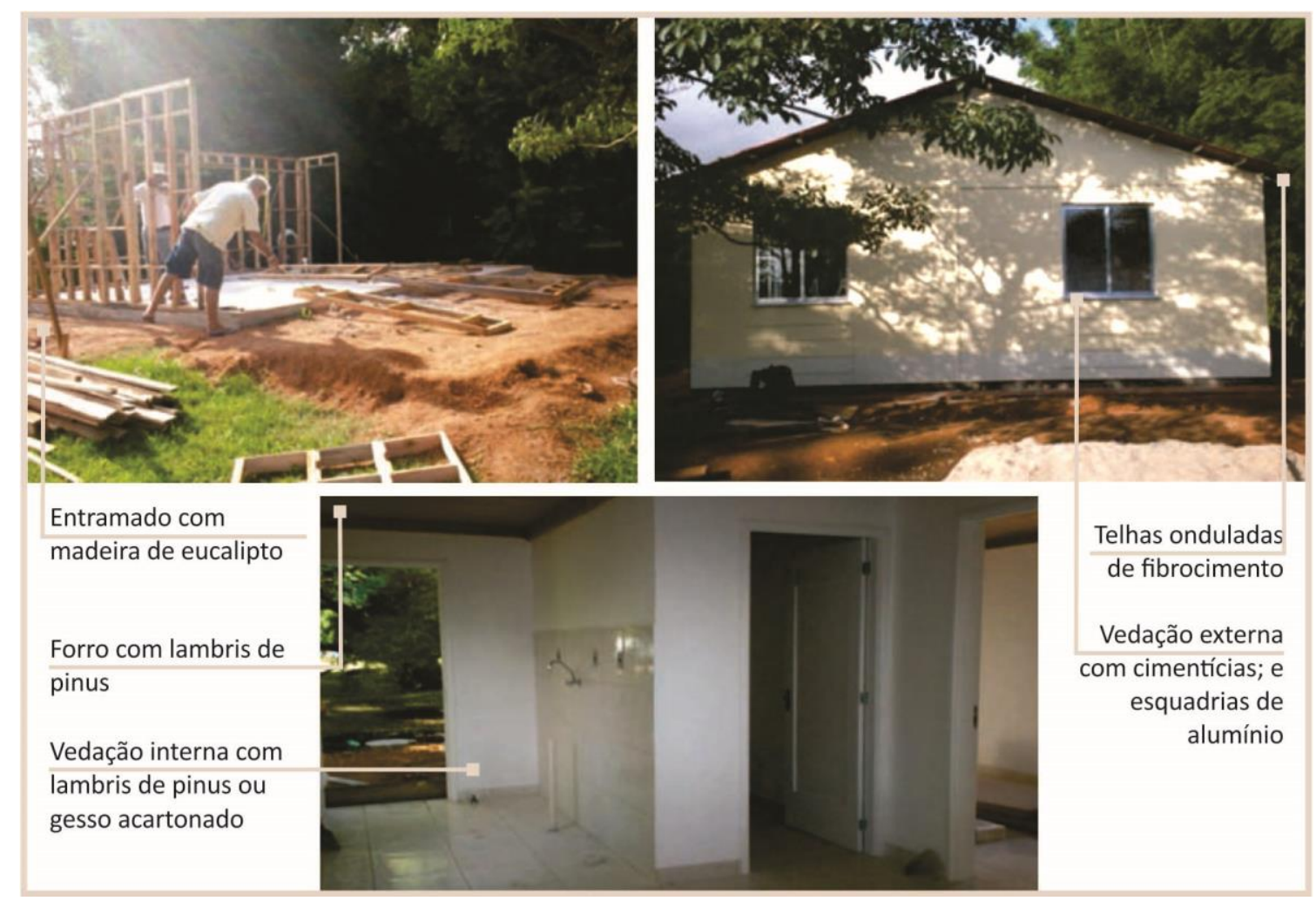

Figura 105: Protótipo do sistema Morar Melhor com algumas alterações de componentes Fonte: adaptado de Roberto Ferreira, 2016. 


\subsubsection{Sistema Morar Melhor Aprimorado}

A partir dessa experiência anterior, a construtora Roberto Ferreira selecionou o sistema Morar Melhor para a construção das UHs do residencial Haragano. Mas, para um empreendimento com 280 UHs, algumas alterações precisaram ser feitas, tanto na técnica construtiva quanto no método de produção. E, como resultado, a composição do sistema proposto inicialmente à CEF foi alterada significativamente e passou a ser denominada Morar Melhor Aprimorado.

O sistema Morar Melhor Aprimorado utilizou as técnicas do wood frame em conformidade com a Diretriz SINAT no 005 em vigor. Portanto, pode-se afirmar que o sistema aplicado nas habitações térreas e nos sobrados deste empreendimento do PMCMV - Faixa 1/FAR foi o wood frame ${ }^{27}$. Seus subsistemas fundação, paredes, entrepiso e cobertura serão descritos a seguir (Figura 106 e Figura 107).

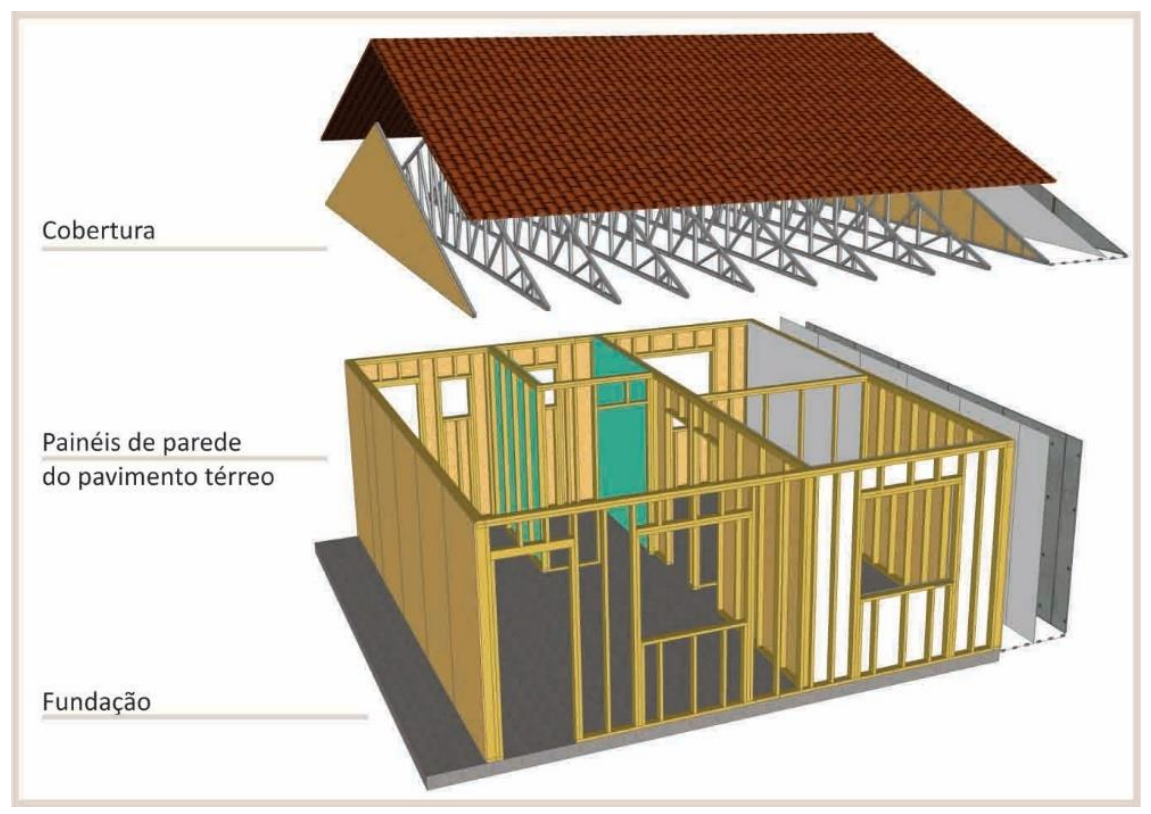

Figura 106: Modelo tridimensional da habitação térrea do residencial Haragano

Fonte: autora.

\footnotetext{
${ }^{27}$ Conforme demonstrado no capítulo 4 deste trabalho, a composição do sistema wood frame mantém o entramado estrutural em madeira e a chapa estrutural derivada de madeira como elementos centrais, ou seja, estes componentes sempre estão presentes, mesmo que variando suas dimensões. No entanto, os materiais que compõem as demais camadas dos painéis de parede podem alterar de acordo com o contexto ou com a empresa. Por exemplo, o capítulo 8 demonstrará as diferentes camadas dos painéis de parede atualmente utilizados no Brasil. Inclusive, a empresa Tecverde, ao realizar aprimoramentos no seu processo de produção, vem disponibilizando painéis com diferentes soluções técnicas destas utilizadas no residencial Haragano.
} 


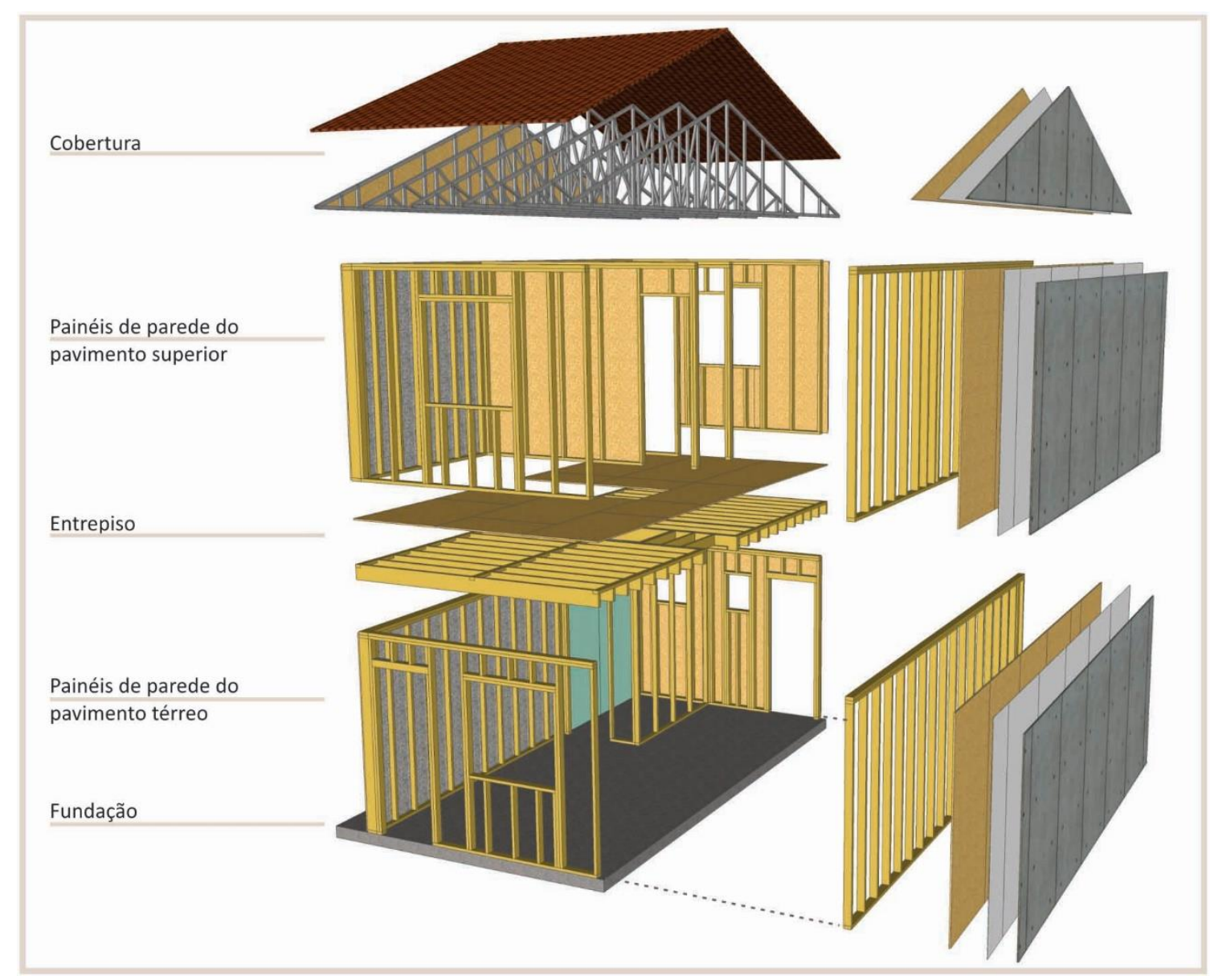

Figura 107: Modelo tridimensional do sobrado do residencial Haragano Fonte: autora.

A fundação das habitações é constituída por uma laje maciça de concreto armado com resistência de $20 \mathrm{MPa}$. Este sistema radier (Figura 108) é possibilitado pela leveza do conjunto estrutural destas habitações em madeira. Após o primeiro nivelamento e a compactação do solo, a locação é feita conforme dimensões exatas estabelecidas no projeto da edificação. Sobre o solo compactado, uma camada de brita no 1 é colocada para um nivelamento mais fino da superfície. Também, nesta etapa, conforme o projeto, as tubulações hidrossanitárias são previamente posicionadas para o embutimento das mesmas nesta estrutura maciça. Sobre toda a camada de brita, coloca-se um material plástico, como lonas, para evitar que parte do concreto não escorra pela brita no momento da execução e, principalmente, para barrar a passagem da umidade do solo para a fundação e para a estrutura em madeira. Após, a armadura é colocada e posicionada com espaçadores para seu cobrimento correto. E, por fim, sobre esta, o concreto é lançado, sarrafeado e desempenado. 


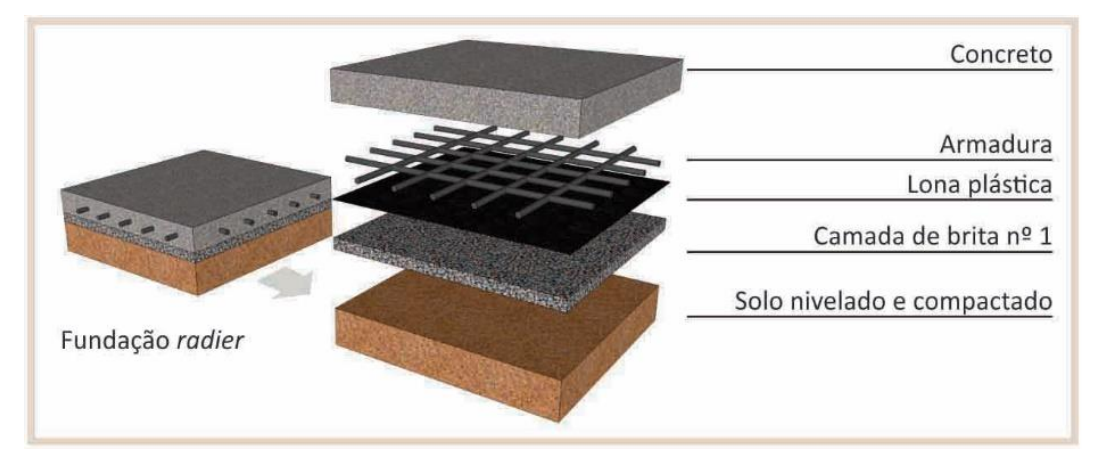

Figura 108: Camadas principais da fundação radier

Fonte: autora.

Sobre a laje de concreto finalizada, nas posições onde os painéis de parede préfabricados serão fixados, uma camada de tinta asfáltica impermeabilizante é passada sobre a laje da fundação para proteger a estrutura em madeira da parede contra a possível umidade proveniente do solo (Figura 109). Após esta impermeabilização da fundação, os painéis de paredes são fixados.

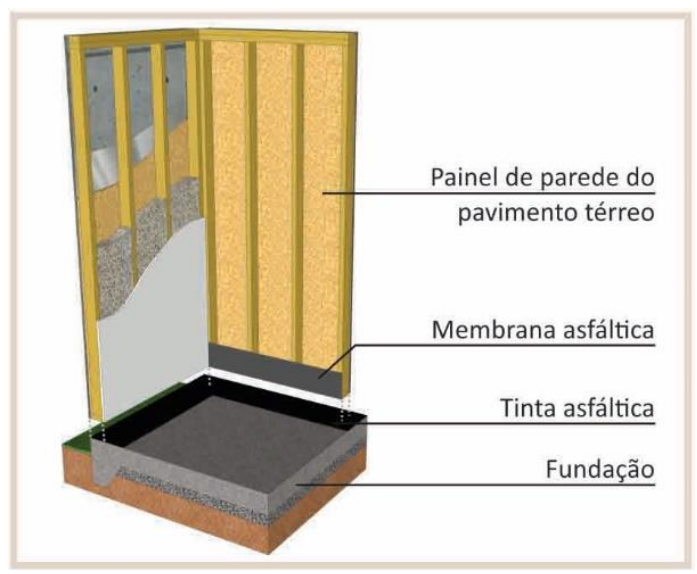

Figura 109: Impermeabilização com tinta asfáltica sobre a laje da fundação, sob as paredes térreas Fonte: autora.

O subsistema de paredes das residências do Haragano é composto por painéis préfabricados com altura total de $255 \mathrm{~cm}$, variando seus comprimentos conforme a dimensão dos ambientes que delimitam. Estes painéis são compostos por uma ossatura, ou seja, um entramado constituído por um conjunto de peças em madeira serrada, tais como montantes, travessa inferior, travessa superior dupla, umbral, verga, contra-verga (Figura 110). A madeira é proveniente de floresta plantada, sendo o pinus a espécie utilizada para estas construções. As peças em madeira são tratadas em autoclave, onde são impregnadas com o produto 
químico Arseniato de Cobre Cromatado (CCA). As seções destas peças variam em: $38 \times 70 \mathrm{~mm}$ para painéis internos, $38 \times 89 \mathrm{~mm}$ para painéis externos e $38 \times 140 \mathrm{~mm}$ para painéis que dividem as UHs.

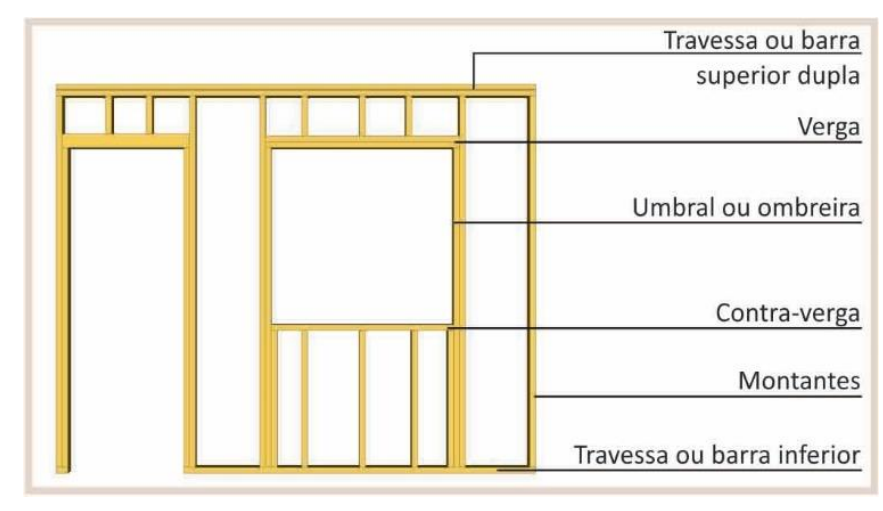

Figura 110: Peças constituintes do entramado da parede Fonte: autora.

Conforme observa-se na Figura 111, o entramado das paredes é estruturado com chapas OSB em uma das faces, garantindo rigidez e contraventamento ao conjunto estrutural. Estas chapas variam a espessura em 11,1 $\mathrm{mm}$ para painéis externos e 9,5 $\mathrm{mm}$ para painéis internos. Os painéis de parede externos recebem placas cimentícias de $10 \mathrm{~mm}$ de espessura aplicadas sobre a membrana hidrófuga, que é uma película de não-tecido que serve como barreira impermeável contra a entrada da umidade externa, mas é permeável e permite a saída do vapor interno. Nas faces internas, todos os painéis recebem chapas de gesso acartonado de 12,5 mm de espessura. As aplicações destas chapas de gesso variam entre os tipos Standard (ST) e Resistente à Umidade (RU), para ambientes secos e molháveis/molhados, respectivamente. Por fim, todos os painéis do térreo, ou seja, todos os que estão em contato direto com a laje da fundação, recebem uma manta asfáltica impermeabilizante de $3 \mathrm{~mm}$ de espessura, como o produto importado Knaulf Katja Sprint. Esta manta envelopa a base do entramado estrutural e da chapa OSB até $20 \mathrm{~cm}$ de altura, para evitar o contato com umidade.

No entanto, esta descrição da composição dos painéis de parede é generalizada para o residencial Haragano (Figura 111). Pois, a constituição de cada painel difere conforme as necessidades do ambiente em que está inserido. Esta variação pode incluir ausência ou presença de determinado material, assim como alterações em dimensões, seções, espessuras 
e especificidades. Como exemplo, a seguir, as constituições dos painéis de parede presentes no pavimento térreo do sobrado geminado do Haragano serão descritas.

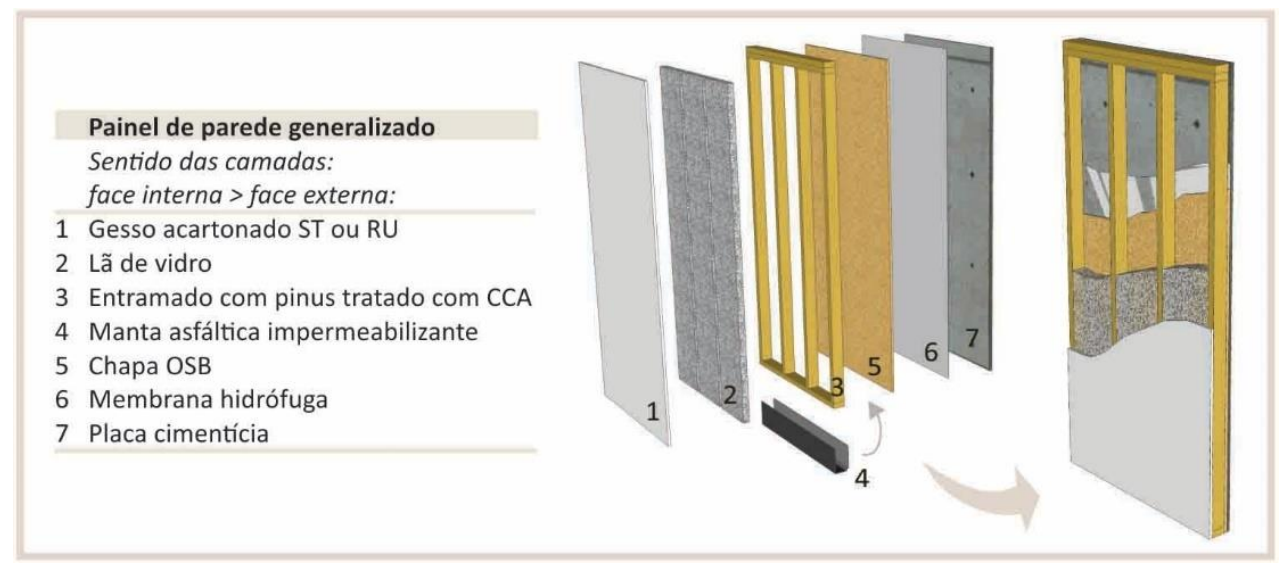

Figura 111: Constituição generalizada das camadas dos painéis de parede Fonte: autora.

No pavimento térreo do sobrado, seis painéis de parede delimitam os ambientes. Nas descrições seguintes, estes painéis estão identificados com a denominação Painel Térreo (PT) seguido de numeração sequencial, sendo estes: PT-1 a PT-6. Pode ser adicionada uma letra ao final da nomenclatura - PT-1a e PT-1b, por exemplo - para indicar que este painel é único, ou seja, seu entramado é inteiro, mas está presente em dois ambientes com necessidades distintas, o que implicará em diferentes camadas de materiais de vedação para estas paredes.

Por exemplo, o PT-1 é um painel de geminação que divide dois sobrados vizinhos e geminados. Assim, esse é o único painel do térreo que apresenta peças em madeira com maior seção - 38×140 mm - e seu interior é preenchido com lã de vidro, como material isolante acústico. No entanto, distingue-se o PT-1a, que está no banheiro, do PT-1b, que está na sala, pois são ambientes com área molhável e seca, respectivamente. Nesse caso, a face interna do PT-1a recebe gesso acartonado tipo RU e a do PT-1b, gesso tipo ST (Figura 112).

Na sequência, o PT-2 é o painel da fachada frontal do sobrado, onde estão a porta e a janela que dão acesso e abertura para a sala de estar. A seção das peças em madeira deste entramado é de $38 \times 89 \mathrm{~mm}$. Sua face externa recebe chapa OSB, membrana hidrófuga e placa cimentícia. E, a face interna recebe gesso tipo ST (Figura 113).

Ainda na sala, a composição do PT-3a é igual à do PT-2. No entanto, a parte que delimita a cozinha, com o PT-3b, é diferenciada como área molhável e, por isso, recebe gesso tipo RU (Figura 114). O PT-4 está localizado na fachada dos fundos do sobrado, em contato 
com o banheiro e a cozinha, áreas molhada e molhável, respectivamente. Por isso, este painel também recebe gesso RU em toda sua face interna (Figura 115).

Por fim, os painéis internos PT-5 e PT-6 apresentam madeira com seção menor $38 \times 70 \mathrm{~mm}$. O PT-5 apresenta gesso ST na face para a sala e gesso RU na face para o banheiro (Figura 116). Enquanto, o PT-6 apresenta gesso RU tanto na face para o banheiro quanto na face para a cozinha (Figura 117).

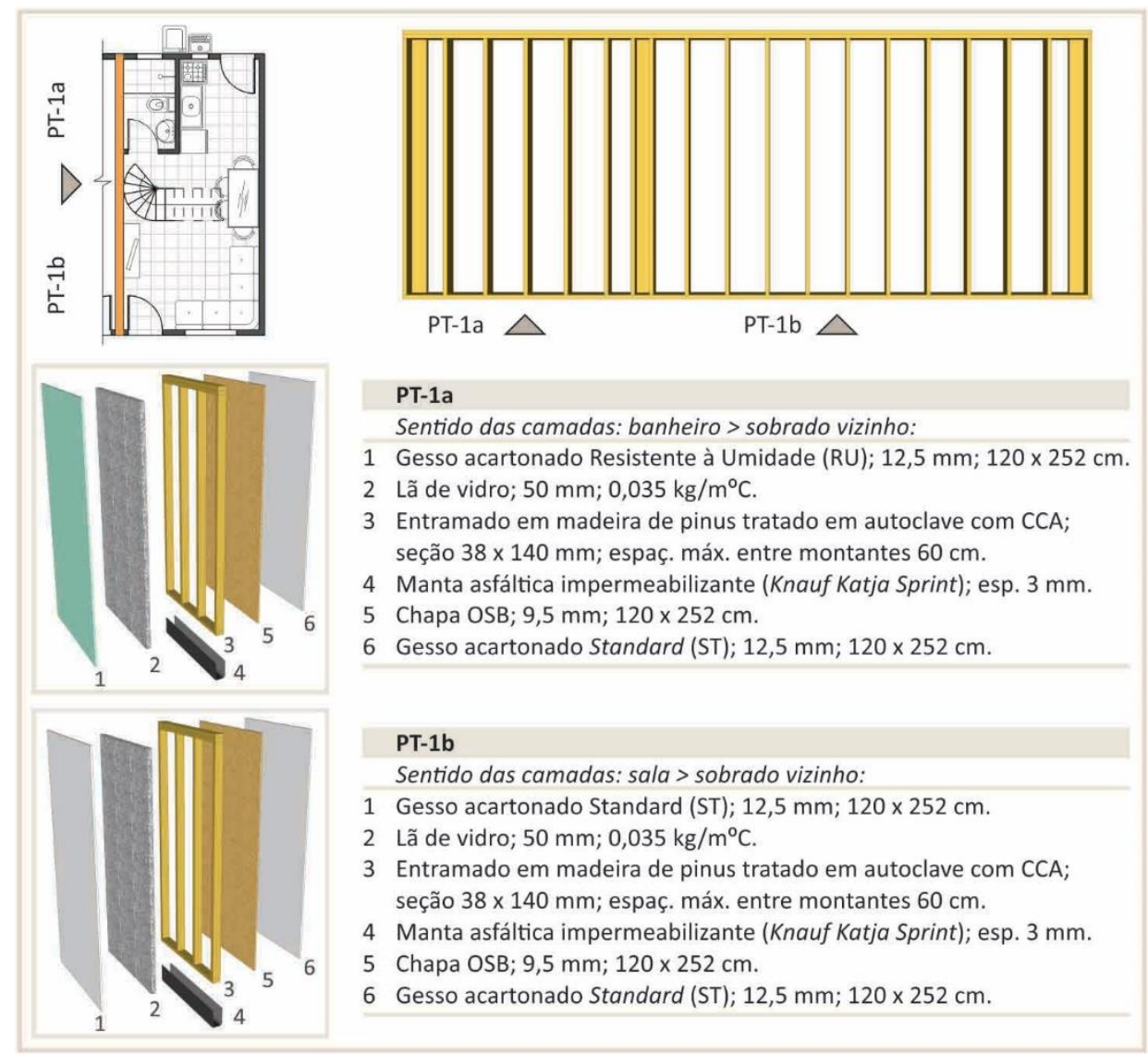

Figura 112: Constituição do painel térreo 01 do sobrado do residencial Haragano Fonte: autora.

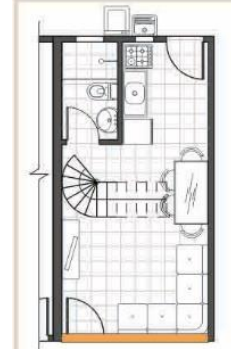

PT-2 $\triangle$

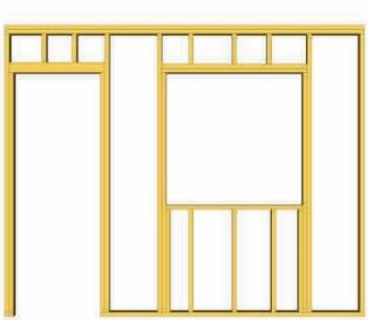

PT-2

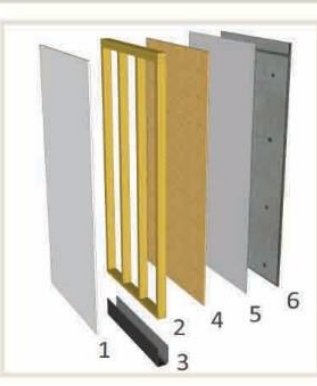

\section{PT-2}

Sentido das camadas: sala > área externa:

1 Gesso acartonado ST; $12,5 \mathrm{~mm} ; 120 \times 252 \mathrm{~cm}$.

2 Entramado com pinus tratado com CCA; seção $38 \times 89 \mathrm{~mm}$;

3 Manta asfáltica impermeabilizante.

4 Chapa OSB; $11,1 \mathrm{~mm} ; 120 \times 252 \mathrm{~cm}$.

5 Membrana hidrófuga impermeável à água e permeável ao vapor.

6 Placa cimentícia; $10 \mathrm{~mm} ; 120 \times 240 \mathrm{~cm}$.

Figura 113: Constituição do painel térreo 02 do sobrado do residencial Haragano Fonte: autora. 


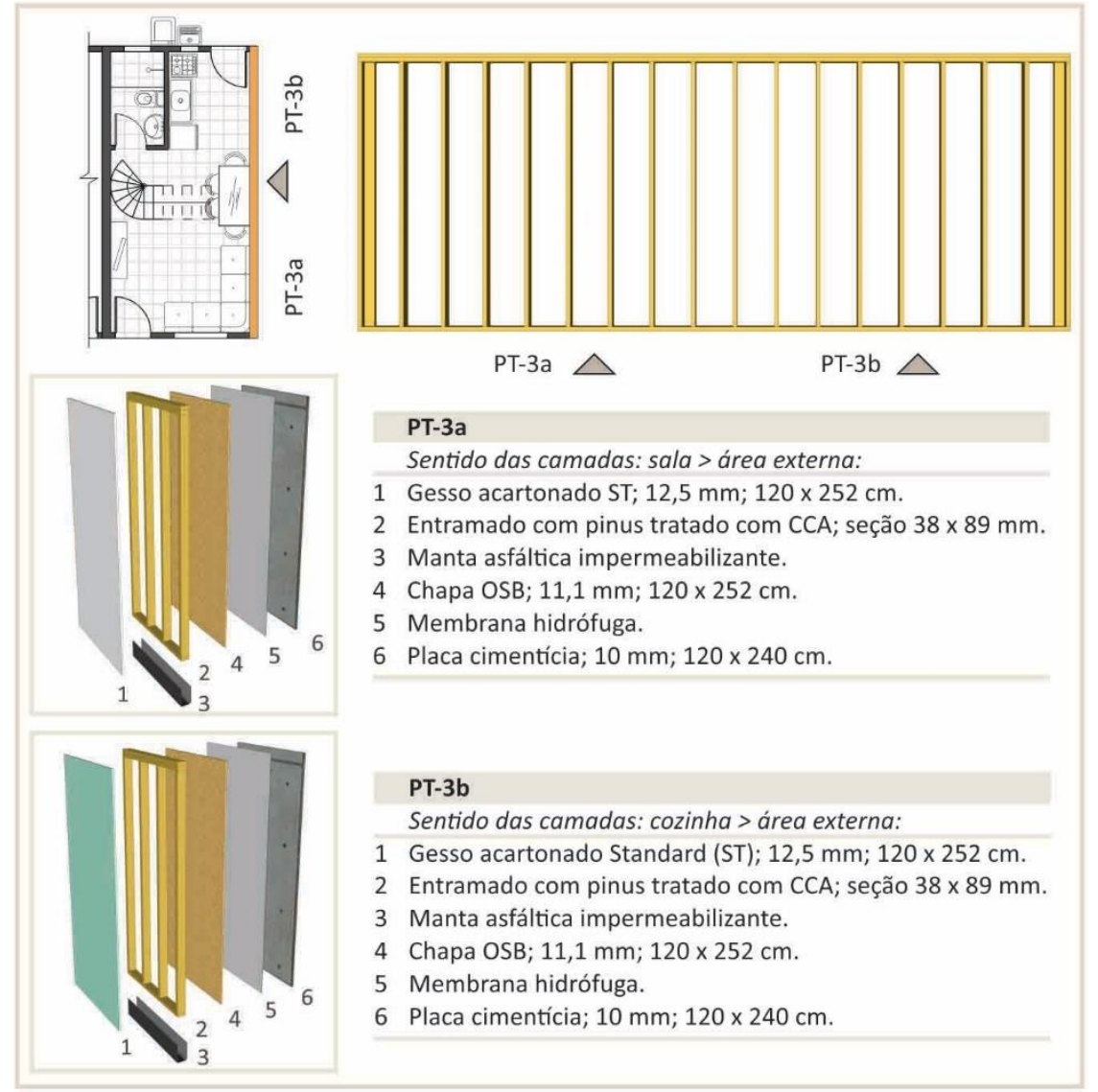

Figura 114: Constituição do painel térreo 03 do sobrado do residencial Haragano Fonte: autora.

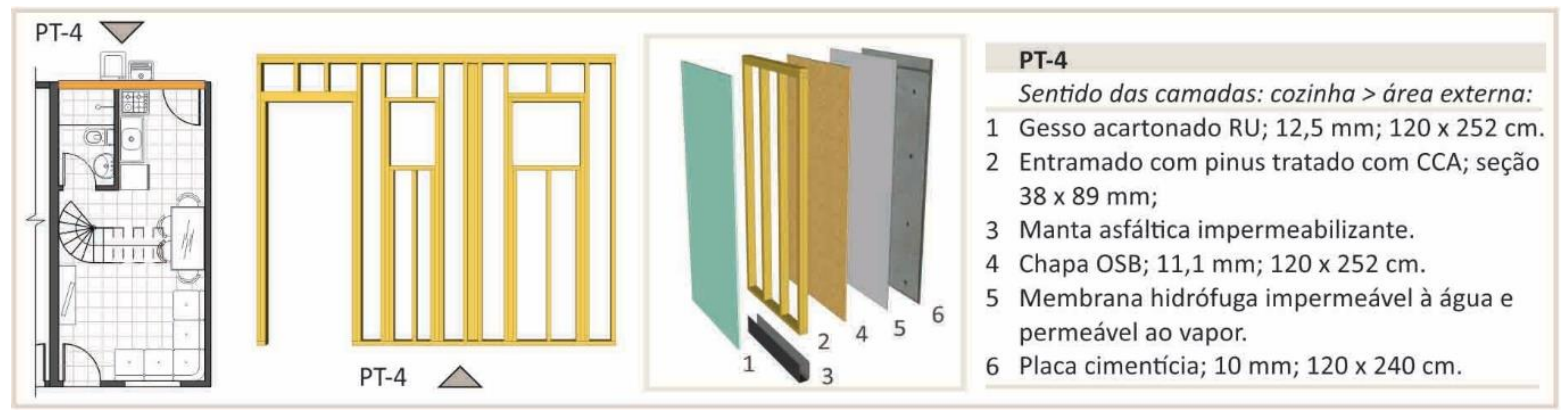

Figura 115: Constituição do painel térreo 04 do sobrado do residencial Haragano Fonte: autora.

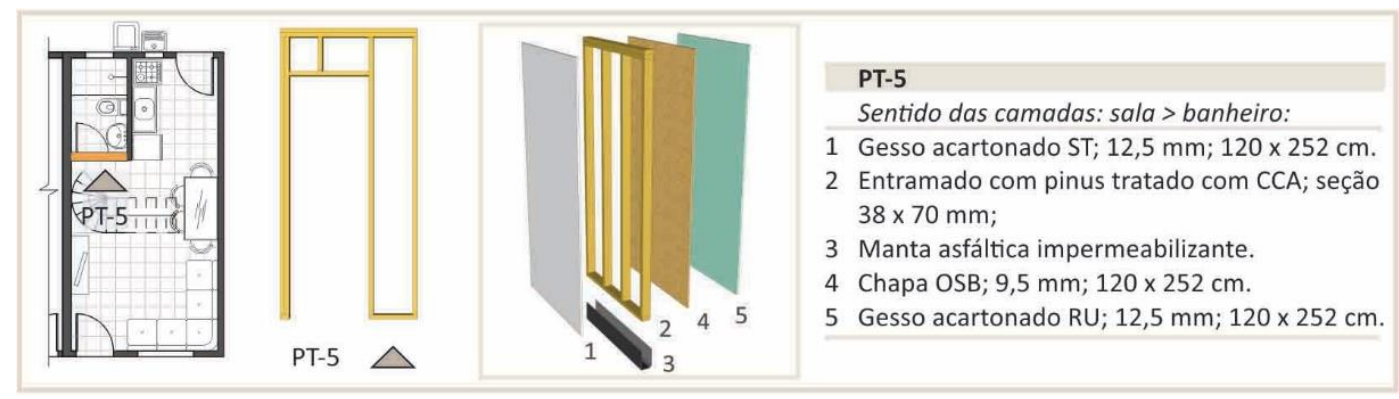

Figura 116: Constituição do painel térreo 05 do sobrado do residencial Haragano Fonte: autora. 


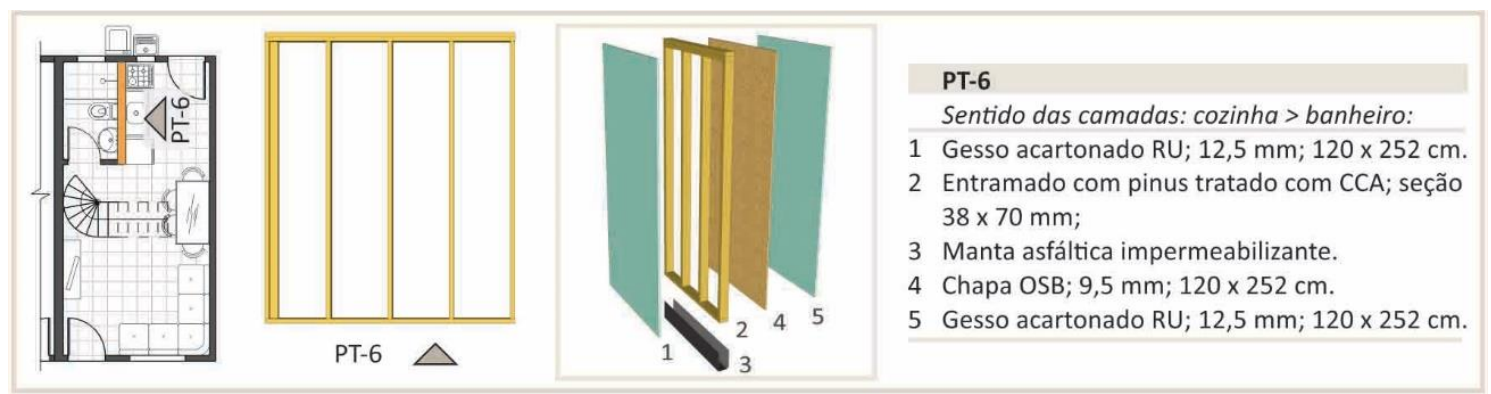

Figura 117: Constituição do painel térreo 06 do sobrado do residencial Haragano Fonte: autora.

No pavimento superior do sobrado, os materiais constituintes dos painéis de parede são semelhantes aos anteriormente detalhados. A Figura 118 apresenta as principais composições dos entramados em madeira que delimitam os ambientes dos quartos e da circulação da escada.

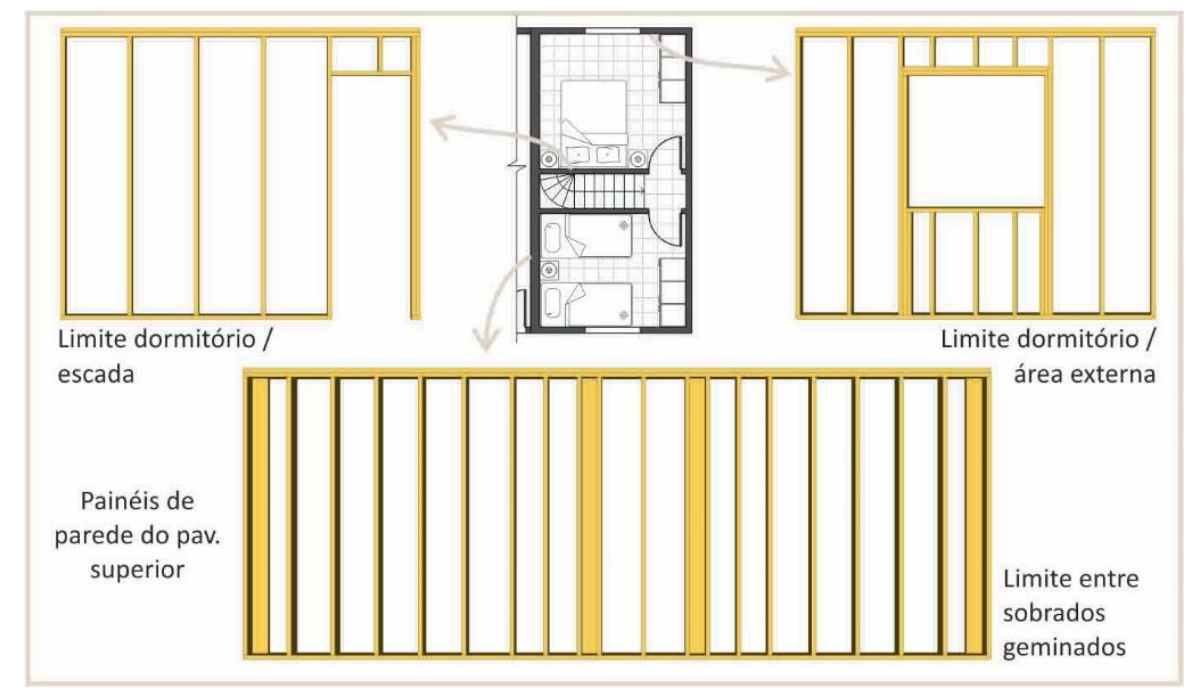

Figura 118: Principais estruturas dos painéis de parede do pavimento superior do sobrado Fonte: autora.

Após da vedação e finalização dos painéis de parede das habitações, as esquadrias são instaladas. A porta da cozinha e as janelas da sala, dos dormitórios, da cozinha e do banheiro são em alumínio. E, as portas da sala, do banheiro e dos dormitórios são em madeira.

Outro subsistema constituinte dos sobrados do residencial Haragano é o entrepiso em madeira, o qual é fixado sobre as paredes térreas e constitui-se de uma plataforma para fixar as paredes do segundo pavimento. Este entrepiso também é composto por painéis préfabricados (Figura 119). Em geral, a estrutura destes painéis é constituída por vigas em 
madeira maciça de pinus tratado em autoclave com CCA. Estas peças apresentam seção de $45 \times 190 \mathrm{~mm}$ e estão espaçadas entre si a $25,5 \mathrm{~cm}$, aproximadamente. Seu comprimento segue a dimensão da largura da edificação.

Na sequência, estas vigas são recortadas nas duas extremidades e no centro, para o encaixe e a fixação de peças em madeira de menor seção. Estas peças menores - também denominadas bloqueadores ou enrijecedores - estão posicionadas no sentido transversal às vigas e, por isso, aumentam a rigidez do conjunto estrutural, facilitam a fixação das chapas OSB sobre as mesmas e diminuem a vibração do piso.

Por fim, sobre esta estrutura em madeira, as chapas OSB são posicionadas no sentido transversal às vigas e pregadas. Estas chapas OSB têm 18,3 mm de espessura e bordas com encaixe macho-fêmea, facilitando a união entre as mesmas.

Em cada sobrado, são observados três painéis que constituem o entrepiso. Desses três, destacam-se duas configurações distintas de painéis: uma para a plataforma/base de cada dormitório e outro com a abertura da escada e a plataforma de circulação (Figura 119). Ainda, sob a plataforma de piso, são colocados forros de régua de PVC em todos os ambientes da edificação.

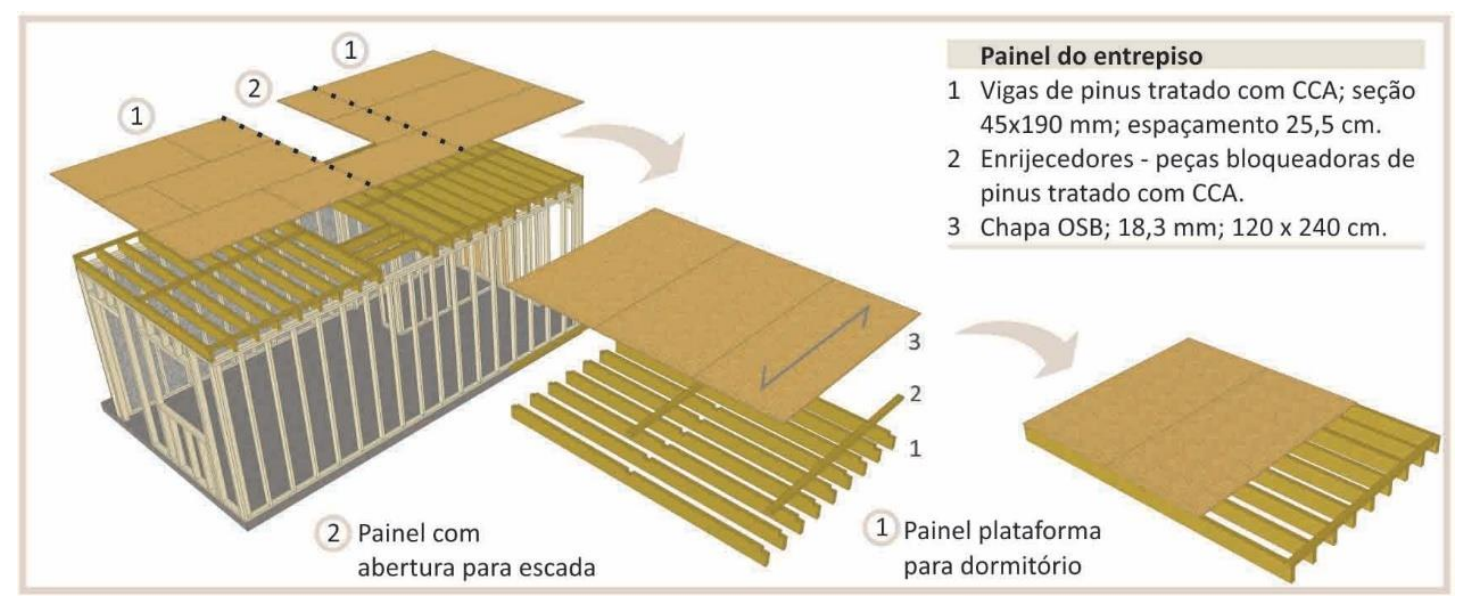

Figura 119: Composição dos painéis do entrepiso do sobrado

Fonte: autora.

O subsistema de cobertura é estruturado por treliças metálicas pré-fabricadas, vedadas com telhas cerâmicas. Para cada sobrado são distribuídas seis treliças. A treliça do oitão é vedada externamente com chapa OSB, membrana hidrófuga e placa cimentícia. E as treliças das divisões dos sobrados geminados são vedadas com chapa OSB. Ainda, nos 
ambientes internos, sobre os dormitórios, a cobertura é fechada com forro de réguas de PVC. Sobre este forro, lã de rocha de $100 \mathrm{~mm}$ de espessura é colocada para o isolamento térmico e acústico (Figura 120).

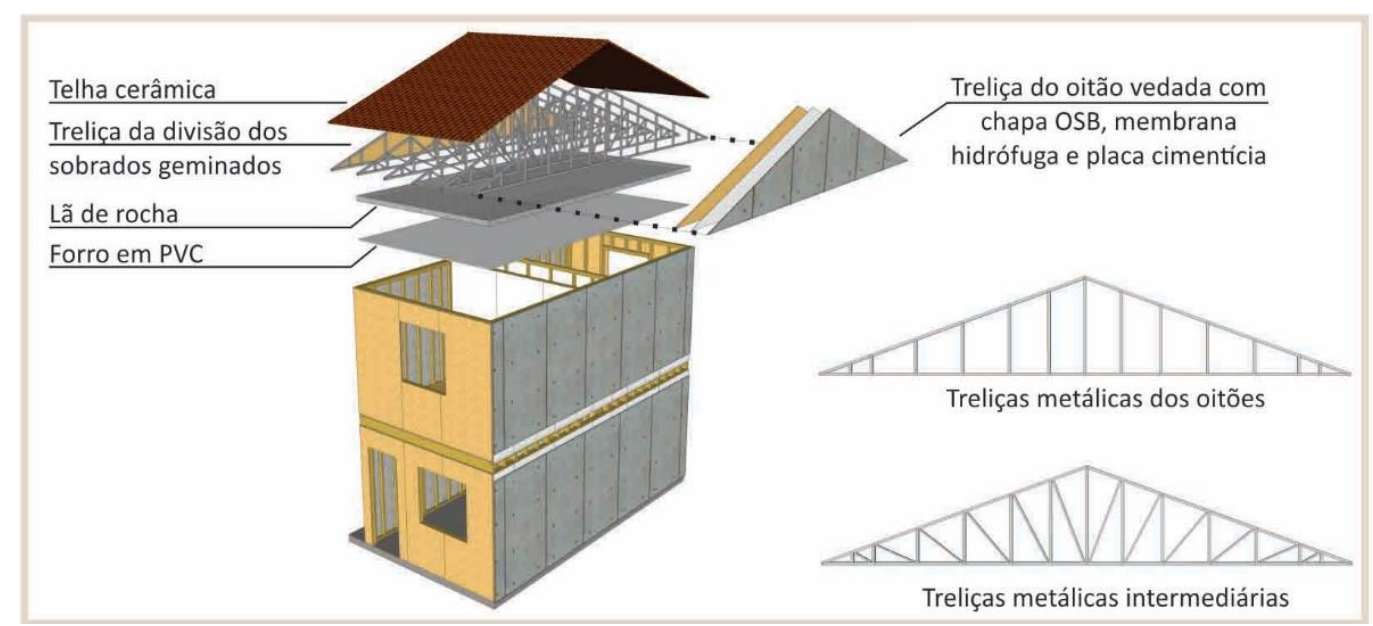

Figura 120: Composição do subsistema de cobertura da UH da extremidade das geminações Fonte: autora.

Os subsistemas complementares hidrossanitário e elétrico são executados com materiais tradicionais da prática construtiva brasileira. As tubulações de água e de esgoto são em PVC e estão embutidas na fundação de concreto e no painel de parede térreo que divide banheiro e cozinha - PT-6 (Figura 117). O reservatório das UHs é externo, assim não existe tubulação de água em outro painel de parede destas habitações.

Por sua vez, as instalações elétricas são passadas em eletrodutos corrugados flexíveis. Para os pontos de luz, estes podem estar fixados nas estruturas da cobertura e do entrepiso sobre os forros em PVC. E, para interruptores e tomadas, os eletrodutos passam pela estrutura em madeira da parede. Assim, o entramado em madeira recebe algumas furações em posições e dimensões adequadas para que a instalação elétrica fique embutida nas paredes.

Para concluir a edificação, as superfícies das paredes e dos pisos recebem os acabamentos finais. Os materiais aplicados variam conforme ambiente: externo exposto às intempéries, interno seco ou interno molhado ou molhável. Por exemplo, as superfícies externas das paredes das fachadas são finalizadas com selador acrílico e textura acrílica aplicados nesta sequência sobre as placas cimentícias. As paredes em ambientes internos secos recebem pintura acrílica sobre o gesso acartonado ST. Por sua vez, nas paredes em ambientes internos molháveis ou molhados, como a cozinha e o banheiro, sobre o gesso RU, 
é aplicado revestimento cerâmico até $150 \mathrm{~cm}$ de altura e o restante superior da parede é completado com pintura acrílica. Por fim, para o acabamento do piso, o andar térreo recebe piso e rodapé cerâmico, enquanto o piso do pavimento superior recebe laminado de madeira.

Portanto, ao analisar todos estes detalhamentos que compõem os subsistemas do Residencial Haragano, observou-se como este empreendimento aplicou o wood frame sistema construtivo não tradicional para as habitações sociais no território brasileiro. Este conjunto de técnicas construtivas, apesar de não ser originário deste país, foi adequado a este contexto. Por fim, as principais diferenças entre os sistemas construtivos Morar Melhor original e Morar Melhor Aprimorado estão apresentados na Tabela 14.

Tabela 14: Principais diferenças entres os sistemas Morar Melhor e Morar Melhor Aprimorado

\begin{tabular}{|c|c|c|c|}
\hline & Itens & \multirow{2}{*}{$\begin{array}{c}\text { Sistema Morar Melhor } \\
\text { Blocos de concreto e laje de concreto } \\
\text { impermeabilizada com tinta asfáltica }\end{array}$} & \multirow{2}{*}{$\begin{array}{c}\text { Sistema Morar Melhor Aprimorado } \\
\text { (Residencial Haragano) }\end{array}$} \\
\hline & FUNDAÇÕES & & \\
\hline \multirow{4}{*}{ 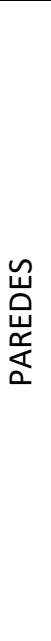 } & Entramado & $\begin{array}{c}\text { Estruturado com montantes, } \\
\text { travessas inferior, superior e } \\
\text { intermediárias. Com peças em } \\
\text { madeira de eucalipto } \\
\end{array}$ & $\begin{array}{c}\text { Estruturado com montantes, travessas } \\
\text { inferior e superior dupla. Com peças em } \\
\text { madeira de pinus, tratadas em autoclave } \\
\text { com CCA }\end{array}$ \\
\hline & $\begin{array}{l}\text { Fechamento } \\
\text { externo das } \\
\text { paredes das } \\
\text { fachadas }\end{array}$ & $\begin{array}{c}\text { Placa cimentícia com junta de } \\
\text { dilatação com sarrafo de madeira ou } \\
\text { mastique }\end{array}$ & $\begin{array}{l}\text { Placa cimentícia com tratamento de junta } \\
\text { aparente realizado com selante a base de } \\
\text { poliuretano, membrana hidrófuga e chapa } \\
\text { OSB }\end{array}$ \\
\hline & $\begin{array}{l}\text { Fechamento } \\
\text { Interno }\end{array}$ & Lambris em madeira de pinus & $\begin{array}{l}\text { Chapa OSB para paredes internas; } \\
\text { preenchimento em lã de vidro para } \\
\text { paredes geminadas; e gesso acartonado } \\
\text { ST ou RU para todas superfícies internas }\end{array}$ \\
\hline & $\begin{array}{l}\text { Acabamento } \\
\text { externo das } \\
\text { fachadas }\end{array}$ & $\begin{array}{l}\text { Selador de base acrílica e tinta } \\
\text { acrílica }\end{array}$ & Selador acrílico e textura acrílica \\
\hline \multicolumn{2}{|r|}{ ESQUADRIAS } & Em madeira com peitoril cerâmico & Em alumínio com peitoril metálico \\
\hline \multicolumn{2}{|r|}{ ENTREPISO } & $x$ & $\begin{array}{c}\text { Vigas em madeira de pinus tratado e } \\
\text { chapas OSB }\end{array}$ \\
\hline \multicolumn{2}{|r|}{ COBERTURA } & $\begin{array}{l}\text { Estruturada com madeira de } \\
\text { eucalipto, coberta com telhas de } \\
\text { fibrocimento e forrada com lambris } \\
\text { de pinus }\end{array}$ & $\begin{array}{c}\text { Estruturada com treliças metálicas pré- } \\
\text { fabricadas, coberta com telhas cerâmicas, } \\
\text { isolada com lã de rocha e forrada com } \\
\text { réguas de PVC. }\end{array}$ \\
\hline \multicolumn{2}{|r|}{ OITÃO } & $\begin{array}{l}\text { Telha de fibrocimento ou placa } \\
\text { cimentícia }\end{array}$ & $\begin{array}{l}\text { Chapa OSB, membrana hidrófuga e placa } \\
\text { cimentícia }\end{array}$ \\
\hline \multicolumn{2}{|r|}{$\begin{array}{l}\text { INSTALAÇÕES } \\
\text { ELÉTRICAS }\end{array}$} & $\begin{array}{l}\text { Eletrodutos corrugados em PVC } \\
\text { embutidos nas paredes }\end{array}$ & $\begin{array}{l}\text { Eletrodutos corrugados de PVC embutidos } \\
\text { nas paredes }\end{array}$ \\
\hline \multicolumn{2}{|c|}{$\begin{array}{l}\text { INSTALAÇÕES } \\
\text { HIDROSSANITÁRIAS }\end{array}$} & $\begin{array}{c}\text { Tubulações em PVC embutidas nas } \\
\text { paredes }\end{array}$ & $\begin{array}{c}\text { Tubulações em PVC embutidas nas } \\
\text { paredes }\end{array}$ \\
\hline
\end{tabular}

Fonte: autora com base em dados coletados. 
As realizações destes aprimoramentos são justificadas, em geral, para facilitar a execução e aumentar a durabilidade, o desempenho estrutural, os confortos térmico e acústico das edificações e o controle de qualidade dos componentes e subsistemas utilizados na construção.

Além destas mudanças nos materiais aplicados, também se fez necessário alterar o modo de produção das habitações. No sistema Morar Melhor original, a construção era inteiramente executada no canteiro. Mas, para o residencial Haragano, a construção com o sistema Morar Melhor Aprimorado exigiu a aplicação de outros métodos para garantir qualidade, eficiência e rapidez, conforme exigências da CEF e do PMCMV para empreendimentos desta escala.

Assim, o item seguinte detalhará como ocorreu a produção das habitações do residencial Haragano utilizando o sistema wood frame.

\subsection{PRODUÇÃO DAS HABITAÇÕES EM WOOD FRAME NA FÁBRICA E NO CANTEIRO}

Antes da execução das UHs do Residencial Haragano, o processo iniciou com estudos preliminares, anteprojeto e projeto definitivo das habitações de um e dois pavimentos. Nessas etapas, ocorreu a seleção dos componentes constituintes e o detalhamento de elementos que integram os subsistemas das edificações, conforme demonstrados no item anterior. Os projetos arquitetônicos, complementares e estruturais foram realizados com base nestas especificações. Neste caso, o grau de detalhamento dos projetos para estas edificações em wood frame foi maior do que o costumeiramente elaborado para construções tradicionais em alvenaria e concreto armado. Pois, além de ser um sistema inovador, a quantidade de componentes diferentes é significativamente maior no wood frame, quando comparada às práticas construtivas tradicionais do país.

O projeto arquitetônico foi inicialmente elaborado pela empresa Roberto Ferreira, com base em suas experiências prévias com habitações sociais. Também, esta teve como referência os critérios estabelecidos pela CEF para empreendimentos enquadrados na Faixa 1 do PMCMV. Por sua vez, a empresa Tecverde, enquanto consultora técnica, auxiliou no ajuste deste projeto conforme as propriedades do sistema wood frame, com objetivo de otimizar o processo e reduzir os custos atribuídos aos materiais aplicados e aos trabalhadores envolvidos nesta produção. 
A elaboração dos diversos projetos constituintes das habitações ocorreu em processos simultâneos para garantir a compatibilidade entre os componentes dos diferentes subsistemas da edificação, incluindo a relação entre o sistema estrutural e as instalações elétricas e hidrossanitárias. Assim, por evitar conflitos durante a montagem dos componentes, a qualidade do conjunto edificado e a eficiência e a racionalização nas etapas de execução seriam prezadas. Estes desenhos eram realizados em Autocad e Revit - softwares tradicionais de projeto.

Após o fechamento deste conjunto de projetos das UHs do Haragano, a cadeia de produção do sistema wood frame iniciou com o fornecimento dos insumos utilizados nas habitações. A procedência destes componentes, na sua maioria, era de produtores nacionais. Por exemplo, a lã de rocha foi produzida e fornecida por uma indústria com instalações nos Estados de São Paulo e de Santa Catarina. As peças em madeira de pinus foram fornecidas por uma empresa do setor florestal situada no município de Ponta Grossa, no Paraná. O tratamento químico destas peças em madeira foi feito por outra empresa deste mesmo município paranaense. Outros componentes da construção, como chapa OSB, placa cimentícia e gesso acartonado, eram de empresas de sedes internacionais, mas que possuem produção e fornecimento em fábricas filiais no Brasil. Ainda, a membrana hidrófuga e a manta asfáltica impermeabilizante foram produzidas no exterior e importadas por fornecedores representantes no Brasil (Figura 121).

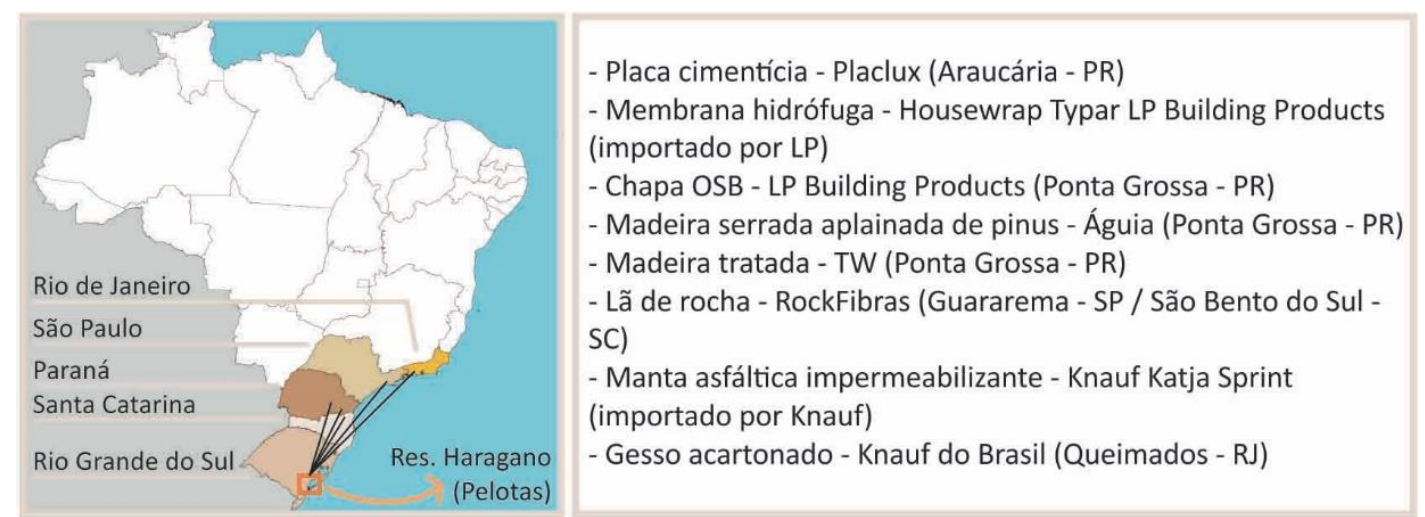

Figura 121: Localização dos principais fornecedores de insumos para o wood frame do Haragano Fonte: autora.

Estes componentes são caracterizados por serem processados mecanicamente ou manufaturados nas suas indústrias específicas, tendo como destino final, neste caso, a 
aplicação no setor da construção civil. Assim, cada um destes componentes industrializados apresenta sua respectiva cadeia de produção. Por exemplo, a seguir, descreve-se de forma sintetizada a cadeia de produção da madeira serrada utilizada nas edificações construídas com o sistema wood frame (Figura 122). A madeira de pinus aplicada nos entramados dos painéis de parede é oriunda de um processo que inicia com a produção florestal, a qual resulta em toras como produtos finais intermediários. Na sequência, estas toras são transportadas para as serrarias, onde passam por um processamento primário. As toras são cortadas longitudinalmente em pranchas e transformadas em peças menores de madeira serrada bruta, como tábuas, vigas, caibros, ripas. Após, estas peças são secas naturalmente ou em estufa. Por fim, no processamento secundário, que ocorre nas beneficiadoras, as peças são beneficiadas com usinagens diversas para transformá-las em produtos com acabamento final. Um tipo de usinagem é o aplainamento das peças que visa uniformizar suas superfícies e suas dimensões. Para o wood frame, utiliza-se madeira serrada aplainada para peças como montantes e travessas. Por fim, antes da aplicação na construção das edificações, estas peças são tratadas em autoclave com produto CCA, para evitar o ataque de insetos xilófagos e a incidência de fungos.

\begin{tabular}{|c|c|c|c|}
\hline \multicolumn{2}{|c|}{ Produção florestal } & & \multirow{2}{*}{$\begin{array}{c}\text { Produto final intermediário: } \\
\text { Toras }\end{array}$} \\
\hline $\begin{array}{c}\text { Produção de } \\
\text { mudas }\end{array} \rightarrow \begin{array}{c}\text { Preparo do } \\
\text { solo }\end{array} \rightarrow$ & Plantio $\rightarrow$ Manejo $\rightarrow \begin{array}{c}\text { Colheita / } \\
\text { Corte }\end{array}$ & $E$ & \\
\hline \multicolumn{2}{|c|}{ Transporte } & & \\
\hline \multicolumn{2}{|c|}{ Produção na serraria - processamento primário } & & \multirow{2}{*}{$\begin{array}{c}\text { Produto final intermediário: } \\
\text { Madeira serrada bruta (tábuas, } \\
\text { vigas, caibros, ripas) }\end{array}$} \\
\hline $\begin{array}{c}\text { Desdobro (corte longitudinal } \\
\text { da tora em pranchas) }\end{array} \rightarrow \begin{array}{c}\text { Corte } \\
\text { (tr }\end{array}$ & $\begin{array}{l}\text { e, esquadrejamento e destopamento } \\
\text { ransformação em peças menores) }\end{array}$ & 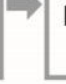 & \\
\hline \multicolumn{2}{|c|}{ Secagem (natural ao ar ou artificial em estufa) } & & \\
\hline \multicolumn{2}{|c|}{ Produção na serraria - processamento secundário } & & \multirow{2}{*}{$\begin{array}{c}\text { Produto final: } \\
\text { Madeira serrada beneficiada } \\
\text { aplainada (exemplo: peças } \\
\text { constituintes do wood frame, } \\
\text { como montantes e travessas) }\end{array}$} \\
\hline $\begin{array}{l}\text { Beneficiamento (usinagem para } \\
\text { transformar a madeira serrada em } \\
\text { processos de acabamento) }\end{array}$ & $\begin{array}{c}\text { Exemplo: aplainamento } \\
\text { para uniformizar superfícies } \\
\text { e dimensões }\end{array}$ & $\Rightarrow$ & \\
\hline \multicolumn{2}{|c|}{ Processo de tratamento químico das peças serradas } & & \multirow{2}{*}{$\begin{array}{c}\text { Produto final: } \\
\text { Madeira serrada beneficiada } \\
\text { tratada com CCA }\end{array}$} \\
\hline $\begin{array}{c}\text { Madeira introduzida } \\
\text { na autoclave }\end{array} \rightarrow \begin{array}{l}\text { Vácuo } \\
\text { inicial }\end{array} \rightarrow \begin{array}{c}\text { Produ } \\
\text { inser }\end{array}$ & $\begin{array}{l}\text { ito químico (CCA) } \\
\text { rido sob pressão }\end{array} \rightarrow \begin{array}{c}\text { Vácuo } \\
\text { final }\end{array} \rightarrow$ Secagem & $\Rightarrow$ & \\
\hline
\end{tabular}

Figura 122: Processo de produção da madeira serrada aplainada aplicada no wood frame Fonte: autora.

Assim como este caso das peças em madeira serrada, os demais insumos das habitações do Residencial Haragano passam por suas cadeias de produção antes de serem 
introduzidos no processo da construção das edificações em wood frame. Com o recebimento destes insumos industrializados, inicia-se a execução das construções das habitações deste empreendimento.

O método de construção adotado para o Haragano consistiu em etapas realizadas na fábrica e no canteiro. Os painéis da parede e do entrepiso foram produzidos na fábrica própria da empresa Roberto Ferreira. Estes painéis de parede pré-fabricados, por serem abertos, como serão detalhados na sequência deste trabalho, foram finalizados no canteiro-de-obras. Os subsistemas fundação, cobertura e instalações elétrica e hidrossanitária foram executados diretamente no canteiro. Também, no canteiro, foram executados os acabamentos finais dos pisos e das superfícies externas e internas das paredes (Tabela 15).

Tabela 15: Elementos do Res. Haragano produzidos na fábrica e no canteiro

\begin{tabular}{|c|c|c|}
\hline Itens & Fábrica própria em Pelotas, RS & Canteiro-de-obras do Res. Haragano \\
\hline FUNDAÇÃO & $x$ & $\begin{array}{l}\text { Radier estruturado com concreto armado e } \\
\text { impermeabilização com tinta asfáltica }\end{array}$ \\
\hline PAREDES & $\begin{array}{c}\text { Painel de parede aberto, que } \\
\text { consiste no entramado em madeira } \\
\text { fechado com chapa OSB, } \\
\text { membrana hidrófuga, manta } \\
\text { asfáltica impermeabilizante e placa } \\
\text { cimentícia }\end{array}$ & $\begin{array}{l}\text { Instalação e fixação dos painéis abertos sobre } \\
\text { a fundação ou sobre o entrepiso. Finalização } \\
\text { e fechamento dos painéis com chapa OSB } \\
\text { para paredes internas, preenchimento em lã } \\
\text { de vidro para paredes geminadas e gesso } \\
\text { acartonado para todas superfícies internas }\end{array}$ \\
\hline ENTREPISO & $\begin{array}{c}\text { Painel de piso, que consiste no } \\
\text { conjunto estruturado com vigas em } \\
\text { madeira serrada e fechamento } \\
\text { superior com chapa OSB }\end{array}$ & $\begin{array}{l}\text { Instalação e fixação dos painéis sobre as } \\
\text { paredes térreas e fixação da escada. } \\
\text { Instalação do forro de PVC sob entrepiso. }\end{array}$ \\
\hline COBERTURA & (Produção terceirizada) & $\begin{array}{l}\text { Instalação das treliças metálicas pré- } \\
\text { fabricadas e fechamento da cobertura com } \\
\text { telhas cerâmicas. } \\
\text { Colocação da lã de rocha e forros em PVC. }\end{array}$ \\
\hline OITÃO & $x$ & $\begin{array}{l}\text { Instalação da estrutura metálica pré- } \\
\text { fabricada e fechamento com chapa OSB, } \\
\text { membrana hidrófuga e placa cimentícia }\end{array}$ \\
\hline $\begin{array}{l}\text { INSTALAÇÕES } \\
\text { ELÉTRICAS } \\
\end{array}$ & $x$ & $\begin{array}{l}\text { Instalação dos eletrodutos corrugados } \\
\text { embutidos nas paredes e nos forros }\end{array}$ \\
\hline $\begin{array}{l}\text { INSTALAÇÕES } \\
\text { HIDROSSANITÁRIAS }\end{array}$ & $\mathrm{X}$ & $\begin{array}{c}\text { Instalação das tubulações em PVC embutidas } \\
\text { na laje radier e nas paredes }\end{array}$ \\
\hline ESQUADRIAS & (Produção terceirizada) & $\begin{array}{l}\text { Instalação das esquadrias prontas e dos } \\
\text { peitoris }\end{array}$ \\
\hline ACABAMENTOS & $\mathrm{x}$ & $\begin{array}{l}\text { Execução dos acabamentos finais de piso, de } \\
\text { paredes internas e externas e dos oitões }\end{array}$ \\
\hline
\end{tabular}

Fonte: autora.

Assim, como será detalhado a seguir, o método de produção das edificações ocorreu em duas etapas diferentes: na fábrica e no canteiro. 


\subsubsection{Produção na fábrica}

A unidade de fabricação estava localizada no município de Pelotas, no bairro Laranjal, na antiga instalação de uma fábrica e distribuidora de produtos alimentícios. Estava distante do Residencial Haragano em 10 km, aproximadamente. Foi estabelecida como resultado da pareceria entre as empresas Roberto Ferreira e a consultoria da empresa Tecverde, haja vista a experiência desta última com sua primeira unidade de fabricação própria em operação desde o fim do ano de 2010, em Pinhais, no Paraná.
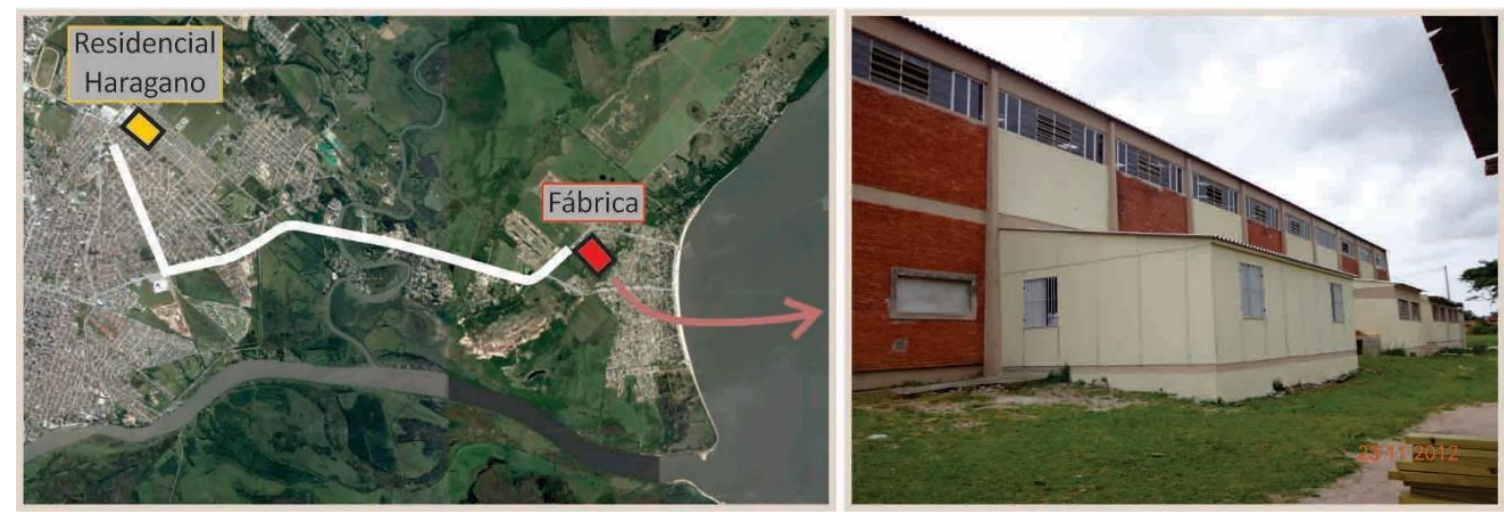

Figura 123: Localização da fábrica de componentes do sistema wood frame no bairro Laranjal, Pelotas

Fonte: elaborado pela autora com base em mapa GoogleMaps (2016) e foto do arquivo pessoal (2012).

A implementação desta fábrica em Pelotas ocorreu no início de 2012 visando, a princípio, a produção dos componentes do sistema wood frame das UHs do Haragano. Conforme citado anteriormente, as atividades foram concentradas nas produções de painéis de parede e de piso. Assim, o layout foi projetado para estas produções, tendo as práticas de pré-fabricação de empresas alemãs como referência principal.

Na planta da fábrica ilustrada na Figura 124, pode-se observar uma área maior, que foi destinada para a produção dos elementos construtivos, e alguns ambientes em compartimentos menores, destinados para escritório, almoxarifado, banheiros masculino e feminino e casa de máquinas, onde situava-se o compressor de ar para os equipamentos mecanizados, como, por exemplo, as pregadeiras pneumáticas (Figura 125). 


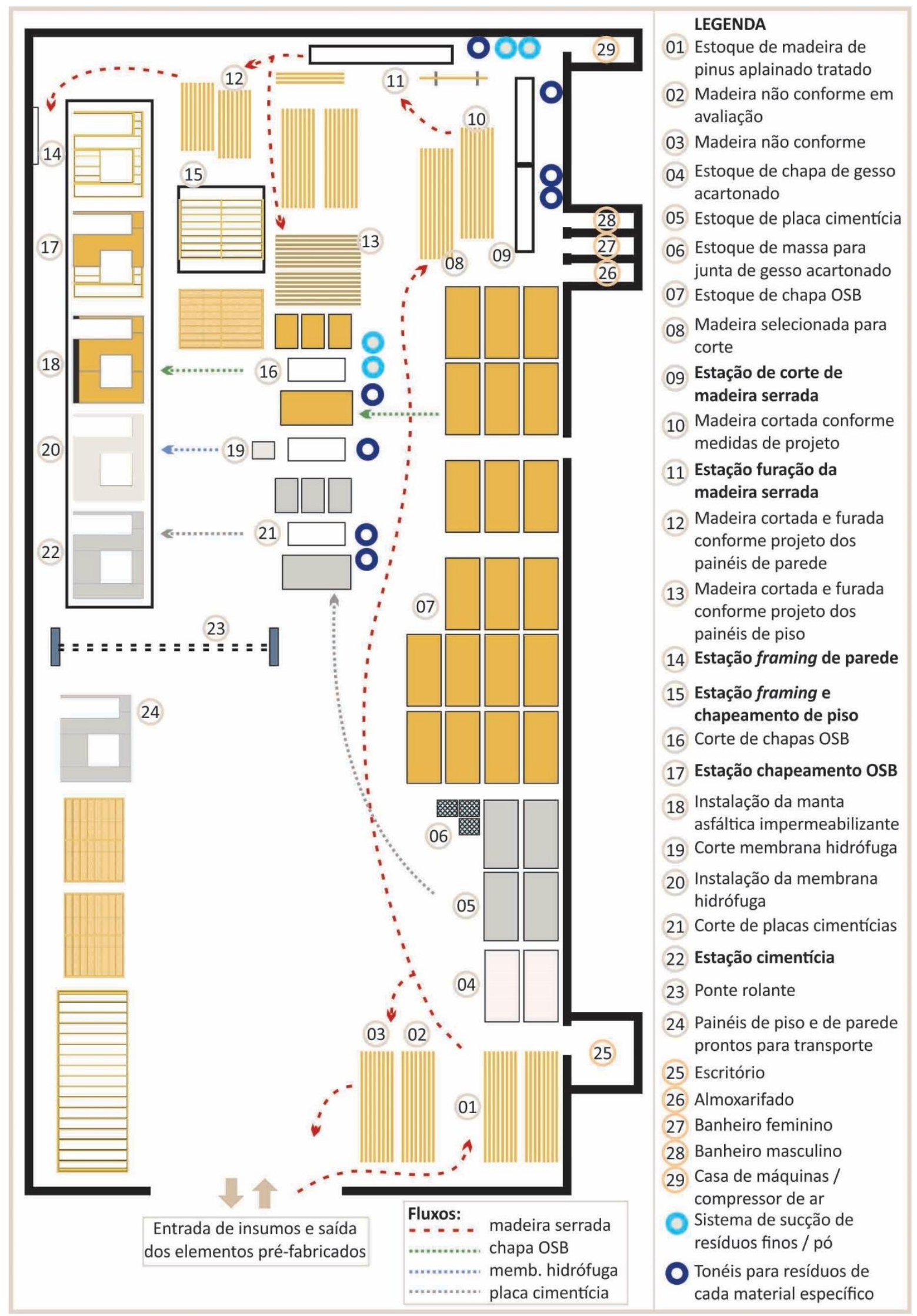

Figura 124: Planta da fábrica com layout e fluxos da produção dos elementos em wood frame Fonte: autora. 

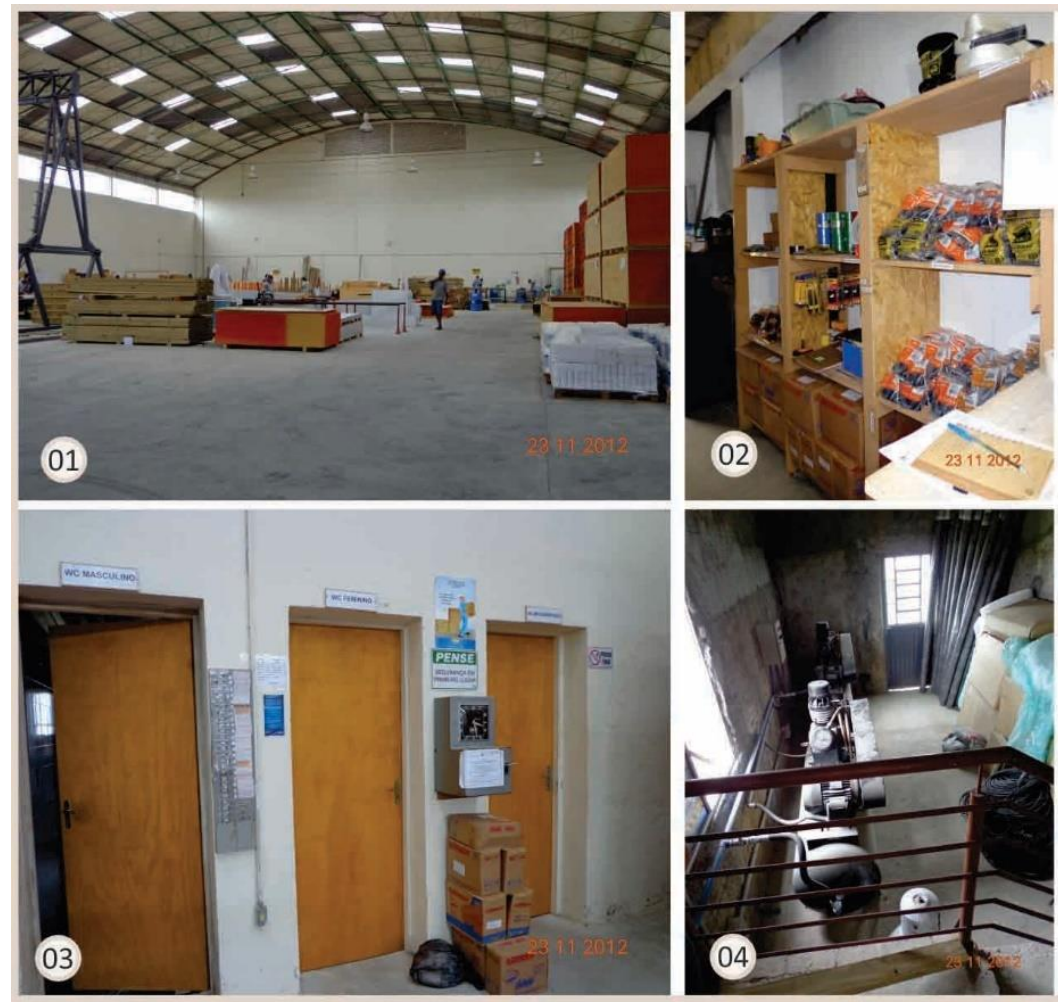

01 Área principal de produção

02 Almoxarifado

03 Banheiros e almoxarifado

04 Casa de máquinas

Figura 125: Principais ambientes da fábrica

Fonte: autora.

Inicialmente, com o recebimento dos insumos, estes eram conferidos e organizados em áreas destinadas para os estoques. Os insumos menores foram depositados no almoxarifado e os maiores, como madeira serrada de pinus, chapa de gesso acartonado, placa cimentícia e chapa OSB foram locados próximos das atividades da produção (Figura 126).

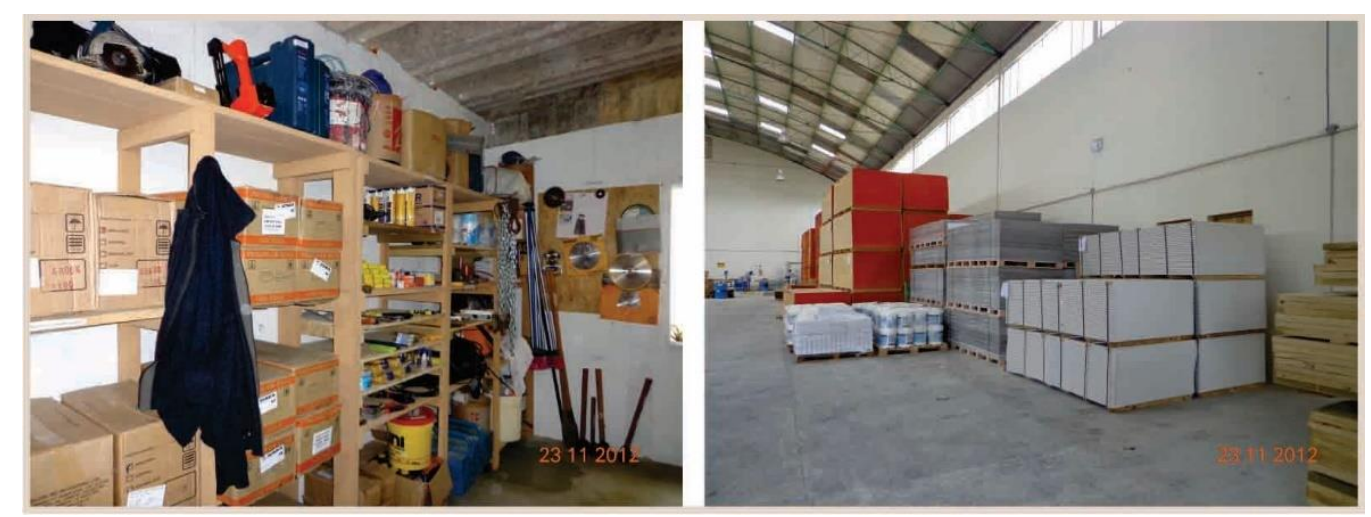

Figura 126: Estoques de insumos na fábrica Fonte: autora.

Após conferência visual, cada grupo de componentes recebeu uma placa de identificação com nome do material, data de produção, lote do fornecedor e especificações 
técnicas simplificadas dos produtos, como espessura, seção, largura, comprimento. Também, com estes dados, esses produtos eram registrados com um código para possibilitar seu rastreamento no elemento pré-fabricado e na edificação finalizada, para garantir a qualidade dos mesmos.

As atividades da produção na fábrica estavam organizadas por uma linha de montagem sequencial, onde os processos foram praticamente simultâneos. Esta produção concentrouse em estações de trabalho, tais como: estação de corte de madeira serrada, estação de furação da madeira serrada, estação framing e chapeamento do painel de piso, estação framing do painel de parede, estação chapeamento e estação cimentícia. A seguir, as etapas principais desta produção serão descritas com mais detalhes.

Primeiro, para produção dos entramados dos painéis, as peças do estoque de madeira, uma por uma, foram analisadas visualmente para conferir se apresentavam defeitos, como deformações ou tortuosidades, rachaduras, variação da seção transversal, presença excessiva de nós. Se sua conformidade não era considerada suficiente nesta primeira análise, as peças eram separadas para uma segunda avaliação, com objetivo de aplicá-las em peças mais curtas do entramado e, assim, reduzir o descarte direto.

Neste aspecto, inicialmente, uma estimativa não oficial constatou que muitas peças em madeira não estavam em conformidade, chegando a perder $10 \%$ deste material ${ }^{28}$. Um dos problemas relatados foi que a madeira proveniente do Paraná chegava ao município de Pelotas com umidade acima do permitido para o processo de produção, com aproximadamente $40 \%$ de umidade. Portanto, para o monitoramento desta condição, foi necessário contratar um engenheiro florestal. O mesmo também verificava a condição de impregnação do CCA nas peças. Em geral, foi observado que a distância entre o local da fonte da matéria-prima até o local da sua aplicação na produção, assim como as diferentes condições climáticas entre estes interferiram neste processo. Inicialmente, isto ocasionou atrasos na produção dos painéis. Com o tempo, muitas peças foram trocadas pelos fornecedores esta perda de material foi reduzida para $1 \%$. Por fim, para garantir a qualidade final da construção, as peças eram devidamente selecionadas (Figura 127).

\footnotetext{
${ }^{28}$ Este dado foi apresentado como uma estimativa sem análise quantitativa oficial. Porém, pela gravidade desta lacuna, ressalta-se a necessidade de ampliar este estudo para procurar melhorar a qualidade e a padronização das peças de madeira fornecidas para a construção civil. Questiona-se se estes fatores podem ser decorrentes de medidas errôneas durante a cadeia de produção da madeira serrada, incluindo o processo florestal, os processamentos mecânicos e o tratamento químico em autoclave.
} 


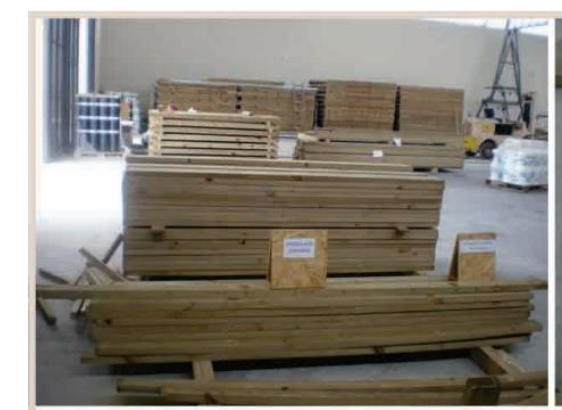

Peças em madeira não conforme

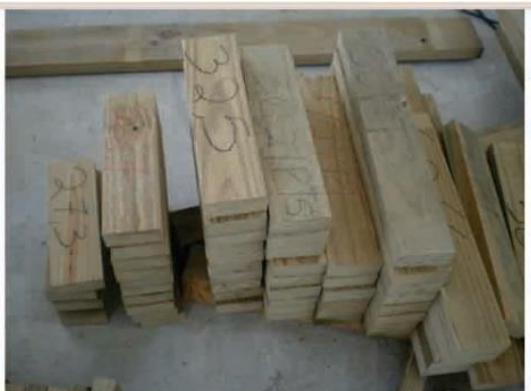

Peças não conforme reaproveitadas

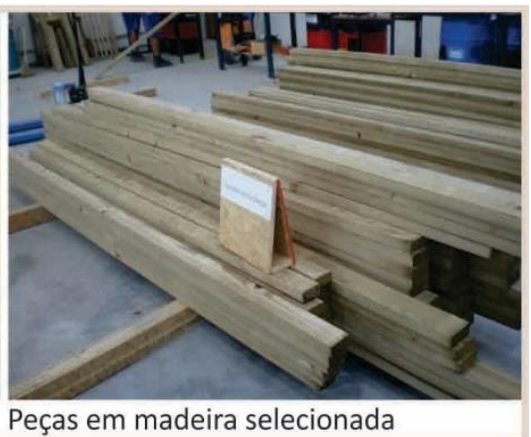

Peças em madeira selecionada

Figura 127: Conferência da qualidade das peças em madeira no início da produção Fonte: autora.

Na sequência, as peças de madeiras em conformidade eram selecionadas e carregadas até a estação de corte. Este carregamento ocorria manualmente ou com auxílio de paleteira hidráulica (Figura 128). Na estação de corte, conforme o projeto de produção, as peças eram medidas, marcadas e cortadas com serras circulares sobre esteira de rolamento. Os pedaços que sobravam do corte eram reaproveitados para outras peças menores do entramado ou viravam resíduos depositados em tonéis ou tambores metálicos com identificação específica para as diferentes seções das peças. E os resíduos finos, como pó, eram limpos com um sistema de sucção (Figura 129).

Logo ao lado, quando necessário, estas peças cortadas eram furadas para possibilitar a passagem das tubulações das instalações elétrica e hidrossanitária. Depois de prontas, as peças eram carregadas para locais próximos das mesas de montagem dos painéis de piso e de parede (Figura 129).

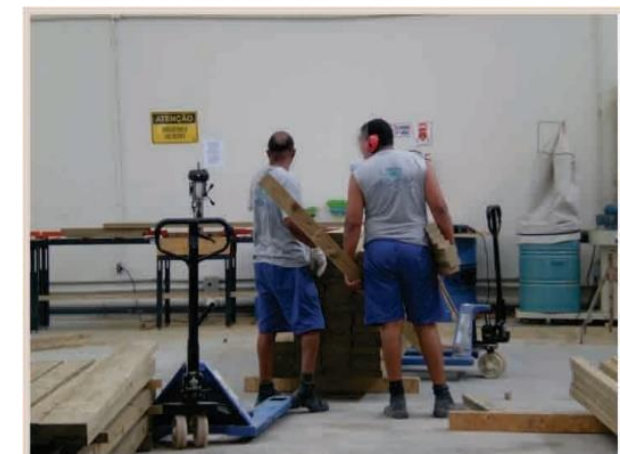

Carregamento com paleteira hidráulica

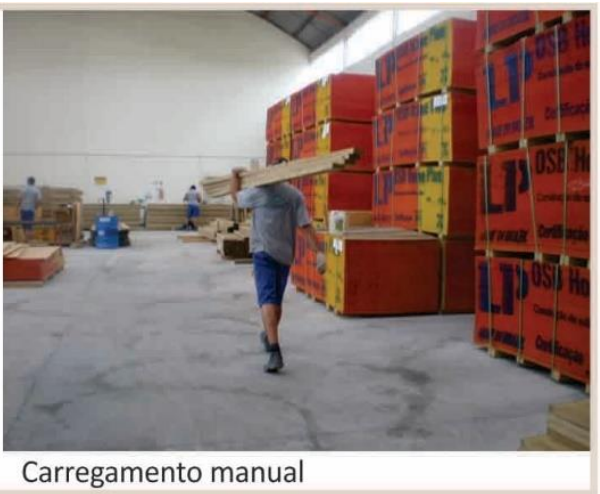

Carregamento manual

Figura 128: Carregamento da madeira até estação de corte Fonte: autora. 


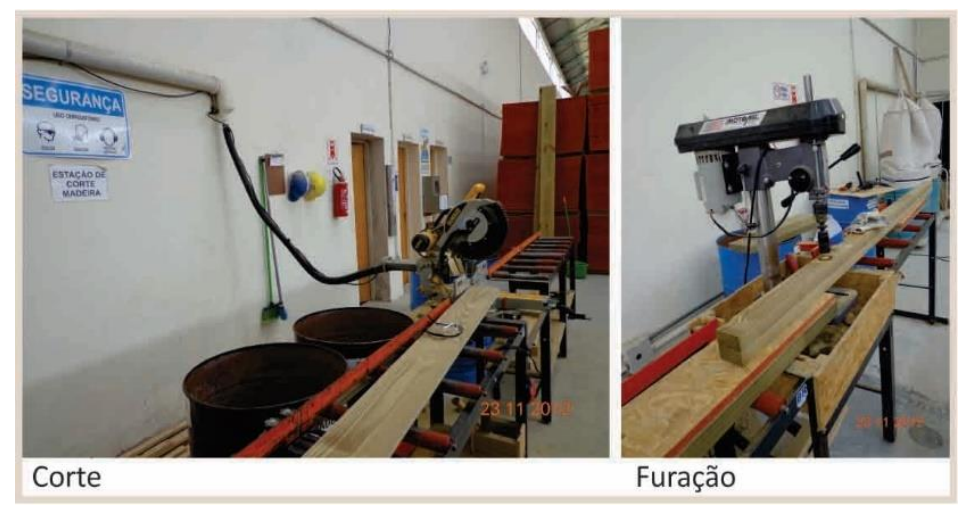

Figura 129: Estações de corte e furação das peças conforme projeto de produção Fonte: autora.

Em paralelo, foram realizados os cortes das chapas OSB e das placas cimentícia. Para auxiliar, O OSB e a cimentícia eram carregados desde o estoque para as suas respectivas bancadas, onde cada material era cortado com serras circulares. Após o corte, as peças eram identificadas e armazenadas na vertical entre cabos para facilitar a sua retirada para a instalação sobre os painéis de parede ou de piso (Figura 130). Nestes locais, os resíduos também eram recolhidos em tonéis específicos e por meio do sistema de sucção de pó.

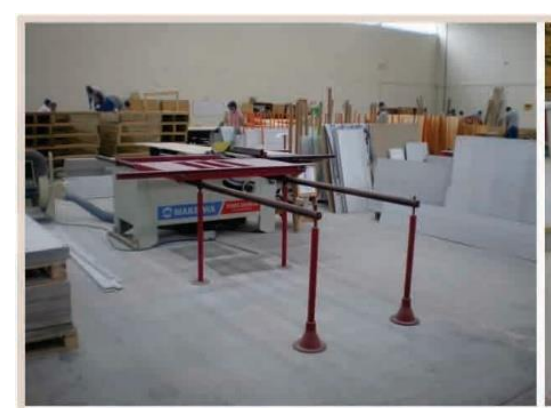

Corte

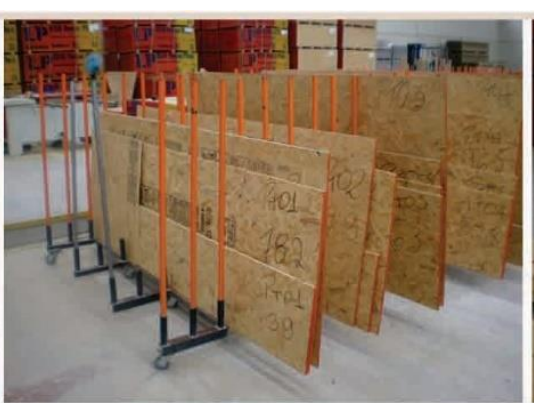

Chapas OSB cortadas

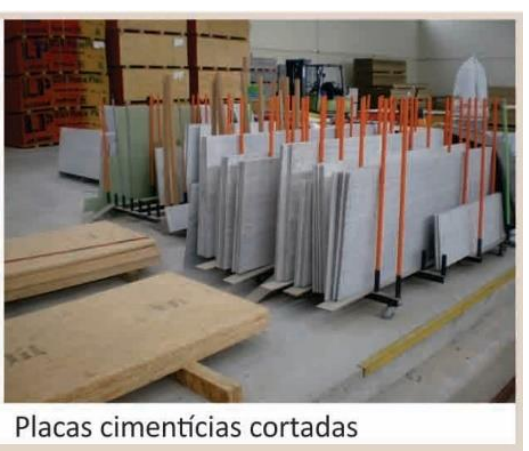

Placas cimentícias cortadas

Figura 130: Bancadas de corte das chapas OSB e placas cimentícias

Fonte: autora.

$\mathrm{Na}$ produção do painel de piso, as peças em madeira cortadas e furadas foram posicionadas próximas da mesa de montagem deste painel. Ali, as vigas em madeira foram posicionadas com afastamento adequado entre si, seguindo as medidas detalhadas no seu projeto de produção. Sobre as vigas, as peças bloqueadoras ou enrijecedores foram colocadas com auxílio de um martelo para o correto encaixe. Por fim, as chapas OSB já cortadas foram posicionadas e, por fim, pregadas com pregadeira pneumática (Figura 131). 


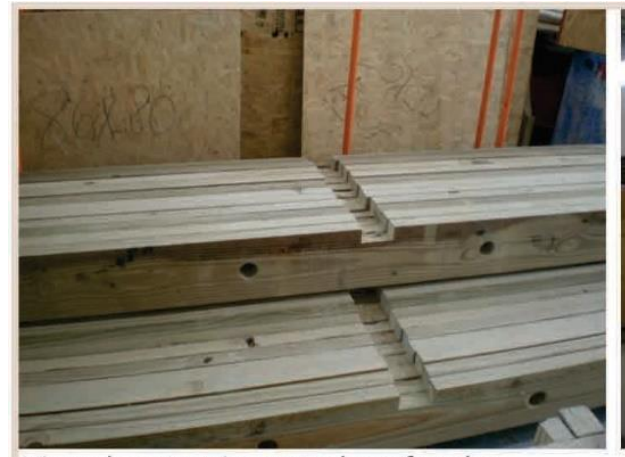

Vigas do entrepiso cortadas e furadas

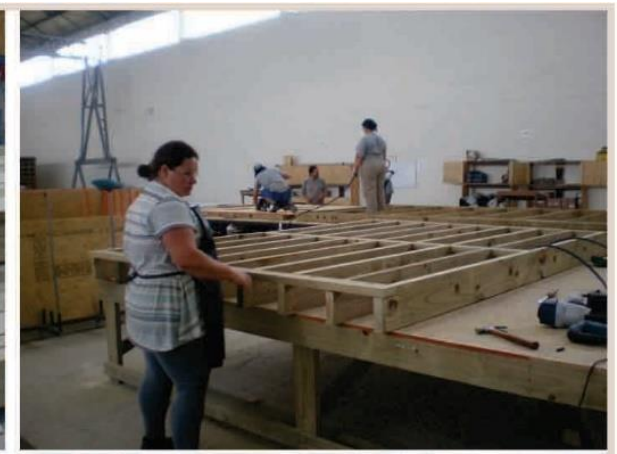

Mesa de montagem do painel de piso

Figura 131: Peças do entrepiso cortadas e montagem do painel Fonte: autora.

Na produção do painel de parede, uma grande mesa de montagem compreendeu as estações framing, chapeamento e cimentícia (Figura 132). Sobre esta mesa, primeiro, as peças em madeira do entramado foram posicionadas conforme seu projeto de produção e com auxílio do guia de instruções para o trabalhador. Respeitando os afastamentos entre as peças e as medidas das aberturas das esquadrias, as peças foram unidas com pregos mediante pregadeira pneumática. Após a finalização, o entramado foi rolado para a próxima fase da montagem. Isso ocorreu com o auxílio dos roletes metálicos inseridos na mesa, movidos por um sistema hidráulico. Nesta sequência, as chapas OSB já cortadas foram posicionadas sobre o entramado e pregadas. Depois, envelopou-se a base do entramado e da chapa OSB com a manta asfáltica impermeabilizante. Sobre a chapa OSB, instalou-se a membrana hidrófuga. E, por fim, a placa cimentícia foi posicionada e fixada com parafusos (Figura 133).

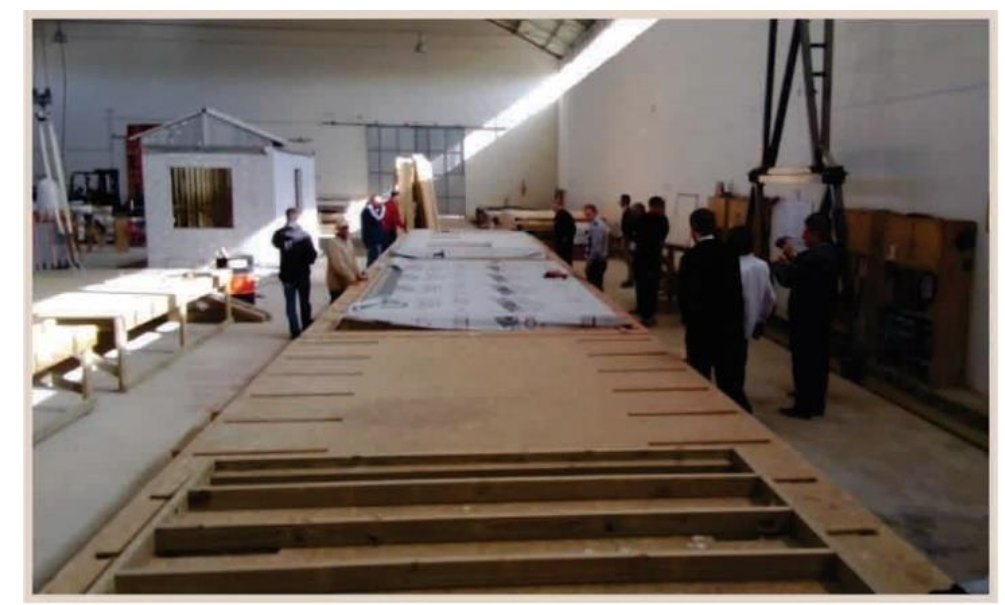

Figura 132: Visão geral da mesa de montagem do painel de parede Fonte: FIEP, 2013. 


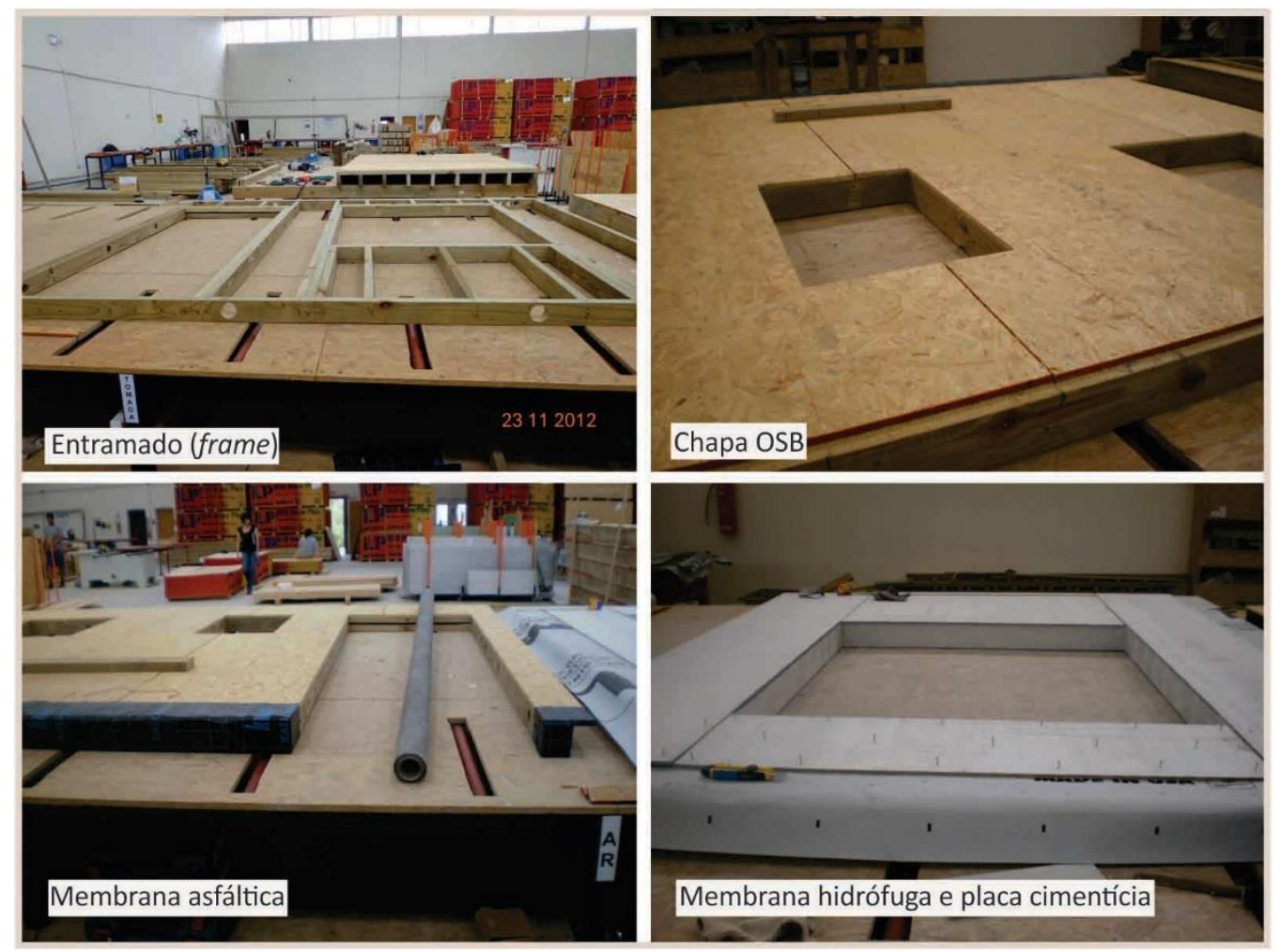

Figura 133: Etapas da montagem do painel de parede Fonte: autora.

Após finalizados, os painéis de piso e de parede foram erguidos e carregados pela ponte rolante até a lateral próxima a saída da fábrica. Ali, ficaram estocados e prontos para serem transportados até o canteiro (Figura 134).

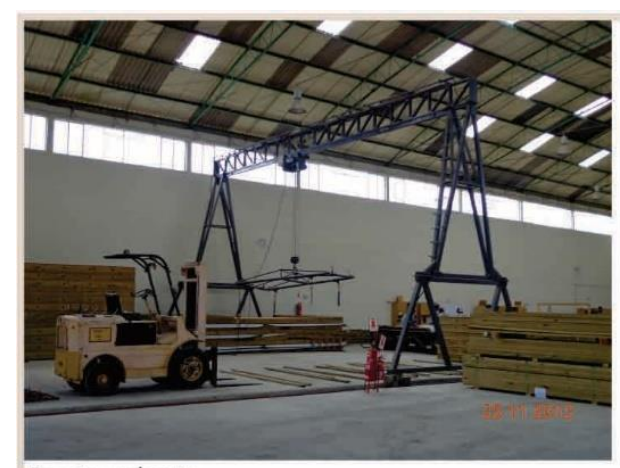

Ponte rolante

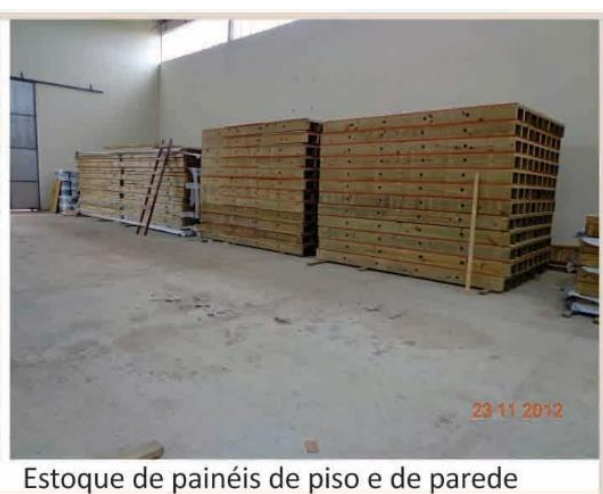

Estoque de painéis de piso e de parede

Figura 134: Ponte rolante e estoque de painéis de piso e de parede pré-fabricados Fonte: autora.

Portanto, sobre o conjunto das etapas da produção dos elementos do Residencial Haragano na fábrica, a empresa Roberto Ferreira (2013) afirma: 
Foi desenvolvido um layout otimizado, visando reduzir as distâncias entre os processos produtivos e aperfeiçoar o fluxo. Foram separadas as etapas de agregação de valor e balanceadas de forma a garantir um fluxo contínuo e uniforme de produção, atingindo-se assim a altos índices de produtividade.

Para otimizar ainda mais o processo na fábrica, em conjunto, as equipes de engenharia de produto e de processo procuraram unificar painéis e reduzir a sua complexidade. Por exemplo, um sobrado do Haragano era composto por 11 tipos de painéis de parede. Isso resultou em projetos de produção otimizados e repetitivos, trazendo, como consequência, maior produtividade na fábrica e redução de custos diretos. Assim, apontou-se a capacidade de produzir diariamente dois sobrados com áreas de $44,54 \mathrm{~m}^{2}$ cada (ROBERTO FERREIRA, 2013). Com base nesta produtividade estimada, estabeleceram-se metas de produção de UHs para o Haragano, conforme a Tabela 16.

Tabela 16: Meta de produção para a fabricação das UHs do Residencial Haragano

\begin{tabular}{|c|c||}
\hline Mês / Ano & Quantidade de UHs a serem produzidas na fábrica \\
\hline \hline Junho / 2012 & 15 \\
\hline Julho / 2012 & 27 \\
\hline Agosto / 2012 & 33 \\
\hline Setembro / 2012 & 36 \\
\hline Outubro / 2012 & 42 \\
\hline Novembro / 2012 & 42 \\
\hline Dezembro / 2012 & 42 \\
\hline Janeiro / 2013 & 42 \\
\hline
\end{tabular}

Fonte: autora com base em dados coletados na empresas construtoras.

Para a produção destas UHs do Residencial Haragano na fábrica, 18 funcionários foram contratados, sendo 16 homens e 2 mulheres. Após a implementação da fábrica, no final do mês de maio de 2012, os trabalhadores participaram de um treinamento específico sobre construções com o sistema wood frame, o qual foi oferecido em parceria pelo SENAI. Neste treinamento de duas semanas de duração, a primeira UH do residencial foi produzida.

Em uma entrevista realizada sobre a experiência prévia destes trabalhadores com construção em madeira, o gerente da fábrica relatou: "Ninguém era qualificado para trabalhar com madeira". Mas, ele "considerou fácil a adaptação da mão-de-obra às novas funções" (DIÁRIO POPULAR, 2012).

Um destes trabalhadores estava no ramo da construção civil há 13 anos atuando como pedreiro. Após trabalhar 8 meses com o sistema wood frame nesta fábrica, ele disse: “A 
mudança foi ótima. Como pedreiro era mais puxado. Foi mais fácil que a gente pensava". Outra trabalhadora foi Célia Carvalho, de 32 anos, a primeira mulher contratada para trabalhar na produção da fábrica. Após 7 meses como carpinteira na fábrica, ela disse que estava gostando de trabalhar com ferramentas deste tipo e ainda acrescentou: "Agora, eu estou fazendo um curso para virar carpinteira profissional [...] Daqui pra frente, é só progredir" (DIÁRIO POPULAR, 2012).

Portanto, este treinamento da mão-de-obra foi essencial e necessário para iniciar a produção na fábrica, pois a maioria dos trabalhadores contratados não tinha experiência prévia como carpinteiros e não conhecia a prática do sistema construtivo inovador wood frame.

Nesse sentido, toda a execução na fábrica foi acompanhada por um engenheiro responsável, mantendo os critérios de controle da qualidade neste processo. As produções ocorreram conforme projetos específicos para a fábrica. Estes projetos para produção eram diferentes dos projetos arquitetônicos, pois aprofundavam o nível de detalhamento de cada painel pré-fabricado que integravam as habitações térreas e os sobrados. Com planilhas descritivas das peças constituintes e desenhos de planta e corte do entramado do painel, demonstravam com clareza informações como: comprimento, largura, altura; espaçamentos entre peças; e, quando existentes, aberturas das esquadrias.

Além do projeto de produção, foi elaborado um conjunto de documentos como guias com instruções para o trabalhador referente a execução de cada painel. Com textos e fotos ilustrativas, estes documentos demonstravam o que fazer e como fazer, respeitando critérios de qualidade e de segurança do trabalho. A linguagem deste material era simples para facilitar a compreensão dos trabalhadores. Estas descrições foram desenvolvidas para guiar cada etapa específica da produção e garantir a segurança do trabalhador, com usos adequados de Equipamentos de Proteção Individual (EPIs). Compreendiam desde a etapa de recebimento dos insumos, passando pelo transporte de materiais entre estações de trabalho, pelas execuções mais elaboradas nas respectivas estações de corte, furação, framing, chapeamento, cimentícia, até, por fim, abranger o carregamento e o estoque dos painéis prontos para o transporte.

Estas produções na fábrica ocorreram de acordo com ordens de serviços. Para elaborar estas ordens, ocorria um diálogo entre fábrica e canteiro para identificar qual a necessidade da produção, indicando quais painéis eram prioridade em determinado momento. Assim, a 
ordem de serviço dizia quais componentes precisavam ser cortados para montar estes painéis. Finalizados, estes painéis eram conferidos e uma planilha de recebimento de produção era preenchida indicando as conformidades dos seus parâmetros de qualidade. E, por fim, cada painel pré-fabricado recebeu um código para rastreabilidade, constando data de produção, lote e local onde seria aplicado no residencial Haragano.

Portanto, como conclusão desta etapa de produção, além da racionalização e da produtividade, pode-se observar que o processo na fábrica buscou prezar a questão da qualidade nas suas diversas etapas de execução, com: treinamento e qualificação da mão-deobra, controle de qualidade dos insumos recebidos, projeto para produção dos painéis, ordens de serviços, instruções e guias de qualidade e de segurança para o trabalhador, aplicação de códigos para rastreabilidade de componentes individuais e de painéis finalizados, e conferência de recebimento do produto finalizado.

Também, observou-se a preocupação das empresas com os resíduos. Procurou-se utilizar o máximo de cada produto. E, quando isto não era possível, o resíduo era descartado, mas separado por classificações específicas de cada material. Após a limpeza da fábrica realizada no fim de cada expediente diário, os resíduos de pós eram retirados com auxílios de equipamentos de sucção, também separados por material. Estes resíduos eram colocados em uma área coberta, localizada na lateral da fábrica, para receberem o destino correto (Figura 135).

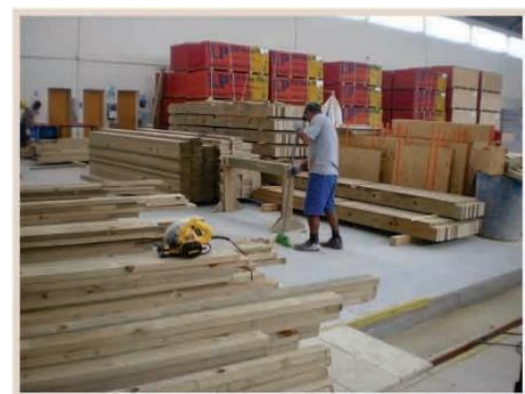

Limpeza manual do setor

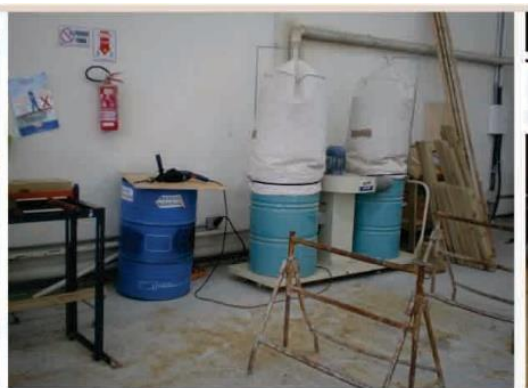

Tonel e sistema de sucção de pó

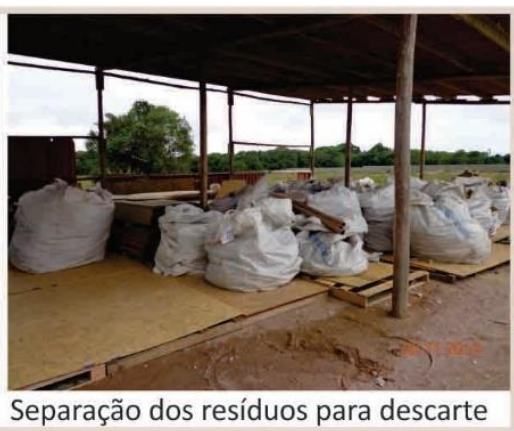

Separação dos resíduos para descarte

Figura 135: Limpeza da fábrica e separação dos resíduos para descarte Fonte: autora.

Por fim, os elementos pré-fabricados de parede e de piso foram colocados no caminhão e transportados até o canteiro do Residencial Haragano para serem montados e finalizados. Esta etapa de produção no canteiro será detalhada no tópico seguinte. 


\subsubsection{Produção e montagem no canteiro-de-obras}

Em abril de 2012, as obras de infraestrutura do Residencial Haragano iniciaram efetivamente (ROBERTO FERREIRA, 2013). Para a construção das habitações térreas e dos sobrados, primeiro, foram executadas as fundações em radier. Esta execução foi realizada por conjuntos de blocos habitacionais. Uma fita de sobrados geminados mais uma habitação térrea compõem um bloco. As tubulações hidrossanitárias do banheiro e da cozinha foram embutidas nesta estrutura durante a execução. Após sua finalização, as fundações foram impermeabilizadas com tinta asfáltica, nos locais onde as paredes pré-fabricadas seriam fixadas (Figura 136).

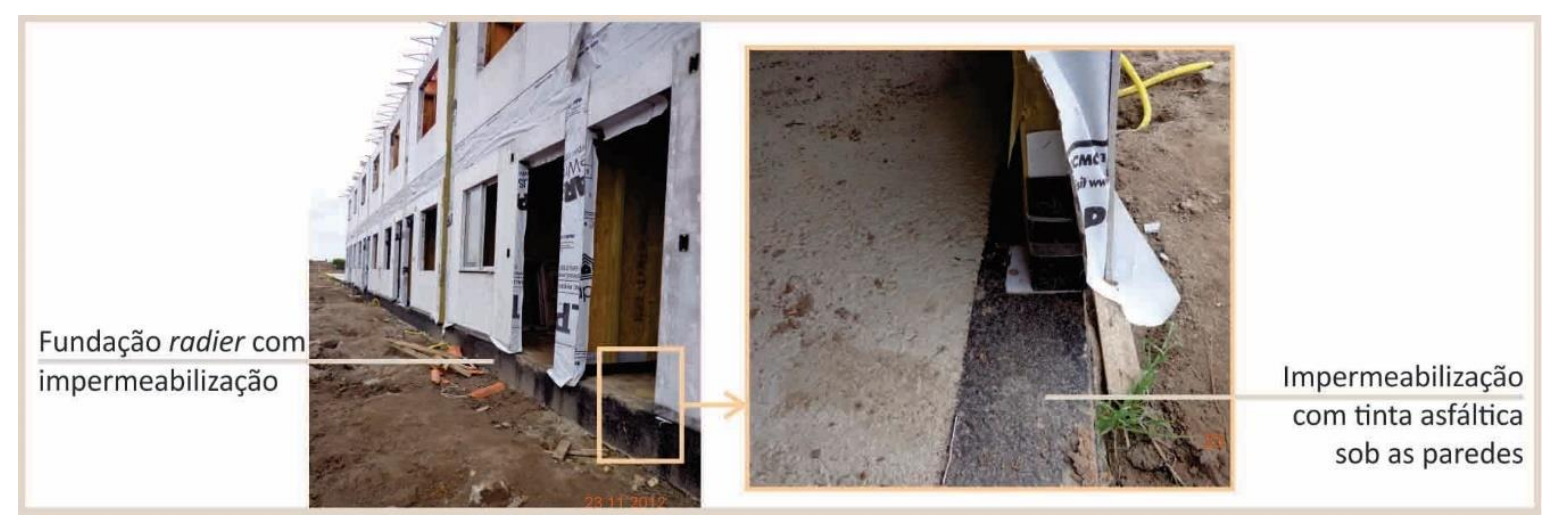

Figura 136: Fundação em radier impermeabilizada com tinta asfáltica Fonte: autora.

Após finalizados em fábrica, os painéis de parede abertos foram transportados até o canteiro, onde foram posicionados e fixados sobre a fundação (Figura 137). Conforme foi detalhado no item anterior, os painéis de parede aberto receberam na fábrica os seguintes insumos principais: placa cimentícia, membrana hidrófuga, membrana asfáltica impermeabilizante, chapa OSB, madeira beneficiada e tratada e conectores em geral. No canteiro, após serem fixados e unidos entre si, estes painéis receberam a lã de vidro, as instalações hidrossanitárias e elétricas e foram fechados com chapa de gesso acartonado completando a cadeia de produção do subsistema parede em wood frame (Figura 138). 

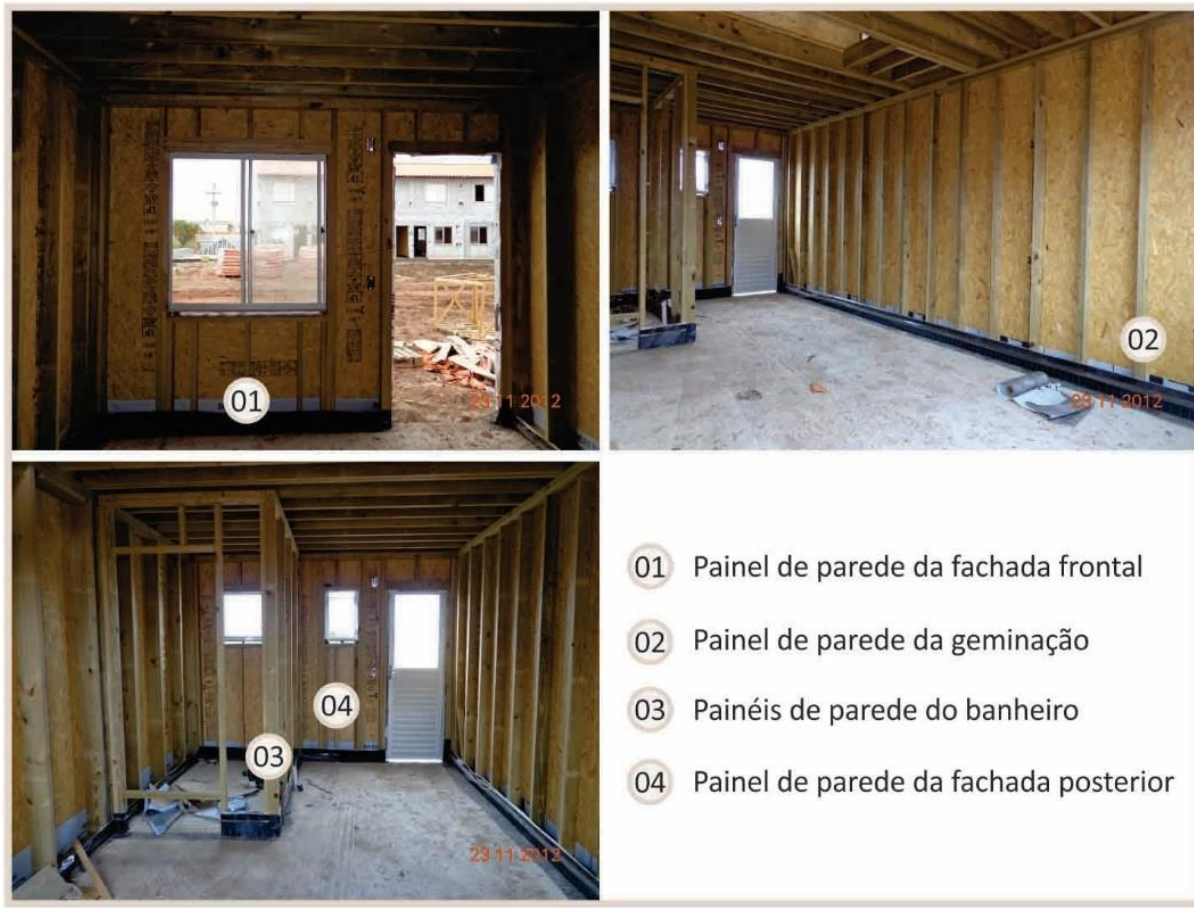

01 Painel de parede da fachada frontal

02 Painel de parede da geminação

03 Painéis de parede do banheiro

04 Painel de parede da fachada posterior

Figura 137: Painéis de parede abertos instalados sobre a fundação Fonte: autora.

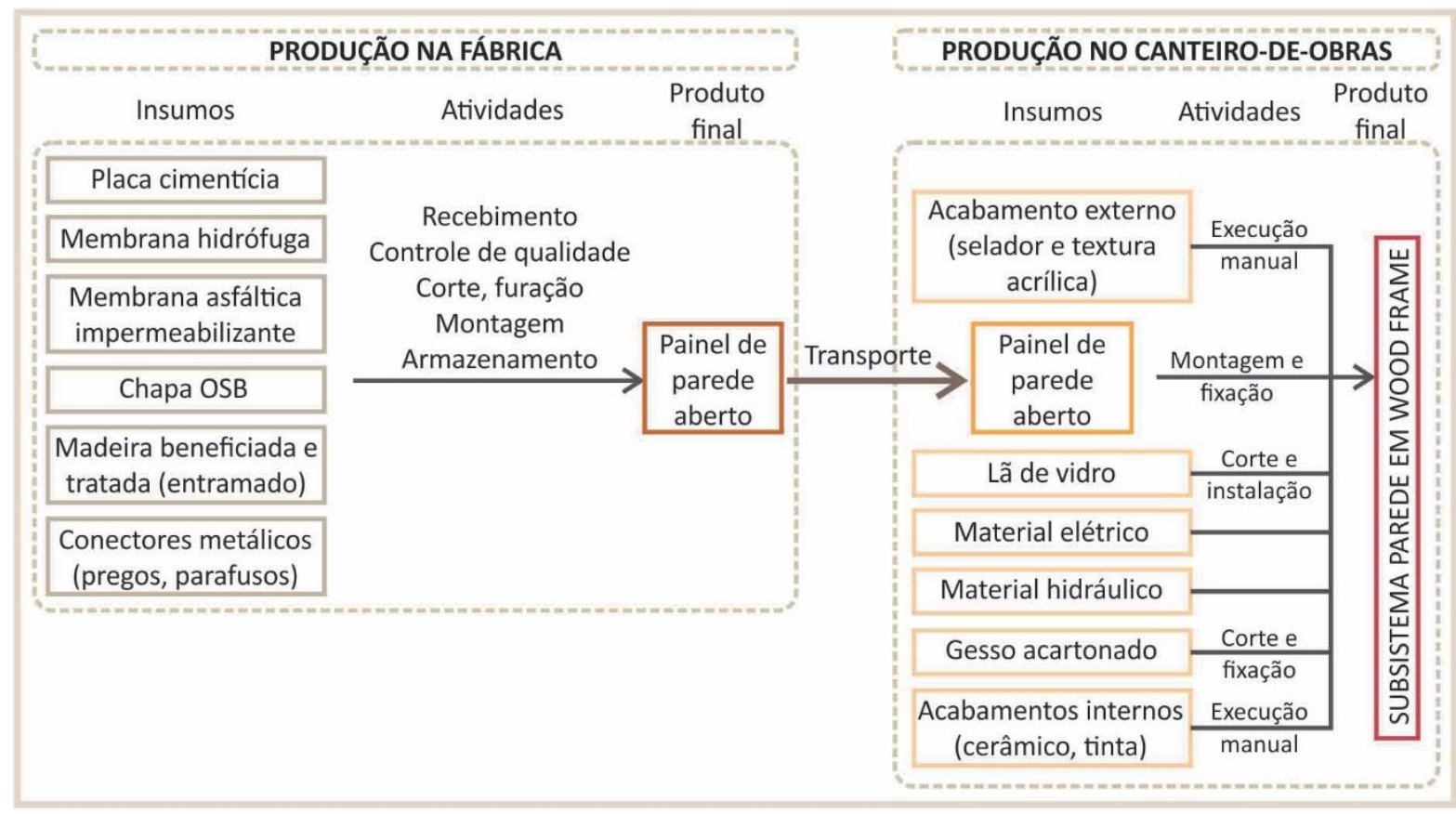

Figura 138: Cadeia de produção dos painéis de parede do sistema wood frame na fábrica e no canteiro

Fonte: autora.

As faces externas dos painéis de parede das fachadas já haviam recebido as placas cimentícias na fábrica. Mas, as junções entre UHs e a entre paredes e entrepiso ainda não tinham este material. Portanto, no canteiro, estas áreas da fachada foram completadas com 
placas cimentícias. Após, as placas receberam o tratamento de junta aparente realizado com selante a base de poliuretano. Por fim, foi aplicado selador acrílico e textura acrílica como acabamentos finais (Figura 139).

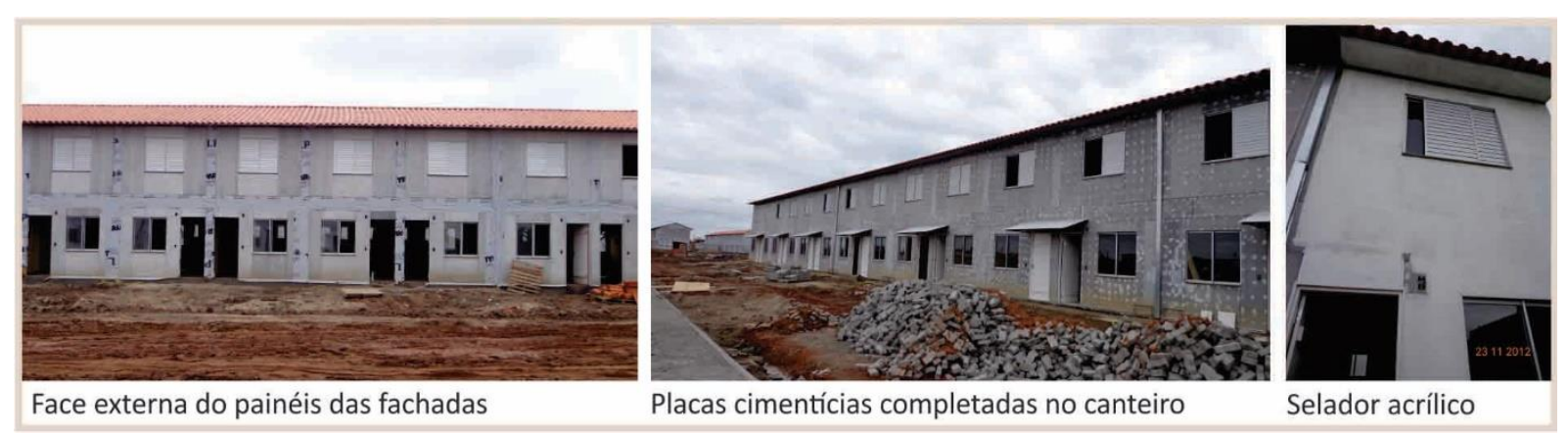

Figura 139: Placas cimentícias com junta aparente e acabamento com textura acrílica Fonte: autora.

As paredes internas, como as paredes divisórias entre banheiro e cozinha, receberam fechamento com chapa OSB, antes da aplicação da chapa de gesso acartonado. No canteiro, o trabalhador cortou as chapas com serra circular sobre apoios como mesas provisórias. Após, fixou as mesmas nos painéis de parede com pregos. Após o OSB, todos os ambientes internos das habitações receberam gesso acartonado do tipo ST para áreas secas e tipo RU para áreas molháveis ou molhadas, os quais também foram cortados e fixados no local (Figura 140).

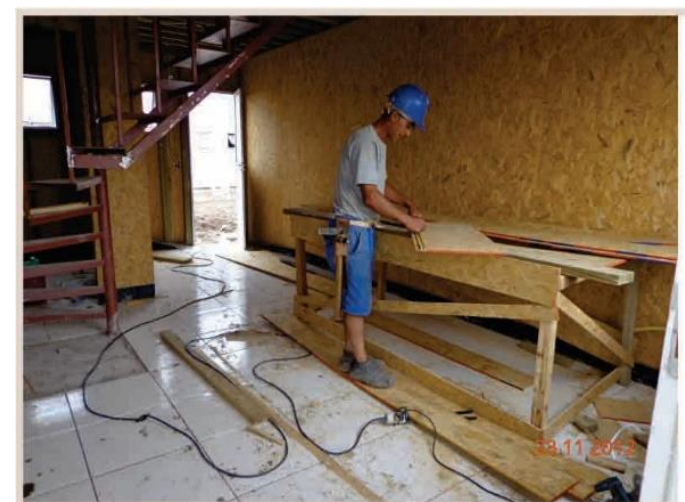

Corte de chapas OSB no canteiro

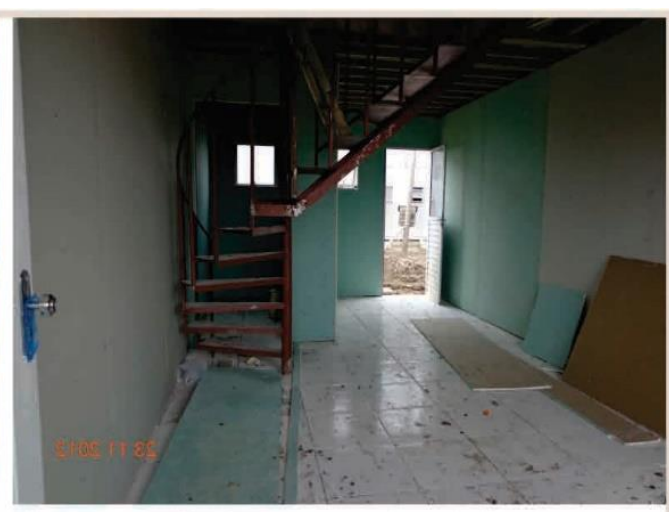

Corte e fixação de gesso acartonado ST e RU

Figura 140: Corte e fechamento das paredes com OSB e gesso acartonado Fonte: autora.

Por exemplo, na cozinha e no banheiro, áreas caracterizadas como molháveis e molhadas, a parede foi fechada com chapa de gesso acartonado RU. Na sequência, para receber o acabamento final, foi passado uma tinta impermeabilizante, onde foi instalado o 
azulejo cerâmico em meia parede. E, a parte superior da parede foi pintada (Figura 141). Os demais ambientes como dormitórios e sala, caracterizado como secos, receberam gesso acartonado ST e acabamento final com pintura.

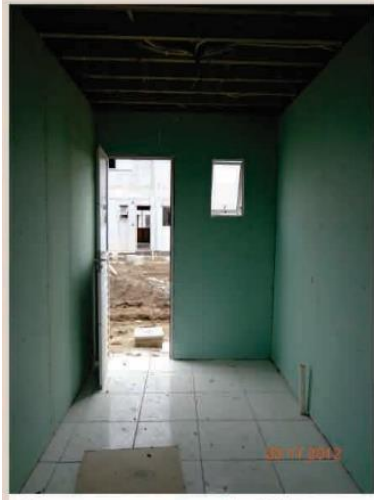

Gesso acartonado RU

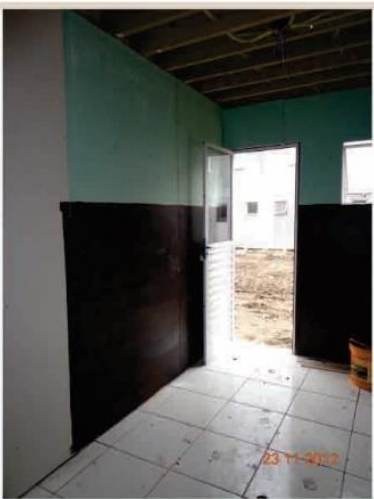

Impermeabilizante

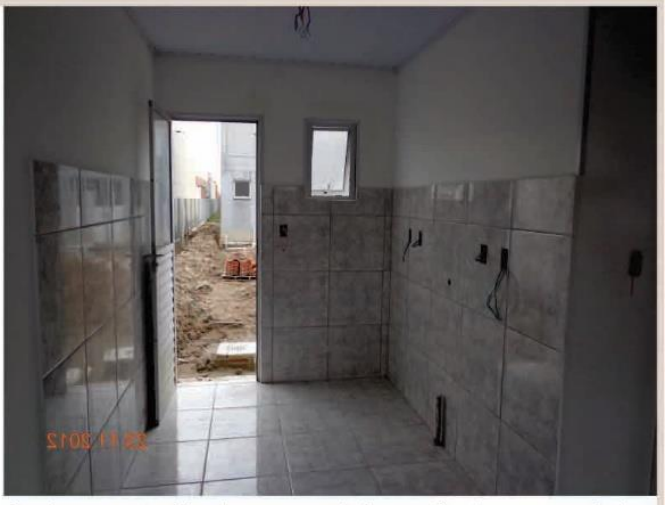

Acabamento final com azulejo cerâmico na cozinha

Figura 141: Vedação com gesso acartonado RU e instalação do azulejo cerâmico na cozinha Fonte: autora.

Na sequência, as esquadrias de alumínio foram instaladas. As dimensões das aberturas nos entramados dos painéis de parede tinham uma folga pré-determinada para permitir a entrada das janelas e das portas. Pois, os entramados estruturais em madeira não poderiam ser recortados se as aberturas fossem menores que as esquadrias prontas. Após o nivelamento das esquadrias, esta folga foi preenchida e vedada (Figura 142).

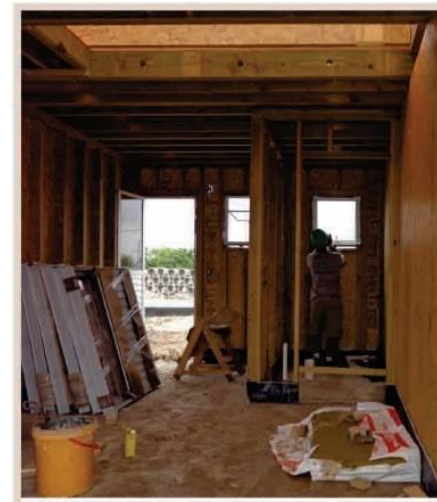

Instalação das janelas

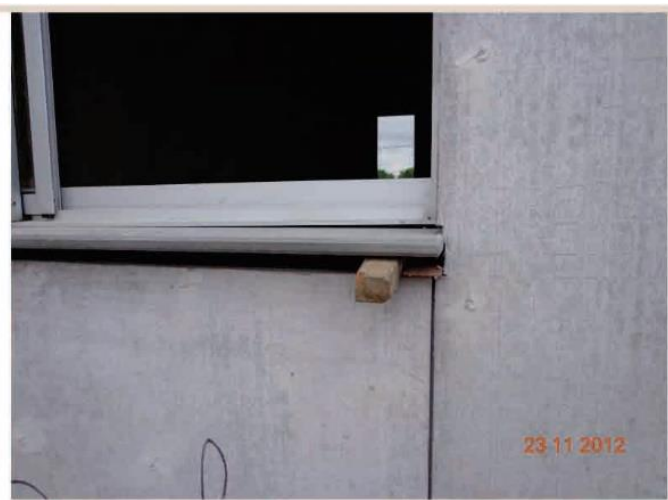

Folga entre peitoril e abertura do entramado

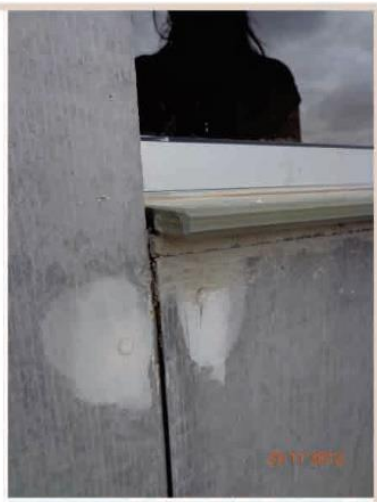

Folga preenchida

Figura 142: Instalação das janelas com folga na abertura do entramado Fonte: autora.

Sobre as paredes térreas dos sobrados, o entrepiso foi montado com painéis préfabricados de piso. Estes painéis foram produzidos na fábrica da empresa, conforme 
detalhado nos itens anteriores. Após o transporte ao canteiro, estes painéis foram içados por uma grua mecânica. E, com auxílio dos trabalhadores, foram posicionados corretamente conforme o projeto de produção desenvolvido para o canteiro (Figura 143).

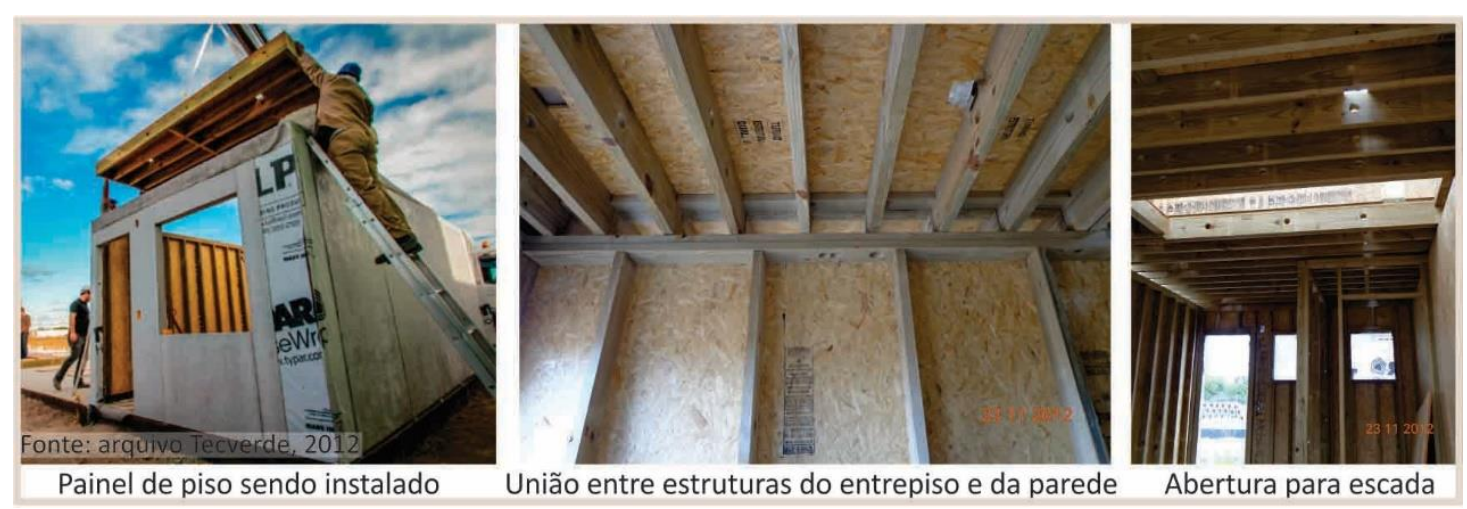

Figura 143: Montagem do painel do entrepiso sobre paredes térreas Fonte: arquivo Tecverde (2012) e autora.

Na sequência, os painéis pré-fabricados das paredes do segundo pavimento foram içados com gruas e posicionados e fixados pelos trabalhadores. Assim como os painéis térreos, estes eram painéis abertos que foram completados e fechados no canteiro.

Sobre as paredes do segundo pavimento dos sobrados, foram instaladas as treliças metálicas pré-fabricadas, cobertas com telhas cerâmicas. Também, no canteiro, os oitões foram fechados externamente com chapa OSB, membrana hidrófuga e placa cimentícia. $E$, as treliças das divisões dos sobrados geminados foram fechadas com chapas OSB (Figura 144).

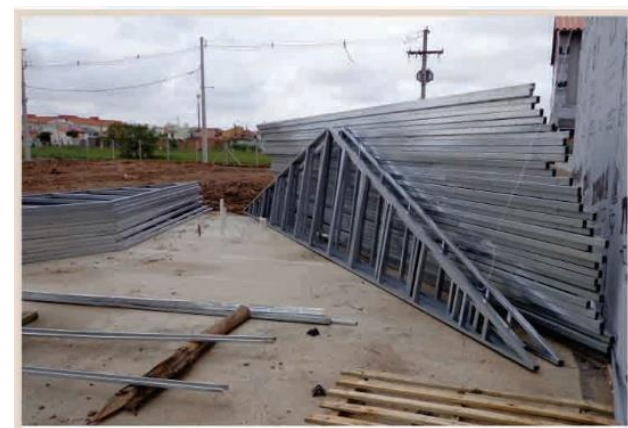

Treliças metálicas pré-fabricadas

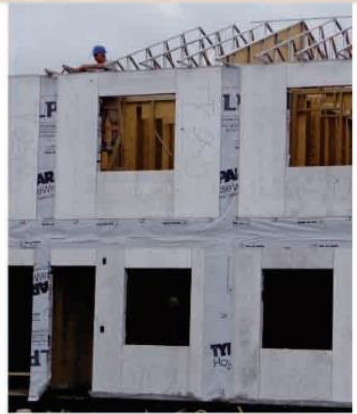

Instalação das treliças

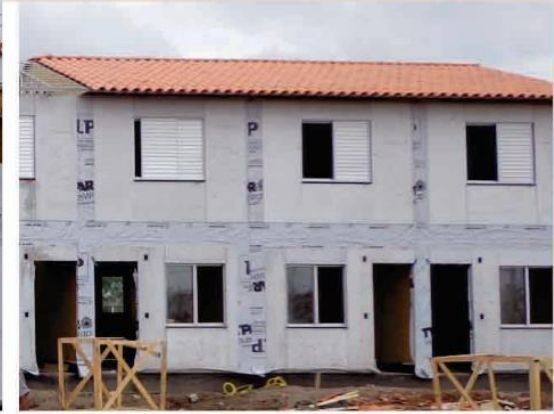

Coberta com telhas cerâmicas

Figura 144: Execução da cobertura com treliças metálicas pré-fabricadas e telhas cerâmicas Fonte: autora.

Após a finalização da montagem das estruturas das paredes, do entrepiso e da cobertura, foram executadas as instalações elétricas e hidrossánitárias. Os eletrodutos 
ficaram embutidos nas paredes, no entrepiso ou sobre o forro, sendo fixados na parte inferior das treliças da cobertura. Por sua vez, os materiais hidráulicos ficaram concentrados no painel divisório entre cozinha e banheiro, assim como embutidos a fundação radier (Figura 145).

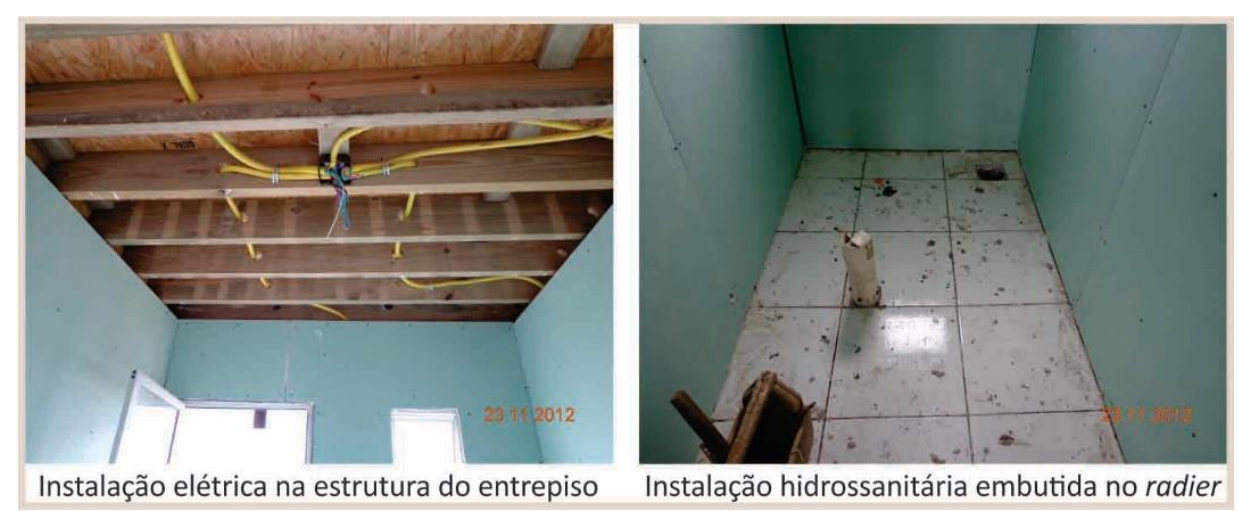

Figura 145: Instalações elétrica e hidrossanitária Fonte: autora.

Por fim, para completar a edificação do sobrado, uma escada metálica pré-fabricada foi instalada para acesso entre o primeiro e o segundo pavimento. Os acabamentos de piso foram em material cerâmico no térreo e laminado de madeira nos dormitórios do segundo pavimento. E, forros em PVC foram colocados sob o entrepiso e sob as treliças da cobertura. Ainda, sobre o forro da cobertura, foi colocado lã de rocha como material isolante (Figura 146).

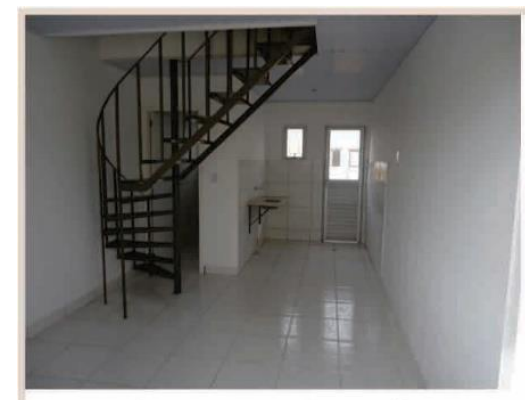

Piso cerâmico e escada metálica

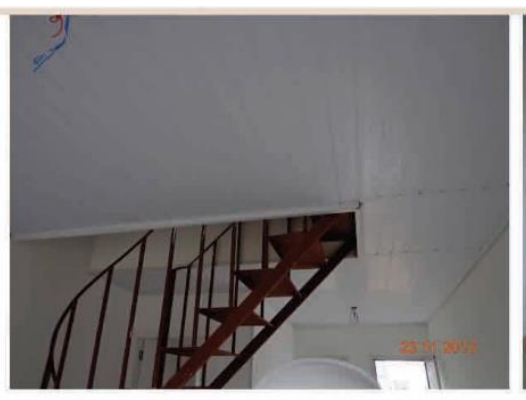

Forro em PVC

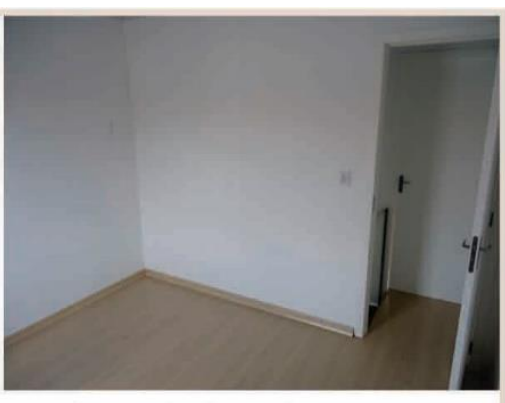

Piso laminado de madeira

Figura 146: Escada metálica e acabamentos finais de piso e de forro Fonte: arquivo Tecverde (2013) e autora.

Em paralelo, no canteiro, ocorriam as obras de infraestrutura de rede de esgoto, drenagem e pavimentação do Residencial Haragano (Figura 147). Observou-se o contraste entre a produção desta infraestrutura geral e a produção seca e limpa da montagem e 
finalização das UHs. Porém, pelo porte desta obra e pelos prazos estipulados, não foi possível finalizar toda a infraestrutura do empreendimento antes da montagem das habitações. Mas, por fim, este contraste não afetou a qualidade das edificações produzidas.

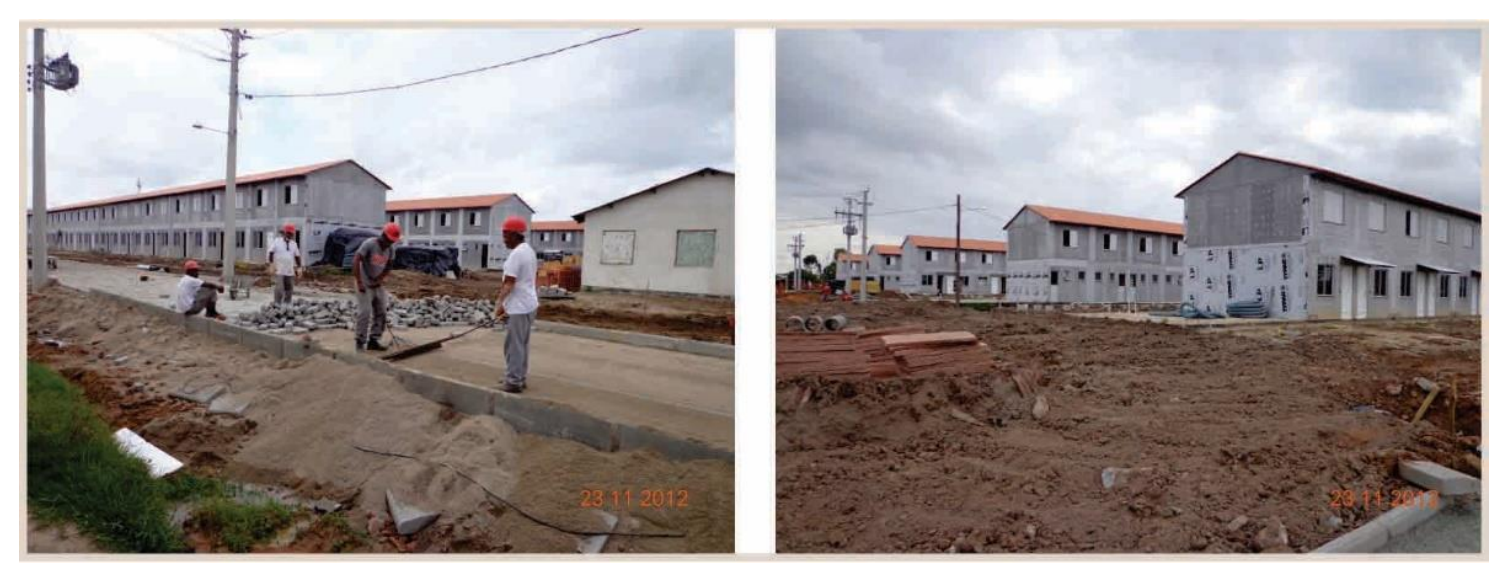

Figura 147: Infraestrutura sendo executada em novembro de 2012

Fonte: autora.

Desde junho até outubro de 2012, em 5 meses de produção, 145 UHs haviam sido préfabricadas e montadas no canteiro (ROBERTO FERREIRA, 2013). No total, aproximadamente, 50 trabalhadores estavam atuando no canteiro, sendo que apenas 4 pessoas estavam designadas para a montagem e finalização das edificações em wood frame.

Após a finalização da produção dos painéis de parede e de piso em fábrica, as montagens das edificações no canteiro-de-obras foram concluídas em março de 2013. Na sequência, o fechamento dos painéis de parede e a execução manual dos acabamentos finais foram concluídos ainda no primeiro semestre de 2013.

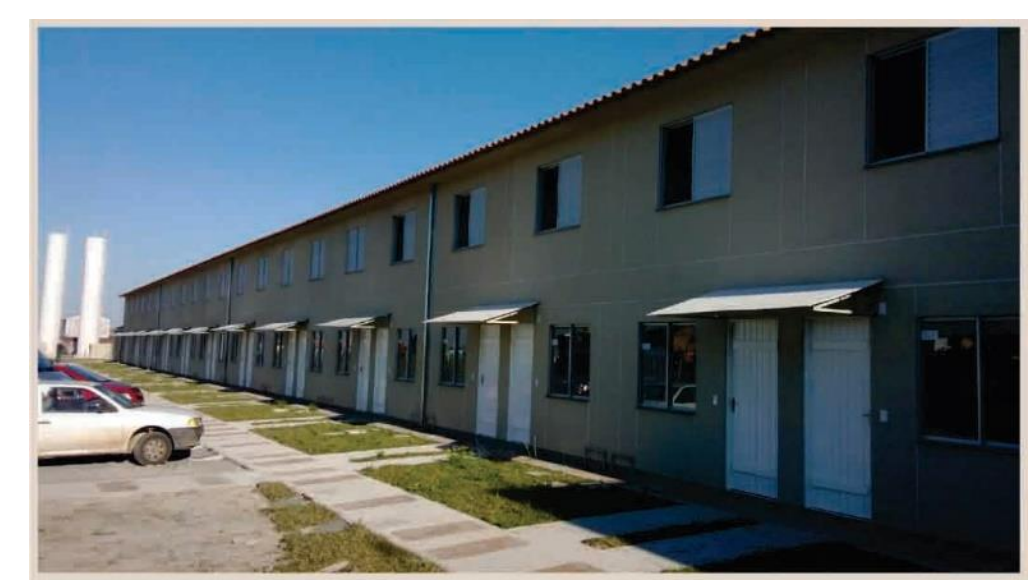

Figura 148: Sobrados geminados finalizados Fonte: FIEP (2013). 
Em conclusão, o resultado destas produções realizadas parcialmente na fábrica e no canteiro apresentou diversas vantagens quando comparado a sistemas tradicionais da construção brasileira. Por exemplo, a produção na fábrica permitiu a modulação e a racionalização dos elementos construtivos de parede e de piso em conformidade com os insumos aplicados. Estes fatores foram aliados ao layout da planta da fábrica, desenvolvido para uma linha de montagem com produção sequencial. A execução destas atividades na fábrica não foi totalmente dependente das atividades realizadas no canteiro. Também, esta produção não estava suscetível às condições climáticas externas. E, com o correto controle de estoque dos insumos recebidos, a linha de produção não era interrompida e, portanto, a produtividade de painéis de piso e de parede era elevada. $O$ auge ocorreu com uma produção mensal de elementos para 42 UHs com $44 \mathrm{~m}^{2}$ de área, montados por 20 trabalhadores, aproximadamente. Ainda, na fábrica, o controle da qualidade dos materiais utilizados e dos produtos finais pôde ser realizado em todas as etapas da produção com métodos criados e organizados pelas empresas envolvidas. E, os trabalhadores receberam treinamento prático específico sobre o sistema inovador e instruções para qualidade da produção e para sua própria segurança. Assim, foi constatado que nesta produção não ocorreu nenhum acidente de trabalho.

Na produção no canteiro-de-obras, as montagens das estruturas de parede, piso e cobertura também foram realizadas com tempo reduzido, com auxílio de equipamentos mecânicos para erguer estes elementos pré-fabricados. E, no canteiro, apenas quatro trabalhadores realizavam a montagem das edificações. O auge desta produção apontou a montagem média de 2,5 UHs de $44 \mathrm{~m}^{2}$ em 2 dias. No entanto, o fechamento dos painéis de parede e os acabamentos finais foram realizados manualmente, reduzindo um pouco esta produtividade. Porém, por ser um sistema construtivo seco e enxuto, toda a execução das habitações no canteiro foi bem qualificada.

Todas as fases de execução das habitações do Residencial Haragano, incluindo as produções na fábrica e no canteiro, foram relatadas mensalmente para o monitoramento e controle tecnológico realizado pela CEF. Para isso, relatórios de monitoramento atestando a conformidade da execução com os projetos do sistema inovador aprovado, ensaios técnicos e relatórios de avaliação efetuados foram emitidos à CEF. 
Por fim, após atestar a qualidade do produto final deste empreendimento em Pelotas e com os resultados dos relatórios técnicos, a CEF autorizou a construção de novos empreendimentos com até 500 UHs com este sistema construtivo inovador wood frame. 0 arquiteto da GIDUR/PO que atuou na análise e no acompanhamento de Propostas de Financiamento de Empreendimentos com Sistemas Construtivos Inovadores afirmou positivamente sobre as edificações do Residencial Haragano:

O sistema construtivo tipo wood frame, por envolver uma série de componentes e elementos pré-fabricados com alto valor agregado, controle de qualidade do processo de produção e excelente acabamento, exige uma nova postura da construtora no canteiro de obra. Tivemos a oportunidade de acompanhar a evolução constante ao longo de toda a obra, do processo de gestão da produção na fábrica, da montagem no canteiro da obra e do controle da qualidade dos serviços executados, que certamente serão incorporados nos próximos empreendimentos tendo como resultado 0 aumento da produtividade.

[...] Ressaltamos ainda o custo competitivo, a redução do prazo da obra e o bom acabamento das paredes internas proporcionado pelas placas de gesso acartonado (BRASIL ENGENHARIA, 2013).

Esta posição do GIDUR/PO da CEF é uma mudança de postura frente ao financiamento de um sistema construtivo estruturado com madeira no Brasil. Isso ocorreu, em especial, aos materiais industrializados selecionados, como placas cimentícias, chapas OSB e chapas de gesso acartonado, que determinaram a modulação e racionalização dos painéis. Também, foi preponderante a utilização da madeira beneficiada de pinus atrelada ao seu tratamento químico com CCA em autoclave para aumentar e garantir sua durabilidade. E, por fim, a gestão da produção, em especial na fábrica, garantiu maior qualidade dos produtos finais, aumentou a produtividade, reduziu tempo de produção e reduziu custos.

Outro reconhecimento importante sobre este processo de produção do Residencial Haragano foi a indicação do sistema wood frame destas habitações sociais como projeto finalista do Prêmio CBIC de Inovação e Sustentabilidade de 2012, recebendo o segundo lugar na classificação final da categoria Sistemas Construtivos ${ }^{29}$. Esta premiação foi uma iniciativa da Câmara Brasileira da Indústria da Construção (CBIC) e considerou parâmetros como:

\footnotetext{
${ }^{29}$ Observa-se que o primeiro lugar classificado nesta premiação de sistemas construtivos sustentáveis foi a Casa Express de Itapira, São Paulo, construída com painéis pré-moldados mistos de concreto armado e blocos cerâmicos (CBIC, 2012).
} 
sustentabilidade ambiental ${ }^{30}$, impacto social, viabilidade, industrialização, funcionalidade, impactos em processos e originalidade (CBIC, 2012).

Por fim, após da conclusão do processo de produção, quando as residências foram entregues aos moradores no ano de 2014, a empresa Roberto Ferreira, no papel de responsável pelo empreendimento, forneceu orientações explicativas e documentais sobre o sistema wood frame aplicado no Residencial Haragano, a fim de garantir a vida útil determinada para a habitação sem reduzir sua qualidade.

\subsection{ORIENTAÇÕES SOBRE O SISTEMA INOVADOR PARA OS MORADORES DO RESIDENCIAL}

Para que um empreendimento de habitação social obtenha o parecer favorável de financiamento, a CEF exige a entrega de um documento denominado Manual do Usuário, que traz informações específicas com as condições de uso e manutenção da UH. E o morador, enquanto usuário, deve respeitar estes requisitos para conservar a qualidade da sua habitação.

Para as habitações do Residencial Haragano, a empresa construtora Roberto Ferreira, com auxílio da empresa Tecverde, desenvolveu duas documentações: primeiro, o Manual do Usuário; e, segundo, um Gibi com ilustrações das práticas do dia-a-dia do morador para este preservar sua edificação. Ainda antes da entrega das chaves, representantes da CEF e das empresas Roberto Ferreira e Tecverde se reuniram com os futuros moradores do residencial para dar estas instruções.

Sobre a manutenção da residência, o Manual do Usuário informa, por exemplo, as ações necessárias para prevenção e quando estas devem ser realizadas pelo morador, conforme demonstra a Tabela 17. Estas descrições abordam alguns pontos básicos que todas residências, independentes da sua tecnologia construtiva, devem ser verificados como limpeza, vedação, pintura.

\footnotetext{
${ }^{30}$ A sustentabilidade do wood frame, referente ao fator ambiental, vai além da utilização de materiais oriundos de florestas plantadas, como a madeira serrada de pinus e a chapa OSB. Por ser caracterizado como um sistema construtivo seco, a utilização de água durante a produção da edificação restringe-se à execução da fundação de concreto tipo radier. Também, com método de pré-fabricação a geração de resíduos é menor e classificada para descarte correto.
} 
Tabela 17: Exemplos de manutenções periódicas descritas no Manual do Usuário do Haragano

\begin{tabular}{|c|c|c|}
\hline Itens & Descrição & Periodicidade \\
\hline \multirow{3}{*}{$\begin{array}{l}\text { Esquadrias de } \\
\text { alumínio }\end{array}$} & Limpeza geral & A cada 3 meses \\
\hline & Limpeza dos orifícios dos trilhos inferiores & A cada 3 meses \\
\hline & Reapertar parafusos aparentes dos fechos & 1 vez por ano \\
\hline \multirow{2}{*}{ Impermeabilização } & Inspecionar os ralos e as peças sanitárias & 1 vez por ano \\
\hline & Inspecionar os rejuntes dos pisos cerâmicos & A cada 6 meses \\
\hline \multirow{3}{*}{ Estruturas / paredes } & Repintar áreas privativas & A cada 2 anos \\
\hline & Repintar elementos metálicos & A cada 1 ano \\
\hline & Repintar fachada da edificação & A cada 2 anos \\
\hline \multirow{6}{*}{$\begin{array}{l}\text { Instalações } \\
\text { hidráulica, louças e } \\
\text { metais }\end{array}$} & Verificar os ralos e sifões das louças, tanques e pias & A cada 6 meses \\
\hline & $\begin{array}{l}\text { Trocar vedantes das torneiras, misturadores de lavatório, de } \\
\text { bidê e registros de pressão }\end{array}$ & A cada 1 ano \\
\hline & Limpar aeradores (bicos removíveis) & A cada 6 meses \\
\hline & Limpar e verificar regulagem do mecanismo de descarga & A cada 1 ano \\
\hline & Verificar a estanqueidade da válvula de descarga & A cada 2 anos \\
\hline & Limpar crivo do chuveiro & A cada 1 ano \\
\hline Observação 1 & \multicolumn{2}{|c|}{$\begin{array}{l}\text { O período de periodicidade acima citado é nas condições corretas de utilização dos } \\
\text { elementos. }\end{array}$} \\
\hline Observação 2 & \multicolumn{2}{|c|}{$\begin{array}{l}\text { Não jogue objetos no vaso sanitário e ralos que possam causar entupimento, tais } \\
\text { como: absorventes higiênicos, folhas de papel, cotonetes, cabelos, fio dental, entre } \\
\text { outros. Não jogue gordura ou resíduos sólidos nos ralos das pias e lavatórios, jogue } \\
\text { diretamente no lixo. }\end{array}$} \\
\hline Observação geral: & \multicolumn{2}{|c|}{$\begin{array}{l}\text { Toda a vez que for realizada uma pintura após a entrega da edificação, deverá ser } \\
\text { feito um tratamento das fissuras, evitando assim infiltrações futuras de água, pois } \\
\text { a tinta também exerce função de impermeabilização. }\end{array}$} \\
\hline
\end{tabular}

Fonte: Arquivo da Tecverde (2013) apud Martins (2015).

Ainda, no Manual há um capítulo específico sobre os critérios de desempenho do sistema wood frame. Neste, além de detalhes estruturais e de composição dos elementos constituintes dos principais subsistemas da edificação, há orientações sobre os modos adequados de limpeza e de reparo dos mesmos. Por exemplo, são indicados: como proceder para realizar reparos nas placas de gesso acartonado; como elaborar a distribuição do mobiliário e objetivos afins para evitar a formação de mofo; entre outros.

Por sua vez, o Gibi não é exigência da CEF, mas foi adotado pelas empresas para uma linguagem mais coloquial e desenhos mais ilustrativos sobre esta tecnologia desconhecida pela população. Inicialmente, este documento deixa claro que a execução de reformas ou de ampliações nas residências não são permitidas. Na sequência, salienta métodos apropriados para: limpeza do piso; instalação de grades em portas e janelas; instalação de móveis fixados nas paredes; entre outros.

Em geral, por ser um sistema construtivo desconhecido para seus moradores, as informações destes documentos são essenciais para preservar o desempenho avaliado e 
aprovado das edificações em wood frame, alertando seus usuários para que evitem danificar algum componente ou elemento que irá gradativamente interferir na qualidade global da construção.

\subsection{AVALIAÇÃO PÓS-OCUPAÇÃO E AJUSTES TÉCNICOS REALIZADOS}

Após a entrega das habitações aos moradores do empreendimento Haragano em junho de 2014, as empresas Roberto Ferreira e Tecverde vêm realizando visitas de acompanhamentos periódicas a cada seis meses para pesquisar o pós-ocupação de todas as famílias deste residencial, levantando fatores como: qualidade da habitação, desempenhos térmico e acústico, desempenho de umidade e fixação de peças suspensas (TECVERDE, 2015).

Em geral, nos dois primeiros anos, os resultados foram considerados positivos pelas empresas, em especial nas questões referentes às condições térmicas e de umidade - fator preocupante pelas condições climáticas da região de Pelotas, com inverno e verão rigorosos e umidade elevada constante (TECVERDE, 2015).

Entretanto, após algumas constatações nas visitas periódicas, as empresas decidiram realizar algumas adequações tecnológicas para aprimorar o sistema implantado nas residências. Por exemplo, o tipo de esquadrias utilizado e a forma de aplicação destas nas aberturas dos painéis de parede precisaram ser refeitos em algumas residências do Haragano, pois apresentaram infiltrações.

Também, no box do banheiro, apesar de já ter sido originalmente aplicado um material impermeabilizante extra entre o piso e as bases das paredes, observou-se que era necessário refazer esta área adotando uma nova solução tecnológica para garantir a qualidade geral deste ambiente, evitando futuras infiltrações entre o piso e a parede.

Ainda, as empresas observaram que muitas famílias não estavam seguindo as instruções de manutenção descritas no Manual do Usuário. Por exemplo, em alguns meses, as condições de rejuntes do banheiro estavam precárias, o que facilitava as infiltrações. Também, muitos estavam fixando móveis e outros objetos em locais inapropriados das paredes, ou seja, em locais onde não havia reforço nas placas, fazendo com que aparecessem fissuras em algumas chapas de gesso.

Portanto, nesta etapa pós-ocupação, em especial quando a população se apropria de um produto inovador, nota-se como o diálogo entre as empresas e os moradores é importante 
para estabelecer um relacionamento que facilite a troca de informações sobre este produto, neste caso a habitação. Pois, por ser um produto relativamente novo tanto para as empresas quanto para o contexto brasileiro, é natural que suas soluções tecnológicas sejam gradualmente adaptadas até que atinjam sua melhor eficiência e qualidade final. Caso contrário, a inexistência deste diálogo pode ocultar possíveis problemas decorrentes de erros de produção ou de erros por parte dos usuários. E, isto acarretaria na má impressão popular sobre o sistema construtivo em si. Ainda, este ponto negativo seria somado a um problema de preconceito popular já frequente com respeito às construções em madeira, o que levaria ao fracasso da difusão do wood frame no Brasil.

Após os resultados observados na produção do Residencial Haragano, novos empreendimentos de habitações foram produzidos nas Faixas 1 e 2 do PMCMV, assim como outras edificações destinadas para rendas mais elevadas. Assim, o capítulo seguinte conclui este trabalho discorrendo sobre como o sistema wood frame vem sendo difundido no Brasil desde o ano de 2011 até 2016. 


\section{DIFUSÃO DO SISTEMA WOOD FRAME NO BRASIL APÓS A PUBLICAÇÃO DA DIRETRIZ SINAT № 005 EM 2011}

Após os resultados das primeiras ações da Comissão Casa Inteligente apresentados nos capítulos anteriores, com destaque à publicação da Diretriz SINAT 005, à homologação do sistema construtivo da empresa Tecvede no SINAT e à construção do Residencial Haragano, observa-se que a produção do wood frame vem sendo difundida gradualmente no Brasil. Novos construtores estão aderindo ao sistema e, por adotarem diferentes soluções tecnológicas, outros agentes passam a integrar esta cadeia de produção que vem se estabelecendo com base neste novo cenário de construções em madeira no país.

Para analisar a difusão do sistema wood frame após esta nova conjuntura do setor, este capítulo procura caracterizar a produção deste sistema no Brasil entre os anos de 2011 e 2016, apontando um quantitativo de construtores envolvidos e suas principais soluções tecnológicas adotadas, como materiais constituintes e métodos de execução. Também, procura-se examinar a quem, em geral, esta produção de edificações em wood frame vem sendo destinada. E, por fim, este capítulo encerra discorrendo sobre como a Comissão Casa Inteligente continuou suas ações para dar continuidade à promoção do wood frame no Brasil.

\subsection{CARACTERIZAÇÃO DA PRODUÇÃO DO WOOD FRAME NO BRASIL APÓS 2011}

Até meados de 2010, constatou-se a presença de um ou outro construtor, assim como de escritórios de arquitetura e engenharia, com intenção de construir utilizando o wood frame no Brasil. Entretanto, desde 2011 até 2016, foram visitadas seis empresas de engenharia e arquitetura e um grupo de construtores autônomos que estavam atuando comercialmente com este sistema inovador. Este fato deu indícios de uma nova tendência do setor de construções em madeira no país, estagnado há mais de décadas. Pesquisadores, como De Araújo (et al., 2016), também observaram esta transformação no cenário brasileiro. Por exemplo, até o fim de 2016, foram constatadas aproximadamente 23 empresas $^{31}$ que utilizaram o sistema wood frame nas suas construções (Tabela 18).

\footnotetext{
${ }^{31}$ Uma investigação mais aprofundada é necessária para conferir se estas empresas realmente atuaram com wood frame ou então com outro tipo de sistema leve em madeira com composições diferenciadas.
} 
Tabela 18: Empresas brasileiras que atuam com wood frame em 2016

\begin{tabular}{|c|c|c|}
\hline Empresa & Atuação / Método de produção & Local \\
\hline Tecverde Engenharia & $\begin{array}{l}\text { Residencial e Institucional/Produção } \\
\text { industrializada - painéis fechados }\end{array}$ & Araucária, PR \\
\hline Ecos Haus / Grupo Kürten & $\begin{array}{c}\text { Residencial /Produção industrializada - painéis } \\
\text { fechados }\end{array}$ & Curitiba, PR \\
\hline Roberto Ferreira & $\begin{array}{c}\text { Residencial /Produção semi-industrializada - } \\
\text { painéis abertos }\end{array}$ & Pelotas, RS \\
\hline Tetti & $\begin{array}{c}\text { Residencial /Produção semi-industrializada - } \\
\text { painéis abertos, painéis fechados }\end{array}$ & Capão Bonito, SP \\
\hline Canteiro & $\begin{array}{c}\text { Construções temporárias / Produção semi- } \\
\text { industrializada - painéis abertos }\end{array}$ & Santa Isabel, SP \\
\hline Caribea - Casa Inteligente & $\begin{array}{c}\text { Residencial / Produção semi-industrializada - } \\
\text { painéis abertos }\end{array}$ & São Manuel, SP \\
\hline Shintech & Residencial e Institucional / Produção no canteiro & Sorocaba, SP \\
\hline Solução madeiras & Construções temporárias / Produção no canteiro & Arujá, SP \\
\hline Buselli Arquitetura & Residencial / Produção no canteiro & Limeira, SP \\
\hline $\begin{array}{l}\text { Novo Horizonte Soluções de } \\
\text { Engenharia }\end{array}$ & Residencial / Produção no canteiro & Rio de Janeiro, RJ \\
\hline Madeiras MG & Residencial / Produção no canteiro & Belo Horizonte, MG \\
\hline Elemental Construtora & Residencial / Produção no canteiro & Uberlândia, MG \\
\hline Casa Certa & Residencial / Produção no canteiro & Brasília, DF \\
\hline $\begin{array}{l}\text { Volver Sistemas Construtivos } \\
\text { Flexíveis }\end{array}$ & Residencial / Produção no canteiro & Curitiba, PR \\
\hline Casa rápida Curitiba & Residencial / Produção no canteiro & Curitiba, PR \\
\hline Embafort Sistemas Construtivos & Residencial / Produção no canteiro & Curitiba, PR \\
\hline Montaggio Wood \& Steel frame & Residencial / Produção no canteiro & Cascavel, PR \\
\hline Bolsoni Carpintaria & Residencial / Produção no canteiro & Florianópolis, SC \\
\hline Holz Haus & Residencial / Produção no canteiro & Florianópolis, SC \\
\hline $\begin{array}{l}\text { Madeframe - Construframe } \\
\text { Montagem e Construções Ltda }\end{array}$ & Residencial / Produção no canteiro & $\begin{array}{c}\text { Joinville, SC / } \\
\text { Vargem Grande } \\
\text { Paulista, SP }\end{array}$ \\
\hline Sperotto Engenharia & Residencial / Produção no canteiro & Erechim, RS \\
\hline Szücs Engenharia e Arquitetura & $\begin{array}{l}\text { Consultoria, Projeto estrutural e executivo, } \\
\text { acompanhamento da obra }\end{array}$ & Florianópolis, SC \\
\hline $\begin{array}{l}\text { Stamade Consultoria em } \\
\text { Estruturas de Madeira }\end{array}$ & $\begin{array}{l}\text { Consultoria, Projeto estrutural e executivo, } \\
\text { acompanhamento da obra }\end{array}$ & São Carlos, SP \\
\hline
\end{tabular}

Fonte: Autora com base em De Araújo (et al., 2016).

Ao pesquisar esta produção recente, observou-se que parte desta difusão do sistema wood frame ocorreu como consequência das ações da Comissão Casa Inteligente que estimularam a relação entre os agentes desta cadeia de produção. Dentre as empresas de construção que em algum momento atuaram nesta conjuntura da comissão, estão: Tecverde, Stamade, Caribea, Tetti, Madezatti, Embafort. A empresa Ecos Haus, enquanto constituída por representantes da empresa de maquinários Weinmann, também participou como integrante da Comissão. E, a atuação da empresa Roberto Ferreira contou com parcerias de integrantes da Comissão. 
No entanto, além dessas, conforme a Tabela 18 listou, outras dezesseis empresas independentes da Comissão Casa Inteligente também estavam atuando com o sistema wood frame. Assim, salienta-se que é necessário aprofundar uma pesquisa sobre este ponto para compreender que fatos incentivaram as atuações destas empresas neste mesmo período. Mas, em uma breve constatação, notou-se o interesse destas por construções secas, racionalizadas e mais sustentáveis. Também, algumas destas construtoras contavam com a presença de trabalhadores que anteriormente eram construtores carpinteiros em outros países, como EUA, Nova Zelândia, Austrália, e estavam retornando neste período para o Brasil, sendo alguns desses motivados pela crise no setor habitacional norte-americano.

Ainda, neste período analisado, observou-se que, em geral, estas empresas brasileiras estavam utilizando o sistema construtivo leve com sua composição básica original, mantendo: fundação em radier ou em blocos de concreto, paredes constituídas por painéis estruturados em madeira, entrepiso com vigas de madeira maciça ou com vigas I compostas por componentes derivados de madeira e cobertura com estrutura em madeira.

Destas composições, observou-se algumas diferenças de materiais aplicados nos painéis de paredes. Geralmente, mantém-se o entramado com travessas e montantes em madeira, o qual é contraventado com chapas OSB, protegidas com membranas hidrófugas. Mas, os demais materiais aplicados nas camadas destes painéis podem variar. O modelo mais usual é similar àquele que vem sendo apresentado até o momento neste trabalho: (1) gesso acartonado e acabamentos internos com pintura ou azulejos cerâmicos, (2) isolante em lã de vidro, de rocha ou de pet, (3) entramado em madeira de pinus tratado com CCA em autoclave, (4) chapa OSB, (5) membrana hidrófuga e (6) vedação externa e acabamentos finais.

A solução tecnológica para a vedação externa é a que mais altera nas composições dos painéis de parede encontradas nas empresas brasileiras. Por exemplo, foram observados três tipos diferentes de camadas externas: (a) placa cimentícia com tratamento de junta aparente ou dissimulada, (b) sidings em madeira ou em PVC e (C) placa de isopor, com tela de reforço em fibra de nylon e poliéster e estuque com massa mineral (Figura 149).

Por sua vez, nos painéis das paredes internas que não apresentam função estrutural, muitas empresas optam por colocar apenas chapas de gesso acartonado para vedar o entramado em madeira. E, quando estes painéis são estruturais ou para dar-lhes maior resistência para pendurar peças suspensas, como móveis ou redes de dormir, as empresas colocam chapas OSB e gesso acartonado em ambas as faces do painel. 

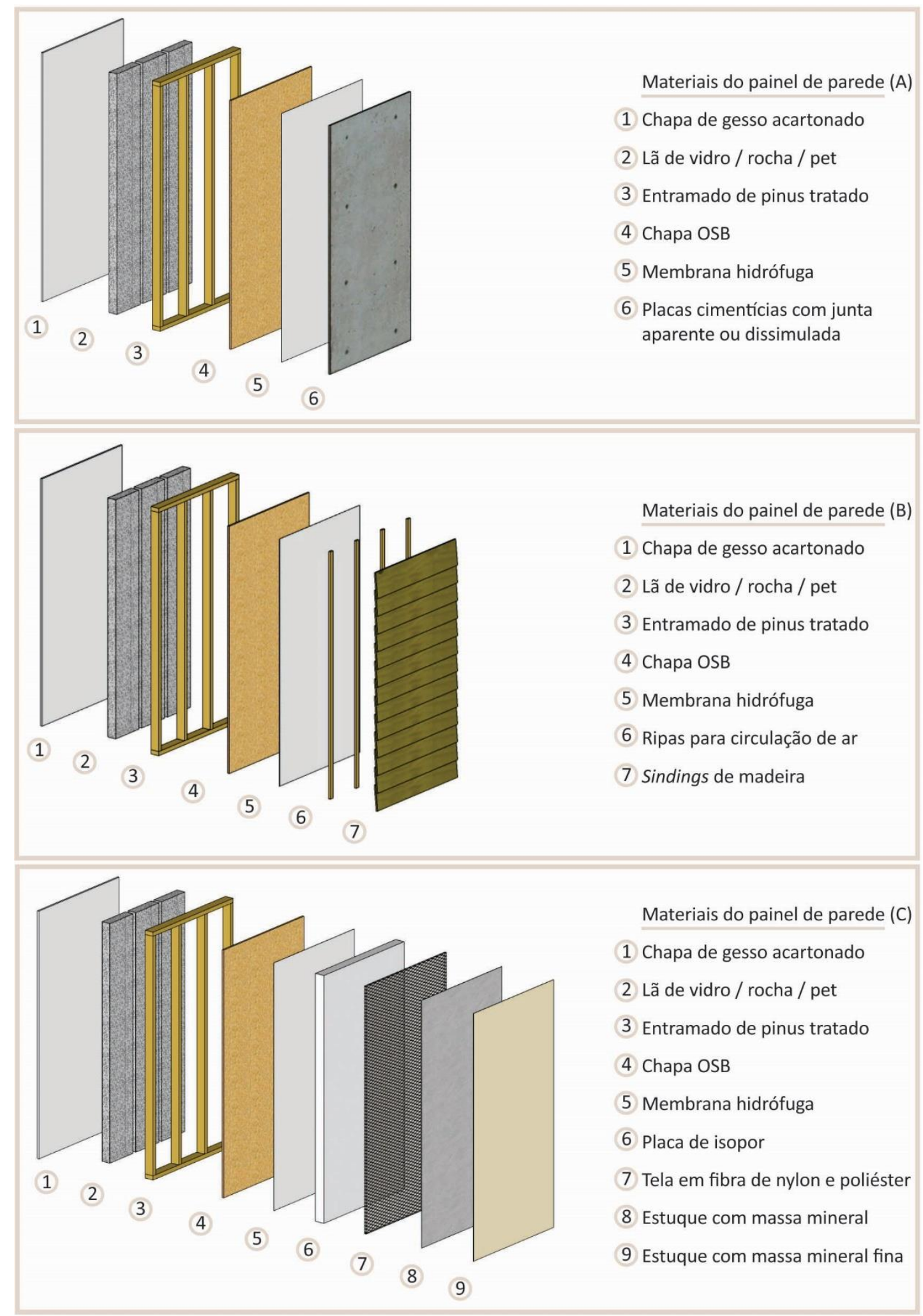

Figura 149: Variações dos materiais externos do painel de parede da fachada Fonte: autora. 
Para produção destes componentes, atualmente, existem três métodos principais de construção no Brasil: (1) produção e montagem dos painéis no canteiro, (2) painéis abertos produzidos nas fábricas e finalizados após montagem no canteiro e (3) painéis fechados produzidos nas fábricas.

A maioria dos construtores brasileiros listados na Tabela 18 produz a edificação em wood frame integralmente no canteiro, com método similar ao denominado stick-built ou sitebuilt nos EUA. Após receber os insumos industrializados, como madeira beneficiada e tratada, chapas OSB, membrana hidrófuga, chapas de gesso e material de vedação externa, os trabalhadores cortam estes componentes conforme as medidas de projeto, com auxílio de equipamentos como a serra circular. Geralmente, o entramado em madeira é montado no chão, utilizando a fundação de concreto como base para este trabalho, onde montantes e travessas são unidos com pregadeiras pneumáticas. E, depois, este entramado é erguido e posicionado com auxílio de escoras temporárias. Na sequência, as chapas OSB e os demais componentes são fixados e a parede é finalizada com os acabamentos selecionados (Figura 150).
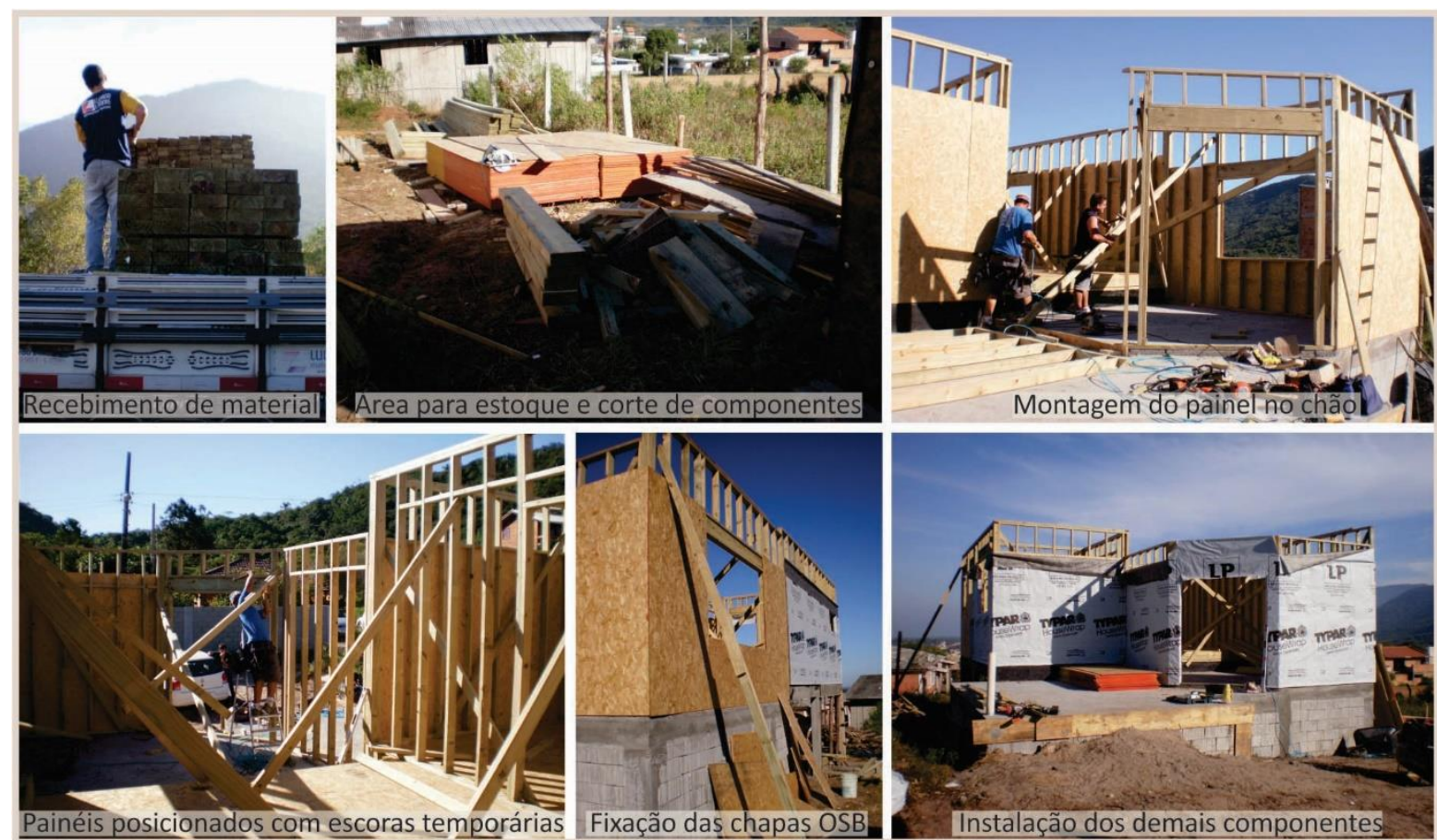

Figura 150: Produção de edificação no canteiro executada por construtores autônomos Fonte: autora. 
Muitos construtores autônomos adotam esta prática construtiva, assim como empresas de arquitetura e engenharia que contratam estes construtores. No entanto, apesar de ser uma construção limpa e seca, cuidados devem ser tomados referentes ao estoque do material e à exposição da edificação às intempéries durante a execução da edificação. Algumas das empresas têm áreas específicas para estocar os insumos da construção, enquanto em outras obras, o material fica no próprio canteiro coberto com lonas (Figura 150). Também, observou-se que, em alguns casos, as obras ocorrem sem supervisão técnica e sem projetos detalhados para produção. Já em outros casos, as obras são supervisionadas por engenheiros que detalham todos elementos constituintes para esta produção no canteiro.

Em um segundo método de construção do wood frame no Brasil, painéis abertos de parede são produzidos na fábrica e depois transportados ao canteiro para serem finalizados. Por exemplo, o método de construção com painéis abertos foi adotado pela empresa Tecverde na sua primeira fábrica em Pinhais, no Paraná (Figura 151) (TECVERDE, 2016). Também, a empresa Roberto Ferreira utilizou painéis abertos na construção do Residencial Haragano demonstrada no capítulo anterior.

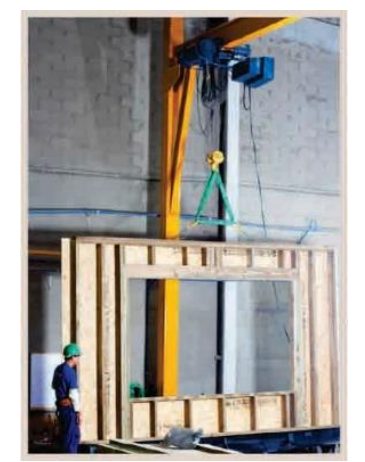

Figura 151: Produção de painéis abertos na fábrica Fonte: Tecverde (2016).

Em geral, as empresas e construtoras que utilizam o método do painel aberto, montam o entramando sobre mesas de montagem nas fábricas e fecham uma das suas faces com chapas OSB. Sua outra face fica aberta para, no canteiro, receber as instalações elétrica e hidráulicas. Depois, é fechado com os componentes especificados e recebe os acabamentos finais. Por manter uma sequência na produção de painéis na fábrica, este método é mais rápido que o anterior descrito. Também, em local fechado está protegido da ação de intempéries que possam interromper o processo. Entretanto, estima-se um maior grau de 
precisão da montagem quando comparado à construção toda executada no canteiro. Mas, ainda permite alguns ajustes quando ocorrem erros de medidas, o que se torna mais difícil no método dos painéis fechados.

Ainda, empresas que não possuem fábricas próprias para produzir os painéis de parede também vêm adotando o método de construção panelizado. Estas procuram soluções alternativas à fábrica para montagem dos painéis abertos fora do canteiro. Por exemplo, a residência projetada pela arquiteta Rosane Zanardo e por Szücs Engenharia \& Arquitetura foi construída na cidade de Erechim, no Rio Grande do Sul, no segundo semestre de 2015, período marcado por estações chuvosas. Entretanto, como o proprietário da residência possuía um galpão à $5 \mathrm{~km}$ de distância do canteiro-de-obras, foi possível produzir os painéis de parede desta residência neste local fechado e transportá-los ao canteiro, onde foram erguidos com auxílio de um caminhão munk, posicionados sobre a fundação de concreto já pronta, fixados e finalizados (Figura 152).

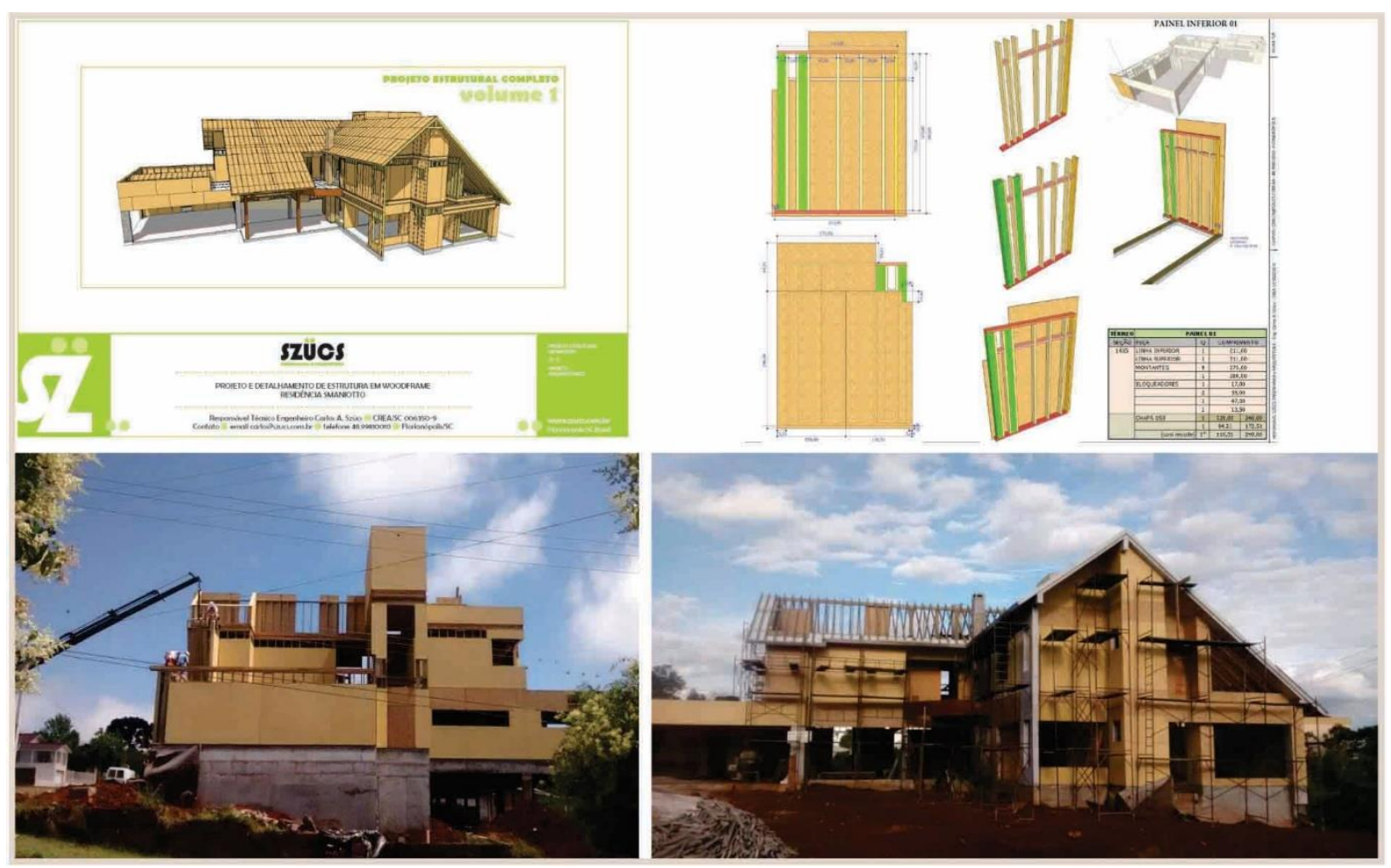

Figura 152: Casa projetada e construída com painéis abertos em Erechim, Rio Grande do Sul Fonte: arquivo da empresa Szücs Engenharia \& Arquitetura, 2015.

Por sua vez, na produção dos painéis fechados - terceiro método de construção em wood frame -, todos os componentes são montados e fixados na fábrica, incluindo a inserção 
dos subsistemas hidrossanitário e elétrico. No canteiro, estes painéis são montados e fixados sobre a fundação de concreto, a qual deve ter sido executada com extrema precisão, haja vista a impossibilidade de alterar estes painéis de parede naquele momento na tentativa de adequá-los a erros decorrentes da etapa de execução da fundação. Por fim, após instalados sobre a fundação, estes painéis de parede recebem os acabamentos finais, como pintura e azulejos. Assim, este método de construção panelizado se destaca por ser mais racionalizado que os outros dois métodos anteriores ofertados pelas empresas brasileiras, e, consequentemente, apresenta menor tempo de produção no canteiro, reduzindo custos com a mão-de-obra envolvida nesta etapa.

Neste período, três empresas brasileiras produzem com painéis fechados, sendo estas: Tetti, Kürten e Tecverde. No entanto, elas apresentam diferentes procedimentos e maquinários para esta produção, variando seu grau de industrialização. Por exemplo, na fábrica da Tetti, os trabalhadores montam os painéis sobre mesas fixas, onde a altura dos painéis é estabelecida conforme as medidas de projeto. Os componentes são cortados e posicionados sobre a mesa, onde são unidos com equipamentos como pregadeira pneumática, parafusadeiras, grampeadores. Também nesta mesa, recebem as instalações elétricas e o kit de instalações hidráulicas. Por fim, o painel é fechado com componentes internos e externos e está pronto para o transporte até o canteiro (Figura 153).

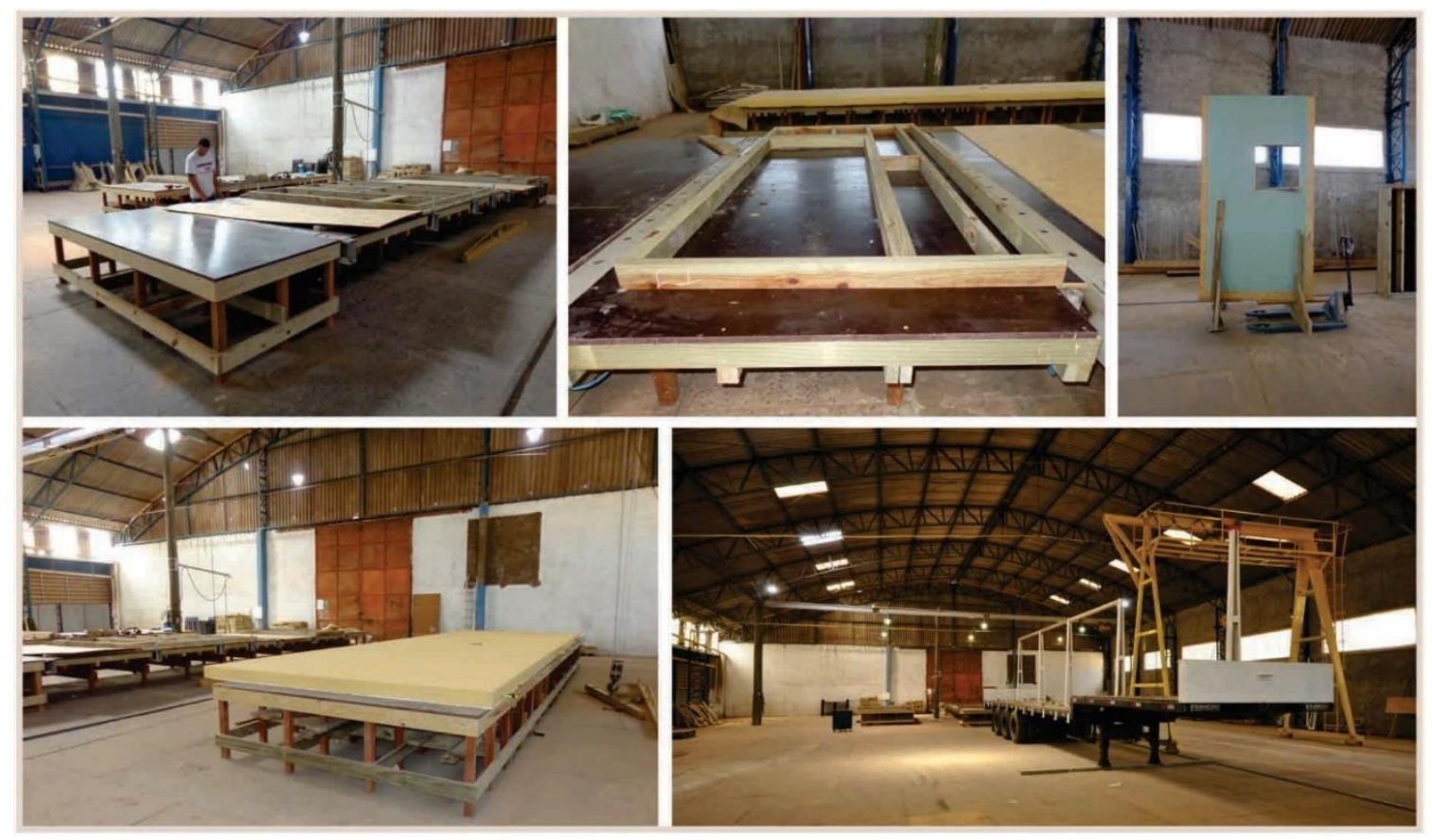

Figura 153: Produção de painéis fechados na fábrica da empresa Tetti em Capão Bonito, São Paulo Fonte: autora. 
A empresa Kürten, a qual já trabalhava tradicionalmente com outros sistemas construtivos em madeira, iniciou uma parceria com a empresa alemã que instalou a fábrica Ecos Haus em Curitiba. Desde meados de 2014, a Ecos Haus foi incorporada ao Grupo Kürten e estima-se que esta fábrica é capaz de produzir uma residência de $150 \mathrm{~m}^{2}$ em aproximadamente 25 horas (KÜRTEN, 2014). Os equipamentos utilizados são mecanizados, com mesas de montagem hidráulicas, que fixam as alturas dos painéis de parede e que são rotacionadas para trabalhar as suas duas faces, sem que o trabalhador precise erguer e mover o painel. Também, outras máquinas são controladas por programas computadorizados e cortam as aberturas das esquadrias conforme dados do projeto. Ainda nestas mesas, são instalados os materiais elétricos e hidrossanitários. Já fechado, o painel recebe o acabamento externo de estuque ainda na fábrica. Por fim, o painel é estocado para o transporte até o canteiro (Figura 154).
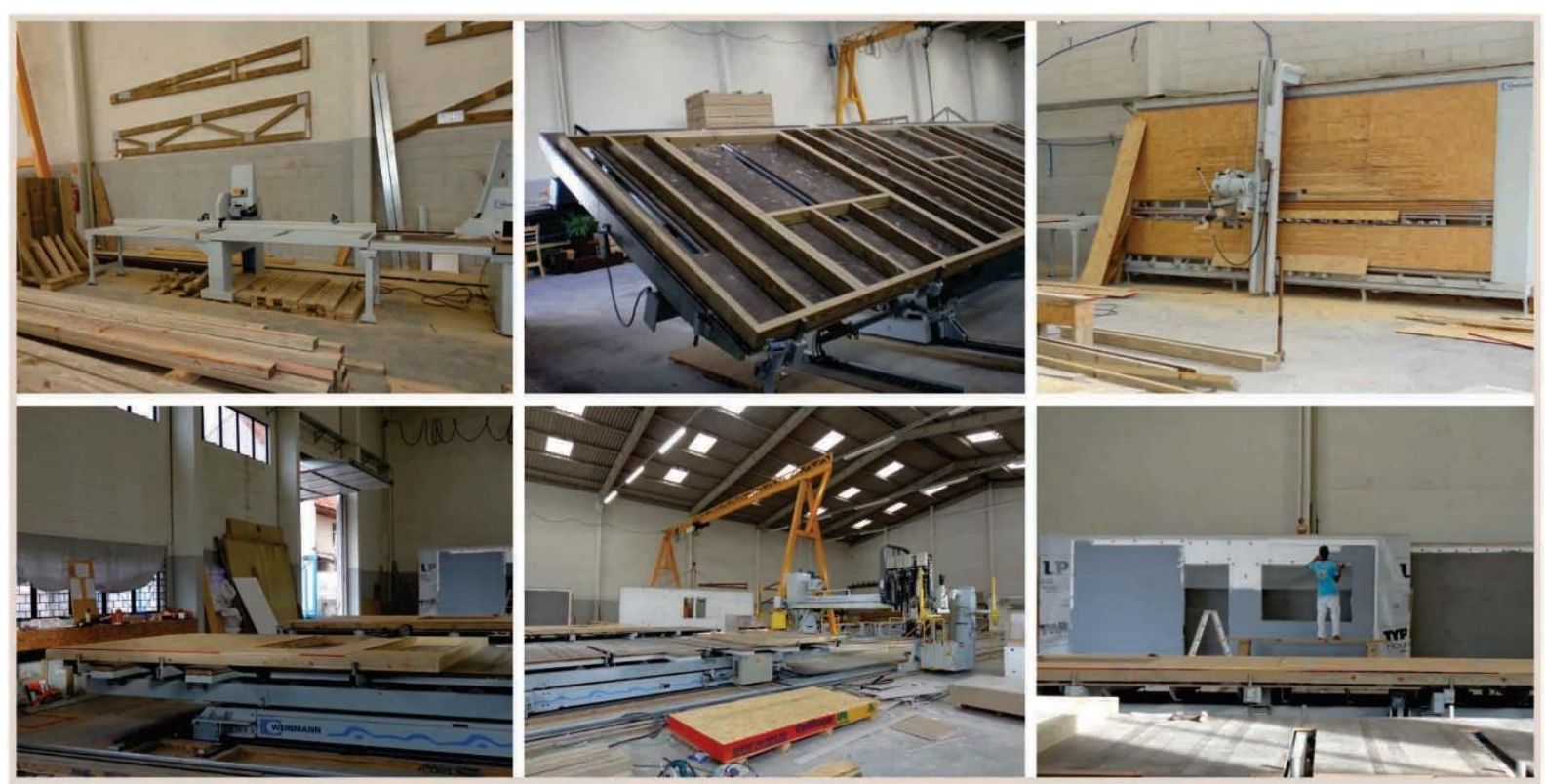

Figura 154: Produção de painéis fechados na fábrica da empresa Ecos Haus em Curitiba, Paraná Fonte: autora.

A empresa Tecverde, conforme relatado no capítulo 6, iniciou sua produção na fábrica de Pinhais em 2010, principalmente com método de painéis abertos. E, em 2014, com aumento da sua produção, a empresa relocou sua fábrica para o município de Araucária, também na região metropolitana de Curitiba. Com uma maior instalação, em uma área de aproximadamente $2.600 \mathrm{~m}^{2}$, a empresa utiliza uma série de equipamentos mecanizados e controlados por dados numéricos computadorizados, com capacidade de produção de $385 \mathrm{~m}^{2}$ 
por dia, adotando o sistema de painéis fechados. Na fábrica, o trabalhador alimenta a máquina com os montantes e as travessas de madeira. Na sequência, ele dá os comandos no computador para que a máquina realize o posicionamento e a fixação dessas peças que constituem o entramado da parede. Na sequência, o painel vai sendo deslizado para as próximas estações de trabalho, onde recebe os demais materiais, incluindo os elétricos e os hidráulicos. Por fim, prontos e fechados, estes painéis são transportados para o canteiro, onde necessitam receber apenas o acabamento final como pinturas e revestimentos cerâmicos (Figura 155) (TECVERDE, 2016).

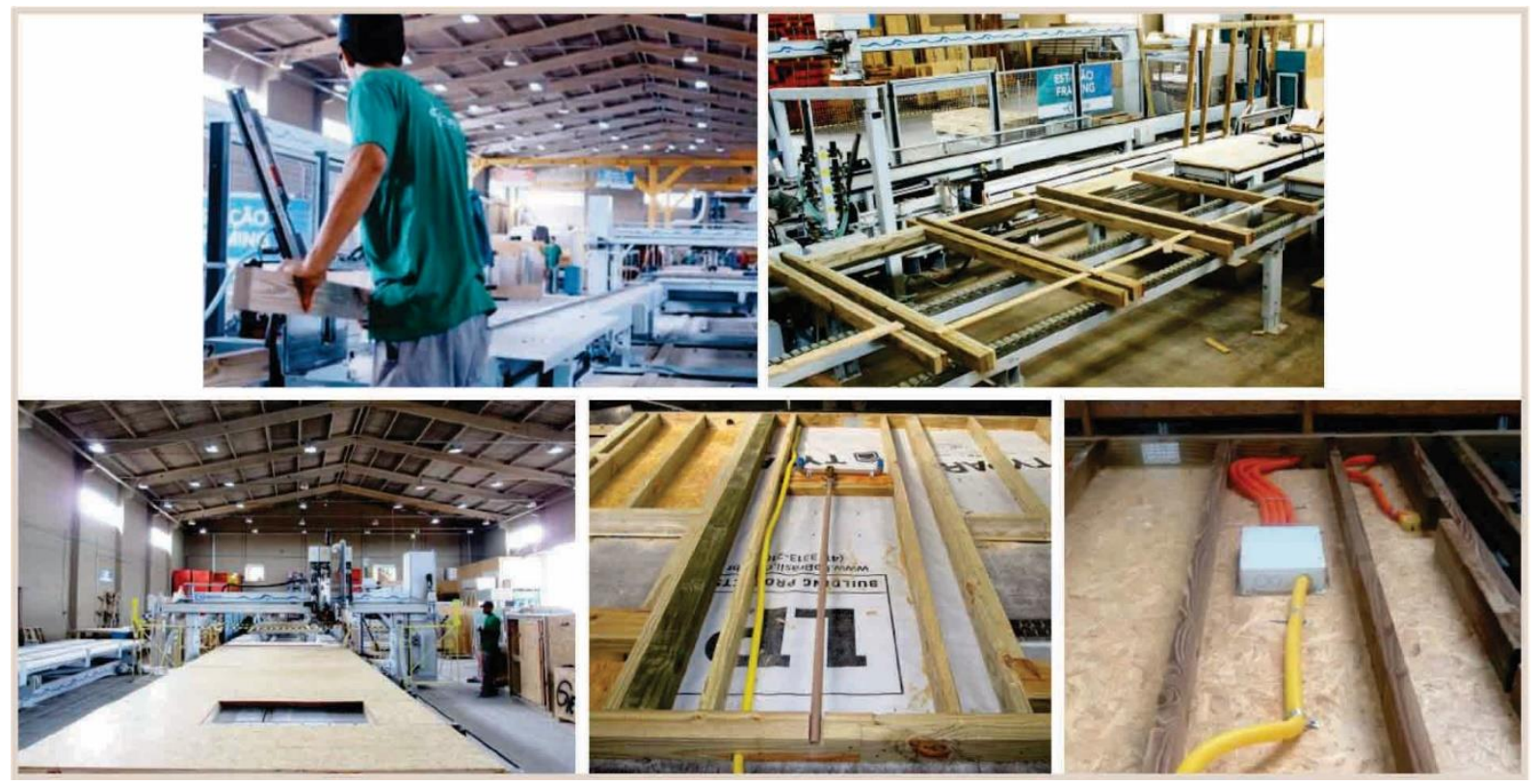

Figura 155: Produção de painéis fechados na fábrica da empresa Tecverde em Araucária, Paraná Fonte: Tecverde, 2016.

Estes métodos de construção no canteiro e na fábrica, vem demonstrando a capacidade das empresas construtoras brasileiras de aplicar o wood frame na produção de edificações no Brasil. São métodos baseados nas experiências dos países que tradicionalmente constroem com este sistema leve em madeira; ainda que, em especial na produção de painéis abertos, algumas adequações estão sendo realizadas pelas empresas brasileiras que não importam mesas e máquinas automatizadas para montagem na fábrica.

Assim, observou-se que o grau de industrialização da produção em wood frame no Brasil atualmente varia entre: não industrializado com construções integralmente no canteiro, semi-industrializado com etapas realizadas na fábrica que são completadas no canteiro e, por 
fim, industrializado, com elementos totalmente pré-fabricados que são levados para serem montados no canteiro.

Com base nestas produções, procurou-se dados sobre qual o principal uso das edificações que vêm sendo construídas com wood frame desde meados de 2010. Por exemplo, foram construídas instituições de ensino, como creche e ambientes para pesquisa. Também, foram construídas edificações para serviços, como áreas para atendimento de motoristas em rodovias entre os estados de Minas Gerais e Goiás. No entanto, verifica-se que o maior uso das edificações construídas atualmente é o residencial. E, com produção inserida em programa de habitação social nacional, financiada por agentes públicos, o maior volume destas residências foi destinado incialmente às famílias com menor renda salarial, conforme o item seguinte abordará.

\subsection{PRODUÇÃO DE HABITAÇÕES EM WOOD FRAME APÓS A DIRETRIZ SINAT № 005/2011}

Os capítulos anteriores mostraram que algumas empresas da cadeia de produção do wood frame no país se organizaram junto a outros agentes para buscar possibilidades de financiamento para estas edificações construídas. Com isso, em 2011, a Comissão Casa Inteligente obteve a publicação da primeira Diretriz SINAT para o sistema wood frame, mediante o MCidades. E, na sequência, com os avanços dos relacionamentos entre agentes deste setor, a empresa Tecverde propôs um sistema construtivo que foi avaliado e aprovado por ITA's, sendo assim homologado e publicado no DATec no 20 em 2013 pelo PBQP-H no MCidades. Este documento oficial permitiu a introdução do wood frame desta empresa no PMCMV, financiado pela CEF. Com base nesta possibilidade, a empresa Tecverde, enquanto detentora deste sistema homologado, iniciou um modelo de negócios de licenciamento, o qual, mediante relações de parcerias, permitiu que outras empresas construtoras interessadas utilizassem sua tecnologia de construção para execução de empreendimentos, em especial daqueles promovidos no âmbito do PMCMV.

Como resultado dessas ações, observa-se que, desde 2012 até 2015, a principal difusão das construções em wood frame no Brasil ocorreu mediante este programa de habitação social nacional, através da empresa Tecverde e outras empresas construtoras parceiras desta. O primeiro empreendimento residencial construído em wood frame no PMCMV foi o Haragano, localizado no município de Pelotas, iniciado em 2012, decorrente da parceria entre 
as empresas Tecverde e Roberto Ferreira, conforme processo de produção apresentado no capítulo anterior. Estas residências foram destinadas para Faixa 1 do PMCMV.

Além deste primeiro empreendimento destinado às famílias com renda mensal de até 3 s.m., outros três também contemplaram as habitações populares, sendo estes: Moradias Nilo, com 70 UHs localizadas em Curitiba, Paraná; Residencial Colina Verde, com 70 UHs em Sapucaia, Rio Grande do Sul; e Loteamento Santo Antônio do Palmital, com 23 UHs em Rio Bom, Paraná (Tabela 19).

Além de contemplar a Faixa 1 do PMCMV, as edificações construídas em wood frame também foram utilizadas em empreendimentos da Faixa 2 deste programa habitacional, ou seja, para famílias com renda mensal entre $\mathrm{R} \$ 1.600,00$ e $\mathrm{R} \$ 3.275,00$. Dentre estes empreendimentos Faixa 2, estão: Residencial Vivendas do Taquaral, com 25 UHs localizadas em Maricá, Rio de Janeiro; Residencial Terra Nova, com 100 UHs em São Mateus do Sul, Paraná; Residencial Castelo de São Jorge, com 443 UHs em Dourados, Mato Grosso do Sul; e Residencial Eccoville Sorocaba, com 50 UHs em Sorocaba, São Paulo (Tabela 19).

Portanto, desde 2012 até 2015, a produção de habitação em wood frame no PMCMC concentrou-se nas parcerias de licenciamento da empresa Tecverde com outras construtoras. E, como resultado, foram construídas 487 UHs inseridas na Faixa 1 e 618 UHs na Faixa 2, somando 1.105 UHs localizadas em quatros estados brasileiros: Rio Grande do Sul, Paraná, Mato Grosso do Sul e Rio de Janeiro. Em geral, estas residências do PMCMV apresentam: 2 dormitórios, 1 banheiro, sala e cozinha conjugadas e área externa para lavanderia, totalizando uma área de $45 \mathrm{~m}^{2}$ em média. Como exceção, o Residencial Vivendas do Taquaral, de Maricá, apresenta uma casa térrea com área de $60 \mathrm{~m}^{2}$, constituída por 2 quartos, 2 banheiros, 1 cozinha, 1 sala de estar e jantar e área externa para lavanderia. E, o Residencial Eccoville Sorocaba apresenta um sobrado com $60 \mathrm{~m}^{2}$, contendo 2 quartos, 1 banheiro, 1 lavabo, sala e cozinha conjugadas e lavanderia em área externa (Tabela 19).

Estes valores demonstram que o PMCMV, ao permitir a utilização de sistemas construtivos inovadores homologados pela CEF e pelo SINAT, possibilitou a difusão do wood frame no Brasil como não havia ocorrido anteriormente. Assim, estas habitações de programas sociais, que não eram o alvo inicial de negócio das empresas, se transformaram em uma oportunidade de crescimento e efetivação de produção em maior escala. E, este fator da escala da produção foi essencial para manter um custo equivalente e competitivo para 
estas construções industrializadas em wood frame quando comparadas a outros sistemas tradicionais em alvenaria.

Tabela 19: Habitações construídas com wood frame no PMCMV desde 2012 a 2015

\begin{tabular}{|c|c|c|c|c|c|c|}
\hline $\begin{array}{l}\text { Emprendim. / } \\
\text { Localização }\end{array}$ & $\begin{array}{c}\text { Unidades } \\
\text { Habitacionais } \\
\text { (UHs) e } \\
\text { tipologia }\end{array}$ & $\begin{array}{l}\text { Programa } \\
\text { de } \\
\text { habitação }\end{array}$ & $\begin{array}{l}\text { Área da } \\
\text { residência }\end{array}$ & $\begin{array}{l}\text { Ano de } \\
\text { início e } \\
\text { conclusão } \\
\text { da obra }\end{array}$ & $\begin{array}{l}\text { Empresas } \\
\text { construtoras } \\
\text { responsáveis }\end{array}$ & $\begin{array}{c}\text { Sistema } \\
\text { construtivo }\end{array}$ \\
\hline $\begin{array}{l}\text { Residencial } \\
\text { Haragano / } \\
\text { Pelotas, RS }\end{array}$ & $\begin{array}{c}10 \text { UHs / } \\
\text { térrea } \\
\text { geminada + } \\
270 \text { UHs / } \\
\text { sobrado } \\
\text { geminado }\end{array}$ & $\begin{array}{c}\text { PMCMV } \\
\text { Faixa } 1 / \\
\text { FAR } \\
\text { (empresas) }\end{array}$ & $47 m^{2}$ & $\begin{array}{c}2012- \\
2013\end{array}$ & Roberto Ferreira & $\begin{array}{c}\text { Morar } \\
\text { Melhor } \\
\text { Aprimorado } \\
\text { / UFPel }\end{array}$ \\
\hline $\begin{array}{l}\text { Moradias Nilo } \\
\text { / Curitiba, PR }\end{array}$ & $\begin{array}{l}70 \text { UHs / } \\
\text { térrea } \\
\text { geminada }\end{array}$ & $\begin{array}{c}\text { PMCMV } \\
\text { Faixa 1/ } \\
\text { FAR } \\
\text { (empresas) }\end{array}$ & $43 m^{2}$ & $\begin{array}{c}2014- \\
2015\end{array}$ & Construtora FKlas & $\begin{array}{l}\text { DATec } 020 \\
\text { Sistema } \\
\text { Tecverde }\end{array}$ \\
\hline $\begin{array}{l}\text { Resid. Colina } \\
\text { Verde / } \\
\text { Sapucaia, RS }\end{array}$ & $\begin{array}{c}114 \text { UHs / } \\
\text { térrea isolada }\end{array}$ & $\begin{array}{c}\text { PMCMV } \\
\text { Faixa 1/ } \\
\text { FAR } \\
\text { (empresas) }\end{array}$ & $42,8 \mathrm{~m}^{2}$ & $\begin{array}{c}2014- \\
2015\end{array}$ & $\begin{array}{c}\text { Kaefe Engenharia } \\
\text { e Empreend } \\
\text { Imobiliários }\end{array}$ & $\begin{array}{l}\text { DATec } 020 \\
\text { Sistema } \\
\text { Tecverde }\end{array}$ \\
\hline $\begin{array}{l}\text { Loteam. } \\
\text { Patrimônio } \\
\text { Santo Antônio } \\
\text { do Palmital / } \\
\text { Rio bom, PR } \\
\end{array}$ & $\begin{array}{l}23 \text { UHs / } \\
\text { térrea } \\
\text { geminada }\end{array}$ & $\begin{array}{c}\text { PMCMV } \\
\text { Faixa } 1 / \\
\text { FDS } \\
\text { (entidades) }\end{array}$ & $43 \mathrm{~m}^{2}$ & $\begin{array}{c}2015- \\
2015\end{array}$ & $\begin{array}{c}\text { União por } \\
\text { Moradia Popular } \\
\text { no Paraná / Baú } \\
\text { Construtora }\end{array}$ & $\begin{array}{l}\text { DATec } 020 \\
\text { Sistema } \\
\text { Tecverde }\end{array}$ \\
\hline $\begin{array}{l}\text { Resid. } \\
\text { Vivendas do } \\
\text { Taquaral / } \\
\text { Maricá, RJ }\end{array}$ & $\begin{array}{l}25 \text { UHs / } \\
\text { térrea isolada }\end{array}$ & $\begin{array}{l}\text { PMCMV } \\
\text { Faixa } 2\end{array}$ & $60 \mathrm{~m}^{2}$ & $\begin{array}{c}2015- \\
2015\end{array}$ & $\begin{array}{c}\text { Simples } \\
\text { Construções }\end{array}$ & $\begin{array}{l}\text { DATec } 020 \\
\text { Sistema } \\
\text { Tecverde }\end{array}$ \\
\hline $\begin{array}{l}\text { Resid. Terra } \\
\text { Nova / São } \\
\text { Mateus do Sul, } \\
\text { PR }\end{array}$ & $\begin{array}{c}100 \mathrm{UHs} / \\
\text { térrea isolada }\end{array}$ & $\begin{array}{l}\text { PMCMV } \\
\text { Faixa } 2\end{array}$ & $43 m^{2}$ & $\begin{array}{c}\text { Em } \\
\text { andamento }\end{array}$ & $\begin{array}{c}\text { Casalot } \\
\text { Empreendimentos } \\
\text { Imobiliários / Casa } \\
\text { Alta Construtora }\end{array}$ & $\begin{array}{c}\text { DATec } 020 \\
\text { Sistema } \\
\text { Tecverde }\end{array}$ \\
\hline $\begin{array}{l}\text { Resid. Castelo } \\
\text { de São Jorge / } \\
\text { Dourados, MS }\end{array}$ & $\begin{array}{c}213 \text { UHs (fase } \\
\text { 1) + } 230 \text { UHs } \\
\text { (fase 2) / } \\
\text { térreas } \\
\text { isoladas e } \\
\text { geminadas }\end{array}$ & $\begin{array}{l}\text { PMCMV } \\
\text { Faixa } 2\end{array}$ & $42,80 \mathrm{~m}^{2}$ & $\begin{array}{c}\text { Em } \\
\text { andamento }\end{array}$ & Baú Construtora & $\begin{array}{l}\text { DATec } 020 \\
\text { Sistema } \\
\text { Tecverde }\end{array}$ \\
\hline $\begin{array}{l}\text { Resid. } \\
\text { Eccoville } \\
\text { Sorocaba / } \\
\text { Sorocaba, SP }\end{array}$ & $\begin{array}{l}50 \text { UHs / } \\
\text { sobrados } \\
\text { geminados }\end{array}$ & $\begin{array}{l}\text { PMCMV } \\
\text { Faixa } 2\end{array}$ & $\begin{array}{l}46,80 \mathrm{~m}^{2} \\
\text { e } 63,8 \mathrm{~m}^{2}\end{array}$ & $\begin{array}{c}\text { Em } \\
\text { andamento }\end{array}$ & $\begin{array}{l}\text { Palatium } \\
\text { Engenharia }\end{array}$ & $\begin{array}{l}\text { DATec } 020 \\
\text { Sistema } \\
\text { Tecverde }\end{array}$ \\
\hline Subtotal 1 & 487 UHs & $\begin{array}{c}\text { PMCMV - } \\
\text { Faixa } 1\end{array}$ & - & - & - & \\
\hline Subtotal 2 & 618 UHs & $\begin{array}{l}\text { PMCMV - } \\
\text { Faixa } 2\end{array}$ & - & - & - & \\
\hline
\end{tabular}

Fonte: Autora. 
Para prosseguir consolidando estas produções de habitações, principalmente as introduzidas no PMCMV, a empresa Tecverde deu continuidade nos processos de renovação do DATec no 20, tendo em vista que o prazo de validade deste documento era datado para setembro de 2015. Assim, conforme sua experiência prática adquirida, a Tecverde propôs ajustes no seu sistema construtivo e, mediante as ITAs contratadas, realizou testes complementares de avaliação técnica destas atualizações. Como resultado, o DATec no 020-A foi publicado em novembro de 2015, contemplando o seguinte produto: "sistema de vedação vertical leve em madeira - Tecverde" (BRASIL, 2015). Com estes novo documento atualizado, a produção e o financiamento de habitações em wood frame no PMCMV poderiam ser continuados para construção de novos empreendimentos.

Entretanto, desde meados de 2015, frente ao contexto econômico brasileiro, o PMCMV vem gradualmente enfraquecendo sua atuação. E, associado ao programa habitacional, o modelo de homologação e de financiamento de sistemas construtivos inovadores por agentes estatais pode sofrer alterações de acordo com os objetivos traçados no futuro para o setor da construção brasileira. Assim, as empresas interessadas neste modelo de construção de empreendimentos habitacionais utilizando sistemas considerados inovadores necessitariam alterar o foco da sua produção para manter seus negócios.

Por exemplo, em paralelo à produção mediante o PMCMV, no início de 2013, a empresa Tecverde já estabeleceu uma importante parceria para inserir o wood frame no mercado imobiliário, atuando em conjunto com uma empresa construtora de grande porte que opera nas diversas regiões brasileiras na produção de empreendimentos residenciais para a classe média. O resultado desta parceria é a construção do Projeto Village Supreme, localizado no município de Suzano, em São Paulo, com 86 sobrados com áreas de $120 \mathrm{~m}^{2}$ cada. São residências de maior padrão, constituídas por: lavabo, cozinha, sala de jantar, sala de estar, área de serviço interna e banheiro de serviço no pavimento térreo; 4 dormitórios, 02 banheiros e varanda no segundo pavimento. A comercialização e o financiamento destas habitações são realizados diretamente com a empresa encarregada, a qual possui relacionamentos firmados com instituições bancárias para este fim.

Também, como outra possiblidade no setor, para viabilizar construções em wood frame para prédios multifamiliares com até 4 pavimentos, a empresa Tecverde junto com uma equipe técnica do IPT e do IFBQ vem realizando, desde 2014, pesquisas e ensaios sobre os requisitos de desempenho para obter nova diretriz SINAT e homologação para este sistema 
inovador neste caso específico. E, no segundo semestre de 2016, essa nova ação em conjunto com a cadeia de produção do wood frame no país obteve seu primeiro resultado com a construção do edifício Vancouver, localizado em Araucária, no Paraná. O projeto deste edifício popular já estava contratado no PMCMV - Faixa 2 mediante a construtora CRM, a qual fez pareceria com a empresa Tecverde para adaptar o projeto e executar o empreendimento utilizando a tecnologia wood frame industrializada. Este edifício apresenta dois blocos com 3 pavimentos cada, com quatro apartamentos de $52 \mathrm{~m}^{2}$ por andar, totalizando 12 apartamentos por bloco.

Apesar destas vantagens obtidas com a homologação do wood frame no SINAT nos últimos anos, as empresas construtoras, em especial aquelas que não solicitaram a homologação de um DATec próprio, vêm sentindo a necessidade de ampliar a questão de regulamentação e de financiamento deste sistema além das possiblidades do SINAT, de forma que possam aplicar o sistema independente de licenciamento de um sistema homologado. Assim, entraram em contato com a Comissão Casa Inteligente para retomar as ações conjuntas deste grupo, conforme o item seguinte discorrerá.

\subsection{NOVAS ARTICULAÇÕES DA COMISSÃO CASA INTELIGENTE APÓS 2013}

Após a publicação do DATec no 20 em outubro de 2013, os integrantes da Comissão Casa Inteligente se reuniram em dezembro de 2013 para avaliar os resultados obtidos desde sua formação em 2009 (Figura 156) e decidir se os trabalhos do grupo deveriam ser continuados ou encerrados.

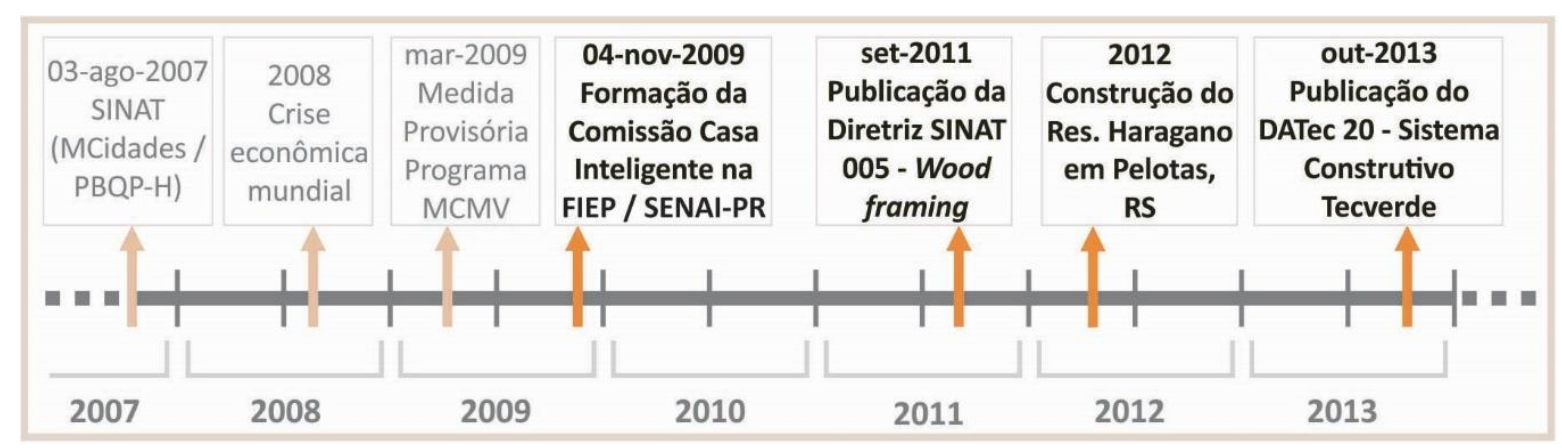

Figura 156: Principais resultados da Comissão Casa Inteligente entre 2009 e 2013

Fonte: autora 
Nesse momento, alguns construtores do estado de São Paulo argumentaram sobre suas dificuldades para produzir e disseminar o wood frame e, por isso, solicitaram o apoio da FIEP com o objetivo de promover o sistema nestes locais. Por exemplo, Marcelo Sacco, diretor da empresa construtora Tetti e da Associação da Indústria Madeireira de Capão Bonito, afirmou: "o papel da FIEP foi fundamental para o desenvolvimento desta tecnologia. Infelizmente em São Paulo não houve a mesma acolhida" (APRE, 2013). Assim, tendo em vista algumas barreiras que o setor continuava enfrentando, foi decidido manter as atividades da Comissão visando facilitar a implementação do wood frame no território brasileiro.

Para prosseguir nesta nova fase da Comissão Casa Inteligente, foram determinados três grupos de trabalho, sendo estes: político, cultural e técnico; coordenados por Marcelo Sacco, Paulo Pupo e Guilherme Stamato, respectivamente. Inicialmente, 32 pessoas representantes de empresas construtoras, produtores de insumos, sindicatos, instituições de ensino e de pesquisa se inscreveram nestes grupos (Tabela 20).

Tabela 20: Participantes da segunda fase de atividades da Comissão Casa Inteligente em 2014

\begin{tabular}{||c|c|c|c||}
\hline $\begin{array}{c}\text { Sindicatos, } \\
\text { Associações, } \\
\text { Federações }\end{array}$ & $\begin{array}{c}\text { Empresas } \\
\text { construtoras }\end{array}$ & $\begin{array}{c}\text { Empresas de } \\
\text { insumos e de } \\
\text { equipamentos }\end{array}$ & $\begin{array}{c}\text { Instituições de } \\
\text { ensino e pesquisa }\end{array}$ \\
\hline APRE & Tecverde & LP Brasil & SENAI-PR \\
\hline FIEP & Concretize & Lavrasul & UFPR \\
\hline SINDUSCON-PR & Caribea & Montana química & \\
\hline ABIMCI & Stamade & Klabin & \\
\hline SIMOV & Tetti & Grupo Lenz & \\
\hline Agência da Madeira & & Perenial woods & \\
\hline & & Saint Gobain - Isover & \\
\hline & & Eternit & \\
\hline & & Homag- Weinmann & \\
\hline
\end{tabular}

Fonte: Autora com base em dados da Comissão Casa Inteligente.

O grupo político foi estabelecido com o intuito de estreitar as relações dos produtores com agentes estatais para obter apoio para viabilizar este sistema construtivo, por exemplo, por facilitar a regulamentação desta tecnologia possibilitando seu uso em larga escala. Além do suporte político, o grupo buscou possibilidades de contribuição financeira de sindicatos e associações do setor madeireiro e da indústria da construção para realizar atualizações, como da diretriz SINAT no 005 vigente naquele momento, ou propor novas documentações normativas. Estes recursos também seriam importantes para promover a disseminação cultural do sistema, mediante diferentes meios de comunicação. 
Por sua vez, o grupo para disseminação cultural foi criado com o objetivo de dar continuidades às tarefas de comunicação social que incentivam o uso popular da madeira nas construções brasileiras, desmistificando preconceitos existentes sobre o material. Para isso, o grupo manteve a sua proposta estabelecida em 2009 com fins de divulgar o sistema e suas possibilidades em campanhas de marketing e em palestras ministradas em seminários e encontros técnicos, (Tabela 21). Inicialmente, o foco destas palestras se concentrava no tema da sustentabilidade. Mas, gradualmente, acrescentaram-se também aspectos sobre as vantagens do sistema, como preço e prazo como fatores determinantes para a seleção desta tecnologia construtiva.

Tabela 21: Palestras sobre o wood frame em eventos entre 2014 e 2016

\begin{tabular}{|c|c|c|c|}
\hline Evento & Data / Local & Palestrante (s) & Tema \\
\hline $\begin{array}{l}\text { Encontro Nacional para } \\
\text { Inovação da Construção } \\
\text { Civil - ENINC } 2014\end{array}$ & $\begin{array}{l}\text { 02-03 junho } 2014 \text { / } \\
\text { FIEP, Curitiba, PR }\end{array}$ & $\begin{array}{l}\text { Reinaldo Tockus (SEINAI / } \\
\text { FIEP) / Bertil Burian } \\
\text { (University of Applied } \\
\text { Forest Sciences } \\
\text { Rottemburg) }\end{array}$ & $\begin{array}{c}\text { Palestra magna - Wood } \\
\text { Frame }\end{array}$ \\
\hline $\begin{array}{l}\text { 2 Simpósio Madeira \& } \\
\text { Construção }\end{array}$ & $\begin{array}{l}\text { 28-29 agosto } 2014 \\
\text { / FIEP, Curitiba, PR }\end{array}$ & $\begin{array}{c}\text { Euclésio Finatti } \\
\text { (SINDUSCON-PR) / } \\
\text { José Márcio Fernandes } \\
\text { (Tecverde) }\end{array}$ & $\begin{array}{l}\text { Wood frame - sistema } \\
\text { construtivo em } \\
\text { estrutura de madeira + } \\
\text { Cases da empresa } \\
\text { Tecverde }\end{array}$ \\
\hline XV EBRAMEM 2016 & 09-11 março 2016 & Pedro Moreira (Tecverde) & $\begin{array}{l}\text { Pre-manufactured Light } \\
\text { Wood Frame House } \\
\text { Construction in Brazil }\end{array}$ \\
\hline $\begin{array}{l}\text { 3o Simpósio Madeira \& } \\
\text { Construção }\end{array}$ & $\begin{array}{l}\text { 13-14 agosto } 2015 \\
\text { / UFPR, Curitiba, PR }\end{array}$ & $\begin{array}{c}\text { Guilherme Stamato } \\
\text { (Stamade) }\end{array}$ & $\begin{array}{c}\text { Soluções de projetos de } \\
\text { estrutura e arquitetura } \\
\text { para Wood Frame }\end{array}$ \\
\hline $\begin{array}{l}\text { Centro Acadêmico de } \\
\text { Engenharia Civil da } \\
\text { PUCPR }\end{array}$ & $\begin{array}{l}02 \text { maio } 2016 \text { / } \\
\text { PUC, Curitiba, PR }\end{array}$ & $\begin{array}{l}\text { Euclésio Finatti } \\
\text { (SINDUSCON-PR) }\end{array}$ & $\begin{array}{l}\text { Wood Frame - Sistema } \\
\text { construtivo em } \\
\text { estrutura de madeira }\end{array}$ \\
\hline $\begin{array}{l}\text { I Encontro Regional de } \\
\text { Estudantes de } \\
\text { Engenharia Civil do Sul }\end{array}$ & $\begin{array}{l}\text { 11-13 agosto } 2016 \\
\text { / Balneário } \\
\text { Camboriú, SC }\end{array}$ & Pedro Moreira (Tecverde) & \\
\hline $\begin{array}{l}\text { Congresso Florestas } \\
\text { Online }\end{array}$ & 17-22 outubro 2016 & Paulo Pupo (ABIMCI) & $\begin{array}{c}\text { Wood frame: uma } \\
\text { oportunidade para o } \\
\text { Brasil e para a indústria } \\
\text { madeireira } \\
\end{array}$ \\
\hline $\begin{array}{l}\text { Lançamento Portal } \\
\text { Madeira e Construção }\end{array}$ & Março 2016 & $\begin{array}{c}\text { Caio Bonatto (Tecverde) / } \\
\text { Ricardo Russo (WWF) / } \\
\text { Paulo Pupo (ABIMCI) }\end{array}$ & $\begin{array}{l}\text { As construções do } \\
\text { futuro: mais } \\
\text { sustentáveis, mais } \\
\text { madeira }\end{array}$ \\
\hline $\begin{array}{l}\text { 1a Plataforma Liderança } \\
\text { Sustentável Setorial - } \\
\text { Indústria da Construção }\end{array}$ & Junho 2016 & Caio Bonatto (Tecverde) & $\begin{array}{l}\text { Construindo casas } \\
\text { como se fossem } \\
\text { automóveis }\end{array}$ \\
\hline
\end{tabular}


Destes eventos, destaca-se o 3ำ Simpósio Madeira \& Construção, realizado em agosto de 2015. Nas suas primeiras edições, este evento estava focado para a indústria do setor madeireiro. No entanto, a terceira edição partiu de uma iniciativa entre a APRE, a UFPR, UTFPR e empresas florestais dos estados do Paraná e de Santa Catarina. Assim, este evento foi programado para integrar universidade, indústria madeireira, construtores, produtores de insumos desta cadeia, agentes financiadores públicos, agentes estatais do setor da habitação popular e sindicatos e associações representantes destas áreas. Este público variado compareceu e participou de palestras, de minicursos práticos e de uma exposição de modelos reduzidos que demonstrou exemplares de construções contemporâneas em madeira. 0 resultado foi interessante, pois muitos dos envolvidos na cadeia de produção do wood frame no país puderam interagir sobre as possibilidades e os interesses de utilizar a madeira em construções mais sustentáveis.

Além das palestras em geral, também, matérias com dados técnicos sobre as principais construções e as atividades recentes desenvolvidas pelo setor vêm sendo publicadas em revistas com ampla divulgação nacional da área de conhecimento da construção civil (Tabela 22). Em paralelo, as emissoras abertas de televisão realizaram entrevistas e reportagens sobre a prática de construção industrializada em wood frame, em programas tais como: MAC Cultura, em maio de 2016, na emissora Band; Pequenas Empresas e Grandes Negócios, em setembro de 2016, na emissora Globo; Negócios da Terra, em outubro de 2016, na emissora SBT.

Tabela 22: Divulgação do wood frame em revistas do setor da construção entre 2013 e 2016

\begin{tabular}{|c|c|c|}
\hline Revista & Edição / Data & Título do artigo \\
\hline $\begin{array}{l}\text { Construção Mercado / } \\
\text { Pini }\end{array}$ & $\begin{array}{c}\text { Ed. } 146- \\
\text { Setembro/2013 }\end{array}$ & MCMV de madeira - Orçamento popular \\
\hline Pini web & Notícias - 08/04/2014 & $\begin{array}{l}\text { Tecverde constrói nova fábrica no Paraná e expande } \\
\text { atuação para São Paulo }\end{array}$ \\
\hline Téchne / Pini & Notícias - 26/03/2015 & $\begin{array}{c}\text { Minha Casa, Minha Vida entrega o primeiro residencial } \\
\text { no Paraná construído com wood frame }\end{array}$ \\
\hline $\begin{array}{l}\text { Construção Mercado / } \\
\text { Pini }\end{array}$ & Ed. 167 - Junho /2015 & $\begin{array}{l}\text { Projeto com } 66 \text { casas em wood frame é construído em } \\
\text { seis meses e ganha ar de alvenaria }\end{array}$ \\
\hline $\begin{array}{l}\text { Construção Mercado / } \\
\text { Pini }\end{array}$ & Ed. 183 - Outubro/2016 & $\begin{array}{l}\text { Sistema wood frame se prepara para avançar no } \\
\text { mercado brasileiro }\end{array}$ \\
\hline
\end{tabular}

Fonte: elaborado pela autora com base em dados coletados na PINI, 2016. 
Além destas publicações mais tradicionais, as empresas e associações envolvidas neste processo de difusão atual do wood frame no Brasil estão divulgando informações importantes em suas redes sociais. Este fato se mostra pertinente, pois permite que o conhecimento popular sobre o sistema seja amplamente divulgado. E, por meio destas mídias, os seguidores, ou seja, o público em geral realiza comentários e interage diretamente com estes produtores do wood frame no país. Por exemplo, atualmente, após ver fotos e vídeos publicados pelas empresas sobre suas construções com esta tecnologia, comentários como estes são frequentes:

\footnotetext{
"Eu já decidi... meu projeto será feito com está tecnologia!" - Comentário realizado por seguidor no Facebook em 06 de agosto de 2015.

"Meu sonho é fazer um projeto aqui na minha cidade. Garuva [Santa Catarina] não tem nada parecido, tecnologia, inovação, sustentabilidade e economia. Espero um dia poder contar com um projeto desses" Comentário realizado por seguidor no Facebook em 26 de setembro de 2016.
}

Além da ênfase à comunicação, o grupo cultural da Comissão Casa Inteligente também argumentou sobre a necessidade de retomar outro de seus objetivos iniciais que visavam organizar cursos e treinamentos para dar capacitação profissional sobre o sistema wood frame. Como os cursos formação superior, técnica ou profissionalizante no Brasil não contemplam este sistema, portanto, o grupo salientou que é necessário dar essa base técnica teórica e prática para os possíveis trabalhadores envolvidos. Entretanto, neste período recente, observou-se que pouco se divulgou a respeito de cursos ofertados ao público de engenharia, arquitetura ou construção civil. E, sobre os treinamentos para mão-de-obra, notou-se que estes, em geral, eram específicos e direcionados para as empresas. Por exemplo, conforme publicado pela FIEP (2015), em 2014, um grupo de técnicos vieram da Alemanha para ministrar um curso para professores do SENAI-PR, para que esta instituição auxiliasse na capacitação dos trabalhadores das empresas construtoras brasileiras. Assim, os trabalhadores de algumas empresas recebiam qualificação profissional.

Ainda, outra iniciativa da FIEP, em parceria com SENAI-PR, ABIMCI e Ministério das Finanças de Baden-Württemberg, foi realizar uma nova viagem técnica para a Alemanha, a qual foi denominada "Missão Casa Sustentável". Dentre os participantes desta viagem realizada em maio de 2015 estavam empresários dos estados de São Paulo, Paraná, Santa Catarina e Rio Grande do Sul, representando vários segmentos do setor madeireiro, tais como 
silvicultura, extração florestal, madeira serrada, compensados, painéis, portas, pisos e empresas fabricantes de edificações em wood frame (CeluloseOnline, 2015).

Nesta viagem, parcerias já existentes entre o governo de Baden-Württemberg e o SENAI-PR foram reafirmadas para promover a cooperação econômica e técnica entre os mesmos, incluindo a temática da construção em madeira no Brasil. E, conforme o relato de um dos participantes desta missão técnica, além de visitar duas fábricas alemãs com diferentes objetivos de produção e de grau de industrialização, tais como a Rikken e a WeberHaus, o grupo visitou uma escola de formação de mão-de-obra, onde os trabalhadores eram treinados de forma prática para aplicação do estuque em acabamentos de painéis de parede. Assim, os visitantes brasileiros observaram a importância da cultura de qualificação da mão-de-obra desenvolvida neste país. Esta cultura também deve ser adotada para garantir a qualidade deste sistema inovador conforme as novas práticas brasileiras.

Por fim, o terceiro grupo da Comissão Casa Inteligente estava dedicado às questões técnicas, ou seja, ações relacionadas à atualização da Diretriz SINAT no 005 vigente desde 2011 e ao desenvolvimento de uma norma técnica para o sistema wood frame no país. Assim, em julho de 2015, foi realizada nova reunião para reafirmar estas metas, onde estavam presentes 40 participantes dos estados de São Paulo, Paraná e Santa Catarina, contemplando 08 sindicatos, associações e federações da indústria madeireira e do setor da construção, 03 empresas construtoras e 02 empresas de insumos para esta construção (SINDUSCON-PR, 2015) (Tabela 23).

Tabela 23: Participantes da reunião da Comissão Casa Inteligente em julho de 2015

\begin{tabular}{|c|c|c|c||}
\hline $\begin{array}{c}\text { Sindicatos, } \\
\text { Associações, } \\
\text { Federações }\end{array}$ & $\begin{array}{c}\text { Empresas } \\
\text { construtoras }\end{array}$ & $\begin{array}{c}\text { Empresas de } \\
\text { insumos e de } \\
\text { equipamentos }\end{array}$ & $\begin{array}{c}\text { Instituições de } \\
\text { ensino e pesquisa }\end{array}$ \\
\hline \hline APRE & Tecverde & Grupo Lenz & $\mathrm{X}$ \\
\hline FIEP & Stamade & Immergrün & \\
\hline SINDUSCON-PR & Embafort & & \\
\hline ABIMCI & Tetti & & \\
\hline SIMOV & & & \\
\hline SINDIMAD-SP & & & \\
\hline CREA & & & \\
\hline IEP & & & \\
\hline
\end{tabular}

Fonte: SINDUSCON-PR (2015). 
Nesta reunião, foi instituído um grupo de trabalho que daria prosseguimento na atualização da Diretriz SINAT do wood frame. E, como resultado das ações deste grupo, após processo de contratação para efetuar atualizações nas recomendações técnicas do sistema construtivo, a Diretriz SINAT no 005 - Revisão 1 para sistemas leves tipo "Light Wood Framing" foi oficialmente publicada pelo MCidades em junho de 2016 (BRASIL, 2016).

Outro objetivo estabelecido por este grupo era criar uma proposta de norma técnica para o wood frame, para "garantir um mesmo padrão de segurança a qualquer obra que utilize o sistema" (SINDUSCON-PR, 2015). Esta meta visa possibilitar a ampliação da aplicação deste sistema inovador para obras maiores, indo além da difusão recente focada nas habitações populares para famílias com menor renda.

Portanto, em meados dos anos de 2015 e 2016, este grupo da Comissão Casa Inteligente estava elaborando um texto-base como modelo inicial para esta norma técnica. $\mathrm{E}$, com isto, encaminhou um pedido de formalização deste processo mediante a ABNT. Com base neste pedido, em julho de 2016, a ABNT instalou uma comissão de estudos com objetivo de criar esta norma técnica específica para o sistema construtivo wood frame no Brasil.

Desde então, esta comissão de estudos da ABNT é coordenada por Euclésio Finatti, também coordenador da Comissão Casa Inteligente. Seus integrantes vêm se reunindo mensalmente para estabelecer, inicialmente, a terminologia e o escopo que esta norma deve abranger. E, na sequência, gradualmente, serão estabelecidos os critérios técnicos para o sistema e seus componentes constituintes. Para isso, a comissão de estudos buscou dividir seus integrantes em subgrupos de trabalho, sendo três os principais temas: projeto, execução e desempenho.

Dentre os agentes participantes deste processo estão associações da indústria madeireira e do setor da construção civil, empresas construtoras, empresas produtoras e fornecedoras de insumos e instituições de ensino e pesquisa. Ter esta multidisciplinaridade de integrantes neste processo pode ser um fator importante, pois os indivíduos agregam ao grupo seus conhecimentos e sua experiências sobre o sistema em questão. Sobre isso, o superintendente do Comitê Brasileiro da Construção Civil, Salavador Benevides, comenta: "O setor é muito participativo e isso é um ponto bastante positivo, ainda mais com lideranças importantes. A comissão em Curitiba é interessante, porque é aqui que está a raiz deste assunto" (PORTAL MADEIRA E CONSTRUÇÃO, 2016). 
Com isso, novamente, observa-se a importância da conjuntura da Comissão Casa Inteligente enquanto principal agente deste processo recente de implementação e de difusão do sistema wood frame no contexto brasileiro. Empresários com esfoços isolados talvez não conseguem obter resultados efetivos na promoção de um sistema inovador. Entretanto, os esforços conjuntos integrando os diversos agentes diretos e indiretos da cadeia de produção, incluindo construtores, fornecedores, associações representativas, instituições financeiras, reguladores técnicos e instituições de ensino e de pesquisa, são um facilitador nesta promoção de um sistema que utiliza madeira na sua constituição. Assim, outro resultado positivo da Comissão Casa Inteligente é o processo recente que tramita para a elaboração da norma técnica do wood frame mediante a ABNT.

Obter a aprovação desta norma técnica parece o começo de um desfecho para a difusão ampla deste sistema inovador. Pois, se regularizado, todas as futuras construções com o sistema wood frame deverão respeitar as regras estabelecidas nesta norma, com um responsável técnico pela obra, como usualmente ocorre para os demais sistemas já normalizados.

Ainda que a homologação do SINAT seja uma possiblidade promissora para estabelecer diretrizes e referências técnicas para o sistema inovador, este processo está restrito ao proponente do sistema. Este fato parece limitar a difusão das construções mediante este proponente. Assim, empresas ou responsáveis técnicos não interessados em participar deste negócio em rede, ficam sem muitas opções de financiamento para suas construções.

Portanto, a aprovação de uma norma pela ABNT possibilita ampliar a utilização do sistema wood frame com determinados padrões de segurança, pois este documento parece ser um critério mais acessível ao público técnico em geral, quando comparado à um DATec que é de responsabilidade de apenas um proponente. Mas, isto não significa que a publicação da norma por si só será o desfecho para uma difusão garantida destas construções. Entretanto, esta norma estabelecerá o início de um novo processo de produção, onde a cadeia deve estar novamente integrada e os técnicos e os trabalhadores devem adquirir e aplicar o conhecimento sobre o sistema para garantir a qualidade das edificações. Também, questões culturais referentes à utilização da madeira e seus produtos derivados devem ser trabalhadas para popularizar o sistema. Assim, conclui-se que, para efetivar a utilização do wood frame no Brasil, é necessário manter as ações conjuntas do setor, tal como a Comissão Casa Inteligente vem desempenhando nestes últimos anos. 


\section{CONCLUSÕES}

Esta pesquisa propôs compreender como ocorreu o processo de inovação do sistema construtivo wood frame inserido em programa habitacional financiado por agentes públicos desde meados de 2010. O que motivou a escolha deste tema foi a transformação tecnológica em um setor que, desde a metade do século XX, não apresentava desenvolvimento nos seus elementos, sistemas e métodos construtivos aplicados popularmente. Pois, historicamente, as construções em madeira enfrentam barreiras como o preconceito e o receio por parte da população brasileira e de agentes produtivos e financeiros em adotar este material para as habitações. Mas, apesar dessas oposições, em 2012, o sistema inovador wood frame foi introduzido na produção de habitação social mediante o PMCMV. Esta transição tecnológica no cenário do setor levantou algumas questões sobre este processo de inovação.

Como visto neste trabalho, o sistema wood frame não é de origem ou de tradição brasileira. Essa tecnologia construtiva vem sendo aplicada em países como Estados Unidos, Canadá, Japão, Austrália, Chile, Alemanha, países nórdicos, entre outros. Assim, assume-se que a aplicação desse sistema no Brasil é, de certa forma, importada dessas experiências externas, espelhando-se nas possibilidades e nas vantagens obtidas nesses diferentes países. Mas, trazer uma tecnologia já consolidada em outros locais não é indicativo seguro que que a mesma será bem sucedida em um contexto diferente.

De forma generalizada, os processos de produção de determinada tecnologia diferenciam entre contextos. As seletividades das tecnologias são específicas de uma conjuntura. Assim, suas implementações em cenários distintos não podem ser exatamente equiparadas entre si. Tampouco existe um único modelo a ser seguido para que uma tecnologia construtiva seja bem ou mal sucedida em qualquer local que se tente implementála como inovação. Entretanto, analisar exemplos externos nos quais a mesma tecnologia em questão está inserida pode fornecer evidências de ações para um novo processo de inovação.

No caso do sistema wood frame, considerou-se importante analisar a perspectiva de desenvolvimento dos sistemas leves entramados em madeira no contexto norte-americano. Nesta análise, foram observados alguns fatores essenciais para a efetivação desta tecnologia naquele território. Entre estes, destacou-se a importância do conhecimento acumulado que 
os imigrantes e colonizadores americanos tinham sobre as práticas das construções típicas em madeira das suas origens na Europa, como os tradicionais enxaiméis.

Com esta base histórica, os construtores norte-americanos, gradualmente, adaptaram e aprimoraram esta tecnologia construtiva conforme seus contextos sociais, econômicos e políticos. Por exemplo, a madeira que era trabalhada artesanal e manualmente passou para os processos mecanizados de serrarias, com maquinários específicos para o beneficiamento das peças. Também, peças longas e de grande seção foram substituídas por peças curtas e esbeltas. Ainda, as ligações entre as peças de madeira, as quais eram entalhadas e encaixadas, foram simplificadas com a adoção de pregos manufaturados.

Em princípio, estas transformações tecnológicas foram motivadas pelo desenvolvimento industrial focado no setor agrícola que necessitava acelerar o processamento da sua matéria-prima. Os maquinários mecanizados desenvolvidos para estas funções também contemplaram o setor das serrarias, o qual se destacou na produtividade e contribuiu diretamente na revolução da construção civil americana.

Em paralelo, a disponibilidade de material com preços acessíveis, tais como a madeira processada mecanicamente e o prego manufaturado, foi essencial para a difusão desta tecnologia construtiva naquele período de colonização das regiões central e oeste do país, assim como de expansão urbana na cidade de Chicago no início do século XX.

Além do apelo do preço, kits com componentes pré-cortados em conformidade com projetos arquitetônicos padronizados foram desenvolvidos por empresas e serrarias para facilitar a aquisição e a aplicação popular das construções leves em madeira sem a necessidade de contratação de um construtor com experiência e habilidade específicas. Complementando, revistas de projetos e de carpintaria divulgavam tais possibilidades de construção própria utilizando as técnicas dos sistemas light wood framing. Assim, a difusão desta tecnologia foi se consolidando fortemente no território norte-americano.

Portanto, sobre este contexto específico norte-americano de transição entre os séculos XIX e XX, conclui-se que as principais transformações técnicas visaram a simplificação do processo de trabalho, substituindo peças estruturais pesadas por leves e processos manuais por mecanizados. Estas mudanças reduziram o tempo de produção, assim como a quantidade de mão-de-obra necessária, afetando diretamente no custo final deste processo. Assim, esta alteração dos modos de produção nas construções em madeira estava vinculada 
ao esforço despendido e às habilidades requeridas dos trabalhadores, e, consequentemente, em como estes afetariam o tempo de trabalho.

Também, a simplificação da execução das construções implicava na dispensa de trabalhadores experientes e especializados como carpinteiros que possuíam o saber-fazer da totalidade do processo de produção. Os sistemas leves em madeira se consolidaram como uma tecnologia que qualquer trabalhador poderia executar. Isso foi importante para a apropriação popular e a difusão em grande escala do sistema naquele primeiro momento.

Entretanto, ainda neste primeiro período de difusão, nas primeiras décadas do século $\mathrm{XX}$, as práticas aplicadas em todo o território norte-americano diferenciavam em diversos quesitos, incluindo variações nas seções das peças estruturais dos entramados das paredes das edificações. Assim, agentes interessados em qualificar e garantir a continuidade do sistema wood frame naqueles locais se uniram em ações para padronizar e normatizar seus componentes constituintes e seus métodos de construção. Dentre os agentes incluídos neste processo estavam: instituições de normatização, departamentos governamentais, agentes imobiliários, empresas fornecedoras de matéria-prima, empresas produtoras de insumos, agentes imobiliários, comitês e associações representativas dos setores habitacional e florestal.

Como resultado desta conjuntura, foram publicados documentos para a regulamentação das construções e para a divulgação da tecnologia construtiva, visando tanto construtores quanto o público em geral. Também, as promoções mediante propagandas reforçaram a questão da confiabilidade da madeira na construção no meio popular. E, desde então, livros, catálogos e manuais continuam embasando a apropriação do wood frame.

Portanto, tal engajamento de agentes de diferentes setores, em especial os pertencentes à esfera produtiva, foram essenciais para garantir a difusão e a consolidação do sistema wood frame naquele mercado. Estas ações, além de representar o setor envolvido, vêm garantindo um padrão básico que define requisitos de qualidade para estas edificações. Com base nestes padrões, novos aprimoramentos estão sendo realizados, incluindo modificações em dimensões de elementos constituintes, inserção de novos componentes alternativos aos originais, adequações nos métodos de produção na fábrica e no canteiro.

Além dos Estados Unidos, outros países apresentam seus próprios processos de produção do wood frame, com difusão em dimensões distintas, variando conforme seus contextos social, cultural, político e econômico. A análise específica destes outros casos 
também pode auxiliar na identificação de fatores facilitadores e de possíveis barreiras nestes processos. Apesar de contextos distintos, estas informações podem ser úteis na concepção para a implementação do sistema construtivo inovador.

Entretanto, esta visão sistêmica raramente é considerada no setor da construção civil em geral. Por exemplo, antes das ações para implementar o sistema wood frame no Brasil no ano de 2010, seria interessante observar as experiências antecessoras com o sistema construtivo em questão ou outros similares. Porém, há pouca divulgação deste contexto histórico das construções leves em madeira no território nacional.

Conforme algumas publicações, constatou-se que o primeiro período de produção com wood frame no Brasil ocorreu em meados da década de 1980. Neste período, as empresas Battistella, Epotec e Madezatti construíram habitações com entramados leves em madeira fechados externamente com chapas derivadas de madeira. Posteriormente, no ano 2000, a empresa Malacon também utilizou o sistema com composições mais aproximadas dos modelos das construções norte-americanas.

Neste mesmo período, dataram os primeiros estudos acadêmicos sobre este sistema leve entramado em madeira. Estas publicações, em geral, elaboravam propostas com base nos manuais técnicos norte-americanos e adaptações na composição do sistema conforme a disponibilidade de insumos e de maquinários para produção no mercado nacional. Algumas dessas propostas foram executadas em parcerias com empresas construtoras, resultando na construção de protótipos de edificações. Enfim, estes estudos salientavam as possibilidades e as vantagens deste sistema para a produção de habitações no país.

Entretanto, observou-se que os relatos e as análises sobre as construções em wood frame já realizadas pelo mercado brasileiro foram pontuais. Não houve um detalhamento técnico destas construções, nem uma análise sistêmica apontando os agentes e suas ações neste primeiro momento de produção. Algumas dessas informações foram generalizadas em catálogos do IPT e em artigos publicados em revistas de engenharia e arquitetura. Resgatar esta análise histórica seria importante para compreender, por exemplo, os motivos pelos quais aquelas empresas pararam suas produções e esta primeira difusão do sistema no Brasil não se efetivou. Estes fatores poderiam dar embasamento para futuras produções com este sistema ou similares em madeira no país. Mas, apesar de algumas pesquisas acadêmicas incentivarem a aplicação do wood frame no Brasil, na década de 2000, este sistema em 
madeira continuava sendo desconhecido tanto na comunidade técnica quanto na população em geral.

Em contrapartida, no início da década de 2010, foi iniciado um segundo momento de produção do sistema wood frame no Brasil. Este período foi marcado por uma transição no cenário das construções em madeira no país. Assim, com base neste fenômeno, esta tese procurou investigar os seguintes aspectos: o que motivou, quem participou, quais estratégias estabeleceram, como ocorreu os procedimentos técnicos e quais resultados foram alcançados. Esta análise foi fundamentada em uma abordagem sistêmica derivada da teoria de desenvolvimento econômico com intuito de compreender os agentes e os contextos que influenciaram as mudanças produtivas do setor de construções em madeira ao efetivar a produção do sistema construtivo wood frame para habitação no país.

Após analisar os dados referentes a este cenário, concluiu-se que a principal motivação para tal transformação tecnológica no setor de construção em madeira brasileiro foi o comportamento econômico naquele período de 2008. Aliados à esta determinação econômica, outros aspectos também foram influentes para iniciar este processo de inovação, tais como os interesses das empresas produtoras de insumos de base florestal e das empresas construtoras e os incentivos das políticas estatais promovidos naquele mesmo momento para o setor da construção civil brasileira. Estas motivações elencadas estão brevemente descritas a seguir.

Conjuntura econômica: Conforme observado, no terceiro trimestre de 2008, a indústria de base florestal brasileira começou a sentir os efeitos da crise econômica mundial. Com a rápida depreciação da taxa de câmbio brasileira e com as reduções nos créditos, os principais segmentos do setor florestal que tinham suas atividades voltadas para a exportação foram afetados. Com isso, o consumo de produtos foi reduzido, ocasionando a diminuição nos preços dos commodities. Assim, as produções, em geral, foram reduzidas e isso afetou diretamente no consumo da matéria-prima - toras de madeira. Em especial, os segmentos de serrados, compensados e PMVA apresentaram uma queda drástica no consumo de toras de pinus, deixando as florestas cultivadas e suas toras de madeira em estoque.

Interesse das empresas produtoras de insumos de base florestal: Com o volume de toras ocioso em estoque, as empresas florestais tinham interesse de reorientar suas produções ao mercado nacional. Nesse sentido, o setor da construção parecia oportuno naquele momento, com o lançamento do PMCMV no início de 2009 que iria aumentar a 
produção de habitações e consequentemente o consumo deste setor. Além dos produtores de madeira serrada, outros componentes industrializados produzidos no país também poderiam ser aplicados na construção nacional, como painéis derivados de madeira - OSB e compensado - e outros PMVA, como portas e janelas.

Interesse das empresas construtoras: Naquele período, algumas empresas construtoras de pequeno porte se interessaram em investir no desenvolvimento tecnológico das construções em madeira no Brasil. E, com isso, procuraram sindicatos e associações de representação do setor da construção civil e do setor florestal para aliar suas necessidades de produção junto aos demais integrantes da cadeia de construção em madeira.

Incentivos e políticas estatais: O PMCMV de âmbito nacional, além de estimular o aumento da demanda de habitações, também possibilitava aplicar componentes, elementos e sistemas construtivos inovadores mediante o programa SINAT do PBQP-H. O SINAT visava fornecer a estes produtos inovadores, ou seja, aqueles sem normas técnicas regulamentadas pela $A B N T$, a possibilidade de avaliação técnica e de publicação de diretrizes e documentos provisórios atestando os requisitos de desempenho.

Assim, no ano de 2009, a fim de promover a aplicação do sistema inovador wood frame no âmbito nacional, agentes do setor produtivo, de instituições de ensino e pesquisa e do Estado se organizaram na Comissão Casa Inteligente oficializada como câmara setorial integrante dos Conselhos Setoriais da Construção Civil e da Indústria de Base Florestal da FIEP.

Do setor produtivo, participaram empresas construtoras, empresas produtoras de insumos, empresas fornecedoras de equipamentos, consultores técnicos e entidades representativas, tais como associações, federações e sindicatos do setor madeireiro e da construção civil. Portanto, os possíveis integrantes da cadeia de produção do wood frame se reuniram para viabilizar o wood frame no cenário brasileiro.

Das instituições de pesquisa e ensino, além das universidades com conhecimento acumulado sobre o sistema, estavam presentes o IPT, enquanto ITA credenciada no SINAT/PBQP-H, e o SENAI-PR, parceiro do Ministério das Finanças e Economia do Estado Baden-Württemberg, estado alemão com tradição na construção em madeira.

Por fim, dentre os agentes estatais estavam a CEF, enquanto agente financiador do PMCMV, e o CREA, órgão regulador das atividades relacionadas à construção.

Estes integrantes da Comissão Casa Inteligente estabeleceram estratégias para esse processo de inovação. Após oficializar o grupo inserido na FIEP, eles trabalharam em quatro 
eixos temáticos: marketing, qualificação profissional, matéria-prima e normatização e financiamento. Os objetivos dessas ações estavam centrados na definição de diretrizes de desempenho para o sistema wood frame, a fim de obter sua homologação no SINAT e possibilitar seu financiamento pela CEF no PMCMV.

Para a publicação da Diretriz SINAT, foi seguido os encaminhamentos estabelecidos no SINAT no âmbito do PBQP-H e MCidades. Mas, antes, os integrantes da Comissão Casa Inteligente estabeleceram entre si qual seria sua demanda neste processo, optando por habitações térreas e sobrados, isolados e geminados. Assim, um grupo desta Comissão, que participava do eixo temático sobre normatização, tomou frente nestes procedimentos e elaborou um primeiro esboço de documento com as diretrizes para o sistema wood frame. $\mathrm{Na}$ sequência, contrataram o IPT, como ITA credenciada ao SINAT, para formalizar este processo. O IPT apresentou a minuta da Diretriz ao comitê técnico do SINAT e, como resultado, em 2011, a Diretriz SINAT no 005 para "Sistema leves tipo Light Wood framing" foi publicada oficialmente pelo MCidades.

Na sequência, para possibilitar o financiamento deste sistema pela CEF, a empresa Tecverde iniciou os procedimentos para a publicação do DATec. Assim, elaborou e determinou os detalhes do sistema construtivo proposto denominado "Tecverde - Sistema leve em madeira", destinado para unidades unifamiliares térreas isoladas ou geminadas. Para homologar este sistema, a empresa contratou ITAs, que seguindo as referências da Diretriz SINAT no 005 para o wood frame, realizaram as seguintes avaliações técnicas principais: desempenho estrutural, estanqueidade à água, desempenho térmico, desempenho acústico, durabilidade e manutenabilidade, segurança ao fogo. Com base nos dados técnicos apresentados pelas instituições em cada ensaio, o Instituto Falcão Bauer de Qualidade (IFBQ) foi o responsável para elaborar o Relatório Técnico de Avaliação (RTA) para este sistema construtivo. Este RTA foi analisado pelo comitê técnico e aprovado e publicado em outubro de 2013 no denominado DATec no 20 - Tecverde. Assim, esta empresa se tornou a detentora deste sistema homologado.

Desde a publicação desta primeira Diretriz SINAT no 005, observou-se que a difusão do wood frame vem ocorrendo gradualmente no Brasil. Enquanto resultado deste processo de produção, inicialmente, destacou-se a construção do Residencial Haragano, o primeiro inserido no PMCMV financiado pela CEF. 
Para a construção do Residencial Haragano, a empresa Roberto Ferreira, em paralelo às ações da Comissão Casa Inteligente, fez parceria com a UFPel com interesse de utilizar o sistema em madeira denominado Morar Melhor. Este sistema construtivo havia sido proposto e analisado pela UFPel e homologado junto à CEF para construção de habitações sociais. Assim, mediante esta parceria, a empresa Roberto Ferreira apresentou ao GIDUR/PO o projeto do empreendimento do Haragano adotando o sistema homologado Morar Melhor.

Entretanto, exigências da CEF e necessidades da empresa implicaram em alterações na constituição deste sistema construtivo, o qual passou a ser denominado Morar Melhor Aprimorado. Adotando essencialmente as técnicas do wood frame, os subsistemas de parede e de piso das residências foram propostos em conformidade com a Diretriz SINAT no 005 já publicada em 2011.

Ainda, com objetivo de otimizar os trabalhos na execução deste empreendimento, a empresa Roberto Ferreira optou por produzir os componentes de parede e de piso em fábrica própria no município de Pelotas. Para este método, a empresa contratou a consultoria técnica da empresa Tecverde, a qual já estava produzindo componentes do wood frame em sua fábrica no Paraná. Por fim, após etapas realizadas na fábrica e no canteiro, o residencial Haragano foi construído nos anos de 2012 e 2013.

Após o Residencial Haragano, outros empreendimentos habitacionais foram construídos com o sistema wood frame no PMCMV. Assim, entre os anos de 2012 e 2016, foram contabilizadas um total de 487 UHs na Faixa 1 e 618 UHs na Faixa 2, localizados nas regiões Sul, Sudeste e Centro-Oeste do país. Com exceção do residencial Haragano que utilizou o sistema Morar Melhor Aprimorado, os demais empreendimentos utilizaram o sistema Tecverde homologado no DATec nํ 20. Desta forma, as empresas construtoras responsáveis por estes empreendimentos do PMCMV realizaram parcerias com a empresa Tecverde enquanto detentora do sistema wood frame homologado pelo SINAT.

Como observado nesse processo de inovação tecnológica, a empresa Tecverde se destacou na produção de habitação social aplicando sua proposta homologada de sistema e métodos construtivos para o wood frame. Apesar das barreiras tradicionais para produzir com sistemas estruturados em madeira no Brasil, esta empresa assumiu esta "função especial". Pois, em uma conjuntura econômica propícia, escolheu sair da rotina de produção tradicional da indústria de construção brasileira e se propôs a trabalhar com uma tecnologia não disseminada nacionalmente. 
Entretanto, a empresa não estava sozinha nesta trajetória tecnológica. Pois, para realizar esta função, era necessário possuir os meios de produção. E como empresa recémformada, a Tecverde não possuía esses meios e precisava adquiri-los. Para isso, recorreu à créditos e financiamentos, como por exemplo em editais e programas específicos para empresas com potenciais de crescimento no mercado nacional.

Também, foi requisito essencial, a integração da empresa com os demais agentes do setor produtivo, das instituições de ensino e pesquisa e do Estado, na formada Comissão Casa Inteligente. Essa união de interesses para estabelecer estratégias em comum levou aos resultados apresentados nesta tese, como a produção de habitação no PMCMV. Também, mediante esta Comissão, a cadeia de construção do wood frame no Brasil vem se firmando e agregando novos produtores e fornecedores interessados. Portanto, esse sistema tríplice vem sendo decisivo para esta disseminação do wood frame no Brasil desde meados de 2010.

Ainda, novos construtores observaram as possibilidades dessa inovação e também investem seus recursos para produzir edificações com o wood frame. Mas, como não possuem um sistema homologado no SINAT, enfrentam desafios e limitações para financiar seus produtos. Acreditam que a aprovação de uma norma técnica brasileira mediante a ABNT seria um modelo mais amplo para a disseminação das construções, mantendo a padronização dos componentes constituintes e os requisitos de desempenho. Portanto, os interessados do setor produtivo se uniram novamente na Comissão Casa Inteligente com os agentes das outras esferas para estabelecer novas estratégias para garantir o desenvolvimento e a difusão do wood frame no Brasil.

Outra necessidade elencada pelo setor com objetivo de ampliar e facilitar a difusão deste sistema foi a elaboração de manuais técnicos padronizando suas principais técnicas e garantindo uma apropriação mais popular deste sistema atrelada à uma uniformização visando a qualidade das edificações. Entretanto, uma dificuldade que ainda se observa neste sentido é a variedade de composições que os construtores vêm aplicando. Notou-se que a constituição do sistema wood frame não é única entre as empresas brasileiras. Então, talvez seja necessário realizar uma análise mais profunda sobre as diferentes possiblidades destas constituições conforme cada contexto do país e conforme as disponibilidades de insumos na cadeia produtiva. Também, com o tempo, as análises de pós-ocupação poderão auxiliar para obter retornos referentes às questões de desempenho e de qualidade. Assim, será necessário 
realizar aprimoramentos nos elementos constituintes, tal como vêm acontecendo gradualmente.

Por fim, em geral, sobre este processo de produção, notou-se que as ações conjuntas, em especial as da Comissão Casa Inteligente, vêm se mostrado como fator facilitador para o desenvolvimento tecnológico do setor de construções em madeira no Brasil. No entanto, este processo de inovação está sujeito aos contextos e ambientes externos como os fatores políticos, econômicos e sociais. Assim, esta análise, que apresentou dados e informações que estavam ocorrendo no mesmo momento da pesquisa e, portanto, em transições constantes, precisa ser revisada posteriormente com o surgimento de novas comprovações sobre estas relações sistêmicas e estas determinações externas.

\section{CONSIDERAÇÕES FINAIS}

Em um cenário onde as tecnologias construtivas já estão estabelecidas historicamente parece difícil ocorrer mudanças técnicas significativas com a introdução de um novo sistema ou método de construção. Como no caso específico do Brasil, a tradição de construir no canteiro utilizando alvenaria e concreto armado parece impedir a apropriação popular de outras técnicas. No entanto, o processo de seleção de uma tecnologia vai além da questão cultural. Também, não basta a técnica em si, já que a tecnologia abrange as necessidades indicadas por um aparato produtivo. Ou seja, os paradigmas tecnológicos são "puxados" pela força desse aparato. Assim, não é apenas um gargalo no mercado ou na cadeia produtiva que diz o que é necessário inovar. Nem o consumidor tem a autoridade ou capacidade própria de ditar essa demanda, já que esta lhe é imposta pelo sistema. Portanto, a implementação de uma determinada inovação tecnológica na construção segue a lógica do sistema econômico e os fatores institucionais, como os interesses dos diversos agentes envolvidos.

Conforme pôde ser observado no caso específico da construção brasileira em wood frame desde 2010, as mudanças técnicas têm uma relação intrínseca com o sistema econômico. Conforme as teorias econômicas, tais mudanças no processo produtivo são fundamentais para o desenvolvimento econômico. Assim, no momento da crise econômica de 2008, os agentes da cadeia produtiva florestal se uniram para rever suas prioridades, pensando em se restabelecer mediante um novo mercado nacional - o mercado da construção civil. 
Em geral, os períodos de crise econômica são mais propícios para a efetivação de inovações, pois a oferta de bens e serviços é mais abundante e, por isso, seus custos são menores para a produção. Portanto, além de motivar as empresas produtoras de insumos, aquele momento também contribuiu para empresas construtoras interessadas em implementar novas tecnologias com estes insumos, tal como o wood frame.

Entretanto, nem todas empresas interessadas em adotar uma inovação tecnológica na construção civil conseguem cumprir esse papel. Pois, não é fácil mudar um ciclo rotineiro de produção, ainda mais se a empresa já está estabelecida com seus meios voltados para um produto e um método específico difundido e aceito no mercado. Mudar essa rotina de produção e trocar a constância pela dúvida de uma inovação não é uma tarefa fácil, e, por isso, nem todos assumem esta "função especial". Dentre vários fatores, esta função inclui ter um novo conhecimento técnico específico, estabelecer novas relações com a cadeia de produção em questão, adquirir equipamentos e maquinários novos, treinar a mão-de-obra. Tudo isso envolve ter capital para efetivar as mudanças no processo de produção.

No caso do wood frame, foi observado que grande parte das empresas construtoras que decidiram produzir com este sistema inovador eram caracterizadas por serem novas no mercado ou já tinham alguma relação com outros sistemas construtivos em madeira. Pois, além de um sistema com técnicas diferentes das tradicionais já aplicadas no Brasil, os métodos de construção do wood frame também são distintos, podendo ocorrer na fábrica e no canteiro. Assim, aquelas empresas que optaram por produzir com métodos de construção mais industrializados, necessitaram adquirir novos meios de produção para suas fábricas, muitos destes importados ou projetados especificamente para produção única no país. Para estas realizações, era necessário ter um capital ou obter um crédito para montar a linha de produção. Enfim, isto requeria determinado esforço das empresas novas, que só teriam lucro após um certo tempo de produção, sendo que os primeiros retornos seriam destinados para liquidar estes investimentos iniciais. Por isso, compreende-se o motivo pelo qual muitas empresas já consolidadas não desejam alterar seus processos de produção com sistemas e métodos inovadores e industrializados.

Além do setor produtivo, outros agentes estão presentes nos processos de inovação e influenciam diretamente esta trajetória tecnológica. Sob a visão sistêmica, incluem-se também órgãos estatais e instituições de ensino e pesquisa. 
Na construção civil brasileira, a seleção da inovação de determinados componentes, sistemas ou métodos construtivos, em alguns períodos históricos, foi limitada por ações de políticas públicas guiadas por uma necessidade do aparato produtivo. Em outros casos, políticas públicas vêm possibilitando a introdução destas inovações, como o caso do SINAT instituído no PBQP-H, que estipula procedimentos para analisar o desempenho de sistemas ainda não normatizados no país. Os sistemas homologados nestes processos do SINAT puderam ser inclusos no PMCMV, financiado por agentes públicos. Ainda que em menor escala de produção quando comparados aos sistemas tradicionais, esta política pública permitiu a entrada de alguns sistemas inovadores no mercado nacional. Esse foi o meio pelo qual se viabilizou a introdução do wood frame no contexto brasileiro desde o ano de 2012.

Por sua vez, as instituições de ensino e de pesquisa, têm exercido a função de estimular e coordenar pesquisas que indicam as possiblidades de inovação. Entretanto, esse novo conhecimento adquirido raramente é passado para aplicação no mercado. Ou ainda, os currículos acadêmicos destas instituições contemplam exclusivamente os sistemas considerados tradicionais e não consideram a inclusão de tecnologias inovadoras já disponíveis. Assim, os profissionais formados não adquirem conhecimento sobre as alternativas possíveis.

A integração sistêmica entre as três esferas "universidade - empresa - governo" para efetivar uma inovação não é usual na indústria da construção civil brasileira. Mas, no caso do processo de produção do wood frame em 2010, foi observado uma conjuntura que procurou envolver os agentes destas três esferas a fim de alcançar a efetivação desta inovação.

Neste caso específico, a empresa, ou seja, o setor produtivo das construções em madeira apareceu como o centro desta relação tríplice, mas dependeu diretamente das relações com as esferas de instituições de ensino e pesquisa e do Estado. Desse tripé, a maior relação ocorreu entre o setor produtivo e o Estado, quando as empresas interessadas na produção de habitação procuraram os órgãos governamentais que atuaram nos papéis de provedor de habitação pelo PMCMV, de financiador mediante a CEF e de promotor da inovação tecnológica pelo SINAT/PBQP-H.

Em paralelo, a relação entre o setor produtivo do wood frame e a instituições de ensino e de pesquisa não foi firmada logo no início deste processo de inovação. A transferência de conhecimento científico não ocorreu mediante parcerias com as universidades brasileiras. Para isso, consultores técnicos com conhecimento acumulado sobre a tecnologia foram 
solicitados para fornecer informações técnicas sobre os requisitos de desempenho deste sistema construtivo em questão. Mas, posteriormente, a integração entre empresas e universidades e outros centros de pesquisa foi aumentando gradualmente visando aprimorar os sistemas aplicados já no mercado. No entanto, neste caso, ainda prevaleceu a relação entre empresas e ITA's, como por exemplo o IPT, para consolidar os documentos técnicos para o SINAT/PBQP-H. Assim, esse elo demonstrou que as instituições de ensino, em geral, nas suas análises e propostas de inovações, vêm agindo de forma independente das empresas construtoras.

A conjuntura "universidade - empresa - governo" é necessária para possibilitar a inserção de novas tecnologias no mercado brasileiro de habitações já consolidado com práticas tradicionais. E, para efetivar a integração deste sistema triplo, é preciso avaliar como essa relação vem ocorrendo para os diferentes sistemas construtivos nacionais, inovadores ou não. Portanto, para compreender os motivos que impulsionam a seleção de determinada tecnologia construtiva é importante realizar esta avaliação com maior profundidade sobre as articulações entre os agentes desse processo de produção, levantando seus atores, seus fluxos de interesse e os contextos em que se inserem.

\section{SUGESTÕES PARA PESQUISAS FUTURAS}

- Aprofundar a análise do processo de produção do wood frame nos Estados Unidos para compreender os demais agentes, seus papéis atribuídos e seus vínculos, em especial as instituições e ensino e pesquisa que não foram evidenciadas nesta tese. Avaliar como a adoção de outros sistemas construtivos no decorrer da história influenciaram a difusão deste sistema em madeira já consolidado.

- Considerar outros cenários da implementação deste sistema construtivo, em países como Alemanha e Chile, onde vêm ocorrendo um aumento nas construções em madeira e onde os métodos de produção são exemplos de industrialização.

- Elaborar resgate histórico do primeiro período de produção dos sistemas leves entramados em madeira no mercado brasileiro na década de 1980, considerando questões técnicas e abordagens sistêmicas para compreender, em especial, porque aquela produção foi descontinuada e o sistema wood frame não foi difundido efetivamente no mercado nacional naquele momento. 
- Levantar e comparar as diferentes composições de sistemas wood frame propostos em pesquisas acadêmicas e aplicados comercialmente pelas empresas construtoras no Brasil;

- Avaliar até que ponto o SINAT contribuiu para difusão efetiva de sistemas construtivos inovadores no país, por comparar a quantidade produzida entre estes sistemas inovadores e os tradicionais, por compreender as empresas construtoras que obtiveram DATec's homologados, e por analisar a atuação desta política pública na melhoria do produto final ofertado no mercado.

- Comparar os requisitos prescritos para sistemas considerados inovadores e para sistemas tradicionais nos processos de avaliação dos agentes públicos de financiamento. 
ABDI (2015), Agência Brasileira de Desenvolvimento Industrial. Manual da construção industrializada - conceitos e etapas, Vol. 1: Estrutura e vedação. Brasília.

ABRAF (2007), Associação Brasileira de Produtores de Florestas Plantadas. Anuário estatístico da ABRAF: ano base 2006. Brasília, 2007.

(2008). Anuário estatístico da ABRAF: ano base 2007. Brasília.

(2009). Anuário estatístico da ABRAF: ano base 2008. Brasília.

(2010). Anuário estatístico da ABRAF: ano base 2009. Brasília.

ABRAMAT (2011), Associação Brasileira da Indústria de Materiais de Construção. Perfil da cadeia produtiva da construção, da indústria de materiais e equipamentos. São Paulo, ABRAMAT \& FGV.

AECWEB (2010). Sistema Wood Frame utiliza chapas OSB estruturais para construção de Casa Modelo. Disponível em: <http://www.aecweb.com.br> Acesso em: 10 jul 2016.

AMORIM, S. R L (1995). Tecnologia, organização e produtividade na construção. Tese (doutorado). Programa de Pós-Graduação em Engenharia de Produção. Universidade Federal do Rio de Janeiro, Rio de Janeiro.

ANJOS DO BRASIL (2016). O que é um investidor-anjo. Disponível em: <http://www.anjosdobrasil.net> Acesso em: 14 nov 2016.

APA (2012), The Engineered Wood Association. Advanced Framing construction guide. Form n. M400. Washington: APAWood.

(2015). Free CAD details for wood-frame construction. APA CAD.

(2016). Engineered Wood Construction Guide. Washington: APAWood.

APRE (2013), Associação Paranaense de Empresas de Base Florestal. Empresários discutem avanços da Comissão da Casa. 06 dez 2013. Disponível em: <http://www.apreflorestas.com.br> Acesso em: 08 abr 2016.

(2016). Casa Inteligente. Disponível em: <http://www.apreflorestas.com.br/programas/casainteligente> Acesso em: 10 maio 2016.

ARCHDAILY (2013). Núcleo Senai de Sustentabilidade / ArqBox. 08 de outubro de 2013. Disponível em: <http://www.archdaily.com.br/br/01-145236/nucleo-senai-de-sustentabilidade-slasharqbox> Acesso em 11 nov 2016.

(2014). Casa Vila / Arquea Arquitetos. 29 de maio de 2014. Disponível em: <http://www.archdaily.com.br/br/606822/casa-vila-slash-arquea-arquitetos> Acesso em: 10 set 2015.

AWC (2014), American Wood Council. Wood Frame Construction Manual for One- and Two-Family Dwellings - 2015.

BATISTA, F. D. (2011). A casa de madeira: um saber popular. Curitiba: Instituto Arquibrasil.

BAUMEISTER-SAPPER (2016). Start, manufacture, building. Disponível em: <http://www.baumeistersapper.de/> Acesso em: 14 nov 2016.

BENEVENTE, V. A. (1995). Durabilidade em construção de madeira: uma questão de projeto. Mestrado (dissertação). Escola de Engenharia de São Carlos. Universidade de São Paulo, São Carlos. 
BENOITT, Y.; PARADIS, T. (2007). Construction de maisons à ossature bois. Centre Technique du Bois et de l'Ameublement (CTBA). Groupe Eyrolles.

BERTOLDI, A. (2008). Setor madeireiro sofre mais com crise mundial. Folha de Londrina: 19 nov 2008. Disponível em: <http://www.fetraconspar.org.br/informativos/2008/1722_19_11_08.htm> Acesso em: 05 abr 2016.

BITTENCOURT, R. M. (1995). Concepção arquitetônica da habitação em madeira. Doutorado (tese). Escola Politécnica da Universidade de São Paulo, São Paulo.

BOCK, G. (1992). The sctructure of wood-frame houses. Old-house Journal, p. 32-35, march-april 1992.

BOLAFFI, G. (1979). Habitação e urbanismo: o problema e o problema falso. In A produção capitalista da casa (e da cidade) no Brasil industrial. São Paulo: Alfa-Ômega.

BORTOLIN, R. (2010). Comissão traz tecnologia europeia ao Brasil. Gazeta do Povo, 23 mar 2010, Disponível em: <http://www.gazetadopovo.com.br/imoveis/comissao-traz-tecnologiaeuropeia-ao-brasil-03awkdwx6erw68gi1zam7z87i> Acesso em 08 de abr de 2016.

BRASIL ENGENHARIA. (2013). Wood Frame recebe concessão da Caixa Econômica Ferderal visando o estímulo a novas tecnologias. Brasil Engenharia, Portal Engenho, jul 2013. Disponível em: $<$ http://www.brasilengenharia.com/portal/construcao/5666-wood-frame-recebe-concessaoda-caixa-economica-federal-visando-o-estimulo-a-novas-tecnologias> Acesso em 13 dez 2013.

BRASIL, Ministério das Cidades (2007a). Institui o Sistema Nacional de Avaliações Técnicas de produtos inovadores - SINAT. Brasília: PBQP-H.

- (2007b). Regimento Geral do Sistema Nacional de Avaliações Técnicas de produtos inovadores. Brasília: PBQP-H.

. (2011). Diretriz SINAT no 005: Sistemas construtivos estruturados em peças de madeira maciça serrada, com fechamentos em chapas delgadas (Sistemas leves tipo "Light Wood Framing"). Brasília: SNH, PBQP-H, SINAT.

. (2013). DATec no 20 - Sistema construtivo TECVERDE: sistema leve em madeira. Brasília: SNH, PBQP-H, SINAT.

. (2015). DATec № 020-A - Produto "Sistema de vedação vertical leve em madeira - Tecverde". Brasília: SNH, PBQP-H, SINAT.

. (2016). Diretriz SINAT no 005 - Revisão 01 - Sistemas construtivos estruturados em peças de madeira maciça serrada, com fechamentos em chapas delgadas, Sistemas leves tipo "Light Wood Framing". Brasília: PBQP-H.

BRASIL. (2004). Lei no 10.793, de 02 de dezembro de 2004. Dispõe sobre incentivos à inovação e à pesquisa científica e tecnológica no ambiente produtivo. Brasília.

. (2009). Lei no 11.977, de 7 de julho de 2009. Programa Minha Casa, Minha Vida - PMCMV e a regularização fundiária de assentamentos localizados em áreas urbanas. Brasília.

BRUNA, P. J. (1976). Arquitetura, industrialização e desenvolvimento. São Paulo: Perspectiva.

BUETTNER, E. V. (2009). Projeto Tecnologia de Construção Sustentável. Relatório de planejamento estratégico. Curitiba: SENAI/PR. Disponível em: <http://www.fiepr.org.br/paraempresas/conselhos/base_florestal/uploadAddress/Relatorio[15473].pdf > Acesso em: $13 \mathrm{dez}$ 2013.

CAMPOS, R. J. (2006). Diretrizes de projeto para produção de habitações térreas com estrutura tipo plataforma e fechamento com placas cimentícias. Mestrado (dissertação). Universidade Estadual de Londrina, Londrina. 
CANTO, D. I. S. (1996). Avaliação pós-ocupação de residências unifamiliares pré-fabricadas com pinus, com possibilidades de uso no Rio Grande do Sul. Dissertação (mestrado). PósGraduação em Engenharia Civil. Universidade Federal do Rio Grande do Sul, Porto Alegre.

CARDOSO, F. F. (2013a). Estratégias para a formulação de política de ciência, tecnologia e inovação para a indústria da construção civil. Brasília: ANTAC, CBIC.

CARDOSO, F. F. (2013b). Ciência, Tecnologia e Inovação e a Indústria da Construção Civil: elementos para a formulação de uma política para o setor. Brasília: ANTAC, CBIC.

CARDOSO, L. R.; ABIKO, A. K.; GONÇALVES, O. M. (2002). Estudo prospectivo da cadeia produtiva da construção civil no Brasil: produção e comercialização de unidades habitacionais. IX Encontro Nacional de Tecnologia do Ambiente Construído, p. 911-920.

CARVALHO, M. M.; NODARI, E. S. (2008). A Lumber, o Contestado e a história do desmatamento da floresta de araucária (1911-1950). Rede Brasileira de História Ambiental.

CASSIOLATO, J. E.; LASTRES, H. M. (2003). Glossário de arranjos e sistemas produtivos e inovativos locais. Rio de Janeiro: Redesist / UFRJ.

. (2005). Sistemas de inovação e desenvolvimento: as implicações de política. São Paulo em Perspectiva, jan/mar 2005, p. 34-45.

. (2007). Inovação e sistemas de inovação: relevância para a área da saúde. RECIIS - Revista Eletrônica de Comunicação, Informação e Inovação em Saúde, jan - jun 2007, p. 153-162.

CASTRO, J. A. (1999). Invento e inovação tecnológica na construção: produtos e patentes na construção. São Paulo: Annablume.

CASTRO, A. M.; LIMA, S. M. (2003). Cadeia produtiva e prospecção tecnológica como ferramentas para formulação de estratégia. Encontro de Estudos em Estratégia.

CAVANAGH, T. (1997). Balloon houses: The original aspects of conventional wood frame construction re-examined. Journal of Architectural Education, n. 51, sep. 1997.

CBIC. (2010). Câmara Brasileira da Indústria da Construção. Projeto de Inovação Tecnológica - PIT. CBIC: Comissões e Fóruns: 25 de mar de 2010. Disponível em: <http://www.cbic.org.br/comissoes-e-foruns/comissao-de-materiais-tecnologia-qualidade-eprodutividade/projetos/pit/pagina/pr> Acesso em: 23 dez 2016.

. (2012). CBIC anuncia vencedores do Prêmio CBIC de Inovação e Sustentabilidade durante festa de confraternização. CBIC: 14 dez 2012. Disponível em: http://www.cbic.org.br/> Acesso em: 10 jul 2015.

CEF (2016). Caixa Econômica Federal. Programa Minha Casa Minha Vida - Construção de Empreendimentos. Disponível em: <http://www1.caixa.gov.br/construcaocivil/cxcc_cns.asp> Acesso em 04 out 2016.

CeluloseOnline (2015). Florestas Plantadas: casas de madeira no Brasil. Será possível? Celulose Online: 22 jul 2015. Disponível em: <http://celuloseonline.com.br/florestas-plantadas-casasde-madeira-no-brasil-sera-possivel-leia-entrevista-exclusiva/> Acesso em: 03 mar 2016.

CETHAC (1979). Centro de Estudos e Pesquisas para a Racionalização da Habitação da Construção e do Desenvolvimento Urbano. Madeira na construção habitacional. Rio de Janeiro: BNH.

CHIARELLI, L. M. (2014). Habitação social em Pelotas (1987-2010) Influências das políticas públicas na promoção de conjuntos habitacionais. Doutorado (tese). Pontífica Universidade Católica do Rio Grande do Sul, Porto Alegre.

CHIESSE, C. V. S. et al. (2013). Núcleo Senai de sustentabilidade. CRIE, p. 18-21. 
CIB (1999). Conseil International du Batiment. Agenda 21 on sustainable construction. CIB Report Publication 237. Rotterdam.

CLARO, A.; SANTOS, C. F. (1991). Arquitetura catarinense em madeira: uma visão preliminar. Síntese Revista de Arquitetura, n. 03, p. 18-32.

CMHC (2013). Canada Mortgage and Housing Corporation. Wood-Frame House Construction. Canada: CMHC.

CRUZ, C. F. (2008). Fazendas do Sul de Minas Gerais Arquitetura rural nos séculos XVIII e XIX. Mestrado (dissertação). Escola de Engenharia de São Carlos. Universidade de São Paulo, São Carlos.

CUNHA, A. (2014). Residencial Haragano: divulgada lista de contemplados e suplentes. Prefeitura de Pelotas. 10 mar 2014. Disponível em: <http://www.pelotas.rs.gov.br/noticias/detalhe.php?codnoticia=36286> Acesso em 08 out 2016.

DE ARAÚJO, V. et al. (2016). Woodframe: light framing houses for developing countries. Revista de la Construcción, v.15, n.2, p. 78-87.

DIÁRIO POPULAR, (2007). Economia: Caixa RS garante viabilidade de casas. Diário Popular, 25 jul 2007. Disponível em: <http://srv-net.diariopopular.com.br/25_07_07/p1101.html> Acesso em 03 jun 2016.

. (2009). Economia: Oportunidade contra a crise. Gráfica Diário Popular - Pelotas: 18 de abr de 2009. Disponível em: <www.diariopopular.com.br>Acesso em 03 jun 2016.

. (2012). Tecnologia sustentável leva construtora ao prêmio CBIC. Diário Popular, 12 dez 2012. Disponível em: <www.diariopopular.com.br> Acesso em 20 set 2014.

DIAS, R. S.; INO, A. (2008). Habitação econômica em madeira no Brasil: estado da arte. XI Encontro Brasileiro em Madeira e Estruturas em Madeira. Londrina: IBRAMEM.

DOCKENDORFF, S. (2014). Residencial Haragano será entregue na próxima segunda-feira. Prefeitura Municipal de Pelotas - Notícias, 27 jun 2014. Disponível em: $<$ http://www.pelotas.rs.gov.br/noticias/detalhe.php?controle=MjAxNCOwNiOyNw==\&codnot icia=36933> Acesso em 13 out 2016.

DOSI, G. (1982). Technological paradigms and technological trajectories. Research Policy 11, p. 147162.

. (2006). Mudança técnica e transformação industrial: a teoria e uma aplicação à indústria dos semicondutores. Campinas: Editora da Unicamp.

DOSI, G. et al. (1988). Technical change and economic theory. London: Pinter Publishers.

EN, Norme Européenne. (2004). Eurocode 5: Design of timber structures - Part 1-1: General - Common rules and rules for buildings. Brussels: CEN.

ENDEAVOR (2012). Empreendedores - Lucas Maceno, Tecverde. Endeavor Brasil. Disponível em: <https://endeavor.org.br/empreendedores-endeavor/lucas-maceno/> Acesso em 14 nov 2016

ENIC (2014). Encontro Nacional da Indústria da Construção. Tecnologia wood frame é tema de palestra magna. ENIC 2014 - Notícias: 22 abr 2014. Disponível em: <http://www.eninc2014.com.br/noticias/wood-frame.html> Acesso em 17 set 2014.

ESCRITÓRIO VERDE (2016). Conheça as etapas da obra. Escritório Verde Online. Disponível em: <http://www.escritorioverdeonline.com.br/artigos/> Acesso em 02 nov 2016. 
ESPÍNDOLA, L. R. (2010). Habitação de interesse social em madeira conforme os princípios de coordenação modular e conectividade. Mestrado (dissertação). Florianópolis: Universidade Federal de Santa Catarina.

ESPÍNDOLA, L. R., INO, A. (2014). Inserção e financiamento do sistema wood frame no programa habitacional Minha Casa Minha Vida. XV Encontro Nacional de Tecnologia do Ambiente Construído.

ESTADO DO RIO GRANDE DO SUL (2009). Lei № 13.284. Autoriza o Poder Executivo a doar imóveis ao Fundo de Arrendamento Residencial - FAR, representado pela Caixa Econômica Federal. Porto Alegre: Assembleia Legislativa.

ETZKOWITZ, H. (2009). Hélice Tríplice: universidade-indústria-governo inovação em movimento. Trad. Cristina Hintz. Porto Alegre: EdiPUCRS.

ETZKOWITZ, H.; LEYDESDORFF, L. (2000). The dynamics of innovation: from national systems and 'mode 2' to a Triple Helix of University-Industry-Government. Research Policy, p. 109-123.

FARAH, M. F. (1996). Processo de trabalho na construção habitacional: tradição e mudança. São Paulo: Annablume.

FERNANDES, C. (2011). Sistemas industrializados à base de cimento para habitação. Inovações tecnológicas na CAIXA. São Paulo: GEPAD/CEF.

FERREIRA, R. (2013). MCMV de madeira. Construção Mercado. São Paulo: Pini, set 2013.

FIELD, W. (1942). A reexamination into the invention of the balloon frame. The Journal of the American Society of Architectural Historians, oct 1942.

FIEP (2011). Federação das Indústrias do Estado do Paraná. Comissão Casa Inteligente. FIEP Conselhos temáticos e setoriais - Base Florestal. Disponível em: http://www.fiepr.org.br/paraempresas/conselhos/base_florestal/comissao-casa-inteligente-1-1135-87186.shtml> Acesso em 07 dez 2013.

. (2012). Desoneração e combate à informalidade são prioridades para a indústria madeireira. Fiep: 21 mar 2012. Disponível em: <http://www.agenciafiep.com.br/noticia/desoneracao-ecombate-a-informalidade-sao-prioridades-para-a-industria-madeireira/> Acesso em $07 \mathrm{dez}$ 2013.

. (2013) Visita Residencial Haragano - Pelotas. Conselhos temáticos e setoriais da FIEP: 19 jul 2013. Disponível em: <http://www.fiepr.org.br/para-empresas/conselhos/visita-residencialharagano---pelotas-11-3998-220564.shtml> Acesso em 07 dez 2013.

. (2014) Vencer preconceito para termos construções mais sustentáveis. 13 fev 2014. Disponível em: <http://www.agenciafiep.com.br/noticia/\%E2\%80\%9Ce-necessario-vencer-opreconceito-para-termos-construcoes-mais-sustentaveis\%E2\%80\%9D-afirma-coordenadorda-comissao-casa-inteligente/> Acesso em 04 mar 2016.

. (2015). Casa Inteligente: o desafio de incentibar uma construção mais sustentável. A Indústria em Revista, jul-set de 2015, p. 30-33.

FIESP (2016). Federação das Indústrias do Estado de São Paulo. Cadeia produtiva da construção. Disponível em: <http://www.fiesp.com.br/infografico-cadeia-da-construcao/> Acesso em 15 mar 2016.

FILHO, R. (2013). Entrevista com superintendente da Caixa Extremo Sul. Amigos de Pelotas, 08 abr 2013. 
FINEP (2016). Financiadora de Estudos e Projetos. Prime - Primeira Empresa Inovadora. FINEP - Apoio e financiamento - Histórico de Programas. Disponível em: <http://www.finep.gov.br/apoio-efinanciamento-externa/historico-de-programa/prime> Acesso em 14 nov 2016.

FJP (2013). Fundação João Pinheiro. Déficit habitacional municipal no Brasil. Belo Horizonte: Centro de Estatísitica e Informações.

GERHARDT, T. E.; SILVEIRA, D. T. (2009). Métodos de pesquisa. Porto Alegre: Editora da UFGRS.

GOL, Linhas Aéreas. (2015). Madeeeira! - entrevista. Revista GOL Linhas aéreas inteligentes, n. 156, março, p. 108-112.

GONÇALVES, M. R. (2006). Sistema construtivo wood frame para habitação de interesse social homologado na Caixa. Pelotas: UFPel.

GONÇALVES, R. B. (2008). 0 sincretismo de culturas sob a ótica da arquitetura vernácula do imigrante japones na cidade de Registro, São Paulo. Anais do Museu Paulista v. 16 n. 1, jan-jun 2008, p. $11-46$.

GUSHI, A. S. (1999). O padrão de geração e difusão de inovações tecnológicas na América Latina: uma abordagem neo-schupeteriana. (Monografia de conclusão de curso de graduação). Campinas: Universidade Estadual de Campinas.

HABITARE (2004). Sistema Battistella-UFSC: Avaliação e Desenvolvimento de Sistema Construtivo em Madeira de Reflorestamento voltado para Programas de Habitação Social. Disponível em: <http://www.habitare.org.br/prototipos_projeto1.aspx\#> Acesso em 03 dez 2016.

HAGA, H. C. (2008). Produção e comercialização de insumos da cadeia produtiva para a construção habitacional: diagnóstico para o desenvolvimento de estudos de prospecção tecnológica Doutorado (tese). São Paulo: USP.

HARRIS, R. (2013). Discovering timber-framed buildings. Oxford: Shire Publications.

HEATH, K. W. (1996). Balloon Frame. The Dictionary of Art.

HELLMEISTER, J. C. (1971). Sobre a determinacao das caracteristicas fisicas da madeira. Doutorado (tese). São Paulo: Universidade de São Paulo.

HIJIOKA, A.; JOAQUIM, B.; INO, A. (2013). Processo construtivo das casas dos imigrantes japoneses do Vale do Ribeira. Encontro Latinoamericano de Edificações e Comunidades Sustentáveis. Curitiba: ELECS.

HIRSCHMAN, C.; MOGFORD, E (2009). Imigration and the American Industrial Revolution from 1880 to 1920 . Soc Sci Res., Dec de 2009, p. 9897-920.

IBGE, Instituto Brasileiro de Geografia e Estatística (2010). Censo demográfico de 2010. Banco de dados agregados. Sistema IBGE de recuperação Automática SIDRA. Disponível em: <http://www.sidra.ibge.gov.br/> Acesso em 10 mar 2016.

ICC (2015). Internacional Code Council. International Building Code.

INO, A. (1991). Sistema estrutural modular em eucalipto rolico para habitação. Doutorado (tese). São Paulo: Universidade de São Paulo.

IPEA (2016). Instituto de Pesquisa Econômica Aplicada. Câmbio real compra e venda. Ipeadata. Disponível em: <http://www.ipeadata.gov.br/> Acesso em 16 maio 2016.

JACKSON, K. T. (1985). Crabgrass frontier: the suburbanization of the United States. New York: Oxford University Press.

JENSEN, R. (1971). Board and batten siding and the balloon frame: theis incompatibility in the Nineteenth Century. Journal of the Society of Architectural Historians, march 1971, p. 140-50. 
JOHNSON, R. (2007). The advantages of Balloon Frame. American Building Construction History, March 2007, p. 1-7.

KOLB, J. (2008). Systems in timber engineering. Switzerland: Lignun, Birkhäuser, DGfH.

KRAMBECK, T. I. (2006). Revisão de sistema construtivo em madeira de floresta plantada para habitação popular. Dissertação (Mestrado). Programa de Pós-Graduação em Arquitetura e Urbanismo. Universidade Federal de Santa Catarina, Florianópolis.

KUCKER, P. (2002). Framework: construction and space in the architecture of Frank Lloyd Wright and Rudolf Schindler. The Journal of Architecture, p. 171-190.

KÜRTEN (2014). Wood Frame Kürten - Sistema construtivo revoluciona as construções em madeira. Referência Produtos de Madeira, ano 06, № 24 - maio, 2014, p. 56-63.

LAHR, F. A. (1983). Sobre a determinação de propriedades de elasticidade da madeira. Doutorado (tese). Escola de Engenharia de São Carlos. Universidade de São Paulo, São Carlos.

LAROCA, C. (2007). Desenvolvimento de protótipo de habitação social em madeira de reflorestamento e avaliação do desempenho termo-acústico. Doutorado (tese). Curitiba: Universidade Federal do Paraná.

LARROCA JÚNIOR, J.; LAROCCA, P. L.; LIMA, C. (2008). Casa Eslavo-Paranaense: Arquitetura de madeira dos colonos poloneses e ucranianos do sul do Paraná. Ponta Grossa: Larocca Associados.

LIMA, S. (2012). Fetter homologa mais um empreendimento imobiliário em Pelotas. Prefeitura Municipal de Pelotas - Notícias, 06 fev 2012. Disponível em: <http://www.pelotas.rs.gov.br/noticias/detalhe.php?controle=MjAxMiOwMiOwNg==\&codno ticia $=29730>$ Acesso em 04 out 2016.

MADEIRA TOTAL (2006). Encontro Brasil Alemanha acontece em Arapongas, paralelo à Movelpar 2007. MadeiraTotal.com.br, 30 ago 2006, disponível em: <http://madeiratotal.com.br/noticia.php?id=1024\&volta=noticias. php?cat=6> Acesso em 20 fev 2016.

MADEZATTI (2016). Empresa: histórias e grandes obras. Disponível em: <http://www.madezatti.com.br/> Acesso em 05 dez 2016.

MARCUSE, H. (1978). A ideologia da sociedade industrial (6 ed.) Rio de Janeiro: Zahar Editores.

. (1997). Algumas implicações sociais da tecnologia moderna. Praga - Revista de estudos marxistas no 1, p. 113-140.

MARICATO, E. (1978). Autoconstrução, a arquitetura possível. In: A produção capitalista da casa (e da cidade) no Brasil industrial. São Paulo: Alfa-Omega. . (1983). Indústria da Construção e Política Habitacional. Doutorado (tese). São Paulo: USP.

MARRYAT, F. (1883). Chicago's first half century, 1833-1883: the city as it was fifty years ago, and as it is today : the trade, commerce, manufactories, railroads, banks, wholesale and retail houses, theaters, hotels, churches, and school. Chicago: Inter Ocean Pub. co.

MARTINS, M. E. (2015). Avaliação de desempenho de tecnologias construtivas inovadoras: manutenção e percepção dos usuários. (monografia de conclusão de curso de graduação). São Carlos: Instituto de Arquitetura e Urbanismo, USP.

MARTUCCI, R. (1990). Projeto tecnologico para edificações habitacionais: utopia ou desafio. Doutorado (tese). São Paulo: USP.

MARX, K. (2002). O capital: crítica da economia política. Rio de Janeiro: Civilização Brasileira. 
MCidades, Ministério das Cidades; SNH, Secretaria Nacional de Habitação (2015). Empreendimentos lançados no PMCMV em Pelotas nas faixa 1, 2 e 3, entre 2009 e 2015. Acesso à informação Governo Federal - Pedido 80200000026201614: 30 set 2015 Disponível em: <http://www.consultaesic.cgu.gov.br/busca/SitePages/principal.aspx>

MILAN, M. (2013). A Crise Financeira nos EUA: causas, consequências e desdobramentos teóricos. Sociedade Brasileira de Economia Política, outubro de 2013, p. 103-145.

MIOZZO, M.; DEWICK, P. (2004). Innovation in construction: a European analysis. Cheltnham, UK: Edward Elgar Publishing.

MOLINA, J. C.; CALIL JÚNIOR, C. (2010). Sistema construtivo em wood frame para casas de madeira. Semina: Ciências Exatas e Tecnológicas, jul./dez. de 2010, p. 143-156.

MONTEIRO FILHA, D. C., et al. (2010). Perspectivas e desafios para inovar na construção civil. BNDES Setorial 31 ed. Rio de Janeiro: BNDES.

MONTEYNE, D. (2004). Framing the American dream. Journal of Architectural Education, p. 24-33.

MORICOCHI, L.; GONÇALVES, J. S. (1994). Teoria do desenvolvimento econômico de Schumpeter: uma revisão crítica. Informações Econômicas, 24, agosto de 1994, p. 27-35.

MORVAN, Y. (1988). Fondements d'economie industrielle. Paris: Economica.

MOWERY, D.; ROSENBERG, N. (1979). The influence of the market demand up-on innovation: a critical review of some recent empirical studies. Research Policy.

NAKAMURA, J. (2009). Light wood frame. Téchne. Ed. 148. Julho de 2009. São Paulo: Pini.

NEGRI, J. A.; KUBOTA, L. C. (2008). Políticas de incentivo à inovação tecnológica. Brasília: IPEA.

NUMAZAWA, C. T. (2009). Arquitetura japonesa no Pará: estuto de caso em edificações de técnica construtiva que favoreceu uma maior durabilidade da arquitetura em madeira no município de Tomé-Açu. Dissertação (mestrado).Universidade Federal de Santa Catarina, Florianópolis.

O'BRIEN, M. J. (2010). Hybrids on the way to the Western Platform Frame: two structures in Western Virginia. Preservation Education \& Research, 3, p. 37-52.

O'BRIEN, M.; WAKEFIELD, R.; BELIVEAU, Y. (2000). Industrializing the residential construction site. Virginia: U.S. Department of Housing and Urban Development.

OCDE, (2006). Organização para Cooperação e Desenvolvimento Econômico. Manual de Oslo: Diretrizes para coleta e interpretação de dados sobre inovação. Rio de Janeiro: OCDE.

. (2007). Manual de Frascati: metodologia proposta para a definição da investigação e desenvolvimento experimental. Coimbra: F-Iniciativas.

OREIRO, J. L.; BASILIO, F. A. (2009). A crise financeira brasileira: uma análise a partir do conceito de fragilidade financeira à la Minsky. Revista de Economia Política 29 (1), p. 146-148.

PAGE, B.; WALKER, R. (1991). From settlement to fordism: the agro-industrial revolution in the American Midwest. Economic Geography, 67, Oct 1991.

PALMER, S. et al (2000). Sustainable homes: timber frame housing. Hastoe Housing Association.

PBQP-H, Programa Brasileiro de Qualidade e Produtividade do Habitat (2016). Projetos: Sistema Nacional de Avaliações Técnicas - SINAT. PBQP-H / Ministério das Cidades. Disponível em: <http://pbqp-h.cidades.gov.br/projetos_sinat.php> Acesso em 18 dez 2016.

PELOTAS (2009). Lei № 5.603. Institui o Programa Habitacional de Interesse Social "Pelotas Habitação Digna. Pelotas: Prefeitura Municipal de Pelotas. 
PEREIRA, A. J.; LOPES, H. C. (2015). Uma perspecitva 'institucionalista evolucionária' do atraso inovativo brasileiro. XVIII Encontro de Economia da Região Sul.

PINHO, F. (2012). Casas ecológicas. Pequenas Empresas \& Grandes Negócios.

PORTAL MADEIRA E CONSTRUÇÃO (2016). ABNT instala comissão para desenvolver norma técnica do sistema wood frame. APRE - Notícias, 14 de junho de 2016. Disponível em: <http://www.apreflorestas.com.br/noticias/construcao-sustentavel/1311/abnt-instalacomissao-para-desenvolver-norma-tecnica-do-sistema-wood-frame> Acesso em 23 nov 2016.

POSENATO, J. (1983). Arquitetura da imigração italiana no Rio Grande do Sul. Porto Alegre: EDUCS.

PREFEITURA MUNICIPAL DE PELOTAS (2009a). Prefeitura aumenta atendimento para cadastro habitacional. (J. Lima, Editor) Notícias: 30 de abril de 2009. Disponível em http://www.pelotas.com.br/noticia/noticia.htm?codnoticia=16699> Acesso em 03 out 2016.

. (2009b). Sinduscon traz novas demandas ao prefeito. (J. Lima, Editor) Notícias: 29 de abril de 2009. Disponível em: <http://www.pelotas.com.br/noticia/noticia.htm?codnoticia=16682> Acesso em 21 set 2016.

REDE TECVERDE (2014). Modelo de Negócio Rede Tecverde. Rede Tecverde Construindo inovações sustentáveis. Disponível em: <http://www.redetecverde.com.br/> Acesso em 16 nov 2016.

REIS FILHO, N. G. (2006). Quadro da arquitetura no Brasil (11 ed.). São Paulo: Perspectiva.

REZENDE, M. A. (2003). Inovação tecnológica nas edificações e a introdução da estrutura metálica em Minas Gerais. Doutorado (tese). São Paulo: Universidade de São Paulo.

REZENDE, M. A.; BARROS, M. M.; ABIKO, A. K. (2002). Barreiras e facilitadores da inovação tecnológica na produção de habitações populares. IX Encontro Nacional de Tecnologia do Ambiente Construído.

ROBERTO FERREIRA (2013). Desenvolvimento de tecnologia wood frame para habitações de interesse social. Disponível em: <www.robertoferreira.com.br>Acesso em 25 out 2015.

. (2016). História, obras, produtos. Disponível em: <http://www.robertoferreira.com.br/> Acesso em 04 out 2016.

ROGERS, E. M. (1995). Diffusion of innovations (4th ed.). New York: The Free Press.

ROSENBERG, N. (2006). Por dentro da caixa-preta: tecnologia e economia. Campinas: Ed. da Unicamp.

SÁBATO, J.; BOTANA, N. (1975). La ciencia y la tecnologia en el desarollo futuro de America Latina. EI pensiamento latinoamericano en la problemática ciencia-tecnología-desarollo.

SABBATINI, F. H. (1989). Desenvolvimento de método, processo e sistemas construtivos: formulação e aplicação de uma metodologia. Doutorado (tese). São Paulo: USP.

SANCHEZ, J. E. (1995). Casa de madera. Associación de Investigación Técnica de las Industrias de la Madera y Corcho, AITIM.

SANTOS, R. E. (2008). A armação do concreto no Brasil: história da difusão da tecnologia do concreto armado e da construção de sua hegemonia. Tese (doutorado). Programa de Pós-Graduação em Educação. Universidade Federal de Minas Gerais, Belo Horizonte.

SCHUMPETER, J. A. (1961). Capitalismo, socialismos e democracia. Rio de Janeiro: Fundo de Cultura S.A.

. (1982). Teoria do desenvolvimento econômico: uma investigação sobre lucros, capital, crédito, juro e o ciclo econômico. São Paulo: Abril Cultural.

SEMA-SOFT (2016). Welcome to SEMA Timber Construction Software. SEMA Experience. Disponível em:<http://sema-soft.com/en/start.php> Acesso em 14 nov 2016. 
SENAI-PR, (2013). Serviço Nacional de Aprendizagem Industrial do Estado do Paraná. SENAI e BadenWüerttemberg: três décadas de cooperação. Agência da FIEP - informe publicitário, junho de 2013. Disponível em: <http://www.agenciafiep.com.br/wp-content/uploads/2013/06/1606_gazeta.pdf>

. (2016). Senai e suas parcerias internacionais. 10 de abril de 2016. Disponível em: <http://www.sistemafiep.org.br/relacoes-internacionais/senai-e-suas-parceriasinternacionais-1-29792-278070.shtml>

SHERWOOD, G. E.; STROH, R. C. (1989). Wood-frame house construction. Agriculture Handbook 73. Washington: USDA, FPL.

SILVA, A. C.; GONÇALVES, M. R. (2007). Sistema construtivo habitacional com materiais cimentícios e madeira de reflorestamento usado em habitações de interesse social na região Sul do RS. Encontro Latino-americano sobre Edificações e Comunidades Sustentáveis, p. 788-797.

. (2008). Avaliação de desempenho térmico de protótipo de unidade habitacional prémoldada de placas lisas cimentíceas em zona bioclimática 2 (verão). XII Encontro Nacional de Tecnologia do Ambiente Construído.

. (2010). Avaliação de desempenho térmico de protótipo de unidade habitacional prémoldada de placas lisas cimentíceas em zona bioclimática 2 (inverno). XIII Encontro Nacional de Tecnologia do Ambiente Construído.

SIMONI, F. J.; HOEFLICH, V. A. (2007). Análise diagnóstica e prospectiva da cadeia produtiva de energia de biomassa de origem florestal. Colombo: Embrapa Florestas.

SINDUSCON-PR (2015). Grupo de trabalho quer normatizar o sistema de wood frame. SINDUSCONPR Notícias: 07 de julho de 2015. Disponível em: <http://sindusconpr.com.br/> Acesso em 08 abr 2016.

SMITH, A. (1996). A riqueza das nações: investigação sobre sua natureza e suas causas. São Paulo: Nova Cultural Ltda.

SPRAGUE, P. E. (1981). The origin of Balloon Faming. Journal of the Society of Achitectural Historians, 40, Dec. de 1981, p. 311-319.

STAMATO, G. C.; OLIVEIRA JUNIOR, A. C. (2008). Projeto Educação em Madeira. XI EBRAMEM.

SZÜCS, C. P., et al. (2006). Sistema Stella-UFSC: avaliação e desenvolvimento de sistema construtivo em madeira de reflorestamento voltado para programas de habitação social. Coletânea Habitare - vol. 6 - Inovação Tecnológica na Construção Habitacional, 66-115.

TAKASE, Y. (1981). An assessment of the potencial of the United States stick-built house for self-help construction (master). Massachusetts: Massachusetts Institute of Technology.

TÉCHNE. (2002). Popular com tecnologia. Téchne, Ed. 59. Fev 2002. São Paulo: Pini. . (2009). Pronta Entrega. Revista Techné(159), São Paulo: Pini.

TECVERDE (2013). Case Tecverde para construções de alto padrão e habitações de interesse social. Curitiba: Expo Madeira \& Construção.

. (2015). Relatório de sustentabilidade 2014/2015. Curitiba: Tecverde.

. (2016). Panorama do sistema construtivo Tecverde. Curitiba: Tecverde Construções eficientes.

TONETO JÚNIOR, R. (coord) (2013). Estudos sobre a Taxa de Câmbio no Brasil. Ribeirão Preto: DEPECON-FIESP. 
TOPPING, R. et al. (2004). Organizing Residential Utilities: A new aproach of housing quality. U.S. Department of Housing and Urban Development.

UTTERBACK, J. M. (1996). Dominando a dinâmica da inovação. Rio de Janeiro: Qualitymark.

VARGAS, N. (1979). Organização do trabalho e capital: estudo da construção habitacional (dissertação). Rio de Janeiro: UFRJ.

VELLOSO, J. G. (2010). Diretrizes para construções em madeira no sistema plataforma. Dissertação (mestrado). Universidade Federal de Santa Catarina, Programa de Pós-Graduação em Engenharia Civil, Florianópolis.

VIANNA, N. S. (1989). Tecnologia e arquitetura. In: Tecnologia e arquitetura. São Paulo: Nobel.

WARZECHA, M. (2015). Your Home by Mail: The Rise and Fall of Catalogue Housing. Archdaily, 15 de March de 2015. Disponível em: <http://www.archdaily.com/609890/your-home-by-mail-therise-and-fall-of-catalogue-housing> Acesso em 12 ago 2016.

WEBER, M. S. (2011). Sistema Nacional de Avaliação Técnica de Produtos Inovadores - SINAT (840 ENIC). Brasília: PBQP-H. Fonte: Ministério das Cidades.

WEIMER, G. (1983). Arquitetura da imigração Alemã: um estudo sobre a adaptação da arquitetura centro-européia ao meio rural do Rio Grande do Sul. Porto Alegre: UFRGS. (2005). Arquitetura popular brasileira. São Paulo: Martins Fontes.

ZANI, A. C. (2005). Repertório arquitetônico das casas de madeira de Londrina - PR. Londrina: Anônio Carlos Zani.

ZENHA, R. M. (1998). Catálogo de processos e sistemas construtivos para habitação (publicação IPT n. 2515). São Paulo: Intituto de Pesquisas Tecnológicas. 